EDSON DE MOURA

\title{
ESTUDO DE DEFORMAÇÃO PERMANENTE EM TRILHA DE RODA DE MISTURAS ASFÁLTICAS EM PISTA E EM LABORATÓRIO
}

Tese apresentada à Escola

Politécnica da Universidade de São Paulo para obtenção do título de

Doutor em Engenharia de Transportes

São Paulo

2010 


\section{ESTUDO DE DEFORMAÇÃO PERMANENTE EM TRILHA DE RODA DE MISTURAS ASFÁLTICAS EM PISTA E EM LABORATÓRIO}

Tese apresentada à Escola

Politécnica da Universidade de São Paulo para obtenção do título de

Doutor em Engenharia de Transportes

Área de Concentração:

Engenharia de Transportes

Orientadora:

Profa. Dra. Liedi Légi Bariani Bernucci

São Paulo 
Este exemplar foi revisado e alterado em relação à versão original, sob responsabilidade única do autor e com a anuência de seu orientador.

São Paulo, de abril de 2010.

Assinatura do autor

Assinatura do orientador

\section{FICHA CATALOGRÁFICA}

Moura, Edson de

Estudo de deformação permanente em trilha de roda mistu-

ras alfásticas em pista e em laboratório / E. De Moura. -- ed.rev. -

- São Paulo, 2010.

$299 \mathrm{p}$.

Tese (Doutorado) - Escola Politécnica da Universidade de São Paulo. Departamento de Engenharia de Transportes.

1.Pavimentação asfáltica 2.Ligantes 3.Asfalto 4.Deformação Permanente em trilha de roda 5.Pista teste I.Universidade de São Paulo. Escola Politécnica. Departamento de Engenharia de Transportes II. t. 
Dedico esse trabalho à minha esposa Bernadete e aos meus filhos Leandro e Thais 


\section{AGRADECIMENTOS}

Em primeiro lugar agradeço a Deus por ser um homem feliz e ter me dado forças para chegar até aqui. Agradeço também por ele ter colocado em meu caminho a Liedi Bernucci, minha amiga e orientadora a quem devo muito dos meus conhecimentos adquiridos ao longo de todos esses anos de convivência. Obrigado pelo incentivo e pela clareza e seriedade no apoio nos momentos de maior dificuldade para a realização desse trabalho.

A minha esposa Bernadete e aos meus filhos Leandro e Thais aos quais dedico esse trabalho e aproveito para pedir desculpas nos períodos de ausência.

Aos meus amigos Zé Mario e Vagner Alba, pelo companheirismo ao longo de todos esses anos e aos funcionários do Centro de Desenvolvimento Tecnológico Paulista de Infraestrutura da OHL pela realização dos ensaios que fazem parte desse trabalho.

Agradeço ao Grupo OHL e à Concessionária Litoral Sul pela oportunidade impar para a realização da pista-teste.

A ANTT no financiamento da pesquisa da pista-teste.

A Diomaria pela simpatia e eficiência, ao Kendi pelo apoio na contagem de tráfego a o Erasmo pelo braço forte e pela ótima companhia ao longo de todos esses anos não só no laboratório, mas também nas árduas viagens para retirada de amostra e placas na pista-teste.

A todos os alunos de pós-graduação e também aos de iniciação científica, do Laboratório de Tecnologia de Pavimentação, que com medo de esquecimentos me reservo o direito de não nomear, pelo fato de serem tantos, meu muito obrigado pela amizade, compreensão e incentivo ao longo de todos esses anos e no desenvolvimento desse trabalho. 
Ao prof. Suzuki e aos funcionários da Planserv e também ao André e o Felipe da Dynatest pelo apóio no tratamento dos dados de campo.

Ao Fernando e a todos os funcionários da Imperpav pela realização dos ensaios de caracterização das amostras de pista

Ao Honório pelo tratamento das figuras apresentadas no trabalho e na ajuda na parte de informática e a todos os alunos da Fatec-SP que de forma indireta me incentivaram a prosseguir por esse caminho.

A Fátima e a Leo, bibliotecárias da Civil pela prontidão e bom humor que the são peculiares.

Agradeço a todos que, de uma forma direta ou indireta, contribuíram para a concretização desse trabalho. 


\section{RESUMO}

Dentre os diversos tipos de defeitos estruturais a que um pavimento está sujeito, a deformação permanente em trilha de roda da camada de rolamento é um dos mais importantes, pois além de propiciar uma degradação acelerada da estrutura do pavimento, ele reduz consideravelmente a segurança do usuário. Este trabalho pesquisa os processos que levam à deformação permanente de revestimentos asfálticos, utilizando como estudo de caso uma pista-teste localizada na Rodovia BR 376 PR, construída com a finalidade principal de estudar os afundamentos em trilha de roda. Foram executados 10 trechos, com 200 m de extensão cada um, em aclive, na 3a faixa de rolamento, sujeita a tráfego pesado de caminhões lentos. Os trechos experimentais consistem de restauração de pista existente, onde foram executados diferentes tipos de revestimentos asfálticos, variando-se o tipo de graduação e também o tipo de ligante asfáltico, todas dosadas pelo método Marshall. Três dos dez trechos foram submetidos ao ensaio acelerado por um simulador de tráfego móvel de pista, em escala real. As misturas asfálticas foram igualmente ensaiadas em laboratório para verificação da dosagem por equipamento giratório francês e por simulador de tráfego tipo LPC. Além disso, foram extraídas placas do revestimento asfáltico da pista-teste as quais foram submetidas ao simulador de tráfego de laboratório. O objetivo central desta pesquisa foi de estudar a consistência dos resultados obtidos em campo e em laboratório, e a previsibilidade de deformações em campo através do método laboratorial. A pesquisa verificou e analisou a redução do volume de vazios das misturas asfálticas em pista e em laboratório associadas à deformação permanente, procurando relacionar a redução do volume de vazios com a deformação. A pesquisa mostrou que os ensaios de laboratório com o simulador de tráfego LPC podem ser empregados para prever as ocorrências de afundamentos em pista. Os resultados indicam a adoção do limite máximo de $5 \%$ de deformação permanente no equipamento de laboratório para os tipos de misturas asfálticas testadas para reduzir as possíveis ocorrências de deformações permanentes de revestimentos asfálticos sujeitos a tráfego muito pesado. Nas condições dos ensaios laboratoriais da pesquisa, que se aplicam à pista-teste, as misturas asfálticas mais recomendadas quanto à resistência à deformação permanente são as misturas com asfalto modificado por polímero SBS e RET, e as misturas com asfalto-borracha. Dependendo das características do ligante, o CAP 30/45 também pode ser empregado; no entanto, o CAP 50/70 mostrou-se inadequado para tráfego pesado e lento. A graduação é uma característica relevante para a estabilidade das misturas asfálticas, devendo os agregados estarem bem entrosados no caso das graduações contínuas e bem-graduadas; no entanto a macrotextura resultante deve ser estudada para evitar superfícies fechadas que reduzam a segurança dos usuários em pistas molhadas. Foram estudadas duas misturas descontínuas gap-graded que se mostraram adequadas para tráfego pesado quanto à deformação permanente e à textura superficial. A pesquisa mostra a importância da seleção criteriosa dos materiais e rigor nos estudos de dosagem, com determinação de propriedades mecânicas para melhor prever comportamento em campo de revestimentos asfálticos sujeitos a tráfego pesado e lento.

Palavras-chave: Pavimentação, Ligantes, Asfalto, Deformação permanente em trilha de roda, Pista teste. 


\begin{abstract}
Among the many types of structural distresses that a pavement is subjected, wheel track rutting is one of the most important because it leads to accelerated deterioration of the pavement structure and also reduces the road safety. This research focus on the processes that lead to rutting in asphalt mixes, using experimental test sites located at Highway BR 376 PR (heavy and slow traffic), which were built with the primary purpose of studying wheel path depressions. Ten testing tracks of $200 \mathrm{~m}$ long (total of $2 \mathrm{~km}$ ) were built on the third lane (upward sloping). The testing tracks were part of the rehabilitation of an existing pavement. Different asphalt mixtures were designed by the Marshall method, varying the aggregate size distribution and the type of asphalt binder. Three of the ten sections were subjected to Accelerated Pavement Testing by the Heavy Vehicle Simulator (in situ). The asphalt mixtures were also prepared and tested in laboratory by the French gyratory compactor and LPC traffic simulator, respectively, in order to verify the mixtures design. In addition, plates were extracted from the asphalt surfaces in the field and then subjected to the traffic simulator in laboratory. The main purpose of this study was to compare the permanent deformation of asphalt mixtures observed in the field to that obtained in the laboratory; and also to evaluate the prediction of permanent deformation based on laboratory evaluation. This research verified the correlation between reduction in the air voids of asphalt mixtures and rutting potential (samples extracted from the field and also prepared in laboratory were analyzed). The research showed that the LPC traffic simulator is a good device to predict permanent deformation of asphalt mixtures in the field. The results indicate $5 \%$ as the threshold for the permanent deformation in laboratory to reduce the occurrence of permanent deformation of asphalt mixtures subjected to heavy traffic. For the test conditions used, the mixtures that presented better resistance to permanent deformation were the ones with asphalt modified by SBS and RET, and the asphalt-rubber mixtures. Depending on the asphalt binder characteristics, the CAP 30/45 (classification by penetration) can be used; however the CAP 50/70 presented inadequate behavior for heavy and slow traffic. The aggregate gradation is another important parameter for the stability of asphalt mixtures, where the stones need to present a good interlocking and be wellgraded. The resulting macrotexture should also be evaluated to avoid surfaces with reduced safety to the users in wet conditions. Two mixtures with gap-graded gradation were evaluated and presented good results in respect to permanent deformation and superficial characteristics (texture). This research shows the importance of materials selection, design procedure, and mechanical behavior evaluation to predict the performance of asphalt surfaces subjected to heavy and slow traffic.
\end{abstract}

Keyword: Pavement, Binder, Wheel track rutting, Experimental test, Hot mix asphalt. 


\section{LISTA DE FIGURAS}

Figura 1 - Deformação permanente em trilha de roda .........................................2 24

Figura 2 - Linha de Densidade Máxima - Potência de 0,45 (ROBERTS et al. 1996)38

Figura 3 - Graduação requerida para DMN = 12,5 mm (KENNEDY, 1994) .............53

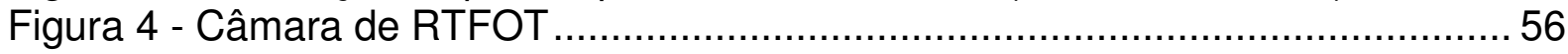

Figura 5 - Frasco de provas após ensaio (recoberto) e antes do ensaio -

http://cauduongbkdn. com/f@rums/showthread.php?p=67906 ........................... 56

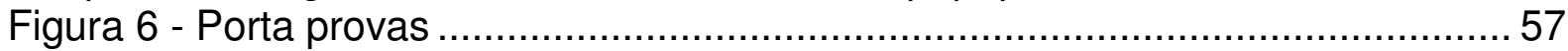

Figura 7 - Acondicionamento das provas no vaso de pressão ..............................57

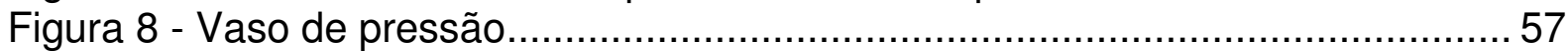

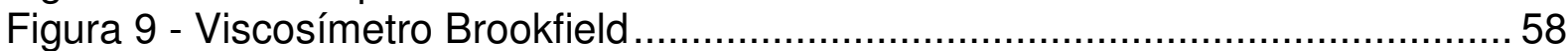

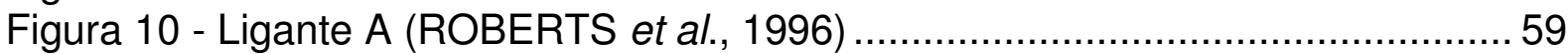

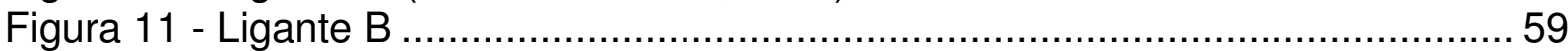

Figura 12 - Comportamento elásticos dos ligantes A e B (ROBERTS et al., 1996).. 59

Figura 13 - Movimentos executados pelo reômetro http://pavementinteractive. ........60

Figura 14 - Placa fixa e móvel superior do DSR .................................................6 60

Figura 15 - Tensão e deformação cisalhante resultante .......................................61

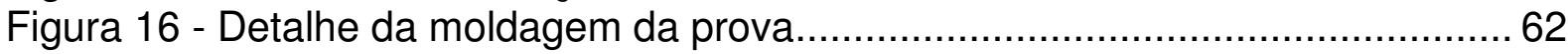

Figura 17 - Esquema do reômetro de cisalhamento em viga - BBR (ROBERTS et

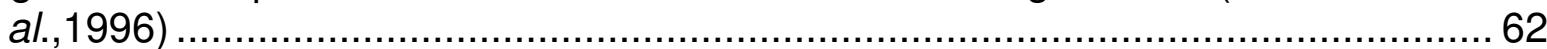

Figura 18 - Deflexão versus tempo - determinação de S(t) (ROBERTS et al.,1996)63

Figura 19 - Determinação de $m$ - módulo de relaxação (ROBERTS et al.,1996).....63

Figura 20 - Ensaio de tração direta - DTT .........................................................64

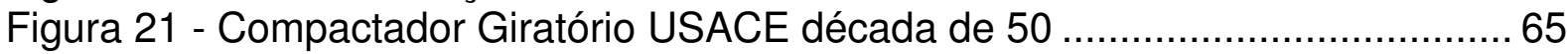

Figura 22 - Compactador Giratório Texas (op. manual)....................................... 65

Figura 23 - Definição de CDI e TDI entre dois tipos de graduação fina e grossa

(BAHIA E FAHEEM, 2007) ....................................................................... 75

Figura 24 - Índices de energia CEI, TEI, CFI e TFI - (BAHIA e FAHEEM, 2007) .....76

Figura 25 - Prensa de cisalhamento giratório - PCG - modelo 2 …........................ 84

Figura 26 - Esquema da prensa de cisalhamento giratório - PCG - modelo 3

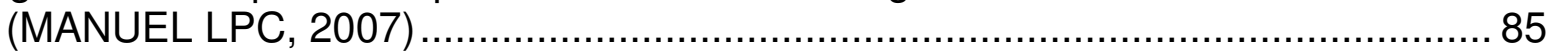

Figura 27 - Prensa de cisalhamento giratório - PCG3 …................................... 85

Figura 28 - Seqüência dos níveis de formulação e respectivos ensaios (LPC, 2007)

Figura 29 - Resposta viscoelástica de um ligante asfáltico submetido ao ensaio de creep, uniaxial estático (DRESCHER et al., 1993).....

Figura 30 - Ensaio de creep uniaxial estático com; (a) histórico de carregamento/descarregamento com variação no intervalo de carga; (b) resposta de deformação/tempo de um material viscoelástico não- linear e (c) resposta de deformação/tempo de um material viscoelastoplástico (DRESCHER et al., 1993)

Figura 31 - Ensaio de deformação de creep cíclico; (a) histórico de carga/descarga repetida com tempo de intervalo finito e (b) resposta da deformação pelo tempo de um material de comportamento viscoelástico linear (DRESCHER et al., 1993) .. 101

Figura 32 - Ensaio de deformação de creep cíclico (a) histórico de carga/descarga repetida com tempo de intervalo finito; (b) resposta da deformação pelo tempo de um material de comportamento viscoelástico não linear, e (c) resposta da deformação pelo tempo de um material viscoelastoplástico ............................. 102

Figura 33 - Modelos mecânicos para materiais viscoelásticos (HUANG 1993) ...... 103 
Figura 34 - As três componentes que compõem a deformação no modelo de Burgers (HUANG, 1993) ............................................................................... 107

Figura 35 - Resultado típico de um ensaio de creep (ROBERTS et al.,1996) ....... 109

Figura 36 Ensaio de creep com confinamento.............................................. 110

Figura 37 - Ensaio de creep axial sem confinamento com emprego de estrutura para adensamento de solos (SÁ, 1996) ................................................................. 111

Figura 38 - Ensaio de creep axial sem confinamento com aplicação da carga em área de contato inferior à área do corpo-de-prova .....

Figura 39 - Instalação dos LVDTs no centro do corpo-de-prova no ensaio de creep por tensão de tração indireta - http://cait.rutgers.edu/prp/prp-testing-facilities ..... 112

Figura 40 - Ensaio de creep, com os três estágios de deformação por fluência (LITTLE et al., 1993)

Figura 41 - Georgia Loaded Wheel Test - GLWT -

http://t2.gstatic.com/images?q=tbn:vYcyYup2s5LXAM\%3Ahttp:

Figura 42 - Asphalt Pavement Analyzer - APA - http://pavementinteractive.org/ ... 115

Figura 43 - Corpos-de-prova após ensaio com o APA -

http://pavementinteractive.org/

Figura 44 - Hamburg Wheel Tracking Devices - HWTD

http://pavementinteractive.org/

Figura 45 - Mesa compactadora tipo LCPC

Figura 46 - Equipamento francês de deformação permanente - Orniéreur (Simulador de Tráfego).....

Figura 47 - Detalhe do equipamento Orniéreur (Simulador de Tráfego)

Figura 48 - Ménege de Fatigue - Nantes na França -

http://www.lcpc.fr/en/presentation/moyens/manege/index.dml.

Figura 49 - Simulador circular IPR/DNER - RJ

http://www.proasfalto.com.br/pdf/ProAsfalto_capitulo_10.pdf

Figura 50 - Simulador linear fixo UFRGS/DAER .............................................. 123

Figura 51 - Linear test track - CEDEX Madrid -

http://www.cedex.es/apt2008/html/docs/apt update/Spain CEDEX

Figura 52 - Pista-teste do NCAT em Alburn, Alabama USA -

http://www.ncat.us/facilities/test-track.html.

Figura 53 - Sistema de simulação do tráfego com veículos -

http://www.ncat.us/facilities/test-track.html

Figura 54 - Características do loop da pista da AASHTO ROAD TEST -

http://training.ce.washington.edu/wsdot/Modules/06_structural_design/aasho_road

test.htm

Figura 55 - Os seis loops da AASHO ROAD TEST construídos entre Illinois e Utica na década de 1950 http://training.ce.washington.edu/wsdot/Modules/06_structural_design/aasho_road

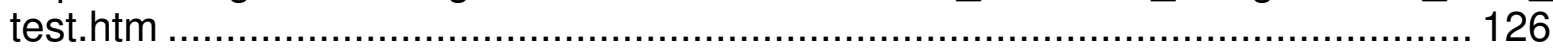

Figura 56 - Simulador de tráfego móvel brasileiro .......................................... 127

Figura 57 - Semi-eixo acionado por pistão hidráulico ....................................... 127

Figura 58 - Barra de reação e cabo de aço ..................................................... 127

Figura 59 - |Aferição da carga estaticamente ................................................. 128

Figura 60 - Aferição da carga dinamicamente ................................................ 128

Figura 61 - Mapa da localização aproximada da pista-teste entre a Cidade de Joinville e Curitiba ................................................................................... 135

Figura 62 - Pista-teste construída na 3ª . faixa de tráfego sentido ascendente ....... 135

Figura 63 - Característica do tráfego na $3^{a}$ faixa ascendente da pista-teste........... 135 
Figura 64 - Volume de veículos por classe e número de eixos registrados na 3aㅡ faixa da pista-teste no período de 15 h nos dias 27, 28 e 29/01/2010 ....................... 138

Figura 65 - Composição granulométrica utilizada no trecho T01 .......................... 149

Figura 66 - Composições granulométricas utilizadas nos trechos T02. T03, T06 e T08.

Figura 67 - Composições granulométricas utilizadas nos trechos T04, T05 e T09. 150

Figura 68 - Composições granulométricas utilizadas nos trechos T07 e T10........ 150

Figura 69 - Levantamento deflectométrico antes e após a execução da obra........ 158

Figura 70 - Levantamento Deflectométrico antes e após execução da pista-teste Trecho T01.

Figura 71 - Levantamento Deflectométrico antes e após execução da pista-teste Trecho T04....

Figura 72 - Levantamento Deflectométrico antes e após execução da pista-teste Trecho T10.

Figura 73 - Determinação da macrotextura da pista-teste

Figura 74 - Perfilômetro a laser para medição da irregularidade de pavimentos.... 163

Figura 75 - Irregularidade antes e após a execução do trecho.

Figura 76 - Afundamentos - após implantação 1, 6 e 13 meses após abertura ao tráfego

Figura 77 - Trecho T01

Figura 78 - Trecho T02

Figura 79 - Trecho T03

Figura 80 - Trecho T04

Figura 81 - Trecho T05

Figura 82 - Trecho T06

Figura 83 - Trecho T07

Figura 84 - Trecho T08

Figura 85 - Trecho T09

Figura 86 - Trecho T10

Figura 87 -Trecho T01

Figura 88 - Trecho T02

Figura 89 - Trecho T03

Figura 90 - Trecho T04

Figura 91 - Trecho T05

Figura 92 - Trecho T06

Figura 93 - Trecho T07

Figura 94 - Trecho T08

Figura 95 - Trecho T09

Figura 96 - Trecho T10

Figura 97 - IGG da pista-teste após 6 meses a abertura ao tráfego ...................... 174

Figura 98 - Demarcação da linha de corte ........................................................ 176

Figura 99 - Corte com a serra circular ....................................................... 176

Figura 100 - Detalhe do corte com a serra circular........................................... 176

Figura 101 - Pavimento cortado prof. média de $6 \mathrm{~cm}$......................................... 176

Figura 102 - Martelete rompedor ................................................................. 176

Figura 103 - Detalhe martelete e placa já extraída ...................................... 176

Figura 104 - Espessura da placa ................................................................. 176

Figura 105 - Acomodação das placas extraídas ............................................. 176

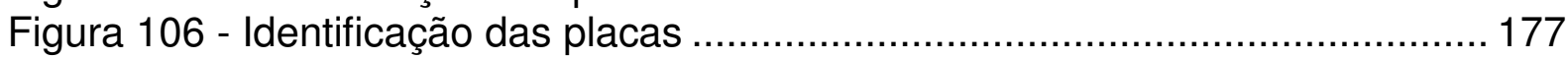

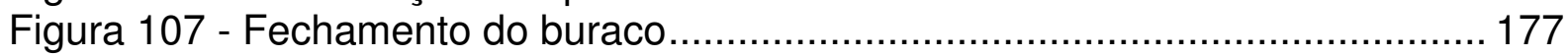


Figura 108 - Compactação da massa do tapa-buraco ....................................... 177

Figura 109 - Acomodação do transporte das placas ......................................... 177

Figura 110 - Granulometria do trecho T01 em pista comparada à de projeto......... 181

Figura 111 - Linha de densificação máxima - distr. granul. de projeto e de pista-

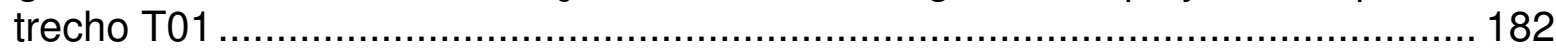

Figura 112 - Granulometria do trecho T02 em pista comparada à de projeto......... 183

Figura 113 - Linha de densificação máxima - distr. granul. de projeto e de pista-

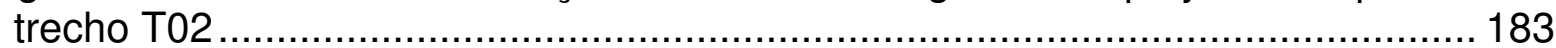

Figura 114 - Granulometria do trecho T03 em pista comparada à de projeto......... 184

Figura 115 - Linha de densificação máxima - distr. granul. de projeto e de pista-

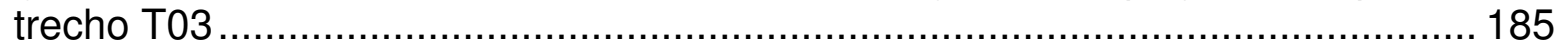

Figura 116 - Granulometria do trecho T04 em pista comparada à de projeto......... 185

Figura 117 - Linha de densificação máxima - distr. granul. de projeto e de pista-

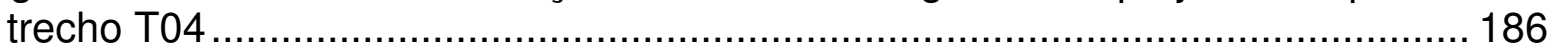

Figura 118 - Granulometria do trecho T05 em pista comparada à de projeto......... 187

Figura 119 - Linha de densificação máxima - distr. granul. de projeto e de pistatrecho T05 ..................................................................................... 188

Figura 120 - Granulometria do trecho T06 em pista comparada à de projeto......... 188

Figura 121 - Linha de densificação máxima - distr. granul. de projeto e de pista-

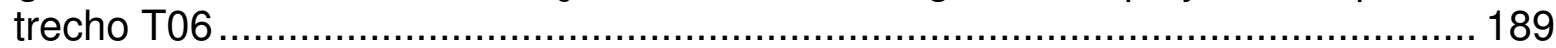

Figura 122 - Granulometria do trecho T07 em pista comparada à de projeto......... 189

Figura 123 - Linha de densificação máxima - distr. granul. de projeto e de pista-

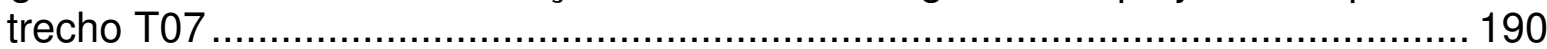

Figura 124 - Granulometria do trecho T08 em pista comparada à de projeto......... 191

Figura 125 - Linha de densificação máxima - distr. granul. de projeto e de pista-

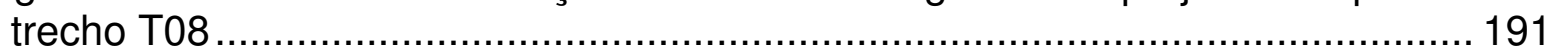

Figura 126 - Granulometria do trecho T09 em pista comparada à de projeto......... 192

Figura 127 - Linha de densificação máxima - distr. granul. de projeto e de pista-

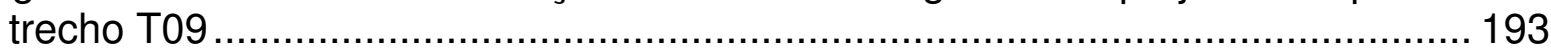

Figura 128 - Granulometria do trecho T10 em pista comparada à de projeto......... 194

Figura 129 - Linha de densificação máxima - distr. granul. de projeto e de pista-

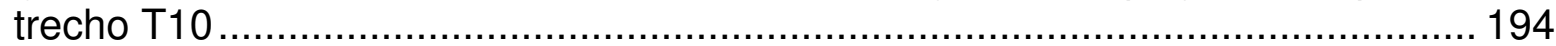

Figura 130 - Croqui de identificação dos materiais do pavimento da pista-teste - T01

Figura 131 - Cava no pavimento do trecho T01 ............................................. 195

Figura 132 - Croqui de identificação dos materiais do pavimento da pista-teste - T04

Figura 133 cava no pavimento do trecho T04

Figura 134 - Croqui de identificação dos materiais do pavimento da pista-teste -

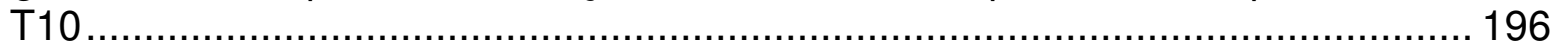

Figura 135 - Estrutura do pavimento da pista-teste do trecho T10 ....................... 196

Figura 136 - Medida do afundamento da trilha de roda .................................... 198

Figura 137 - Macrotextura superficial - ensaio de mancha de areia - HS.............. 198

Figura 138 - Deflexão máxima - viga Benkelman ............................................. 198

Figura 139- Variação da área de contato em função da pressão de inflagem......... 201

Figura 140 - Sistema de aquecimento e painéis de fechamento do simulador usado

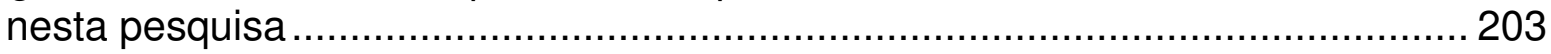

Figura 141 - Corte longitudinal da placa...................................................... 206

Figura 142 - Corte da altura da placa. ……………................................... 206

Figura 143 - Confinamento da placa no molde com argamassa............................ 206 
Figura 144 - Placas extraídas de pista e cortadas .............................................. 206

Figura 145 - Pesagem hidrostática das placas de pista...................................... 206

Figura 146 - Detalhe da pesagem hidrostática ................................................. 206

Figura 147 - Redução do volume de vazios com a deformação permanente em trilha

de roda de laboratório deste experimento com placas de campo ........................208

Figura 148 - Aptidão de compactação - PCG e DP - trecho T01 ........................214

Figura 149 - Aptidão de compactação - PCG e DP - trecho T02 …...................... 214

Figura 150 - Aptidão de compactação - PCG e DP - trecho T03 .......................... 215

Figura 151 - Aptidão de compactação - PCG e DP - trecho T04 ........................215

Figura 152 - Aptidão de compactação - PCG e DP - trecho T05 …...................... 216

Figura 153 - Aptidão de compactação - PCG e DP - trecho T06 .......................216

Figura 154 - Aptidão de compactação - PCG e DP - trecho T07 ..........................217

Figura 155 - Aptidão de compactação - PCG e DP - trecho T08 ........................217

Figura 156 - Aptidão de compactação - PCG e DP - trecho T09 ….....................2 218

Figura 157 - Aptidão de compactação - PCG e DP - trecho T10 ......................... 218

Figura 158 - Deformação permanente após 30.000 ciclos do simulador de tráfego LCPC de misturas asfálticas usinadas nos teores de ligante de projeto, de pista e corrigidos pela PCG

Figura 159 - Deformação permanente de misturas asfálticas de laboratório com teor de pista e de placas extraídas de pista ............................................................ 233

Figura 160 - Evolução da flecha após 1 mês de solicitação pelo tráfego comparada à deformação permanente de misturas asfálticas usinadas com o teor de pista após 30.000 ciclos

Figura 161 - Evolução da flecha após 6 mês de solicitação pelo tráfego comparada à deformação permanente de misturas asfálticas usinadas com o teor de pista .... 239

Figura 162 - Textura superficial com ensaio de mancha de areia (HS) - trecho T01

Figura 163 - Deflexões com a viga Benkelman no trecho T01 ............................ 242

Figura 164 - Textura superficial com ensaio de mancha de areia (HS) - trecho T04

Figura 165 - Deflexões com a viga Benkelman no trecho T04

243

Figura 166 - Textura superficial com ensaio de mancha de areia (HS) - trecho T10

Figura 167 - Deflexões com a viga Benkelman no trecho T04. ........................... 245

Figura 168 - Flechas registradas com o simulador de tráfego móvel de campo para

os três trechos T01, T04 e T10 e as temperatura médias durante a simulação .. 246

Figura 169 - Efeito temporal do simulador de tráfego móvel de campo - Trecho T04

Figura 170 - Efeito temporal do simulador de tráfego móvel de campo - Trecho T10 


\section{LISTA DE TABELAS}

Tabela 1 - Projeto Marshall com 50 golpes de compactação por face de corpos-deprova de misturas asfálticas (ROBERTS et al. 1996).

Tabela 2 - Projeto Marshall para 75 golpes para CBUQ - Critério de compactação forte (ROBERTS et al. 1996) .................................................................. 36

Tabela 3 - Tipos de ligantes asfálticos da especificação Superpave(KENNEDY, 1994)

Tabela 4 - Recomendações para agregados graúdos quanto a angularidade em função da espessura da camada de rolamento (KENNEDY, 1994)

Tabela 5 - Recomendações para agregados miúdos quanto a angularidade em função da espessura da camada de rolamento (KENNEDY, 1994) ....................51

Tabela 6 - Recomendações de partículas lamelares ou alongadas para agregados graúdos (KENNEDY, 1994).

Tabela 7 - Equivalente de areia especificação (KENNEDY, 1994) ......................... 52

Tabela 8 - Pontos de controle da distribuição granulométrica - Superpave

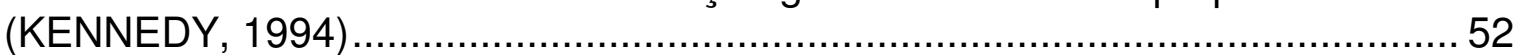

Tabela 9 - Equipamento, finalidade e parâmetros do Superpave ............................55

Tabela 10 - Valores de $\mathrm{N}_{\text {ini, }} \mathrm{N}_{\text {des }}$ e $\mathrm{N}_{\text {máx }}$ para diferentes níveis de tráfego (AASHTO R 35-04)

Tabela 11 - Requisitos volumétricos da dosagem Superpave (AASHTO M 323-04)67

Tabela 12 - Valores médios dos trechos da pesquisa (WATSON et. al. 2008)......... 69

Tabela 13 - Deformação permanente e tráfego relacionados ao tipo de ligante asfáltico (WATSON et. al. 2008)

Tabela 14 - Volume de vazios após construção e após solicitação pelo tráfego (WATSON et. al. 2008).

Tabela 15 - Evolução histórica da - PCG Francesa (HARMAN et al, 2001) ............. 86

Tabela 16 - Resumo comparativo de características dos simuladores, LCPC, Hamburg e APA (LEAHY e MCGENNIS, 1999)

Tabela 17 - Comparação entre equipamentos de laboratório e de campo para análise de desempenho em misturas asfálticas .............................................. 133

Tabela 18- Misturas asfálticas e localização dos trechos da pista-teste................. 137

Tabela 19 - Fatores de distribuição do volume de tráfego doc. técnico n. 8879/00-IX$\mathrm{RL}-0102-0$

Tabela 20 - VDMA da pista-teste no período de jan.2009 a jan.2010 ................... 140

Tabela 21 - Fatores de carga do USACE e da AASHTO - eixo máximo legal ....... 141

Tabela 22 - Fatores de carga USACE e AASHTO - excesso de carga................... 141

Tabela 23 - Fator de veículo do USACE/DNIT ................................................... 142

Tabela 24 - Fator de veículo do AASHTO (pavimento flexível) ........................... 142

Tabela 25 - FEC com eixo máximo legal e com excesso de carga em 30\% .......... 142

Tabela 26 - Média das 7 temperaturas máxima e a mínima de 2009 da região próxima a pista-teste .......................................................................... 144

Tabela 27 - PG correspondente às temperaturas de projeto do pavimento............ 146

Tabela 28 Valor do PG para as condições da pista-teste ..................................... 146

Tabela 29 - Seleção do PG do ligante asfáltico com base no clima, velocidade e no volume do tráfego, Cominski et. al. 1994) …………................................ 147

Tabela 30 - Material pétreo, fornecedor e origem mineralógica .......................... 148

Tabela 31 - Caracterização dos ligantes asfálticos convencionais CAP 50/70 e CAP $30 / 45$ desta pesquisa

Tabela 32 - Caracterização dos ligantes asfálticos modificados pelos polímeros SBS e RET e por borracha desta pesquisa 
Tabela 33 - Dados de Projeto Marshall das Misturas Asfálticas....

Tabela 34 - Controle das misturas asfálticas de usina e de pista....

Tabela 35 - Média e o desvio padrão das deflexões e temperatura de cada trecho

Tabela 36 - Planilhas de cálculos dos valores de mancha de areia dos kms 675,150 ao 674,250

Tabela 37 - Planilhas de cálculos dos valores de mancha de areia dos kms 674,150 ao 673,250

Tabela 38 -Valores de IRI antes da construção da pista-teste dos trechos T01 ao T05

Tabela 39 - Valores de IRI antes da construção da pista-teste dos trechos T06 ao T10

Tabela 40 - Valores de IRI após a construção da pista-teste dos trechos T01 ao T05

Tabela 41 - Valores de IRI após a construção da pista-teste dos trechos T06 ao T10

Tabela 42 - Valores médios e desvio padrão das flechas com 1, 6 e 13 meses .... 170

Tabela 43 - Recuperação e caracterização dos ligantes asfálticos da pista-teste.. 178

Tabela 44 - Diferença entre teores de ligante asfáltico de pista e de projeto ......... 179

Tabela 45 - Trechos escolhidos para ensaio acelerado com o simulador .............. 198

Tabela 46 - Tensões atuantes na fibra inferior da camada asfáltica nova .............. 200

Tabela 47 - Diferença entre teores de ligante asfáltico de pista e de projeto ......... 205

Tabela 48 - Volume de vazios - 0/10 e 0/14 (MANUEL LCP, 2007) ....................... 213

Tabela 49 - Resumo dos valores da PCG e deformação permanente dos 10 trechos

Tabela 50 - Número N calculado para os período de 1, 6 e 13 meses com FEC da USACE e as flechas medidas em pista para os mesmos períodos.

Tabela 51 - Número de ciclos submetidos por tipo de carga utilizada nos trechos T04 e T10

Tabela 52 - FEC do USACE e AASHTO para as cargas do simulador de tráfego . 249

Tabela 53 - Número N dos trechos T04 e T10 e as flechas encontradas com o simulador.

Tabela 54 - Hierarquização de deformação permanente dos tipos de condições ensaiados de laboratório, flecha em campo e simulador de tráfego móvel de campo. 


\section{LISTA DE ABREVIATURAS}

$\begin{array}{ll}\text { AASHTO } & \text { American Association of State Highway Officials } \\ \text { ABNT } & \text { Associação Brasileira de Normas Técnicas } \\ \text { AFNOR } & \text { Association Française de Normalisation } \\ \text { AMB } & \text { Asfalto modificado por borracha } \\ \text { APA - } & \text { Asphalt Pavement Analyzer } \\ \text { ASTM } & \text { American Society for Testing and Materials } \\ \text { BBR } & \text { Bending Beam Rheometer } \\ \text { BGS } & \text { Brita graduada simples } \\ \text { BPN } & \text { British Pendulum Tester } \\ \text { BR } & \text { Petrobrás } \\ \text { CAP } & \text { Cimento asfáltico de petróleo } \\ \text { CBUQ } & \text { Concreto betuminoso usinado à quente } \\ \text { CDI } & \text { Construction Densification Index } \\ \text { CFI } & \text { Compaction Force Index } \\ \text { CNT } & \text { Confederação Nacional do Transporte } \\ \text { CONTRAN } & \text { Conselho Nacional de Trânsito } \\ \text { CTB } & \text { Código de Transito Brasileiro } \\ \text { DAER } & \text { Departamento Autônomo de Estradas de Rodagem - RS } \\ \text { DMN } & \text { Diâmetro máximo nominal } \\ \text { DMT } & \text { Densidade máxima teórica } \\ \text { DNER } & \text { Departamento Nacional de Estradas de Rodagem } \\ \text { DNIT } & \text { Departamento Nacional de Infraestrutura e Transportes } \\ \text { DP - } & \text { Deformação permanente em trilha de roda } \\ \text { DSR } & \text { Dynamic Shear Rheometer } \\ \text { DTT } & \text { Direct Tension Tester } \\ \text { ESALs } & \text { Eixo simples roda dupla } \\ \text { EUA } & \text { Estados Unidos da América } \\ \text { FHWA } & \text { Federal Highway Administration } \\ \text { FWD } & \text { Falling Weight Deflectometer } \\ \text { GDOT } & \text { Georgia Department of Transportation } \\ \text { GLPA } & \text { Gyratory Load Plate Assembly } \\ \text { GLWT - } & \text { Georgia Loaded Wheel Test } \\ \text { HVS } & \text { Heavy Vehicle Simulator } \\ \text { HWTD- } & \text { Hamburg Wheel Tracking Devices } \\ \text { IA } & \text { Instituto do Asfalto } \\ \text { IPR } & \text { Instituto de Pesquisas Rodoviárias } \\ \text { IRI } & \text { Índice de Irregularidade Longitudinal } \\ \text { LCPC } & \text { Laboratoire Central des Ponts Chaussess } \\ \text { LPC } & \text { Laboratoire des Ponts Chaussess } \\ \text { LTP } & \text { Laboratório de Tecnologia de Pavimentação } \\ \text { NBR } & \text { Norma brasileira } \\ \text { NCAT } & \text { National Center Asphalt Technology } \\ \text { NCHRP } & \text { National Cooperative Highway Research Program } \\ \text { OHL - } & \text { Obrascón Huarte Lain Brasil S/A } \\ \text { PA } & \text { Ponto de Amolecimento } \\ \text { PAV } & \text { Pressure Aging Vessel } \\ \text { PBT } & \text { Peso bruto total } \\ & \end{array}$




$\begin{array}{ll}\text { PBTC } & \text { Peso Bruto Total Combinado } \\ \text { PCG - } & \text { Prensa de Cisalhamento Giratório } \\ \text { PDA } & \text { Pressure Distribution Analyzer } \\ \text { PG } & \text { Performance Graded } \\ \text { RBV } & \text { Relação Betume Vazios } \\ \text { RET } & \text { Asfalto modificado por polímero RET } \\ \text { RRT } & \text { Relação de Resistência à Tração por compressão diametral } \\ \text { RTFOT } & \text { Rolling Thin Film Oven Test } \\ \text { RV } & \text { Rotational Viscometer } \\ \text { SBS } & \text { Asfalto Modificado por SBS } \\ \text { SHPR } & \text { Strategic Highway Performance Research } \\ \text { SUPERPAVE } \quad \text { Superior Performance Asphalt Pavement } \\ \text { TDI } & \text { Traffic Densification Index } \\ \text { TFI } & \text { Traffic Force Index } \\ \text { TFO } & \text { Thin Film Oven } \\ \text { UFGS } & \text { Universidade Federal do Rio Grande do Sul } \\ \text { USACE } & \text { United States Army Corps of Engineers } \\ \text { USP } & \text { Universidade de São Paulo } \\ \text { VAM } & \text { Vazios do Agregado Mineral }\end{array}$




\section{LISTA DE SÍMBOLOS}

\begin{tabular}{|c|c|}
\hline$\%$ & porcentagem \\
\hline $\begin{array}{l}\mathrm{cm}^{3} \\
\mathrm{~cm}^{3}\end{array}$ & $\begin{array}{l}\text { centímetro } \\
\text { centímetros cúbico }\end{array}$ \\
\hline$G^{*}$ & Módulo complexo \\
\hline $\mathrm{g} / \mathrm{cm}^{3}$ & gramas por centímetro cúbico \\
\hline & $\begin{array}{l}\text { massa específica média máxima } \\
\text { massa específica aparente }\end{array}$ \\
\hline $\mathrm{Hz}$ & Hertz \\
\hline & módulo de riqueza de Duriez \\
\hline $\mathrm{kgf} / \mathrm{cm}^{2}$ & quilograma força por centímetro quadrado \\
\hline km & quilômetro \\
\hline $\mathrm{km} / \mathrm{h}$ & quilômetros por hora \\
\hline $1 / m^{2}$ & litros por metro quadrado \\
\hline $\mathrm{m}$ & metro \\
\hline$m_{2}$ & módulo de relaxação \\
\hline $\mathrm{m}^{2}$ & metro quadrado \\
\hline $\mathrm{mm}$ & milímetro \\
\hline $\mathrm{MPa}$ & Mega Pascal \\
\hline $\mathrm{N}$ & Newton \\
\hline$N$ & número $\mathrm{N}$ \\
\hline$N_{d}$ & número de projeto \\
\hline $\mathrm{N}_{\mathrm{i}}$ & número inicial \\
\hline $\mathrm{N}_{\mathrm{m}}$ & número máximo \\
\hline$\underline{0}$ & grau \\
\hline${ }^{\circ} \mathrm{C}$ & grau Celsius \\
\hline psi & libra por polegada quadrada \\
\hline $\mathrm{rd} / \mathrm{s}$ & radianos por segundo \\
\hline $\mathrm{s}$ & segundo \\
\hline tf & tonelada-força \\
\hline $\mathrm{Tl}_{\text {ext }}$ & teor de ligante asfáltico externo \\
\hline $\mathrm{Tl}_{\text {int }}$ & teor de ligante asfáltico interno \\
\hline V & Volume \\
\hline Vv & Volume de vazios \\
\hline$\Sigma$ & somatória \\
\hline$\delta$ & ângulo de fase \\
\hline$\delta_{\text {máx }}$ & deformação cisalhante máxima \\
\hline$\mu \varepsilon$ & micro deformação \\
\hline$\tau_{\operatorname{máx}}$ & tensão de deformação máxima \\
\hline
\end{tabular}




\section{SUMÁRIO}

FICHA CATALOGRÁFICA

Erro! Indicador não definido.

Capítulo 01

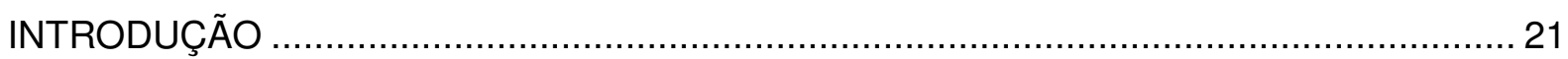

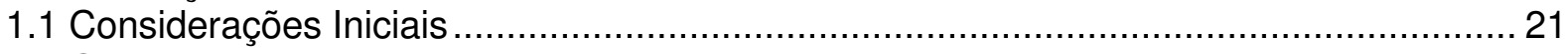

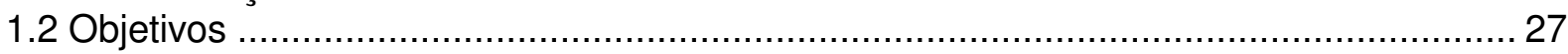

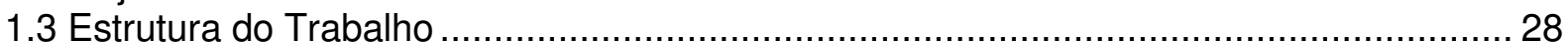

Capítulo 02

PESQUISA BIBLIOGRÁFICA

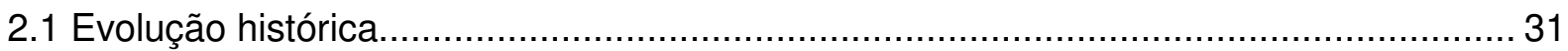

2.2 Método de dosagem de misturas asfálticas Hveem e Marshall ..................................... 33

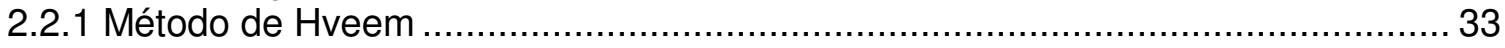

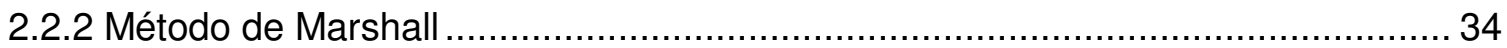

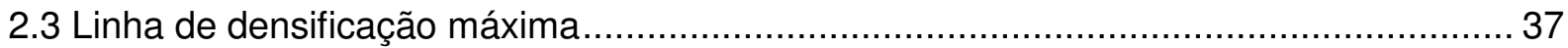

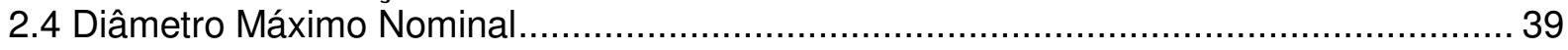

2.5 Dosagem de misturas asfálticas método Superpave ................................................ 44

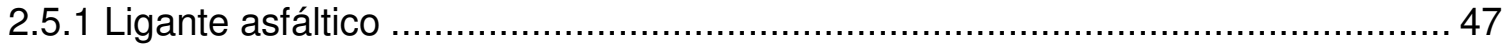

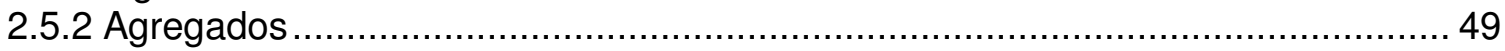

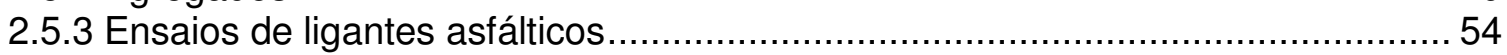

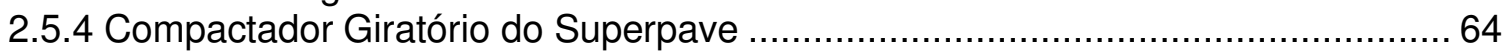

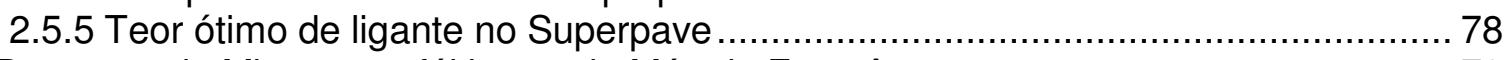

2.6 Dosagem de Misturas asfálticas pelo Método Francês ............................................. 79

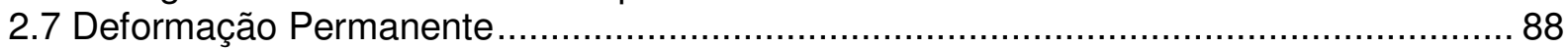

2.7.1 Fatores Causadores de Deformação Permanente nas misturas asfálticas .......... 92

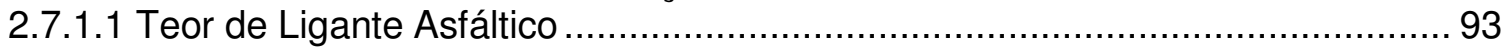

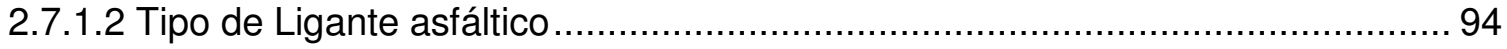

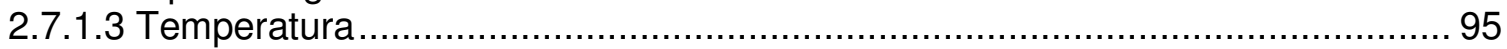

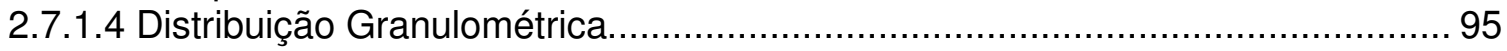

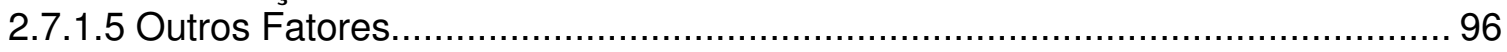

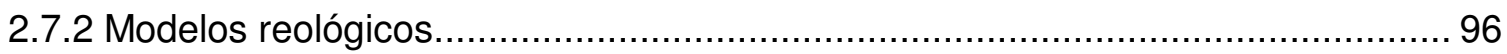

2.7.3 Ensaios para medida de deformação permanente em laboratório .......................... 108

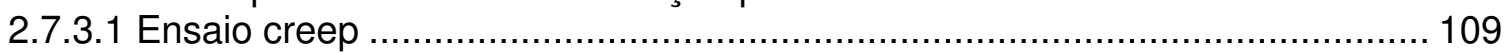

2.7.3.2 Ensaio com simuladores de tráfego de laboratório ...................................... 113

2.7.3.3 Simuladores de tráfego em escala real................................................. 120

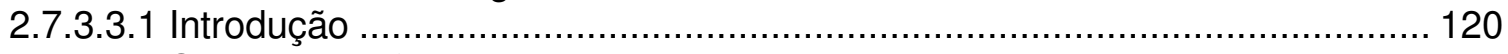

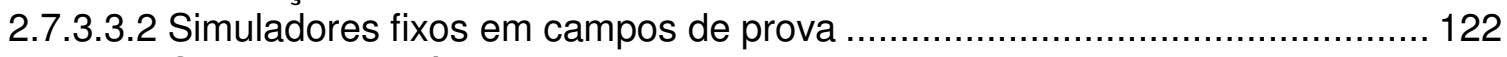

2.7.3.3.3 Simuladores móveis para pistas-testes.................................................... 126

2.7.3.3.4 Comparativo entre os equipamentos empregados para simulação de tráfego

$\begin{array}{ll}\text { Capítulo } 03 & 134\end{array}$

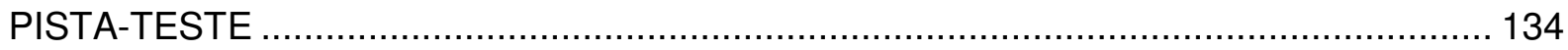

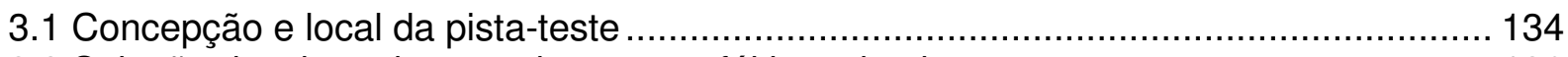

3.2 Seleção dos tipos de revestimentos asfálticos da pista-teste ...................................... 136

3.3 Tráfego 137

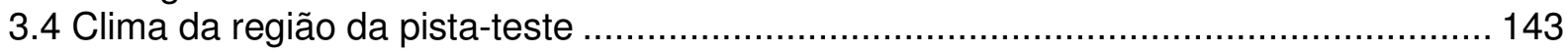

3.5 Materiais 148

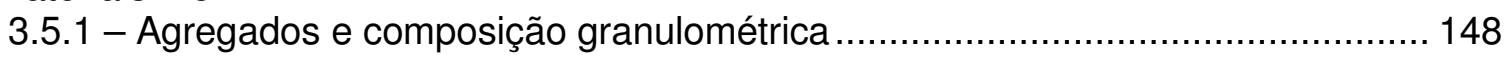

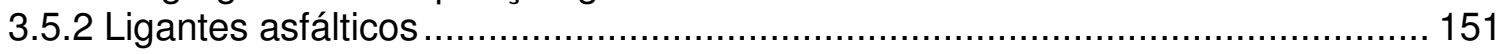

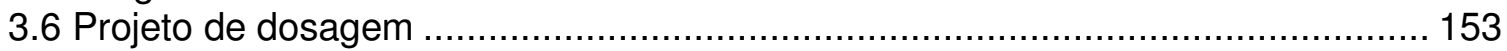

3.7 Controle de usina e pista ................................................................................ 154

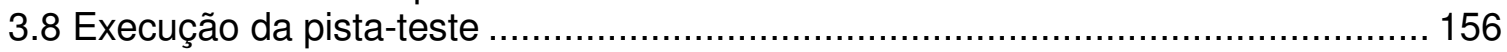

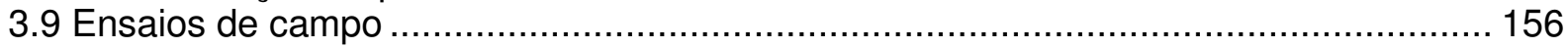




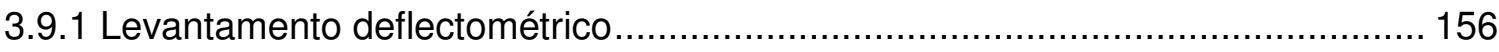

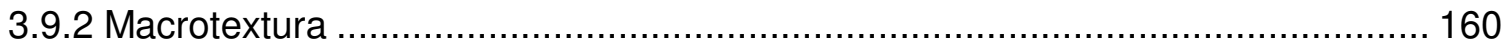

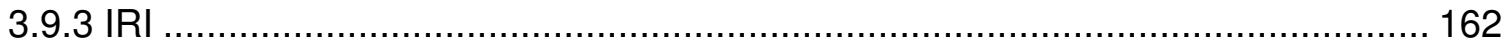

3.9.4 Afundamentos nas trilhas de rodas (flechas) …………………………….... 168

3.9.5 IGG - Índice de Gravidade Global............................................................ 173

3.10 Extração de placas de pista........................................................................ 175

3.10.1 Recuperação, caracterização dos ligantes e granulometria............................. 177

3.11 Camadas do pavimento da pista-teste ............................................................... 194

3.12 Simulador de tráfego móvel de campo........................................................... 197

3.12.1 Trechos escolhidos para serem submetidos ao simulador de tráfego móvel de campo

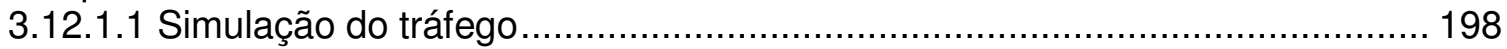

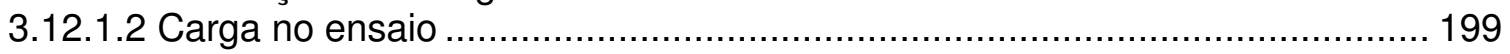

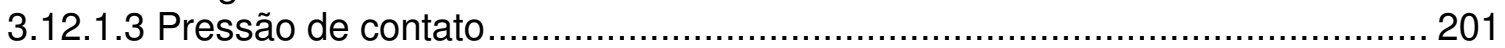

3.12.1.4 Temperatura no ensaio acelerado ………………………………… 202

3.12.1.6 Local da faixa de tráfego submetido ao ensaio com o simulador de tráfego 203 Capítulo 04

4.1 Redução do volume de vazios com a deformação permanente de placas extraídas de pista 205

4.2 Aptidão da compactação - PCG e deformação permanente em trilha de roda.

4.2.1 Ensaio com a prensa de cisalhamento giratório - PCG....................................... 212

4.2.2 Deformação permanente - teores de ligante asfáltico de projeto, de pista e

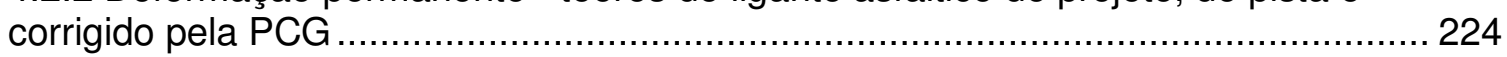

4.2.2.1 Deformação permanente no teor de projeto ……………………………….... 225

4.2.2.2 Deformação permanente no teor de pista................................................. 227

4.2.2.3 Deformação permanente no teor corrigido com os resultados obtidos da PCG

4.2.2.4 Deformação permanente de placas extraídas de pista e placas usinadas em laboratório no teor de ligante asfáltico de pista......................................................... 233

4.3 Flecha de campo e deformação permanente em laboratório ……………………..... 235

4.4 Deformação permanente de pista com simulador de tráfego de campo..................... 239

4.4.1 Evolução da textura e deflexões com simulador de tráfego móvel de campo …240

4.4.2 Evolução das flechas com simulador de tráfego móvel de campo ...................... 245

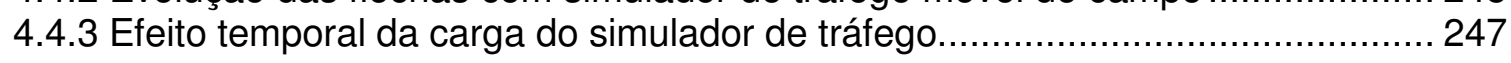

Capítulo $05 \quad 255$

CONCLUSÃO E RECOMENDAÇÕES

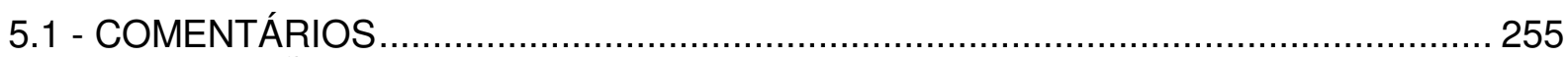

5.2 - CONCLUSÃO

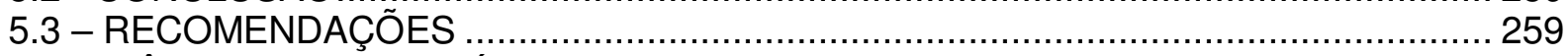

REFERÊNCIAS BIBLIOGRÁFICAS 261

Anexo I 268

Anexo II 274

Anexo III 280

Anexo IV 286

Anexo V 293

Anexo VI 295 


\section{Capítulo 01}

\section{INTRODUÇÃO}

\subsection{Considerações Iniciais}

O principal objetivo do pavimento é o de proporcionar ao usuário: conforto, segurança e economia ao rolamento. O conforto é a sensação de bem estar que o usuário percebe quando do deslocamento de seu veículo no pavimento, e está relacionado com a ausência ou pequena presença de perturbações na suspensão do veículo. A segurança reside na facilidade com que o usuário mantém a trajetória do veículo. O fator economia está associado às características de desgaste do veículo, consumo de combustível e tempo de deslocamento. Todos os aspectos que influenciam no conforto ao rolamento, na segurança e na economia relacionam-se com o estado do pavimento, em especial com o estado da camada de rolamento e da superfície desta camada. Portanto, a existência de pavimento e o estado de conservação da camada de rolamento são essenciais para garantir os principais objetivos que afetam aos usuários.

O conforto, a segurança e a economia são obtidas se os veículos trafegam em rodovias pavimentadas e em boas ou excelentes condições de superfície. A malha rodoviária no Brasil no ano de 2009 era de $1.634 .071 \mathrm{~km}$ de vias rurais, sendo apenas cerca de 13\%, $211.678 \mathrm{~km}$ de vias pavimentadas. Atualmente, do total da rede de rodovias pavimentadas, 6,5\% são concessionadas (CNT, 2009). Das vias pavimentadas avaliadas cerca de $45 \%$ apresentam condições ótimas ou boas de trafegabilidade e o restante condições deficientes, ruins ou péssimas. Os itens avaliados foram defeitos em geral como buracos, ondulações, afundamentos e condições do acostamento (COPPEAD, 2009). Como se pode observar pelos dados acima, ainda há muito que pavimentar no Brasil para ampliação das condições de 
conforto e uma parte expressiva da malha necessita de restauração para manter a boa trafegabilidade.

O estado das camadas de rolamentos e das superfícies destas camadas dependem da execução e da manutenção periódica, e do tipo de solicitação de carga e climática das estruturas de pavimentos. A solicitação de carga feita por veículos comerciais, como os caminhões e ônibus, é aquela que provoca deterioração e desgaste da superfície dos pavimentos. No Brasil, o modo de transporte rodoviário prevalece nas estáticas, sendo responsável por mais de $61 \%$ do transporte de carga e mais de $54 \%$ do transporte interestadual de passageiros (CNT, 2009). A presença significativa de veículos comerciais nas estradas brasileiras é, portanto, uma realidade. Assim, a solicitação dos pavimentos é bastante elevada, o que afeta as condições de conservação do estado de superfície.

A regulamentação de cargas por eixo no Brasil foi introduzida pelo Estado de São Paulo, em 1960, que introduziu lei sobre o peso bruto dos veículos. Em 1961, o governo Federal baixou um decreto federal $n^{0} 50.903 / 61$, que tratava exclusivamente dos limites de cargas por eixo, vindo com ela a "lei da balança". Não se previu, no entanto, qualquer multa ou punição para os infratores. Somente em 1968 o Decreto federal foi incorporado pelo Decreto $n^{\circ}$ 62.127/68, que regulamentou a Lei $n^{\circ}$ 5.108/66, que modificava o Código Nacional de Trânsito. Os limites de pesos por eixo eram de $5 \mathrm{tf}$ no eixo dianteiro, $10 \mathrm{tf}$ por eixo isolado, 8,5 tf por eixo em tandem e 40 tf de peso bruto total. A Lei $n^{0} 7.408 / 85$ introduziu tolerância de $5 \%$ no peso por eixo e no peso bruto total na pesagem dos veículos de carga. O decreto $n^{\circ} 98.933$ de 1990 autorizou o limite de carga do eixo dianteiro de 5 t para 6 t. Em 1998, devido às pressões dos caminhoneiros e transportadores, o Código de Trânsito Brasileiro CTB foram modificados por meio de Resolução $n^{\circ} 104$ do CONTRAN, (1998) que manteve a tolerância de 5\% no peso bruto total - PBT ou peso bruto total combinado - PBTC, mas aumentou de 5\% para 7,5\% a tolerância por eixo e extinguiu a multa por excesso nos eixos. Se há excesso por eixo, mas o PBT ou PBTC está dentro da tolerância, é permitido remanejar ou transbordar a carga, para sanar a irregularidade. Se houver excesso no PBT ou PBTC, este excesso será multado e transbordado antes que o veículo prossiga viagem. 
Embora exista a lei da balança, resolução 258/07 do Contran, que limita a carga por eixo, o avanço tecnológico da indústria automobilística, produzindo caminhões capazes de transportar cargas mais pesadas, impele os órgãos regulamentadores a abrirem concessões, como as alterações de configurações de eixos permitidas. A Resolução 184, de 2005, autoriza alguns caminhões a circularem com PBTC de 48,5 toneladas, ao invés do limite de 1998 de 45,0 toneladas, e de algumas configurações, que também seguiam o mesmo limite de 45,0 toneladas, estarem autorizadas a circularem com 57 toneladas - eixo triplo com rodagens duplas (12 pneus) com eixos distanciados, totalizando nesta combinação, outrora tandem triplo, a circularem com 30 toneladas ( $3 \times 10$ toneladas).

Com o avanço tecnológico acentuado que vem ocorrendo na indústria automobilística, estão produzindo veículos mais econômicos, mais seguros e também mais velozes, não só na linha de veículos leves, mas também nos veículos pesados. Um segmento de destaque nesse avanço tecnológico da indústria automobilística diz respeito às indústrias fabricantes de pneus. Os pneus extralargos vêm se popularizando nos últimos anos pelas vantagens econômicas que proporciona, e seu uso está regulamentado pela resolução № 62/98 do Conselho Nacional de Trânsito (CONTRAN, 2009). Cabe lembrar, no entanto, que no artigo 1ำ dessa resolução, regulamenta o uso do pneu do tipo 385/65 R 22.5 em semireboques e reboques dotados de suspensão pneumática com eixos em tipo tandem.

A somatória de reduzida malha rodoviária pavimentada do Brasil, com mais de $50 \%$ em condições precárias, aumentos de carga transportada por veículo, e ainda o aumento do volume de cargas transportadas pelo modo rodoviário nos últimos anos, traz ao engenheiro rodoviário um desafio de melhorar as características dos pavimentos rodoviários, tanto em condições funcionais como principalmente em características estruturais do pavimento. As melhorias funcionais dizem respeito à economia no transporte e à segurança dos usuários; as melhorias estruturais dizem respeito à redução de custos de manutenção pelos órgãos responsáveis pela via, seja público ou privado. A falta de previsibilidade da periodicidade das manutenções também leva a custos adicionais operacionais, de logística de obras, de interdições e de desgaste de imagem dos órgãos responsáveis pela manutenção. 
Dentre os diversos tipos de defeitos a que um pavimento está sujeito, sem dúvida, a deformação permanente em trilha de roda da camada de rolamento é um dos mais importantes, pois esse tipo de defeito além de propiciar uma degradação acelerada da estrutura do pavimento, reduz consideravelmente o conforto ao rolamento, a segurança do usuário, e aumenta os custos operacionais. A Figura 1 ilustra uma rodovia com afundamentos nas trilhas de rodas.

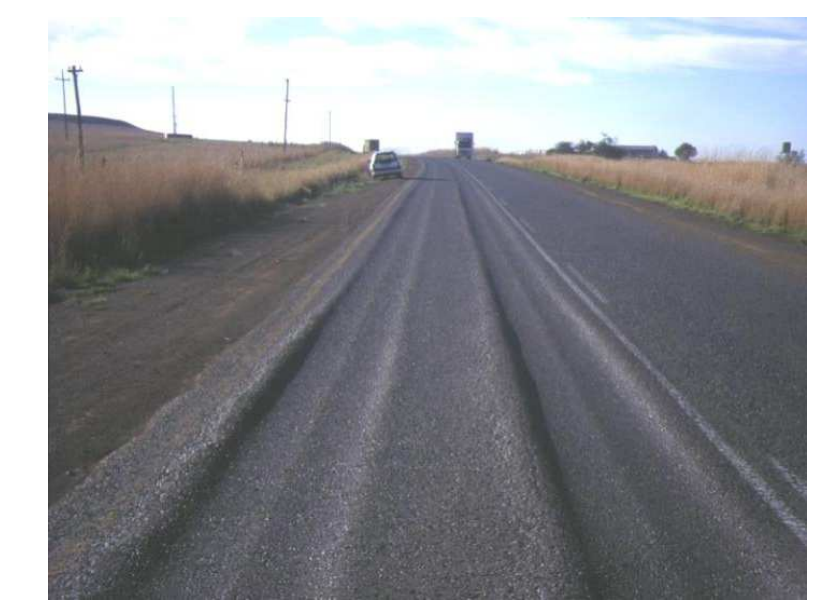

Figura 1 - Deformação permanente em trilha de roda

Em dias chuvosos, há formação de uma lâmina d'água ao longo de todo o trecho nos afundamentos das trilhas de roda, ocasionando uma dificuldade de escoamento da água, e propiciando um menor contato entre o pneu e as acículas dos agregados, podendo ocorrer a hidroplanagem.

Huang (1993) comenta que a utilização da tensão no topo do subleito como critério de falha de deformação permanente para toda a estrutura do pavimento, somente é válida quando a deformação permanente é ocasionada por um subleito com baixa capacidade de suporte, e desprotegido pelas outras camadas superiores. Uma parcela significativa da deformação permanente em pavimentos asfálticos ocorre nas camadas assentes sobre o subleito. As causas da deformação permanente que surge na superfície dos pavimentos são múltiplas. Um dos motivos a ser destacado, mesmo em estruturas bem projetadas e misturas asfálticas bem dosadas, é o aumento da carga de roda e, também, o aumento da pressão de inflagem dos pneumáticos. 
O processo de definição e de produção da mistura asfáltica, assim como da execução de um revestimento asfáltico é complexo, embora aparentemente apresente-se sem maiores dificuldades. Pode ser dividido em quatro etapas: A primeira inicia-se com a definição do projeto da mistura; nessa etapa ocorre a escolha do material a ser utilizado de maneira a atender às características préestabelecidas pelo projetista, e aprovadas pelo órgão contratante. Tarefa por vezes difícil de ser executada, pois, deve-se nessa etapa conciliar qualidade dos materiais, atendimento ao especificado em projeto e custo. Na etapa seguinte os materiais são caracterizados e procede-se à dosagem da mistura asfáltica, obtendo-se os parâmetros que a mistura deve apresentar quando em serviço. Passa-se então para a terceira etapa, a de produção propriamente dita da mistura, onde esta deve necessariamente ser fabricada atendendo as especificações de projeto de dosagem. Em seguida, na quarta etapa, a mistura asfáltica é transportada para o campo, espalhada ou distribuída, e comprimida ou densificada (compactada).

Note-se que várias etapas são necessárias e ocorrem em locais diferentes, por diversos técnicos envolvidos: escritório, laboratório, usina e campo. Exceto na primeira etapa, o controle tecnológico é de fundamental importância para garantir a qualidade final do pavimento.

O problema da deformação permanente em trilha de roda, segundo Joliet \& Mallot (2000), é um processo que ocorre de forma simultânea, envolvendo a deformação viscosa do ligante asfáltico e deformação plástica da estrutura mineral da mistura asfáltica. Estes autores comentam que tanto o ligante como o agregado exercem papel fundamental no desempenho da mistura asfáltica. O ligante com o resultado de sua consistência e reologia, e o agregado com as forças de fricção interna entre suas partículas (ângulo de atrito interno advindo do entrosamento).

Conforme a definição do Departamento Nacional de Infraestrutura de Transportes (DNIT), a deformação permanente em trilha de roda de misturas asfálticas ocorre em duas parcelas: o afundamento plástico e o afundamento por consolidação, (DNER700 GTTR 1997). O afundamento plástico é, segundo o Órgão, a deformação permanente que ocorre em uma ou mais camadas dos pavimentos flexíveis ou semirígidos, ou ainda no subleito. Em se tratando de camada asfáltica, o adjetivo plástico 
está associado ao comportamento visco-elástico do ligante asfáltico. Assim, melhor seria denominar esse deslocamento de afundamento causado pela viscosidade do ligante asfáltico. O mesmo Órgão define como o afundamento por consolidação a deformação permanente que ocorre nos pavimentos flexíveis ou semi-rígidos devida à consolidação diferencial que se verifica em camadas do pavimento ou subleito. Como se trata de uma deformação diferencial, pode-se denominar essa parcela de deformação como afundamento da estrutura mineral da mistura asfáltica, decorrente densificação complementar ou de ruptura por cisalhamento.

A camada asfáltica bem dosada e bem executada, no início da vida de serviço, está sujeita a uma pequena deformação permanente caracterizada mais por consolidação que por características viscosas do ligante asfáltico. Essa deformação inicial deve ser pequena ou inexpressiva. Mesmo reduzida, ela possibilita um fechamento da mistura asfáltica com uma pequena redução do volume de vazios. Já a deformação permanente causada pela viscosidade do ligante asfáltico associada à lubrificação das partículas é mais pronunciada ao longo da vida de serviço da mistura asfáltica. Evidentemente que nas misturas asfálticas mal dosadas e com ligantes inadequados ao clima e ao tráfego solicitante, as deformações causadas pela lubrificação e viscosidade podem ser importantes já no início da vida de serviço. Camadas asfálticas mal executadas também poderão rapidamente mostrar problemas de deformação permanente nos primeiros meses de abertura ao tráfego, seja por consolidação, seja por fluência.

Os principais fatores que contribuem, de forma isolada ou em conjunto, diretamente para a formação de deformação permanente de camadas asfálticas em trilha de roda são:

1) teor de ligante asfáltico acima do teor ótimo de projeto,

2) emprego de ligante asfáltico com consistência inadequada às temperaturas da região onde a mistura asfáltica é empregada,

3) distribuição granulométrica inadequada, incluindo a presença de porcentagens excessivas da fração areia (areia lavada),

4) forma e textura superficial de agregados inadequados,

5) excesso de carga, comum em rodovias, 
6) temperatura,

7) grau de compactação das misturas asfálticas e,

8) tráfego canalizado

Esses tópicos serão abordados com maior profundidade no capítulo 2.

\subsection{Objetivos}

Esta pesquisa tem como objetivo estudar a relação entre a deformação permanente de misturas asfálticas em trilha de roda obtida em laboratório com simulador de tráfego francês tipo LPC, com valores de deformação permanente em trilha de roda medidos em campo em pista-teste em real grandeza, de forma a estabelecer os limites de deformação em laboratório que assegurarão com elevada probabilidade a não ocorrência de deformações permanentes significativas dos revestimentos asfálticos de pavimentos.

Para tanto foram construídas 10 seções-teste em campo, com diferentes tipos de misturas asfálticas como camada de rolamento, variando em alguns casos a distribuição granulométrica, bem como também os tipos de ligantes asfálticos. A pista-teste foi construída na terceira faixa (faixa mais solicitada) da rodovia BR 376, que liga Florianópolis a Curitiba, no sentido ascendente, com 200m de extensão cada seção-teste, utilizada praticamente com exclusividade por caminhões carregados. Três trechos selecionados foram submetidos a um simulador de tráfego de pista. Placas de misturas asfálticas foram retiradas de pista e testadas em laboratório do simulador de tráfego tipo LPC, cujos resultados foram comparados ao da pista.

Além disso, foram fabricadas misturas asfálticas em laboratório para estudo de deformações permanentes para entender a previsibilidade da ocorrência deste problema. Os estudos abordaram complementarmente as características dos materiais e a dosagem das misturas asfálticas. Quanto à seleção de materiais para o projeto da mistura, procedeu-se a uma análise da composição granulométrica das 
misturas asfálticas empregadas na pesquisa, comparando-as com a linha de densificação máxima, segundo procedimento proposto por Goode e Lufsey, (1962). A pesquisa analisou a dosagem das misturas asfálticas pelo método Marshall e pelo processo francês utilizando a prensa de cisalhamento giratório - PCG, para comparação entre os dois procedimentos.

\subsection{Estrutura do Trabalho}

A tese está organizada em 5 capítulos, cujos conteúdos encontram-se descritos sucintamente a seguir:

Capítulo 1

Introdução

O capítulo I introduz o tema e sua relevância, circunscrevendo o assunto da pesquisa na realidade brasileira. Apresenta ainda o objetivo central da pesquisa e também a estrutura do trabalho.

Capítulo 2

Revisão Bibliográfica

A revisão bibliográfica consiste em verificar o estágio do desenvolvimento, tanto nacional como internacional, sobre o tema do estudo, abordando estudos e pesquisas pertinentes ao comportamento mecânico das misturas asfálticas quanto à deformação permanente em trilha de roda.

Capítulo 3

Pista-Teste Descreve-se o local do experimento e suas características relevantes, tipos de misturas asfálticas empregadas como camada de rolamento de cada trecho, e apresenta as atividades programadas para o simulador de tráfego. Consta no capítulo III também as características dos materiais empregados na camada de rolamento e os métodos de dosagem e de 
determinação de propriedades em laboratório, bem como os testes de controle tecnológico e de pista que são utilizados na pesquisa

Capítulo 4

Resultados e Análise São apresentados os resultados dos ensaios em laboratório e em campo, e tecidas análises e comentários pertinentes aos resultados obtidos.

\section{Capítulo 5}

Conclusão e Recomendações Nesse capítulo são apresentados comentários, as conclusões da pesquisa e as recomendações para futuros trabalhos.

Referências Bibliograficas

Anexo I Ensaios de deformação permanente de misturas asfálticas usinadas nos teores de ligante asfáltico de projeto

Anexo II Ensaios de deformação permanente de placas extraídas de pista

Anexo III Ensaios de deformação permanente de misturas asfálticas usinadas no teor de ligante asfáltico de pista

Anexo IV Resultados do levantamento de flechas da TRI e TRE da $1^{\underline{a}}, 2^{\underline{a}}$ e $3^{\underline{a}}$ campanhas de ensaio.

Anexo V Levantamento das temperaturas diárias da Cidade de INDAIAL SC, local da estação meteorológica próxima ao local da pista-teste e de mesma altitude. 


\section{Capítulo 02}

\section{PESQUISA BIBLIOGRÁFICA}

Nesse capítulo é abordada a evolução quanto às experiências sobre projetos de misturas asfálticas e sua relação com o desempenho frente à ocorrência de deformação permanente em trilha de roda, empregando tanto ensaios laboratoriais como avaliações de campo com emprego de simuladores de tráfego em escala real.

\subsection{Evolução histórica}

Data de 1870 a primeira aplicação de mistura asfáltica em pavimento em Newark, NJ nos EUA; para a realização da obra foram importados os materiais da Europa. No ano seguinte, além dos materiais, também importados da Europa, foi utilizado pela primeira vez nos EUA o alcatrão de origem mineral como material aglutinante em pavimentação em Washington, DC. Em 1876, dois tipos de misturas asfálticas foram aplicadas em duas seções na Avenida Pensylvania em Washington, DC, uma com características granulométricas mais finas, com emprego de areia e asfalto de Trinidade, aplicados no local, e outra seção que utilizou agregados e asfalto europeus, sendo que esta segunda foi alisada por uma chapa quente logo após sua aplicação. O primeiro tipo de mistura mostrou-se mais favorável, pois além de menor custo, apresentou uma textura superficial mais suave ao rolamento (LEAHY \& MCGENNIS, 1999).

No período de 1920 a 1940, Leahy e McGennis (1999) registram que houve um acréscimo significativo no uso de pavimentos asfálticos, atingindo marca de 1 milhão de toneladas na produção de misturas asfálticas no início da década de 20 , chegando a 4 milhões de toneladas ao final da década de 40. Comentam ainda que nesse período podem-se destacar quatro etapas de utilização de misturas asfálticas e de projetos: 
- primeira - método dedutível, elaborado por Richardson, que através de observações de desempenho de vários tipos de misturas asfálticas, desenvolveu duas graduações de areia para serem utilizadas em tráfego leve e pesado;

- segunda - macadame betuminoso desenvolvido por Warren, que utilizou agregados de dimensões maiores e apresentava a preocupação de reduzir os vazios a um mínimo objetivando maior estabilidade o que proporcionou uma camada de rolamento mais suave ao rolamento;

- terceira -Hugh Skidmore de Chicago desenvolveu uma base de brita com asfalto, semelhante ao proposto por Warren, e que apresentava a fração de fíler mineral para preenchimento dos vazios da fração do agregado. O ligante asfáltico foi adicionado com o propósito de preencher os vazios e recobrir a superfície dos agregados. Com esse processo de dosagem obtiveram-se misturas com baixo teor de vazios e melhorou a resistência ao cisalhamento;

- quarta - Prevost Hubbard e Frederick Field, do Instituto de Asfalto norteamericano, desenvolveram um procedimento para misturas asfálticas predominantemente finas. Eles objetivavam encontrar um tipo mistura de materiais que propiciassem um mínimo de estabilidade, denominada de estabilidade de Hubbard-Field, baseada no exame de pavimentos que exibiram um desempenho satisfatório. Esse método foi criado no início da década de 20 e foi utilizado até os anos 50.

Leahy e McGennis (1999) relatam ainda que no período entre os anos de 1940 e 1960 observou-se um crescimento acentuado no uso de materiais betuminosos e também um avanço nos procedimentos de dosagem de misturas asfálticas, principalmente durante a II Grande Guerra em que os métodos Marshall e Hveem foram os preferidos pelos projetistas.

Roberts et al. (1996) relatam o desenvolvimento do método de dosagem de Hveem e do método de dosagem Marshall, cujo conteúdo foi utilizado para esta revisão bibliográfica, apresentada nos próximos dois itens. 


\subsection{Método de dosagem de misturas asfálticas Hveem e Marshall}

\subsubsection{Método de Hveem}

Francis Hveem, engenheiro residente na Califórnia, começou a trabalhar com misturas a frio, com emulsão asfáltica, no final da década de 20. Essas misturas eram basicamente de agregados na fração areia e um tipo de emulsão asfáltica de cura lenta, utilizadas na Califórnia e apresentavam um tipo de textura superficial intermediária para melhorar as condições de tráfego. Hveem constatou que existia uma relação entre a graduação do material pétreo e a quantidade de emulsão necessária para manter uma coloração aparentemente homogênea da mistura. $\mathrm{O}$ engenheiro californiano adotou um método para calcular a área superficial dos agregados desenvolvida por um engenheiro canadense, L.N. Edwards. Hveem observou que a espessura do filme de ligante diminuía com a diminuição do diâmetro das partículas e que através do ensaio de equivalente de querosene, desenvolvido pelo próprio pesquisador, foi possível quantificar o teor de ligante necessário para recobrimento do agregado, considerando a absorção e também a rugosidade superficial do agregado.

Hveem percebeu que o teor ótimo de ligante asfáltico encontrado não garantia um desempenho satisfatório frente à deformação permanente em trilha de rodas decorrente das repetições de solicitação de carga pelo tráfego. Assim, desenvolveu um equipamento capaz de medir a susceptibilidade de misturas asfálticas a apresentarem baixa resistência aos esforços de cisalhamento, denominado de estabilômetro de Hveem. O corpo-de-prova era o de uma amostra de mistura asfáltica previamente compactada estaticamente por um compactador hidráulico, com diâmetro de $101,6 \mathrm{~mm}$ e altura de $63,5 \mathrm{~mm}$. O estabilômetro transmite uma carga vertical (axial) à amostra através de um prato de igual diâmetro ao corpo-deprova e a magnitude de carga vertical transmitida horizontalmente é medida. Valores empíricos de estabilidade de Hveem foram encontrados para diversos teores de ligante asfáltico. 
Um segundo equipamento, também desenvolvido por Hveem, concomitantemente ao estabilômetro, foi o coesímetro. Um corpo-de-prova, de uma mistura já testada no estabilômetro de Hveem, era submetido a um esforço de coesão através de seu diâmetro. Com esse ensaio podia-se mensurar a resistência de misturas asfálticas a frio, frente à desagregação superficial causada pela ação do tráfego. Os resultados encontrados com o coesímetro para misturas a quente sempre foram de baixa representatividade para prevenir a desagregação e, quando da substituição de misturas a frio por misturas a quente, após a II Guerra Mundial, o propósito do ensaio foi sendo gradualmente abandonado.

\subsubsection{Método de Marshall}

O método de dosagem Marshall foi desenvolvido no Mississipi Highway Department por Bruce Marshall em 1939. O United States of American Corps of Engineering USACE começaram a estudar em 1943 o desenvolvimento de um equipamento portátil para moldagem de corpos-de-prova de misturas asfálticas destinadas a pistas de aeroportos. Essa necessidade se deu devido ao aumento da carga de roda de aeronaves durante a II Guerra Mundial. Com o aumento da pressão dos pneus e, por conseguinte, o aumento da pressão de contato, foi necessária a busca por um método de dosagem de misturas asfálticas mais eficiente que tornasse as misturas mais resistentes a maiores solicitações de carga. O USACE iniciou testando o equipamento proposto por Bruce Marshall em uma série de experimentos de campo e de laboratório.

Diversos tipos de misturas asfálticas foram testadas, variando-se os esforços de compactação na tentativa de produzir "densidades"1 em laboratório similares àquelas encontradas em campo de pistas-teste, submetidas a simuladores de tráfego de aeronaves. A compactação de laboratório envolveu diferentes tipos de soquete, diferentes tipos de combinação de números de golpes por face e/ou carga de compressão estática, diversos tipos de sapatas dos soquetes em tamanho e forma,

\footnotetext{
${ }^{1}$ A designação no texto corresponde ao peso específico aparente, que por facilidade, está sendo chamado por "densidade".
} 
e diferentes moldes quanto à forma e materiais. O objetivo da compactação de laboratório era o de adotar um procedimento que envolvesse um esforço mínimo de compactação e de tempo, e que pudesse selecionar um teor ótimo de ligante asfáltico para uma dada composição granulométrica previamente selecionada.

Em pista-teste submetidas a um gama de cargas variando desde 6,8 tf até 27,2 tf, e pressões de pneus desde $3,5 \mathrm{kgf} / \mathrm{cm}^{2}$ até $14 \mathrm{kgf} / \mathrm{cm}^{2}$ respectivamente, para um número de 3500 coberturas, várias misturas asfálticas dosadas pelo Método Marshall foram testadas e não apresentaram um aumento significativo na "densidade" após a ação do tráfego, mostrando-se praticamente indiferente à carga de roda. Usando os resultados de campo, os seguintes limites foram estabelecidos para projetos de misturas asfálticas, reproduzidos na Tabela 1.

Tabela 1 - Projeto Marshall com 50 golpes de compactação por face de corpos-de-prova de misturas asfálticas (ROBERTS et al. 1996)

\begin{tabular}{l|c|c|c|c}
\hline \multirow{2}{*}{ Parâmetros de Ensaio } & \multicolumn{2}{|c|}{ Teor de ligante asfáltico } & \multicolumn{2}{c}{ Limites } \\
\cline { 2 - 5 } & $\begin{array}{c}\text { concreto } \\
\text { asfáltico }\end{array}$ & $\begin{array}{c}\text { areia asfalto a } \\
\text { quente }\end{array}$ & $\begin{array}{c}\text { concreto } \\
\text { asfáltico }\end{array}$ & $\begin{array}{c}\text { areia asfalto } \\
\text { a quente }\end{array}$ \\
\hline Estabilidades (N) & Pico & Pico & 2220 & 2200 \\
Fluência $(0,25 \mathrm{~mm})$ & - & - & 5,0 & 5,0 \\
$\begin{array}{l}\text { Massa Espec. Aparente da } \\
\text { mistura (g/cm }{ }^{3} \text { ) }\end{array}$ & Pico & Pico & - & - \\
Volume de vazios (\%) & 4 & 6 & $3-5$ & $5-7$ \\
RBV (\%) & 80 & 70 & $75-85$ & $65-75$ \\
\hline
\end{tabular}

No final da década de 40 e início da década de 50, o tamanho e o peso das aeronaves continuavam aumentando, as pressões dos pneus chegaram à ordem de $14 \mathrm{kgf} / \mathrm{cm}^{2}$. Novamente o USACE iniciou estudos para estabelecer um processo de compactação mais forte, ou mais intenso, que pudesse correlacionar a densificação da mistura asfáltica causada por essas novas cargas das aeronaves. Assim, novos critérios de projetos para CBUQ (concreto asfáltico) foram estabelecidos, aumentando a energia de compactação dos tradicionais 50 golpes por face para 75 golpes - Tabela 2. 
Tabela 2 - Projeto Marshall para 75 golpes para CBUQ - Critério de compactação forte (ROBERTS et al. 1996)

\begin{tabular}{l|c|c}
\hline \multicolumn{1}{c|}{ Parâmetros de ensaio } & Teor de ligante asfáltico & Valores Limites \\
\hline Estabilidades $(\mathrm{N})$ & Pico & 4440 (mín) \\
Fluência $(0,25 \mathrm{~mm})$ & - & 4 (máx) \\
Peso espec. do agregado $(\mathrm{g} / \mathrm{cm} 3)$ & Pico & - \\
Peso espec. Aparente $(\mathrm{g} / \mathrm{cm} 3)$ & Pico & - \\
Volume de vazios $(\%)$ & 5 & $4-6$ \\
RBV $(\%)$ & 80 & $75-82$ \\
\hline
\end{tabular}

Em resumo, o desenvolvimento do procedimento de dosagem de misturas asfálticas Marshall apresenta dois parâmetros importantes para projeto que devem ser atendidos em campo: o teor de ligante asfáltico e a "densidade" da mistura asfáltica compactada. Já em laboratório, as características importantes são a seleção da energia de compactação compatível com a densificação induzida pela ação do tráfego, para a produção de corpos-de-prova que, através dos parâmetros de ensaios Marshall, aponte o teor ótimo de ligante asfáltico, resultando em uma mistura asfáltica com desempenho satisfatório quando submetida à ação do tráfego.

Roberts et al. (1996) elencam os principais objetivos que uma mistura asfáltica deve apresentar:

- Resistência à deformação permanente em trilha de roda;

- Resistência à fadiga;

- Resistência ao trincamento a baixas temperaturas;

- Durabilidade;

- Resistência ao dano causado pela água;

- Resistência ao polimento (derrapagem); e,

- Trabalhabilidade.

O teor de ligante asfáltico, além de sua natureza e reologia, é um parâmetro importantíssimo para atender as propriedades desejáveis das misturas asfálticas. Paralelamente, a graduação empregada também responde conjuntamente para todas estas propriedades enumeradas. A seguir, serão abordados os aspectos da graduação e como estas características interferem nas propriedades citadas. 


\subsection{Linha de densificação máxima}

A composição granulométrica nas misturas asfálticas tem um papel fundamental para o bom desempenho da mistura. Goode e Lufsey (1962) propuseram uma relação matemática para verificar os vazios existentes entre os agregados de maior e menor tamanho. Essa relação, baseada na curvas de Fuller, descreve a graduação de densidade máxima, promovendo um mínimo de vazios do agregado mineral (VAM) na mistura. Entretanto, os autores notaram que se a composição granulométrica de uma dada mistura asfáltica corresponde ao expoente de 0,5, proposto inicialmente por Fuller, essa mistura pode apresentar um baixo VAM, o que não assegura um volume de vazios e/ou um teor de ligante asfáltico satisfatório para imprimir durabilidade à mistura asfáltica.

A fim de fornecer uma maneira de relacionar uma granulometria real de agregados à máxima densidade de graduação, um novo método de correlação gráfica foi criado. Estes autores propuseram uma nova escala horizontal nos gráficos de graduação para diversos tamanhos de peneiras, cuja marcação é a abertura da peneira elevada a uma potência no caso específico 0,45 , ao invés de logaritmo de aberturas de peneiras em mícron. A escala vertical é aritmética. Uma característica importante do gráfico é que ele atribui um zero teórico ao tamanho da peneira, na escala das abscissas. Conseqüentemente, em termos práticos, todas as linhas retas são plotadas a partir da origem, onde se dá a intersecção entre os eixos (zero por cento passantes $x$ zero teórico do tamanho da peneira). Estas retas finalizam-se no ponto correspondente ao diâmetro máximo nominal - (DMN) dos agregados que é igual a $100 \%$ em peso passante. Estas retas representam para qualquer tamanho específico máximo de agregado, as densidades máximas das graduações, ou seja, ao seguir exatamente esta distribuição granulométrica, a graduação tende a ser de máxima densidade, ou seja, menor volume de vazios do agregado mineral -(VAM). O expoente proposto é de potência 0,45 , isto é, a escala horizontal representa as várias aberturas de peneiras elevadas à potência 0,45 .

Os autores comentam que a seleção desta potência foi baseada na pesquisa realizada por L. W. Nijboer da Holanda e que foi publicada em 1943. Nijboer empregou um gráfico de graduação di-log em um estudo sobre a influência da 
granulometria do agregado no VAM. Todas as graduações usadas neste estudo produziram linhas retas com várias inclinações quando plotadas em seu gráfico. Esta variação na inclinação resultou do uso de uma série de granulometrias diferentes de mesmo tamanho máximo nominal (3/4"). O pesquisador realizou duas séries de ensaios com misturas betuminosas compactadas e determinou o volume de vazios do agregado mineral para todas elas. Foram plotados os volumes de vazios do agregado mineral em relação às inclinações da linha reta das curvas de graduação. Um tipo de cascalho arredondado foi usado para o agregado graúdo em uma parte do teste e uma brita angular em uma outra. Em ambos os casos, ocorreram volume de VAM mínimo, ou seja, máxima densidade do agregado, para uma granulometria cuja curva se encontra nas proximidades da inclinação de referência a potência 0,45 no gráfico di-log.

A Federal Highway Administration - FHWA recomenda o uso da potência de 0,45 para avaliar o ajuste da graduação. Roberts et al. (1996) apresentam uma carta de linha de densidade máxima, baseada na proposta de Goode e Lufsey, para diversos diâmetros nominais máximos reproduzida na Figura 2.

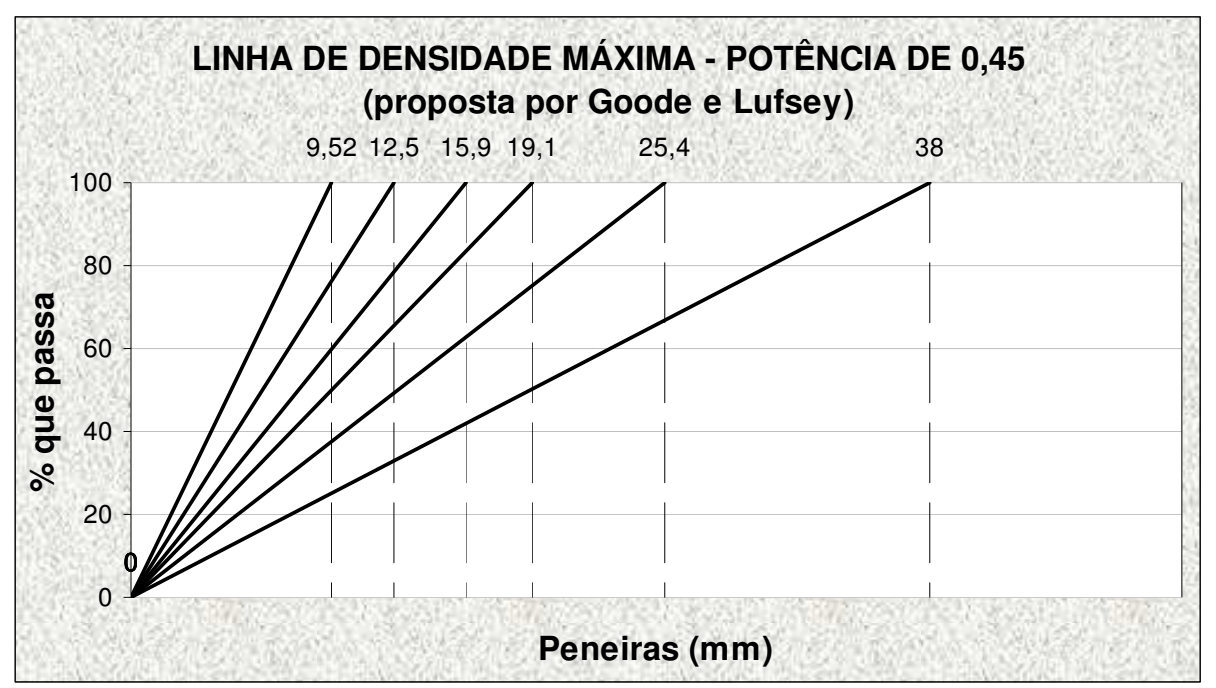

Figura 2 - Linha de Densidade Máxima - Potência de 0,45 (ROBERTS et al. 1996)

Goode e Lufsey (1962) apresentam como principal conclusão: graduações plotadas na carta de linha de densidade máxima com potência de 0,45 que se situam nas proximidades desta linha máxima, apresentam VAM satisfatório e com uma 
quantidade de ligante asfáltico suficiente que resulte em $4 \%$ de volume de vazios, essa mistura apresentará um bom desempenho mecânico. Logicamente todos estes comentários e conclusões são válidos para materiais bem-graduados e densos.

Os autores concluem também que para graduações com o mesmo tipo de agregado que se mostram com curvas idênticas, exceto no que se refere à porção entre as peneiras no 8 (abertura de 2,38mm) e n 200 (abertura de 0,075) - fração areia, aquelas que apresentam significativas curvaturas nos segmentos entre essas peneiras, acima da linha de densidade máxima, aproximadamente na peneira $n=30$ (abertura 0,59mm), irão produzir maiores VAM e, por conseguinte, menores estabilidades Marshall que as que se mostrarem com curvaturas menores nesta região da curva.

Finalmente, estes pesquisadores constatam que graduações do tipo com baixo volume de vazios do agregado mineral (VAM) estão associadas com curvas que estão significativamente abaixo da linha de densidade máxima no lado direito ou na parte de materiais grossos no gráfico.

\subsection{Diâmetro Máximo Nominal}

A norma da ASTM C 125 especifica as dimensões máximas dos agregados de duas formas:

1. diâmetro máximo do agregado é a menor abertura da malha de peneira através da qual passam 100\% das partículas; e

2. diâmetro máximo nominal, é a maior abertura de malha de peneira que retém alguma partícula de agregado.

Entretanto, cabe salientar que a referida norma da ASTM C 125 especifica agregados para finalidades de concreto de cimento hidráulico.

Roberts et al. (1996) comentam que a metodologia Superpave especifica:

1. diâmetro máximo do agregado é definido como a abertura de malha imediatamente maior que a correspondente ao diâmetro máximo nominal; e 
2. diâmetro máximo nominal é a abertura de peneira imediatamente maior do que a da peneira que retém mais de $10 \%$ do material.

O Instituto de Asfalto norte-americano define:

1. diâmetro máximo do agregado como sendo o tamanho da menor peneira que permite a passagem de todo material; e

2. diâmetro máximo nominal é a primeira peneira, da especificação, que retém algum material.

O procedimento de dosagem de misturas asfálticas francês não utiliza as denominações diâmetro máximo nominal e diâmetro máximo. No procedimento francês tem-se $M$ como sendo a menor peneira que permite a passagem de $100 \%$ dos agregados, sendo M o diâmetro máximo dos agregados (LCP, 2007). A denominação de uma granulometria ou fração é identificada pela combinação das letras $d / D$ em que $d$ é o menor diâmetro dos agregados que compõem a mistura asfáltica ou a fração, e $\mathrm{D}$ depende de $\mathrm{M}$ e da distribuição, definido como sendo o maior valor dentre as seguintes condições:

1. $\mathrm{M} / 1,4$ ou,

2. a menor peneira que permite a passagem de $85 \%$ dos agregados em peso.

Departamento Nacional de Infraestrutura de Transportes (DNIT) não especifica o diâmetro máximo nominal, somente o diâmetro máximo do agregado, como sendo a abertura nominal, em $\mathrm{mm}$, da malha da peneira, série normal, a qual corresponde uma porcentagem acumulada igual ou imediatamente inferior a $5 \% \mathrm{em}$ peso.

A importância do tamanho do agregado está intimamente ligada à espessura mínima recomendável da camada de mistura asfáltica. Logo, a escolha da faixa granulométrica deve, necessariamente, estar ligada ao tamanho do agregado. Assim, a especificação do diâmetro do agregado em tamanho máximo do agregado e diâmetro máximo nominal acaba por especificar a espessura mínima da camada asfáltica. 
A norma DNIT 031- ES (2004) recomenda que a "faixa usada deva ser aquela cujo diâmetro máximo é inferior a $2 / 3$ da espessura da camada asfáltica". Ou seja, a espessura mínima da camada asfáltica é uma vez e meia o diâmetro máximo do agregado escolhido.

Considerando o diâmetro máximo dos agregados em distribuição granulométrica Momm (1998) pesquisou em laboratório vários aspectos de propriedades mecânicas e de superfície de misturas asfálticas. As misturas foram dosadas pelo método Marshall, apresentavam distribuição granulométrica contínua e foram usinadas com ligante asfáltico convencional CAP 20 (classificação anterior à vigente, correspondente aproximadamente ao ligante asfáltico CAP 50/70). O pesquisador variou o diâmetro máximo do agregado em $19.1 \mathrm{~mm}, 12,5 \mathrm{~mm}$ e 9,5 mm e também os expoentes n entre 0,41 e 0,67, que regem a distribuição granulométrica baseado na composição de Talbot.

O autor concluiu que o aumento do diâmetro máximo dos agregados e a diminuição dos finos constituem-se a combinação que melhor apresentou características adequadas para a aderência pneu/pavimento em pavimentos molhados. Para a deformação permanente em trilha de roda, todas as misturas asfálticas apresentaram resultados satisfatórios. Os resultados indicaram que a distribuição granulométrica bem graduada, próxima à densificação máxima, contribui enormemente para o bom comportamento à deformação permanente.

Os resultados mostraram que o diâmetro máximo e a \% de finos afetam o módulo complexo; entretanto, a literatura mostra que o tipo e o teor de ligante asfáltico têm maior influência nos resultados desse ensaio. Os ensaios de fadiga indicaram que as misturas asfálticas de diâmetro máximo maiores, tornaram as misturas mais rígidas, o que leva a uma vida de fadiga menor nas estruturas de revestimentos asfáltico delgados.

Huber e Shuler (1992), engenheiros pesquisadores do Instituto do Asfalto norteamericano, apresentam um experimento para avaliar o efeito das características superficiais e da graduação sobre o desempenho de misturas asfálticas. 0 experimento teve dois objetivos: 
1. comparar o VAM de misturas com graduação idênticas, mas com agregados de diferentes origens; $\mathrm{e}$

2. comparar o VAM de misturas de mesmo tipo de agregado de maior para o menor tamanho, mas de graduação diferente.

Inicialmente questionam as definições sobre o diâmetro máximo nominal de agregados, que além das definições do Asphalt Institute e da American Society for Testing and Materials (ASTM) anteriormente apresentadas, comentam a definição proposta por McLeod:

1. diâmetro máximo do agregado como sendo o tamanho da menor peneira que permite a passagem de todo material; e

2. diâmetro máximo nominal como sendo a primeira peneira da especificação que retém no mínimo $10 \%$ do material.

Os autores citados comentam que a definição de diâmetro máximo nominal e diâmetro máximo são motivos de muita confusão no meio técnico rodoviário.

Huber e Shuler (1992) plotaram seis curvas granulométricas de misturas asfálticas que tinham sido aplicadas em campo e das quais conheciam o desempenho; o experimento foi baseado na linha de densidade máxima proposta por Goode e Lufsey. Essas curvas ficaram abaixo da linha de densidade máxima para o diâmetro máximo nominal de $12,5 \mathrm{~mm}$ de forma relativamente ordenada. Pelas conclusões apresentadas por Goode e Lufsey, conforme as graduações se distanciam abaixo da linha de densidade máxima, o VAM dessas misturas diminui proporcionalmente com a distância. Entretanto, o experimento com as seis curvas apresentavam valores de VAM não ordenados em função dessa distância.

Devido à duvida dos autores acerca do diâmetro máximo nominal utilizado de $12,5 \mathrm{~mm}$, quatro graduações, sendo três com gap entre as peneiras $4,76 \mathrm{~mm}$ e 2,36mm, com VAM conhecidos, foram plotadas em uma carta com duas linhas de densidade máxima: uma considerando o diâmetro máximo nominal e outra com o diâmetro máximo, conforme definição de McLeod. Verificou-se que dentre as duas linhas de densidade máxima, a de base no diâmetro máximo de $19,0 \mathrm{~mm}$ foi a que apresentou correlação satisfatória entre o VAM e o volume de vazios das misturas. 
No mesmo trabalho, Huber e Shuler (1992) apresentam um estudo feito pela Federal Highway Administration - FHWA, sobre uma coletânea de 74 projetos de mistura asfáltica, cada qual com número significativo de dados. Esses projetos foram avaliados através de correlações do VAM com a linha de densidade máxima para os diâmetros máximos nominais e também para os diâmetros máximos, tendo os autores concluído que a correlação é ruim, apresentando valores de $r^{2}$ baixíssimos. Quanto a definição de diâmetro máximo nominal e diâmetro máximo propostos por McLeod, os autores concluem que por ser a definição mais consistente, categorizam as misturas asfálticas corretamente.

Além das questões dimensionais dos agregados, as características superficiais de textura e a angularidade influenciam na compactação das misturas asfálticas.

Uma das importantes questões levantadas por Huber e Shuler (1992) é que a comparação de graduação com a linha de densidade máxima pode ser feita somente para agregados de mesma origem. A linha de densidade máxima pode ser utilizada para avaliação de projeto de misturas asfálticas. Composições granulométricas com diferenças acentuadas na peneira de n. 200 (abertura de 0,075mm), a utilização da linha de densidade máxima, pode não ser adequada.

Brock e May (2009) registram que misturas muito próximas da linha de densidade máxima não possuem volume de vazios suficiente para ser preenchido com ligante asfáltico e, se for adicionado ligante asfáltico suficiente para se obter $4 \%$ de volume de vazios, provavelmente a mistura asfáltica apresentar-se-á com características plásticas. Os autores apontam como uma das possibilidades de aumento no teor de ligante o uso de misturas tipo gap-graded, empregadas com sucesso na Inglaterra, apresentando alto teor de ligante asfáltico e conseqüentemente espessura de filme de ligante maior que das misturas convencionais.

Estes autores sugerem que, no desenvolvimento do projeto, posicionem-se as distribuições granulométricas em torno de $2 \%$ a $4 \%$ abaixo ou acima da linha de densidade máxima.. Se acima, tem-se misturas com texturas superficiais mais finas; se abaixo, a textura tende para mais grossa. Os autores recomendam que esse não 
seja o único parâmetro a ser seguido. Recomenda conhecer o VAM, a estabilidade e outras características para definir a dosagem da mistura asfáltica.

\subsection{Dosagem de misturas asfálticas método Superpave}

O processo de compactação de misturas asfálticas em laboratório, baseado nos métodos de Hveen e também no método de Marshall, sem dúvida, utilizavam energia de moldagem de maneira a reproduzir em laboratório corpos-de-prova com características referenciadas às condições encontradas em campo. As condições de campo não são baseadas nas densidades após a construção da camada asfáltica, mas sim, após ter sido submetida à ação de certo nível de solicitação pelo tráfego.

A energia de moldagem, inicialmente proposta no ensaio Marshall de 50 golpes por face, foi modificada para 75 golpes por face frente à necessidade de obter misturas asfálticas mais resistentes à ação das cargas impostas pelas aeronaves durante a II Guerra Mundial. Embora tenha sido tomada esta precaução, pistas de aeroportos ainda apresentavam deformação permanente em trilha de roda devido a essas elevadas cargas. Além da energia de compactação os ensaios físicos dos ligantes asfálticos e as especificações dos materiais, até então empregados para fins de sua caracterização na área de pavimentação, apresentavam muitas limitações e falta de relação com o comportamento em campo. Roberts et al. (1996) elencam seis constatações que demonstram a deficiência destas propriedades empíricas dos ligantes e a falta de relação direta com o desempenho de misturas asfálticas:

1. a penetração e a dutibilidade em ligantes asfálticos não se correlacionam diretamente com o desempenho de misturas asfálticas em serviço; algumas relações entre os valores obtidos nesses ensaios e o desempenho foram feitas com a experiência, mas com resultados relativamente incipientes;

2. ensaios de penetração e viscosidade são conduzidos a temperaturas padrão, a $25^{\circ} \mathrm{C}$ e a $60^{\circ} \mathrm{C}$, respectivamente, apesar das diferentes condições climáticas a que o pavimento é submetido; 
3. a gama de temperaturas diferentes a que o pavimento é submetido não é contemplado no projeto de mistura; os autores ilustram o fato com a inexistência de um método de ensaio empírico que contemple a rigidez do ligante asfáltico à baixa temperatura para controle de trincamento térmico;

4. os ensaios empíricos consideram um curto período de misturação na produção e na aplicação da mistura asfáltica, simulados com a estufa filme delgado - thin film oven (TFO) ou a estufa de filme fino rotativo - rolling thin film oven test - (RTFOT). Entretanto, longos períodos de misturação e de compactação não são considerados, que são mais danosos ao desempenho das misturas asfálticas;

5. a classificação por penetração ou por viscosidade não contemplam características de desempenho de misturas asfálticas. Ligantes asfálticos com mesmos valores de penetração e de viscosidade para a mesma granulometria podem apresentar valores de desempenho distintos.

6. as especificações dos ensaios de ligante asfáltico baseiam-se na experiência observacional dos técnicos rodoviários. Não existia uma especificação, nesses moldes empíricos, para ligantes asfálticos modificados por polímeros.

Considerando as limitações dos ensaios anteriormente mencionados, em 1987, o Strategic Highway Research Program (SHRP), com investimento de 150 milhões de dólares do governo americano, desenvolveu uma pesquisa durante 5 anos, que culminou no lançamento de novos procedimentos de ensaios baseados em reologia e desempenho de ligantes asfálticos e de misturas asfálticas (ROBERTS et al.,1996). O Lançamento contemplou um programa denominado de Superior Performing Asphalt Pavements (Superpave); nesse programa são apontados ensaios com ligantes asfálticos e especificações de materiais abrangendo os seguintes aspectos:

1. nas especificações dos ligantes asfálticos foram incluídos os ligantes convencionais e os ligantes modificados por polímero;

2. os critérios especificados permanecem constantes, entretanto, as condições climáticas passam a serem consideradas na escolha do tipo de ligante asfáltico a ser empregado; 
3. as propriedades físicas avaliadas dos ligantes asfálticos, são baseadas nas propriedades reológicas que regem os princípios de engenharia e, por este motivo, estão diretamente relacionadas com o desempenho em campo;

4. a nova especificação do Superpave recomenda o uso do ligante asfáltico após ter sido submetido a três estágios de testes:

a) o primeiro estágio contempla ensaios com o ligante original, como foi transportado, estocado e manipulado antes de ser adicionado à mistura,

b) no segundo estágio verifica-se a conseqüência nas propriedades do ligante asfáltico após a usinagem e compactação (envelhecimento a curto tempo) e,

c) no terceiro estágio avalia-se o ganho de rigidez do ligante asfáltico associado à vida de serviço;

5. a variação de temperatura dos pavimentos é considerada em projeto;

6. ensaios e especificações são realizados e foram concebidos com o objetivo de eliminar ou controlar três tipos de danos ao pavimento: deformação permanente em trilha de roda, trincamento por fadiga e trincamento térmico. Deformação permanente, normalmente, ocorre em altas temperaturas, trincamento por fadiga ocorre em temperaturas intermediárias e em baixas temperaturas ocorrem os trincamentos térmicos; e,

7. os procedimentos de ensaios e as especificações foram desenvolvidos no sistema internacional de unidades - SI.

O comportamento dos ligantes asfálticos é o principal produto do SHRP. O objetivo da pesquisa do programa Superpave foi o de identificar e validar as propriedades de engenharia que pudessem estar diretamente vinculadas ao comportamento do ligante asfáltico (resposta à ação do tráfego e ao carregamento em condições ambientais variáveis). Os ensaios realizados simulam o envelhecimento do ligante asfáltico, procurando verificar eventual enrijecimento causado pela idade do ligante asfáltico. Esses ensaios simulam um longo período - equivalente entre 5 a 10 anos de vida de serviço, curto período - enrijecimento do ligante causado pela usinagem, e também contemplam ensaios em ligantes virgens (KENNEDY, 1994). 
A especificação do programa Superpave é baseada na temperatura do pavimento em serviço e desempenhos desejados de engenharia. As especificações fixam as propriedades desejadas de engenharia e verifica-se em qual PG (Performance Grade - conjunto definido por um par de temperaturas de trabalho do pavimento em serviço, abordado em maior detalhe no item 2.5.1) o ligante asfáltico deve ser enquadrado de modo que essas propriedades sejam atingidas (KENNEDY, 1994).

\subsubsection{Ligante asfáltico}

Sabe-se que o comportamento das misturas asfálticas e as estruturas dos pavimentos são afetadas significativamente pelas propriedades do ligante asfáltico. Uma mudança significativa introduzida pelo Superpave foi a especificação do ligante asfáltico no desempenho a baixas e altas temperaturas de serviço. Incluem nessa especificação tanto os ligantes convencionais como os modificados por polímeros. A especificação considera a rigidez do ligante asfáltico causada pelo envelhecimento, associada à ação do tráfego e a condições climáticas. Nessa classificação as condições de carregamento para altas temperaturas de serviço correlaciona-se com velocidades de veículos a $100 \mathrm{~km} / \mathrm{h}$ e a volume de tráfego inferior a $10^{7} \mathrm{ESALs}$ (KENNEDY, 1994).

A especificação utiliza a nomenclatura de performance grade - PG seguidos de mais dois números " $x$ " e "y" - PG x-y, que são as temperaturas máximas e mínimas do pavimento, a $2 \mathrm{~cm}$ de profundidade em relação à superfície, recomendadas para projeto. A temperatura máxima especificada é a média dos sete dias, durante um período de um ano, que apresentou os maiores valores; a temperatura mínima é a menor temperatura, de um único dia, observada no mesmo período de um ano.

Três ensaios, que serão abordados mais adiante, baseados nas propriedades de engenharia, são utilizados para classificar o ligante asfáltico quanto aos valores das temperaturas "x" e "y" do PG (KENNEDY, 1994): 
reômetro de cisalhamento em viga - BBR;

reômetro de cisalhamento dinâmico - DSR; e,

ensaio de tensão direta - DTT

A defasagem entre os valores de temperatura é de $6^{\circ} \mathrm{C}$, tanto para as temperaturas máximas como as mínimas. Apresentam-se na tabela 3 os tipos de ligante asfáltico da especificação Superpave (KENNEDY, 1994).

Tabela 3 - Tipos de ligantes asfálticos da especificação Superpave(KENNEDY, 1994)

\begin{tabular}{c|c}
\hline $\begin{array}{c}\text { Classificação - altas } \\
\left.\text { temperaturas "x" (em }{ }^{~} \mathbf{C}\right)\end{array}$ & $\begin{array}{c}\text { Classificação possível - baixas } \\
\text { temperaturas "y" (em }{ }^{\circ} \mathbf{C} \text { negativos) }\end{array}$ \\
\hline PG 46 & 34,40 e 46 \\
PG 52 & $10,16,22,28,34,40$ e 46 \\
PG 58 & $16,22,28,34$ e 40 \\
PG 64 & $10,16,22,28,34$ e 40 \\
PG 70 & $10,16,22,28,34$ e 40 \\
PG 76 & $16,22,28$ e 34 \\
PG 82 & $16,22,28$ e 34 \\
\hline
\end{tabular}

Leite (1999) classificou pelo Superpave, diversos tipos de ligantes asfálticos brasileiros convencionais, denominados de CAP-7, CAP-20 e CAP-40 (classificação por viscosidade anterior à vigente), ligantes asfálticos modificados por diversos teores de polímeros, SBS, EVA, SBR e também asfalto modificado por borracha (AMB). Os ligantes, CAP-20 e CAP-40, correlatos aos ligantes asfálticos CAP 50/70 e CAP 30/45 pela classificação vigente, apresentaram o PG 64-16 e PG 70-10, com a adição de $3 \%$ de polímero SBS no CAP-20 resultou em um ligante asfáltico com PG 70-22 e a adição de 5,5\% no ligante asfáltico CAP-40 passou a apresentar PG 76-28. A incorporação de $15 \%$ de borracha de pneu moído, ao CAP-20 propiciou modificações na reologia do ligante passando para um PG76-28. Salienta-se que a pesquisadora utilizou diversos tipos de diluentes, diversos tipos de polímeros SBS, vários períodos de agitação dentre outras variáveis. 
Cominski et al. (1994) alertam para a determinação do PG do ligante asfáltico para rodovias que possuem volume de tráfego superior a $3^{*} 10 E^{7} E$ SLs $^{2}$ e com baixa velocidade. Para essas condições os autores recomendam que seja acrescido $6^{\circ} \mathrm{C}$ ao PG considerado. Esse acréscimo no valor de $P G$ é para propiciar à mistura asfáltica, maior resistência à formação de deformação permanente em trilha de roda.

Os mesmos autores recomendam que para as regiões dos EUA sudoeste-deserto ou continentais, cujas rodovias apresentem baixas velocidades e com tráfego pesado, os valores de PG dos ligantes asfálticos a serem utilizados sejam de no mínimo $70^{\circ} \mathrm{C}$.

\subsubsection{Agregados}

Especialistas em pavimentos foram consultados quanto às propriedades mais relevantes dos agregados em misturas asfálticas. Em consenso, os especialistas apontaram que a deformação permanente em trilha de roda é a propriedade mais afetada pelos agregados. Por sua vez, o trincamento por fadiga e por retração térmica são mais afetados pelo comportamento do ligante asfáltico. Os ensaios dos agregados não sofreram alterações significativas no Superpave. Basicamente as propriedades que são especificadas pelo programa SHRP são: angularidade dos agregados graúdos e miúdos, forma das partículas (lamelares, alongadas, entre outras) e o ensaio de equivalente-areia. (ROBERTS et al.1996).

Devido ao uso intenso de agregados naturais nos Estados Unidos, não provenientes da britagem de rochas, uma das preocupações do SHRP era definir o número de faces fraturadas (por britagem), por entender que a existência destas faces contribuem para o entrosamento entre grãos e aumento da resistência ao cisalhamento. A angularidade do agregado graúdo é medida pela porcentagem de partículas que apresentam faces fraturadas. Observe-se que a exigência de faces fraturadas é dependente do volume de tráfego no período de projeto. $O$

\footnotetext{
${ }^{2}$ Trafégo segundo os critérios da AASHTO
} 
procedimento, em linhas gerais, estipula que de uma pilha de agregados toma-se uma amostra, dividindo-a em três pilhas, uma pilha com todos os agregados com nenhuma face fraturada, uma segunda pilha com agregados com uma única face fraturada $\mathrm{e}$, a terceira pilha com agregados com duas ou mais faces fraturadas. $\mathrm{O}$ resultado é expresso com dois números, sendo o primeiro a porcentagem de agregados com uma face fraturada "a" e o segundo a porcentagem de agregados com duas ou mais faces fraturadas denominados de "b" e estão dispostos a/b, conforme tabela 4.

Tabela 4 - Recomendações para agregados graúdos quanto a angularidade em função da espessura da camada de rolamento (KENNEDY, 1994)

\begin{tabular}{|c|c|c|}
\hline Tráfego (ESALs) & $<100 \mathrm{~mm}$ & $>100 \mathrm{~mm}$ \\
\hline$<0,3^{*} 10^{5}$ & $55 / \ldots *$ & 1 \\
\hline$<10^{6}$ & $65 /$ & 1 \\
\hline$<3^{*} 10^{6}$ & $75 /$ & $50 /$ \\
\hline$<10^{7}$ & $85 / 80$ & $60 /$ \\
\hline$<3^{*} 10^{7}$ & $95 / 90$ & $80 \overline{75}$ \\
\hline$<10^{8}$ & $100 / 100$ & $95 / 90$ \\
\hline$\geq 10^{8}$ & $100 / 100$ & $100 / 100$ \\
\hline
\end{tabular}

$\left(^{*}\right)$ O primeiro número, corresponde à letra "a" - porcentagem mínima para uma face fraturada e o segundo número corresponde à letra $b$ - porcentagem mínima para duas ou mais faces fraturadas.

A angularidade dos agregados miúdos, partículas com diâmetro inferiores a 4,76 $\mathrm{mm}$, é obtida com a medida da quantidade de vazios, em amostras não compactadas, quando o agregado é derramado dentro de um cilindro. Os vazios em amostras não compactadas pode ser determinado pela equação 1 .

$$
\text { Vazios }=\frac{V-W / G_{s b}}{V} * 100
$$

onde: $\mathrm{V}=$ volume do cilindro $\left(\mathrm{mm}^{3}\right)$

$$
\begin{aligned}
& \mathrm{W}=\text { massa do agregado fino (solto) }(\mathrm{g}) \\
& \mathrm{G}_{\mathrm{sb}}=\text { densidade aparente do agregado }
\end{aligned}
$$

Estão apresentados na tabela 5 os valores de vazios em amostras não compactadas associados ao volume de tráfego de projeto. 
Tabela 5 - Recomendações para agregados miúdos quanto a angularidade em função da espessura da camada de rolamento (KENNEDY, 1994)

\begin{tabular}{c|c|c}
\hline Tráfego (ESALs) & $<\mathbf{1 0 0 ~} \mathbf{~ m m}$ & $>\mathbf{1 0 0} \mathbf{~ m m}$ \\
\hline$<0,3^{*} 10^{5}$ & $-0-$ & $-0-$ \\
$<10^{6}$ & 40 & $-0-$ \\
$<3^{*} 10^{6}$ & 40 & 40 \\
$<10^{7}$ & 45 & 40 \\
$<3^{*} 10^{7}$ & 45 & 40 \\
$<10^{8}$ & 45 & 45 \\
$\geq 10^{8}$ & 45 & 45 \\
\hline
\end{tabular}

Outro ensaio recomendado pelo Superpave é a quantificação de partículas lamelares ou alongadas. Uma partícula é considerada lamelar ou alongada se seu comprimento for suficientemente maior que sua largura. Observe-se que os termos lamelar e alongado estão associados a uma única determinação. As partículas serão consideradas lamelares ou alongadas se a maior dimensão dividida pela menor dimensão exceder a 5 vezes. Na tabela 6 apresentam-se os valores de aceitação para partículas lamelares ou alongadas associadas ao volume de tráfego de projeto.

Tabela 6 - Recomendações de partículas lamelares ou alongadas para agregados graúdos (KENNEDY, 1994)

\begin{tabular}{c|c}
\hline $\begin{array}{c}\text { Tráfego } \\
(\text { ESALs) }\end{array}$ & $\begin{array}{c}\text { Máxima porcentagens de partículas com relação } \\
\text { de comprimento/espessura menor que 5 }\end{array}$ \\
\hline$<0,3^{*} 10^{5}$ & $-0-$ \\
$<10^{6}$ & $-0-$ \\
$<3^{*} 10^{6}$ & 10 \\
$<10^{7}$ & 10 \\
$<3^{*} 10^{7}$ & 10 \\
$<10^{8}$ & 10 \\
$\geq 10^{8}$ & 10 \\
\hline
\end{tabular}

A quantidade de argila presente na superfície dos agregados pode acarretar problemas de adesividade entre o ligante asfáltico e a superfície dos agregados, acarretando problemas de arrancamento dos agregados pela ação do tráfego e também de trincamento ocasionado por essa má adesividade levando o pavimento à ruína precocemente (MOURA, 2001). 
A propriedade de consenso dos especialistas consultados pelo programa Superpave foi a determinação do teor de argila presente nos agregados. A não consideração dessa propriedade pode acarretar em danos ao pavimento. O Superpave recomenda o uso do ensaio de equivalente de areia para essa finalidade. O ensaio está preconizado nas normas da American Association of State Highway Officials (AASHTO) T 176 e ASTM D 2419. Apresentam-se na tabela 7 os valores mínimos em porcentagem de equivalente de areia associado ao volume de tráfego de projeto (ROBERTS et al., 1996 e KENNEDY, 1994).

Tabela 7 - Equivalente de areia especificação (KENNEDY, 1994)

\begin{tabular}{c|c}
\hline $\begin{array}{c}\text { Tráfego } \\
(\text { ESALs) }\end{array}$ & $\begin{array}{c}\text { Equivalente de areia } \\
\text { Mínimo }(\%)\end{array}$ \\
\hline$<0,3^{*} 10^{5}$ & 40 \\
$<10^{6}$ & 40 \\
$<3^{*} 10^{6}$ & 40 \\
$<10^{7}$ & 45 \\
$<3^{*} 10^{7}$ & 45 \\
$<10^{8}$ & 50 \\
$\geq 10^{8}$ & 50 \\
\hline
\end{tabular}

Outro aspecto considerado pelo programa Superpave diz respeito aos pontos de controle e à zona de restrição. Os pontos de controle para uma distribuição granulométrica que possui DMN, conforme abordado no item 2.4 e diâmetro máximo de $12,5 \mathrm{~mm}$ e $19,0 \mathrm{~mm}$, respectivamente, estão apresentados na tabela 8 , salienta-se que os pontos de controle dependem da série de peneiras.

Tabela 8 - Pontos de controle da distribuição granulométrica - Superpave (KENNEDY, 1994)

\begin{tabular}{c|c|c}
\hline \multirow{2}{*}{ Peneiras $(\mathbf{m m})$} & \multicolumn{2}{|c}{ Pontos de controle (\% que passa) } \\
\cline { 2 - 3 } & Mínimo & Máximo \\
\hline 0,075 & 2 & 10 \\
2,36 & 28 & 58 \\
9,5 & - & 90 \\
$\operatorname{DMN}(12,5 \mathrm{~mm})$ & 90 & 100 \\
$\mathrm{DM}(19,0 \mathrm{~mm})$ & 100 & - \\
\hline
\end{tabular}


A zona de restrição é outro requisito do programa Superpave. Roberts et al. (1996) comenta que se trata de uma região mal compreendida ainda, tendo sido adotada para assegurar o emprego de areia natural em quantidade que não comprometesse o desempenho da mistura asfáltica. Afirmam também que a distribuição granulométrica pode passar pela zona de restrição sem prejuízos ao desempenho da mistura asfáltica desde que os agregados da fração areia tenham origem do mesmo material britado que compõem o material granular.

Apresenta-se na figura 3 a graduação requerida para $D M N=12,5 \mathrm{~mm}$ com os pontos de controle e a zona de restrição.

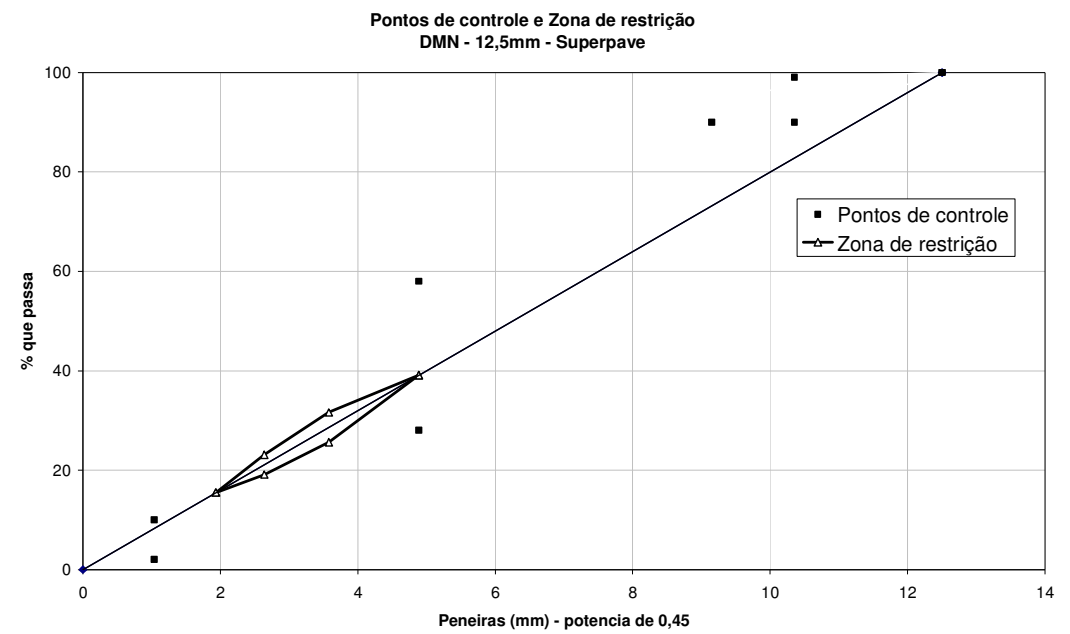

Figura 3 - Graduação requerida para DMN = 12,5 mm (KENNEDY, 1994)

Os mesmos autores alertam para a durabilidade de misturas com distribuição granulométrica muito próxima a linha de densificação máxima, geralmente apresentam baixos valores de VAM e, por conseguinte, resultam em misturas asfálticas menos duráveis uma vez que essas misturas são mais sensíveis a variação do teor de ligante asfáltico. Recomendam que se mantenha um distanciamento da linha de densificação máxima, podendo-se obter três condições:

a) se os agregados finos for predominantemente de areia natural, é recomendado que se disponha a distribuição granulométrica abaixo da linha de densificação máxima, com a finalidade tanto de minimizar a quantidade 
de areia utilizada como também o efeito ${ }^{3}$ da areia no comportamento da mistura asfáltica;

b) caso os agregados finos sejam constituídos de grãos britados, pode-se dispor a distribuição granulométrica acima da linha de densificação máxima, entretanto, essas misturas podem não serem econômicas visto que os a quantidade de ligante asfáltico utilizado deverá ser maior para atender os o critério de vazios de projeto.

c) é indesejável que a distribuição granulométrica cruze a linha de densificação máxima entre as peneiras de n. 30 e 50 (aberturas 0,6 mm e 0,3 mm respectivamente) principalmente quando se utiliza areia natural com grãos arredondados. Misturas com essas características são denominadas de tender mixes, misturas que exibem elevada plasticidade quando normalmente compactadas após distribuição da mistura em pista.

Essas recomendações de procedimento podem ser consideradas especialmente quando a mistura asfáltica apresenta problemas de distribuição ou compactação ou ainda tenha-se vivenciado deformação permanente em trilha de roda apreciáveis durante a vida de serviço.

\subsubsection{Ensaios de ligantes asfálticos}

Apresenta-se na tabela 9 os equipamentos de ensaios físicos/reológicos dos ligantes asfálticos do Superpave, bem como de maneira sucinta os propósitos dos ensaios e os parâmetros de desempenho influenciados pelo ligante asfáltico.

\footnotetext{
${ }^{3}$ de deformação permanente em trilha de roda
} 
Tabela 9 - Equipamento, finalidade e parâmetros do Superpave

\begin{tabular}{|c|c|c|}
\hline Equipamento & Finalidade & Parâmetro de Desempenho \\
\hline $\begin{array}{l}\text { Estufa de filme fino } \\
\text { rotativo - (RTFO) }\end{array}$ & $\begin{array}{l}\text { Simula o envelhecimento do } \\
\text { ligante } \\
\text { durante a produção e } \\
\text { compactação da mistura }\end{array}$ & $\begin{array}{l}\text { Resistência ao envelhecimento } \\
\text { (durabilidade) durante a construção }\end{array}$ \\
\hline $\begin{array}{c}\text { Vaso de } \\
\text { envelhecimento sobre } \\
\text { pressão - (PAV) }\end{array}$ & $\begin{array}{l}\text { Simula o envelhecimento } \\
\text { (enrijecimento) da mistura em } \\
\text { vida de serviço }\end{array}$ & $\begin{array}{l}\text { Resistência ao envelhecimento } \\
\text { (durabilidade) durante a vida de } \\
\text { serviço }\end{array}$ \\
\hline $\begin{array}{l}\text { Viscosímetro } \\
\text { rotacional } \\
(\mathbf{R V})\end{array}$ & $\begin{array}{l}\text { Mede as propriedades do } \\
\text { ligante a a elevadas } \\
\text { temperaturas de usinagem }\end{array}$ & $\begin{array}{l}\text { Trabalhabilidade do ligante asfáltico } \\
\text { (transporte por bombeamento) }\end{array}$ \\
\hline $\begin{array}{l}\text { Reômetro de } \\
\text { cisalhamento dinâmico } \\
\text { (DSR) }\end{array}$ & $\begin{array}{l}\text { Mede as propriedades dos } \\
\text { ligantes asfálticos a altas e } \\
\text { médias temperaturas de } \\
\text { serviço }\end{array}$ & $\begin{array}{l}\text { Resistência à deformação } \\
\text { permanente em trilha de roda e } \\
\text { trincamento por fadiga }\end{array}$ \\
\hline $\begin{array}{c}\text { Reômetro de } \\
\text { cisalhamento em viga } \\
\text { (BBR) } \\
\text { Ensaio de tração } \\
\text { direta } \\
\text { (DTT) }\end{array}$ & $\begin{array}{l}\text { Mede as propriedades dos } \\
\text { ligantes asfálticos em baixas } \\
\text { temperaturas de serviço }\end{array}$ & Resistência ao trincamento térmico \\
\hline
\end{tabular}

Com os ensaios apresentados na tabela 9 podem-se obter os seguintes valores de expressam o comportamento dos ligantes asfálticos (KENNEDY, 1994):

rigidez mínima de $1 \mathrm{kPa}$ é especificada para ligantes virgens; esse valor atende às características que o ligante deve possuir para se evitar misturas asfálticas que apresentem problemas de compactação (são densificadas rapidamente no início da rolagem e ao final não permitem atingir o grau de compactação) - medida feita no DSR;

rigidez mínima de 2,2 $\mathrm{kPa}$ associa-se a um envelhecimento do ligante em um curto período; o objetivo desse limite é prevenir a deformação permanente em trilha de roda imediatamente após a construção - medida feita no DSR;

rigidez máxima de $5,0 \mathrm{kPa}$ associa-se a um envelhecimento do ligante que ocorre em um longo período; esse valor contribui para prevenir o trincamento por fadiga causado pela rigidez excessiva do ligante - medida feita no DSR;

módulo de rigidez máximo de $300 \mathrm{MPa}$ e um valor mínimo de módulo de relaxação $m=0,30$, obtido com o ensaio de deformação estática BBR; esses limites são utilizados para evitar a rigidez excessiva a baixas temperaturas; 
elevada rigidez estática é permitida pela especificação se for detectada falha causada pela tensão de deformação de $1 \%$. Isso pode ser observado em ligante asfáltico modificado por polímeros que apresentem elevada rigidez a baixas temperaturas e, entretanto, apresentam elevada deformação para que ocorra a falha - medida feita no DTT.

A seguir serão relatadas as principais características dos equipamentos, associados às propriedades de engenharia, recomendados pelo Superpave (ROBERTS et al.,1996).

O ensaio de rolling thin film oven test - RTFOT, normatizado pelas normas AASHTO T 240 e ASTM D2871, simula o envelhecimento do ligante asfáltico no processo de usinagem e de compactação da mistura asfáltica, figuras 4 e 5. Esse tipo de ensaio foi selecionado pelo Superpave pelo fato de avaliar o potencial do ligante asfáltico quanto à oxidação e à evaporação, permitindo quantificar a presença de óleos mais leves e a oxidação que ocorre durante ao aquecimento a $163^{\circ} \mathrm{C}$ durante 85 minutos.

A quantificação do envelhecimento se dá através dos ensaios de penetração, viscosidade e dutilidade com o ligante, sendo este um procedimento indireto, usado pelas classificações que utilizam a penetração e outras medidas empíricas para caracterização de estado físico do ligante. No SHRP, o envelhecimento é avaliado pelo enrijecimento do ligante, com mudanças que podem ser medidas por meio do reômetro de cisalhamento dinâmico, dentre outros ensaios.

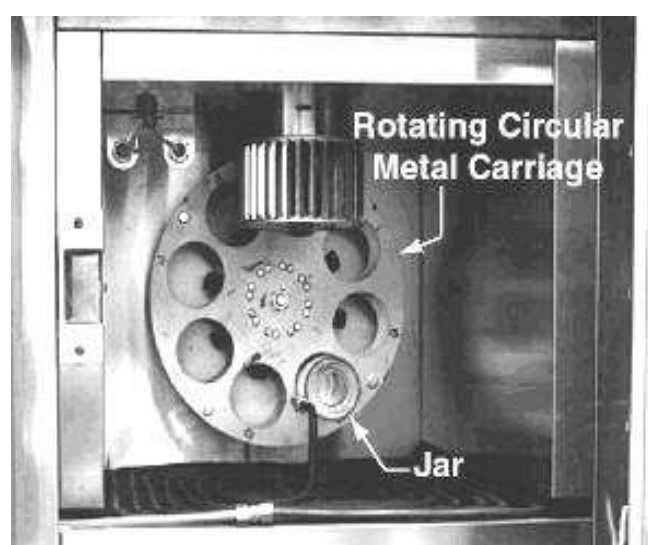

Figura 4 - Câmara de RTFOT http://cauduongbkdn.com/f@ rums/showthread.php?p=67906

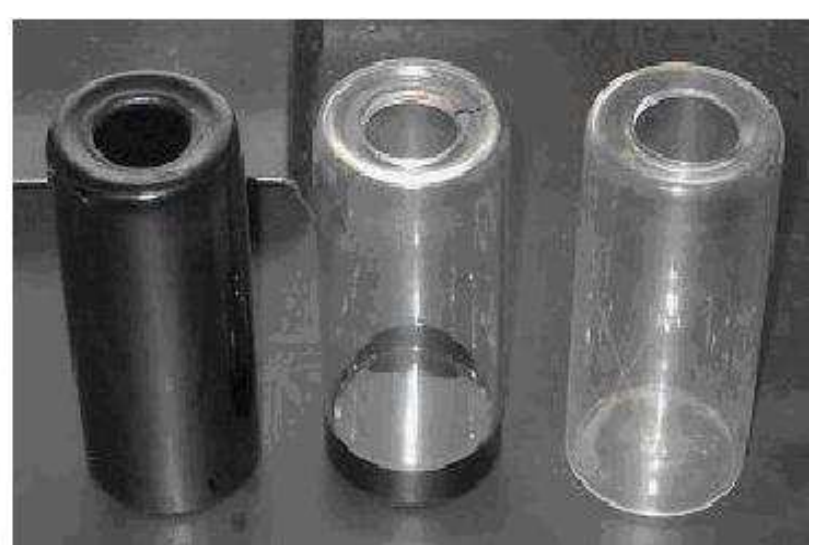

Figura 5 - Frasco de provas após ensaio (recoberto) e antes do ensaio -http://cauduongbkdn. com/f@rums/showthread.php?p=67906 
Vaso de envelhecimento sob pressão, denominado de PAV foi desenvolvido pelo Superpave para simular o envelhecimento do ligante asfáltico que ocorre entre $5 \mathrm{a}$ 10 anos da vida de serviço da mistura asfáltica, figuras 6,7 e 8 . O equipamento foi baseado em um procedimento de ensaio que foi idealizado por D.Y.Lee na Universidade de lowa - USA e que por muitos anos foi utilizado para medir o envelhecimento de produtos com borracha, padronizados pelas normas ASTM D454 e ASTM D572. As vantagens do equipamento desenvolvido pelo Superpave são:

a) limitar a perda de voláteis;

b) o processo de oxidação é acelerado sem necessariamente recorrer a altas temperaturas;

c) uma quantidade adequada de ligante asfáltico pode ser envelhecida a um tempo maior de ensaio; e,

d) o ensaio pode fazer parte da rotina de laboratório por não ser um ensaio de grande dificuldade de execução.

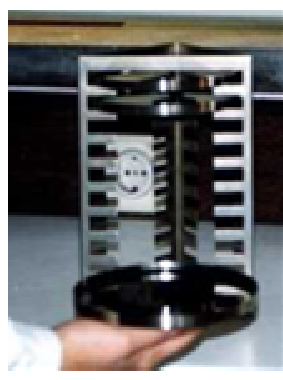

Figura 6 - Porta provas

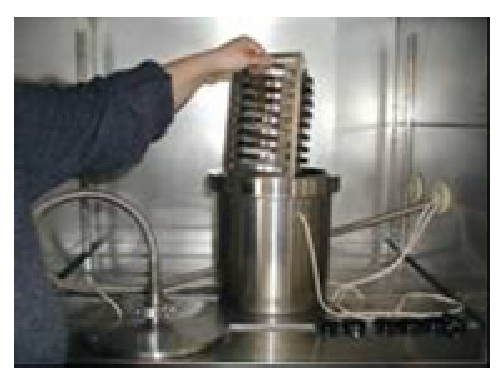

Figura 7 - Acondicionamento das provas no vaso de pressão

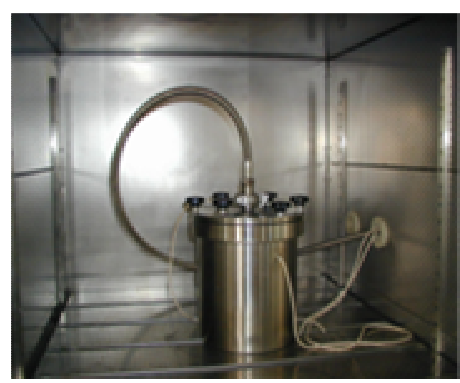

Figura 8 - Vaso de pressão

A amostra de ligante asfáltico submetida ao ensaio de PAV é a residual do ensaio de RTFOT. Os ensaios que são realizados na amostra de ligante após o ensaio de RTFOT, também são utilizados nas amostras após o ensaio de PAV para avaliar a perda de voláteis.

Viscosímetro rotacional $(R V)$ tem sido utilizado pelo Superpave para medir a viscosidade do ligante asfáltico a temperaturas elevadas, acima de $100^{\circ} \mathrm{C}$, no intuito de se quantificar se o ligante asfáltico possui fluidez suficiente para ser bombeado e para a estocagem. Muitos ligantes asfálticos comportam-se como fluídos Newtonianos e, por conseguinte, a medida da viscosidade do ligante asfáltico é 
suficiente para representar a trabalhabilidade do ligante asfáltico. O ensaio é padronizado pelas normas da ASTM D4422 e ASSHTO TP48, e pela norma brasileira ABNT NBR 15184.

O equipamento utilizado no Superpave é o viscosímetro Brookfield, figura 9, que permite obter gráfico de temperatura $x$ viscosidade para projeto de misturas asfálticas, por meio de medida do comportamento do fluido a diferentes taxas de cisalhamento e a diferentes tensões de cisalhamento, obtidas por rotação de hastes coaxiais que ficam mergulhados na amostras em teste.

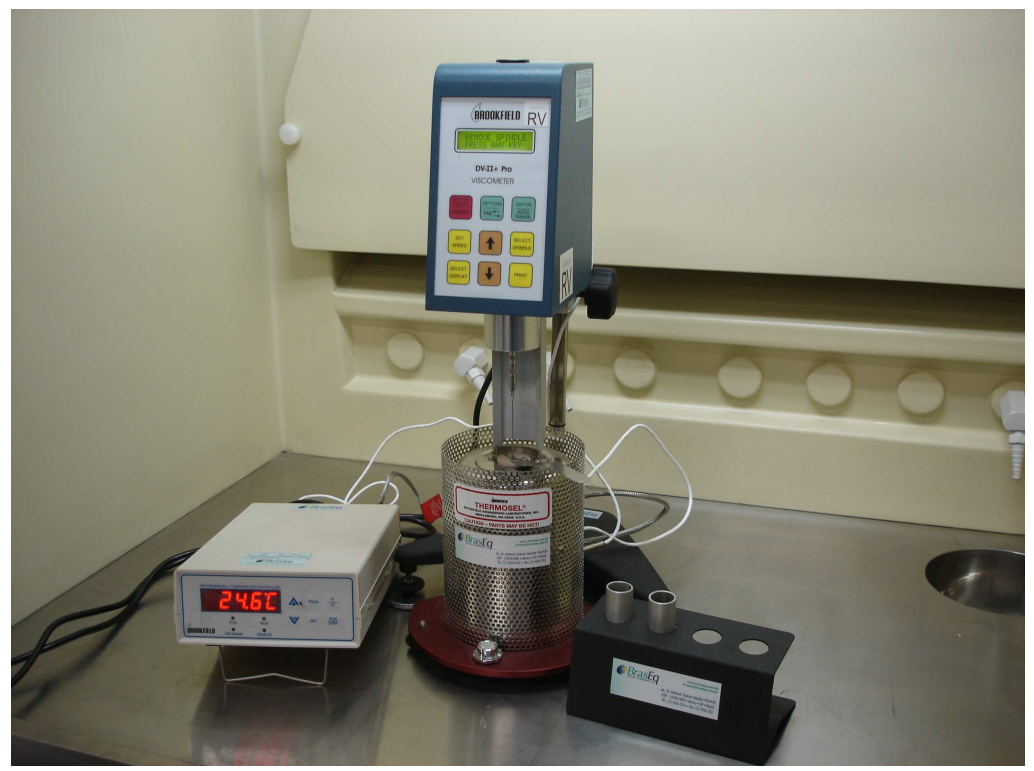

Figura 9 - Viscosímetro Brookfield

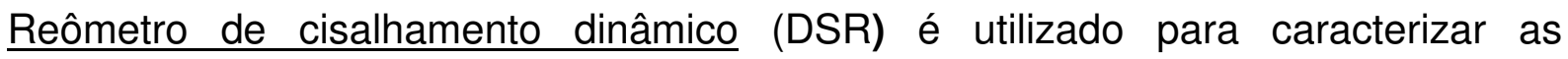
propriedades viscoelásticas do ligante asfáltico, a temperaturas altas e intermediárias, segundo a AASHTO TP5. O DSR, conhecido genericamente como reômetro dinâmico ou reômetro de cisalhamento oscilatório, tem sido utilizado pelas indústrias plásticas há vários anos. O DSR mede o módulo de cisalhamento complexo $G^{*}$ e o ângulo de fase $\delta$, de ligantes asfálticos a temperaturas e carregamento desejados. 
O módulo complexo $G^{*}$ pode ser considerado como sendo a resistência total do ligante asfáltico à deformação quando submetido à aplicação de uma dada tensão de cisalhamento.

Apresentam-se como exemplos dois tipos de ligantes asfálticos denominados de ligante $A$ e ligante $B$. Observe-se que na figura 10 tem-se a parte viscosa mais pronunciada que a parte elástica do ligante $A$ e na figura 11 a parcela mais pronunciada é a elástica para o ligante B. A parte elástica G' compreende a parte recuperável (elástica) e parte viscosa G' a não recuperável. A temperatura e freqüência de carregamento afetam significativamente o módulo complexo $G^{*}$ e o ângulo de fase $\delta$ (ROBERTS et al.,1996).

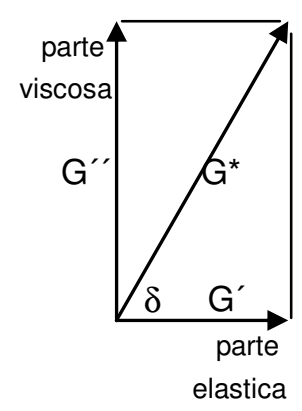

Ligante A

Figura 10 - Ligante A (ROBERTS et al., 1996)

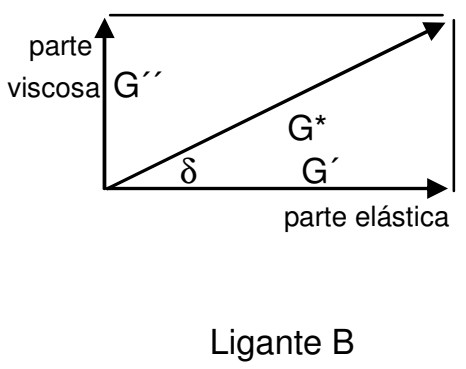

Figura 11 - Ligante B (ROBERTS et al., 1996)

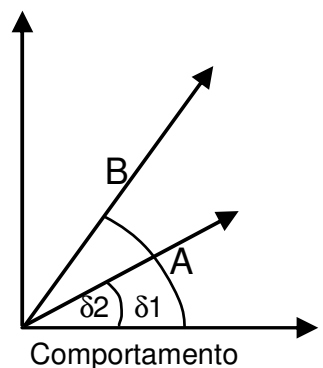

elastico

Ligante A e B

Figura 12 -

Comportamento elásticos dos ligantes $A$ e $B$

(ROBERTS et al., 1996)

À temperaturas baixas o ligante asfáltico comporta-se como um sólido, representado pela seta horizontal da figura 12. Por outro lado, o ligante comporta-se como fluido a altas temperaturas, representado pela seta vertical da mesma figura. Ocorre que os ligantes asfálticos comportam-se como materiais viscoelásticos, representados pelas setas $A$ e $B$ da figura 12. Resumidamente, pode-se constatar que os ligantes asfálticos comportam-se como sólidos e líquidos viscosos. O DRS mostra 0 comportamento do ligante asfáltico, a temperaturas de serviço do pavimento, através das medidas de $G^{*}$ e $\delta$. 


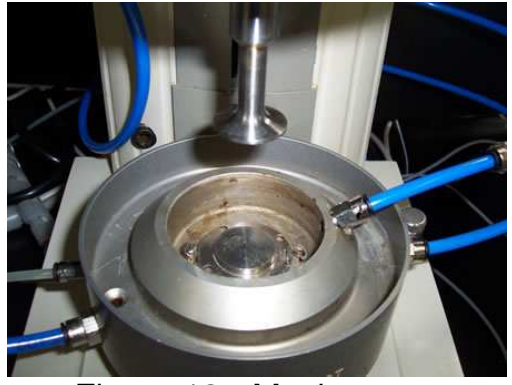

Figura 13 - Movimentos executados pelo reômetro http://pavementinteractive. org/index.php?title=DSR
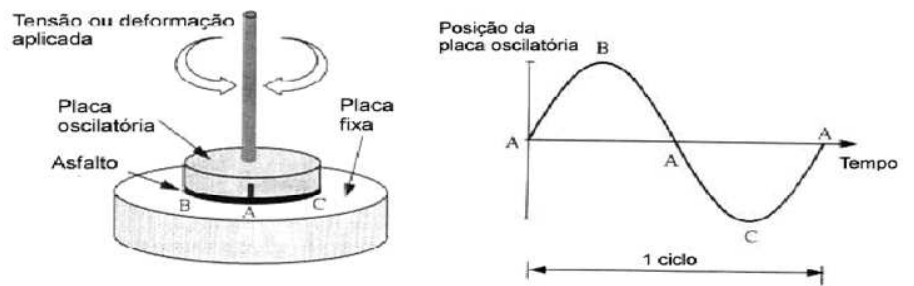

Figura 14 - Placa fixa e móvel superior do DSR. (ROBERTS et al.,1996)

O princípio de funcionamento do DRS é relativamente simples: uma película de ligante asfáltico, na ordem de $1 \mathrm{~mm}$ de espessura para temperaturas acima de $46^{\circ} \mathrm{C}$ e na ordem de $2 \mathrm{~mm}$ para temperaturas inferiores, é colocada dentro de uma banho térmico, pressionada entre as placas fixa (base) e móvel (topo) do reômetro, figura 13. Com o acionamento do equipamento, a placa móvel superior oscila, conforme mostrado na figura 14 , do ponto $A$ para 0 ponto $B$ e retorna para 0 ponto $A$ novamente, em seguida oscila do ponto $A$ para o ponto $C$, retornando para o ponto $A$ novamente, esses movimentos compreendem um ciclos de oscilação. Especifica-se que os modelos de DRS devem operar a uma freqüência de $10 \mathrm{rd} / \mathrm{s}$ ou $1,59 \mathrm{~Hz}$ e à tensão constante, embora, existam reômetros com controle de deformação constante. Essa freqüência de operação correlaciona-se com a velocidade de 100 $\mathrm{km} / \mathrm{h}$ desenvolvidas pelos veículos que irão utilizar a via. Nesse sentido pode-se utilizar freqüências menores, por exemplo, $5 \mathrm{rd} / \mathrm{s}$, para que esta freqüência simule uma velocidade correspondente de $50 \mathrm{~km} / \mathrm{h}$ e, para velocidades dos veículos muito baixas e constantes pode-se utilizar a freqüência de $1 \mathrm{rd} / \mathrm{s}$ (KENNEDY, 1994).

Como recomendação, em vez de alterar a freqüência do ensaio, pode-se fazer uso de um ligante asfáltico que apresente um valor da temperatura correspondente a um valor de PG, maior. Essa modificação é recomendada para baixas velocidades, elevado volume de tráfego e carregamento muito pesado.

A relação entre a tensão aplicada e a deformação resultante fornece $\circ \mathrm{G}^{*}$, sendo que $\mathrm{G}^{*}$ é a relação entre a tensão máxima $\tau_{\text {máx }}$ e a deformação cisalhante resultante 
máxima $-\delta_{\text {máx. }}$ O tempo de defasagem transcorrido entre a tensão aplicada e a deformação máxima resultante é o ângulo de fase $\delta$, figura 15.

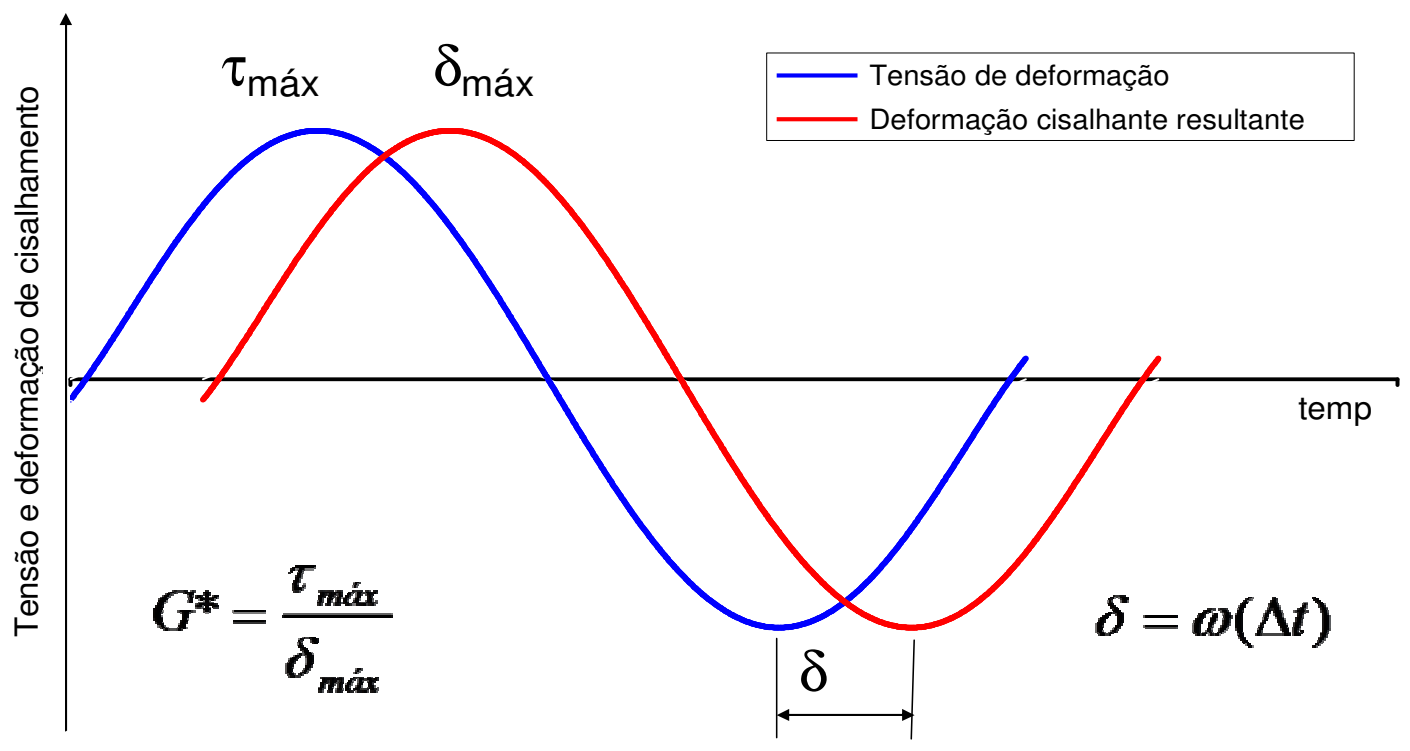

Figura 15 - Tensão e deformação cisalhante resultante http://pavementinteractive.org/index.php?title=DSR

Reômetro de cisalhamento em viga (BBR) é um ensaio em ligantes asfálticos realizado a baixas temperaturas, utilizado para determinar a vulnerabilidade do ligante asfáltico em apresentar trincamento térmico. O trincamento térmico, normalmente presente em países de clima frio e temperado, ocorre devido ao resfriamento abrupto, com queda rápida da temperatura, fazendo com que a camada do pavimento contraia-se mais rápida do que a tensão de relaxação da mistura suporte. Quando isso ocorre o pavimento desenvolve trincas numa forma de aliviar as tensões.

O trincamento causado por um único ciclo térmico é relacionado com a rigidez do ligante asfáltico na temperatura em que ocorreu o trincamento. Essa temperatura é denominada de temperatura limite de rigidez e define a temperatura de serviço do pavimento, após um determinado tempo de serviço. 
O equipamento reômetro de cisalhamento em viga do Superpave foi baseado em um equipamento desenvolvido nos anos de 1980. O procedimento de ensaio está normatizado pela AASHTO TP1. O ensaio consiste basicamente em submeter uma vigota de dimensões: $125 \mathrm{~mm}$ de comprimento, 6,25 $\mathrm{mm}$ de espessura e 12,5 mm de largura, a um carregamento estático (creep), figura 16. A vigota é mantida em banho por $60 \pm 5$ minutos, após um pré-carregamento, aplica-se uma carga de $100 \mathrm{~g}$ por um período de 240 s, figura 17.

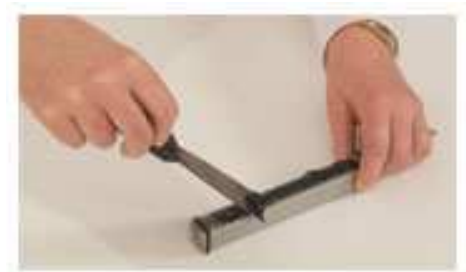

Figura 16 - Detalhe da moldagem da prova http://pavementinteractive.org/in dex.php?title=BBR

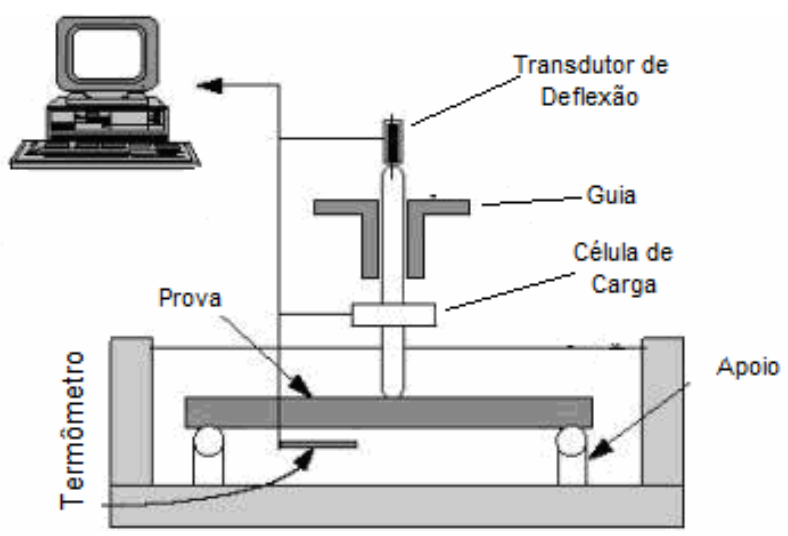

Figura 17 - Esquema do reômetro de cisalhamento em viga BBR (ROBERTS et al.,1996)

Apresenta-se na figura 18 a deflexão versus o tempo de carregamento do ensaio. Para o tempo de 60 s obtém-se a rigidez no ensaio e pode ser determinada pela equação 2. O Superpave especifica que a rigidez $S$ do ligante asfáltico deve ser inferior a $300 \mathrm{MPa}$.

$$
S(t)=\frac{P L^{3}}{4 b h^{3} \Delta(t)}
$$

onde: $\mathrm{S}(\mathrm{t})=$ rigidez estática à $60 \mathrm{~s}$

$$
\begin{aligned}
& \mathrm{P}=\quad \text { carga constante aplicada } 100 \mathrm{~g}(980 \mathrm{mN}) \\
& \mathrm{L}=\quad \text { distância ente os apoios }(102 \mathrm{~mm}) \\
& \mathrm{b}=\quad \text { largura da vigota }(12,5 \mathrm{~mm}) \\
& \mathrm{h}=\quad \text { espessura da vigota }(6,25 \mathrm{~mm}) \\
& \Delta(\mathrm{t})=\text { deflexão a } 60 \mathrm{~s} .
\end{aligned}
$$


$\mathrm{Na}$ figura 19 mostra-se a relação entre a rigidez e o tempo e para $60 \mathrm{~s}$ a inclinação correspondente tem-se o módulo de relaxação $(m)$.

Deflexão

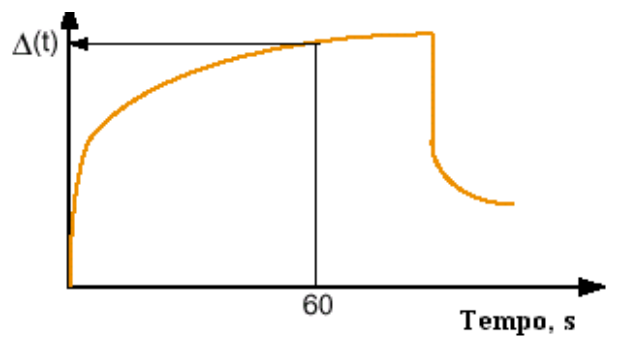

Figura 18 - Deflexão versus tempo - determinação de $\mathrm{S}(\mathrm{t})$ (ROBERTS et al.,1996)

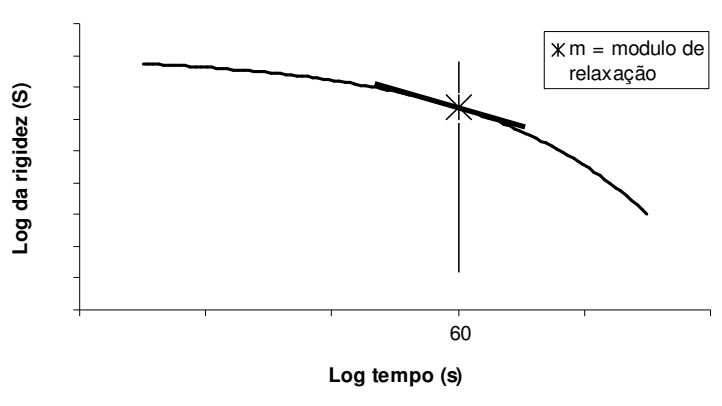

Figura 19 - Determinação de $m$ - módulo de relaxação (ROBERTS et al.,1996)

Ensaio de tração direta (DTT). A relação entre a rigidez do ligante asfáltico e dutibilidade a baixas temperaturas é relativamente boa, antes da ocorrência de quebra ou ruptura do ligante. A rigidez do ligante asfáltico obtido com o ensaio de BBR deve apresentar valores inferiores a $300 \mathrm{MPa}$, com o objetivo de se limitar a rigidez do ligante asfáltico; entretanto, o ensaio de BBR é um ensaio que caracteriza parcialmente o comportamento do ligante asfáltico a baixas temperaturas, quanto ao trincamento térmico. Existem ligantes asfálticos, principalmente os modificados por polímeros, que podem apresentar valores de rigidez acima de $300 \mathrm{MPa}$, mas não apresentam trincamento quando submetidos a uma determinada tensão, porque eles podem se deformar sem ruptura, dentro de certos limites.

Assim, o ensaio de tração direta foi desenvolvido pelo Superpave para atender a essa rigidez dútil do ligante asfáltico. Ligantes asfálticos que apresentam valores de $S$ entre $300 \mathrm{MPa}$ e $600 \mathrm{MPa}$ devem ser submetidos ao ensaio de tração direta, já para ligante asfáltico com valores de $S$ inferiores a $300 \mathrm{MPa}$ o ensaio de tração direta pode ser dispensado. Apresenta-se na figura 20 o ensaio de tração direta DTT em dois estágios, o ligante asfáltico sendo tracionado, parte a e o ligante asfáltico após ruptura, parte b. 


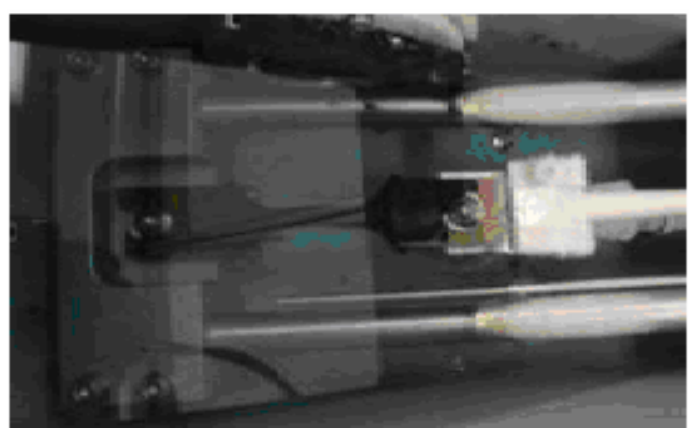

Parte a

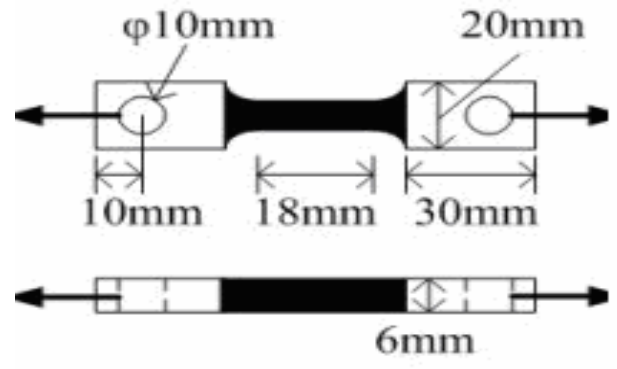

$1 \mathrm{~mm} / \mathrm{min}$

Figura 20 - Ensaio de tração direta - DTT

\subsubsection{Compactador Giratório do Superpave}

Leahy e McGennis (1999) comentam que no Superpave um outro método de compactação de misturas asfálticas passou a ser considerado, utilizando um equipamento denominado de compactador giratório, originalmente desenvolvido no Departamento de Estradas do Texas, no final da década de 30 . O conceito foi atribuído a Philippi, Raines e Love. O primeiro compactador giratório era manual, figura 21, e foi utilizado como base de um experimento entre 1940 e 1946, quando foi padronizado no Estado do Texas com especificação de método de ensaio.

Leahy e McGennis (1999) atribuem ao compactador do Texas o desenvolvimento do compactador giratório do USACE em 1950, com acionamento por motor elétrico. Este último, com projeto básico atribuído a Joseph P. Wislocki, que obteve a patente, é apresentado na figura 22. McRae ${ }^{4}$ (1957, apud Leahy e McGennis ,1999) acreditava que as propriedades das misturas asfálticas produzidas por impacto eram diferentes das propriedades das misturas asfálticas de campo. Assim, o processo de densificação de misturas asfálticas com o compactador giratório era semelhante ao que ocorre em campo, e que a compactação em laboratório de misturas asfálticas poderia ser atingida por esforço de cisalhamento.

\footnotetext{
${ }^{4}$ McRae, J.L. Compaction of Bituminous Concrete, "Proceedings" (1957), apud Leahy e McGennis (1999)
} 


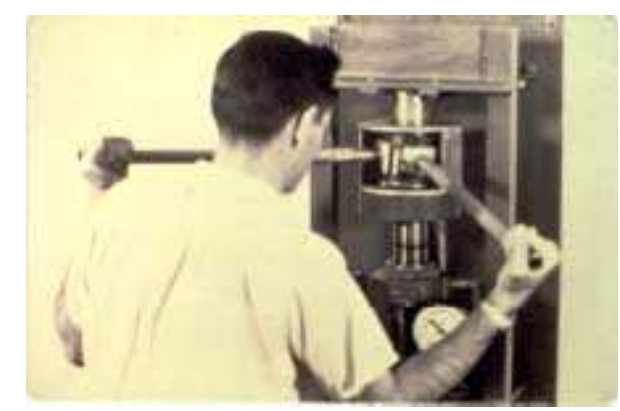

Figura 21 - Compactador Giratório USACE década de 50 http://www.tfhrc.gov/pavement/asphalt

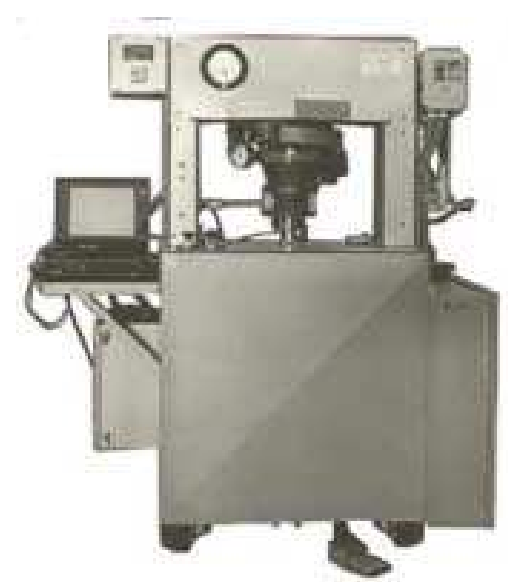

Figura 22 - Compactador Giratório Texas (op. manual) http://www.tfhrc.gov/pavement/asphalt/labs/mixtures

O equipamento compactador giratório consiste basicamente em um cilindro de 15 $\mathrm{cm}$ ou de $16 \mathrm{~cm}$ de diâmetro, em que a amostra de mistura asfáltica, nas condições de compactação, é colocada dentro desse molde e duas bases cilíndricas e paralelas pressionam a amostra a uma pressão constante. Uma das extremidades do molde sofre uma oscilação de um lado para o outro a um determinado ângulo. $O$ número de oscilações é o número de giros que a amostra é submetida.

Leahy e McGennis (1999) relatam que o compactador giratório do Superpave foi desenvolvido no início dos anos 90 como parte do programa SHRP, criado em 1987. O compactador giratório do Superpave é uma soma do equipamento desenvolvido no Texas e do equipamento giratório do LPC francês. Os pesquisadores do SHRP ficaram impressionados com o princípio de funcionamento do compactador francês, semelhante ao equipamento desenvolvido inicialmente no Texas em 1939 e, logo as modificações feitas pelos franceses foram somadas ao compactador giratório do Superpave. A avaliação da compactação de misturas asfálticas com o compactador giratório do Superpave envolve parâmetros volumétricos. O equipamento fixa três parâmetros: ângulo de compactação $=1,25^{\circ}$, pressão de compactação de $0,6 \mathrm{MPa} e$ velocidade de giro de 30RPM.

A chave principal do projeto de misturas asfálticas do programa Superpave é o compactador giratório do Superpave. O processo de compactação com esse equipamento gera corpos-de-prova de misturas asfálticas em estados similares às 
amostras obtidas em campo, submetidas à ação do tráfego. No compactador giratório do Superpave o número de giros é variado para simular o nível de tráfego (ROBERTS et al.1996).

Os mesmos autores citam a correlação do número de giros com o nível de tráfego que a mistura asfáltica será submetida em serviço. Misturas que serão submetidas a altas temperaturas e a elevadas cargas de tráfego em campo, deverão ser mais densas e em laboratório essas misturas deverão ser compactadas com densidades mais altas. Essas densidades mais altas, em laboratório, são obtidas com o aumento do número de giros.

Três índices: $\mathrm{N}_{\mathrm{i}}, \mathrm{N}_{\mathrm{d}}$ e $\mathrm{N}_{\mathrm{m}}$ são necessários para definir o projeto de misturas asfálticas pelo método do Superpave. $\mathrm{N}_{\mathrm{d}}$, denominado de número de projeto, é o número de giros para produzir uma densidade na amostra que é equivalente à densidade que se espera em campo, após ter sido submetida à ação inicial do tráfego. Nesse processo o teor de ligante asfáltico na mistura é selecionado para que a mistura asfáltica tenha $4 \%$ de volume de vazios para $N_{d}$ giros (ROBERTS et al.,1996).

$\mathrm{N}_{\mathrm{i}}$, denominado número inicial, é uma medida da compatibilidade da mistura. Misturas que, quando submetidas ao compactador giratório do Superpave, compactam rapidamente, são misturas que apresentarão dificuldades de serem compactadas em campo e podem ser instáveis quando submetidas à ação do tráfego, normalmente tratam-se de misturas finas e misturas que possuem grande quantidade de areia natural, ou ainda misturas que apresentam descontinuidades na distribuição granulométrica na fração areia. Misturas com essas características são denominadas de tender mix. Misturas com 4\% para $\mathrm{N}_{d}$ devem ter pelo menos $11 \%$ de vazios para $\mathrm{N}_{\mathrm{i}}$.

$\mathrm{N}_{\mathrm{m}}$, denominado de número máximo, é o número de giros necessários para produzir uma densidade em laboratório que absolutamente nunca deverá ser excedida em campo. $\mathrm{N}_{d}$ fornece uma estimativa da última densidade de campo. $\mathrm{N}_{m}$ fornece uma densidade como um fator de segurança, para assegurar que a mistura não atinja 
valores de volume de vazios susceptíveis à formação de trilha de roda. O volume de vazios para $\mathrm{N}_{\mathrm{m}}$ deve ser até no máximo $2 \%$.

O número de giros para $\mathrm{N}_{d}$ foi estabelecido com base em ensaios de laboratório e de campo, comparando as densidades encontradas em campo com as densidades de laboratório para vários números de giros. Uma vez que o $\mathrm{N}_{d}$ foi estabelecido para cada nível de tráfego e a respectiva temperatura do ar, os números de giros para os índices $\mathrm{N}_{\mathrm{i}}$ e $\mathrm{Nm}$ foram estabelecidos com base em $\mathrm{N}_{\mathrm{d}}$. As equações 3 e 4 para $\mathrm{N}_{\mathrm{i}}$ e $\mathrm{N}_{\mathrm{m}}$, respectivamente, são apresentadas abaixo.

$$
\begin{aligned}
& N_{i}=\left(N_{d}\right)^{0,45} \\
& N_{M}=\left(N_{d}\right)^{1,10}
\end{aligned}
$$

O método de dosagem do Superpave propõe, tabela 10, valores para os três índices, associados a quatro níveis de tráfego (AASHTO R 35-04).

\begin{tabular}{c|c|c|c} 
Tabela 10 - Valores de $\mathbf{N}_{\text {ini }}, \mathbf{N}_{\text {des }}$ e $\mathbf{N}_{\text {máx }}$ para diferentes níveis de tráfego (AASHTO R 35-04) \\
\hline \multirow{2}{*}{$\begin{array}{c}\text { Tráfego de projeto } \\
\text { ESALs x 10 }\end{array}$} & \multicolumn{3}{|c}{ Parâmetros de compactação } \\
\cline { 2 - 4 } & $\mathbf{N}_{\text {ini }}$ & $\mathbf{N}_{\text {des }}$ & $\mathbf{N}_{\text {máx }}$ \\
\hline$<0,3$ & 6 & 50 & 75 \\
03 a 3,0 & 7 & 75 & 115 \\
3,0 a 30 & 8 & 100 & 160 \\
$>$ 30 & 9 & 125 & 205 \\
\hline
\end{tabular}

Apresentam-se na tabela 11 os requisitos volumétricos da dosagem Superpave (AASHTO M 323-04).

\begin{tabular}{|c|c|c|c|c|c|c|c|c|c|c|c|}
\hline \multirow{3}{*}{$\begin{array}{c}\text { Tráfego } \\
\mathrm{N} \\
\text { AASHTO } \\
10^{6}\end{array}$} & \multirow{2}{*}{\multicolumn{3}{|c|}{$\begin{array}{l}\text { Densidade relativa } \\
\text { requerida, } \% \mathrm{G}_{\mathrm{mm}}\end{array}$}} & \multicolumn{6}{|c|}{$\begin{array}{l}\text { Vazios do agregado mineral (VAM), \% } \\
\text { mínima }\end{array}$} & \multirow{3}{*}{$\begin{array}{c}\text { Relação } \\
\text { betume } \\
\text { vazios } \\
\text { (RBV), \% }\end{array}$} & \multirow{3}{*}{$\begin{array}{c}\text { Relação } \\
\text { pó/betum } \\
\text { e efetivo } \\
\text { (RPB), \% }\end{array}$} \\
\hline & & & & \multicolumn{6}{|c|}{$\begin{array}{l}\text { Diâmetro Máximo Nominal (DMN), } \\
\text { mm }\end{array}$} & & \\
\hline & $\mathbf{N}_{\text {ini }}$ & $\mathbf{N}_{\text {des }}$ & $\mathbf{N}_{\text {máx }}$ & 37,5 & 25,0 & 19,0 & 12,5 & 9,5 & 4,75 & & \\
\hline$<0,3$ & $\leq 91,5$ & 96,0 & $\leq 98,0$ & 11,0 & 12,0 & 13,0 & 14,0 & 15,0 & 16,0 & & 0,6 a 1,2 \\
\hline 0,3 a 3 & $\leq 90,5$ & 96,0 & $\leq 98,0$ & 11,0 & 12,0 & 13,0 & 14,0 & 15,0 & 16,0 & $65-78$ & 0,6 a 1,2 \\
\hline 3 a 10 & $\leq 89,0$ & 96,0 & $\leq 98,0$ & 11,0 & 12,0 & 13,0 & 14,0 & 15,0 & 16,0 & $65-75$ & 0,6 a 1,2 \\
\hline 10 a 30 & $\leq 89,0$ & 96,0 & $\leq 98,0$ & 11,0 & 12,0 & 13,0 & 14,0 & 15,0 & 16,0 & $65-75$ & 0,6 a 1,2 \\
\hline$>30$ & $\leq 89,0$ & 96,0 & $\leq 98,0$ & 11,0 & 12,0 & 13,0 & 14,0 & 15,0 & 16,0 & $65-75$ & 0,6 a 1,2 \\
\hline
\end{tabular}

Tabela 11 - Requisitos volumétricos da dosagem Superpave (AASHTO M 323-04) 
No processo de dosagem do Superpave, os autores relatam que, após a usinagem, a mistura deve permanecer em estufa à temperatura de compactação por duas horas. Esse período é para que ocorra a absorção do ligante asfáltico pelo agregado, e é de fundamental importância para alguns tipos de agregados. A não consideração pode acarretar em misturas com menor durabilidade (BERTOLLO, 2002)

Para a compactação no compactador giratório do Superpave são fornecidos os parâmetros de entrada e a massa da mistura, a densidade aparente pode ser estimada com esses valores. Essa estimativa não reflete a densidade do corpo-deprova, pois, o corpo-de-prova compactado não apresenta uniformidade de densidade em seu volume. Após cada amostra ter sido compactada até $\mathrm{N}_{\mathrm{m}}$, o corpode-prova é removido do molde é procede-se ao cálculo da densidade aparente por pesagem hidrostática. A densidade obtida para $\mathrm{N}_{\mathrm{m}}$ é comparada com a densidade calculada, obtendo-se um fator de correção. As densidades para $N_{i}$ e $N_{d}$ são corrigidas com esse fator.

Watson et al. (2008) em pesquisa de campo e laboratório com objetivo de avaliar o desempenho das misturas da Geórgia USA, projetadas pelo compactador giratório Superpave e compará-las com o Marshall, procuraram consolidar o número de giros estabelecidos pelo método, pois, quando o número de giros designados no projeto é muito alto, a mistura pode ser resistente à deformação permanente, entretanto, sua compactação em campo pode ser difícil, além de haver comprometimento da durabilidade do pavimento, face à vida de fadiga, devido ao menor teor de ligante.

$\mathrm{Na}$ pesquisa foram utilizados: ligante com classificação PG e agregados que também atendessem as especificações do Superpave. Foram feitos ensaios em campo (deformação permanente, trincamento e volume de vazios) e em laboratório (suscetibilidade à deformação permanente, suscetibilidade à água, fadiga).

Nos ensaios de laboratório empregou-se o teor ótimo de ligante determinado para vários níveis de giros. Os resultados foram usados para estabelecer um nível de giros ótimo para as misturas asfálticas usadas na Geórgia, USA. 
Estudos de campo conduzidos por Watson et al. (2008) foram feitos como base comparativa de projeto de mistura, com 16 projetos Marshall e 16 projetos Superpave, com características próximas entre si quanto à idade, condições de tráfego, tipo de mistura, proveniência do agregado, região geográfica e mesma espessura 12,5 mm. Na tabela 12, estão apresentadas as características médias de cada trecho.

Tabela 12 - Valores médios dos trechos da pesquisa (WATSON et. al. 2008)

\begin{tabular}{l|c|c}
\hline & Marshall & Superpave \\
\hline Idade média & 6,1 anos & 4,7 anos \\
Tráfego médio diário & 21.245 & 21.420 \\
Teor médio de ligante & $5,28 \%$ & $4,94 \%$ \\
\hline
\end{tabular}

A determinação da deformação permanente para cada trilha de roda foi feita manualmente, usando uma régua e uma escala, dos 32 projetos analisados 11 Marshall e 8 Superpave apresentaram deformação permanente mensuráveis de 1,5 $\mathrm{mm}$ e $1,3 \mathrm{~mm}$, respectivamente.

Além disso, comparou-se a deformação permanente dos projetos Superpave em que foram empregadas misturas asfálticas com ligante PG 76-22 - ligante modificado por polímero, com as misturas asfálticas usinadas com asfalto convencional PG 67-22, denominadas de misturas-padrão, a fim de avaliar o quão efetivo é o ligante modificado por polímeros no controle da deformação permanente. Os resultados estão compilados na tabela 13.

Tabela 13 - Deformação permanente e tráfego relacionados ao tipo de ligante asfáltico (WATSON et. al. 2008)

\begin{tabular}{l|c|c}
\cline { 2 - 3 } & $\begin{array}{c}\text { PG 76-22 } \\
\text { Ligante modificado por } \\
\text { polímeros }\end{array}$ & $\begin{array}{c}\text { PG 67-22 } \\
\text { Ligante padrão }\end{array}$ \\
\hline $\begin{array}{l}\text { Deformação } \\
\text { permanente média }\end{array}$ & $1,5 \mathrm{~mm}$ & $1,0 \mathrm{~mm}$ \\
\hline Tráfego médio diário & 38.323 & 10.152 \\
\hline
\end{tabular}


Pelos valores medidos, verificou-se que não houve diferença significativa, mas as misturas com polímeros foram utilizadas nos projetos Superpave com os maiores volumes de tráfego; no caso da tabela 13, o tráfego é praticamente 4 vezes maior que o do outro trecho com asfalto convencional.

Outro aspecto também contemplado na pesquisa foi o pouco trincamento tanto nos trechos com as misturas asfálticas com os projetos Marshall, quanto nos Superpave. Esperava-se que as misturas com polímero tivessem menor tendência ao trincamento, mas os resultados não se mostraram significativos, apresentando correlação fraca.

Foram extraídos corpos-de-prova das trilhas de roda de cada um dos projetos para determinar a densidade e o percentual de vazios de campo, os resultados estão apresentados na tabela 14.

Tabela 14 - Volume de vazios após construção e após solicitação pelo tráfego (WATSON et. al. 2008)

\begin{tabular}{lcc} 
& Marshall & Superpave \\
\hline Volume de vazios de campo & $3,8 \%$ & $5,7 \%$ \\
\hline $\begin{array}{l}\text { Volume de vazios no controle de compactação da } \\
\text { construção }\end{array}$ & $6,1 \%$ & $7,3 \%$ \\
\hline
\end{tabular}

Os resultados mostram que os vazios no Superpave estavam longe dos $4 \%$ de projeto, indicando que o nível $\mathrm{N}_{d}$ utilizado foi maior que o necessário. As misturas dosadas com o Superpave poderiam ter sido aplicadas com maior teor de ligante porque houve pouca deformação permanente nos projetos analisados. Para as misturas Superpave, um aumento do teor de ligante pode ser alcançado em parte pela redução do número de giros de compactação giratória. Entretanto, se o nível de giros for reduzido, o projeto da mistura pode ser modificado quanto à graduação para se obter os requisitos volumétricos sem necessitar de um aumento do teor de ligante.

Nos estudos em laboratório a pesquisa contemplou o efeito que os níveis de giros têm sobre o desempenho da mistura (35, 60, 85 e 110 giros). A mistura Superpave 
com DMN de 12,5mm, agregado granítico, foi utilizada como referência. Foram feitas diversas análises estatísticas.

A primeira análise foi o locking point. Esse parâmetro é o ponto no qual a estrutura de agregados começa a travar, fazendo com que um acréscimo no número de giros gere um potencial para fratura dos agregados, além de aumentar a dificuldade em se obter a compactação desejada em campo. Com o aumento do número de giros depois que o locking point é alcançado, a densidade das amostras continuará a crescer porque os agregados fraturados preencherão os vazios da estrutura. Não se deseja ter agregados fraturados nas condições de campo devido à criação de superfícies não recobertas, fazendo com que haja uma tendência da mistura a ser mais suscetível à água, acelerando a deterioração do pavimento.

Um dos aspectos mais difíceis de usar o conceito do locking point tem sido a definição de quando ele é realmente alcançado. Nesta pesquisa, foi considerado locking point quando a altura da amostra permaneceu a mesma por 2, 3 e 4 giros consecutivos. A partir dos resultados obtidos, verificou-se uma tendência de que 69 giros representassem melhor a densidade obtida em campo. Segundo a equação 5, 69 giros resultaram em amostras com massa específica média máxima da mistura $\left(\mathrm{G}_{\mathrm{mm}}\right)$ de $94,6 \%$ (ou 5,4\% de volume de vazios). Este valor se assemelha ao volume de vazios médio em campo das misturas Superpave estudadas (5,7\%). Isto indica que o nível $\mathrm{N}_{d}$ previamente especificado para as misturas Superpave era maior que o necessário e que o locking point de 69 giros pode resultar em uma densidade de laboratório próxima a densidade indesejável de campo.

$$
\% G_{m m} x x=100 \times \frac{G_{m b} \times h_{d}}{G_{m m} \times h_{x x}}
$$

onde: $\quad \% G_{m m} x x=$ porcentagem de $G_{m m}$ a um nível de giros xx;

$\mathrm{G}_{\mathrm{mb}}=$ massa específica aparente da mistura $\left(\mathrm{g} / \mathrm{cm}^{3}\right)$;

$\mathrm{h}_{\mathrm{d}}=$ altura do corpo-de-prova nos giros do $\mathrm{N}_{\text {projeto; }}$;

$\mathrm{h}_{\mathrm{xx}}=$ altura da amostra no nível de giros $(\mathrm{mm})$. 
Quanto à suscetibilidade à deformação permanente em trilha de roda foram realizados ensaios de acordo com a especificação número115 do Georgia Department of Transportation (GDOT), com volume de vazios de 5,0\% $\pm 1 \%$. Foram utilizadas misturas Superpave com agregado de DMN de $25 \mathrm{~mm}\left(64^{\circ} \mathrm{C}\right.$ e $\left.50^{\circ} \mathrm{C}\right)$ e de $12,5 \mathrm{~mm}\left(64^{\circ} \mathrm{C}\right)$. A deformação máxima deve ser de $5 \mathrm{~mm}$ a $64^{\circ} \mathrm{C}$ para o ensaio com o Asphalt Pavement Analyzer - (APA). Entretanto, os dados indicaram basicamente que todas as misturas com DMN de $25 \mathrm{~mm}$ poderiam ser projetadas com um máximo de 50 giros se o ensaio com o APA fosse realizado a $50^{\circ} \mathrm{C}$.

A resistência das misturas asfálticas à ação da água, para todas as misturas, foi medida utilizando-se o ensaio especificado pelo GDOT (Lottman modificado). Acredita-se que esse ensaio seja mais severo e mais representativo das condições reais de campo que o da AASHTO T 283. Há uma diferença em termos de dimensão de corpo-de-prova entre os ensaios, uma vez que o da AASHTO T 283 usa corposde-prova tipo Marshall de 4" de diâmetro e o outro 6". A suscetibilidade à água foi determinada com corpos-de-prova de 4" (compactação com soquete Marshall) e 6" (compactador giratório). Entretanto, não se verificou diferença estatisticamente significativa entre ambas as medidas de corpos-de-prova nesta avaliação.

Complementando o estudo, o ensaio de fadiga foi realizado de acordo com a AASHTO TP8. Foram usados 2 níveis de tensão (250 e $500 \mu \varepsilon$ ). O rompimento à fadiga ficou definido como sendo o número de ciclos no qual a rigidez da mistura asfáltica cai a $50 \%$ do valor inicial. Verificou-se que o fator giros não foi estatisticamente significante. Entretanto, a proveniência do agregado e o nível de tensões, assim como a interação entre ambos, afetaram os resultados significativamente. A média de vida de fadiga de várias misturas testadas a $250 \mu \varepsilon$ foi aproximadamente 25 vezes maior em comparação com as ensaiadas a $500 \mu \varepsilon$. A vida de fadiga média de várias misturas em um mesmo nível de tensão, compactadas com 35 e 60 giros foi aproximadamente $200 \%$ da vida de fadiga média das misturas compactadas a 85 e 110 giros.

Watson et al. (2008) concluem que tanto as misturas asfálticas dosadas com o Marshall, como também as misturas dosadas com o Superpave apresentaram, de 
maneira geral, desempenho bom, com pouca deformação permanente e trincamento após um período de 4 a 6 anos.

Os resultados de deformação permanente foram similares entre os projetos Superpave que utilizaram ligantes modificados e os que empregaram ligante não modificado. Entretanto, as misturas com polímeros foram submetidas a volumes de tráfego quase 4 vezes maiores. Os autores comentam que não se sabe se as misturas não modificadas teriam desempenho semelhante sob as mesmas condições de tráfego, embora, a prática de escolher um ligante com maior PG para considerar diferenças quanto ao tráfego é efetiva.

A média de teor de ligante nos projetos Marshall foi da ordem de 0,34\% maior que a média dos teores obtidos pelo Superpave. As misturas Superpave provavelmente não atingirão o volume de vazios de projeto de 4,0\% durante a vida do pavimento. Após quase 5 anos a média de volume de vazios medida nas trilhas de roda foi de $5,7 \%$ nos projetos Superpave e 3,8\% nos do Marshall. Considerando as comparações em campo, as especificações das misturas Superpave poderiam ser modificadas para aumentar o teor de ligante e as propriedades dos VAM sem alterar a resistência à deformação permanente.

Com os resultados de deformação permanente de campo comparado com os resultados obtidos em laboratório com o APA, concluíram que a temperatura no ensaio APA de 50ㄷ para misturas a quente, representa melhor as altas temperaturas de serviço de misturas, ao invés dos $64^{\circ} \mathrm{C}$, para a localidade onde 0 experimento foi realizado.

Os resultados quanto a suscetibilidade à água das amostras Marshall de 4" poderiam explicar 19\% da variação nas amostras de 6" do giratório. A comparação não foi boa o bastante para estabelecer um fator de correlação entre amostras de 4" e 6". A procedência do agregado foi o fator que afetou mais significantemente os resultados de suscetibilidade à água. Entretanto, houve alguma interação entre a procedência do agregado e o nível de giros (teor de ligante) que não poderia ser separada. 
Por fim, concluem que as misturas de laboratório com 69 giros deram resultados de densidade similares àqueles encontrados com as amostras de campo. Além disso, 0 GDOT estabeleceu o uso de 65 giros como o nível $\mathrm{N}_{d}$ para as misturas Superpave. Ajustes quanto ao PG podem considerar diferenças quanto aos níveis de tráfego. $\mathrm{A}$ procedência do agregado e os níveis de tensão foram os fatores mais significativos nos resultados de fadiga. Entretanto, as amostras com 85 e 110 giros apresentaram apenas metade da vida de fadiga das amostras com teor ótimo a 35 e 60 giros. A vida de fadiga foi aproximadamente 25 vezes maior quando o nível de tensão foi reduzido de 500 para $250 \mu \varepsilon$. Para aumentar a vida de fadiga, o nível de tensão na fibra inferior da estrutura da camada asfáltica deveria ser reduzido por meio do aumento da espessura da estrutura quando necessário, com base na análise mecanicista do projeto do pavimento.

Bahia e Faheem (2007) comentam da possibilidade de se extrair do compactador giratório do Superpave, parâmetros que se correlacionem com as propriedades mecânicas das misturas asfálticas. Um método, para a interpretação dos resultados do compactador giratório do Superpave, com o objetivo de determinar o desempenho de misturas asfálticas, pode ser dividido em dois estágios:

a) simular o comportamento da compactação em campo, Isto é, medir a energia necessária para densificar a mistura asfáltica entre os números de giros de 8 e o número de giros necessários para atingir 92\% densidade máxima da mistura com compactador giratório do Superpave. Essa medida é denominada de contruction densification index - CDI, que em uma tradução livre seria: índice de densificação de construção.

b) o segundo estágio reflete o desempenho da mistura asfáltica sob a ação do tráfego, isto é, a medida da energia necessária para compactar a mistura asfáltica entre $92 \%$ e $98 \%$ da densidade máxima da mistura. Essa medida é denominada de traffic densification indexTDI, da mesma forma: índice de densificação pelo tráfego. 
O valor de $98 \%$ da densidade máxima da mistura é considerado crítico, pois a mistura asfáltica nessas condições apresenta $2 \%$ de volume de vazios e ela se encontra no limite da zona de falha por fluência. Misturas asfálticas com valores elevados de TDI tendem a apresentar boa resistência à deformação permanente em trilha de roda. Na figura 23 apresenta-se a definição das medidas de CDI e TDI e a diferença entre a densificação de dois tipos de misturas asfálticas, uma com distribuição granulométrica considerada fina e outra mais grossa.

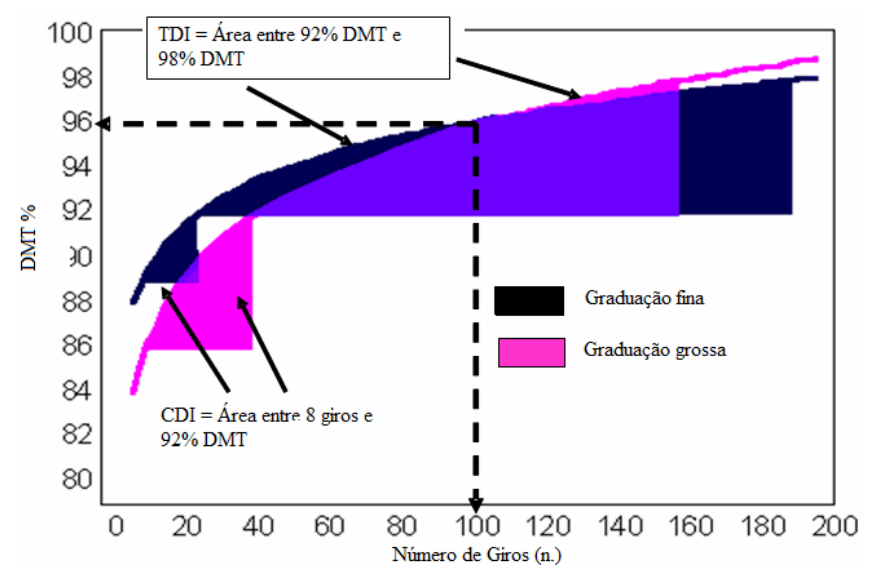

Figura 23 - Definição de CDI e TDI entre dois tipos de graduação fina e grossa (BAHIA E FAHEEM, 2007)

Mostra-se na figura 23 que é possível detectar desempenho de misturas asfálticas diferentes com o emprego dos índices CDI e TDI. A mistura com graduação fina apresenta baixo valor de CDI, o que denota baixa resistência de densificação na construção, ou facilidade excessiva de densificação. Entretanto, a mistura apresenta elevado valor de TDI o que indica uma boa resistência à densificação pelo tráfego.

Embora, os conceitos de CDI e TDI parecessem lógicos e úteis quando foram introduzidos, ainda pairava dúvidas sobre a utilização das medidas volumétricas sem a consideração da tensão de distribuição da carga no topo do corpos-de-prova durante a compactação. GULER et al (2000) descreve um equipamento desenvolvido com a finalidade de medir a força de compactação gerada no topo do corpo-de-prova, denominado de Giratory Load Plate Assembly - GLPA. 


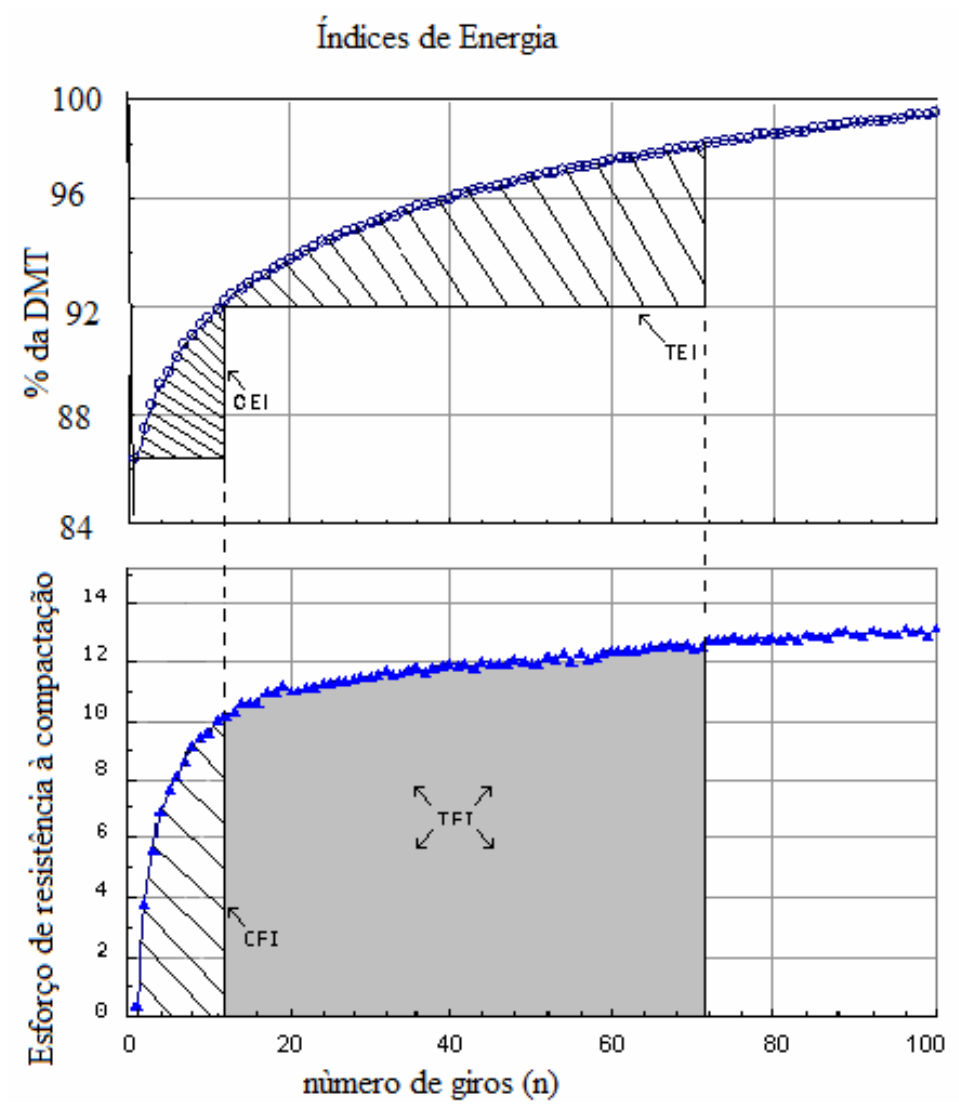

Figura 24 - Índices de energia CEI, TEI, CFI e TFI - (BAHIA e FAHEEM, 2007)

Com esse equipamento foi possível medir a energia produzida para a densificação das misturas asfálticas durante o processo de compactação com a prensa de compactação giratória. A energia gerada pela resistência à compactação entre o $\mathrm{Ni}$ e $\mathrm{N}$ necessária para atingir $92 \%$ da densidade máxima teórica foi denominada de compaction force index - CFI, índice de força de compactação. Já a energia depreendida pela prensa de compactação giratória para densificar a amostra entre $92 \%$ e $98 \%$ da densidade máxima teórica foi denominada de traffic force index - TFI, figura 24.

Bahia e Faheem (2007) relatam que em 2002 estudos patrocinados pelo National Cooperative Highway Research Program - NCHRP foram conduzidos para investigar a relação entre os parâmetros da prensa de compactação giratória e a deformação permanente em trilha de roda em serviço. Os estudos mostraram que a tensão máxima de compactação relaciona-se satisfatoriamente com a deformação permanente. 
$\mathrm{Na}$ mesma linha, um segundo equipamento foi desenvolvido para medir a excentricidade que ocorre durante a compactação. Denominado de pressure distribution analyzer - PDA - para o português, analisador de distribuição de pressão. Devido ao esforço de compactação necessário para vencer o cisalhamento da amostra e, por conseguinte, propiciar a misturação, com esse equipamento é possível determinar a excentricidade através do sinal da célula de carga. A equação 6 , fornece o esforço de resistência à compactação (ळ):

$$
\omega=\frac{4 e P \theta}{A h}
$$

onde: $\quad \omega=$ esforço de resistência à compactação $(\mathrm{N} / \mathrm{m} 2)$,

$e=$ excentricidade da força resultante $(\mathrm{m})$,

$P=$ Intensidade da força resultante $(\mathrm{N})$,

$\theta=$ ângulo de inclinação $1,25^{\circ}$,

$A$ = área do corpo-de-prova $\left(\mathrm{m}^{2}\right) \mathrm{e}$,

$h=$ altura do corpo-de-prova a qualquer número de giros (m)

Os autores concluem que os estudos sobre os índices, CEI, TEI, CFI e TFI extraídos da prensa de compactação giratória, ainda carecem de estudos que direcionem o estabelecimento de um fator campo x laboratório.

Utilizando o conceito de índice de densificação de construção, do inglês contruction densification index - CDI, a tese de mestrado apresentada por (Nascimento 2008) propõe a dosagem de misturas asfálticas tipo densa, com foco na prevenção da deformação permanente em trilha de roda, baseada em critérios oriundos do comportamento dos materiais na compactação giratória pelo equipamento do Superpave e em ensaios mecânicos. Constatou que os índices obtidos com o compactador giratório do Superpave são sensíveis ao grau de intertravamento do esqueleto pétreo e ao teor de ligante, tendo boa correlação entre si e com o comportamento das misturas asfálticas quanto à deformação permanente em trilha de roda. A pesquisa consistiu em avaliar oito tipos de misturas asfálticas: com dois tipos de ligantes asfálticos denominados de CAP 20 (especificação anterior à vigente) correlato ao CAP 50/70 (especificação atual) de origem das refinarias 
distintas: REVAP e REGAP, variou-se também a distribuição granulométrica em tamanho máximo nominal - TMN de 25, 19, 12,5 e 9,5 mm.

A pesquisa se pautou em correlacionar os teores de ligantes asfálticos em misturas compactadas com o Marshall com 75 golpes por face e a Superpave Gyratory Compactor - SGC com $\mathrm{N}_{d}=100$ giros. Conforme dados obtidos, os teores de ligante com o compactador giratório foram inferiores aos teores obtidos com o Marshall. O trabalho contempla também a avaliação da deformação permanente em trilha de roda com emprego do simulador de tráfego tipo LCP. Os resultados apontaram boa correlação, não só entre os próprios índices: CDI, TDI, ponto de travamento dos agregados (PTA) também denominado de locking point e Flow Number - (FN) obtido com o ensaio de creep, como também desses índices com os resultados obtidos com o simulador de tráfego francês tipo LCP, principalmente para índice TDI e em correlação menor com os índices CDI e FN. Dentre as várias conclusões do trabalho autor comenta que o ligante asfáltico exerce pouca influência na resistência a deformação permanente além de não garantir estabilidade do material. $O$ autor recomenda, dentre outros pontos, que esse estudo deve servir de base para nortear outras pesquisas que contemple o comportamento a vida de fadiga.

\subsubsection{Teor ótimo de ligante no Superpave}

A determinação do teor ótimo de ligante asfáltico em misturas asfálticas pelo método do Superpave subdivide-se em duas etapas. Na primeira, a determinação do teor ótimo de ligante asfáltico no Superpave é definido como o teor de ligante que produz $4 \%$ de volume de vazios com $\mathrm{Nd}$. Na segunda etapa, para que o teor encontrado anteriormente seja melhor definido, procede-se à moldagem de mais três corpos-deprova variando-se o teor de ligante de $-0,5 \%+0,5 \%$ e $+1,0 \%$ em relação ao teor encontrado na primeira etapa. Os quatro ensaios são plotados em um único gráfico de número de giros versus densidade máxima teórica - DMT, em que a DMT assume valor de $100 \%$. Adotando o teor ótimo de ligante asfáltico para $4 \%$ de volume de vazios, obtém-se o teor ótimo para $96 \%$ da DMT. É recomendado que após a escolha do teor ótimo de projeto seja realizado ensaio para verificação da 
susceptibilidade da mistura à água com o ensaio AASHTO T 283 (ROBERTS et al., 1996).

\subsection{Dosagem de Misturas asfálticas pelo Método Francês}

O procedimento de dosagem de misturas asfálticas utilizado na França difere bastante dos procedimentos norte-americano e também do brasileiro. Grande parte de suas especificações normativas já foram incorporadas à União Européia. A dosagem de uma mistura asfáltica é resultado de um processo que envolve 5 níveis de ensaios, identificados: 0, 1, 2, 3 e 4. Em cada nível são realizados um determinado conjunto de ensaios que se correlacionam com a importância da rodovia: conforme a rodovia passa a ter características estruturais maiores, devido ao aumento de tráfego de caminhões, passa-se a utilizar um nível maior.

O nível 0 é a definição das características da composição das misturas, com sua formulação propriamente dita, antes da execução dos ensaios, em que são prédefinidos os tipos de misturas e as faixas granulométricas adotadas (não há especificação de faixa nas normas francesas), o tipo de ligante asfáltico a ser empregado, os materiais pétreos e também tipos de aditivos caso seja necessário (AFNOR NF EN 13108-1, 2007). No Brasil, esse nível correlaciona-se com as especificações de projeto dos órgãos rodoviários e as especificações de projeto executivo, quando detalhadas neste nível. Em geral, as especificações são mais genéricas, pois não se conhece o tipo de pedreira, os ligantes que poderão ser fornecidos, etc. Isto acarreta problemas futuros de especificações ou para alterações.

O teor de betume de partida que fará parte dos testes para determinação do teor ótimo a ser incorporado aos esqueletos minerais pode ser expresso de duas formas: considerando o teor de betume externo ou interno. O primeiro diz respeito à quantidade de ligante que irá ser adicionada em relação à massa de agregados secos. Esse teor é denominado de: teor de ligante externo - $\mathrm{Tl}_{\text {ext }}$, calculado pela equação 7 , sendo esse o mais empregado na França, enquanto que o segundo 
corresponde à massa de ligante em relação à massa total, ou seja, a massa de ligante e a massa de agregados secos, esse teor é denominado de: teor de ligante interno - Tlint, calculado pela equação 8 , bastante utilizado em vários países da Europa e também no Brasil.

$$
\begin{aligned}
& T l_{\text {ext }}=\frac{M l}{M A S} \times 100 \\
& T l_{\text {int }}=\frac{M l}{M A S+M l} \times 100
\end{aligned}
$$

onde:

$$
\begin{aligned}
& \mathrm{T} \mathrm{l}_{\text {ext }}=\text { teor de ligante asfáltico externo }(\%), \\
& \mathrm{T} \mathrm{l}_{\text {int }}=\text { teor de ligante asfáltico interno }(\%), \\
& \mathrm{Ml}=\text { massa de ligante asfáltico }(\mathrm{g}), \\
& \mathrm{MAS} \text { = massa de agregado seco }(\mathrm{g})
\end{aligned}
$$

O módulo de riqueza K foi estudado por DURIEZ em 1950, sendo uma variável proporcional à espessura de uma película de ligante encobrindo as partículas granulares. É independente da massa volumétrica do esqueleto granular, estando somente relacionado ao teor de betume selecionado como teor de partida para a execução dos ensaios. Este teor inicial de teste pode ser determinado pela equação 9. As normas francesas AFNOR NF P 98-130 a 141 (1993) especificam limites mínimos de "K", referentes a cada tipo de mistura, para utilização em dosagens de partida. A superfície específica $\Sigma$ é calculada a partir da distribuição granulométrica dos agregados (curva), equação 10.

$$
\begin{aligned}
& T l_{\text {ext }}=K * \alpha * \sqrt[5]{\Sigma} \\
& 100 . \Sigma=0,25 . G+2,3 . S+12 . s+150 . f
\end{aligned}
$$

onde:

$$
\begin{aligned}
& \mathrm{Tl}_{\mathrm{ext}}=\text { teor de ligante asfáltico externo (\%) } \\
& \mathrm{K}=\mathrm{K}=\text { módulo de riqueza; } \\
& \alpha=\text { coeficiente de correção relativo à densidade real dos agregados, }
\end{aligned}
$$


$\Sigma=$ superfície específica $\left(\mathrm{m}^{2} / \mathrm{kg}\right)$;

$\mathrm{G}=$ porcentagem de agregados na curva superior a $6,3 \mathrm{~mm}$;

$\mathrm{S}=$ porcentagem de agregados na curva entre $6,3 \mathrm{~mm}$ e $0,250 \mathrm{~mm}$;

$\mathrm{s}=$ porcentagem de agregados na curva entre $0,250 \mathrm{~mm}$ e $0,063 \mathrm{~mm}$;

$f=$ porcentagem de agregados na curva abaixo de $0,063 \mathrm{~mm}$.

Caso na composição granulométrica tenha algum tipo de finos, denominados de especiais como: cal virgem ou hidratada, ou também a adição de aditivos como fibras, as equações 9 e 10 não poderão ser aplicadas. Nesses casos é atribuído um teor inicial de ligante asfáltico, baseado na equação 8 , conforme especificado na norma AFNOR NF EN 13108-1 (2007).

A seqüência de ensaios segue em mais quatro níveis distintos, denominados de níveis 1, 2, 3 e 4, em que cada nível depende geralmente do tipo de mistura a ser formulada, da posição e da espessura da camada da estrutura do pavimento, do tráfego previsto ao qual deverá ser submetida em serviço, de solicitações particulares como: rampas, interseções, condições ambientais, drenagem, entre outros, e também do objetivo de pesquisa pretendido para aplicação desta camada, assim como da natureza das camadas inferiores que compõem o pavimento LPC, (2007).

Finalizando o nível 0 de dosagem de misturas asfálticas pelo método francês, temse o nível 1 , nesse nível as misturas asfálticas são submetidas a dois tipos de ensaios, resistência à ação da água e a aptidão da compactação ou compacidade com emprego da prensa de cisalhamento giratório - PCG.

O ensaio de resistência à ação da água de misturas asfálticas a quente é denominado de ensaio de Duriez e é prescrito pela norma NF 98 251. Esse ensaio consiste em moldar estaticamente dois conjuntos de corpos-de-prova, um conjunto é submetido a condicionamento em água à temperatura controlada e outro é condicionado em câmara com umidade e temperatura controladas. Em seguida os dois conjuntos são rompidos axialmente, obtendo-se a relação entre as resistências à compressão simples da média dos corpos-de-prova submetidos ao condicionamento em água e a média dos corpos-de-prova do $2^{\circ}$ jogo. Ensaio 
semelhante, embora mais rigoroso, bastante difundido em nosso meio rodoviário é o ensaio de dano por umidade induzida, preconizados pelas normas ABNT NBR 15617-08, baseada em parte na AASHTO T 283/89.

A aptidão de compactação ou a compacidade é um parâmetro muito importante para o domínio da formulação de misturas asfálticas. Essa aptidão da compactação das misturas mede-se a partir do cumprimento de determinados limites de porcentagens de vazios (AFNOR NF P 98-252, 1999), em relação a uma escala de giros do eixo compactador. O desempenho das misturas asfálticas é função do esqueleto resultante da distribuição granulométrica dos agregados, do tipo e teor de ligante asfáltico e principalmente do volume de vazios. A porcentagem de vazios impostos pela ação da compactação é determinada pela PCG.

No caso de misturas sujeitas a baixo volume tráfego (< 150 veículos pesados por dia), o nível 1 é suficiente para critério de avaliação, sem que haja a necessidade de ensaios complementares. Porém, no caso de misturas de módulo elevado, por exemplo, como o próprio nome define, necessitam da realização dos níveis subseqüentes, por serem projetadas para tráfegos médios e pesados (> 150 veículos pesados por dia). Salienta-se que a denominação de tráfego pesado para os franceses difere da adotado no Brasil.

Moutier (1982) comenta que até os anos 1973 e 1974 não se dispunha na França de outro procedimento de compactação de misturas asfálticas a quente, a não ser o procedimento estático de Duriez ou o de compactação dinâmica Marshall. O primeiro tipo simulava muito mal as características de compactação de campo, a estrutura granular é auto-bloqueante, impossibilitando a orientação dos agregados e, devido à pressão exercida, ocorria a quebra de agregados alterando a mistura. Já o segundo método - Marshall, embora melhor que o primeiro, trata-se de um ensaio disperso, ou seja, os resultados podem não ser compatíveis com o comportamento de campo. A partir de 1974 passou-se a utilizar a PCG na França.

O primeiro protótipo da PCG, historicamente denominada de PCG1, foi baseado na prensa giratória manual desenvolvida no Departamento de Estradas do Texas - EUA em 1939. O modelo francês era tecnologicamente diferente e realizava 
automaticamente a operação. Nesse primeiro equipamento o funcionamento já ocorria a um ângulo "fixo" de 1‥ Uma força F variável, deslocava o prato da prensa em $4 \mathrm{~mm}$, fazendo com que o molde com a amostra inclinasse $1^{\circ}$ em relação à geratriz passante pelo centro do corpo-de-prova. O ângulo de inclinação causado pela aplicação da força $F$ era relacionado com a altura inicial do corpo-de-prova e com a redução da altura conforme o corpo-de-prova era densificado, esse ângulo variava. A força F era mantida até o final do ensaio. Para os moldes de Duriez, com misturas com diâmetro do agregado máximo de $10 \mathrm{~mm}$, a pressão de ensaio exercida pelos pratos paralelos foi 1,2 MPa e para misturas com diâmetro máximo de $20 \mathrm{~mm}$ a pressão foi de 0,6 MPa (MOUTIER, 1973).

A partir de 1974 foi fabricado o primeiro modelo de série da PCG francesa. Procurou-se nesse modelo eliminar certos inconvenientes do equipamento anteriormente abordado, como: compactação a um ângulo variável mesmo com um ângulo inicial constante e melhor determinação do ciclo de compactação em função de riscos de não repetibilidade do ensaio. As alterações foram profundas, tornando esse novo modelo tecnologicamente muito diferente. O módulo de comando possui grupos hidráulicos para alimentar o eixo, automação por comandos elétricos, regulagem de temperatura e sistema de registros do ensaio e um sistema de medição do esforço estático de compressão (MONTIER, 1974).

O autor citado conclui que os avanços do modelo de série em relação ao protótipo foram:

ângulo de compactação absolutamente constante, registro permanente da reação do material, automaticidade na condução dos ciclos de funcionamento gerando uma dispersão menor e, leitura direta da altura do corpo-de-prova durante o ensaio.

Harman et al. (2001), em pesquisa da compacidade de misturas asfálticas com o auxílio da PCG francesa (modelo de série - denominada de PCG2) figura 25, correlacionaram a compacidade de corpos-de-prova produzidos na PCG e em placas compactadas por compactadores pneumáticos em laboratório. Como resultado, os autores apresentam uma boa correlação entre os dois tipos de 
compactação e comenta que o ensaio de compactação com a PCG exerceria um papel de destaque na formulação de misturas asfálticas na França.

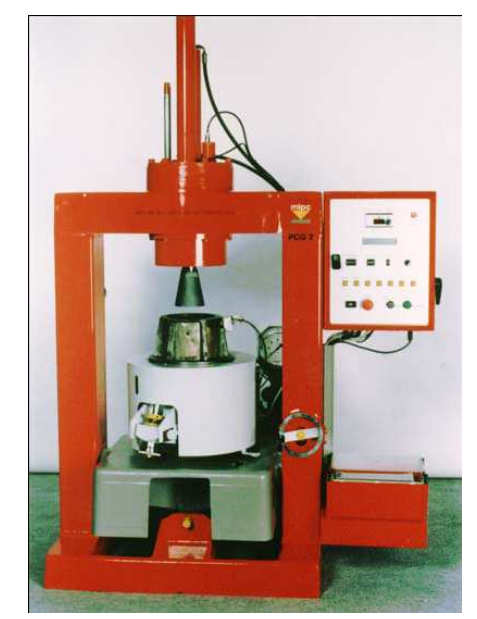

Figura 25 - Prensa de cisalhamento giratório - PCG - modelo 2.

Harman et al.(2001) comentam ainda a relação entre a compactação de campo e de laboratório, que deveriam ser diretamente proporcionais. Caso essa relação não seja observada, qualquer metodologia que indique alteração de parâmetros da mistura torna-se inócua, tanto para compactação como também para ensaios mecânicos. Entretanto, tem-se observado algumas relações ruins entre resultados de campo e laboratório. Comenta que essas incompatibilidades possam estar associadas à variedade de equipamentos de compactação de campo e possivelmente de um utilização incorreta das ferramentas de laboratório. Fez-se necessário um estudo comparativo entre os resultados de ensaios de laboratório com os de campo.

Para simular a compactação de campo, Moutier (1974) compactou camadas de concreto asfáltico de várias espessuras, usando um equipamento pneumático. Várias passadas do rolo foram usadas. Analisando-se os resultados obtidos e comparando as porcentagens de compactação versus o número de giros do compactador giratório, e a porcentagem de compactação versus o número de passadas do rolo, notou-se que existe um fator de proporcionalidade $(k)$ entre 0 número de passadas e o número de giros.

Corté et al. (1999) apresentam o esquema de esforços a que o corpo-de-prova está submetido na compactação por cisalhamento, figura 26, e a nova versão da PCG3 - 
figura 27. Nesta nova versão, trata-se de um equipamento que contempla tanto a metodologia francesa de compactação de misturas asfálticas, como também a metodologia do SHRP norte-americana. As modificações são:

aumento da velocidade de rotação de 6 para 30rpm, com a possibilidade de atender a especificação do SHRP;

informações permanentes ao operador sobre as coerências dos parâmetros descritivos, da mistura teste antes do início do ensaio;

máquina de menor dimensões, com abandono do sistema de aquecimento durante o ensaio e modelo móvel disponível;

manter a competitividade dos equipamentos franceses face à multiplicidade dos equipamentos necessários para a metodologia SHRP.

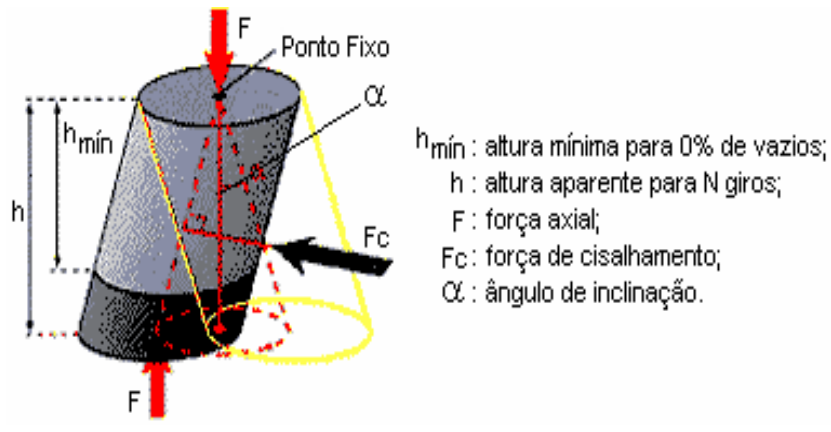

Figura 26 - Esquema da prensa de cisalhamento giratório - PCG - modelo 3 (MANUEL LPC, 2007) http://www.lcpc.fr/fr/produits/materiels_mlpc/

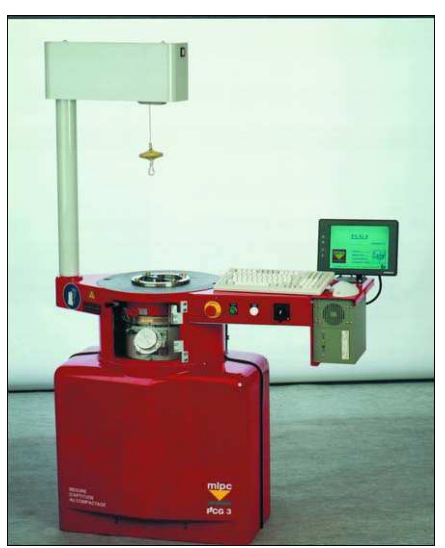

Figura 27 - Prensa de cisalhamento giratório - PCG3

Resumidamente apresentam-se na tabela 15 a evolução histórica do desenvolvimento da - PCG francesa (HARMAN et al, 2001). 
Tabela 15 - Evolução histórica da - PCG Francesa (HARMAN et al, 2001)

\begin{tabular}{|c|c|}
\hline Ano & Desenvolvimento \\
\hline 1940 & Desenvolvimento da $1^{\circ}$. compactador giratório pelo DOT do Texas. \\
\hline 1960 & $\begin{array}{l}\text { Criado o } 1^{\circ} \text {. Protótipo Francês da PCG, baseado no compactador giratório do } \\
\text { Texas }\end{array}$ \\
\hline 1968 & Criado o $2^{\circ}$.protótipo da prensa francesa. \\
\hline 1972 & $\begin{array}{l}\text { Apontam as primeiras possibilidades de medir a compacidade relacionada com o } \\
\text { número de giros. Estabeleceu-se a primeira geração da PCG-1 }\end{array}$ \\
\hline 1973/74 & $\begin{array}{l}\text { Avaliação do ângulo de cisalhamento conduziu a prensas diferentes, regando } \\
\text { corpo-de-prova com densidades diferentes. }\end{array}$ \\
\hline $1974 / 80$ & $\begin{array}{l}\text { Primeiros estudos da correlação da eficiência de compactação da prensa com a } \\
\text { compactação de campo, obtendo-se um fator } k \text { que é função do tipo de rolo } \\
\text { compactado e a espessura da camada }\end{array}$ \\
\hline $1980 / 81$ & $\begin{array}{l}\text { Elaboração do primeiro esboço de curvas de compactação e realização do } \\
\text { primeiro interlaboratorial da PCG }\end{array}$ \\
\hline $1985 / 86$ & Lançamento da PCG-2 $2^{\text {a }}$. geração da, preservou-se as características da PCG-1 \\
\hline 1992 & $\begin{array}{l}\text { Visou fazer uma terceira geração de PCGs que seria mais compacta e, } \\
\text { portanto, facilmente transportável para testes em campo. Além disso, a } \\
\text { rigidez de cisalhamento do dispositivo foi adaptado para que um ângulo } \\
\text { constante de cisalhamento pudesse ser mantida durante todo o processo de } \\
\text { compactação. }\end{array}$ \\
\hline 1996 & $\begin{array}{l}\text { Seminário sobre PCG organizado pela LCPC em Nantes (França). Nesta } \\
\text { ocasião, o protótipo de PCG3 foi apresentado }\end{array}$ \\
\hline 1999 & $\begin{array}{l}\text { PCG3 é comercializado no lugar dos antigos modelos. Os procedimentos de } \\
\text { qualificação e de conformidade de acordo com a Apêndice A2 das normas } \\
\text { NF P98-252 e EN 12697-31 desenvolvidos para cada modelo permitem } \\
\text { gerir o controle de produção bem como o acompanhamento anual sem } \\
\text { problemas }\end{array}$ \\
\hline 2001 & $\begin{array}{l}\text { Uma experiência recente com o sensor de ângulo de AVK FHWA permitiu } \\
\text { confirmar, que das três PCGs comerciais, o comportamento da PCG3 tem: } \\
\text { a) excelente estabilidade de ângulo de ataque durante a compactação, e b) } \\
\text { valores semelhantes para o ângulo medido no fundo e no topo da amostra. }\end{array}$ \\
\hline
\end{tabular}

O nível 2 testa as misturas aprovadas nos níveis 0 e 1 e inclui a esses últimos 0 ensaio de deformação permanente, (AFNOR NF P 98-253-1, 1993), em que as misturas são avaliadas quanto à resistência à formação de trilhas de rodas. Este assunto, sendo o enfoque principal desta tese, será abordado em maior detalhe no item 2.7.

Tendo sido aprovadas no segundo nível, as misturas são submetidas ao ensaio de módulo complexo (AFNOR NF P 98-260-2, 1992) no nível 3, sendo especificado para situações importantes, em que a mistura formulada assumirá função estrutural na composição do pavimento. O quarto e último nível comporta o ensaio de fadiga (AFNOR NF P 98-261-1, 1993). 
Em cada um destes níveis descritos, para que as novas formulações possam ser consideradas aprovadas, deverão ter um desempenho mínimo que esteja de acordo com as especificações (AFNOR NF P 98-130 a 141, 1993) referentes ao tipo de mistura em que se enquadram as suas composições. A figura 28 ilustra a seqüência de ensaios para cada nível de formulação.

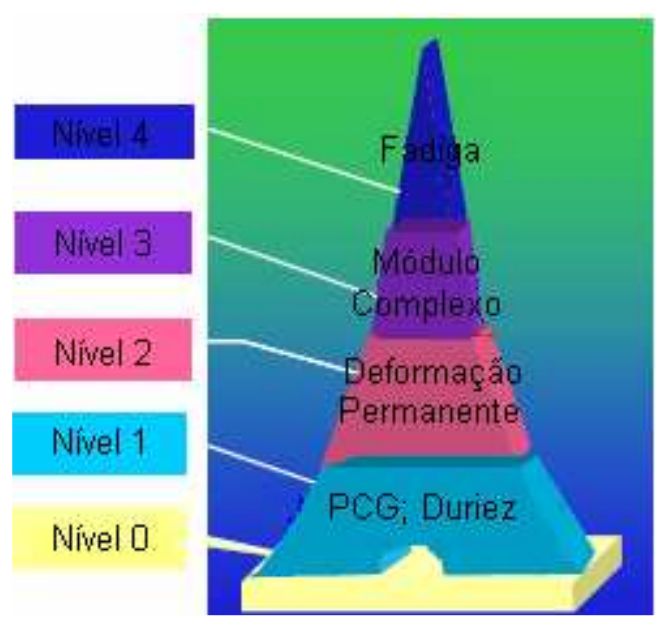

Figura 28 - Seqüência dos níveis de formulação e respectivos ensaios (LPC, 2007)

Conforme abordado, observe-se que o procedimento de dosagem de misturas asfálticas pelo método francês distancia-se do processo de dosagem especificado pelo SHRP. O processo francês de dosagem de misturas asfálticas tem como base as propriedades das misturas asfálticas, envolvendo toda uma dinâmica de ensaios, que abrange as características principais de reprodução dos procedimentos executivos reais de campo, como a compactação por amassamento das misturas como resultado dos esforços cisalhantes de acomodação das partículas dos agregados durante esse processo, nos ensaios com a PCG, de compactação das placas e de deformação permanente, e a flexão alternada contínua com sinal senoidal de carregamento, nos ensaios de módulo complexo e de fadiga, conforme ocorre no campo. A única exceção é o ensaio de Duriez à compressão direta (simples), que não possui relação direta com esforços provenientes das solicitações práticas; mesmo assim, possui coeficientes de repetibilidade (r) (situação em que os ensaios são feitos no mesmo laboratório, com o mesmo corpo de prova, a partir de um mesmo operador e em um curto intervalo de tempo), e de reprodutibilidade $(R)$ (condição em que todas as condições descritas para "r" são distintas) de 0,65 e 1,0, respectivamente (MANUEL LPC, 2007). 
O efeito prático desta eficiência se observa após a análise de uma grande gama de resultados determinados ao longo de vários anos de pesquisas e coletas de amostras que apresentam estreitas correlações campo-laboratório, com ordens de grandeza de valores de $\pm 1,0 \%$ a $\pm 1,5 \%$ para misturas asfálticas utilizadas como camada de rolamento.

A correlação campo-laboratório para o ensaio com a PCG; apontam valores entre \pm $1,0 \%$ e $\pm 2,0 \%$ para materiais pouco sensíveis aos efeitos de deformação permanente (afundamento $<5,0 \%$ após 30000 ciclos). Já o ensaio de módulo complexo a correlação foi entre $\pm 20 \%$ e $\pm 30 \%$ e por fim para o ensaio de fadiga à flexão alternada a faixa de valores situou entre; $\pm 10 \%$ e $\pm 15 \%$, (LPC, 2007).

No processo de dosagem pelo método SHRP, tem-se como base de desempenho de misturas asfálticas, as condições ambientais, o comportamento do ligante asfáltico e dos agregados, e a granulometria, como já mencionado no item 2.5. As condições climáticas somadas às propriedades de engenharia obtidas com ensaios que indicam o desempenho dos ligantes asfálticos, conduzem a classificação do ligante asfáltico, em grau de desempenho - performance grade - PG e a granulometria associada às características dos agregados e também a pontos de controle e a uma zona de restrição, somados aos índices CDI, TDI, CFI e TFI, que são energias associadas à compactação das misturas asfálticas com a prensa de compactação giratória conduz ao processo de dosagem de misturas asfálticas pelo método Superpave.

\subsection{Deformação Permanente}

Os defeitos estruturais mais comumente encontrados nos pavimentos com revestimentos asfálticos nas rodovias brasileiras são: o trincamento por fadiga e a deformação permanente em trilha de roda. Os defeitos como perda de durabilidade por oxidação, desagregação por falta ou falhas na adesividade também são importantes, mas podem ser contornados e resolvidos na fase de definição dos materiais (nível 0 francês) e no controle de usinagem e obra. Os defeitos centrais 
(fadiga e deformação permanente) devem ser evitados realizando-se um projeto estrutural adequado e um projeto de mistura asfáltica condizente com o projeto estrutural.

A deformação permanente em trilha de roda é um problema de desempenho de pavimentos asfálticos. É definida como o acúmulo de pequenas quantidades de deformação não recuperável resultante da aplicação das cargas dos veículos. No contexto desta tese, será tratada a deformação permanente advinda da camada asfáltica e não de outras camadas do pavimento que também contribuem para os afundamentos que aparecem na superfície.

As misturas asfálticas sob a ação do tráfego podem apresentar pequenas deformações por consolidação ou por movimentos laterais que são falhas por cisalhamento, em geral, e que ocorrem no topo da camada superficial do pavimento (KANDHAL e COOLEY, 2003).

A deformação permanente em trilha de roda, segundo Joliet e Malot (2000), é simultaneamente a deformação viscosa do ligante asfáltico e deformação plástica da estrutura mineral da mistura asfáltica. Comentam que tanto o ligante como o agregado exercem papel fundamental no comportamento mecânico da mistura asfáltica: o ligante, como resultado de sua consistência e reologia, e o agregado com as forças de fricção interna entre suas partículas.

Conforme definição do DNIT-PRO 008 (2003), já comentado na introdução, existem duas vertentes que justificam o defeito denominado de deformação permanente em trilha de roda: o afundamento plástico e o afundamento por consolidação. $O$ afundamento plástico é segundo o Órgão a deformação permanente que ocorre em uma ou mais camadas dos pavimentos flexíveis ou semi-rígidos, ou ainda no subleito. Em se tratando de camada asfáltica, o adjetivo plástico está associado ao comportamento visco-elástico do ligante asfáltico. O mesmo Órgão define como o afundamento por consolidação a deformação permanente que ocorre nos pavimentos flexíveis ou semi-rígidos devida a consolidação diferencial que se verifica em camadas do pavimento ou subleito. 
As irregularidades superficiais causadas por deformação permanente em trilha de roda podem ser traduzidas em três mecanismos, segundo DNIT-PRO 008 (2003), e salienta que esses três mecanismos podem atuar isoladamente ou em conjunto:

Deformação permanente da estrutura,

Deformação permanente causada por fluência,

Deformação permanente ocasionada pelo uso.

Estas são assim definidas:

A deformação permanente estrutural é resultado do sub-dimensionamento das camadas do pavimento face à ação do tráfego. Pode também estar relacionada a falhas no processo construtivo do pavimento, como também a problemas de drenagem e de falta de suporte do subleito.

Deformação permanente causada por fluência do ligante asfáltico reside em problemas de dosagem da mistura asfáltica, e está associado à má combinação dos materiais constituintes da mistura.

Por último, a deformação permanente ocasionada pelo uso, trata-se de um defeito menos encontrado em nossos pavimentos. Ocorrem em países de regiões frias em que os pavimentos, devido à neve, são recobertos por uma camada de gelo e, os pneus são recobertos por uma corrente ou pinos para melhorar a aderência.

Em geral, na Mecânica de Pavimentos, as análises de deformação permanentes enfocam as deformações provenientes por repetição de carga no subleito, camada mais sensível a este problema, principalmente em regiões com problemas de capacidade de suporte de solo. Os modelos de previsão de deformação permanente em trilha de roda empregados em geral são apresentados na forma genérica como aquele expresso pela equação 11, (HUANG, 1993):

$$
N_{d}=f_{4}\left(\epsilon_{c}\right)^{-f_{5}}
$$

onde: $N_{d}=$ número admissível de ciclos

$\epsilon_{c}=$ deformação no subleito 
$f_{4}$ e $f_{5}=$ constantes obtidas em pistas experimentais de deformação permanente em campo.

Os valores de $\mathrm{f} 4$ e $\mathrm{f} 5$ podem ser determinados em ensaios ou podem ser aqueles sugeridos pelo Asphalt Institute, pela Shell e pela University de Nottingham.

Conforme já comentado na introdução (Huang, 1993) a utilização da tensão no topo do subleito como critério de falha de deformação permanente, só é válido quando a deformação permanente é ocasionada por um subleito com baixa capacidade de suporte. Ocorre que uma parcela significativa da deformação permanente em pavimentos flexíveis ocorre nas camadas acima do subleito. Isso se deve ao aumento da carga de roda e também ao aumento da pressão de inflagem dos pneumáticos.

Estabilidade é a característica que tem uma mistura asfáltica de resistir às deformações permanentes (SANTANA E GONTIJO, 1984). Estas deformações irreversíveis que se produzem devido a uma fluência plástica (sem variação de volume) e/ou uma diminuição de volume, e devido ao aumento de densificação provocada pelo tráfego canalizado (redução da espessura do revestimento). Dois são os fenômenos da deformação permanente em trilha de roda que se apresentam extremamente prejudiciais:

1. os sulcos causados pela deformação permanente em trilha de roda canalizam a condução dos veículos, principalmente os veículos mais leves, e interferem na dirigibilidade; e,

2. a possibilidade de ocorrer os fenômenos da viscoplanagem e de hidroplanagem devido ao acúmulo de água neste afundamento na trilha de roda.

A camada asfáltica, no início da vida de serviço, está sujeita a uma pequena deformação permanente caracterizada mais por consolidação que por características viscosas do ligante asfáltico. Essa deformação inicial deve ser sempre de pequena magnitude, resultante de uma pequena redução do volume de vazios. Esta variação faz com que a mistura asfáltica torne-se mais impermeável. Já 
a deformação permanente causada pela viscoelasticidade do ligante asfáltico é, em geral, o mecanismo de deformação preponderante (caso a obra tenha sido bem executada conforme a boa técnica em termos de compactação), e mais pronunciada, ocorrendo principalmente ao longo da vida de serviço da mistura asfáltica. Este tipo de deformação permanente, por exemplo, é susceptível à época do ano e às temperaturas ambientes. Os problemas também podem ser intensificados com as alterações do perfil de usuários de carga da rodovia. Portanto, este tipo de deformação permanente, além de ocorrer sempre, pode ser intensificado por algum motivo externo - clima, carga do tráfego, velocidade dos veículos pesados, etc.

Harun e Morosiuk (1995) comentam que o benefício do uso de misturas asfálticas em rodovias somente é alcançado se o grau de compactação é atendido durante a construção, e ainda, alertam que para a compactação adicional pela ação do tráfego deve ser limitada, caso contrário ocorrerá problemas de deformação permanente em trilha de roda por falha de cisalhamento. Brown (1988) estimou que se os vazios da camada asfáltica após a ação do tráfego forem mantidos acima de $2 \%$, a mistura asfáltica apresentará boa resistência à formação de trilha de roda.

\subsubsection{Fatores Causadores de Deformação Permanente nas misturas asfálticas}

Diversos fatores, tanto isoladamente como em conjunto, contribuem para a formação da deformação permanente em trilha de roda em misturas asfálticas. É difícil estabelecer correlações entre a formulação de misturas asfálticas e a ocorrência da deformação permanente.

O aumento da energia de compactação em misturas asfálticas com distribuição granulométrica contínua, acabam por propiciar à mistura um ganho na resistência a deformação permanente em trilha de roda, entretanto, quando esse aumento na energia de compactação é muito intenso os finos da mistura asfáltica começam a ocupar o volume de vazios e, por conseguinte, reduz os contatos entre os agregados 
graúdos, o que acaba por induzir menor resistência a deformação permanente em trilha de roda. O projeto da mistura asfáltica deve contemplar a compactação exercida pela ação tráfego e que a redução causada por essa pós-compactação não deve reduzir o volume de vazios e o VAM a níveis inferiores a $2 \%$ e $15 \%$ respectivamente (COOPER et al, 1988).

Para o nosso clima, em que a média da temperatura anual é elevada, valores de volume de vazios na ordem de $2 \%$ ou inferior são prejudiciais, pois, nossas condições climáticas associadas ao baixo volume de vazios, podem tornar as misturas asfálticas mais vulneráveis à formação de afundamentos em trilha de roda. Logo, é recomendável que a pós-compactação exercida pela ação do tráfego ocasione reduções no volume de vazios de forma a manter esses níveis em valores superiores a $3 \%$ preferencialmente.

Quanto ao VAM, o DNIT 031/2004 especifica que misturas com DMN 19 mm seja no mínimo 15\% e para misturas com DMN de $12,5 \mathrm{~mm}$ e $9,5 \mathrm{~mm}$ esse valor seja no mínimo 16\%, valores para projeto. Entretanto, salienta-se que o efeito da póscompactação não deve alterar esses valores de VAM para limites inferiores aos especificados, caso essa redução no VAM ocorra, a mistura apresentará um volume de vazios indesejável. Uma parcela significativa dos concretos asfálticos produzidos seguindo a mesma norma, não atinge valores de VAM desta ordem especificada, principalmente se atendem os demais parâmetros.

\subsubsection{Teor de Ligante Asfáltico}

O excesso do teor de ligante asfáltico é um dos principais causadores da deformação permanente em trilha de roda em misturas asfálticas. Brousseaud et al. (1993) relatam que não existe uma proporcionalidade entre o aumento da deformação permanente em trilha de roda e o aumento do teor de ligante asfáltico, mas afirmam que existem grandes riscos de deformação permanente em trilha de roda com o aumento do teor de ligante asfáltico na mistura. $O$ aumento da deformação nestes casos advém do aumento da espessura do filme asfáltico ao 
entorno de agregados, interferindo na resistência ao cisalhamento resultante do atrito entre grãos, pois aumenta a mobilidade entre eles, lubrificando mais intensamente os contatos.

Porém, o que é mais difícil de definir é qual variação positiva no teor de ligante acarreta deformação permanente indesejada. Este fator depende também da graduação - há graduações mais sensíveis que outras ao pequeno aumento de teor, e do tipo de ligante. Deve-se ressaltar que no Brasil o limite aceitável de variação do teor de ligante asfáltico em misturas asfálticas é de $\pm 0,3 \%$, para variação na fabricação da mistura. Em certas misturas asfálticas, esta variação positiva permitida é extremamente danosa. Em pesquisa realizada para verificação da sensibilidade na formulação de CBUQ, face à resistência à deformação permanente em trilha de roda com simulador de tráfego de laboratório tipo LPC, Bernucci et al (1996) constataram a importância do teor de ligante asfáltico nesse parâmetro. Os resultados mostraram que, dependendo do tipo de ligante, como o CAP 20 (aproximadamente equivalente ao CAP 50/70 da atualidade), as misturas asfálticas densas e bem-graduadas como os CBUQs, apresentam afundamentos nas trilhas de roda indesejáveis e expressivos com excesso de apenas $0,3 \%$ de ligante com relação ao ótimo de projeto Marshall (BERNUCCl et al, 2008, MOTTA et al,2009)

\subsubsection{Tipo de Ligante asfáltico}

O emprego de ligante asfáltico convencional mais consistente ou mesmo modificado por polímero ou por borracha pode reduzir substancialmente a deformação permanente devido à fluência. Os parâmetros de ensaios de ligantes asfálticos como: penetração e ponto de amolecimento anel e bola - PA e, por conseguinte, o índice de susceptibilidade térmica são indicativos da propensão do ligante asfáltico contribuir para a formação de deformação permanente em trilha de roda ocasionada por fluência (GRIMAUX et al. 1977). Porém, o mais importante é caracterizar o ligante por ensaios reológicos que melhor darão uma previsão de comportamento. É necessário, no entanto, reafirmar que os ensaios de ligante, mesmo os reológicos previstos pelo SHRP, não são suficientes para prever comportamento da mistura e 
não substituem os ensaios na mistura asfáltica. No Brasil ficou evidenciada a importância dos ligantes asfálticos modificados por polímero (como SBS e EVA) e por borracha, nas propriedades de deformação permanente em trilha de roda em simulador de tráfego de laboratório, como demonstrado em pesquisa da USP para 0 CENPES-PETROBRAS (Bernucci et al., 2002).

\subsubsection{Temperatura}

Um outro fator que está associado ao tipo de ligante asfáltico é a temperatura de trabalho da mistura asfáltica. As misturas asfálticas herdam características viscosas dos ligantes asfálticos que, dependendo do tipo de ligante asfáltico, apresentam-se mais ou menos susceptíveis à temperatura.

Brosseaud et al. (1993), em pesquisa desenvolvida no Laboratoire Central des Ponts et Chausseés - LCPC, puderam constatar uma forte relação entre o aumento da temperatura e o aumento da deformação permanente em trilha de roda de misturas asfálticas. Merighi (1999) também verificou este efeito da temperatura nos afundamento em trilha de roda.

\subsubsection{Distribuição Granulométrica}

A distribuição granulométrica em misturas asfálticas é responsável pelo embricamento ou entrosamento dos agregados, de maneira que os agregados menores ocupem os vazios deixados pelos agregados maiores (MOMM, 1998). Nesse trabalho, Momm demonstra a importância do diâmetro máximo dos concretos asfálticos e a função importante do entrosamento das partículas que pode ser verificada em parte pela forma da curva granulométrica.

Brosseaud et al. (1993) estudaram o efeito de alguns componentes nas misturas asfálticas que interferem nos afundamentos: 
- a redução da fração areia natural implica diretamente na redução da deformação permanente em trilha de roda em misturas asfálticas;

- a utilização de agregados britados, ao invés de seixos naturais, melhora sistematicamente a resistência à deformação permanente; $\mathrm{e}$,

- a introdução de uma descontinuidade na distribuição granulométrica pode ocasionar instabilidade quanto à deformação permanente se não for estudada em detalhes.

\subsubsection{Outros Fatores}

Outros fatores, não de menor importância, mas que se muito pronunciados, podem contribuir para a formação da deformação permanente em trilha de roda em misturas asfálticas são: a aspereza da superfície do agregado, a tensão superficial no contato ligante asfáltico/agregado, composição química do ligante e do agregado, porosidade superficial do agregado, forma do agregado, limpeza do agregado, umidade do agregado, temperatura e tempo de usinagem (TERREL e AL-SWAILMI, 1993).

Pinilla (1965) aborda o tipo de superfície do agregado como relevante na aderência do ligante asfáltico à superfície do agregado. Considera também, embora com menos importância, as características químicas e geológicas do agregado, a presença de pó na superfície do agregado e a presença de água na superfície do agregado.

\subsubsection{Modelos reológicos}

Huang (1993) apresenta as formas de se caracterizar o comportamento viscoelástico dos materiais por meio de ensaios de creep e modelos mecânicos, também denominados de modelos reológicos.

Os modelos reológicos de previsão de desempenho de pavimentos são ferramentas tecnológicas de grande importância para a análise econômica de investimentos em 
rodovias, pois apontam tanto para verificação de compatibilidade estrutural dos materiais em projeto, como também para determinar estratégias de manutenção e reabilitação, além de prever o desempenho da rodovia sob o ponto de vista funcional e/ou estrutural.

Os modelos reológicos para previsão de desempenho de estruturas de pavimentos têm como base o estado de tensão e de deformação. Entretanto, é sabido que cada modelo reológico deve ser particularizado para o tipo de estrutura, os tipos de materiais empregados e as condições climáticas.

A principal dificuldade em empregar esses modelos para a previsão do comportamento de materiais asfálticos está em ajustá-los às características mecânicas reais das misturas, cuja resposta é função da temperatura e também ao tempo de atuação da carga submetida.

Quando uma mistura asfáltica é submetida a um ensaio com carregamento uniaxial estático (ensaio de creep), em que se mantém uma carga por um determinado período de tempo e em seguida essa carga é retirada, pode-se verificar a ocorrência de uma deformação instantânea elástica seguida por uma deformação gradual com o tempo. Essa última é função da característica viscosa do material, que cessa com a retirada da carga. Apresenta-se na figura 29 a relação de tensão e deformação em função do tempo que caracteriza comportamento mecânico de misturas asfálticas (DRESCHER et al. 1993).

$\mathrm{Na}$ área hachurada da figura 29a mostra-se esquematicamente o histórico de carregamento/descarregamento que ocasionou a deformação instantânea elástica e a deformação gradual com o tempo. Na figura 29b mostram-se as parcelas de deformação com tempo, de forma que depois de cessado o carregamento, pode-se obter três tipos de deformações: (i) reversível elástica instantânea, (ii) reversível retardada, e (iii) permanente, caracterizando um material de comportamento viscoelástico. 


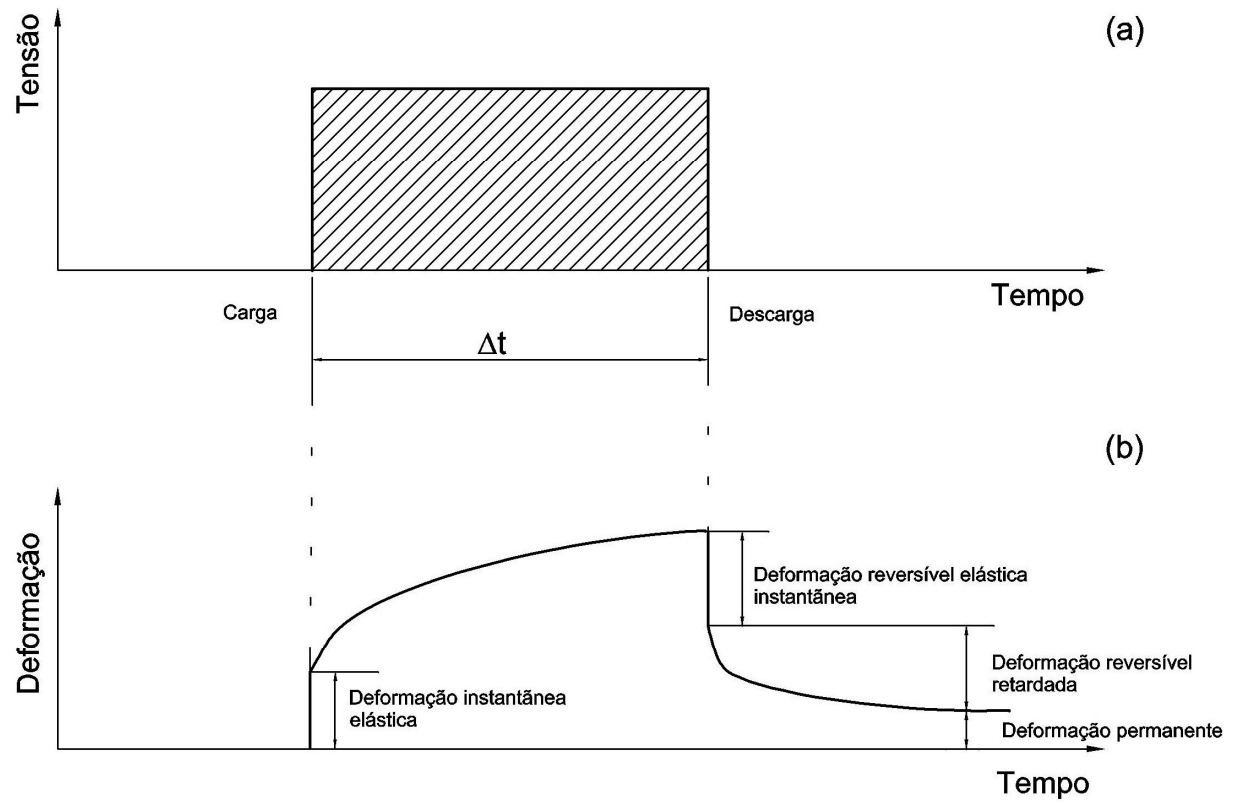

Figura 29 - Resposta viscoelástica de um ligante asfáltico submetido ao ensaio de creep, uniaxial estático (DRESCHER et al., 1993)

As deformações geradas pela parcela elástica são totalmente recuperáveis e independentes do tempo de aplicação de carga, assim, nos ciclos de carregamento/descarregamento não são geradas deformações permanentes. Já para as deformações geradas pela parte viscosa do material, tem-se duas parcelas, uma de deformação recuperável, que é dependente do tempo de carregamento, e que por conseguinte está associada à parcela viscosa do material, e outra parcela irrecuperável, também denominada de deformação plástica (permanente), sendo essa última independente do tempo de aplicação de carga mas dependente da taxa de carregamento/descarregamento (DRESCHER et al. 1993; Huang, 1993).

Drescher et al. (1993) mencionam que toda descrição de comportamento viscoelástico não-linear prevê a diminuição das diferenças entre as deformações ocorridas durante o carregamento (creep strain) e as deformações recuperáveis, quanto o tempo até o descarregamento é diminuído (ilustrado na figura 30b). Quando o tempo de carga tende a zero, não existem deformações dependentes do tempo, logo, as deformações são totalmente recuperáveis. Por definição, somente as deformações elásticas podem ser instantâneas em um material viscoelástico. Isso 
significa que se em um ciclo de carregamento/descarregamento a deformação instantânea não for totalmente recuperável, a parte irrecuperável é plástica.

A presença de deformações plásticas pode também ser obtida através da condução de ensaios com carregamento uniaxial estático, com registros das deformações para diversos tempos de carregamento, $t_{1}$. No carregamento verifica-se que a deformação total do material apresenta uma parcela instantânea e outra parcela dependente do tempo e que, após cessada a ação da carga, registra-se a recuperação parcial da deformação. Apresentam-se esquematicamente na figura 30 as duas respostas, viscoelástica não-linear e viscoelastoplástica, respectivamente. A resposta de um material é considerada viscoelástica não-linear quando a deformação reversível elástica instantânea registrada, quando 0 tempo $t_{1}=0$, for igual à deformação instantânea elástica, $\varepsilon_{\mathrm{e}}$. A não linearidade está associada à viscoelasticidade dependente do tempo de aplicação da carga - figura 30b. Caso as deformações reversíveis elásticas instantâneas sejam menores, a resposta do material é considerado viscoelastoplástico; nesse caso, registra-se deformações plásticas $\varepsilon_{p}$ ilustradas na figura 30c. 


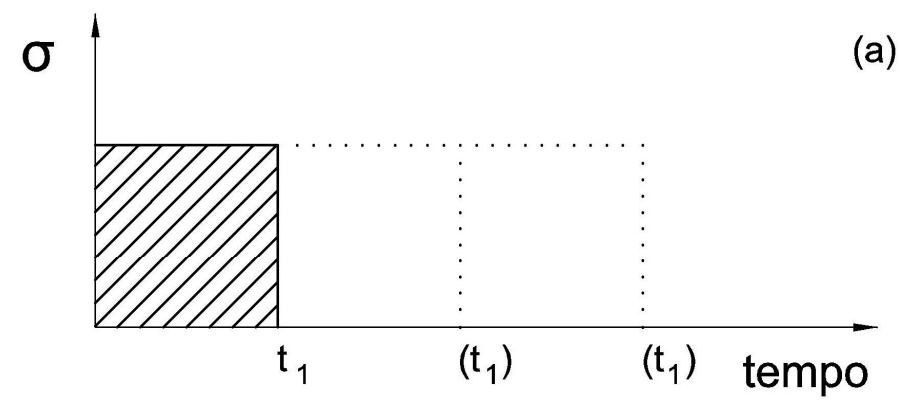

(a)

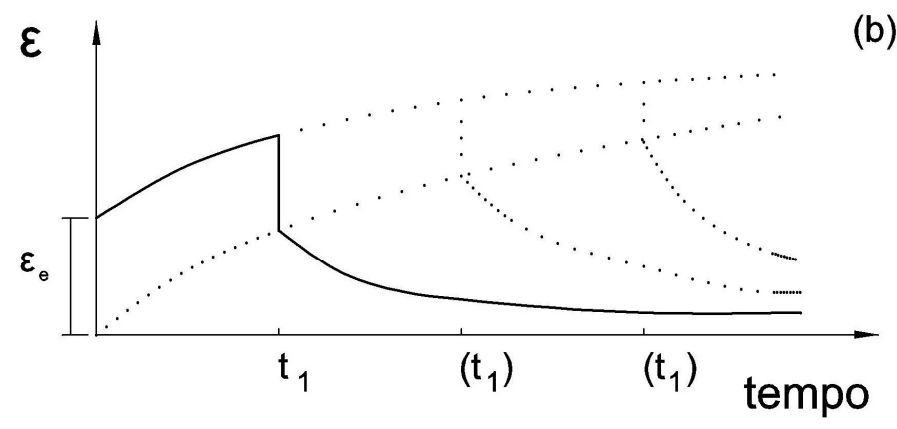

(b)

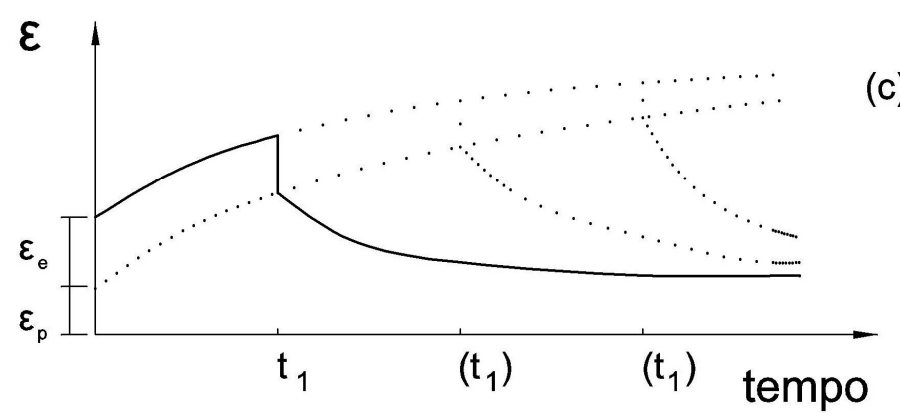

Figura 30 - Ensaio de creep uniaxial estático com; (a) histórico de carregamento/descarregamento com variação no intervalo de carga; (b) resposta de deformação/tempo de um material viscoelástico não- linear e (c) resposta de deformação/tempo de um material viscoelastoplástico (DRESCHER et al., 1993)

A presença da parcela viscoelastoplástica pode também ser observada em casos de ensaios de creep realizados com várias aplicações de carga. Após sucessivos ciclos de carga e descarga de duração finita, se as deformações instantâneas no descarregamento forem constantes e inferiores à deformação na recarga, pode-se afirmar que se trata de deformações plásticas que vão se acumulando com a sucessiva aplicação dos ciclos de carga - figura 31 (Drescher et al., 1993). 

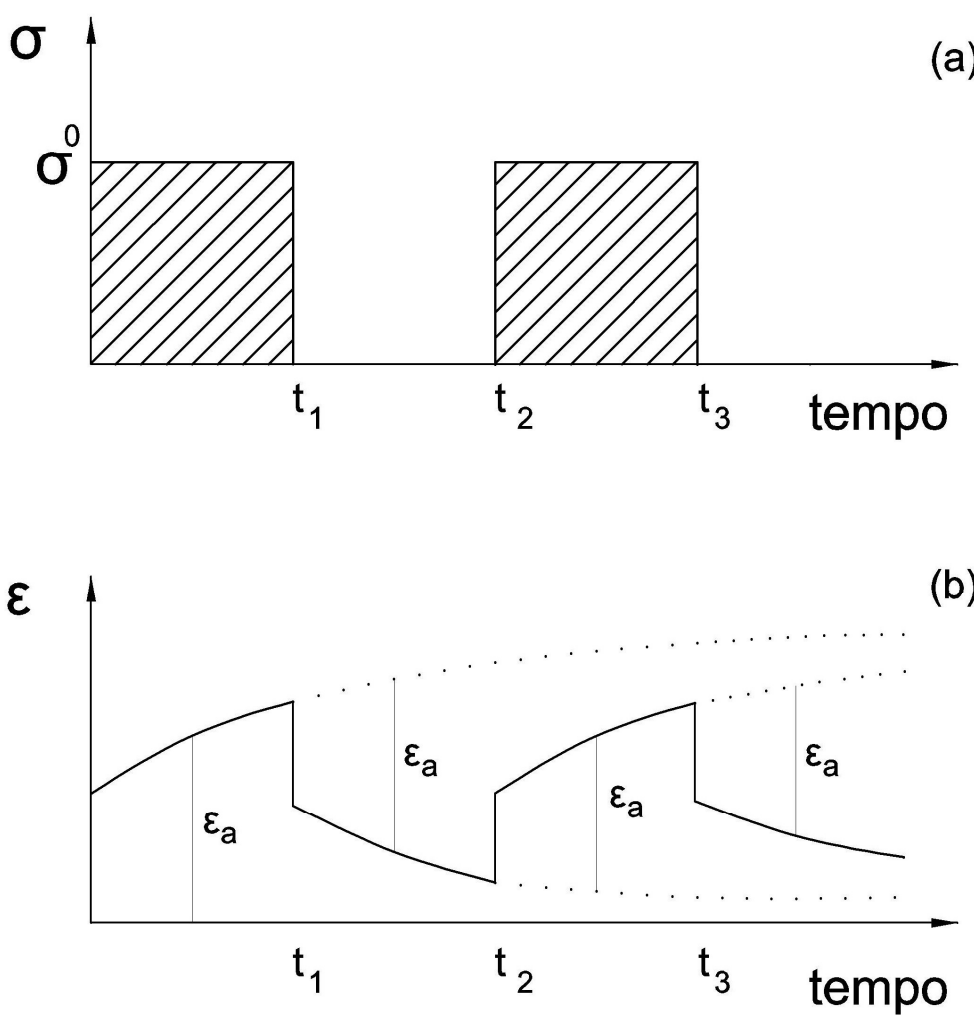

(b)

Figura 31 - Ensaio de deformação de creep cíclico; (a) histórico de carga/descarga repetida com tempo de intervalo finito e (b) resposta da deformação pelo tempo de um material de comportamento viscoelástico linear (DRESCHER et al., 1993)

$\mathrm{Na}$ figura 32a, tem-se esquematicamente 0 histórico de carregamento/ descarregamento onde os intervalos de descarregamento são muito curtos.

Na figura 32b, percebe-se que a deformação instantânea elástica (carregamento) e a deformação recuperável elástica (descarregamento) são iguais, porém com valores diferentes de um ciclo para o outro, ilustrando um comportamento viscoelástico não-linear. Para o caso ilustrado na figura 32c, onde a deformação instantânea elástica difere da recuperável elástica para um mesmo ciclo, tem-se um comportamento característico de material viscoelastoplástico. 


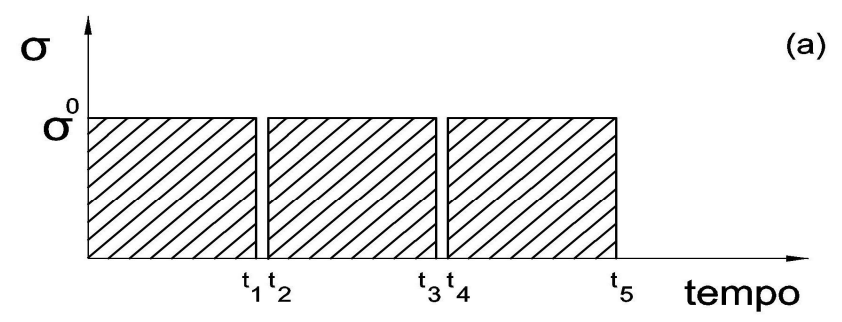

(a)
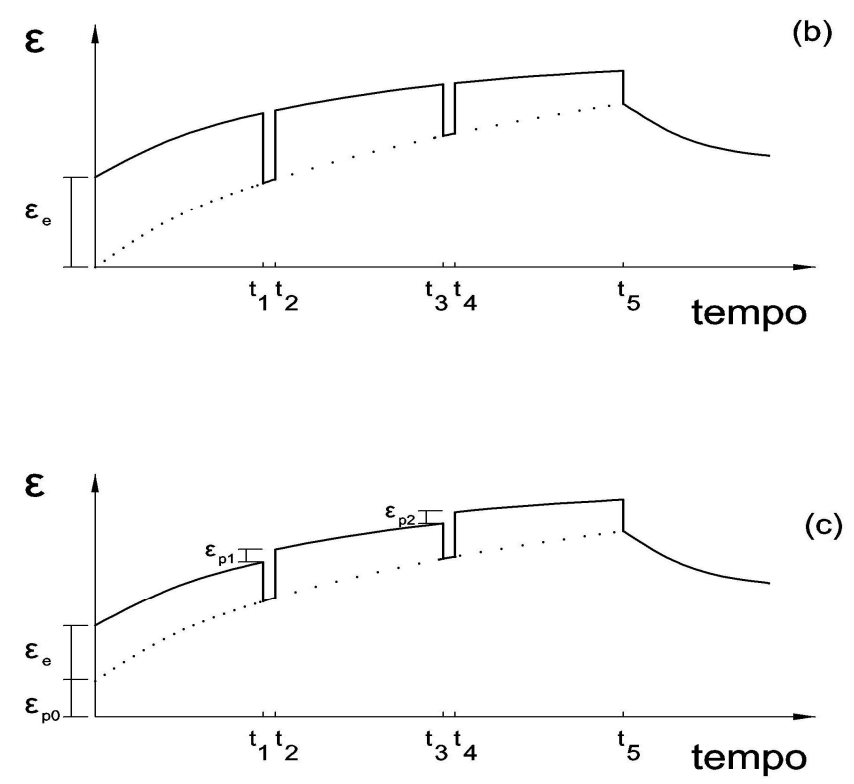

Figura 32 - Ensaio de deformação de creep cíclico (a) histórico de carga/descarga repetida com tempo de intervalo finito; (b) resposta da deformação pelo tempo de um material de comportamento viscoelástico não linear, e (c) resposta da deformação pelo tempo de um material viscoelastoplástico

(DRESCHER et al., 1993)

A modelagem matemática do comportamento das misturas asfálticas torna-se complexa pelo fato dessas misturas serem compósitos de materiais que apresentam comportamento mecânicos distintos quando ensaiados isoladamente. Parte da mistura é constituída por ligante asfáltico: devido às suas propriedades termoplásticas, seu comportamento é condicionado pela temperatura e apresentam valores de módulo de rigidez na ordem de $1 \mathrm{MPa}$ a $300 \mathrm{MPa}$. A rocha que constitui os agregados, por sua vez, apresentam módulos de deformabilidade de cerca de $240 \mathrm{GPa}$ e, dimensões máximas que variam desde $1 \mu \mathrm{m}$ podendo chegar a até 30 mm, (Hopman ${ }^{5}$ et al. 1992, apud Freire, 2002).

\footnotetext{
${ }^{5}$ Hopman, P.; Pronk, A.; Kunst, P.; Molenaar, A.A.; Molenaar, J., 1992- Application of the Viscoelastic Properties of Asphalt Concrete, Proceedings of the 7th International Conference on Asphalt Pavements, pp. 7388, Derry and Sons, Lda, Nottingham
} 
Para facilitar a compreensão do comportamento dos materiais, podem ser utilizados os modelos reológicos, que descrevem as deformações frente às solicitações. Os modelos reológicos considerados por Huang (1993) e abordados nesse trabalho são: de Maxwell, de Kelvin, de Burgers e o modelo generalizado.

Os modelos são formados basicamente por dois elementos: uma mola, que corresponde à parte elástica, e um amortecedor, que corresponde à parte viscosa. $\mathrm{Na}$ figura 33 estão apresentados os modelos reológicos.
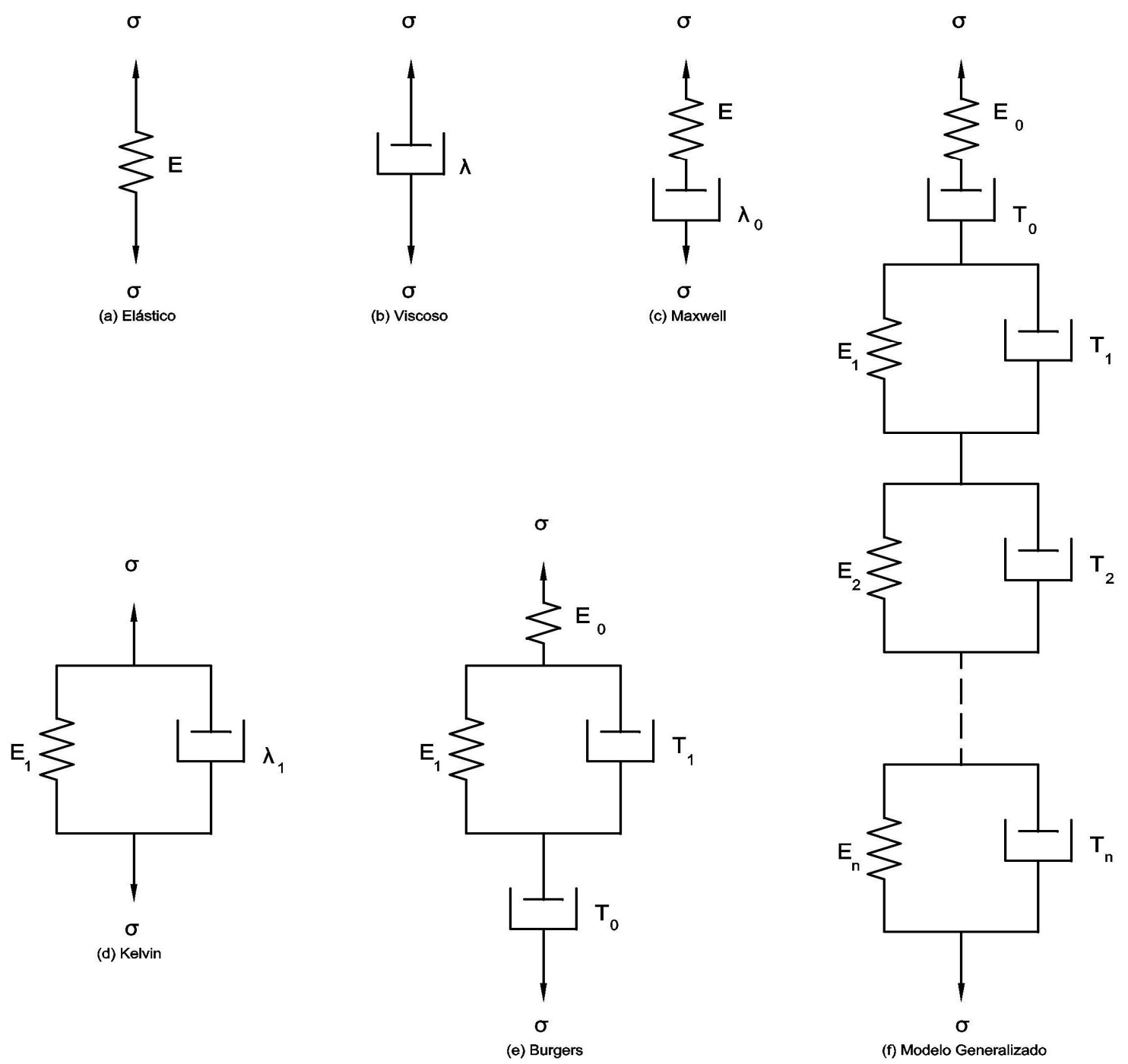

Figura 33 - Modelos mecânicos para materiais viscoelásticos (HUANG 1993)

Os materiais elásticos são caracterizados por uma mola, figura 33a, e obedecem a lei de Hooke, em que a deformação é proporcional à tensão - equação 12. 


$$
\text { onde: } \begin{aligned}
\tau & =\text { tensão } \\
& E=\text { módulo de elasticidade } \\
\varepsilon & =\text { deformação }
\end{aligned}
$$

Os materiais com propriedades viscosas são caracterizados por um amortecedor, figura 33b, e obedecem a lei de Newton, em que a tensão é proporcional a taxa de deformação que o material é submetido (descrito pela equação 13):

$$
\sigma=\lambda \frac{\partial \varepsilon}{\partial t}
$$

Sob uma tensão constante, pode-se integrar obtendo a equação 14:

$$
\varepsilon=\frac{\pi t}{\lambda}
$$

onde: $\lambda=$ viscosidade

$\mathrm{t}=$ tempo

Modelo de Maxwell

Esse modelo é a combinação de uma mola e um amortecedor em série, conforme apresentado na figura 33c. Sob uma tensão constante, a deformação total é a soma das deformações da mola e do amortecedor, conforme descrito na equação 15 :

$$
\varepsilon=\frac{\tau}{\mathrm{E}_{0}}+\frac{\tau t}{\lambda_{0}}=\frac{\tau}{\mathrm{E}_{0}}\left(1+\frac{t}{T_{0}}\right)
$$

onde: $T_{0}=\lambda_{0} / \mathrm{E}_{0}=$ tempo de relaxação ${ }^{6}$

O índice 0 é utilizado como identificador do modelo de Maxwell. Se a tensão $\tau_{0}$ é aplicada instantaneamente, a deformação na mola também será instantânea, $\varepsilon=$ $\tau_{0} / E_{0}$. Se a deformação permanece constante, gradualmente ocorre a relaxação da tensão tendendo a zero com o tempo e a equação 16 indica esse comportamento.

\footnotetext{
${ }^{6}$ Relaxação - diminuição gradual do estado de tensão de um corpo sob deformação constante
} 


$$
\frac{\partial \varepsilon}{\partial t}=\frac{1}{\mathrm{E}_{0}} * \frac{\partial \tau}{\partial t}+\frac{\tau}{\lambda_{0}}
$$

Com a deformação constante, $\partial \mathcal{\varepsilon} / \partial t=0$, ou com a integração da equação 16 , temse equação 17.

$$
\tau=\tau_{0} e^{\left(-\frac{t}{T_{0}}\right)}
$$

Da equação 17, quando $\mathrm{tf}=0$ implica em $\tau=\tau_{0}$, e para $\mathrm{tf}=\infty$, o valor de $\tau=0$. Assumindo $t f=T_{0}$ resulta em $\tau=0,368 \tau_{0}$. Isso implica que o tempo de relaxação $T_{0}$ no modelo de Maxwell é o tempo necessário para a deformação reduzir $36,8 \%$ da deformação total. Esse modelo é mais conveniente para especificar o tempo de relaxação do que o comportamento viscoso propriamente dito, responsável pela deformação permanente.

No ensaio de deformação de creep estático, devido à ação da carga constante, ocorre a relaxação do material e a determinação de falha por deformação plástica fica prejudicada.

\section{Modelo de Kelvin}

Esse modelo é a combinação de uma mola e um amortecedor associados em paralelo, conforme apresentado na figura 33d. No modelo de Kelvin a mola e o amortecedor tem a mesma deformação, entretanto, a tensão total é a soma das tensões na mola e no amortecedor. Utilizando o índice 1, o modelo é descrito na equação 18:

$$
\tau=\mathrm{E}_{1} \varepsilon+\lambda_{1} \frac{\partial \varepsilon}{\partial t}
$$

Se uma deformação constante é aplicada, a equação 18 resulta na equação 19: 


$$
\varepsilon=\frac{\tau}{\mathrm{E}_{1}}\left[1-e^{\left(-\frac{t}{T_{1}}\right)}\right]
$$

Dessa equação, tem-se $T_{1}=\lambda_{1} / \mathrm{E}_{1}=$ tempo de retardo. Quando $\mathrm{tf}=0, \tau=0$ e para tf $=\infty$ a deformação assume $\mathcal{E}=\tau / \mathrm{E}_{1}$, ou ainda a mola é totalmente distendida em sua deformação retardada. Agora, quando $\mathrm{tf}=\mathrm{T}_{1}, \varepsilon=0,632 \tau / \mathrm{E}_{1}$. O tempo de retardo $\mathrm{T}_{1}$ no modelo de Kelvin é o tempo para alcançar $62,3 \%$ da deformação de retardada total. Ou seja, quando é cessada a ação da carga no modelo de Kelvin, $\mathrm{T}_{1}$ é o tempo necessário para atingir $62,3 \%$ da parcela de deformação retardada total.

Observa-se que o modelo de Maxwell baseia-se no tempo de relaxação e o modelo de Kelvin no tempo de retardo, devido ao significado físico dos dois modelos.

\section{Modelo de Burgers}

O modelo de Burgers é a combinação dos modelos de Maxwell e Kelvin associados em série, conforme apresentado na figura 33e. Sob uma tensão constante, as equações 15 e 19 resultam na equação 20:

$$
\varepsilon=\frac{\tau}{\mathrm{E}_{0}}\left(1+\frac{t}{T_{0}}\right)+\frac{\tau}{\mathrm{E}_{1}}\left[1-e^{\left(-\frac{t}{T_{1}}\right)}\right]
$$

A deformação total é composta por três partes, uma deformação elástica instantânea, uma deformação viscosa e uma deformação elástica retardada, conforme apresentada na figura 34 . 


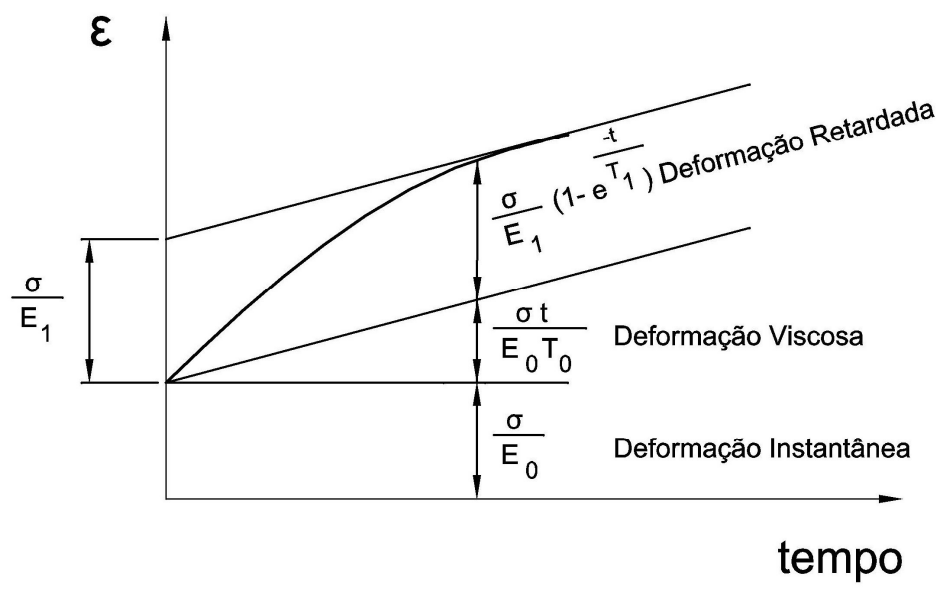

Figura 34 - As três componentes que compõem a deformação no modelo de Burgers (HUANG, 1993)

Um único modelo de Kelvin não é suficiente para reproduzir o comportamento viscoelástico dos materiais por um longo período de tempo em que ocorre a deformação retardada; logo, torna-se necessária a utilização de diversos modelos de Kelvin. O modelo de Burgers, por sua vez, representa melhor a viscoelasticidade dos materiais.

\section{Modelo generalizado}

Com esse modelo pode-se caracterizar qualquer material viscoelástico. Na figura $33 f$ apresenta-se o esquema do modelo generalizado. Sob uma tensão constante a deformação pode ser escrita pela equação 21.

$$
\varepsilon=\frac{\tau}{\mathrm{E}_{0}}\left(1+\frac{t}{T_{0}}\right)+\sum_{i=1}^{n} \frac{\tau}{\mathrm{E}_{1}}\left[1-e^{\left(-\frac{t}{T_{1}}\right)}\right]
$$

Em que $n$ é o número de modelos de Kelvin. Esse modelo mostra o efeito da duração da carga na resposta do pavimento. Sob um único carregamento, registramse predominantemente as deformações elásticas retardadas e instantâneas e a deformação viscosa é negligenciada. Entretanto, caso ocorra carregamentos cíclicos no modelo generalizado, a parcela viscosa torna-se evidente resultando no surgimento da deformação permanente.

Os modelos reológicos procuram através de formulações matemáticas quantificar as parcelas viscoelásticas e viscoelastoplásticas das misturas asfálticas. O modelo de 
Maxwell apresenta a propriedade de relaxação dos materiais betuminosos, já o modelo de Kelvin mostra o tempo de retardo que é necessário para atingir uma parcela correspondente à deformação retardada total do material que é associada à deformação plástica. A soma em série desses dois modelos é o modelo de Burgers, que é aquele que melhor reproduz o comportamento das misturas asfálticas devido à soma das características físicas dos dois modelos. Por fim, comenta Huang (1993) que devido à característica cíclica do tráfego, deve-se utilizar um modelo de Maxwell associado em série a vários modelos de Kelvin também em série.

Os dados de entrada dos modelos reológicos são o módulo de elasticidade (E) que difere do módulo de resiliência devido ao tempo de carregamento na realização do ensaio, a tensão $(\tau)$ que a camada de rolamento será submetida, o tempo $(t)$ de carregamento que a camada está sujeita pela ação do tráfego e a viscosidade $(\lambda)$ que é uma propriedade do ligante asfáltico. Embora o teor de ligante nas misturas asfálticas seja próximo de $5 \%$, esse valor é suficiente para imprimir à mistura características correlatas à sua propriedade viscosa.

Nos modelos reológicos aplicados em misturas asfálticas, torna-se difícil quantificar o efeito da distribuição granulométrica, das variações no teor de ligante asfáltico, e também da variação da temperatura a que as misturas asfálticas estão sujeitas em vida de serviço. Outra limitação dos modelos reológicos está em associar o resultado da parcela de deformação plástica com o desempenho em campo quanto à ocorrência da deformação permanente.

\subsubsection{Ensaios para medida de deformação permanente em laboratório}

Devido aos numerosos fatores que intervém no fenômeno da deformação permanente e às variações destes fatores, há dificuldades de modelagem da deformação permanente que reproduza as verdadeiras ocorrências que teriam em campo. A complexidade destes materiais faz com que os afundamentos em misturas 
asfálticas sejam ainda determinados ou avaliados em laboratório por ensaios empíricos.

Dois ensaios são os mais utilizados para previsão das deformações permanentes: o ensaio de carregamento axial (creep) e os ensaios com simuladores de tráfego de laboratório, descritos nos itens a seguir.

\subsubsection{Ensaio creep}

Roberts et al. (1996) comentam que o ensaio de creep passou a ser empregado em materiais asfálticos para estimar o potencial de deformação permanente de misturas asfálticas a quente. O ensaio é conduzido por aplicação de uma carga estática e o resultado é descrito por uma curva de deformação permanente axial versus o tempo de ensaio. Apresenta-se na figura 35 um típico resultado do ensaio de creep.

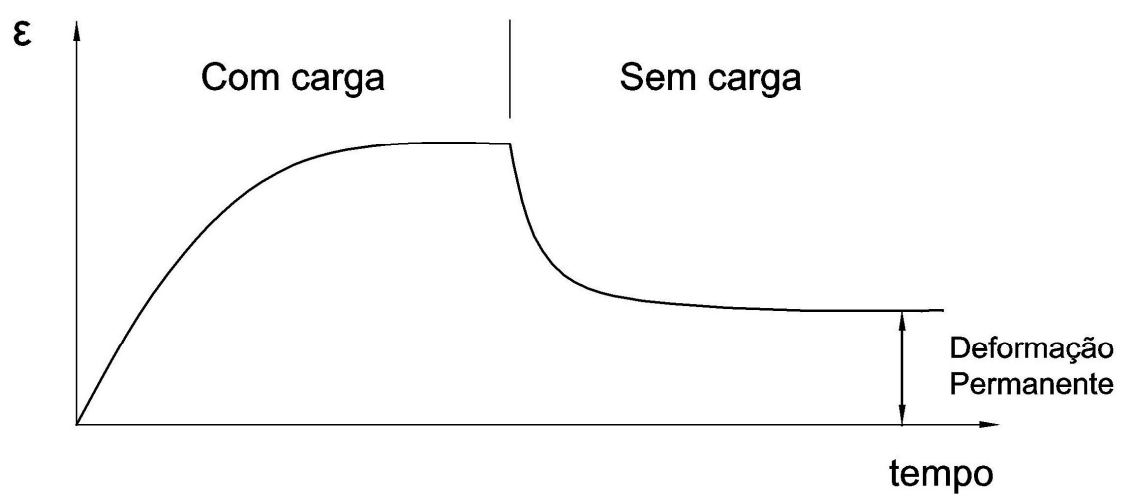

Figura 35 - Resultado típico de um ensaio de creep (ROBERTS et al.,1996)

O ensaio pode ser realizado de três diferentes maneiras em corpos-de-prova cilíndricos:

- aplicação de carga axialmente em corpo-de-prova sem confinamento;

- aplicação de carga axialmente em corpos-de-prova confinados; e

- aplicação de carga diametralmente por ensaio por compressão diametral.

Os ensaios de creep do primeiro e segundo tipos são realizados com uma carga aplicada axialmente, em uma das faces de corpos-de-prova cilíndricos, durante certo 
período, com o registro dos deslocamentos axiais provocados por este carregamento de magnitude constante. Passado certo período, submete-se ao descarregamento e mede-se o retorno dos deslocamentos, ou parte dele por um determinado período.

Estes ensaios, devido à certa facilidade de execução, são empregados por vários pesquisadores. Dentre alguns trabalhos brasileiros, citam-se Sá (1996), que verificou a influência de vários fatores nas deformações permanentes empregando o ensaio de creep; Taira e Fabbri (2001) que modelam o comportamento das misturas asfálticas usando os resultados de ensaios de creep estático e dinâmico; Coutinho Neto e Fabbri (2004), que comparam o comportamento de diferentes misturas asfálticas pelos ensaios de creep estático e de cargas repetidas; Vianna et al (2003) que estudaram em detalhes a aparelhagem de laboratório para o ensaio de creep e propuseram alguns melhoramentos nos equipamentos. Bottin Filho (1997) avaliou a deformação permanente de areia-asfalto empregadas no Rio Grande do Sul utilizando o ensaio de creep e concluiu quanto à deformação permanente que o material ensaiado apresenta boa resistência quando submetido a baixo volume de tráfego.

A figura 36 ilustra uma montagem de um equipamento de creep com confinamento para o ensaio de deformação permanente. Na figura 37 é utilizada uma estrutura destinada ao ensaio de adensamento em solos para a determinação do ensaio de creep axial sem confinamento

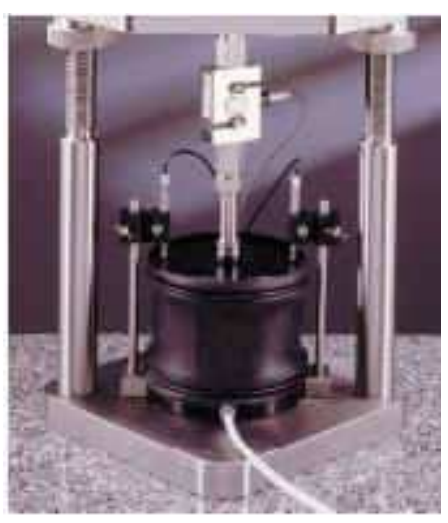

Figura 36 Ensaio de creep com confinamento 


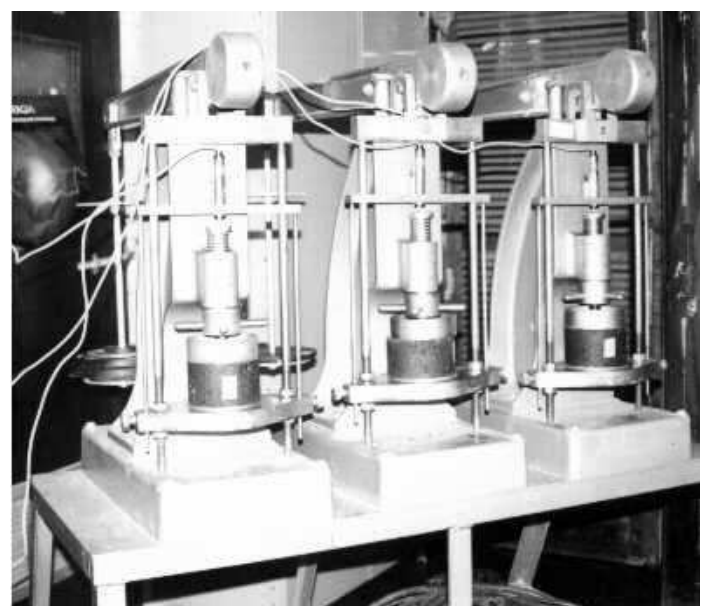

Figura 37 - Ensaio de creep axial sem confinamento com emprego de estrutura para adensamento de solos (SÁ, 1996)

Apresenta-se na figura 38 uma estrutura de ensaio de creep axial sem confinamento e com diâmetro do prato superior inferior ao diâmetro do corpo-de-prova.

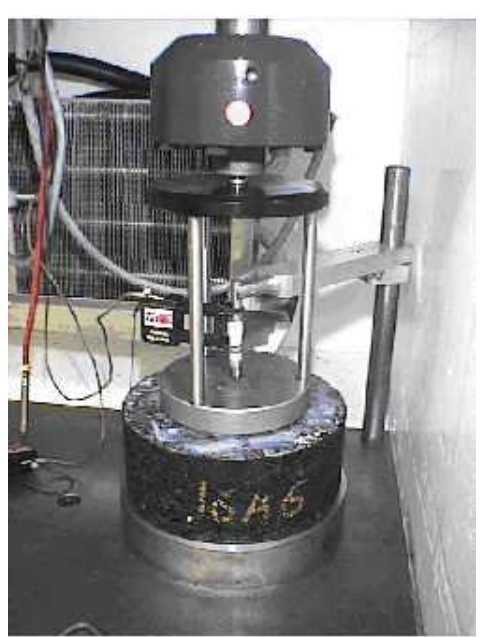

Figura 38 - Ensaio de creep axial sem confinamento com aplicação da carga em área de contato inferior à área do corpo-de-prova

O ensaio de creep, nas condições, figura 38, é normalizado pela ASTM D 2990-09.

Roberts et al. (1996) comentam ainda que o ensaio de creep diametral normalmente se aplica para determinação do potencial de trincamento de misturas asfálticas para baixas temperaturas. Já os ensaios de creep axial, tanto em corpos-de-prova confinados como não confinados, sendo esse último o mais usual, são aplicados para prever o potencial de deformação permanente.

O método de ensaio preconizado pela AASTHO T 322 especifica os procedimentos de ensaio de creep estático por tensão de tração por compressão diametral, 
simplificadamente designado por creep estático por tração indireta. As deformações verticais e horizontais são registradas com utilização de LVDTs locados no centro do corpo-de-prova - figura 39.

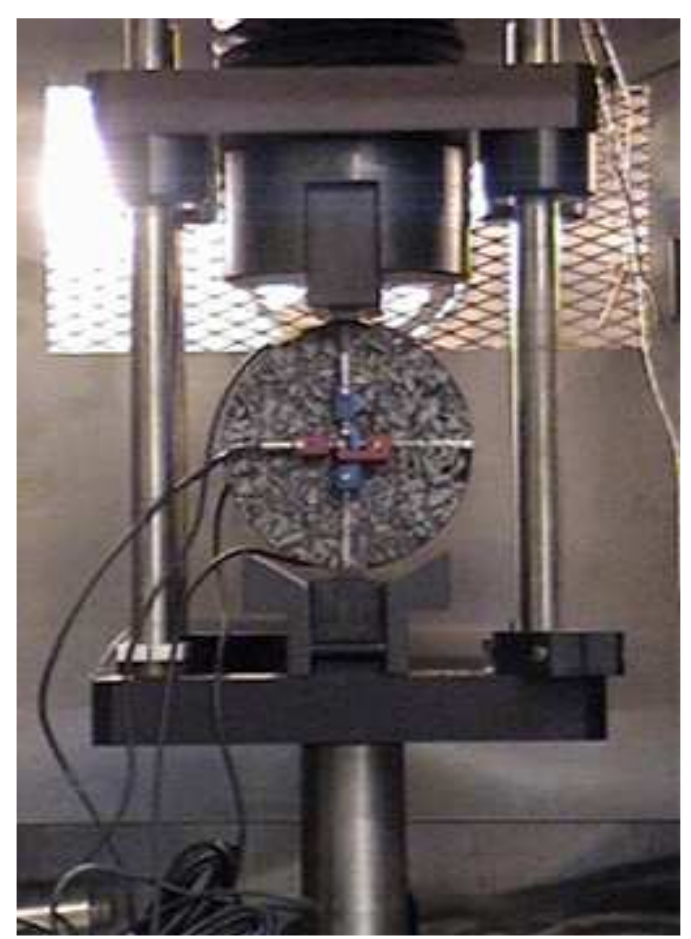

Figura 39 - Instalação dos LVDTs no centro do corpo-de-prova no ensaio de creep por tensão de tração indireta - http://cait.rutgers.edu/prp/prp-testing-facilities

Na figura 40 representa-se esquematicamente os três estágios de comportamento à fluência referentes ao ensaio de deformação de creep, segundo Little et al. (1993). No primeiro estágio registra-se uma velocidade de deformação elevada, no segundo estágio a taxa de deformação tende a ser constante e no terceiro estágio ocorre a falha. Nesse último, a velocidade de deformação cresce rapidamente. 


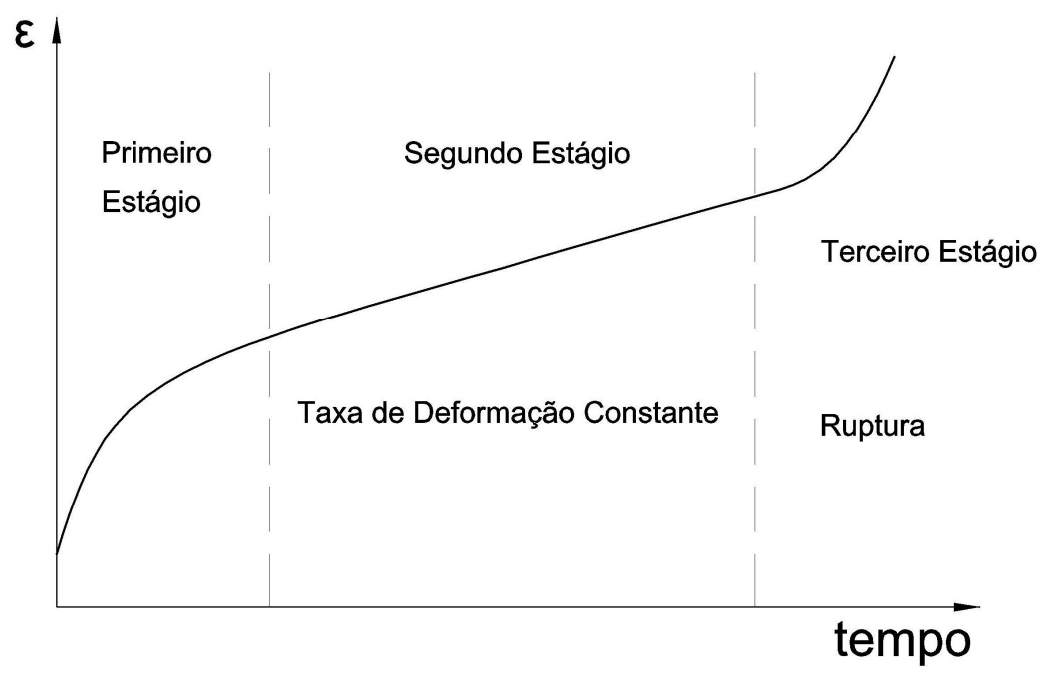

Figura 40 - Ensaio de creep, com os três estágios de deformação por fluência (LITTLE et al., 1993)

Apesar do ensaio creep não apresentar aparentemente dificuldades de execução e os resultados podem ser interpretados com certa facilidade, a variabilidade nos resultados e os problemas de repetibilidade fazem com que este ensaio mostre restrições para ser usado para previsão de comportamento em campo. Os ensaios de carregamento axial estático mostram-se limitados para comparar misturas asfálticas com ligante modificado por polímero ou por borracha em relação às misturas com asfalto convencional. Já os ensaios com repetição de carga mostramse mais aptos para comparação entre diferentes materiais.

\subsubsection{Ensaio com simuladores de tráfego de laboratório}

Uma forma de determinação do potencial que uma mistura asfáltica possui para resistir à deformação permanente é através de ensaios em laboratório com equipamentos simuladores de tráfego.

$\mathrm{Na}$ concepção do método do Superpave de dosagem de misturas asfálticas a quente, previa-se um procedimento da medida do desempenho das misturas asfálticas quanto à formação da trilha de roda, entretanto, a pesquisa não evoluiu a contento de modo a finalizar esse procedimento. Vários equipamentos foram 
testados e dentre eles o mais promissor para atender a essa necessidade foi 0 Asphalt Pavement Analyzer - APA (ROBERTS et al., 1996).

Nesse equipamento é possível ensaiar dois tipos de corpos-de-prova, um em forma de placa com dimensões de $12,5 \mathrm{~cm}$ x $30 \mathrm{~cm}$ e $7,5 \mathrm{~cm}$ de espessura e corpos-deprova cilíndricos com dimensões de $15 \mathrm{~cm}$ de diâmetro e $7,5 \mathrm{~cm}$ de espessura. Os corpos-de-prova são compactados por amassamento com volume de vazios entre 4\% e 7\%. O corpo-de-prova cilíndrico pode ser também obtido com o compactador giratório do Superpave. Uma roda metálica aplica uma carga de $445 \mathrm{~N}$ sobre a superfície do corpo-de-prova através de uma mangueira inflada a uma pressão de $690 \mathrm{MPa}$ que repousa sobre esta superfície. A temperatura de ensaio varia entre $35^{\circ} \mathrm{C}$ e $60^{\circ} \mathrm{C}$, sendo a temperatura mais usual a de $35^{\circ} \mathrm{C}$ por ser a temperatura média do pavimento da Geórgia. O ensaio é conduzido até 8.000 ciclos e com o auxílio de um micrômetro determina-se o afundamento. O equipamento também permite o ensaio em corpos-de-prova imersos em água (COOLEY et al. 2000).

A versão original do APA foi a Georgia Loaded Wheel Test - GLWT, que foi desenvolvido no início da década de 1980 em cooperação entre a DOT da Georgia e o Georgia Institute Technology. O APA foi baseado no equipamento para ensaio de lama asfáltica desenvolvido por C.R. Benedict da empresa Benedict Slurry Seals Inc. O propósito inicial do APA foi o de verificar em laboratório, rotineiramente, 0 comportamento de misturas asfálticas e também de controle da qualidade de produção de campo. O APA, figura 42, é uma modificação da versão GLWT - figura 41, e tem sido utilizado para avaliar a resistência de misturas asfálticas frente a: deformação permanente em trilha de roda, fadiga e dano por umidade. O APA é capaz de ensaiar corpos-de-prova de dois tipos, placas ou cilíndricos, ambos podem ser preparados em laboratório como extraídos de pista, no caso de corpo-de-prova cilíndrico utiliza-se o produzido pela SGC. Apresenta-se na figura 43, corpos-deprova cilíndricos após o ensaio com o APA (KANDHAL \& e COOLEY, 2003). 


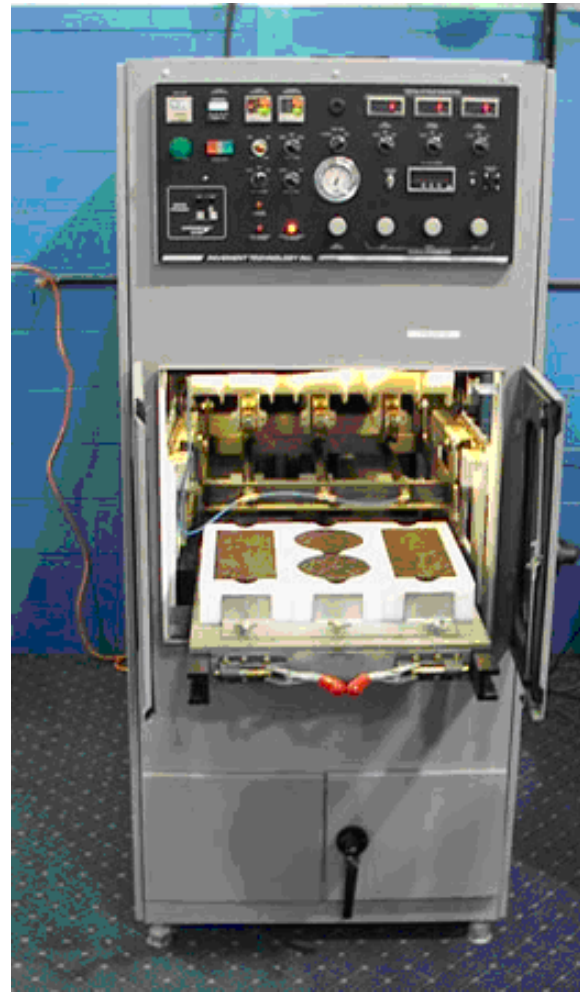

Figura 42 - Asphalt Pavement Analyzer APA - http://pavementinteractive.org/

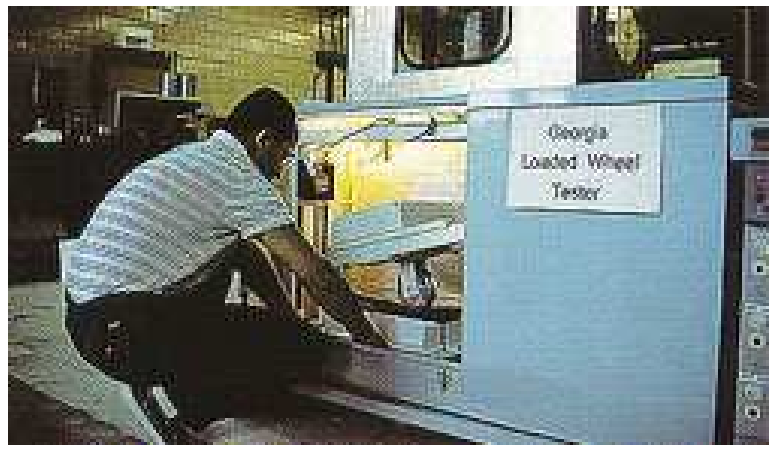

Figura 41 - Georgia Loaded Wheel Test - GLWT http://t2.gstatic.com/images?q=tbn:vYcyYup2s5LX AM\%3Ahttp:

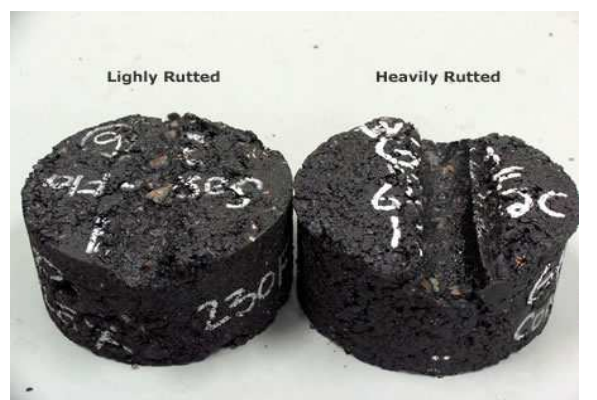

Figura 43 - Corpos-de-prova após ensaio com o APA - http://pavementinteractive.org/

Kandhal e Cooley (2003) comentam que a pesquisa dividiu-se em duas fases:

- a primeira etapa foi para determinar as condições de ensaios de maneira a relacionar os resultados obtidos no APA com aqueles encontrados em campo; e

- a segunda fase da pesquisa foi conduzida para validar e propor um método de ensaio com o APA.

Concluem os autores que a medida de deformação permanente em trilha de roda com o APA apresenta boa correlação com desempenho de misturas asfálticas, uma vez conhecidas as condições ambientais e de tráfego. Comentam também que, em geral, não é possível prever o desempenho da mistura asfáltica frente à deformação permanente em trilha de roda, quando se desconhecem as condições de tráfego e ambientais a que a mistura será submetida.

O Hamburg Wheel Tracking Devices - HWTD, figura 44, é um equipamento destinado a medir a deformação permanente em trilha de roda e resistência à desagregação de misturas asfálticas de rodovias na Alemanha. Foi desenvolvido por 
Helmut-Wind Incorporated de Hamburgo. Os corpos-de-prova são placas com dimensões de $26 \mathrm{~cm}$ x $32 \mathrm{~cm}$ e espessura de $4 \mathrm{~cm}$ e são compactadas por amassamento com $7 \%+/-1 \%$ de volume de vazios. O ensaio é conduzido com 0 corpo-de-prova imerso em água à temperatura variando entre $20^{\circ} \mathrm{C}$ e $70^{\circ} \mathrm{C}$, sendo $\mathrm{O}$ mais usual à temperatura de 50ํ․ Uma roda de aço com largura de $47 \mathrm{~mm}$ solicita a placa no sentido de vai-e-vem com a aplicação de uma carga de $705 \mathrm{~N}$. O critério de parada é quando atinge 20.000 ciclos ou quando ocorrer $20 \mathrm{~mm}$ de deformação (COOLEY et al. 2000).

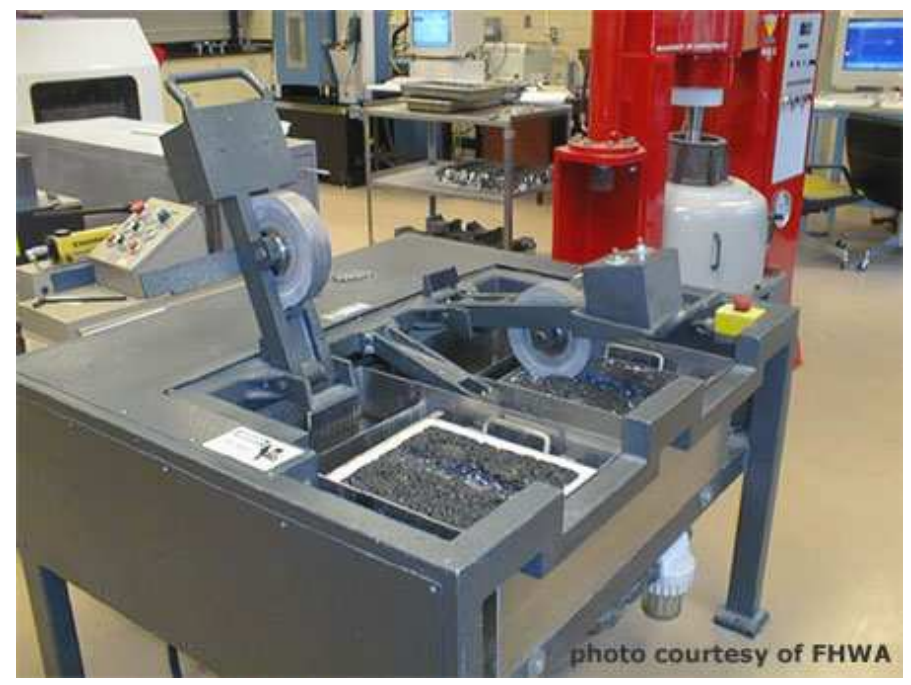

Figura 44 - Hamburg Wheel Tracking Devices - HWTD http://pavementinteractive.org/

O equipamento francês utilizado para determinação da deformação permanente em trilha de roda de misturas asfálticas é o orniéreur - que em tradução livre significa produtor de trilhas. Primeiramente os corpos-de-prova são preparados no equipamento denominado de mesa compactadora, figura 450 processo de compactação das placas das misturas asfálticas é preconizado na norma AFNOR NF 98-250-2. A mistura asfáltica é compactada por amassamento. O processo de compactação assemelha-se muito com as condições de compactação da mistura em campo, logo o volume de vazios encontrado da misturas asfálticas após a compactação com a mesa é próximo do volume de vazios encontrado em campo após a compactação. 


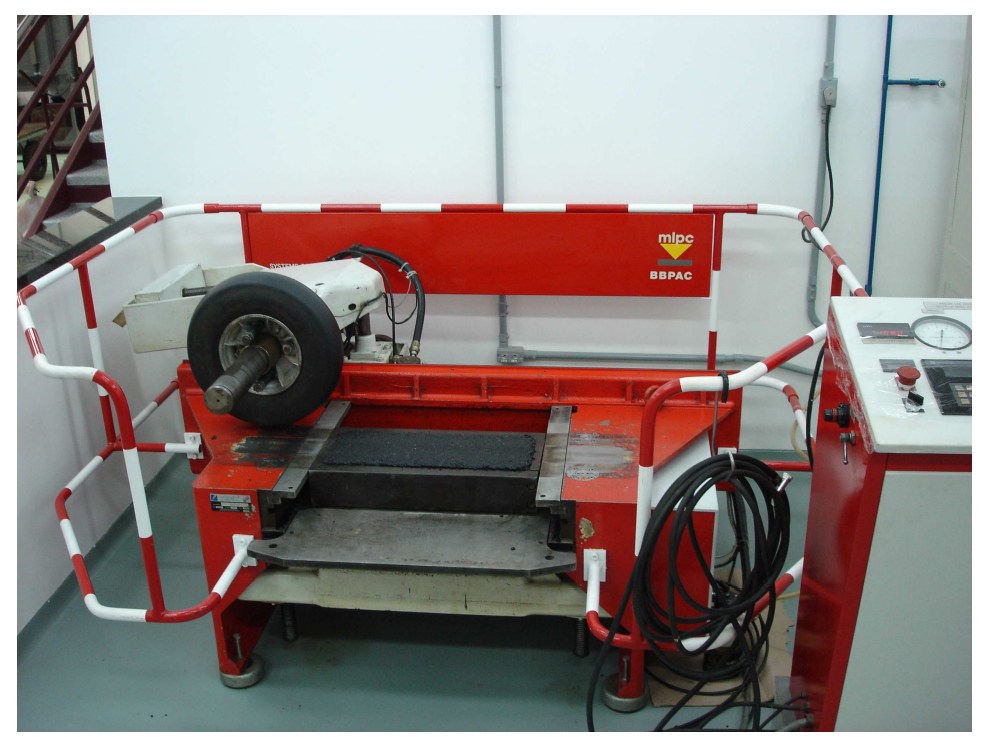

Figura 45 - Mesa compactadora tipo LCPC

O equipamento permite selecionar a pressão de inflagem do pneu, a carga do eixo, o número de passadas e permite também, selecionar o local de passadas de maneira a sobrepor parcialmente a área de uma passada em relação à anteriormente aplicada, como normalmente ocorre na compactação de campo. As placas tem dimensões de $18 \mathrm{~cm}$ x $50 \mathrm{~cm}$ e $5 \mathrm{~cm}$ ou $10 \mathrm{~cm}$ de espessura.

Preparadas as placas, normalmente aos pares, após resfriamento e "cura" de dois a três dias, são submetidas ao ensaio de deformação permanente em trilha de roda no equipamento orniéreur. É apresentado na figura 46 o equipamento orniereur - que em português foi traduzido por simulador de tráfego, a partir da denominação para o mesmo equipamento orniéreur Francês que na Suíça francesa é chamado de Simulateur de Trafic. Na figura 47 são apresentados os detalhes do corpo-de-prova, do pneu e do sistema de leitura do afundamento na trilha de roda. 


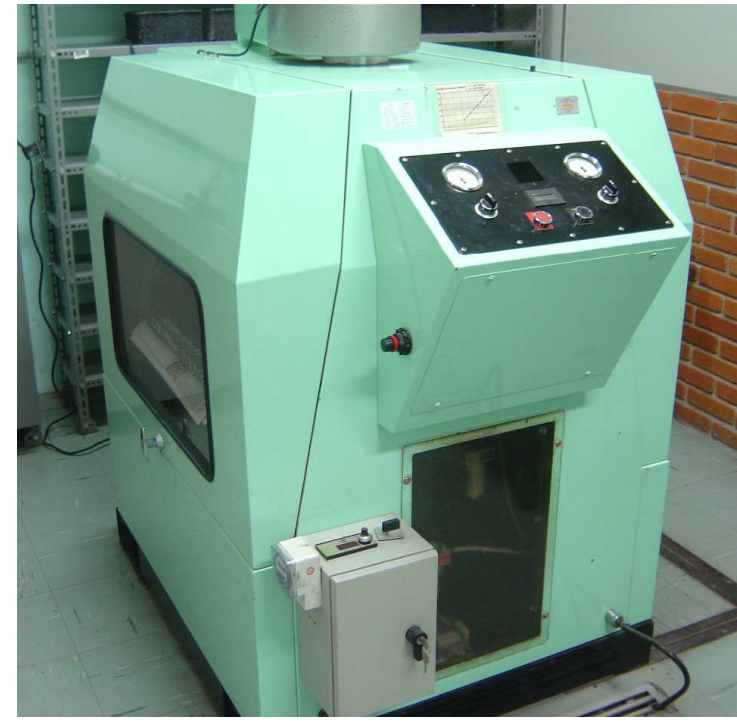

Figura 46 - Equipamento francês de deformação permanente - Orniéreur (Simulador de Tráfego)

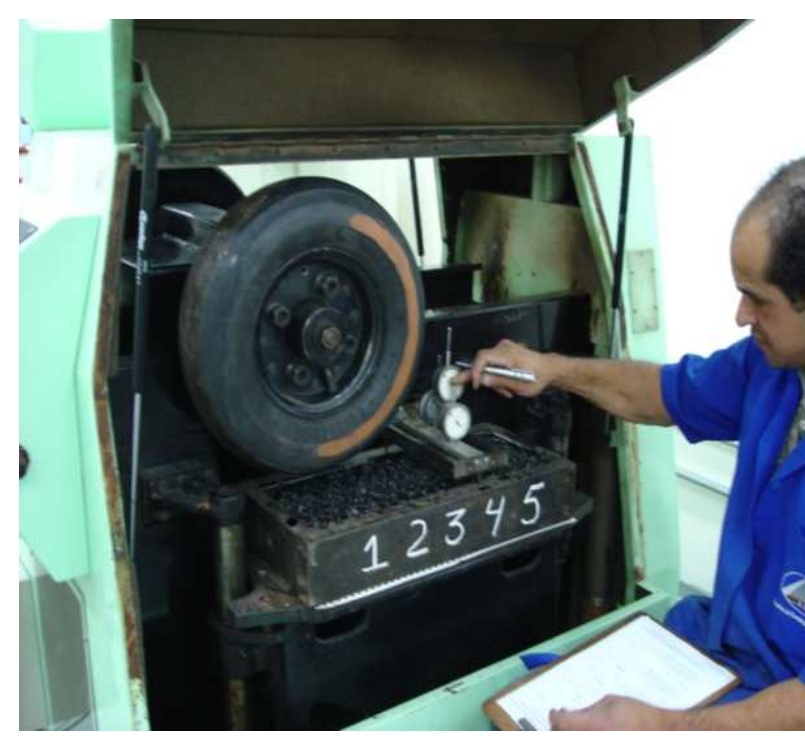

Figura 47 - Detalhe do equipamento Orniéreur (Simulador de Tráfego)

No ensaio de deformação permanente em trilha de roda a pressão de inflagem dos pneus é de 0,6 MPa, a carga de ensaio é de $5 \mathrm{kN}$, aplicada em cada placa. Apesar da carga e pressão de inflagem estarem especificadas na norma francesa de ensaio de afundamento em trilha de roda, estes parâmetros podem ser alterados para estudos e pesquisas. Merighi (1999) estudou a influência da carga nos afundamentos em trilha de roda. A freqüência de ensaio é de $1 \mathrm{~Hz}$ e em 1 ciclo ocorrem duas passadas. $\mathrm{O}$ ensaio é conduzido à temperatura de $60^{\circ} \mathrm{C}$, o sistema de medidas do afundamento é realizado em 15 pontos distribuídos em toda a área solicitada pelo pneu e o resultado é a média dessas medições.

O ensaio termina quando a placa é submetida a um número máximo de 30.000 ciclos (60.000 passadas) ou quando a mistura asfáltica se deforma excessivamente de maneira a prejudicar as leituras de afundamento.

As diretrizes francesas para o problema de deformação permanente têm limitado o valor obtido no simulador de tráfego em $10 \%$ como sendo o limite aceitável para camadas de concreto asfáltico utilizadas como revestimentos, com espessuras entre 6 a $8 \mathrm{~cm}($ LCP, 2007)

Há ainda diretrizes de dimensionamento européias do Grupo COST 333 que limitam as deformações permanentes em $5 \%$ no caso de misturas asfálticas densas, 
utilizadas como revestimento, para tráfego pesado (fort) - acima de 2000 veículos comerciais diários, com eixo traseiro carregado de no mínimo 5 toneladas.

A norma européia, na versão espanhola UNE-EN 12697-22:2008+A1, para determinação de deformação permanente em trilha de roda, prescreve o procedimento de ensaio para três tipos de equipamentos, diferenciados quanto ao tamanho das amostras testadas: tamanho grande, extragrande e pequeno, sendo que o equipamento denominado de tamanho grande refere-se ao tipo francês orniéreur, a norma não faz comentários de limites de afundamentos. Com referência aos limites de afundamentos com o orniéreur francês, segundo informações do $\mathrm{LCPC}^{7}$, para tráfego pesado, são especificados valores.

Leahy e McGennis (1999) apresentam resumo das principais características e critério de aceitabilidade dos três tipos de simuladores de tráfego de laboratório: LCPC, Hamburg e APA, tabela 16.

\footnotetext{
${ }^{7}$ Informação fornecida pelo Eng. Yves Brosseaud do LCPC de Nantes, França.
} 
Tabela 16 - Resumo comparativo de características dos simuladores, LCPC, Hamburg e APA (LEAHY e MCGENNIS, 1999)

\begin{tabular}{|c|c|c|c|}
\hline \multirow{2}{*}{ Parâmetro } & \multicolumn{3}{|c|}{ Equipamento } \\
\hline & LCPC & Hamburg & APA \\
\hline $\begin{array}{c}\text { Dimensões dos } \\
\text { corpos-de- } \\
\text { prova } \\
\end{array}$ & $\begin{array}{c}50 \mathrm{~cm} \times 18 \mathrm{~cm} \\
\text { (espessura de } 2 \text { a } 10 \\
\mathrm{~cm} \text { ) }\end{array}$ & $\begin{array}{c}25 \mathrm{~cm} \times 28 \mathrm{~cm} \\
\text { (espessura } 6 \text { a } 9 \mathrm{~cm} \text { ) }\end{array}$ & $\begin{array}{l}7,5 \mathrm{~cm} \times 38,1 \mathrm{~cm} \\
(\text { espessura } 3 \mathrm{~cm})\end{array}$ \\
\hline $\begin{array}{l}\text { Amplitude de } \\
\text { carga }\end{array}$ & $\begin{array}{c}5000 \mathrm{~N} \text { regulável } \\
\text { Pressão de inflagem } \\
\text { dos pneus }=0,6 \mathrm{MPa} \\
\text { regulável }\end{array}$ & $\begin{array}{c}705 \mathrm{~N} \\
\text { Roda metálica }\end{array}$ & $\begin{array}{c}445 \mathrm{~N} \\
\text { Carga de roda } \\
\text { aplicada através de } \\
\text { mangueira inflada = } \\
0,7 \mathrm{MPa} \\
\end{array}$ \\
\hline $\begin{array}{l}\text { Aplicação da } \\
\text { carga }\end{array}$ & $\begin{array}{c}1 \text { ciclo }=1 \mathrm{~Hz} \\
1 \text { ciclo duas passadas }\end{array}$ & $\begin{array}{c}1 \text { ciclo }=1 \mathrm{~Hz} \\
1 \text { ciclo duas } \\
\text { passadas }\end{array}$ & $\begin{array}{c}1 \text { ciclo }=1 \mathrm{~Hz} \\
1 \text { ciclo duas passadas }\end{array}$ \\
\hline $\begin{array}{l}\text { Tempo de } \\
\text { ensaio }(\mathrm{h})\end{array}$ & 9 & 6 & 4 \\
\hline Critério & $\begin{array}{c}\text { Até } 10 \% \text { de } \\
\text { deformação em relação } \\
\text { à espessura para } \\
30.000 \text { ciclos é } \\
\text { considerada adequada }\end{array}$ & $\begin{array}{l}\text { Até } 4 \mathrm{~mm} \text { de } \\
\text { deformação após } \\
20.000 \text { ciclos é } \\
\text { considerada } \\
\text { adequada }\end{array}$ & $\begin{array}{c}\text { Até } 7,6 \mathrm{~mm} \text { de } \\
\text { deformação após } \\
8.000 \text { ciclos é } \\
\text { considerada } \\
\text { adequada }\end{array}$ \\
\hline
\end{tabular}

\subsubsection{Simuladores de tráfego em escala real}

\subsection{Introdução}

Metcalf (1996) relata que ensaios acelerados de pavimentos em verdadeira grandeza consistem na "aplicação controlada de uma carga de roda igual ou acima da carga máxima legal permitida em um pavimento estruturado, seja ele um pavimento-teste ou uma via existente, para se determinar a resposta do sistema e seu desempenho sob condições controladas e aceleradas de acúmulo de danos num espaço de tempo limitado".

O mesmo autor comenta ainda que a aceleração no dano no pavimento pode ser atingido por meio dos seguintes itens:

- incremento das repetições de cargas

- modificação do carregamento

- alteração das condições ambientais (umidade e temperatura)

- utilização de pavimentos delgados com reduzida capacidade estrutural e por conseguinte menor vida útil de dimensionamento, e,

- ou pela combinações de dois ou mais fatores acima descritos. 
O emprego de simuladores de tráfego em escala real tem sido cada vez mais difundido como ferramenta de apoio ao processo de tomada de decisão e para 0 entendimento quanto ao real comportamento dos pavimentos e de novos materiais, e também auxiliar na redução das incertezas dos modelos de desempenho utilizados para o dimensionamento de pavimentos novos ou mesmo de projetos de restauração. Esses equipamentos permitem a obtenção de dados mais precisos na modelagem das condições futuras dos pavimentos e os investimentos associados que se farão necessários, permitindo assim programar as estratégias de manutenção preventiva e corretiva, bem como a reabilitação dos pavimentos ao longo de um determinado período de análise (FRITZEN, 2005).

O emprego dos simuladores de tráfego em escala real, conforme apresentado por Metcalf (1996), permite a realização de ensaios dentro de condições de contorno mais próximo das que o pavimento será submetido em vida de serviço, podendo ser empregado para diversos fins, tais como:

- para pavimentos existentes, avaliar a capacidade de resistir a solicitações de tráfego mais elevada, uma vez que a maioria dos métodos de dimensionamento vigentes, foram baseados, quanto ao conceito coberturas, em número inferior aos praticados atualmente;

- estimar o desempenho de novos materiais e estruturas de pavimentos em métodos de dimensionamento;

- avaliar materiais não convencionais;

- constatar os processos de estabilização e tratamentos com geossíntéticos para subleitos;

- determinar o processo de deterioração dos pavimentos;

- avaliar os efeitos de novos eixos, cargas e configurações de rodas;

- investigar os efeitos ambientais; e,

- determinar a vida remanescente de um pavimento.

Entretanto, diversos autores, dentre eles Guo e Prozzi, (2008) afirmam que, embora as utilizações de simuladores de tráfego submetam os pavimentos às condições próximas de campo, esses não consideram os efeitos da deterioração causada ao longo do tempo. Consideram que os resultados dos ensaios acelerados com 
simuladores são complementos aos ensaios laboratoriais, levando assim a avanços práticos e a ganhos econômicos no estudo de pavimentos.

\subsection{Simuladores fixos em campos de prova}

Desde o início do século 20, sendo mais acentuado no período da 2ª.Grande Guerra, os simuladores de tráfego tem sido cada vez mais utilizados. Observou-se um crescimento acentuado nas últimas seis décadas. Basicamente podem-se dividir os simuladores de tráfego fixos de campo em três tipos: simuladores circulares, simuladores lineares e veículos simuladores em pistas-teste fechadas.

Os simuladores circulares possuem o rodado do semi-eixo fixo a um braço, que por sua vez está acoplado a um pivô central. Exemplos: Mànege de fatigue do LCPC em Nantes, na França - figura 48 e, simulador tráfego do IPR/DNER- figura 49.

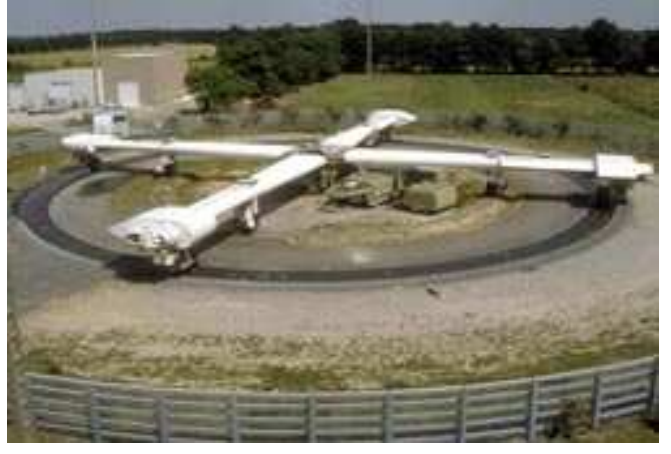

Figura 48 - Ménege de Fatigue - Nantes na França -

http://www.lcpc.fr/en/presentation/moyens/man ege/index.dml

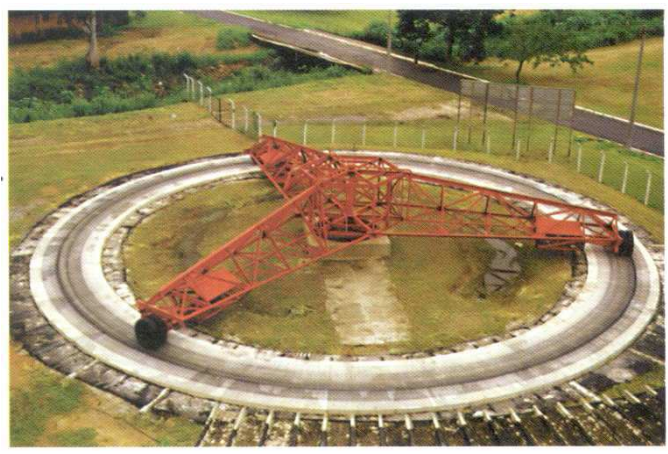

Figura 49 - Simulador circular IPR/DNER - RJ http://www.proasfalto.com.br/pdf/ProAsfalto_c apitulo_10.pdf

Silva (2001) em pesquisa desenvolvida em 1998, com a Pista Circular Experimental do IPR/DNER, recebeu prêmio de melhor trabalho pela Associação de Empresas de Engenharia do Rio de Janeiro - AEERJ, em 2002, com a pesquisa de reforço de pavimento com emprego Whitetopping. A pesquisa contou com a instalação de extensômetros e células de carga que foram instalados a cerca de $20 \mathrm{~mm}$ acima da camada de CBUQ, camada esta de assentamento do whitetopping, com o cuidado de ficarem imersos no concreto, mas o mais próximo possível da fibra inferior (contato entre CCP e CBUQ) e no centro da faixa de rolamento do carrossel. Foram 
instalados também strain gauges, próprios para instalação em concreto ainda no estado pastoso, e os cabos de ligação foram protegidos por dutos metálicos com a finalidade de proteger as ligações elétricas da umidade do solo e minimizar as interferências eletromagnéticas. Foi possível registrar valores de tensão na ordem de $14 \%$ a $24 \%$ da tensão de tração do concreto, indicando que a camada de Whitetopping dificilmente sofreria trincamento por fadiga à flexão nas condições da estrutura do pavimento e do local instalado.

Também foram instalados 11 termopares na pista experimental com o objetivo de monitorar a temperatura das placas de whitetopping, sendo monitoradas geralmente em intervalos de 10 ou 15 minutos em ciclos de 24 horas. Neste estudo observou-se que as temperaturas medidas no pavimento foram maiores que a temperatura média do ar durante todo o período de análise e que as variações diárias de temperaturas foram maiores na superfície comparadas com as temperaturas em camadas mais profundas.

Os Simuladores lineares possuem o rodado que se move linearmente através da seção-teste. As solicitações podem ser em uma única direção ou em ambas (sem perda de contato do pneu com o pavimento). Como exemplos desses tipos de simuladores fixos em campos de testes, tem-se o simulador de tráfego linear da UFRGS/DAER - figura 50, e o simulador do CEDEX em Madrid, na Espanha, que embora apresente uma pista oval, a seção de teste considerada é o trecho linear figura 51.

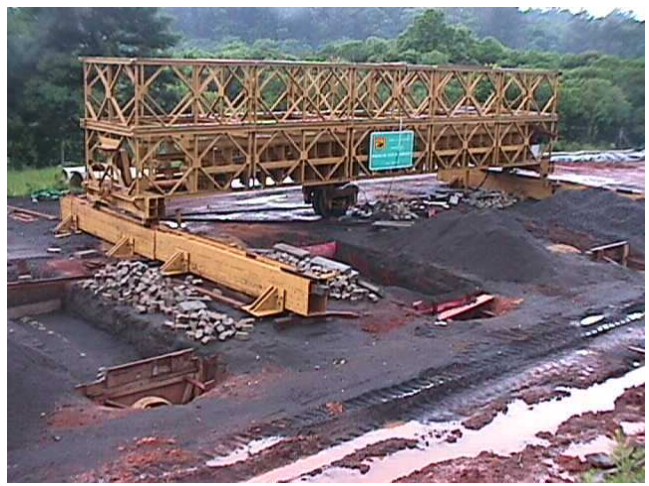

Figura 50 - Simulador linear fixo UFRGS/DAER.

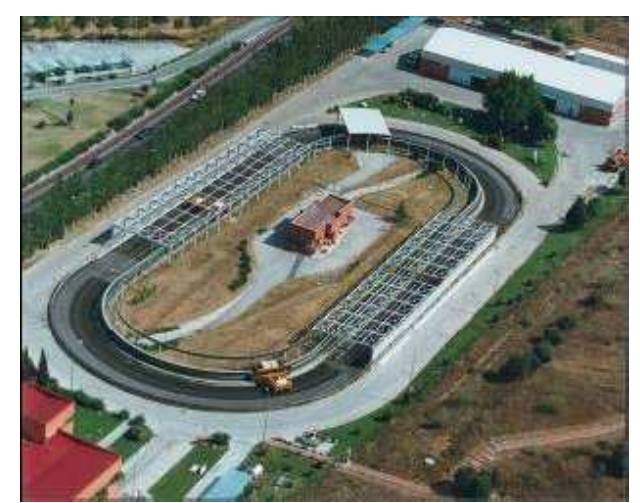

Figura 51 - Linear test track - CEDEX Madrid http://www.cedex.es/apt2008/html/docs/apt_update/Spai n_CEDEX 
Núñes et al. (1995), em trabalho premiado pela $A B P v$ que posteriormente fez parte de doutorado de Núñes apresentado à UFRGS em 1997, aborda a utilização do simulador de tráfego fixo na verificação do desempenho do basalto alterado como camada estrutural de pavimentos. A pesquisa contemplou a construção de 10 pistastestes, divididas em dois grupos de 5 pistas cada, sendo em cada grupo a utilização de basaltos provenientes de jazidas distintas. Variaram-se as espessuras das camadas e também a intensidade das cargas do simulador de tráfego. Núñes concluiu com base nos bons resultados encontrados nas simulações nas pistastestes que o basalto alterado pode ser empregado na pavimentação de rodovias coletoras, proporcionando boa qualidade técnica e notável economia.

Gonçalves (2002) avaliou o desempenho funcional e estrutural de seis pistas experimentais construídas no campo de provas da UFRGS. As pistas foram instrumentadas com medidores de tensões e deformações verticais no subleito e submetidas a ensaios acelerados com simulador de tráfego linear. Com os resultados foi possível estabelecer modelos de regressão que reproduzissem 0 desempenho dos pavimentos em termos de evolução do trincamento do revestimento asfáltico. Verificou que existe uma tendência logarítmica de crescimento dos afundamentos em trilha de roda com o tráfego acumulado e que os módulos retroanalisados, obtidos com o FWD ou com a viga Benkelman eletrônica mostraram-se adequados para a interpretação do desempenho estrutural dos pavimentos experimentais. Gonçalves comparou os resultados de afundamentos encontrados no simulador fixo com resultados laboratoriais com o simulador LCPC e verificou tendências de progressão de afundamentos similares.

Os veículos simuladores em pistas-testes fechadas se dá de forma livre ao longo da pista-teste, com emprego de veículos-padrão pilotados ou controlados remotamente. As pistas podem apresentar diferentes formas geométricas. As figuras 52 e 53 mostram ao pista do NCAT na Cidade de Alburn, Alabama - EUA. 


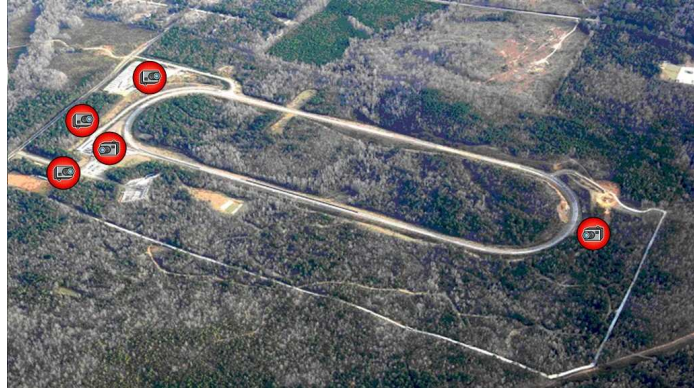

Figura 52 - Pista-teste do NCAT em Alburn, Alabama USA -

http://www.ncat.us/facilities/test-track.html.

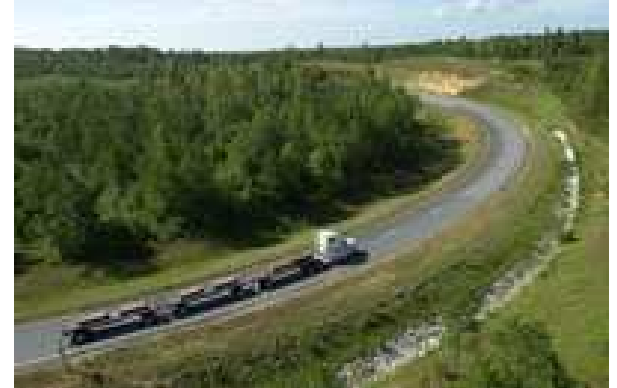

Figura 53 - Sistema de simulação do tráfego com veículos -

http://www.ncat.us/facilities/test-track.html

Embora, fosse uma pista experimental aberta ao tráfego, a pista da AASHO reuniu o que se dispunha de mais avançado sobre pavimentação em sua concepção e construção. Os dados coletados da pista experimental balizaram o método de dimensionamento de pavimentos flexíveis da AASHTO. Foi projetada a partir de 1951 e construída entre 1956 e 1958 na cidade Ottawa, Illinois - EUA. Teve seu tráfego monitorado e utilizado na elaboração do método de dimensionamento, entre 1958 e 1960. Na figura 54 apresenta-se de forma esquemática uma das pistas da AASHTO, com as características do loop normalmente utilizado neste experimento.

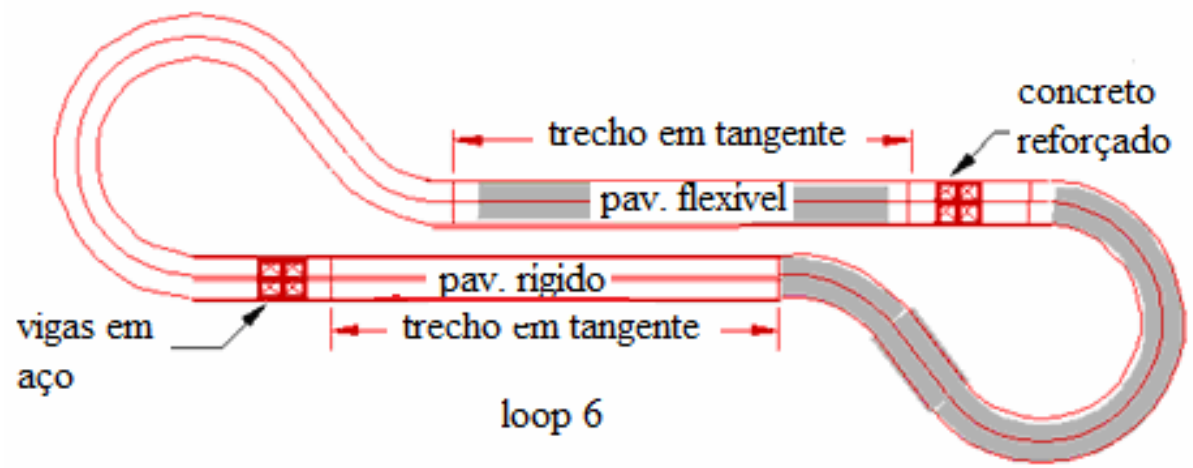

Figura 54 - Características do loop da pista da AASHTO ROAD TEST -

http://training.ce.washington.edu/wsdot/Modules/06_structural_design/aasho_road_test.htm

$\mathrm{Na}$ figura 55 estão apresentados os seis loops construídos entre a cidade de Ottwa e Utica no Estado de Illinois - EUA. 


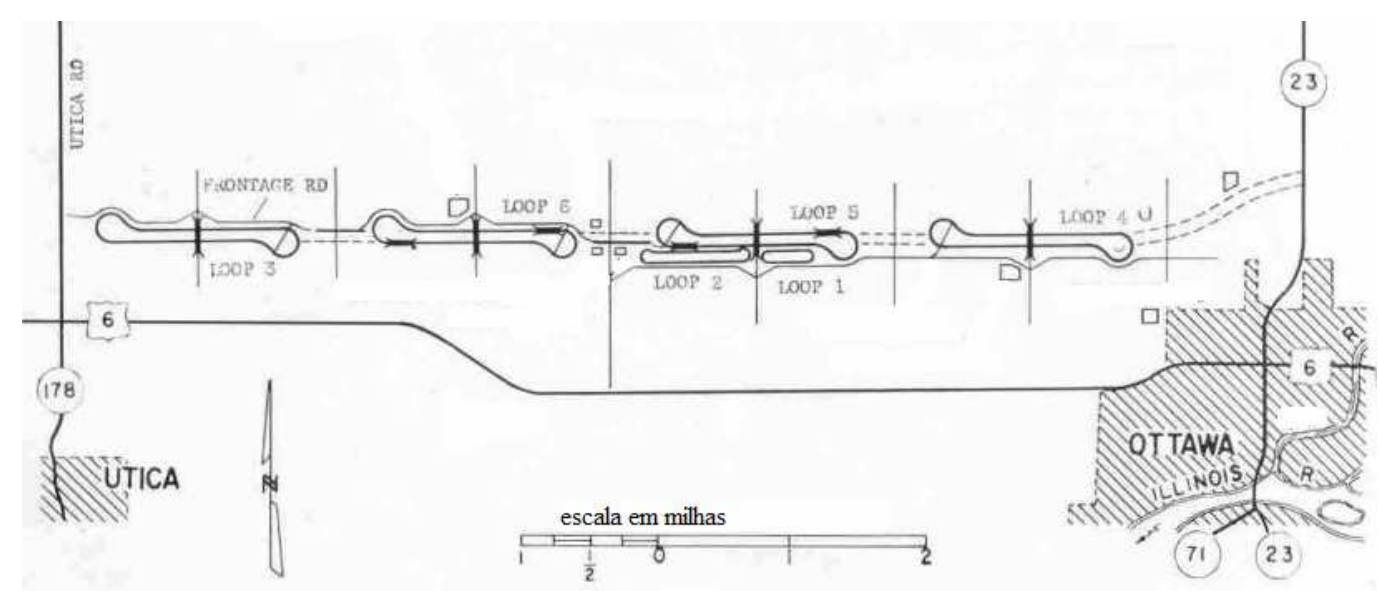

Figura 55 - Os seis loops da AASHO ROAD TEST construídos entre Illinois e Utica na década de 1950

http://training.ce.washington.edu/wsdot/Modules/06_structural_design/aasho_road_test.htm

\subsection{Simuladores móveis para pistas-testes}

O simulador de tráfego móvel, do inglês Heavy Vehicle Simulator - (HVS), foi concebido na África do Sul por um Conselho de Pesquisa Científica e Industrial. Trata-se de um equipamento projetado para medir de forma acelerada o desempenho de pavimentos. A vantagem de seu emprego é que fornece, em um curto espaço de tempo, dados que permitem uma melhor compreensão dos fenômenos e utilização de resultados de ensaios laboratoriais e de campo em projetos de estrutura de pavimento mecanicista.

Antes do desenvolvimento do simulador de tráfego móvel, os projetistas tinham que aguardar o tempo de vida de serviço para extrair resultados confiáveis quanto ao desempenho dos pavimentos por meio de observações e monitoramentos periódicos. Já para um pavimento novo, o HVS pode simular as condições de tráfego reais a que o pavimento serão submetidos em curto período, acelerando a obtenção de respostas. Dependendo do tipo de teste que se deseja, o HVS é capaz de simular até 20 anos de solicitações de tráfego pesado, em cerca de dois a três meses de operação. Isso é possível graças à operação do HVS por 24 horas diárias, e durante os 7 dias por semana. Outra vantagem é que o HVS apresenta a possibilidade de aumento na carga do semi-eixo em até 2,5 vezes em relação à carga do eixo-padrão (UCPRC, 2009). 
Fritzen (2005) comenta que com os primeiros registros da utilização de simulador de tráfego móvel HVS na África do Sul, seus bons resultados estimularam diversos centros de pesquisas e universidades de vários países a utilizarem estas facilidades, de ensaio de forma acelerada, para antever o desempenho de pavimentos. $O$ simulador tem sido usado para avaliar a eficiência de novos materiais, produtos e processos construtivos e incorporar os resultados aos projetos rodoviários.

A Figura 56 mostra um equipamento simulador móvel concebido e construído no Brasil para estas finalidades.

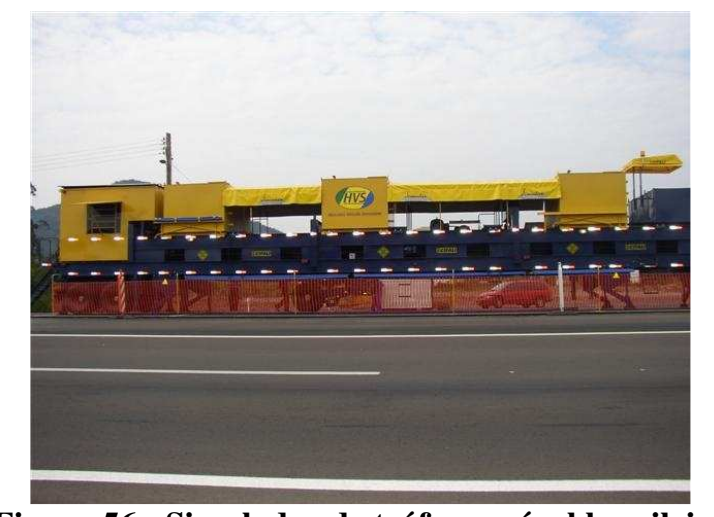

Figura 56 - Simulador de tráfego móvel brasileiro

O simulador de tráfego móvel brasileiro foi utilizado no experimento desta tese. $O$ equipamento possui 25 m de extensão e largura total de $3 \mathrm{~m}$; a carga é aplicada no pavimento por um semi-eixo, que é acionado por um sistema hidráulico - figura 57.0 simulador conta com uma barra de reação que também tem a função de guia do semi-eixo, e o deslocamento de vai-e-vem do semi-eixo se dá pelo tracionamento de um cabo - figura 58.

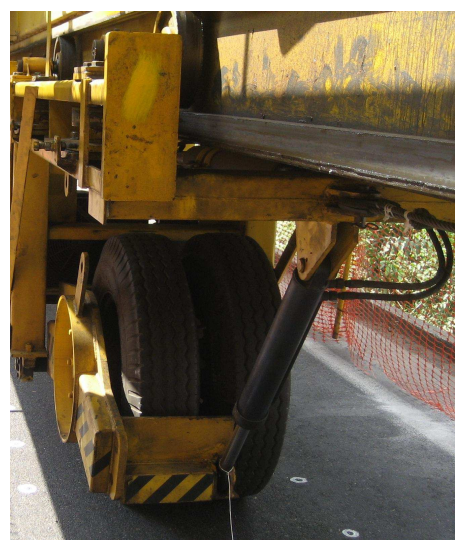

Figura 57 - Semi-eixo acionado por pistão hidráulico

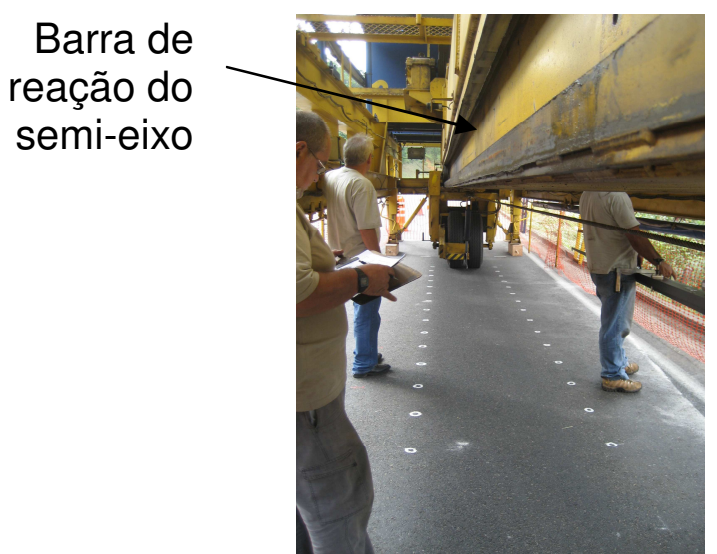

Figura 58 - Barra de reação e cabo de aço 
O peso bruto total (com lastro) do simulador é de 50 t, o comprimento máximo da área simulada é de $10 \mathrm{~m}$ e a largura máxima de $1 \mathrm{~m}$. O simulador permite que 0 rodado tenha um deslocamento lateral de $0,8 \mathrm{~m}$, simulando melhor as condições de tráfego. A velocidade média de deslocamento do semi-eixo é de $10 \mathrm{~km} / \mathrm{h}$. O número médio de ciclos diários é de 4000, se a solicitação for unidirecional, e de 8.000 ciclos por dia, se a solicitação for bidirecional. A manutenção no equipamento dependia das horas de funcionamento, normalmente eram efetuadas a cada cerca de 24 horas de operação.

No estudo desta tese, foram empregadas duas cargas no semi-eixo: 6,2 tf (62 kN que equivalem a uma carga $20 \%$ acima do eixo legal) para 500.000 ciclos, e 8,3 tf (83 kN, 60\% acima do eixo legal) para 250.000 ciclos. A carga de roda aplicada pelo semi-eixo é aferida com o emprego de uma balança móvel, cuja aferição é feita de duas formas: estaticamente figura 59 e em movimento figura 60. A aferição estática tem sido adotada para os cálculos.

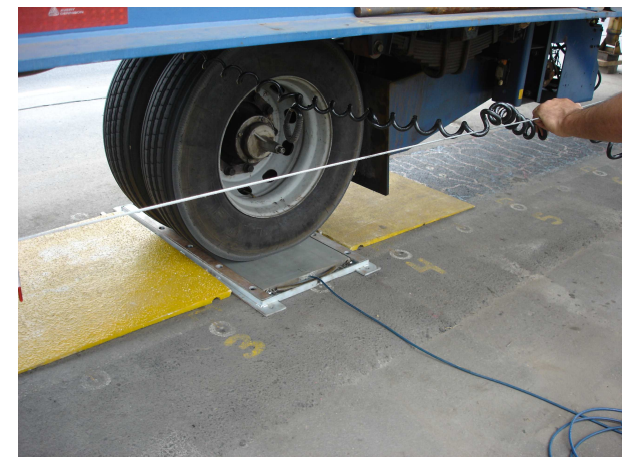

Figura 59 - |Aferição da carga estaticamente

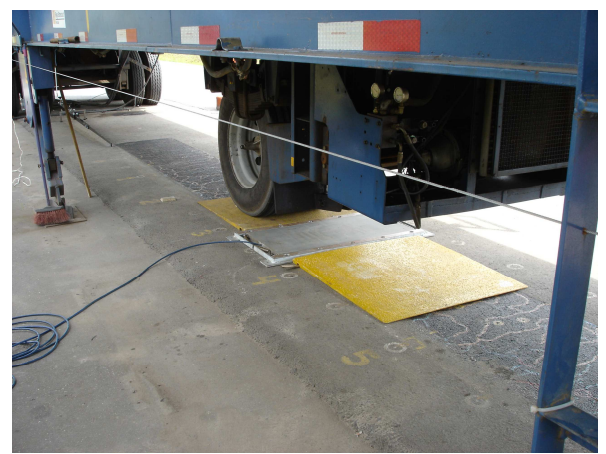

Figura 60 - Aferição da carga dinamicamente

Vários experimentos tem sido realizados no Brasil com o simulador de tráfego brasileiro, que vem sendo utilizado para esta finalidade a cerca de 5 anos. llustramse a seguir alguns experimentos com o simulador de tráfego brasileiro cujos resultados foram utilizados em dissertações e teses no país.

Fritzen (2005) relata em sua dissertação de mestrado a construção de quatro trechos experimentais, na Rodovia Rio Teresópolis, com soluções diferentes que foram testadas por meio de ensaios acelerados com a utilização do simulador de tráfego móvel. Em três dos trechos foram empregadas soluções de fresagem de 
parte do revestimento e aplicação de concreto asfáltico convencional, concreto asfáltico com geogrelha e concreto asfáltico com asfalto borracha. O número de solicitações do simulador equivalem a 3,6x $10^{6}, 4,1 \times 10^{6}$ e $3,8 \times 10^{6}$ repetições do eixo padrão rodoviário, respectivamente. Para determinação do número $\mathrm{N}$ foi admitido o correspondente ao critério de desempenho de uma área de trincamento de aproximadamente $40 \%$ da superfície solicitada pelo trem-de-prova. Após terem sido solicitados pelo simulador de tráfego móvel, esses três trechos apresentaram trincamento, sendo que as trincas no trecho com geogrelha ocorreram de cima para baixo. O quarto trecho, que usou concreto rolado na base e concreto asfáltico como revestimento, mesmo após $4,7 \times 10^{6}$ repetições de carga do eixo padrão, não apresentou trincamento.

Victorino et al. (2009), em pesquisa de campo, submeteram dois segmentos da Rodovia BR 290/RS, com estruturas idênticas ao simulador de tráfego móvel brasileiro. Testaram dois segmentos sendo que o número de solicitações com simulador de tráfego móvel foi de 170.000 ciclos e 255.000 ciclos para os segmentos 1 e 2 respectivamente, com a carga do semi-eixo foi 8,2 t. Durante os ensaios foram verificadas as evoluções das deflexões, dos afundamentos nas trilhas de roda e dos trincamentos superficiais.

Os afundamentos registrados para o segmento 1, pelo fato de ter sido previamente submetidos à ação do tráfego apresentava um valor de $15 \mathrm{~mm}$, e após o ensaio com o simulador de tráfego móvel, o valor registrado contunuou bastante próximo, ligeiramente acima do existente. O segmento 2 partiu de $1 \mathrm{~mm}$ chegando ao final na ordem de $3 \mathrm{~mm}$, apresentando uma variação aproximadamente de $2 \mathrm{~mm}$. Conforme registros, a temperatura média ambiente manteve-se entre $10^{\circ} \mathrm{C}$ e $20^{\circ} \mathrm{C}$ durante a realização do experimento, propiciando uma resistência à formação de afundamentos em trilha de roda. Por outro lado, essa média baixa de temperatura contribuiu para o enrijecimento da mistura asfáltica colaborando para o trincamento da mistura asfáltica.

Os autores citados relacionaram a velocidade do semi-eixo do simulador de tráfego móvel com a velocidade média de operação da rodovia para caminhões e, através 
das características do ligante asfáltico, inferiram esses dados na equação de Van der Poel, obtendo um valor de módulo de rigidez da mistura asfáltica. Em seguida, com emprego do software Everstress 5.0 de análise de tensão-deformação de camada asfáltica, foi possível deduzir a correlação entre o número de solicitações do simulador de tráfego móvel com o número $\mathrm{N}$ da rodovia. A relação encontrada foi de 30 a 40 vezes, ou seja, uma solicitação do simulador de tráfego móvel equivale entre 30 a 40 vezes a solicitação de um eixo simples de rodas duplas padrão, usado para calcular o número $\mathrm{N}$. Concluem que o simulador de tráfego móvel é uma ferramenta importante para análise de comportamento de pavimento em escala real.

Vale (2008), embasado nas análises dos resultados de ensaios com simuladores de tráfego móvel, realizados em cinco trechos-teste das rodovias RS-122, SP-330, BR116 RJ, SP-147 e BR-116 SP levanta pontos positivos e desfavoráveis em cada estudo e apresenta uma metodologia de utilização de simulador de tráfego móvel. $O$ autor elenca 22 atividades que devem ser consideradas em uma pesquisa e apontam os produtos resultantes dessas atividades. As atividades destacadas por Vale (2008) são:

- Definir o objetivo da pesquisa

- Definir a malha rodoviária onde os resultados serão aplicados

- Levantar todos os aspectos operacionais dos trechos da pista-teste

- Obter os dados de clima - regime de chuvas e variações de temperatura

- Conhecer o pavimento existente, suas características estruturais e funcionais

- Definir a carga de roda para o experimento ou a progressão de carga a ser empregada

- Definir o deslocamento lateral transversal do trem de carga

- Definir o sentido de carregamento, se único ou em ambos sentidos com contato do pneu com o pavimento

- Definir o tipo de configuração do eixo

- Definir as características dos pneus e pressão de contato

- Definir a suspensão e efeitos dinâmicos

- Definir a velocidade do carregamento, quando esta for possível de ser regulada

- Definir a faixa de temperatura ambiente para o trabalho de simulação 
- Definir se haverá alteração da umidade nas camadas do pavimento

- Registrar todas as características geométricas da pista

- Definir todas as etapas do controle de qualidade

- Definir se haverá instrumentação da pista

- Estipular como será o transporte e posicionamento do simulador

- Realizar os ajustes iniciais

- Definir a periodicidade e campanhas de monitoramento do pavimento

- Definir como será organizada a apresentação dos resultados

- Realizar ensaios complementares pós-simulação de tráfego no pavimento.

\subsection{Comparativo entre os equipamentos empregados para simulação de tráfego}

Pode-se dividir em dois tipos os simuladores de tráfego, como já mencionado anteriormente, para previsão de deformação permanente em trilha de roda: equipamentos de laboratório e equipamentos de campo.

Os simuladores de tráfego de laboratório trazem a facilidade de, em curto espaço de tempo, determinar valores de afundamentos de misturas asfálticas, mostrando as possíveis tendências de comportamento que o material exibirá em campo como revestimento ou base. Empregam-se, neste caso, valores limites de afundamento para definir sua potencialidade de utilização como camada de pavimento.

Os simuladores em verdadeira grandeza, sejam móveis ou fixos em pistas-testes, possuem a grande vantagem de acelerar os danos numa estrutura real de pavimento, e não apenas em uma camada, como nos simuladores de laboratório. Os simuladores de verdadeira grandeza mostram as respostas da interação entre as diferentes camadas, podendo ser empregados para prever o desempenho de estruturas de pavimentos. Tem como desvantagem que demandam mais tempo para a realização destes ensaios e os custos envolvidos são expressivos. 
Os simuladores de tráfego de laboratório devem ser empregados para a previsão e melhoria, se for o caso, dos projetos de dosagem de misturas asfálticas. Eles não substituem os simuladores de tráfego de campo. Por sua vez, os simuladores de tráfego em verdadeira grandeza não substituem os simuladores de laboratórios pois as finalidades são diferentes.

$\mathrm{Na}$ tabela 17 apresenta-se um comparativo entre equipamentos, com as diferentes características e facilidades de cada um. 
Tabela 17 - Comparação entre equipamentos de laboratório e de campo para análise de desempenho em misturas asfálticas

\begin{tabular}{|c|c|c|c|}
\hline \multirow{2}{*}{ Variáveis } & \multicolumn{3}{|c|}{ Simuladores } \\
\hline & Laboratório & Fixos & Móveis \\
\hline Tipos & $\begin{array}{l}\text { LCPC, } \\
\text { HWTD - Hamburg Wheel Tracking Devices, } \\
\text { APA - Asphalt Pavement Analyzer }\end{array}$ & $\begin{array}{l}\text { UFRGS/DAER (RGS), Circular do IPR } \\
\text { (RJ), NCAT (Alabama USA), Ménage de } \\
\text { Fatigue (Franca). }\end{array}$ & Heavy Vehicle Simulator - HVS \\
\hline $\begin{array}{l}\text { Condições } \\
\text { climáticas }\end{array}$ & $\begin{array}{l}\text { LCPC }-60^{\circ} \mathrm{C}-\text { sem banho } \\
\text { Hamburg }-20^{\circ} \mathrm{C} \text { a } 70^{\circ} \text { com banho } \\
\text { APA - 35ㄷ a } 60^{\circ} \mathrm{C}-\text { opção de banho }\end{array}$ & \multicolumn{2}{|c|}{$\begin{array}{l}\text { As condições de temperatura e de umidade são as ambientais. Podem-se utilizar fontes } \\
\text { de calor para simular temperaturas mais elevadas e também a opção de jogar água para } \\
\text { ensaiar em condições de chuva }\end{array}$} \\
\hline Camada & Camada de rolamento. & \multicolumn{2}{|c|}{ Todas as camadas do pavimento são solicitadas } \\
\hline Materiais ensaios & $\begin{array}{l}\text { Os corpos-de-prova podem ser produzidos } \\
\text { em laboratório como também extraídos de } \\
\text { pista. }\end{array}$ & $\begin{array}{l}\text { Pavimentos construídos para serem } \\
\text { submetidos exclusivamente ao simulador } \\
\text { de tráfego. }\end{array}$ & $\begin{array}{l}\text { Os materiais submetidos ao simulador é a } \\
\text { própria pista de rolamento. }\end{array}$ \\
\hline $\begin{array}{l}\text { Espessura do } \\
\text { revestimento }\end{array}$ & $\begin{array}{l}\text { LCPC }-5 \mathrm{~cm} \text { e } 10 \mathrm{~cm} \\
\text { Hamburg }-4 \mathrm{~cm} \\
\text { APA }-7,5 \mathrm{~cm}\end{array}$ & $\begin{array}{l}\text { Construído de acordo com o interesse da } \\
\text { pesquisa }\end{array}$ & Espessura da camada de rolamento da pista \\
\hline $\begin{array}{l}\text { Ensaios } \\
\text { complementares }\end{array}$ & & \multicolumn{2}{|c|}{$\begin{array}{l}\text { Levantamentos de deflexão máxima e bacia de deformação, textura da superfície do } \\
\text { pavimento (HS), IRI, levantamento de trincamento, atrito (BPN) }\end{array}$} \\
\hline Carga aplicada & $\begin{array}{l}\text { LCPC } 5 \mathrm{kN} \\
\text { Hamburg }-0,7 \mathrm{kN} \\
\text { APA }-0,44 \mathrm{kN}\end{array}$ & \multicolumn{2}{|c|}{ Semi-eixo 6t (5t máximo + 20\%) - 3t por roda. Possibilidades de cargas diferentes. } \\
\hline $\begin{array}{l}\text { Pressão dos } \\
\text { pneus }\end{array}$ & $\begin{array}{l}\text { LCPC - 0,6 MPa } \\
\text { Hamburg e APA - roda metálica }\end{array}$ & \multicolumn{2}{|l|}{$0,7 \mathrm{MPa}$} \\
\hline Velocidade $(\mathrm{Hz})$ & LCPC, Hanburg e APA $1 \mathrm{~Hz}$ (2 passadas/s) & & Aproximadamente $10 \mathrm{~km} / \mathrm{h}$ \\
\hline $\begin{array}{l}\text { Área de } \\
\text { cobertura }\end{array}$ & LCPC - ensaio com trilha fixa & \multicolumn{2}{|c|}{$\begin{array}{l}\text { Ensaio sobre a faixa de rolamento ou entre elas. Possui deslocamento lateral - permite } \\
\text { sobreposição para melhor simular a ação do tráfego real. }\end{array}$} \\
\hline Tempo de ensaio & $\begin{array}{l}\text { LCPC - } 30.000 \text { ciclos ( } 60.000 \text { solicitações) - } \\
10 \text { hs. }\end{array}$ & \multicolumn{2}{|c|}{$\begin{array}{l}\text { Depende do critério de falha escolhido. Fadiga, surgimento de trincas, Deformação } \\
\text { permanente, características de textura. }\end{array}$} \\
\hline $\begin{array}{l}\text { Critérios } \\
\text { admitidos }\end{array}$ & $\begin{array}{l}\text { LCPC - Diretrizes francesas } 10 \% \text { e a Cost } \\
333 \text { recomenda } 5 \% \\
\text { Hamburg }-20.000 \text { ciclos ou } 20 \mathrm{~mm} \\
\text { APA }-8.000 \text { ciclos ou } 7,6 \mathrm{~mm}\end{array}$ & \multicolumn{2}{|c|}{ Fadiga, deformação permanente, textura, tempo de ensaio } \\
\hline
\end{tabular}




\section{Capítulo 03}

\section{PISTA-TESTE}

Nesse capítulo são apresentados, o local da pista-teste, o tipo de tráfego e clima, os tipos e as características das misturas asfálticas, controles de usina e pista, escolhas dos trechos que serão submetidos ao ensaio acelerado com o simulador de tráfego de campo, características estruturais dos trechos quanto às deflexões medidas com o Falling Weight Deflectometer - FWD, características da textura superficiais com o ensaio de mancha de areia, o IRI e por fim o simulador de tráfego móvel de campo.

\subsection{Concepção e local da pista-teste}

Com a concessão das rodovias BR-116/376 PR e BR-101 trecho Curitiba/Florianópolis-SC, a Concessionária Litoral Sul do Grupo OHL Brasil, responsável por este trecho, concebeu uma pesquisa de grande interesse desta concessionária e de muitos órgãos rodoviários na atualidade, que diz respeito à previsão de problemas de afundamentos em trilhas de roda dado o elevado volume de tráfego de caminhões pesados. Em parceria com a Escola Politécnica da USP e com a Dynatest, com a aprovação da ANTT, a concessionária resolveu aplicar os Recursos para Desenvolvimento Tecnológico - RDT, geridos pela Agência Nacional de Transportes Terrestres ANTT, em um estudo para avaliar a resistência à deformação permanente em trilha de roda de dez tipos de misturas asfálticas utilizadas como camada de rolamento.

A pista-teste localiza-se entre os kms 675+200 e 673+200 da Rodovia BR 376 PR, que liga Florianópolis a Curitiba, pista no sentido norte, na $3^{\text {a }}$.faixa, em aclive de cerca de $6 \%$, direção de Joinvile-SC para Curitiba-PR, na altura da cidade de Guaratuba - SC - figura 61. O local escolhido para implantação da pista-teste possui características representativas da rodovia quanto ao tráfego 
e à estrutura de pavimento, tornando possível o uso dos resultados obtidos com a pista-teste em outros locais da rodovia.

Esta Rodovia encontra-se sob concessão federal, sendo administrada desde 15/02/2008 pela Autopista Litoral Sul, pertencente ao grupo da OHL OBRASCÓN HUARTE LAIN BRASIL S/A

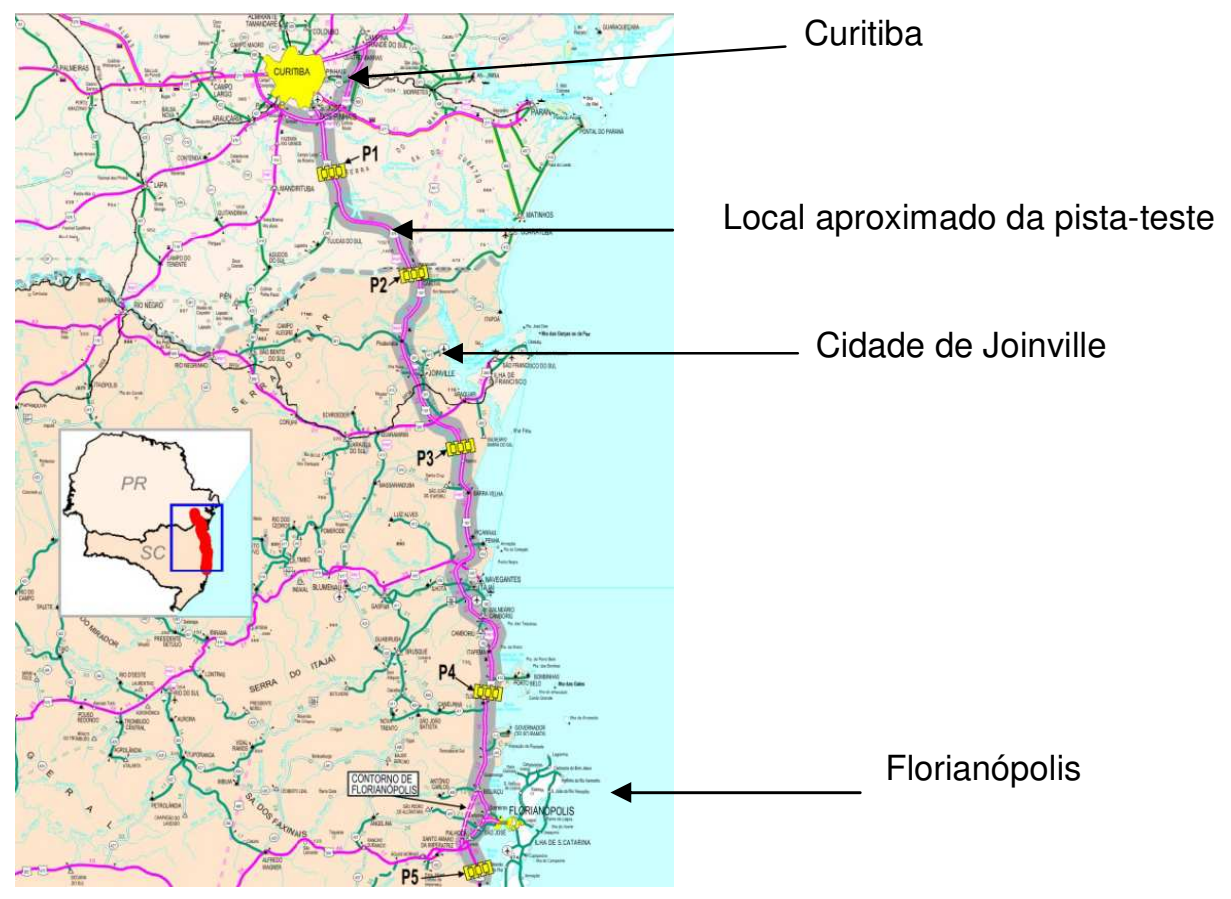

Figura 61 - Mapa da localização aproximada da pista-teste entre a Cidade de Joinville e Curitiba

$\mathrm{Na}$ figura 62 apresenta-se a $3^{\mathrm{a}}$. faixa da rodovia em um pequeno trecho com acostamento, onde foi implantada os dez trechos da pista-teste, e na figura 63 a característica do tráfego da rodovia.

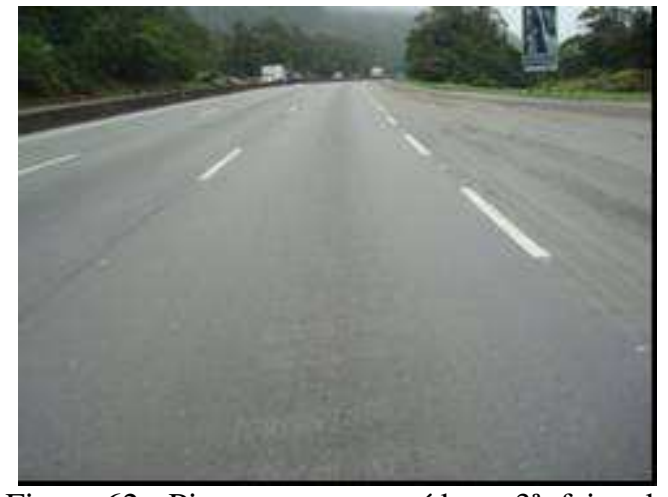

Figura 62 - Pista-teste construída na $3^{\text {a }}$. faixa de tráfego sentido ascendente

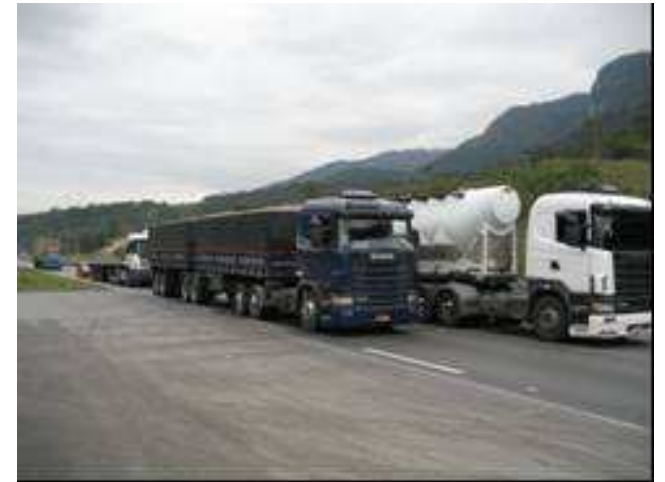

Figura 63 - Característica do tráfego na $3^{\text {a }}$ faixa ascendente da pista-teste. 


\subsection{Seleção dos tipos de revestimentos asfálticos da pista-teste}

A seleção das dez misturas asfálticas para serem empregadas como camada de rolamento da pista-teste, concebida especialmente para estudo de afundamentos em trilhas de rodas, deu-se segundo as características mais promissoras de revestimentos a serem usados pela Concessionária na região em questão.

Além das graduações já bem conhecidas do Grupo OHL, como as misturas de concreto asfáltico densas e contínuas, seguindo padrão do Instituto de Asfalto - denominada de referência neste experimento, e do SHRP norte-americano, algumas novas concepções de misturas semidescontinuas foram usadas, como o gap-graded. Foram empregados ligantes asfálticos convencionais e modificados por polímeros ou por borracha para avaliação de durabilidade e da resposta a este problema crônico de deformação permanente em rodovias de tráfego pesado com as características da BR 376 atualmente sob a responsabilidade da Concessionária Litoral Sul.

A escolha contemplou tipos de misturas asfálticas que pudessem atender tanto as características de desempenho como também possibilitar, sem maiores dificuldades, a fabricação e a aplicação dessas misturas asfálticas em campo, com os recursos locais.

Cada trecho possui $200 \mathrm{~m}$ de extensão. Os tipos de misturas asfálticas e os respectivos quilômetros estão apresentados na tabela 18.

Estão citadas na tabela 18 os seguintes materiais:

Ligantes asfálticos:

- 50/70 - cimento asfáltico de petróleo convencional de classificação 50/70 conforme Regulamento Técnico ANP n. 3/2005 de 11/07/2005;

- 30/45 - cimento asfáltico de petróleo convencional de classificação 30/45 conforme Regulamento Técnico ANP n. 3/2005 de 11/07/2005;

- $4 \%$ SBS -denominação de asfalto modificado por $4 \%$ de polímero SBS, cuja classificação enquadra-se no tipo 55/75 conforme Regulamento Técnico ANP n. 3/2007 de 09/10/2007; 
- $\mathrm{AMB}$ - asfalto-borracha, cuja classificação enquadra-se no tipo AB-8 conforme Regulamento Técnico ANP n. 5/ 2008 de 24/12/2008;

- $1,2 \%$ de RET - asfalto modificado por $1,2 \%$ de polímero denominado de RET

Tabela 18- Misturas asfálticas e localização dos trechos da pista-teste

\begin{tabular}{|c|c|c|c|c|c|}
\hline \multirow{2}{*}{ Trecho } & \multirow{2}{*}{$\begin{array}{l}\text { Data da } \\
\text { Execução }\end{array}$} & \multicolumn{2}{|c|}{ Km dos trechos } & \multirow{2}{*}{$\begin{array}{c}\text { Tipo de ligante } \\
\text { asfáltico }\end{array}$} & \multirow{2}{*}{$\begin{array}{c}\text { Faixa } \\
\text { Granulometrica }\end{array}$} \\
\hline & & Início & Fim & & \\
\hline 1 & $14 / 01 / 2009$ & $675+200$ & $675+000$ & $50 / 70$ & Mix Ivb I.A. \\
\hline 2 & $14 / 01 / 2009$ & $675+000$ & $674+800$ & $50 / 70$ & SPV- $12,5 \mathrm{~mm}$ \\
\hline 3 & $15 / 01 / 2009$ & $674+800$ & $674+600$ & $4 \%$ SBS & SPV- $12,5 \mathrm{~mm}$ \\
\hline 4 & $15 / 01 / 2009$ & $674+600$ & $674+400$ & $4 \%$ SBS & SPV- $9,5 \mathrm{~mm}$ \\
\hline 5 & $19 / 01 / 2009$ & $674+400$ & $674+200$ & 1,2\% de RET & SPV- $9,5 \mathrm{~mm}$ \\
\hline 6 & $20 / 01 / 2009$ & $674+200$ & $674+028$ & $1,2 \%$ de RET & SPV- $12,5 \mathrm{~mm}$ \\
\hline 7 & $23 / 01 / 2009$ & $674+028$ & $673+800$ & AMB & Gap Graded \\
\hline 8 & $23 / 01 / 2009$ & $673+800$ & $673+600$ & $30 / 45$ & SPV- $12,5 \mathrm{~mm}$ \\
\hline 9 & $24 / 01 / 2009$ & $673+600$ & $673+400$ & $30 / 45$ & SPV- $9,5 \mathrm{~mm}$ \\
\hline 10 & $24 / 01 / 2009$ & $673+400$ & $673+200$ & $30 / 45$ & Gap Graded \\
\hline
\end{tabular}

Os tipos de faixas granulométricas empregados foram os seguinte:

- Mix IVbl.A - graduação densa e contínua, seguindo especificação da faixa IVb do Instituto de Asfalto norte-americano;

- SPV 9,5mm - graduação densa e continua com diâmetro máximo de 12,5 mm cuja distribuição granulométrica não cruza a zona de restrição especificada pelo Superpave;

- SPV $12,5 \mathrm{~mm}$ - graduação densa e continua com diâmetro máximo de 19,1 mm cuja distribuição granulométrica não cruza a zona de restrição especificada pelo Superpave;

- Gap-graded - graduação semidescontinua concebida pelo California Department Transportation - Caltrans

\subsection{Tráfego}

Para obtenção do número N correspondente a 12 meses (janeiro de 2009 a janeiro de 2010), período em que a pista-teste, após sua implantação, foi submetida à ação do tráfego, realizou-se uma contagem dos veículos no 5․․ trecho da pista-teste, designado de T05.

Para a determinação, optou-se por realizar um levantamento de campo por meio de filmagem dos veículos que solicitam somente a $3^{\text {a }}$ faixa. Para tanto foi 
adquirida uma câmera filmadora com capacidade suficiente de registro. Foram 15 horas de filmagem entre 6:00 hs e 21:00 hs, distribuídas em três dias 27, 28 e 29/01/2010. Através dessa filmagem foi possível quantificar o volume de veículos por classes.

Apresenta-se na figura 64 o resultado da contagem do volume de veículos correspondentes às classes e números de eixos.

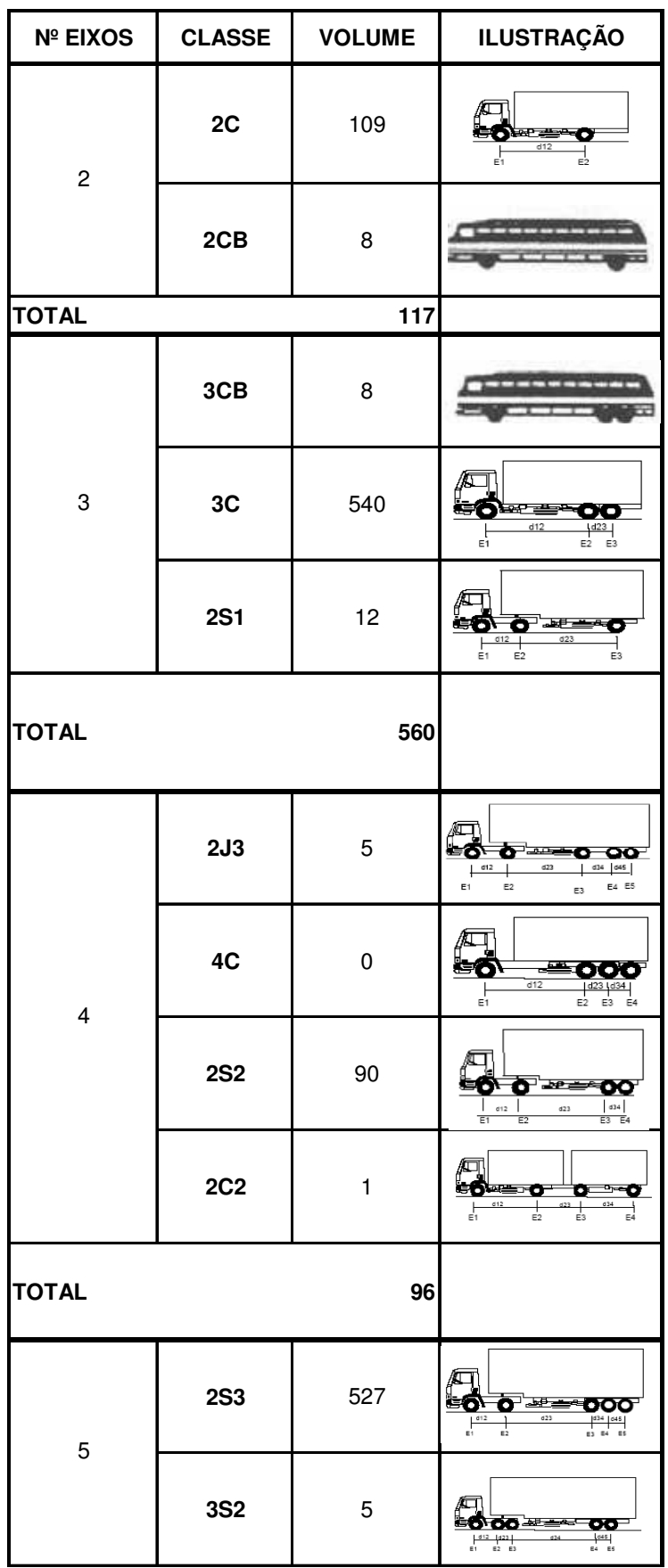

\begin{tabular}{|c|c|c|c|}
\hline № EIXOS & CLASSE & VOLUME & ILUSTRAÇÃO \\
\hline \multirow{2}{*}{5} & 213 & 5 & 0 \\
\hline & $2 \mathrm{C} 3$ & 0 & 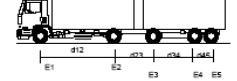 \\
\hline TOTAL & & 537 & \\
\hline \multirow{5}{*}{6} & $3 \mathrm{C} 2$ & 9 & 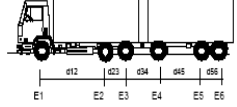 \\
\hline & $3 \mathrm{~S} 3$ & 407 & 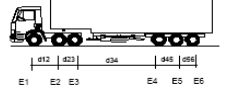 \\
\hline & 313 & 48 & 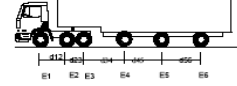 \\
\hline & 3J3 & 13 & 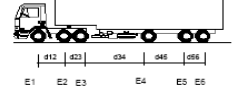 \\
\hline & $3 C 3$ & 2 & 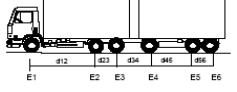 \\
\hline \multicolumn{3}{|l|}{ TOTAL } & \\
\hline 7 & 3D4 & 219 & 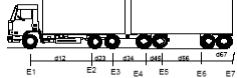 \\
\hline \multicolumn{3}{|l|}{ TOTAL } & \\
\hline 9 & 3T6 & 31 & 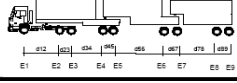 \\
\hline \multicolumn{4}{|l|}{ TOTAL } \\
\hline GERAL & & 2039 & \\
\hline
\end{tabular}

Figura 64 - Volume de veículos por classe e número de eixos registrados na 3 a faixa da pista-teste no período de 15 h nos dias 27, 28 e 29/01/2010 
Para a determinação do volume diário médio anual - VDMA, tomou-se como base os fatores de distribuições diárias, semanais e mensais dos volumes de tráfego. Foi disponibilizada pela Concessionária Auto Pista Litoral Sul a distribuição mensal correspondente ao mês de abril/2009 do volume de tráfego registrado na praça de pedágio P2, localizada na Cidade de Guaratuba - SC a $6 \mathrm{~km}$ da pista-teste.

O Departamento de Estrada de Rodagem do Estado de São Paulo - DER-SP, através de um sistema permanente de contagem e controle de tráfego nas rodovias do Estado, publicou no documento técnico n. 8879/00-IX-RL-0102-0 a análise da variação do volume de tráfego em praças de pedágio do estado de São Paulo. Esse documento serviu de subsídio para a obtenção dos fatores de distribuições diárias, semanais e mensais utilizados para a determinação do VDMA na pista-teste por extrapolação dos valores do estado de São Paulo para a região em análise. Na tabela 19 são apresentados os fatores das distribuições baseados no documento técnico e o cálculo do VDMA foi determinado pela equação 22 , constante do mesmo documento.

Tabela 19 - Fatores de distribuição do volume de tráfego doc. técnico n. 8879/00-IX-RL-0102-0

\begin{tabular}{l|c}
\multicolumn{1}{c|}{ Período } & Fator de distribuição (\%) \\
\hline Diário (16 h/24 h) & 80 \\
Semanal (quarta, quinta e sexta-feira) & 48,3 \\
Mensal (abril/2009) & 7,6 \\
\hline
\end{tabular}

$V D M A=\frac{\left[\frac{\sum_{d p}^{n d p} V D_{d p}}{\sum_{d p}^{n d p} P_{d s}}\right] * 4,35}{365 * p_{m} * P_{24 h}}$

onde: $\quad V D M A=$ volume diário médio anual

$\mathrm{VD}=$ volume diário resultante da contagem de 3 dias

$\mathrm{dp}=$ fator de variação semanal

$\mathrm{p}_{\mathrm{m}}=$ percentual do volume anual no mês $\mathrm{m}$

$\mathrm{P}_{24 \mathrm{~h}}=$ fator de variação diária

4,35 = número médio de semanas no mês 
Na tabela 20 apresenta-se o VDMA individual por classe de veículos e o total correspondente ao tráfego que solicitou a pista-teste calculados pela eq 22. Observe-se que os fatores utilizados são baseados na contagem de tráfego realizada em janeiro de 2010 e a variação mensal de abril de 2009, e o VDMA relaciona-se ao período de janeiro de 2009 a janeiro de 2010, período em que a pista-teste foi solicitada pelo tráfego.

Tabela 20 - VDMA da pista-teste no período de jan.2009 a jan.2010

\begin{tabular}{|c|c|c|c|}
\hline Classe & Tipo & $\begin{array}{l}\text { Volume } \\
\text { (3 dias) }\end{array}$ & $\begin{array}{c}\text { VDMA } \\
\text { na 3a.faixa }\end{array}$ \\
\hline $2 \mathrm{C}$ & Com. $2^{*}$ & 117 & 47 \\
\hline $3 C$ & Com. 3 & 560 & 227 \\
\hline $2 S 2$ & Com. 4 & 96 & 38 \\
\hline $2 S 3$ & Com. 5 & 537 & 217 \\
\hline $3 S 3$ & Com. 6 & 479 & 194 \\
\hline 3D4 & Com. 7 & 219 & 88 \\
\hline 3T6 & Com. 9 & 31 & 12 \\
\hline & & 2039 & 823 \\
\hline
\end{tabular}

$\left(^{*}\right)$ Com.2 - veículo comercial com 2 eixos

Os fatores e equivalência de carga FEC, também denominado de fator de carga - FC adotados são os especificados pelo USACE e pela AASHTO e estão apresentados na tabela 21. Os valores obtidos foram determinados considerando eixo carregado máximo legal. Os valores obtidos pela AASHTO são menores que a USACE devido aos menores fatores de equivalência adotados pela AASHTO, exceto para o tipo de eixo simples (roda simples). O critério adotado pelo USACE é a igualdade da deformação vertical máxima (deflexão máxima), verificada em uma profundidade igual à espessura total do pavimento; o critério adotado pela AASHTO é baseado no Present Serviceability Index - PSI, em português índice de serventia e Structural Number - SN, número estrutural na língua portuguesa. No caso para a obtenção do FC desse último, foram adotados para os índices $\mathrm{PSI}=2,5$ e SN = 4. 
Tabela 21 - Fatores de carga do USACE e da AASHTO - eixo máximo legal

\begin{tabular}{l|c|c|c|c|c|c}
\hline \multirow{2}{*}{\multicolumn{1}{c}{ Tipo de Eixo }} & \multicolumn{2}{|c|}{ Cargas (tf) } & \multicolumn{2}{c|}{ FC-USACE $^{*}$} & \multicolumn{2}{c}{ FC-AASHTO } \\
\cline { 2 - 7 } & Carregado** & Vazio & Carregado & Vazio & Carregado & Vazio \\
\hline simples (roda simples) & 6 & 3 & 0,28 & 0,02 & 0,33 & 0,02 \\
simples (roda dupla) & 10 & 5 & 3,29 & 0,13 & 2,39 & 0,12 \\
tandem duplo (roda dupla) & 17 & 6 & 8,55 & 0,08 & 1,64 & 0,02 \\
tandem triplo (roda dupla) & 25,5 & 9 & 9,30 & 0,13 & 1,56 & 0,02 \\
\hline
\end{tabular}

$\left(^{*}\right)$ Mesmo FC utilizado pelo DNIT

$\left(^{* *}\right)$ Carregado conforme eixo máximo legal

Devido ao excesso de carga ser uma constante em diversas rodovias no Brasil, foram também determinados os FEC para excesso de carga admitido igual a $30 \%$. Apresentam-se na tabela 22 os fatores de equivalência de carga para o USACE e para AASHTO, levando em consideração o excesso de carga.

Tabela 22 - Fatores de carga USACE e AASHTO - excesso de carga

\begin{tabular}{|c|c|c|c|c|c|c|c|c|c|}
\hline \multirow{2}{*}{ Tipo de Eixo } & \multicolumn{3}{|c|}{ Cargas (tf) } & \multicolumn{3}{|c|}{ FC-USACE } & \multicolumn{3}{|c|}{ FC-AASHTO } \\
\hline & Sobrecarga* & Carregado & Vazio & Sobrecarga & Carregado & Vazio & Sobrecarga & Carregado & Vazio \\
\hline simples (roda simples) & 7,8 & 6 & 3 & 0,80 & 0,28 & 0,02 & 1,02 & 0,33 & 0,02 \\
\hline simples (roda dupla) & 13 & 10 & 5 & 16,97 & 3,29 & 0,13 & 7,44 & 2,39 & 0,12 \\
\hline tandem duplo (roda dupla) & 22,1 & 17 & 6 & 36,04 & 8,55 & 0,08 & 4,87 & 1,64 & 0,02 \\
\hline tandem triplo (roda dupla) & 33,15 & 25,5 & 9 & 40,19 & 9,30 & 0,13 & 4,72 & 1,56 & 0,02 \\
\hline
\end{tabular}

(*) sobrecarga de $30 \%$

Os fatores de veículo - FV que a interação dos diversos tipos de eixos do tráfego registrado, correlacionados com seus respectivos fatores de carga, no caso para tráfego com eixo máximo legal $(80 \%$ dos veículos comerciais trafegando com a carga legal e $20 \%$ vazios), estão apresentados na tabela 23 para o USACE, e na tabela 24 para a AASHTO. 
Tabela 23 - Fator de veículo do USACE/DNIT

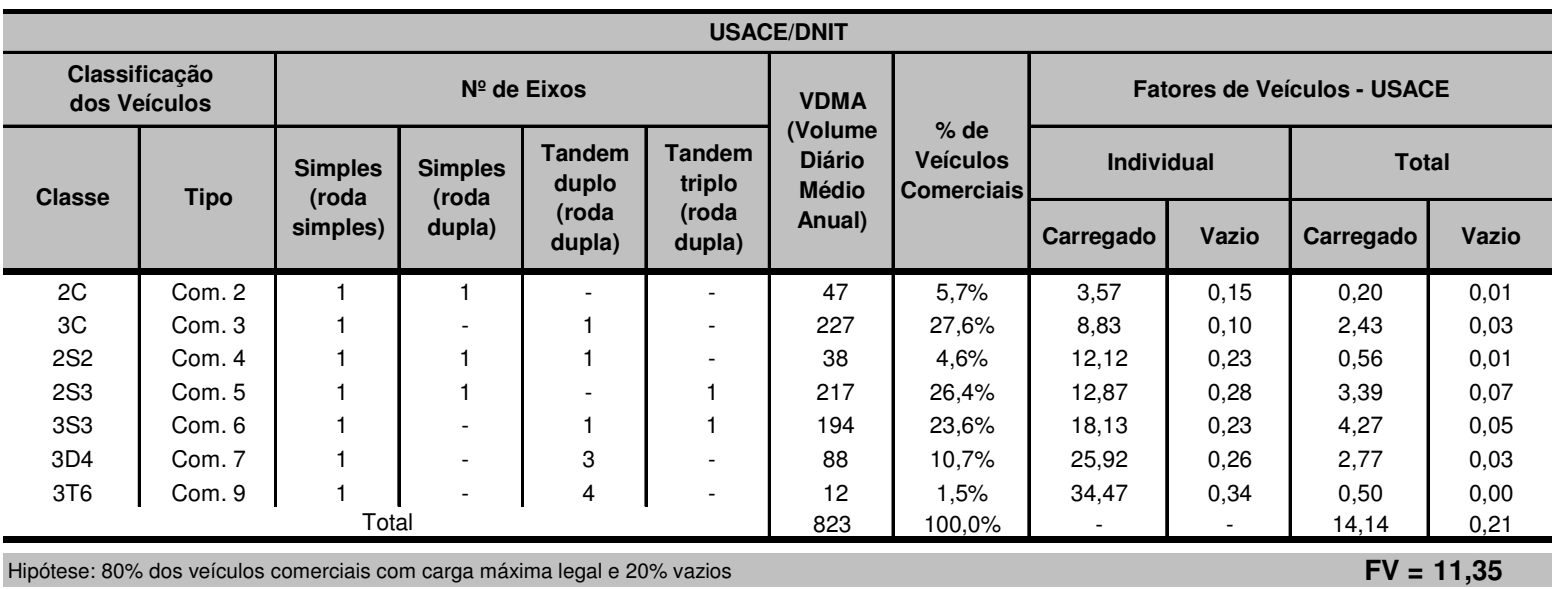

Tabela 24 - Fator de veículo do AASHTO (pavimento flexível)

\begin{tabular}{|c|c|c|c|c|c|c|c|c|c|c|c|}
\hline \multicolumn{12}{|c|}{ AASHTO - Pavimento flexível } \\
\hline \multicolumn{2}{|c|}{$\begin{array}{l}\text { Classificação } \\
\text { dos Veículos }\end{array}$} & \multicolumn{4}{|c|}{ № de Eixos } & \multirow{3}{*}{$\begin{array}{c}\text { VDMA } \\
\text { (Volume } \\
\text { Diário } \\
\text { Médio } \\
\text { Anual) }\end{array}$} & \multirow{3}{*}{$\begin{array}{c}\% \text { de } \\
\text { Veículos } \\
\text { Comerciais }\end{array}$} & \multicolumn{4}{|c|}{ Fatores de Veículos - AASHTO } \\
\hline \multirow{2}{*}{ Classe } & \multirow{2}{*}{ Tipo } & \multirow{2}{*}{$\begin{array}{l}\text { Simples } \\
\text { (roda } \\
\text { simples) }\end{array}$} & \multirow{2}{*}{$\begin{array}{c}\text { Simples } \\
\text { (roda } \\
\text { dupla) }\end{array}$} & \multirow{2}{*}{$\begin{array}{c}\text { Tandem } \\
\text { duplo } \\
\text { (roda } \\
\text { dupla) }\end{array}$} & \multirow{2}{*}{$\begin{array}{c}\text { Tandem } \\
\text { triplo } \\
\text { (roda } \\
\text { dupla) }\end{array}$} & & & \multicolumn{2}{|c|}{ Individual } & \multicolumn{2}{|c|}{ Total } \\
\hline & & & & & & & & Carregado & Vazio & Carregado & Vazio \\
\hline $2 \mathrm{C}$ & Com. 2 & 1 & 1 & - & - & 47 & $5,7 \%$ & 2,72 & 0,14 & 0,16 & 0,01 \\
\hline $3 C$ & Com. 3 & 1 & - & 1 & - & 227 & $27,6 \%$ & 1,97 & 0,04 & 0,54 & 0,01 \\
\hline $2 \mathrm{~S} 2$ & Com. 4 & 1 & 1 & 1 & - & 38 & $4,6 \%$ & 4,36 & 0,16 & 0,20 & 0,01 \\
\hline $2 \mathrm{~S} 3$ & Com. 5 & 1 & 1 & - & 1 & 217 & $26,4 \%$ & 4,28 & 0,16 & 1,13 & 0,04 \\
\hline $3 S 3$ & Com. 6 & 1 & - & 1 & 1 & 194 & $23,6 \%$ & 3,53 & 0,06 & 0,83 & 0,01 \\
\hline 3D4 & Com. 7 & 1 & - & 3 & - & 88 & $10,7 \%$ & 5,25 & 0,08 & 0,56 & 0,01 \\
\hline 3T6 & Com. 9 & 1 & - & 4 & - & 12 & $1,5 \%$ & 6,90 & 0,10 & 0,10 & 0,00 \\
\hline \multicolumn{6}{|c|}{ Total } & 823 & $100,0 \%$ & - & - & 3,52 & 0,09 \\
\hline
\end{tabular}

$\mathrm{Na}$ tabela 25 estão os fatores de equivalência de carga para eixo com carga máxima legal e eixo com excesso de $30 \%$ de carga e os respectivos valores do número $\mathrm{N}$ para o USACE e para AASHTO. Foram neste estudo variados também a porcentagem de veículos com sobrecarga dentre os veículos comerciais carregados. Foram mantidos os $20 \%$ de veículos vazios nos cálculos.

Tabela 25 - FEC com eixo máximo legal e com excesso de carga em $30 \%$

\begin{tabular}{c|c|c|c|c|c}
\hline \multirow{2}{*}{ FEC } & Participação da & \multicolumn{2}{|c|}{ FV } & \multicolumn{2}{c}{ N } \\
\cline { 3 - 6 } & sobrecarga & USACE & AASHTO & USACE & AASHTO \\
\hline Eixo máximo legal & 0 & 11,35 & 2,84 & $3,41 \mathrm{E}+06$ & $8,52 \mathrm{E}+05$ \\
\hline & 10 & 16,02 & 3,55 & $4,81 \mathrm{E}+06$ & $1,07 \mathrm{E}+06$ \\
Excesso de 30\% & 20 & 20,70 & 4,26 & $6,22 \mathrm{E}+06$ & $1,28 \mathrm{E}+06$ \\
& 30 & 25,37 & 4,98 & $7,62 \mathrm{E}+06$ & $1,50 \mathrm{E}+06$ \\
\hline
\end{tabular}


Esclareça-se que na determinação do número $\mathrm{N}$, não foi considerado o eixo tanden duplo do Mercosul, que é de $18 \mathrm{tf}$, e a presença de veículos com pneus extralargos, que são por sua vez mais danosos ao pavimento que os pneus usuais comerciais brasileiros, conforme análise e conclusão de Fernandes Jr. (1995). Na contagem realizada no local da pista-teste, alguns veículos apresentaram disposições dos eixos diferentes dos aqui considerados, seguindo as recentes resoluções do CONTRAN, (2006) 184/05 e 189/06, tornando-os mais danosos aos pavimentos. Esses veículos, por estarem ainda em um número reduzido presentes no total considerado, foram somados aos que melhor os representassem.

\subsection{Clima da região da pista-teste}

O clima da cidade de Guaratuba - SC, região por onde passa a rodovia em estudo e onde se localiza especificamente a pista-teste, é classificado como subtropical superúmido, sem estação seca definida e isento de geadas. A média de temperatura dos meses mais quentes é superior a $30^{\circ} \mathrm{C}$, e nos meses mais frios inferior a 15ㄷ (PREFEITURA MUNICIPAL DE GUARATUBA, 2009). Observe-se que essa classificação atende a Cidade de Guaratuba, ocorre que a pista-teste, embora esteja localizada nessa cidade, se encontra cerca de 100 m acima do nível do mar e a Cidade esta no nível do mar.

Segundo a classificação climática do pesquisador Wilhelm Koeppen, muito difundida no Brasil, o território catarinense no local da pista-teste, é classificado como (Cfa), mesotérmico úmido com verões quentes nas regiões baixas, (BALDO et al. 2000). Nessa classe têm-se temperaturas superiores a $22^{\circ} \mathrm{C}$ no verão e com mais de $30 \mathrm{~mm}$ de chuva no mês mais seco, (EMBRAPA, 2009). Esse tipo de clima predomina no litoral e sul do Rio Grande do Sul, litoral de Santa Catarina, planalto norte e centro-leste do Paraná, bacias dos rios Uruguai e Paraná (Gollfari et al. 1978). Na região norte e noroeste do Paraná, o tipo climático também é designado como $\mathrm{Cfa}(\mathrm{h})$, sendo $\mathrm{h}$, clima tropical original modificado pela altitude (Maack, 1968). 
Nogami (1995) comenta sobre a classificação de Koeppen que é bastante antiga (1931) e pouco precisa para finalidade em questão. A classificação (Cfa), por exemplo, ocorre tanto no Estado de são Paulo, ambiente nitidamente tropical como em Washington, USA, onde o subleito das rodovias fica congelado durante cerca de 1 mês, devido ao congelamento.

Conforme descrito no item 2.5.1, com a média das temperaturas máximas correspondente a sete dias em um período de 1 ano e a menor temperatura registrada para o mesmo período, somado à latitude, pode-se determinar as temperaturas correspondentes ao performance grade - PG pelo método SHRP (KENNEDY et al. 1994). O PG é utilizado pelo método do Superpave para designar o tipo de ligante asfáltico a ser empregado de forma a atender as solicitações do tráfego e do clima.

Para a determinação do PG correspondente ao local da pista-teste, as temperaturas foram as fornecidas pelo Instituto Nacional de Meteorologia INMET (2010), dados que são registrados através da estação meteorológica de observação de superfície convencional, instalada na Cidade de Idaial SC, local com a estação mais próxima da pista-teste. Os registros das temperaturas para cada dia do ano de 2009 estão apresentados no anexo V. As 7 temperaturas mais elevadas e a menor desse período estão apresentadas na tabela 26.

Tabela 26 - Média das 7 temperaturas máxima e a mínima de 2009 da região próxima a pista-teste

\begin{tabular}{c|c|c}
\hline \multirow{2}{*}{ Dias } & \multicolumn{2}{|c}{ Temperaturas $\left({ }^{\circ} \mathrm{C}\right)$} \\
\cline { 2 - 2 } & Máximas & Mínima \\
\hline 1 & 37,8 & \\
2 & 37,6 & \\
3 & 37,6 & \\
4 & 36,0 & \\
5 & 35,8 & \\
6 & 35,7 & \\
7 & 35,7 & \\
\hline \multirow{2}{*}{ Média } & 36,6 & \multirow{2}{*}{3,5} \\
\hline
\end{tabular}

O procedimento para a obtenção do PG recomendado por Kennedy et al. (1994) tem como base os seguintes procedimentos de conversão: 
Para a conversão da máxima temperatura do ar para temperatura da superfície do pavimento (média dos 7 dias de temperatura mais elevadas), aplica-se a equação 23.

$$
T_{s}=T_{a}+0,00618 \phi^{2}+0,2289 \phi+24,4
$$

onde: $\quad T_{s}=$ temperatura da superfície do pavimento $\left({ }^{\circ} \mathrm{C}\right)$

$T_{a}=$ temperatura do ar

$\Phi=$ latitude ()

A máxima temperatura no pavimento à profundidade de projeto $d$, pode ser determinada pela equação 24 .

$\left.T_{d}(\max )=\left[T_{s(\max )}+17.8 \| 1-2.48\left(10^{-3}\right) d+1.085\left(10^{-5}\right) d^{2}-2.441\left(10^{-8}\right) d^{3}\right)\right]-17.8$

onde $\quad T_{d(m a ́ x)}=$ temperatura máxima do pavimento na profundidade $d\left(^{\circ}\right)$ $d=$ profundidade da superfície $(\mathrm{mm})$

Para a conversão da temperatura mínima do ar para a mínima temperatura da superfície do pavimento, aplica-se inicialmente a equação 25 que considera a temperatura do ar, igual à temperatura na superfície do pavimento. Em seguida, a temperatura à profundidade $d$ de projeto é determinada com a equação 26.

$$
T_{s(\min )}=T_{a(\min )}
$$

Onde $\quad T_{a(\min )}=$ temperatura mínima do ar $\left({ }^{\circ} \mathrm{C}\right)$

$T_{s(\min )}=$ temperatura mínima na superfície do pavimento $\left({ }^{\circ} \mathrm{C}\right)$

$$
T_{d(\min )}=T_{s(\min )}+5.1\left(10^{-2}\right) d-6.3\left(10^{-5}\right) d^{2}
$$

onde $\quad T_{d(m i n)}=$ temperatura mínima do pavimento à profundidade $d\left({ }^{\circ} \mathrm{C}\right)$

$T_{s(\min )}=$ temperatura

Após a obtenção das temperaturas $T_{d(\text { máx) }}$ e $T_{d(\text { mín) }}$ O PG é determinado conforme apresentado na tabela 27. 
Tabela 27 - PG correspondente às temperaturas de projeto do pavimento

\begin{tabular}{c|c|c|c}
\hline $\begin{array}{c}\text { Temperaturas } \\
\text { altas (-C) }\end{array}$ & $\begin{array}{c}\text { PG (máximo) } \\
(\mathbf{x})\end{array}$ & $\begin{array}{c}\text { Temperaturas } \\
\text { baixas }(-\mathbf{C})\end{array}$ & $\begin{array}{c}\text { PG (mínimo) } \\
(\mathbf{y})\end{array}$ \\
\hline$<46$ & 46 & $>-10$ & -10 \\
$<52$ & 52 & $>-16$ & -16 \\
$<58$ & 58 & $>-22$ & -22 \\
$<64$ & 64 & $>-28$ & -28 \\
$<70$ & 70 & $>-34$ & -34 \\
$<76$ & 76 & $>-40$ & -40 \\
$<80$ & 80 & $>-46$ & -46 \\
\hline
\end{tabular}

$\mathrm{Na}$ tabela 28 apresentam-se os valores encontrados, com base nas temperaturas dispostas na tabela 26 e, o respectivo PG do ligante asfáltico recomendado, tabela 27 .

Tabela 28 Valor do PG para as condições da pista-teste

\begin{tabular}{c|c|c|c|c}
\hline \multicolumn{5}{c}{ Temperatura máxima } \\
\hline $\begin{array}{c}\mathbf{T}_{\mathrm{a}} \\
\left({ }^{\circ} \mathbf{C}\right)\end{array}$ & $\boldsymbol{\Phi ( { } ^ { \circ } )}$ & $\begin{array}{c}\mathbf{T}_{\mathbf{s}} \\
\left({ }^{\circ} \mathbf{C}\right)\end{array}$ & $\begin{array}{c}\mathbf{d} \\
(\mathbf{m m})\end{array}$ & $\begin{array}{c}\mathbf{T}_{\mathrm{d}(\mathbf{m a ́ x})} \\
\left({ }^{\circ} \mathbf{C}\right)\end{array}$ \\
\hline 36,6 & $-26,897778$ & 59,3 & 20 & 55,8 \\
\hline
\end{tabular}

\begin{tabular}{|c|c|c|}
\hline \multicolumn{2}{|c|}{ Temperatura mínima } & \multirow[b]{2}{*}{ PG } \\
\hline $\begin{array}{c}T_{S(\operatorname{mí})=} T_{a(\operatorname{mí})} \\
(\stackrel{o}{*})\end{array}$ & $\begin{array}{c}T_{d(\min )} \\
\left({ }^{\circ} \mathrm{C}\right)\end{array}$ & \\
\hline 3,5 & 4,5 & 58-10 \\
\hline
\end{tabular}

O valor obtido foi PG 58-10 e conforme descrito no item 2.5.1, Cominski et al. (1994) alertam para a correção do PG do ligante asfáltico para rodovias que possuem volume de tráfego elevado e com baixa velocidade, condições que a pista-teste está submetida. Essa correção consiste em somar $6^{\circ} \mathrm{C}$ ao $\mathrm{PG}$ anteriormente determinado e através da tabela 29 obtém-se o PG corrigido. Essa correção no valor de PG, segundo os autores, é para propiciar à mistura asfáltica, maior resistência à formação de deformação permanente em trilha de roda. 
Tabela 29 - Seleção do PG do ligante asfáltico com base no clima, velocidade e no volume do tráfego, Cominski et. al. 1994)

\begin{tabular}{|c|c|c|c|c|c|c|c|c|c|}
\hline & & & & & eraturas & náximas & projeto & & \\
\hline & & Cargas/Normal & $28-34$ & $34-40$ & $40-46$ & $46-52$ & $52-58$ & $58-64$ & $64-70$ \\
\hline & & $(50 \mathrm{~km} / \mathrm{h})$ lentas & $34-40$ & $40-46$ & $46-52$ & $52-58$ & $58-64$ & $64-70$ & $70-76$ \\
\hline & & (100km/h) rápidas & $34-46$ & $46-52$ & $52-58$ & $58-64$ & $64-70$ & $70-76$ & $76-82$ \\
\hline $\mathscr{D}$ & & $>-10$ & PG46-10 & PG52-10 & PG58-10 & PG64-10 & PG70-10 & PG76-10 & PG82-10 \\
\hline .ह & & $-10-16$ & PG46-10 & PG52-16 & PG58-16 & PG64-16 & PG70-16 & PG76-16 & PG82-16 \\
\hline & & $-16 a-22$ & PG46-22 & PG52-22 & PG58-22 & PG64-22 & PG70-22 & PG76-22 & PG82-22 \\
\hline$\stackrel{\mathscr{D}}{=}$ & OI & $-22 a-28$ & PG46-28 & PG52-28 & PG58-28 & PG64-28 & PG70-28 & PG76-28 & PG82-28 \\
\hline$\stackrel{乛}{\pi}$ & $\frac{0}{0}$ & $-28 a-34$ & PG46-34 & PG52-34 & PG58-34 & PG64-34 & PG70-34 & PG76-34 & PG82-34 \\
\hline 읕 & 음 & $-34 a-40$ & PG46-40 & PG52-40 & PG58-40 & PG64-40 & $P G 70-40$ & & \\
\hline & $\frac{1}{0}$ & $-40 a-46$ & PG46-46 & PG52-46 & PG58-46 & PG64-46 & & & \\
\hline & & & $\begin{array}{l}\text { Alaska } \\
\text { Norte }\end{array}$ & $\begin{array}{l}\text { anada } \\
\text { s EUA }\end{array}$ & $\begin{array}{c}\text { Canada } \\
\text { Norte EUA }\end{array}$ & $\begin{array}{l}\text { SUL } \\
\text { EUA }\end{array}$ & Sud & $\begin{array}{l}\text { te EUA- } \\
\text { tinental } \\
\text { l/tráfec }\end{array}$ & $\begin{array}{l}\text { erto } \\
\text { esado }\end{array}$ \\
\hline
\end{tabular}

O resultado do $P G$ para os ligantes asfálticos que suportariam as condições impostas pelo tráfego e pelo clima na região da pista-teste é PG 70-10.

A faixa entre os valores mínimos de PG 70-10 e máximos de PG 82-34 corresponde aos tipos de ligantes asfálticos recomendados para as regiões desérticas do sudoeste e continental dos EUA. Esta região norte-americana é aquela que mais se aproxima de regiões com temperaturas médias elevadas, como as encontradas na maior parte do território Nacional e, em especial a área da pista-teste, embora no Brasil haja maior umidade e as temperaturas médias anuais são um pouco superiores às norte-americanas. Associando a região climática da pista-teste às baixas velocidades dos veículos comerciais e também ao tráfego pesado, as mesmas recomendações da tabela 28 podem ser estendias para os tipos de ligantes asfálticos brasileiros que serão submetidos às mesmas condições. Ou seja, deve-se empregar ligantes com mínimo de PG 70, podendo ser PG 76 ou ainda PG 82. A classificação para baixas temperaturas poderá ser $\circ \mathrm{PG}-10$ pois as mínimas na região não atingem sequer temperaturas negativas. 


\subsection{Materiais}

\subsection{1 - Agregados e composição granulométrica}

Os materiais pétreos utilizados na construção da pista-teste, seus respectivos fornecedores e sua origem mineralógica, estão apresentados na tabela 30.

Tabela 30 - Material pétreo, fornecedor e origem mineralógica

\begin{tabular}{c|c|c}
\hline Material & Fornecedor & Origem mineralógica \\
\cline { 1 - 2 } Brita 1" & \multirow{2}{*}{ Pedreira Rudnick - SC } & Gnaisse \\
\cline { 1 - 2 } Pó-de-pedra & & Granito \\
\cline { 1 - 2 } Pedrisco & Pedreira Morro Grande - SC & Calcítica \\
\hline Cal CH-I & - & -
\end{tabular}

Ao todo, foram utilizados quatro tipos de distribuições granulométricas na pesquisa, sendo uma do Instituto de Asfalto dos EUA denominada de mix IVb, considerada como sendo a mistura de referência, duas do SHRP, SPV 12,5 $\mathrm{mm}$ e $9,5 \mathrm{~mm}$ (as iniciais SPV é abreviatura de Superpave e as dimensões 12,5 mm e 9,5 mm referem-se aos diâmetros máximos nominais - DMN), e uma quarta semidescontinua denominada de gap-graded do California Department Transportation - Caltrans As composições granulométricas dos materiais brita 1", pedrisco, pó-de-pedra e cal, suas proporções em peso, a faixa granulométrica e a curva resultante, utilizadas na construção da pista-teste, estão apresentadas nas figuras 63 a 66.

$\mathrm{Na}$ figura 65, apresenta-se a composição granulométrica na faixa mix IVb I.A. utilizada no trecho T01, usinada com CAP 50/70. Na figura 66, tem-se a composição granulométrica utilizada nos trechos T02, T03, T06 e T08 dentro da distribuição compreendida pela faixa SHRP Superpave $12,5 \mathrm{~mm}$, sendo que esta curva se enquadra na faixa $C$ do DNIT. 


\begin{tabular}{|c|c|c|c|c|c|c|c|c|}
\hline \multicolumn{9}{|c|}{ COMPOSIÇÃO DA FX. MIX Ivb - T01 } \\
\hline \multirow{3}{*}{\multicolumn{2}{|c|}{$\begin{array}{l}\text { Peneiras } \\
\text { n. } \quad(\mathrm{mm}) \\
\text { Pedreira }\end{array}$}} & \multicolumn{4}{|c|}{ Materiais } & \multirow{3}{*}{$\begin{array}{c}\text { Composi } \\
\text { ção }\end{array}$} & \multirow{2}{*}{\multicolumn{2}{|c|}{ Fx Mix Ivb }} \\
\hline & & \begin{tabular}{|l|} 
Brita 1" \\
\end{tabular} & \multirow{2}{*}{$\begin{array}{l}\text { Pedrisco } \\
\text { Morro Gde }\end{array}$} & Pó-de-pedra & $\mathrm{Cal}$ & & & \\
\hline & & Rudnick & & \multicolumn{2}{|l|}{ Rudnick } & & Inf. & Sup \\
\hline $3 / 4 "$ & 19,1 & 98,6 & 100 & 100 & 100 & 99,7 & 100 & 100 \\
\hline $1 / 2^{\prime \prime}$ & 12,5 & 49 & 100 & 100 & 100 & 87,3 & 80 & 100 \\
\hline 3/8" & 9,52 & 15,2 & 98,3 & 100 & 100 & 78,4 & 70 & 90 \\
\hline 4 & 4,76 & 1,3 & 25,5 & 100 & 100 & 57,4 & 50 & 70 \\
\hline 10 & 2,0 & 0,8 & 1,6 & 76,2 & 100 & 39,8 & 33 & 48 \\
\hline 40 & 0,42 & 0,4 & 1,5 & 32,8 & 100 & 18,2 & 15 & 25 \\
\hline 80 & 0,17 & 0,6 & 1,4 & 19,9 & 98,8 & 11,8 & 8 & 17 \\
\hline 200 & 0,075 & 0,5 & 1,2 & 12,1 & 97,7 & 7,9 & 4 & 10 \\
\hline c & & 0,25 & 0,24 & 0,495 & 0,015 & & & \\
\hline
\end{tabular}

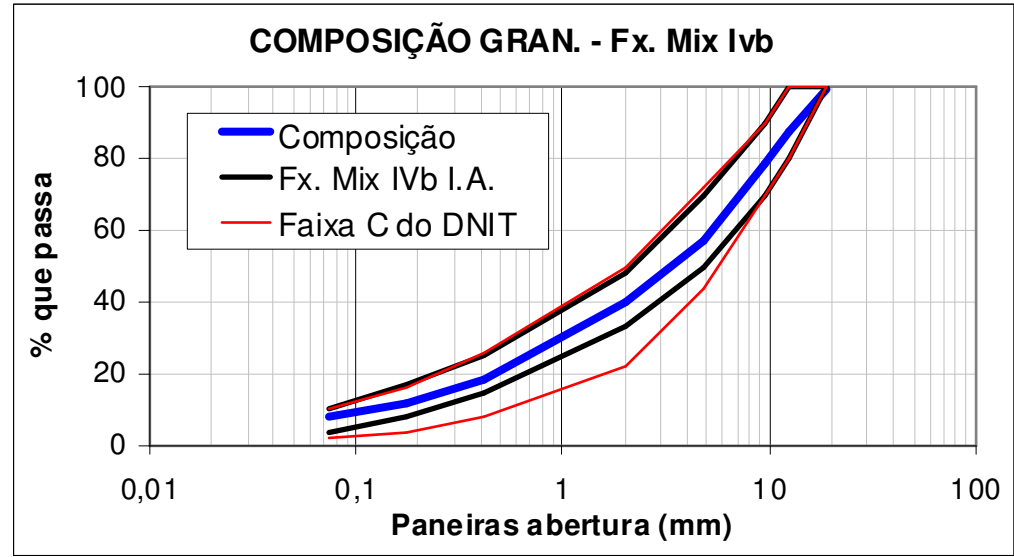

Figura 65 - Composição granulométrica utilizada no trecho T01

\begin{tabular}{|c|c|c|c|c|c|c|c|c|}
\hline \multicolumn{9}{|c|}{ COMPOSIÇÄO SPV 12,5 mm e FX C DNIT } \\
\hline \multicolumn{9}{|c|}{$\mathrm{T} 02, \mathrm{~T} 03, \mathrm{~T} 06$ e T08 } \\
\hline \multirow{3}{*}{\multicolumn{2}{|c|}{$\begin{array}{c}\text { Peneiras } \\
\text { n. } \quad(\mathrm{mm} \\
\text { Pedreira }\end{array}$}} & \multicolumn{4}{|c|}{ Materiais } & \multirow{3}{*}{$\begin{array}{c}\text { Composi } \\
\text { ção }\end{array}$} & \multirow{2}{*}{\multicolumn{2}{|c|}{ Fx Sup. $12,5 \mathrm{mn}$}} \\
\hline & & \multirow{2}{*}{\begin{tabular}{|l} 
Brita 1" \\
Rudnick
\end{tabular}} & \multirow{2}{*}{$\frac{\text { Pedrisco }}{\text { Morro Gde }}$} & \multirow{2}{*}{$\frac{\text { Pó-de-pedra }}{\text { Rudnick }}$} & \multirow[t]{2}{*}{ Cal } & & & \\
\hline & & & & & & & Inf. & Sup. \\
\hline 3/4" & 19,1 & 98,6 & 100 & 100 & 100 & 99,8 & 100 & 100 \\
\hline $1 / 2 "$ & 12,5 & 49 & 100 & 100 & 100 & 92,9 & 90 & 100 \\
\hline 3/8" & 9,52 & 15,2 & 98,3 & 100 & 100 & 87,3 & 75 & 90 \\
\hline 4 & 4,76 & 1,3 & 25,5 & 100 & 100 & 50,4 & & 65 \\
\hline 10 & 2 , & 0,8 & 1,6 & 76,2 & 100 & 30,2 & 25 & 35 \\
\hline 40 & 0,42 & 0,4 & 1,5 & 32,8 & 100 & 14,2 & 8 & 17 \\
\hline 80 & 0,177 & 0,6 & 1,4 & 19,9 & 98,8 & 9,5 & 5 & 13 \\
\hline 200 & 0,075 & 0,5 & 1,2 & 12,1 & 97,7 & 6,5 & 2 & 10 \\
\hline & osição & 0,14 & 0,48 & 0,365 & 0,015 & & & \\
\hline
\end{tabular}

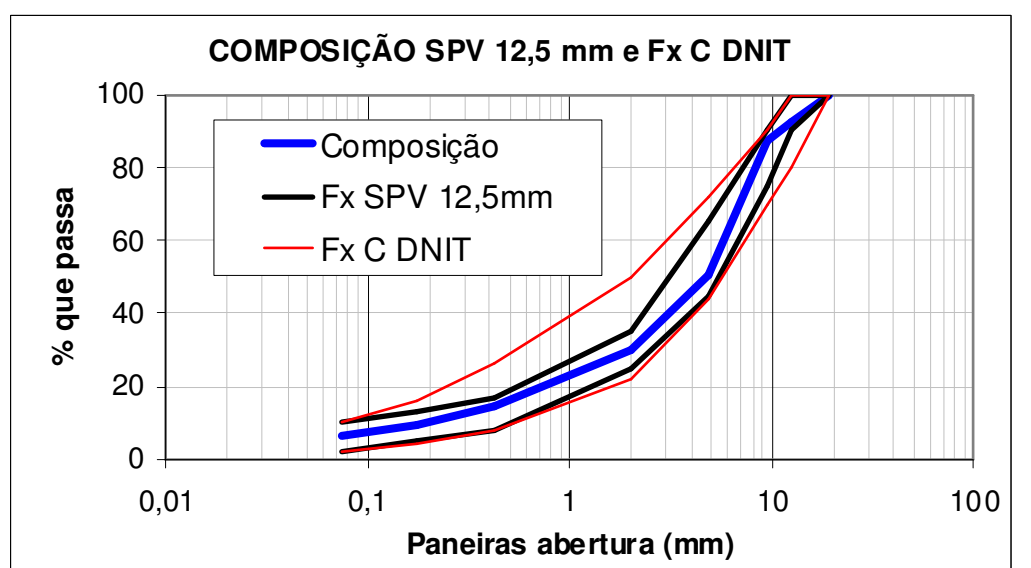

Figura 66 - Composições granulométricas utilizadas nos trechos T02. T03, T06 e T08 


\begin{tabular}{|c|c|c|c|c|c|c|c|c|}
\hline \multicolumn{9}{|c|}{ COMPOSIÇÃO SPV 9,5 mm e FX C DNIT } \\
\hline \multicolumn{9}{|c|}{ T04, T05 e T09 } \\
\hline \multirow{3}{*}{\multicolumn{2}{|c|}{$\begin{array}{l}\text { Peneiras } \\
\text { n. } \quad(\mathrm{mm} \\
\text { Pedreira }\end{array}$}} & \multicolumn{4}{|c|}{ Materiais } & \multirow{3}{*}{$\begin{array}{c}\text { Composi } \\
\text { ção }\end{array}$} & \multirow{2}{*}{\multicolumn{2}{|c|}{ Fx Sup.9,5mm }} \\
\hline & & \multirow{2}{*}{\begin{tabular}{|l} 
Brita 1" \\
Rudnick
\end{tabular}} & Pedrisco & \multirow{2}{*}{$\begin{array}{l}\text { Pó-de-pedra } \\
\text { Rudnick }\end{array}$} & \multirow[t]{2}{*}{$\mathrm{Cal}$} & & & \\
\hline & & & Morro Gde & & & & Inf. & Sup. \\
\hline 3/4" & 19,1 & 98,6 & 100 & 100 & 100 & 100,0 & 100 & 100 \\
\hline 1/2" & 12,5 & 49 & 100 & 100 & 100 & 100,0 & 100 & 100 \\
\hline 3/8" & 9,52 & 15,2 & 98,3 & 100 & 100 & 99,2 & 90 & 100 \\
\hline 4 & 4,76 & 1,3 & 25,5 & 100 & 100 & 65,0 & 65 & 90 \\
\hline 10 & 0 & 0 & 1,6 & 76,2 & 100 & 41,5 & 25 & 45 \\
\hline 40 & 0,42 & 0,4 & 1,5 & 32,8 & 100 & 19,1 & 7 & 24 \\
\hline 80 & 0,177 & 0,6 & 1,4 & 19,9 & 98,8 & 12,4 & 4 & 17 \\
\hline 200 & 0,075 & 0,5 & 1,2 & 12,1 & 97,7 & 8,3 & 2 & 10 \\
\hline & & & 0,47 & 0,515 & 0,015 & & & \\
\hline
\end{tabular}

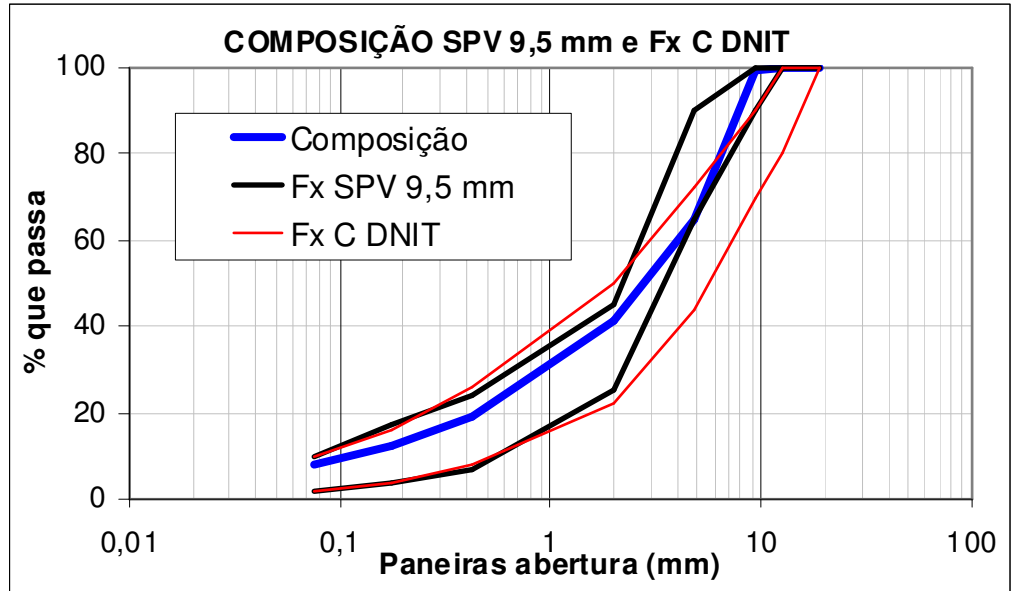

Figura 67 - Composições granulométricas utilizadas nos trechos T04, T05 e T09

\begin{tabular}{|c|c|c|c|c|c|c|c|c|}
\hline \multicolumn{9}{|c|}{ COMPOSIÇÃO GAP GRADED - CALTRANS - T07 e T10 } \\
\hline \multirow{3}{*}{\multicolumn{2}{|c|}{$\begin{array}{l}\text { Peneiras } \\
\text { n. } \quad(\mathrm{mm} \\
\text { Pedreira }\end{array}$}} & \multicolumn{4}{|c|}{ Materiais } & \multirow{3}{*}{$\begin{array}{c}\text { Composi } \\
\text { ção }\end{array}$} & \multirow{2}{*}{\multicolumn{2}{|c|}{ Gap-Graded }} \\
\hline & & \multirow{2}{*}{\begin{tabular}{|l} 
Bita 1n \\
Rudnick
\end{tabular}} & \multirow{2}{*}{$\begin{array}{c}\text { Pedrisco } \\
\text { Morro Gde }\end{array}$} & \multirow{2}{*}{$\frac{\text { Pó-de-pedra }}{\text { Rudnick }}$} & \multirow{2}{*}{$\mathrm{Cal}$} & & & \\
\hline & & & & & & & Inf. & Sup \\
\hline 3/4" & 19,1 & 100 & 100 & 100 & 100 & 100,0 & 100 & 100 \\
\hline $5 / 8 "$ & 15,9 & 100 & 100 & 100 & 100 & 100,0 & 100 & 100 \\
\hline $1 / 2 "$ & 12,5 & 49,7 & 100 & 100 & 100 & 90,9 & 90 & 100 \\
\hline 3/8" & 9,52 & 15,4 & 9 & 100 & 10 & 83 & 65 & 90 \\
\hline 4 & 4,8 & 1, & 25,5 & 100 & 100 & 37,5 & 25 & 45 \\
\hline 8 & 2,38 & 0,8 & 1,5 & 82,3 & 100 & 19,4 & 7 & 24 \\
\hline 30 & 0,6 & 0,7 & 1,4 & 44,3 & 98,8 & 11,5 & 4 & 17 \\
\hline 200 & 0,075 & 0,5 & 1,2 & 12,1 & 93,7 & 4,7 & 2 & 10 \\
\hline $\mathrm{Co}$ & osição & 0,18 & 0,6 & 0,205 & 0,015 & & & \\
\hline
\end{tabular}

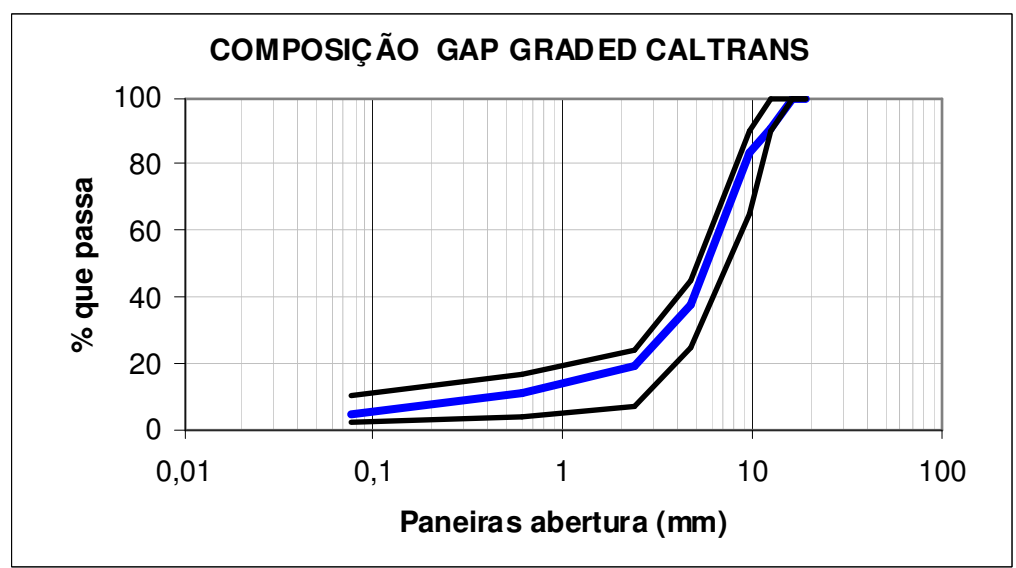

Figura 68 - Composições granulométricas utilizadas nos trechos T07 e T10 
Na figura 67 está apresentada a composição granulométrica utilizada nos trechos T04, T05 e T09, associada à faixa denominada de SHRP Superpave 9,5 mm, compreendida em grande parcela na faixa $C$ do DNIT. Essa composição possui diâmetro máximo de $9,5 \mathrm{~mm}$, estando fora do limite superior faixa C do DNIT, que é de $12,5 \mathrm{~mm}$.

$\mathrm{Na}$ figura 68, apresenta-se a composição granulométrica empregada nos trechos T07 e T10, faixa do gap-graded idealizada pelo California Department Transportations - Caltrans. Trata-se de uma faixa granulométrica semidescontínua.

\subsubsection{Ligantes asfálticos}

Os ligantes asfálticos utilizados nessa pesquisa não foram classificados pelo PG. Segundo informações de Constantino ${ }^{8}$ os ligantes brasileiros CAP 50/70 pode apresentar valor de PG de 58-16 e 64-16 já o CAP 30/45 pode apresentar valor de PG 70-16, salienta que essas classificações estão sujeitas aos valores de penetração de cada ligante asfáltico. Da mesma forma, Constantino comenta que ligante asfáltico modificado por $4 \%$ de SBS normalmente apresenta valor de PG para temperatura máxima $76^{\circ} \mathrm{C}$, para ligante modificado por RET na ordem de $P G 70^{\circ} \mathrm{C}$ e ligante modificado por borracha pode atingir valor de $\mathrm{PG} 76^{\circ} \mathrm{C}$ até $82^{\circ} \mathrm{C}$, a determinação dessas temperaturas estão intimamente ligadas a viscosidade dos ligantes, principalmente para o ligante modificado pro borracha.

Todos os ligantes asfálticos: CAP 50/70, CAP 30/45, CAP modificado por $4 \%$ de SBS (denominado por Flexpave), CAP modificado por 1,2\% de RET (denominado por Elvaloy) e o CAP modificado por borracha - AMB (denominado de Ecoflex), utilizados na pista-teste, foram fornecidos pela empresa Greca Asfaltos Ltda. A tabela 31 apresenta as caracterizações dos ligantes asfálticos convencionais denominados de CAP 50/70 E CAP 30/45, já

\footnotetext{
${ }^{8}$ Informação fornecida pelo Eng. Rômulo Constantino da empresa Betunel Tecnologia em Asfaltos
} 
a tabela 32 mostra-se as características dos ligantes modificados por polímeros SBS e RET e borracha.

Tabela 31 - Caracterização dos ligantes asfálticos convencionais CAP 50/70 e CAP 30/45 desta pesquisa

\begin{tabular}{|c|c|c|c|c|c|c|c|}
\hline \multirow{2}{*}{\multicolumn{3}{|c|}{$\begin{array}{l}\text { CARACTERIZAÇÃO DOS LIGANTES ASFÁLTICOS } \\
\text { CONVENCIONAIS }\end{array}$}} & Re sultado & Especifi-cação & Resultado & Especifi-cação & \multirow{3}{*}{$\begin{array}{c}\text { Métodos de } \\
\text { Ensaios } \\
\end{array}$} \\
\hline & & & $058 / 2009$ & CAP & $077 / 2009$ & CAP & \\
\hline Item & Características & Unidade & \multicolumn{2}{|c|}{ CAP 50-70 } & \multicolumn{2}{|c|}{ CAP 30-45 } & \\
\hline 1 & Faixa de temperatura para usinagem & ${ }^{\circ} \mathrm{C}$ & 152 a 175 & & 157 a 175 & - & \\
\hline 2 & Temp. mínima para compactação & ${ }^{\circ} \mathrm{C}$ & 142 & & 145 & - & \\
\hline 3 & Densidade & $\mathrm{g} / \mathrm{cm} 3$ & 1,011 & & 1,016 & - & DNIT ME-193 \\
\hline 4 & Visc. Brookfield a $135^{\circ} \mathrm{C}$ (SP-21 - 20 RPM) & $\mathrm{Cp}$ & 410 & Mín. 274 & 525 & Mín. 374 & NBR - 15184 \\
\hline 5 & Viscosidade Brookfield a $150^{\circ} \mathrm{C}(\mathrm{SP}-21)$ & $\mathrm{Cp}$ & 204 & Mín. 112 & 249 & Mín. 203 & NBR -15184 \\
\hline 6 & Viscosidade Brookfield a $177^{\circ} \mathrm{C}(\mathrm{SP}-21)$ & $\mathrm{Cp}$ & 74 & $57-285$ & 86 & $76-285$ & NBR - 15184 \\
\hline 7 & Viscosid ad e Saybolt-Fu rol a $135^{\circ} \mathrm{C}$ & $s$ & 168 & Mín. 141 & 251 & Mín. 192 & NBR -14950 \\
\hline 8 & Viscosidade Saybolt-Furol a $150^{\circ} \mathrm{C}$ & $s$ & 138 & Mín. 50 & 120 & Mín. 90 & NBR -14950 \\
\hline 9 & Viscosidade Saybolt-Furol a $177^{\circ} \mathrm{C}$ & $\mathrm{s}$ & 33 & 30- 150 & 44 & $40-150$ & NBR -14950 \\
\hline 10 & Penetração $\left(100 \mathrm{~g}, 5 \mathrm{~s}, 25^{\circ} \mathrm{C}\right) \quad$ (Pen) & $0,1 \mathrm{~mm}$ & 55,5 & $50-70$ & 35,5 & $30-45$ & NBR 6576 \\
\hline 11 & Ponto de Amolecimento (Pa) & ${ }^{\circ} \mathrm{C}$ & 50 & Mín. 46 & 52,4 & Mín. 52 & NBR 6560 \\
\hline 12 & Índice de Susceptibilidade Térmica (I) & & $-1,0$ & $-1,5<\hat{1}<0,7$ & $-1,3$ & $-1,5<i<0,7$ & ANP-R19 \\
\hline 13 & Ponto de fulgor & ${ }^{\circ} \mathrm{C}$ & 282 & $>235$ & 288 & $>235$ & NBR 11341 \\
\hline 14 & Espuma a $177^{\circ} \mathrm{C}$ & & Neg. & Neg. & Neg. & Neg. & ANP-R19 \\
\hline 15 & Recuperação Elástica por Torção & $\%$ & & & - & - & OHL T- 329-91 \\
\hline
\end{tabular}

Tabela 32 - Caracterização dos ligantes asfálticos modificados pelos polímeros SBS e RET e por borracha desta pesquisa

\begin{tabular}{|c|c|c|c|c|c|c|}
\hline \multirow{2}{*}{\multicolumn{3}{|c|}{$\begin{array}{c}\text { CARACTERIZAÇÃODOS LIGANTES ASFÁLTICOS } \\
\text { MODIFICADOS }\end{array}$}} & \multirow{2}{*}{$\begin{array}{l}\text { Resultado } \\
057 / 2009\end{array}$} & \multirow{2}{*}{$\begin{array}{c}\text { Especifi-cação } \\
\text { CAP4\%SBS }\end{array}$} & \multirow{2}{*}{$\begin{array}{l}\text { Resultado } \\
078 / 2009 \\
\end{array}$} & \multirow{2}{*}{$\begin{array}{c}\text { Especifi-cação } \\
\text { CAP 1,2RET }\end{array}$} \\
\hline & & & & & & \\
\hline Item & Características & Unidade & \multicolumn{2}{|c|}{ FLEXPAVE } & \multicolumn{2}{|c|}{ ELVALOYRET 1,2 } \\
\hline 1 & Faixa de temperatura para usinagem & ${ }^{\circ} \mathrm{C}$ & 182 a 175 & & 167 a 175 & \\
\hline 2 & Temp. mínima para compactação & ${ }^{\circ} \mathrm{C}$ & 169 & & 155 & \\
\hline 3 & Densidade & $\mathrm{g} / \mathrm{cm} 3$ & 1,009 & & 1,013 & \\
\hline 4 & Visc. Brookfield a $135^{\circ} \mathrm{C}(\mathrm{SP}-21$ - $20 \mathrm{RPM})$ & $C p$ & 540 & & 765 & \\
\hline 5 & Viscosidade Brookfield a $150^{\circ} \mathrm{C}$ (SP-21) & $\mathrm{Cp}$ & 320 & & 365 & \\
\hline 6 & Viscosidade Brookfiedd a $177^{\circ} \mathrm{C}(\mathrm{SP}-21)$ & $\mathrm{Cp}$ & 81 & & 129 & \\
\hline 7 & Viscosidade Saybolt-Furol a $135^{\circ} \mathrm{C}$ & $\mathrm{s}$ & 643 & & 391 & \\
\hline 8 & Viscosidade Saybolt-Furol a $150^{\circ} \mathrm{C}$ & $\mathrm{s}$ & 309 & & 187 & \\
\hline 9 & Viscosidade Saybolt-Furol a $177^{\circ} \mathrm{C}$ & s & 116 & Mín. 115 & 65 & Mín. 115 \\
\hline 10 & Penetração $\left(100 \mathrm{~g}, 5 \mathrm{~s}, 25^{\circ} \mathrm{C}\right) \quad$ (Pen) & $0,1 \mathrm{~mm}$ & 48,5 & $45-70$ & 44,5 & $45-70$ \\
\hline 11 & Ponto de Amolecimento ( $\mathrm{Pa})$ & ${ }^{\circ} \mathrm{C}$ & & & 54,0 & Mín. 65 \\
\hline 12 & Índice de Susceptibili idade Térmica (I) & - & & & & \\
\hline 13 & Ponto de fulgor & ${ }^{\circ} \mathrm{C}$ & 278 & $>235$ & 278 & $>235$ \\
\hline 14 & Espuma a $177^{\circ} \mathrm{C}$ & - & $\mathrm{Neg}$ & Neg. & Neg. & Neg. \\
\hline 15 & Recuperação Elástica por Torção & $\%$ & 69,4 & Mín. 60 & 69,0 & Mín. 60 \\
\hline
\end{tabular}

\begin{tabular}{|c|c|c|}
\hline Resultado & Especifi-cação & Métodos de \\
\hline $128 / 2009$ & AMB & Ensaios \\
\hline \multicolumn{3}{|c|}{ ECOFLEXB } \\
\hline - & - & \\
\hline - & - & \\
\hline 1,023 & - & DNIT ME-193 \\
\hline - & - & NBR - 15184 \\
\hline- & - & NBR - 15184 \\
\hline - & . & NBR - 15184 \\
\hline - & - & NBR - 14950 \\
\hline - & - & NBR - 14950 \\
\hline - & - & NBR - 14950 \\
\hline 56,5 & $25-75$ & NBR 6576 \\
\hline 53,1 & $55-62$ & NBR 6560 \\
\hline - & - & ANP-R19 \\
\hline 265 & $>235$ & NBR 11341 \\
\hline Neg. & Neg. & ANP-R19 \\
\hline 55 & Min. 50 & OHLT-329-91 \\
\hline
\end{tabular}


Registra-se que os ligantes asfálticos utilizados na pesquisa laboratorial foram entregues no Laboratório de Tecnologia de Pavimentação vindos diretamente da unidade de Araucária PR da empresa fornecedora (Greca Asfaltos Ltda).

\subsection{Projeto de dosagem}

Para a realização dos projetos de dosagem da pista-teste, os materiais selecionados para execução dos 10 trechos foram entregues no laboratório do Centro de Desenvolvimento Tecnológico Paulista de Infraestrutura da OHL em Atibaia - SP. Os mesmos materiais também foram entregues no Laboratório de Tecnologia de Pavimentação da Escola Politécnica de SP para a realização de ensaios de deformação permanente em trilha de roda, baseados nos parâmetros de projeto.

Após a confecção dos projetos pelo Centro de Desenvolvimento Tecnológico Paulista de Infraestrutura da $\mathrm{OHL}$ dos 10 trechos e a determinação da deformação permanente em trilha de roda de somente 5 dos 10 projetos de mistura, a empreiteira responsável pela execução da obra e que forneceu os materiais foi substituída. Por conseguinte, os materiais que iriam ser utilizados na construção da pista-teste passaram a ser outros. Devido a problemas contratuais, a determinação de uma segunda empreiteira provocou um atraso de definição dos novos materiais.

Com a nova empreiteira contratada, um novo lote de materiais, brita 1" pedrisco, pó-de-pedra e também a cal, foram entregue nos mesmos locais acima já descritos. Deu-se início imediatamente a uma nova bateria de ensaios de dosagem e também de deformação permanente em trilha de roda.

Quando da execução dos trechos da pista-teste, a empreiteira comunicou que não dispunha de quantidade suficiente do material pedrisco para a realização da obra e que seria utilizado outro material. A origem do novo material era distinta daquele de projeto. Infelizmente não se dispunha mais de tempo hábil 
para que fossem realizadas pela terceira vez novas dosagens. Assim o Centro de Desenvolvimento Tecnológico Paulista de Infraestrutura da OHL corrigiu o teor de ligante asfáltico, considerando a variação da densidade real do novo material no ensaio Marshall. Os dados de projeto da dosagem Marshall com o material pedrisco fornecido pela pedreira Morro Grande estão apresentados na tabela 33.

Tabela 33 - Dados de Projeto Marshall das Misturas Asfálticas

\begin{tabular}{c|c|c|c|c|c|c|c|c|c|c}
\hline Trecho & $\begin{array}{c}\text { Tipo de } \\
\text { mistura }\end{array}$ & $\begin{array}{c}\text { Tipo de } \\
\text { ligante }\end{array}$ & $\begin{array}{c}\text { Teor de } \\
\text { projeto } \\
(\%)\end{array}$ & DMT & $\begin{array}{c}\text { \% de } \\
\text { vazios }\end{array}$ & $\begin{array}{c}\text { VCB } \\
(\%)\end{array}$ & $\begin{array}{c}\text { VAM } \\
(\%)\end{array}$ & $\begin{array}{c}\text { RBV } \\
(\%)\end{array}$ & $\begin{array}{c}\text { Estab. } \\
\text { (kN) }\end{array}$ & $\begin{array}{c}\text { Fluência } \\
(\mathbf{m m})\end{array}$ \\
\hline 1 & Mix Ivb I.A. & CAP 50/70 & 5,20 & 2,514 & 4,0 & 12,1 & 16,1 & 75,4 & 12,9 & 10,4 \\
2 & SPV 12,5 mm & CAP 50/70 & 5,46 & 2,507 & 4,0 & 12,6 & 16,6 & 76,0 & 12,6 & 7,8 \\
3 & SPV 12,5 mm & $4 \%$ SBS & 6,20 & 2,481 & 4,0 & 14,1 & 18,2 & 77,8 & 15,2 & 13,2 \\
4 & SPV 9,5 mm & $4 \%$ SBS & 6,70 & 2,462 & 4,3 & 15,2 & 19,5 & 78,1 & 15,6 & 11,5 \\
5 & SPV 9,5 mm & $1,2 \%$ RET & 7,00 & 2,450 & 4,3 & 15,8 & 20,1 & 78,6 & 11,3 & 9,6 \\
6 & SPV 12,5 mm & $1,2 \%$ RET & 6,14 & 2,483 & 4,0 & 14,0 & 18,0 & 77,9 & 11,5 & 10,4 \\
7 & Gap graded & AMB & 8,20 & 2,397 & 4,9 & 17,9 & 22,8 & 78,6 & 5,8 & 18,0 \\
8 & SPV 12,5 mm & CAP 30/45 & 5,40 & 2,524 & 3,9 & 12,0 & 15,9 & 75,3 & 12,3 & 9,9 \\
9 & SPV 9,5 mm & CAP 30/45 & 5,72 & 2,512 & 4,0 & 12,7 & 16,7 & 76,2 & 13,2 & 7,7 \\
10 & Gap graded & CAP 30/45 & 6,41 & 2,418 & 5,0 & 17,9 & 22,9 & 78,2 & 8,8 & 11,8 \\
\hline
\end{tabular}

\subsection{Controle de usina e pista}

$\mathrm{Na}$ ocasião da usinagem das misturas asfálticas foram coletadas amostras das misturas asfálticas em duas etapas para realização de ensaios a posteriori:

- 1a . etapa: executada na usina, após a usinagem de cada tipo de mistura, onde parte da mistura antes do transporte à pista foi separada. Foram moldados corpos-de-prova tipo Marshall e os corpos-de-prova correspondentes aos trechos 1, 3, 6 e 7 foram submetidos ao ensaio de Misturas asfálticas - determinação do dano por umidade induzida ABNT NBR 15617; as misturas correspondentes aos outros trechos foram submetidos ao ensaio de estabilidade Marshall.

- 2a . etapa: coleta das amostras de misturas asfálticas foi feita na pista, antes de sua aplicação e compactação para cada tipo de mistura asfáltica. Foram moldados corpos-de-prova tipo Marshall e submetidos 
ao ensaio de Misturas asfálticas - determinação do dano por umidade induzida ABNT NBR 15617.

Apresentam-se na tabela 34 os resultados dos ensaios obtidos com os corposde-prova tipo Marshall moldados nas duas etapas acima descritas.

Tabela 34 - Controle das misturas asfálticas de usina e de pista

\begin{tabular}{|c|c|c|c|c|c|c|c|c|c|}
\hline \multicolumn{3}{|c|}{ Identificação } & \multicolumn{4}{|c|}{ Ensaios da 1a. Etapa (mistura de usina) } & \multicolumn{3}{|c|}{$\begin{array}{l}\text { Ensaios da } 2 a . \text { eta pa } \\
\text { (mistura de pista ) }\end{array}$} \\
\hline Trecho & $\begin{array}{l}\text { Tipo de } \\
\text { mistura } \\
\text { asfáltica }\end{array}$ & $\begin{array}{l}\text { Tipo de } \\
\text { Ligante } \\
\text { asfáltico }\end{array}$ & $\begin{array}{c}\text { Estabilidade( } \\
\text { kN) }\end{array}$ & $\begin{array}{c}\text { Resistência } \\
\text { à tração } \\
(\mathrm{MPa})\end{array}$ & $\begin{array}{l}\text { Resistência à } \\
\text { tração } \\
\text { Condicionado } \\
\text { (MPa) }\end{array}$ & $\begin{array}{c}\% \text { de } \\
\text { Resistência } \\
\text { Retida (RRT) }\end{array}$ & $\begin{array}{c}\text { Resistênci } \\
\text { a à tração } \\
\text { (MPa) }\end{array}$ & $\begin{array}{c}\text { Resistência } \\
\text { à tração } \\
\text { Condicionad } \\
\text { o (MPa) }\end{array}$ & $\begin{array}{c}\% \text { de } \\
\text { Resistênci } \\
\text { a Retida } \\
\text { (RRT) }\end{array}$ \\
\hline 1 & Mix Ivb I.A. & CAP $50 / 70$ & - & 1,92 & 1,75 & 91,1 & 1,78 & 1,84 & $*$ \\
\hline 2 & SPV $12,5 \mathrm{~mm}$ & CAP 50/70 & 14,3 & - & - & - & 1,74 & 1,68 & 96,2 \\
\hline 3 & SPV $12,5 \mathrm{~mm}$ & $4 \%$ SBS & - & 1,78 & 1,65 & 92,7 & 1,31 & 1,29 & 98,0 \\
\hline 4 & SPV 9,5 mm & $4 \%$ SBS & 14,1 & - & - & - & 1,86 & 1,88 & $*$ \\
\hline 5 & SPV 9,5 mm & $1,2 \%$ RET & 15,4 & 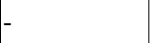 & - & - & 1,62 & 1,46 & 90,0 \\
\hline 6 & SPV $12,5 \mathrm{~mm}$ & $1,2 \%$ RET & - & 1,67 & 1,53 & 91,7 & 1,61 & 1,58 & 97,9 \\
\hline 7 & Gap graded & AMB & - & 1,06 & 0,94 & 88,8 & 0,83 & 0,64 & 77,1 \\
\hline 8 & SPV $12,5 \mathrm{~mm}$ & CAP $30 / 45$ & 19,0 & - & - & - & 1,50 & 1,63 & $*$ \\
\hline 9 & SPV $9,5 \mathrm{~mm}$ & CAP $30 / 45$ & 16,7 & - & - & - & 1,69 & 1,48 & 87,6 \\
\hline 10 & Gap graded & CAP $30 / 45$ & 13,4 & - & - & - & 1,05 & 1,18 & $*$ \\
\hline
\end{tabular}

(*) - valores de resistência à tração por compressão diametral retida acima de $100 \%$

Observe-se na tabela 34 que nenhuma mistura asfáltica apresentou valores de RRT $<70 \%$, mostrando que as misturas não apresentam problemas de susceptibilidade à água medida pelo ensaio de dano ${ }^{9}$ por umidade induzida, previstos pelo ensaio da referida norma, no estado de compactação e grau de compactação previstos em projeto. Não se dispõe do grau de compactação dos corpos-de-prova, de forma a validar o volume de vazios de $7 \% \pm 1 \%$ conforme exige o método de ensaio. As resistências à tração obtidas são elevadas para o estado de $7 \pm 1 \%$ requerido em norma.

As diferenças nos valores de RRT entre as misturas de pista e de usina provavelmente estejam relacionadas ao fato de as misturas asfálticas na pista apresentarem temperatura inferior à mistura na usina, dificultando a obtenção de volumes de vazios na mesma faixa de variação que foi obtido na usina. Adicionalmente, é provável que a mistura de pista tenha o teor de ligante

\footnotetext{
${ }^{9}$ Dano - denominação de falha na resistência à tração de mistura asfáltica causada pela ação da água
} 
asfáltico efetivo inferior ao teor de ligante da mistura de usina devido à absorção de ligante pelos agregados ocorrido durante o transporte.

\subsection{Execução da pista-teste}

$\mathrm{Na}$ execução da pista-teste, primeiramente foi fresada uma espessura de 50 $\mathrm{mm}$ pela largura da 3a .faixa da antiga camada de revestimento asfáltico existente. Após varreção, foi aplicada uma pintura de ligação com emulsão RR$2 \mathrm{C}$ a uma taxa de $1,0 \mathrm{l} / \mathrm{m}^{2}$. Após ruptura da emulsão, foram aplicadas as misturas asfálticas para o estudo em cada trecho, seguidas de compressão, resultando em espessura final após compactação de $50 \mathrm{~mm}$. O processo de fresagem/pintura de ligação/aplicação da massa foi paulatinamente, devido à impossibilidade de se interromper o tráfego ao longo de toda a extensão de 2 $\mathrm{km}$ da pista-teste. Fresavam-se 2 trechos no total de $400 \mathrm{~m}$, executava-se a pintura de ligação e aplicavam-se as misturas asfálticas, cada qual em seu trecho selecionado e seguia-se a compressão. Ou seja, a pista-teste foi executada em 5 etapas (dias), com dois trechos por etapa, conforme descrito na tabela 18.

\subsection{Ensaios de campo}

\subsubsection{Levantamento deflectométrico}

Para a verificação das características estruturais do pavimento anteriormente à execução da pista-teste, foram realizados levantamentos das deflexões, com o emprego do equipamento Falling Weight Deflectometer - FWD na $3^{\text {a }}$ faixa, a cada $10 \mathrm{~m}$ ao longo de todos os trechos. Os levantamentos foram feitos em duas etapas: uma inicial antes de fresagem da antiga camada de rolamento, e a segunda após a fresagem e a execução da pista-teste. Não foi possível a realização dos ensaios após fresagem, pois a pista-teste foi construída em 
etapas, inviabilizando a permanência do FWD por todo o período. Além disso, havia problemas operacionais de interdição de toda extensão da pista-teste, o que obrigou a execução em etapas, por trechos, como descrito no início deste capítulo.

A temperatura média na superfície do pavimento durante o levantamento deflectométrico antes da execução da obra foi de $29,7^{\circ} \mathrm{C}$, com desvio padrão 4,3 ${ }^{\circ} \mathrm{C}$ e a temperatura média na superfície do pavimento durante $\mathrm{O}$ levantamento deflectométrico após a execução da obra foi de $35,5 \stackrel{\circ}{\mathrm{C}}$ e desvio padrão de 5,4 ํㅡ. Os valores encontrados de deflexão, anterior a execução da pista-teste e nos valores posteriormente a obra, foram corrigidos em função da temperatura da superfície do pavimento, conforme preconiza a instrução de projeto IP-DE-P00/003 - Avaliação funcional e estrutural de pavimento - DERSP.

Na figura 69 é possível verificar as variações encontradas nas deflexões. Observe-se que não houve variações apreciáveis; pode-se notar um pequeno acréscimo uniforme nas deflexões, ao longo de todo o trecho. Somente no km 674,6 e km 674,67, referente à extensão no trecho T4, os valores de deflexão foram relativamente elevados, 90,2 e 98,2 (0,01 $\mathrm{mm})$ respectivamente, trecho correspondente à camada de rolamento com mistura denominada de Superpave 9,5mm com ligante asfáltico modificado por $4 \%$ de SBS.

Os trechos 1, 2 e 5 apresentaram valores de deflexão considerados baixos, na ordem de $20(0,01 \mathrm{~mm})$ e os demais trechos com valores médios na ordem de 50 a $60(0,01 \mathrm{~mm})$ de deflexão. 


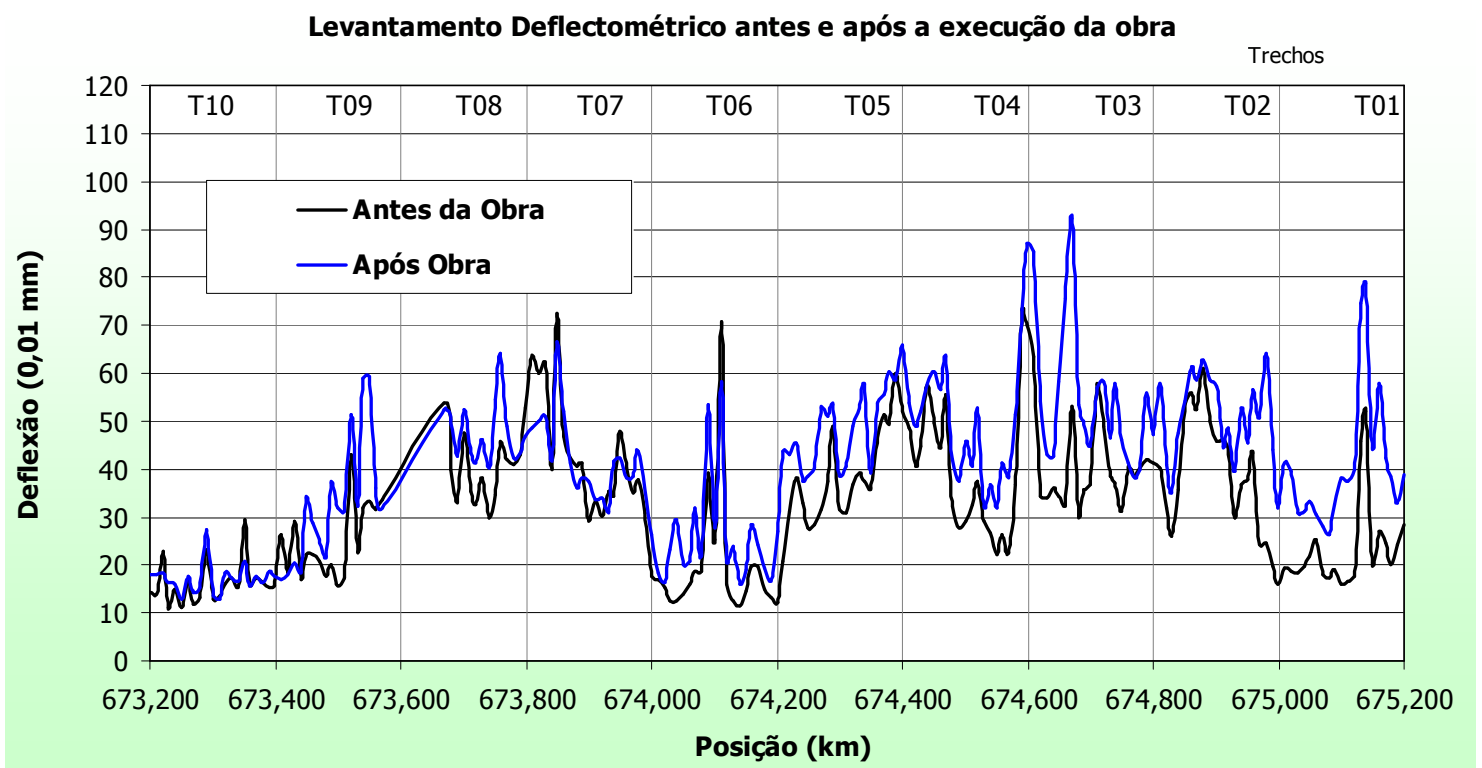

Figura 69 - Levantamento deflectométrico antes e após a execução da obra

Nas figuras 70, 71 e 72 estão apresentadas as deflexões antes e após a execução da pista-teste.

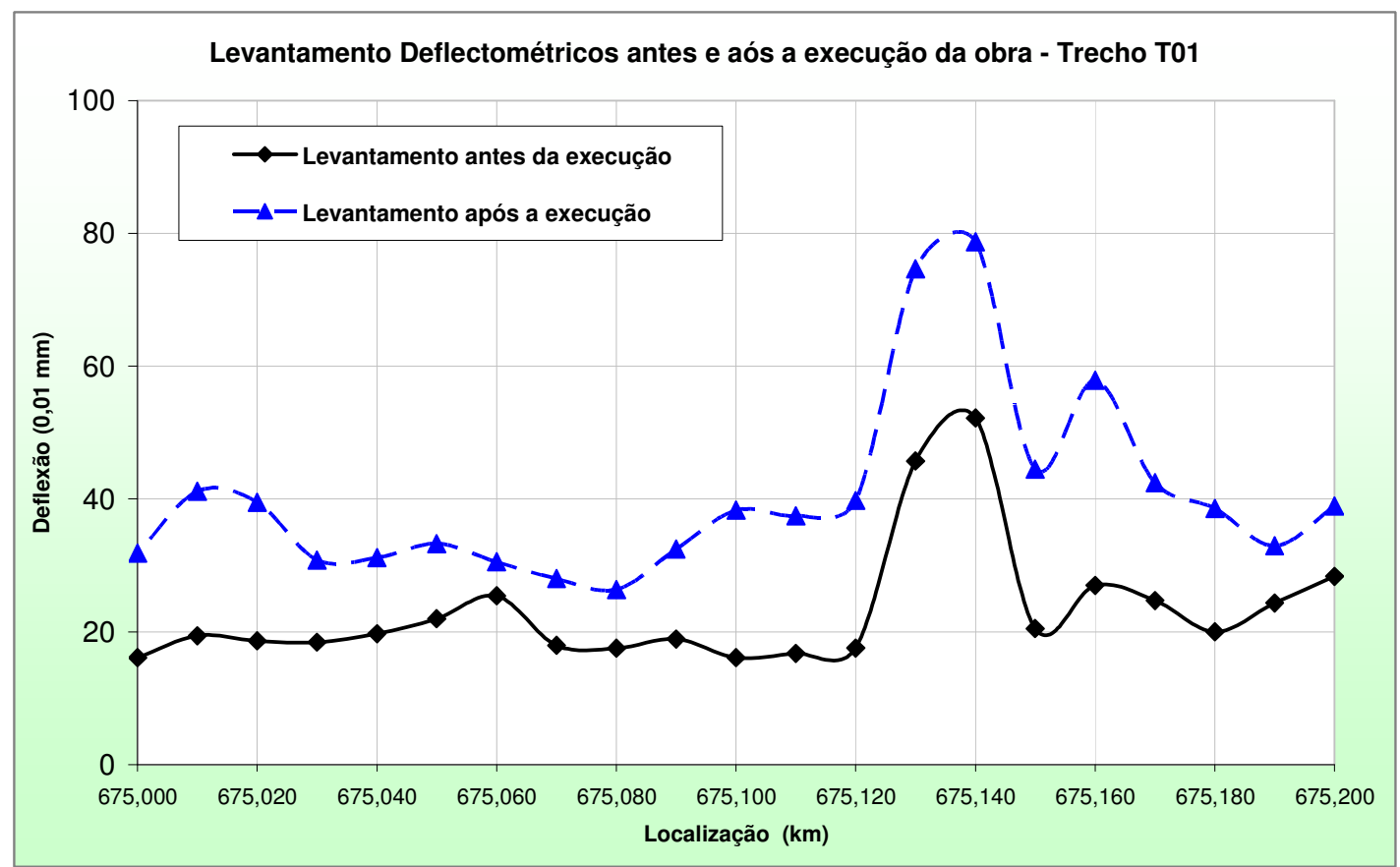

Figura 70 - Levantamento Deflectométrico antes e após execução da pista-teste - Trecho T01 


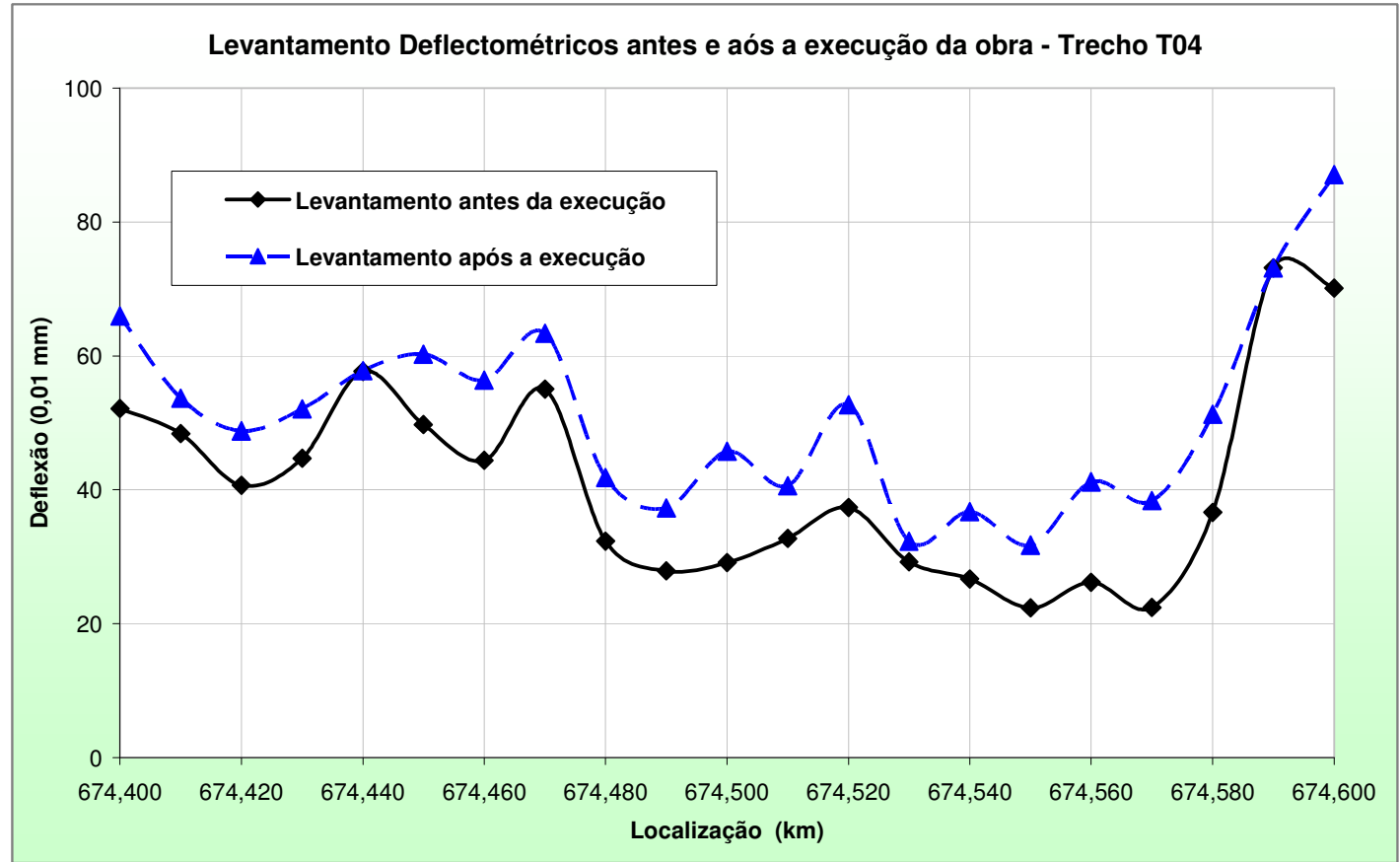

Figura 71 - Levantamento Deflectométrico antes e após execução da pista-teste - Trecho T04

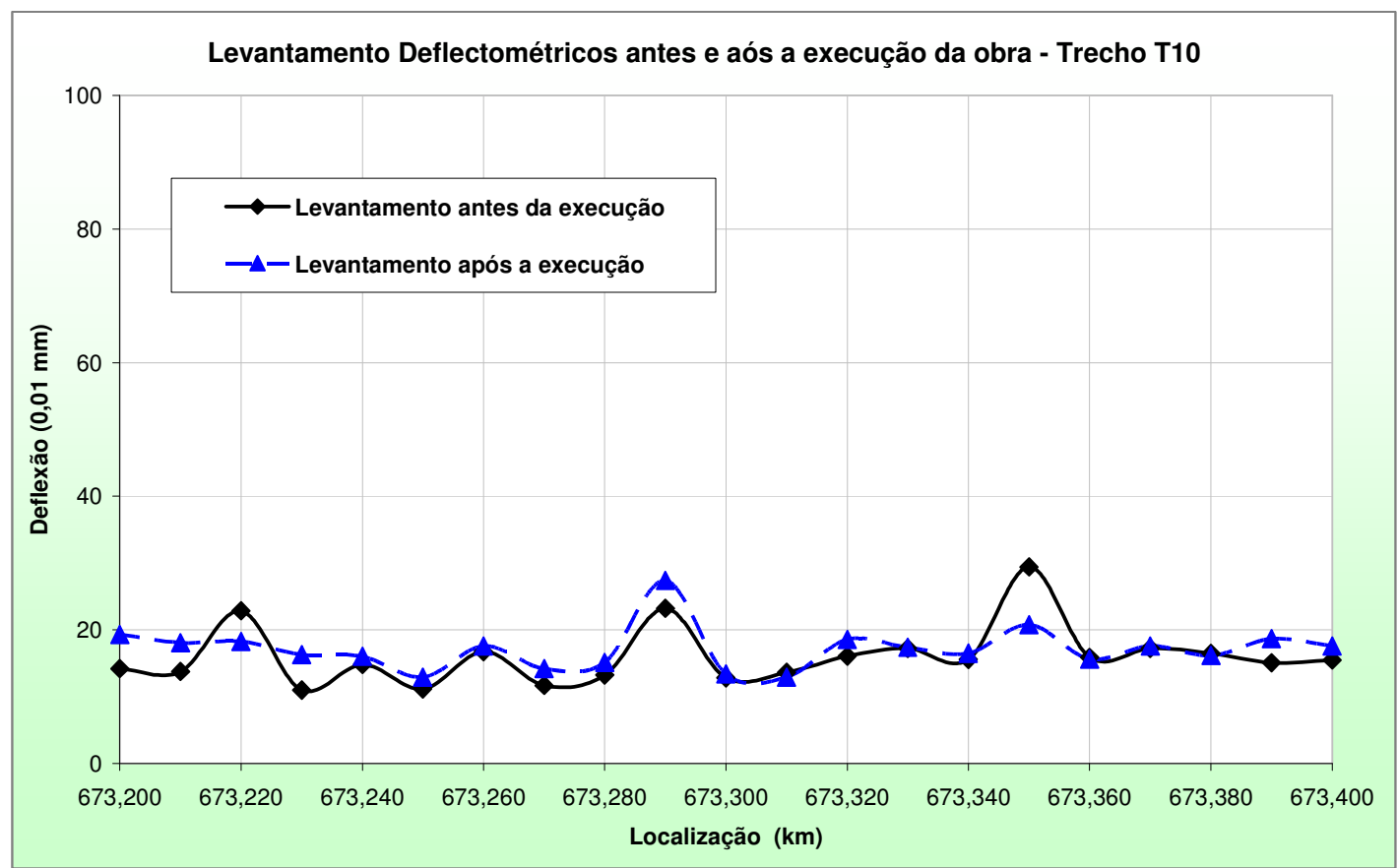

Figura 72 - Levantamento Deflectométrico antes e após execução da pista-teste - Trecho T10

A média e o desvio padrão dos levantamentos deflectométricos de cada trecho da pista-teste estão apresentados na tabela 35. 
Tabela 35 - Média e o desvio padrão das deflexões e temperatura de cada trecho

\begin{tabular}{|c|c|c|c|c|c|c|c|c|}
\hline \multirow{4}{*}{ Trecho } & \multicolumn{8}{|c|}{ Levantamento Deflectométrico } \\
\hline & \multicolumn{4}{|c|}{ Antes da execução da pista teste } & \multicolumn{4}{|c|}{ Após a execução da pista teste } \\
\hline & \multicolumn{2}{|c|}{ Deflexões } & \multicolumn{2}{|c|}{ Temp. pav. $\left({ }^{\circ} \mathrm{C}\right)$} & \multicolumn{2}{|c|}{ Antes da pista teste } & \multicolumn{2}{|c|}{ Temp. pav. $\left({ }^{\circ} \mathrm{C}\right)$} \\
\hline & Média & D. Padrão & Média & D. Padrão & Média & D. Padrão & Média & D. Padrão \\
\hline T01 & 23,6 & 9,4 & 29,5 & 0,8 & 43,6 & 14,6 & 41,9 & 0,3 \\
\hline T02 & 40,9 & 11,8 & 29,1 & 6,5 & 55,1 & 8,9 & 38,7 & 8,8 \\
\hline T03 & 43,0 & 11,4 & 30,6 & 5,6 & 59,9 & 17,2 & 37,5 & 6,6 \\
\hline T04 & 40,6 & 13,9 & 30,7 & 5,8 & 51,8 & 12,2 & 35,9 & 6,7 \\
\hline T05 & 37,4 & 11,3 & 29,9 & 5,6 & 49,4 & 9,3 & 35,1 & 6,5 \\
\hline T06 & 20,5 & 13,7 & 30,1 & 5,7 & 27,1 & 11,8 & 34,6 & 6,4 \\
\hline T07 & 44,7 & 12,4 & 28,8 & 5,5 & 44,7 & 8,7 & 33,9 & 6,3 \\
\hline T08 & 40,5 & 6,8 & 30,1 & 0,7 & 49,8 & 7,2 & 33,2 & 6,2 \\
\hline T09 & 25,3 & 7,8 & 27,8 & 6,6 & 33,8 & 13,7 & 32,1 & 6,0 \\
\hline T10 & 16,4 & 4,5 & 29,8 & 0,4 & 17,7 & 3,2 & 32,1 & 0,5 \\
\hline
\end{tabular}

Outro fato que influenciou com a não diminuição nos valores de deflexão com a obra da pista-teste é que foi retirado revestimento asfáltico antigo, envelhecido, ainda com poucas trincas, e substituído por igual espessura de revestimento novo. Revestimentos asfálticos novos tendem a apresentar módulo de resiliência menores que revestimentos mais antigos, com ligantes endurecidos, e sem trincas. A razão do teste não foi propriamente para reforço estrutural, mas para estudo de deformação permanente, problema do local do teste por se tratar de aclive, solicitado por veículos pesados e lentos.

\subsubsection{Macrotextura}

Após a construção da pista-teste foram realizados ensaios para a determinação da macrotextura por mancha de areia em todo o trecho. O levantamento foi feito com espaçamento de 100 em 100 metros de maneira que cada trecho tivesse duas determinações. Os resultados obtidos estão apresentados na figura 73 e A planilha de cálculos está apresentada nas tabelas 36 e 37. 


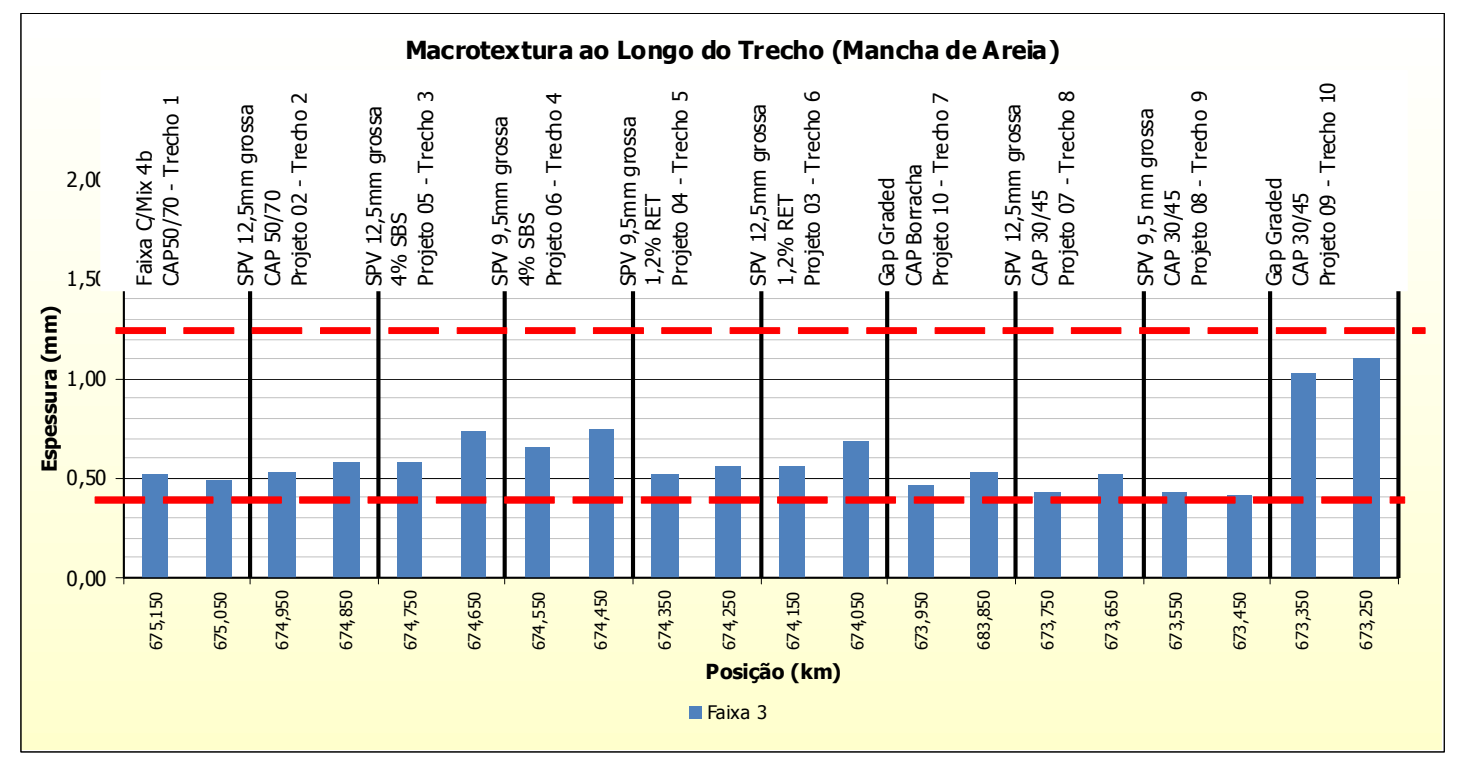

Figura 73 - Determinação da macrotextura da pista-teste

Tabela 36 - Planilhas de cálculos dos valores de mancha de areia dos kms 675,150 ao 674,250

\begin{tabular}{|c|c|c|c|c|c|c|c|c|c|c|}
\hline \multicolumn{11}{|c|}{ ENSAIO DE MANCHA DE AREIA - PISTA-TESTE - kms 675.150 ao 674,250} \\
\hline \multirow{2}{*}{$\begin{array}{l}\text { Rodovia: } \\
\text { Trecho } \\
\end{array}$} & BR-376 & & Data: & $13 / 02$ & 12009 & & & ume de Ar & $a\left(\mathrm{~mm}^{3}\right)=$ & 25.000 \\
\hline & \multicolumn{2}{|c|}{ T01 } & \multicolumn{2}{|c|}{ T02 } & \multicolumn{2}{|c|}{ T03 } & \multicolumn{2}{|c|}{ T04 } & \multicolumn{2}{|c|}{ T05 } \\
\hline km & $675+200$ & $675+000$ & $675+000$ & $674+800$ & $674+800$ & $674+600$ & $674+600$ & $674+400$ & $674+400$ & 674,200 \\
\hline FAIXA & 3 & 3 & 3 & 3 & 3 & 3 & 3 & 3 & 3 & 3 \\
\hline TRILHA & EXT & EXT & EXT & EXT & EXT & EXT & EXT & EXT & EXT & EXT \\
\hline REVEST. & CBUQ & CBUQ & CBUQ & CBUQ & CBUQ & CBUQ & CBUQ & CBUQ & CBUQ & CBUQ \\
\hline D1 & 245 & 265 & 245 & 200 & 235 & 200 & 220 & 210 & 245 & 230 \\
\hline D2 & 255 & 250 & 240 & 255 & 235 & 210 & 215 & 205 & 245 & 245 \\
\hline D3 & 245 & 255 & 245 & 250 & 245 & 210 & 215 & 200 & 240 & 245 \\
\hline D4 & 240 & 250 & 250 & 230 & 225 & 210 & 230 & 210 & 265 & 230 \\
\hline D médio & 246 & 255 & 245 & 234 & 235 & 208 & 220 & 206 & 249 & 238 \\
\hline S mancha & 47626 & 51071 & 47144 & 42913 & 43374 & 33816 & 38013 & 33410 & 48598 & 44301 \\
\hline Espes.(mm) & 0,52 & 0,49 & 0,53 & 0,58 & 0,58 & 0,74 & 0,66 & 0,75 & 0,51 & 0,56 \\
\hline Tipo de Sup. & Média & Média & Média & Média & Média & Média & Média & Média & Média & Média \\
\hline
\end{tabular}

Tabela 37 - Planilhas de cálculos dos valores de mancha de areia dos kms 674,150 ao 673,250

\begin{tabular}{|c|c|c|c|c|c|c|c|c|c|c|}
\hline \multicolumn{11}{|c|}{ ENSAIO DE MANCHA DE AREIA - PISTA-TESTE - kms 674,150 ao 673,250 } \\
\hline \multirow{2}{*}{$\begin{array}{l}\text { Rodovia: } \\
\text { Trecho }\end{array}$} & BR-376 & & Data: & $13 / 02$ & $/ 2009$ & & & ume de Ar & $a\left(\mathrm{~mm}^{3}\right)=$ & 25.000 \\
\hline & \multicolumn{2}{|c|}{ T06 } & \multicolumn{2}{|c|}{ T07 } & \multicolumn{2}{|c|}{ T08 } & \multicolumn{2}{|c|}{ T09 } & \multicolumn{2}{|c|}{ T10 } \\
\hline km & 674,200 & $674+000$ & $674+000$ & $673+800$ & $673+800$ & $673+600$ & $673+600$ & 673,400 & 673,400 & $673+200$ \\
\hline FAIXA & 3 & 3 & 3 & 3 & 3 & 3 & 3 & 3 & 3 & 3 \\
\hline TRILHA & EXT & EXT & EXT & EXT & EXT & EXT & EXT & EXT & EXT & EXT \\
\hline REVEST. & CBUQ & CBUQ & CBUQ & CBUQ & CBUQ & CBUQ & CBUQ & CBUQ & CBUQ & CBUQ \\
\hline D1 & 230 & 210 & 265 & 250 & 270 & 255 & 275 & 275 & 170 & 170 \\
\hline D2 & 245 & 220 & 255 & 240 & 275 & 245 & 265 & 285 & 185 & 170 \\
\hline D3 & 245 & 210 & 265 & 245 & 275 & 245 & 280 & 280 & 165 & 170 \\
\hline D4 & 230 & 220 & 260 & 245 & 270 & 245 & 270 & 270 & 185 & 170 \\
\hline D médio & 238 & 215 & 261 & 245 & 273 & 248 & 273 & 278 & 176 & 170 \\
\hline S mancha & 44301 & 36305 & 53605 & 47144 & 58321 & 48111 & 58321 & 60481 & 24398 & 22698 \\
\hline Espes.(mm) & 0,56 & 0,69 & 0,47 & 0,53 & 0,43 & 0,52 & 0,43 & 0,41 & 1,02 & 1,10 \\
\hline Tipo de Sup. & Média & Média & Média & Média & Média & Média & Média & Média & Grossa & Grossa \\
\hline
\end{tabular}


Segundo os limites apresentados no Manual de Reabilitação de Pavimentos Asfálticos do DNIT, a macrotextura é caracterizada como média para valores compreendidos entre $0,4 \mathrm{~mm}$ e $0,8 \mathrm{~mm}$ para altura média de mancha de areia, e aberta ou grosseira entre $0,8 \mathrm{~mm}$ e $1,2 \mathrm{~mm}$.

Observe-se que somente o trecho T10 usinado com a mistura asfáltica gapgraded e com o ligante asfáltico CAP 30/45 apresentou valores com a macrotextura grossa ou aberta, para os demais trechos a macrotextura determinada através do ensaio de mancha de areia foi de textura média, característica comum em concretos asfálticos. Observe-se que a altura média de mancha de areia atualmente mais requisitada para camadas de rolamento deve estar na faixa de $0,6 \mathrm{~mm}$ a $1,2 \mathrm{~mm}$.

A mistura asfáltica aplicada no trecho T1 não atende a esta faixa. A faixa Mix IV4 do Instituto de Asfalto em geral resulta em superfície mais fechada quanto à textura devido à distribuição granulométrica muito próxima à máxima densificação, não proporcionando a presença de agregados graúdos à superfície para aumentar a macrotextura. No caso do trecho T4, a composição granulométrica favorece o aumenta da macrotextura e tem-se em média $0,75 \mathrm{~mm}$ para este trecho.

\subsubsection{IRI}

Foram feitos dois levantamentos da irregularidade longitudinal da pista-teste, uma no pavimento antes da construção da pista-teste e outro após 30 dias da execução dos trechos experimentais. Os levantamentos foram executados com o equipamento a laser - figura 74 . 


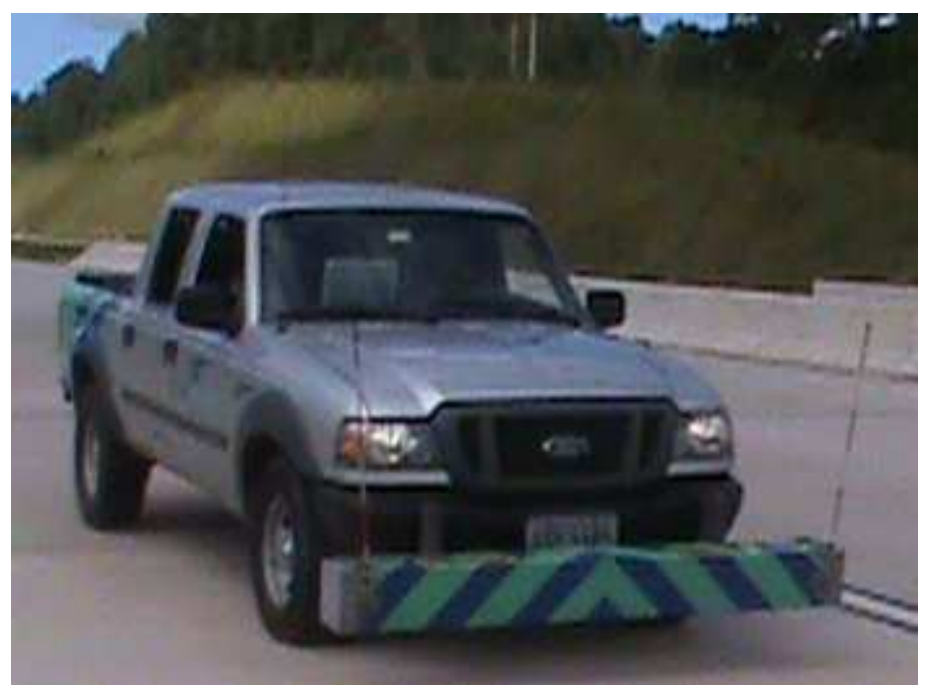

Figura 74 - Perfilômetro a laser para medição da irregularidade de pavimentos

As contagens na unidade de $\mathrm{m} / \mathrm{km}$, ao longo de toda a pista-teste, foram feita a cada $40 \mathrm{~m}$ e $0 \mathrm{QI}$ foi obtido a partir da relação $\mathrm{QI}=13 \mathrm{IRI}$. O resumo dos valores obtidos para os dois levantamentos estão apresentados na figura 75 e nas tabelas 38 a 41 estão apresentados os valores dos levantamentos, bem como a média e o desvio padrão de cada trecho.

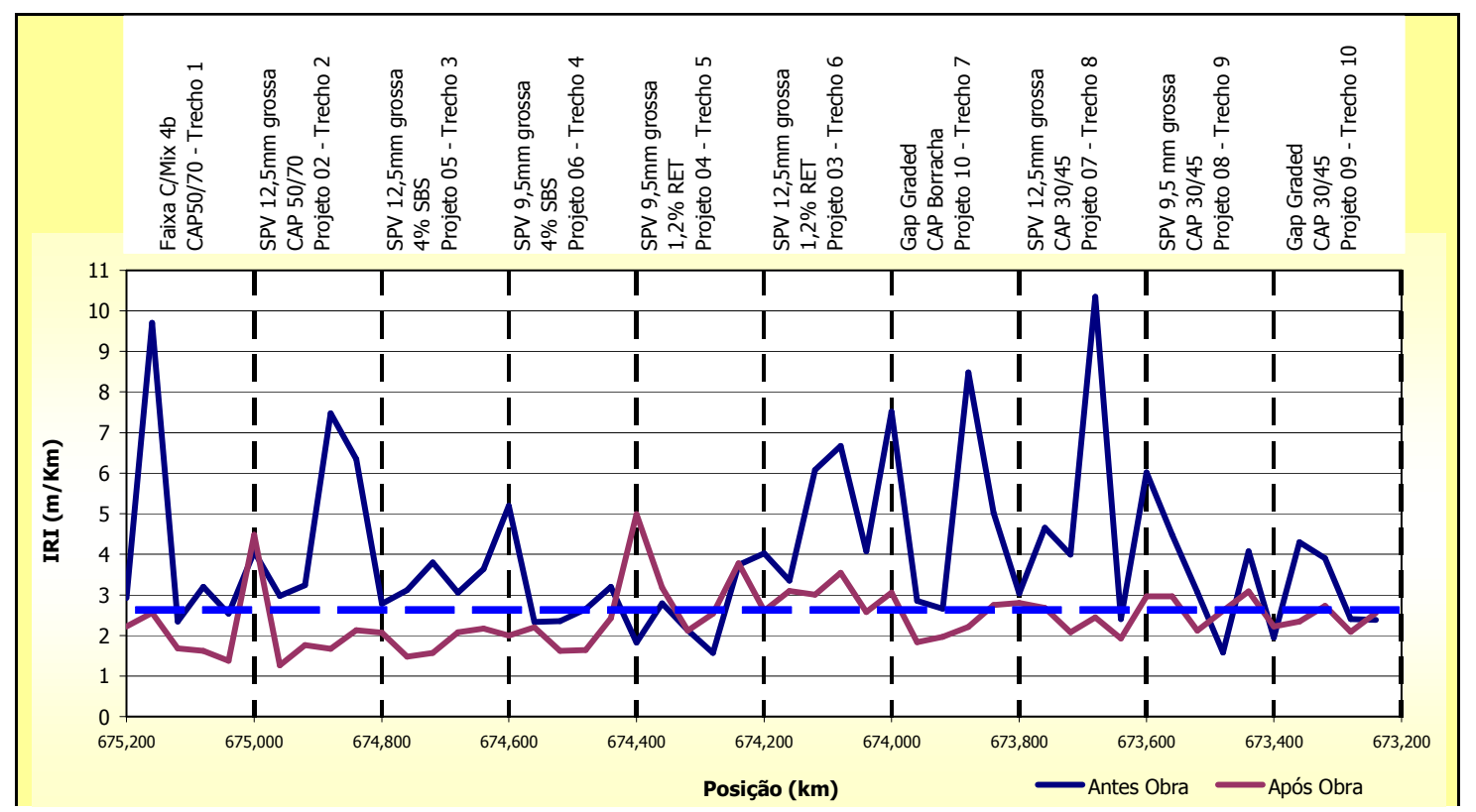

Figura 75 - Irregularidade antes e após a execução do trecho 
Tabela 38 -Valores de IRI antes da construção da pista-teste dos trechos T01 ao T05

Rodovia: BR-376/PR Sentido: Norte - Km 675,200 ao 674,200

\begin{tabular}{|c|c|c|c|c|c|c|c|}
\hline \multirow{2}{*}{$\frac{\overline{T r e c h o}}{(200 \mathrm{~m})}$} & \multicolumn{2}{|c|}{ Segmento } & \multirow{2}{*}{$\begin{array}{l}\text { Veloc. } \\
(\mathrm{km} / \mathrm{h})\end{array}$} & \multicolumn{3}{|c|}{ IRI (m/ km) } & \multirow{2}{*}{$\begin{array}{c}\mathrm{QI} \\
\text { (cont/km) }\end{array}$} \\
\hline & Início & Fim & & TRI & TRE & Média & \\
\hline \multirow{7}{*}{ T01 } & 675,200 & 675,160 & 77 & 2,15 & 3,70 & 2,93 & 38,0 \\
\hline & 675,160 & 675,120 & 77 & 4,67 & 14,75 & 9,71 & 126,2 \\
\hline & 675,120 & 675,080 & 77 & 1,83 & 2,86 & 2,35 & 30,5 \\
\hline & 675,080 & 675,040 & 77 & 1,34 & 5,07 & 3,21 & 41,7 \\
\hline & 675,040 & 675,000 & 77 & 1,51 & 3,57 & 2,54 & 33,0 \\
\hline & \multicolumn{2}{|c|}{ Média } & 77 & 2,30 & 5,99 & 4,15 & 53,9 \\
\hline & \multicolumn{2}{|c|}{ Desvio padrão } & 0 & 1,36 & 4,96 & 3,13 & 40,7 \\
\hline \multirow{7}{*}{ T02 } & 675,000 & 674,960 & 77 & 2,77 & 5,35 & 4,06 & 52,8 \\
\hline & 674,960 & 674,920 & 77 & 2,06 & 3,88 & 2,97 & 38,6 \\
\hline & 674,920 & 674,880 & 80 & 2,60 & 3,89 & 3,25 & 42,2 \\
\hline & 674,880 & 674,840 & 80 & 5,67 & 9,27 & 7,47 & 97,1 \\
\hline & 674,840 & 674,800 & 80 & 6,07 & 6,63 & 6,35 & 82,6 \\
\hline & \multicolumn{2}{|c|}{ Média } & 79 & 3,83 & 5,80 & 4,82 & 62,6 \\
\hline & \multicolumn{2}{|c|}{ Desvio padrão } & 2 & 1,88 & 2,25 & 1,99 & 25,9 \\
\hline \multirow{7}{*}{ T03 } & 674,800 & 674,760 & 80 & 2,26 & 3,31 & 2,79 & 36,2 \\
\hline & 674,760 & 674,720 & 80 & 3,08 & 3,16 & 3,12 & 40,6 \\
\hline & 674,720 & 674,680 & 80 & 3,54 & 4,05 & 3,80 & 49,3 \\
\hline & 674,680 & 674,640 & 80 & 3,68 & 2,44 & 3,06 & 39,8 \\
\hline & 674,640 & 674,600 & 80 & 2,56 & 4,72 & 3,64 & 47,3 \\
\hline & \multicolumn{2}{|c|}{ Média } & 80 & 3,02 & 3,54 & 3,28 & 42,6 \\
\hline & \multicolumn{2}{|c|}{ Desvio padrão } & 0 & 0,61 & 0,87 & 0,42 & 5,5 \\
\hline \multirow{7}{*}{ T04 } & 674,600 & 674,560 & 79 & 2,73 & 7,67 & 5,20 & 67,6 \\
\hline & 674,560 & 674,520 & 79 & 2,27 & 2,39 & 2,33 & 30,3 \\
\hline & 674,520 & 674,480 & 79 & 2,85 & 1,87 & 2,36 & 30,7 \\
\hline & 674,480 & 674,440 & 79 & 1,91 & 3,39 & 2,65 & 34,5 \\
\hline & 674,440 & 674,400 & 79 & 3,54 & 2,86 & 3,20 & 41,6 \\
\hline & \multicolumn{2}{|c|}{ Média } & 79 & 2,66 & 3,64 & 3,15 & 40,9 \\
\hline & \multicolumn{2}{|c|}{ Desvio padrão } & 0 & 0,62 & 2,32 & 1,20 & 15,6 \\
\hline \multirow{7}{*}{ T05 } & 674,400 & 674,360 & 79 & 1,78 & 1,87 & 1,83 & 23,7 \\
\hline & 674,360 & 674,320 & 79 & 3,04 & 2,54 & 2,79 & 36,3 \\
\hline & 674,320 & 674,280 & 79 & 2,19 & 2,07 & 2,13 & 27,7 \\
\hline & 674,280 & 674,240 & 79 & 1,39 & 1,75 & 1,57 & 20,4 \\
\hline & 674,240 & 674,200 & 79 & 3,76 & 3,70 & 3,73 & 48,5 \\
\hline & \multicolumn{2}{|c|}{ Média } & 79 & 2,43 & 2,39 & 2,41 & 31,3 \\
\hline & \multicolumn{2}{|c|}{ Desvio padrão } & 0 & 0,96 & 0,79 & 0,87 & 11,3 \\
\hline
\end{tabular}


Tabela 39 - Valores de IRI antes da construção da pista-teste dos trechos T06 ao T10

Faixa: 3 Sentido Norte $-\mathrm{Km} 674,200$ ao 673,200

\begin{tabular}{|c|c|c|c|c|c|c|c|}
\hline \multirow{2}{*}{$\begin{array}{l}\text { Trecho } \\
(200 \mathrm{~m}) \\
\end{array}$} & \multicolumn{2}{|c|}{ Segmento } & \multirow{2}{*}{$\begin{array}{l}\text { Veloc. } \\
\text { (km/h) }\end{array}$} & \multicolumn{3}{|c|}{ IRI (m/km) } & \multirow{2}{*}{$\begin{array}{c}\text { QI } \\
\text { (cont/km) }\end{array}$} \\
\hline & Início & Fim & & TR I & TRE & Média & \\
\hline \multirow{7}{*}{ T06 } & 674,200 & 674,160 & 79 & 2,71 & 5,33 & 4,02 & 52,3 \\
\hline & 674,160 & 674,120 & 79 & 3,65 & 3,04 & 3,35 & 43,5 \\
\hline & 674,120 & 674,080 & 79 & 6,66 & 5,49 & 6,08 & 79,0 \\
\hline & 674,080 & 674,040 & 79 & 9,15 & 4,19 & 6,67 & 86,7 \\
\hline & 674,040 & 674,000 & 79 & 4,66 & 3,48 & 4,07 & 52,9 \\
\hline & \multicolumn{2}{|c|}{ Média } & 79 & 5,37 & 4,31 & 4,84 & 62,9 \\
\hline & \multicolumn{2}{|c|}{ Desvio padrão } & 0 & 2,57 & 1,09 & 1,45 & 18,8 \\
\hline \multirow{7}{*}{ T07 } & 674,000 & 673,960 & 79 & 8,01 & 7,02 & 7,52 & 97,7 \\
\hline & 673,960 & 673,920 & 78 & 2,72 & 2,99 & 2,86 & 37,1 \\
\hline & 673,920 & 673,880 & 78 & 2,60 & 2,73 & 2,67 & 34,6 \\
\hline & 673,880 & 673,840 & 78 & 6,05 & 10,92 & 8,49 & 110,3 \\
\hline & 673,840 & 673,800 & 78 & 3,30 & 6,74 & 5,02 & 65,3 \\
\hline & \multicolumn{2}{|c|}{ Média } & 78 & 4,54 & 6,08 & 5,31 & 69,0 \\
\hline & \multicolumn{2}{|c|}{ Desvio padrão } & 0 & 2,39 & 3,37 & 2,65 & 34,4 \\
\hline \multirow{7}{*}{ T08 } & 673,800 & 673,760 & $\overline{78}$ & 262 & 345 & 3.04 & 395 \\
\hline & 673,760 & 673,720 & 78 & 4,87 & 4,44 & 4,66 & 60,5 \\
\hline & 673,720 & 673,680 & 78 & 3,72 & 4,27 & 4,00 & 51,9 \\
\hline & 673,680 & 673,640 & 78 & 11,63 & 9,06 & 10,35 & 134,5 \\
\hline & 673,640 & 673,600 & 75 & 2,98 & 1,82 & 2,40 & 31,2 \\
\hline & \multicolumn{2}{|c|}{ Média } & 78 & 5,16 & 4,61 & 4,89 & 63,5 \\
\hline & \multicolumn{2}{|c|}{ Desvio padrão } & 1 & 3,72 & 2,70 & 3,17 & 41,2 \\
\hline \multirow{7}{*}{ T09 } & 673,600 & 673,560 & 75 & 6,15 & 5,89 & 6,02 & 78,3 \\
\hline & 673,560 & 673,520 & 75 & 3,48 & 5,49 & 4,49 & 58,3 \\
\hline & 673,520 & 673,480 & 75 & 3,06 & 3,09 & 3,08 & 40,0 \\
\hline & 673,480 & 673,440 & 75 & 1,58 & 1,58 & 1,58 & 20,5 \\
\hline & 673,440 & 673,400 & 75 & 4,09 & 4,05 & 4,07 & 52,9 \\
\hline & \multicolumn{2}{|c|}{ Média } & 75 & 3,67 & 4,02 & 3,85 & 50,0 \\
\hline & \multicolumn{2}{|c|}{ Desvio padrão } & 0 & 1,67 & 1,77 & 1,65 & 21,5 \\
\hline \multirow{7}{*}{ T10 } & 673,400 & 673,360 & 75 & 1,88 & 2,01 & 1,95 & 25,3 \\
\hline & 673,360 & 673,320 & 75 & 6,12 & 2,48 & 4,30 & 55,9 \\
\hline & 673,320 & 673,280 & 76 & 3,40 & 4,41 & 3,91 & 50,8 \\
\hline & 673,280 & 673,240 & 76 & 2,14 & 2,68 & 2,41 & 31,3 \\
\hline & 673,240 & 673,200 & 76 & 2,36 & 2,41 & 2,39 & 31,0 \\
\hline & \multicolumn{2}{|c|}{ Média } & 76 & 3,18 & 2,80 & 2,99 & 38,9 \\
\hline & \multicolumn{2}{|c|}{ Desvio padrão } & 0 & 1,74 & 0,93 & 1,04 & 13,6 \\
\hline
\end{tabular}


Tabela 40 - Valores de IRI após a construção da pista-teste dos trechos T01 ao T05

Rodovia: BR-376/PR Sentido: Norte - Km 675,200 ao 674,200

\begin{tabular}{|c|c|c|c|c|c|c|c|}
\hline \multirow{2}{*}{$\begin{array}{l}\text { Trecho } \\
(200 \mathrm{~m}) \\
\end{array}$} & \multicolumn{2}{|c|}{ Segmento } & \multirow{2}{*}{$\begin{array}{l}\text { Veloc. } \\
\text { (km/h) }\end{array}$} & \multicolumn{3}{|c|}{ IRI $(\mathrm{m} / \mathbf{k m})$} & \multirow{2}{*}{$\begin{array}{c}\text { QI } \\
\text { (cont/km) }\end{array}$} \\
\hline & Início & Fim & & T R I & TRE & Média & \\
\hline \multirow{7}{*}{ T01 } & 675,200 & 675,160 & 33 & 1,63 & 2,81 & 2,22 & 28,9 \\
\hline & 675,160 & 675,120 & 35 & 1,35 & 3,77 & 2,56 & 33,3 \\
\hline & 675,120 & 675,080 & 36 & 1,02 & 2,33 & 1,68 & 21,8 \\
\hline & 675,080 & 675,040 & 38 & 1,06 & 2,17 & 1,62 & 21,0 \\
\hline & 675,040 & 675,000 & 39 & 0,94 & 1,81 & 1,38 & 17,9 \\
\hline & \multicolumn{2}{|c|}{ Média } & 36 & 1,20 & 2,58 & 1,89 & 24,6 \\
\hline & \multicolumn{2}{|c|}{ Desvio padrão } & 2 & 0,29 & 0,76 & 0,49 & 6,3 \\
\hline \multirow{7}{*}{ T02 } & 675,000 & 674,960 & 37 & 2,53 & 6,45 & 4,49 & 58,4 \\
\hline & 674,960 & 674,920 & 37 & 1,20 & 1,34 & 1,27 & 16,5 \\
\hline & 674,920 & 674,880 & 40 & 1,20 & 2,33 & 1,77 & 22,9 \\
\hline & 674,880 & 674,840 & 41 & 1,77 & 1,56 & 1,67 & 21,6 \\
\hline & 674,840 & 674,800 & 40 & 1,94 & 2,32 & 2,13 & 27,7 \\
\hline & \multirow{2}{*}{\multicolumn{2}{|c|}{$\begin{array}{c}\text { Média } \\
\text { Desvio padrão }\end{array}$}} & 39 & 1,73 & 2,80 & 2,26 & 29,4 \\
\hline & & & 2 & 0,56 & 2,09 & 1,28 & 16,7 \\
\hline \multirow{7}{*}{ T03 } & 674,800 & 674,760 & 39 & 1,58 & 2,56 & 2,07 & 26,9 \\
\hline & 674,760 & 674,720 & 39 & 1,56 & 1,39 & 1,48 & 19,2 \\
\hline & 674,720 & 674,680 & 38 & 1,32 & 1,82 & 1,57 & 20,4 \\
\hline & 674,680 & 674,640 & 32 & 1,95 & 2,22 & 2,09 & 27,1 \\
\hline & 674,640 & 674,600 & 23 & 2,10 & 2,25 & 2,18 & 28,3 \\
\hline & \multirow{2}{*}{\multicolumn{2}{|c|}{$\begin{array}{c}\text { Média } \\
\text { Desvio padrão }\end{array}$}} & 34 & 1,70 & 2,05 & 1,88 & 24,4 \\
\hline & & & 7 & 0,32 & 0,45 & 0,33 & 4,2 \\
\hline \multirow{7}{*}{ T04 } & 674,600 & 674,560 & 28 & 2,25 & 1,75 & 2,00 & 26,0 \\
\hline & 674,560 & 674,520 & 35 & 2,13 & 2,28 & 2,21 & 28,7 \\
\hline & 674,520 & 674,480 & 41 & 2,00 & 1,23 & 1,62 & 21,0 \\
\hline & 674,480 & 674,440 & 46 & 1,72 & 1,56 & 1,64 & 21,3 \\
\hline & 674,440 & 674,400 & 48 & 2,32 & 2,53 & 2,43 & 31,5 \\
\hline & \multicolumn{2}{|c|}{ Média } & 40 & 2,08 & 1,87 & 1,98 & 25,7 \\
\hline & \multicolumn{2}{|c|}{ Desvio padrão } & 8 & 0,24 & 0,53 & 0,35 & 4,6 \\
\hline \multirow{7}{*}{ T05 } & 674,400 & 674,360 & 49 & 5,65 & 4,33 & 4,99 & 64,9 \\
\hline & 674,360 & 674,320 & 49 & 2,81 & 3,56 & 3,19 & 41,4 \\
\hline & 674,320 & 674,280 & 48 & 2,08 & 2,14 & 2,11 & 27,4 \\
\hline & 674,280 & 674,240 & 46 & 2,58 & 2,49 & 2,54 & 33,0 \\
\hline & 674,240 & 674,200 & 46 & 3,42 & 4,14 & 3,78 & 49,1 \\
\hline & \multicolumn{2}{|c|}{ Média } & 48 & 3,31 & 3,33 & 3,32 & 43,2 \\
\hline & \multicolumn{2}{|c|}{ Desvio padrão } & 1 & 1,39 & 0,98 & 1,13 & 14,7 \\
\hline
\end{tabular}


Tabela 41 - Valores de IRI após a construção da pista-teste dos trechos T06 ao T10

Faixa: $\quad 3 \quad$ Sentido Norte - Km 674,200 ao 673,200

\begin{tabular}{|c|c|c|c|c|c|c|c|}
\hline \multirow{2}{*}{$\frac{\text { Trecho }}{\text { (200 m) }}$} & \multicolumn{2}{|c|}{ Segmento } & \multirow{2}{*}{$\begin{array}{l}\text { Veloc. } \\
(\mathrm{km} / \mathrm{h})\end{array}$} & \multicolumn{3}{|c|}{ IRI (m/km) } & \multirow{2}{*}{$\begin{array}{c}\text { QI } \\
\text { (cont/ km) }\end{array}$} \\
\hline & Início & Fim & & TR I & TRE & Média & \\
\hline \multirow{7}{*}{ T06 } & 674,200 & 674,160 & $\overline{46}$ & 2,04 & 3,18 & 2,61 & 33,9 \\
\hline & 674,160 & 674,120 & 47 & 2,36 & 3,84 & 3,10 & 40,3 \\
\hline & 674,120 & 674,080 & 48 & 2,59 & 3,42 & 3,01 & 39,1 \\
\hline & 674,080 & 674,040 & 48 & 3,79 & 3,30 & 3,55 & 46,1 \\
\hline & 674,040 & 674,000 & 48 & 2,23 & 2,93 & 2,58 & 33,5 \\
\hline & \multicolumn{2}{|c|}{ Média } & 47 & 2,60 & 3,33 & 2,97 & 38,6 \\
\hline & \multicolumn{2}{|c|}{ Desvio padrão } & 1 & 0,69 & 0,34 & 0,40 & 5,2 \\
\hline \multirow{7}{*}{ T07 } & 674000 & 673960 & 48 & 334 & 277 & 306 & 397 \\
\hline & 673,960 & 673,920 & 47 & 2,10 & 1.58 & 1.84 & 23,9 \\
\hline & 673,920 & 673,880 & 47 & 2,25 & 1,69 & 1,97 & 25,6 \\
\hline & 673,880 & 673,840 & 48 & 2,24 & 2,19 & 2,22 & 28,8 \\
\hline & 673,840 & 673,800 & 48 & 2,68 & 2,84 & 2,76 & 35,9 \\
\hline & \multicolumn{2}{|c|}{ Média } & 48 & 2,52 & 2,21 & 2,37 & 30,8 \\
\hline & \multicolumn{2}{|c|}{ Desvio padrão } & 0 & 0,51 & 0,59 & 0,52 & 6,8 \\
\hline \multirow{7}{*}{ T08 } & 673.800 & 673.760 & $\overline{48}$ & 291 & 270 & 281 & 36.5 \\
\hline & 673,760 & 673,720 & 48 & 2,84 & 2,52 & 2,68 & 34,8 \\
\hline & 673,720 & 673,680 & 47 & 2,05 & 2,11 & 2,08 & 27,0 \\
\hline & 673,680 & 673,640 & 48 & 2,50 & 2,38 & 2,44 & 31,7 \\
\hline & 673,640 & 673,600 & 47 & 1,89 & 1,96 & 1,93 & 25,0 \\
\hline & \multicolumn{2}{|c|}{ Média } & 47 & 2,44 & 2,33 & 2,39 & 31,0 \\
\hline & \multicolumn{2}{|c|}{ Desvio padrão } & 0 & 0,46 & 0,30 & 0,38 & 4,9 \\
\hline \multirow{8}{*}{ T09 } & & & & & & & \\
\hline & 673,600 & 673,560 & 47 & 2,57 & 3,36 & 2,97 & 38,5 \\
\hline & 673,560 & 673,520 & 46 & 2,06 & 3,86 & 2,96 & 38,5 \\
\hline & 673,520 & 673,480 & 46 & 2,19 & 2,04 & 2,12 & 27,5 \\
\hline & 673,480 & 673,440 & 47 & 3,23 & 2,00 & 2,62 & 34,0 \\
\hline & 673,440 & 673,400 & 48 & 2,98 & 3,19 & 3,09 & 40,1 \\
\hline & \multicolumn{2}{|c|}{ Média } & 47 & 2,61 & 2,89 & 2,75 & 35,7 \\
\hline & \multicolumn{2}{|c|}{ Desvio padrão } & 1 & 0,50 & 0,83 & 0,39 & 5,1 \\
\hline \multirow{7}{*}{ T10 } & 673,400 & 673,360 & $\overline{48}$ & 2.24 & 2,21 & 223 & 28.9 \\
\hline & 673,360 & 673,320 & 46 & 2,75 & 1,94 & 2,35 & 30,5 \\
\hline & 673,320 & 673,280 & 43 & 2,24 & 3,22 & 2,73 & 35,5 \\
\hline & 673,280 & 673,240 & 37 & 2,16 & 2,02 & 2,09 & 27,2 \\
\hline & 673,240 & 673,200 & 30 & 2,39 & 2,74 & 2,57 & 33,3 \\
\hline & \multicolumn{2}{|c|}{ Média } & 41 & 2,36 & 2,43 & 2,39 & 31,1 \\
\hline & \multicolumn{2}{|c|}{ Desvio padrão } & 7 & 0,24 & 0,54 & 0,26 & 3,3 \\
\hline
\end{tabular}


Observe-se que os valores de IRI encontrados antes da implantação da pista eram elevados, basicamente todos superiores a 2,7 m/ $\mathrm{km}$ - limite recomendado e aceitável associado a conforto e segurança do usuário pelo Departamento Nacional de Infraestrutura de Transportes - DNIT. Além disso, o desvio padrão era elevado. Após a implantação da pista-teste ocorreu uma significativa redução nos valores anteriormente encontrados. Os valores apresentam-se entre os limites de 2 a $3 \mathrm{~m} / \mathrm{km}$, exceto para as proximidades dos

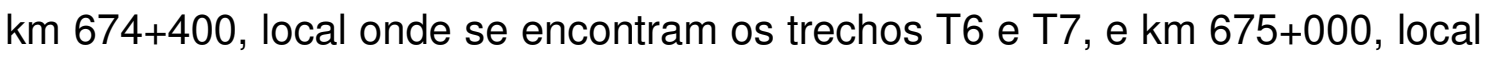
entre os trechos T9 ao T10. Nestes locais foram encontrados valores da ordem de 5 e $4,5 \mathrm{~m} / \mathrm{km}$, respectivamente. A alteração do tipo de camada, com parada e retomada da acabadora, gera um desnível na pista, difícil de ser corrigido pela compactação. Estes valores não devem ser considerados para a avaliação geral da irregularidade da pista após recapeamento.

Essa condição superficial indicada pela irregularidade sofreu alterações com a ação do tráfego. De fato, com as medições das flechas após 6 meses e 13 meses após a execução (2o e $3^{\circ}$ levantamentos), registraram-se flechas e defeitos que certamente alteraram os valores de IRI anteriormente registrados devido ao elevado tráfego.

\subsubsection{Afundamentos nas trilhas de rodas (flechas)}

Após a construção da pista-teste foram executados levantamentos das flechas (afundamentos em trilhas de roda), conforme preconizado na norma do DNIT 006/2003-PRO, em toda extensão da pista-teste. Foram executados três levantamentos: após 30 dias da execução da pista-teste, após 6 e 13 meses de abertura ao tráfego. Os valores das flechas encontradas referentes à $1^{\underline{a}}$ e $2^{\underline{a}}$ campanhas é a média de 10 leituras efetuadas em cada trecho na trilha externa TRE e as flechas referentes à $3^{\underline{a}}$ campanha de ensaios é a média de 20 leituras na TRE em cada trecho e estão apresentadas na figura 76, a média e 0 desvio padrão de cada leitura estão apresentadas na tabela 42. A planilha com 
a média e o desvio padrão de todas as leituras de todos os trechos referentes às 3 campanhas encontram-se no anexo IV.

A ANTT, através do programa de exploração de rodovias - PER para as rodovias BR 116/376PR e BR 101 SC - Trecho Curitiba/Florianópolis, especifica o limite de 7,0 mm como sendo o valor máximo da flecha admissível; acima deste limite, indica-se a necessidade de intervenção. Observe-se na figura 76 que após 13 meses da abertura ao tráfego da pista-teste, todos os valores de flecha registrados ultrapassam o limite acima especificado, exceto o trecho T10 que apresentou um valor de $6,6 \mathrm{~mm}$ de flecha. Por este motivo, como continuidade da pesquisa, está sendo proposta a fresagem total de $50 \mathrm{~mm}$, e execução de dois trechos cobrindo toda a extensão da pista-teste, sendo que as duas soluções serão realizadas de acordo com os resultados desta presente pesquisa atual.

Observe-se ainda que os trechos T01, T05, T06 e T07, já apresentavam valores acima do especificado após apenas 6 meses de ação do tráfego.

EVOLUÇÃO DA FLECHA (AFUNDAMENTO) NA PISTA TESTE

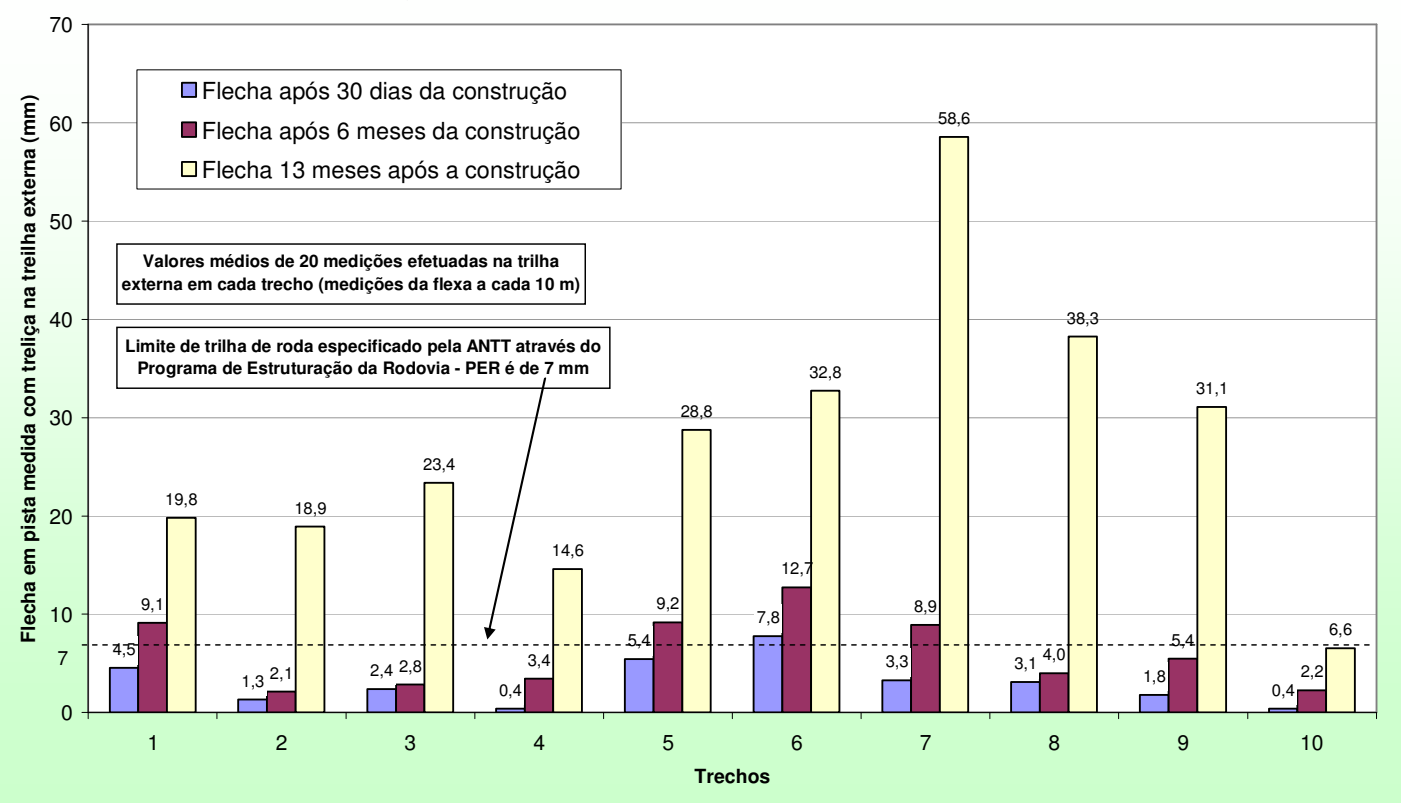

Figura 76 - Afundamentos - após implantação 1, 6 e 13 meses após abertura ao tráfego

Considerando as deflexões da pista-teste, apresentadas no item 3.9.1, com valores situados entre $20(0,01 \mathrm{~mm})$ e $60(0,01 \mathrm{~mm})$, associados à estrutura do pavimento, conforme mostrado no item 3.11, pode-se concluir que os 
afundamentos medidos foram causados principalmente pela camada de rolamento asfáltica aplicada.

Tabela 42 - Valores médios e desvio padrão das flechas com 1, 6 e 13 meses

\begin{tabular}{|c|c|c|c|c|c|c|c|c|}
\hline \multirow{3}{*}{$\begin{array}{c}\text { Trecho } \\
\text { N. }\end{array}$} & \multirow{2}{*}{\multicolumn{2}{|c|}{ Tipo de mistura asfáltica }} & \multicolumn{6}{|c|}{ FLECHAS NA TRE } \\
\hline & & & \multicolumn{2}{|c|}{1 mês } & \multicolumn{2}{|c|}{6 meses } & \multicolumn{2}{|c|}{13 meses } \\
\hline & Fx. & Ligante & Média & D.Pad. & Média & D.Pad. & Média & D.Pad. \\
\hline T01 & Mix Ivb I.A. & CAP 50/70 & 4,5 & 6,1 & 9,1 & 7,6 & 19,1 & 17,3 \\
\hline T02 & SPV $12,5 \mathrm{~mm}$ & CAP 50/70 & 1,3 & 0,5 & 2,1 & 1,7 & 18,8 & 19,1 \\
\hline T03 & SPV $12,5 \mathrm{~mm}$ & $4 \%$ SBS & 2,4 & 4,5 & 2,8 & 1,0 & 23,4 & 30,3 \\
\hline T04 & SPV $9,5 \mathrm{~mm}$ & $4 \%$ SBS & 0,4 & 0,3 & 3,4 & 2,0 & 14,6 & 18,5 \\
\hline T05 & SPV $9,5 \mathrm{~mm}$ & $1,2 \%$ RET & 5,4 & 5,9 & 9,2 & 2,3 & 28,8 & 9,5 \\
\hline T06 & SPV $12,5 \mathrm{~mm}$ & 1,2\% RET & 7,8 & 19,7 & 12,7 & 5,5 & 32,8 & 12,3 \\
\hline T07 & Gap Graded & AMB & 3,3 & 2,2 & 8,9 & 4,5 & 58,6 & 19,1 \\
\hline T08 & SPV $12,5 \mathrm{~mm}$ & CAP 30/45 & 3,1 & 2,3 & 4,0 & 2,2 & 38,3 & 16,4 \\
\hline T09 & SPV $9,5 \mathrm{~mm}$ & CAP $30 / 45$ & 1,8 & 0,8 & 5,4 & 1,2 & 31,1 & 10,2 \\
\hline $\mathrm{T} 10$ & Gap Graded & CAP 30/45 & 0,4 & 0,5 & 2,2 & 2,0 & 6,6 & 1,1 \\
\hline
\end{tabular}

$\mathrm{Na}$ ocasião dos levantamentos das flechas na pista-teste, após 6 meses de abertura ao tráfego, foram tiradas fotos evidenciando os pontos que apresentavam as características superficiais da pista-teste. Esses registros estão apresentados nas figuras 77 a 86 , com as fotos correspondentes de segmentos que apresentaram os maiores afundamentos.

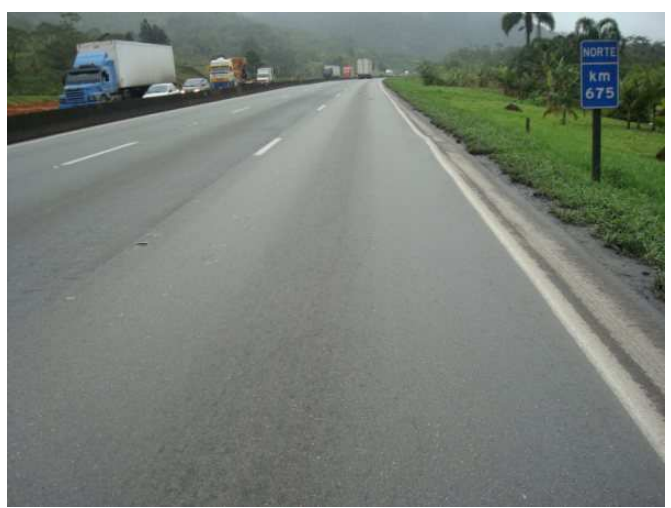

Figura 77 - Trecho T01

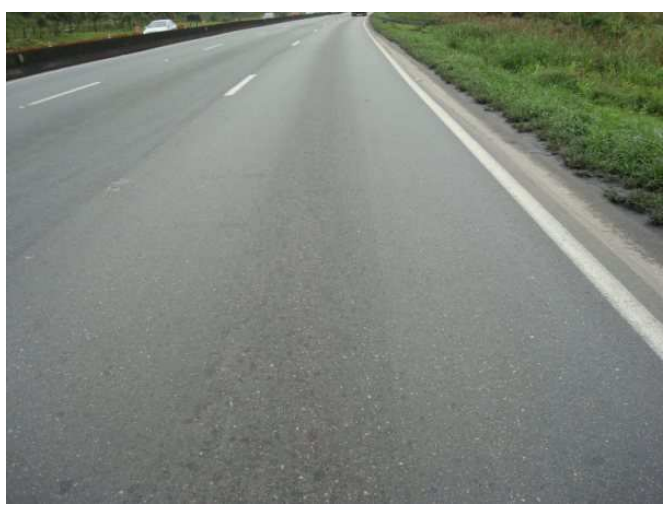

Figura 78 - Trecho T02 


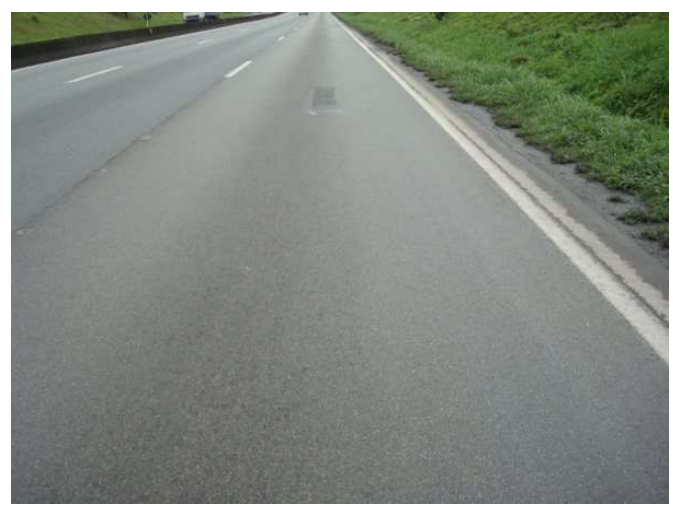

Figura 79 - Trecho T03

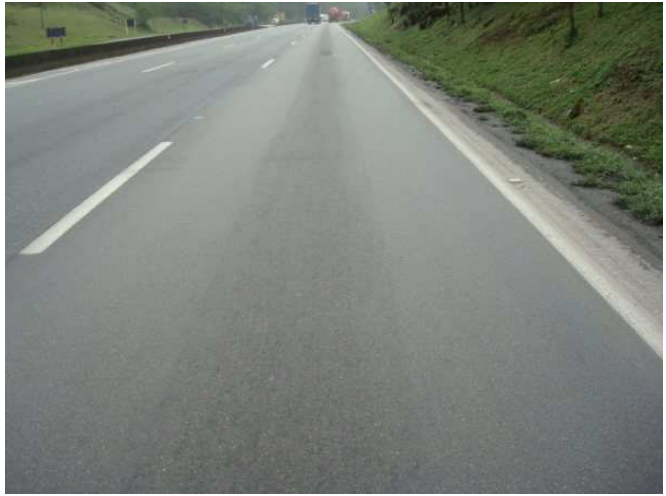

Figura 81 - Trecho T05

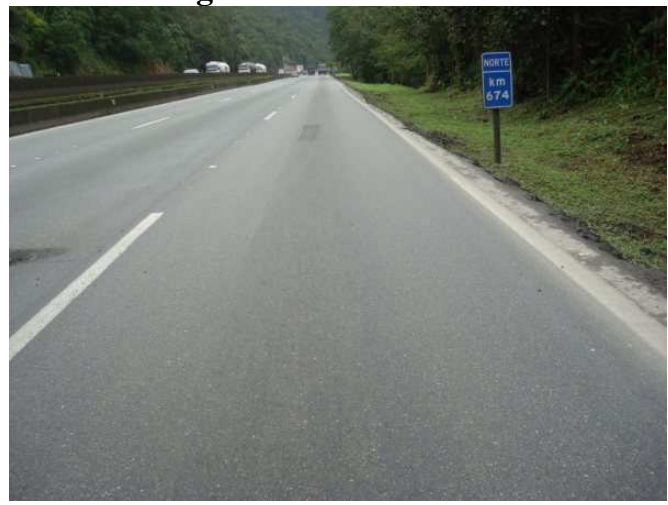

Figura 83 - Trecho T07

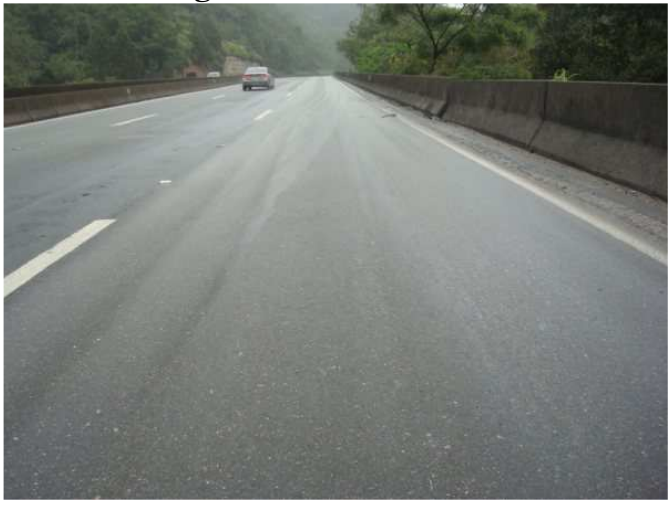

Figura 85 - Trecho T09

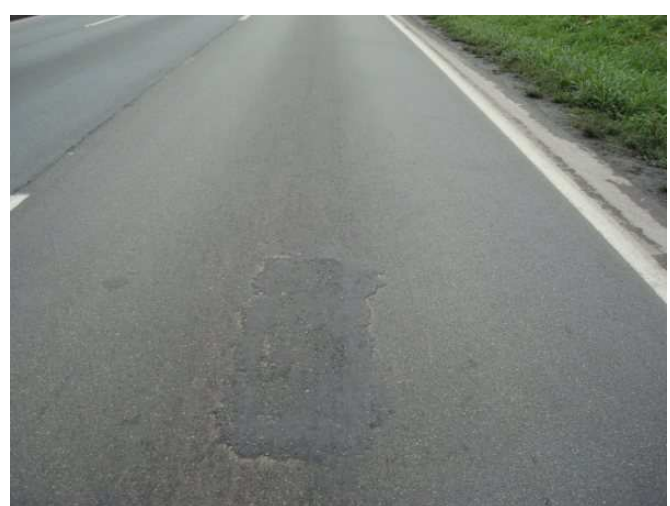

Figura 80 - Trecho T04

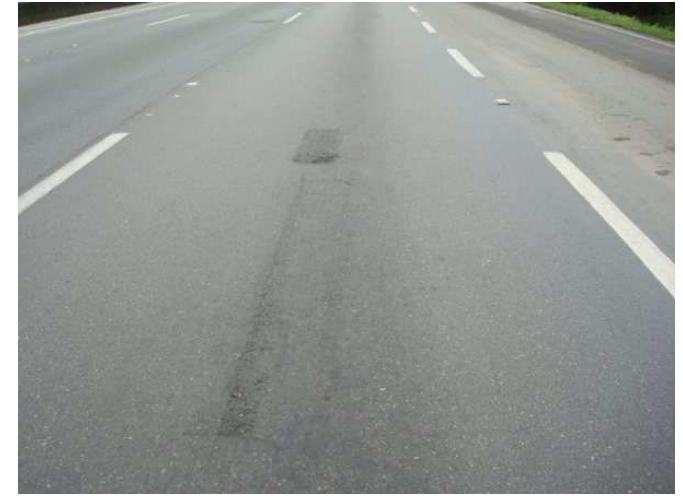

Figura 82 - Trecho T06

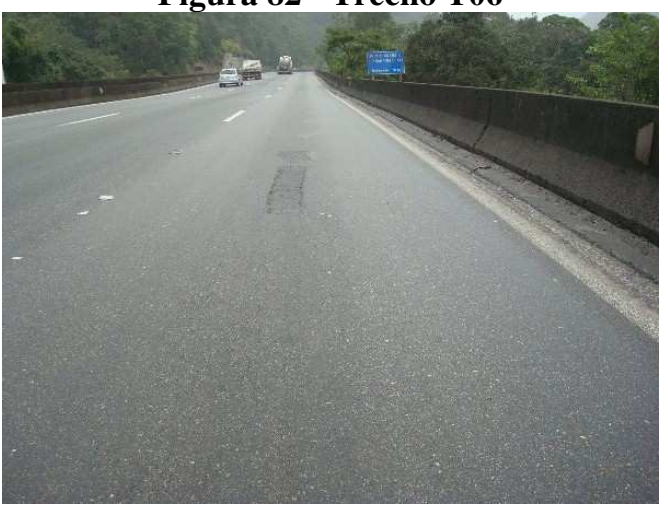

Figura 84 - Trecho T08

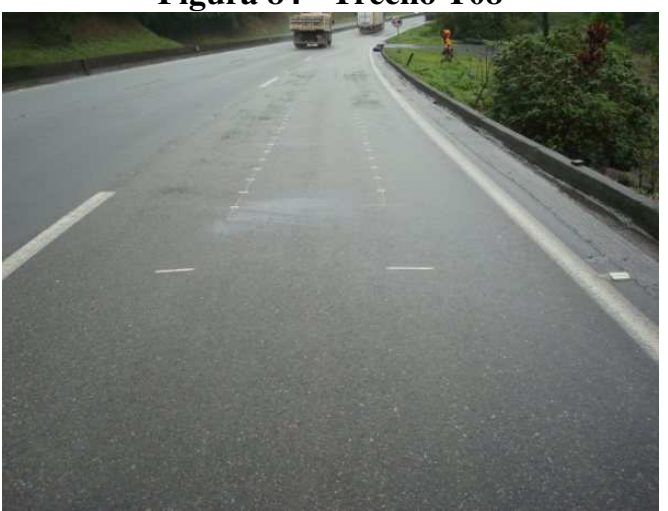

Figura 86 - Trecho T10

O $3^{\text {o }}$ levantamento foi realizado 13 meses após a abertura do tráfego, em fevereiro de 2010, com a pista-teste sujeita às temperaturas elevadas 
referentes aos meses de dezembro de 2009 e janeiro de 2010. Da mesma forma, no levantamento das flechas, foram tiradas fotos, apresentadas nas figuras 87 a 96, evidenciando o estado crítico em que se encontra a pista-teste quanto à formação de afundamentos por deformação permanente.

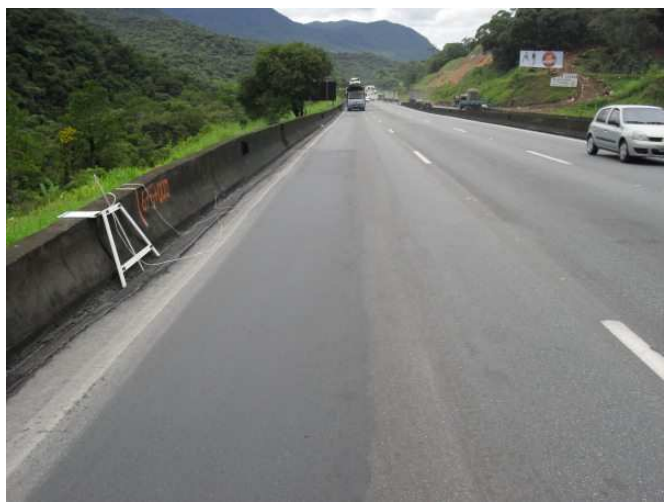

Figura 87 -Trecho T01

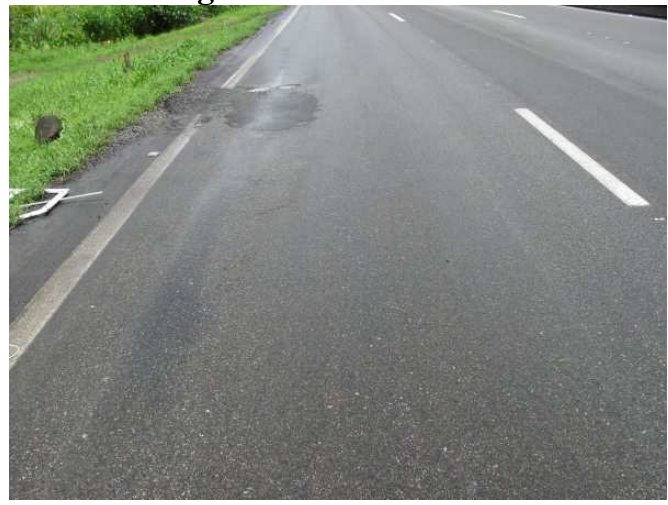

Figura 89 - Trecho T03

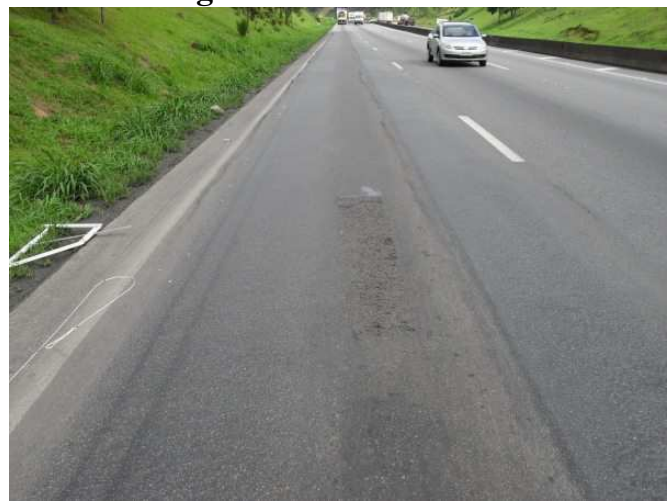

Figura 91 - Trecho T05

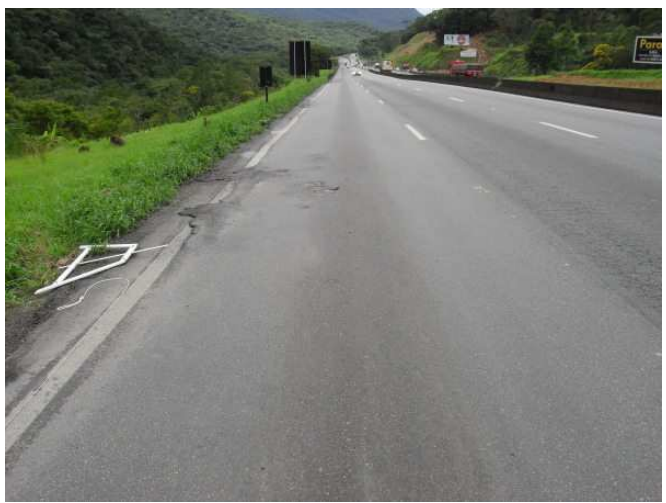

Figura 88 - Trecho T02

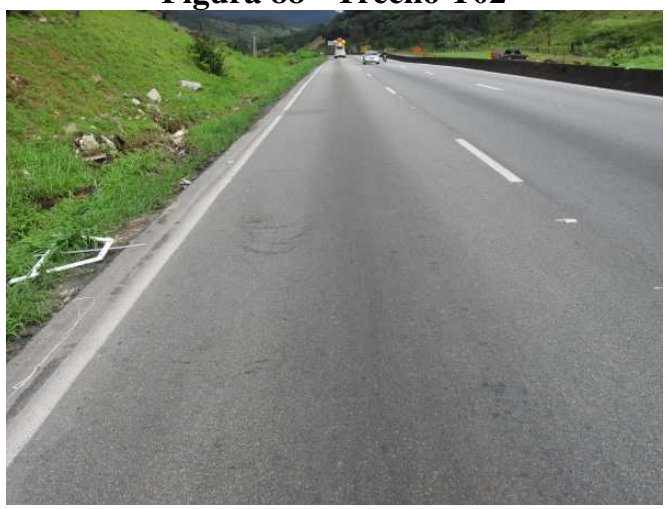

Figura 90 - Trecho T04

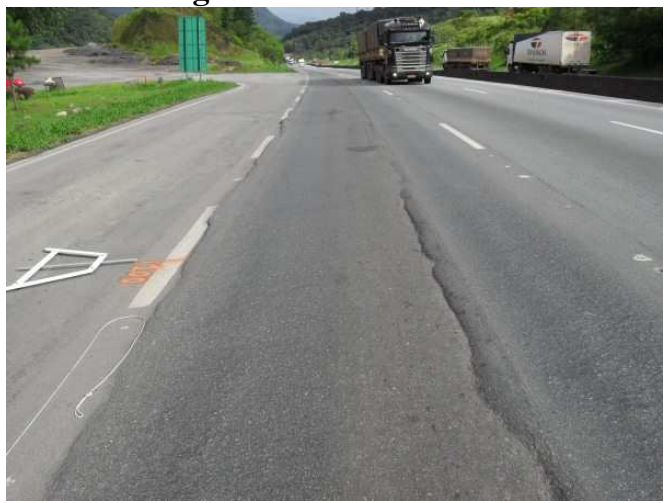

Figura 92 - Trecho T06 

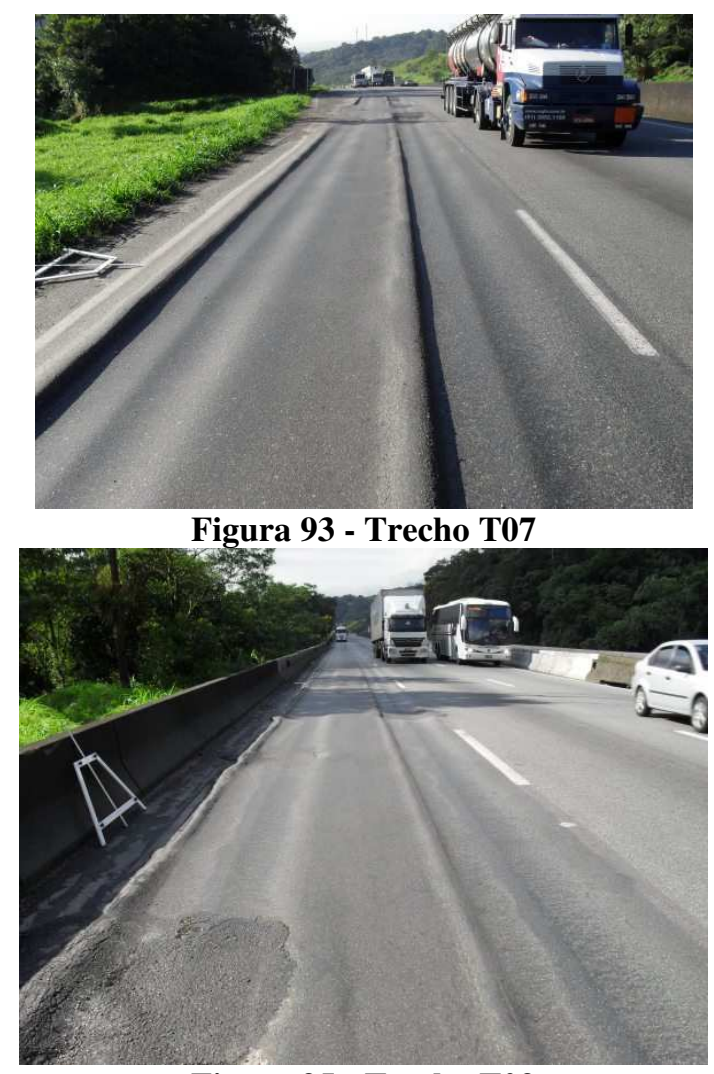

Figura 95 - Trecho T09

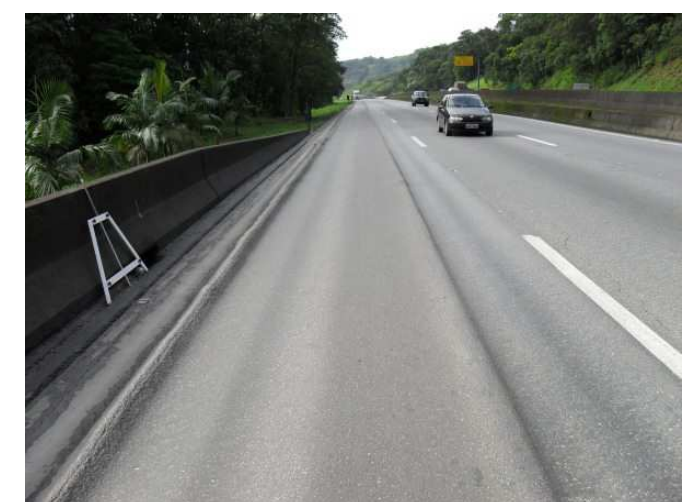

Figura 94 - Trecho T08

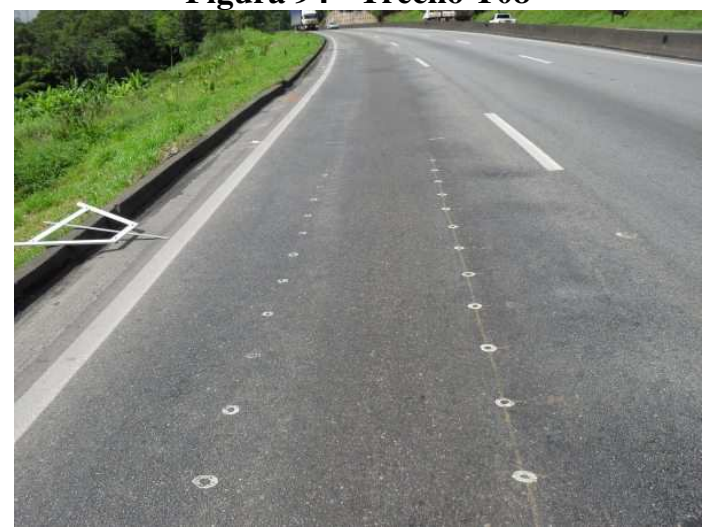

Figura 96 - Trecho T10

Pelas fotos tiradas no $3^{\circ}$ levantamento, pode-se observar que as condições de superfície da pista-teste são muito críticas. Como recomendação (capítulo 6 desse trabalho) sugere-se que as camadas que compõem a pista-teste sejam fresadas e recompostas com novas misturas asfálticas. A seleção das misturas e seu projeto são baseados nos resultados obtidos com essa pesquisa e também de acordo com as possibilidades operacionais da Concessionária Litoral Sul que administra a rodovia.

\subsubsection{IGG - Índice de Gravidade Global}

Juntamente com os registros dos afundamentos, 6 meses após a abertura ao tráfego, foram feitos levantamentos dos defeitos da superfície do pavimento, com o objetivo de determinar Índice de Gravidade Global - IGG, especificado pela norma DNIT 006/2003-PRO, figura 97. Salienta-se que a avaliação pelo IGG fica prejudicado devido a pequena extensão de cada trecho. 
Ocorreu um acréscimo do índice de gravidade global - IGG para todos os trechos. Os trechos T01 e T05 apresentaram comportamento semelhantes após 1 mês da abertura ao tráfego, com as condições de superfície dos dois trechos na classe bom (IGG entre 21 e 40). No segundo levantamento, as características da superfície passaram para a condição de regular. No trecho T07 passou da condição bom para a condição ruim.

Os trechos T02, T03, T04 e T10 mantiveram a condição de ótimo, pois os valores de IGG, embora tenham sofrido alterações, não ultrapassaram o valor de 20, limite que divide a condição de ótimo e bom.

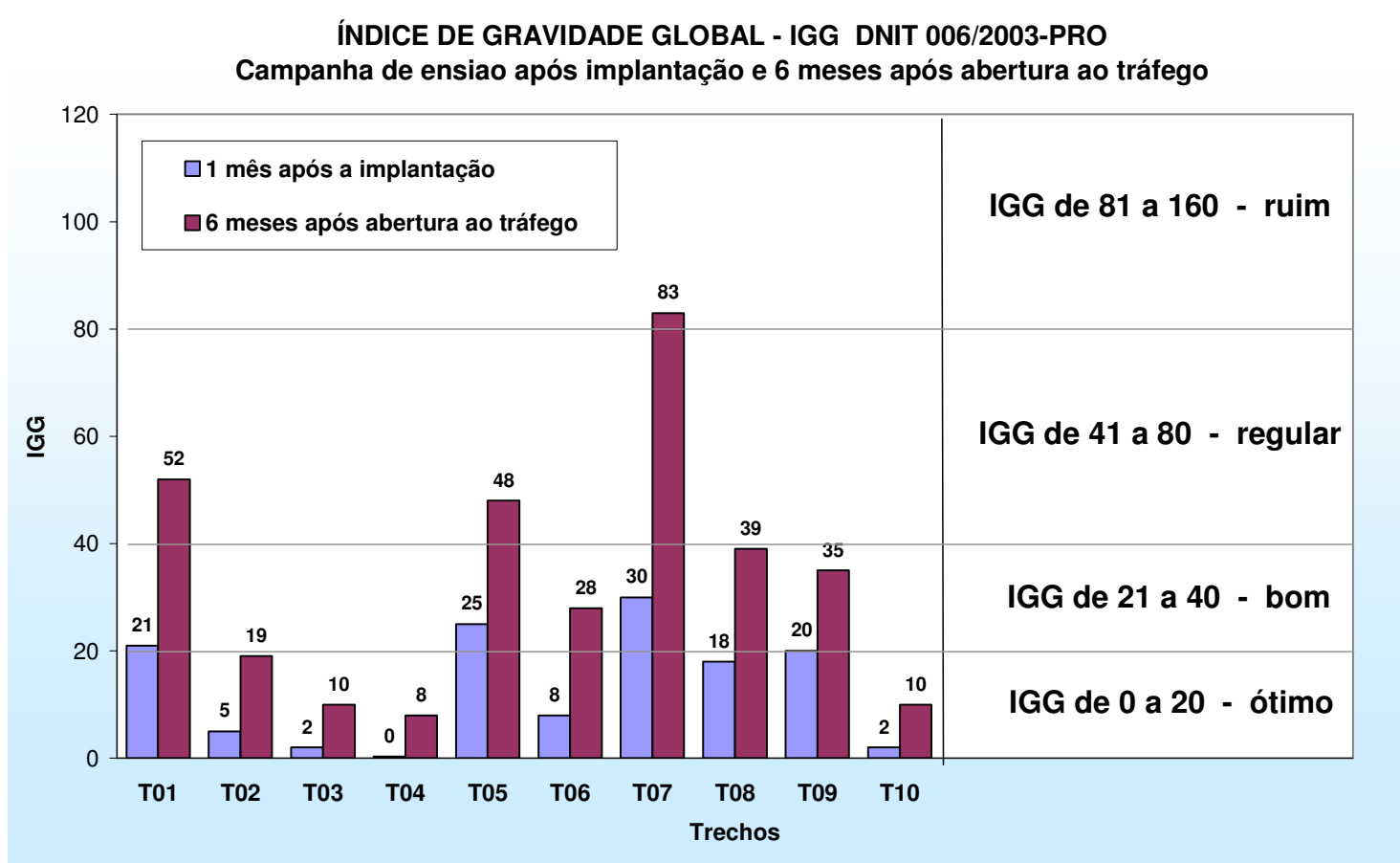

Figura 97 - IGG da pista-teste após 6 meses a abertura ao tráfego

Os demais trechos T06, T08 e T09 apresentaram a condição inicial de ótimo passando, após 6 meses, para a condição de bom.

No km 674+000, início do trecho T07, mistura com distribuição granulométrica gap-graded segundo especificação do Caltrans e usinado com ligante asfáltico modificado por borracha, ocorreu um problema isolado com extensão de aproximadamente $20 \mathrm{~m}$ de afundamento excessivo com $50 \mathrm{~mm}$ na trilha de 
roda interna - TRI e $19 \mathrm{~mm}$ na trilha de roda externa - TER. Esse fato levou a valores de IGG = 83, considerado ruim, no levantamento realizado após 6 meses de abertura ao tráfego. Após o levantamento feito do IGG o defeito foi corrigido, passando a ser considerado como remendo.

Foi observado ao longo dos trechos T05, T06, T08 e T09, após a implantação da pista-teste, um espelhamento nas misturas asfálticas aplicadas; observe-se que este indício já mostrava o efeito do excesso de ligante na execução dos trechos. No segundo levantamento, foi considerado o defeito de exsudação, associado aos afundamentos, resultando nos valores de IGG de 48, 28, 39 e 35 para os trechos T05, T06, T08 e T09, respectivamente.

Observando a evolução das flechas de todos os trechos, registrados na figura 76, nota-se que os valores das flechas no terceiro levantamento (13 meses após a abertura ao tráfego) tiveram um acréscimo expressivo. Considerando essa evolução das flechas no IGG, certamente, toda a pista-teste apresentaria a condição entre regular e ruim, podendo atingir a condição de péssimo, para valores de IGG > 160. Os afundamentos são tão expressivos que decidiu-se que a fresagem e recomposição é imperativa, não necessitando mais nenhum cálculo complementar.

\subsection{Extração de placas de pista}

Foram extraídas um total de 70 placas, sendo 7 de cada trecho. O local escolhido em cada trecho foi o centro da faixa, entre a trilha interna e externa. As extrações foram feitas com auxílio de serra circular e martelete; o processo da extração das placas está apresentado na série de figuras 98 a 109. 


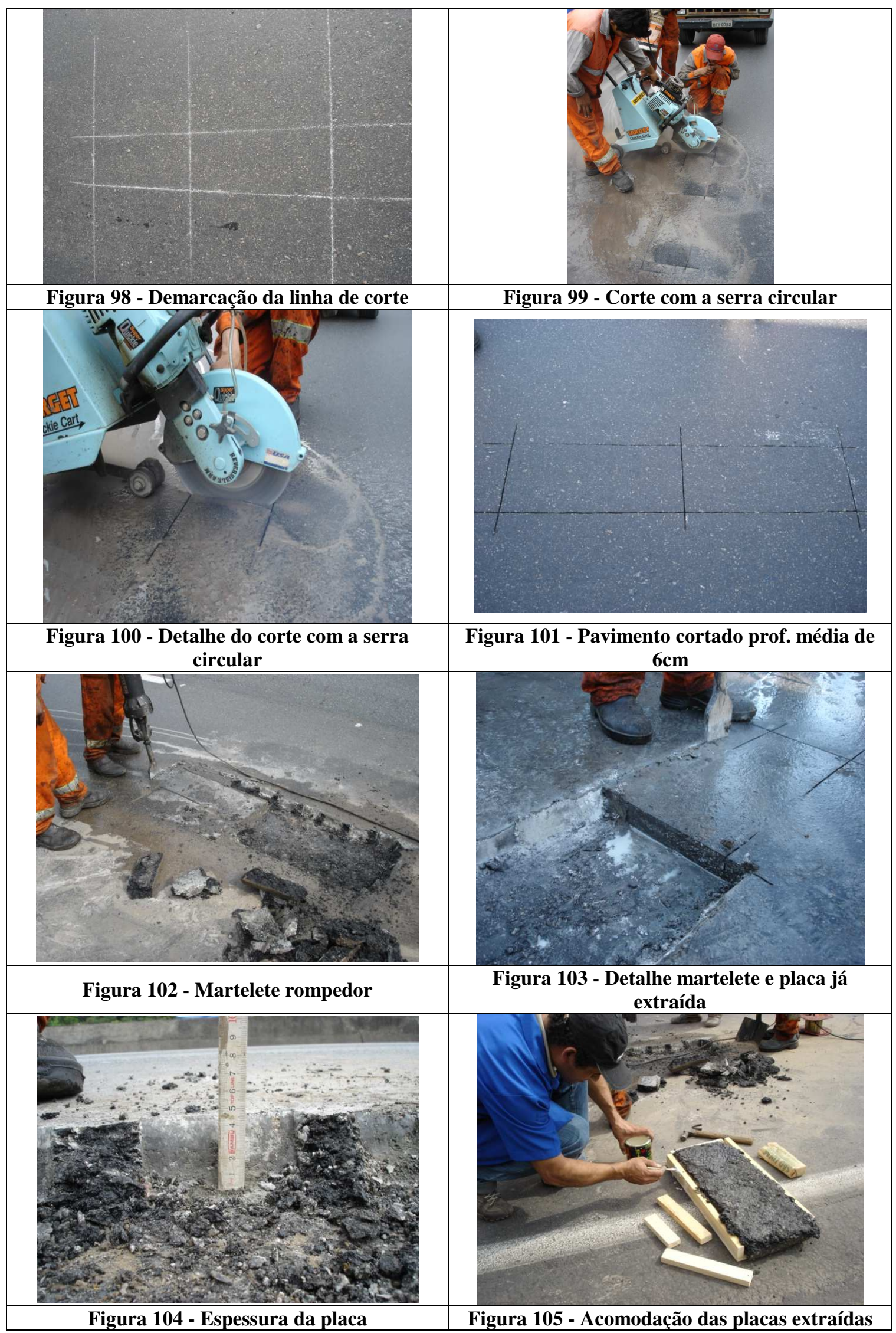




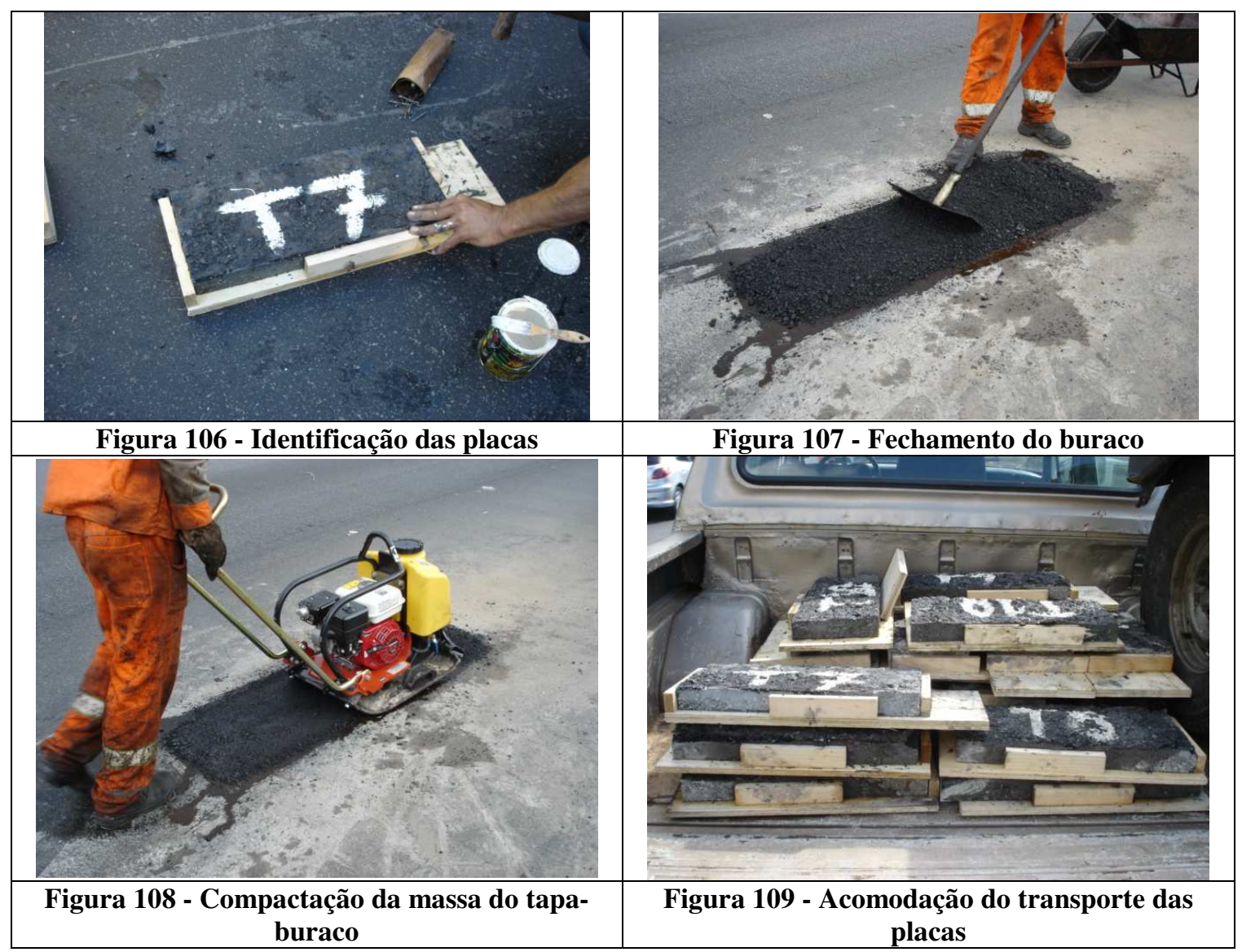

Um dado importante da pesquisa é a comparação entre a deformação permanente em trilha de roda de misturas asfálticas usinadas em laboratório e de misturas asfálticas extraídas de pista em forma de placas retangulares, 0 detalhamento dos procedimentos e os resultados estão apresentados no item 4.2.2.4.

Um outro ensaio realizado com as placas extraídas da pista-teste foi a verificação da evolução do volume de vazios com a deformação permanente em trilha de roda. No item 4.1 estão apresentados tanto os resultados como também os procedimentos adotados.

\subsubsection{Recuperação, caracterização dos ligantes e granulometria}

Com as placas extraídas da pista-teste foram feitos os seguintes ensaios:

- extração de ligante asfáltico pelo método soxlet (refluxo); 
- recuperação do ligante asfáltico pelo método de Abson;

- caracterização da penetração, do ponto de amolecimento e da recuperação elástica com os ligantes recuperados;

- viscosidade Brookfield para as temperaturas $135^{\circ} \mathrm{C}, 150^{\circ} \mathrm{C}$ e $177^{\circ} \mathrm{C}$;

- granulometria dos agregados.

Os resultados de ponto de amolecimento, penetração, viscosidade, teor de ligante, e de recuperação elástica estão apresentados na tabela 43.

Tabela 43 - Recuperação e caracterização dos ligantes asfálticos da pista-teste

\begin{tabular}{|c|c|c|c|c|c|c|c|c|c|}
\hline \multirow{2}{*}{\multicolumn{3}{|c|}{ Identificação }} & \multirow{3}{*}{$\begin{array}{l}\text { PA - Ponto de } \\
\text { amolecimento } \\
\left({ }^{\circ} \mathrm{C}\right)\end{array}$} & \multirow{3}{*}{$\frac{\text { Pentração }}{(1 / 10 \mathrm{~mm})}$} & \multicolumn{3}{|c|}{ Visc. Brokfield } & \multirow{3}{*}{$\begin{array}{c}\text { Teor de } \\
\text { ligante }\end{array}$} & \multirow{3}{*}{$\begin{array}{c}\begin{array}{c}\text { Recuperação } \\
\text { Elástica }\end{array} \\
(\%)\end{array}$} \\
\hline & & & & & $135^{\circ} \mathrm{c}$ & $150^{\circ} \mathrm{C}$ & $177^{\circ} \mathrm{C}$ & & \\
\hline Trecho & Mistura & Ligante asfáltico & & & $(\mathrm{cP})$ & $(\mathrm{cP})$ & $(\mathrm{cP})$ & & \\
\hline $\mathrm{T}-01$ & Mix Ivb I.A. & CAP-50/70 & 54,5 & 32,0 & 512 & 249 & 87 & 5,51 & 12,0 \\
\hline T-02 & SPV 12,5 & CAP-50/70 & 55,5 & 29,7 & 552 & 262 & 89 & 4,73 & 10,5 \\
\hline $\mathrm{T}-03$ & SPV 12,5 & $4 \%$ de SBS & 69,0 & 22,3 & 2214 & 933 & 284 & 4,21 & 80,0 \\
\hline $\mathrm{T}-04$ & SPV 9,5 & $4 \%$ de SBS & 66,0 & 34,3 & 1402 & 641 & 210 & 5,37 & 80,0 \\
\hline T-05 & SPV 9,5 & 1,2\% RET. & 56,0 & 34,0 & 635 & 303 & 104 & 6,61 & 30,0 \\
\hline T-06 & SPV 12,5 & 1,2\% RET. & 58,0 & 25,8 & 705 & 329 & 110 & 6,18 & 29,0 \\
\hline $\mathrm{T}-07$ & Gap-Graded & AMB & 54,0 & 49,2 & * & * & * & 7,28 & 45,5 \\
\hline $\mathrm{T}-08$ & SPV 12,5 & CAP-30/45 & 55,5 & 30,8 & 605 & 288 & 99 & 5,82 & 10,0 \\
\hline T-09 & SPV 9,5 & CAP-30/45 & 55,8 & 33,7 & 673 & 320 & 109 & 6,13 & 38,5 \\
\hline $\mathrm{T}-10$ & Gap-Graded & CAP-30/45 & 56,0 & 33,7 & 633 & 301 & 103 & 5,38 & 41,5 \\
\hline
\end{tabular}

(*) $O$ ensaio de viscosidade Brokfield não foi realizado para o ligante asfáltico modificado por borracha.

A determinação da viscosidade Brokfield do ligante modificado por borracha não foi possível de ser realizada porque a norma ABNT NBR 15529-2007 especifica que a quantidade de ligante asfáltico deve ser suficiente para o ensaio ser realizado dentro de um béquer de $800 \mathrm{ml}$ de capacidade (cerca de $600 \mathrm{ml}$ de amostra). Como o processo de obtenção da amostra de ligante asfáltico, é através da extração por refluxo (sox-let) e da recuperação do ligante é pelo método de Abson, a quantidade que se obtém é relativamente pequena para a determinação do ensaio de viscosidade.

$\mathrm{Na}$ execução da pista-teste ocorreram variações na usinagem das misturas asfálticas quanto ao teor de ligante asfáltico de cada trecho. Na tabela 44, apresentam-se os teores de ligante asfáltico encontrados em cada trecho, os teores de projeto e a diferença entre eles. 
Tabela 44 - Diferença entre teores de ligante asfáltico de pista e de projeto

\begin{tabular}{c|c|c|c|c|c}
\hline \multirow{2}{*}{ Trecho } & \multirow{2}{*}{ Tipo de mistu ra } & \multirow{2}{*}{$\begin{array}{c}\text { Tipo de } \\
\text { ligante }\end{array}$} & \multicolumn{2}{|c|}{ Teor de Ligante (\%) } & \multirow{2}{*}{$\begin{array}{c}\text { Diferença } \\
\text { (\%) }\end{array}$} \\
\cline { 4 - 5 } & Projeto & Pista & (\%) \\
\hline 1 & Mix Ivb I.A. & CAP 50/70 & 5,20 & 5,51 & 0,31 \\
3 & SPV 12,5 mm & CAP 50/70 & 5,46 & 4,73 & $-0,73$ \\
4 & SPV 12,5 mm & $4 \%$ SBS & 6,20 & 4,21 & $-1,99$ \\
5 & SPV 9,5 mm & $4 \%$ SBS & 6,70 & 5,37 & $-1,33$ \\
6 & SPV 9,5 mm & $1,2 \%$ RET & 7,00 & 6,61 & $-0,39$ \\
7 & SPV 12,5 mm & 1,2\% RET & 5,50 & 6,18 & 0,68 \\
8 & Gap graded & AMB & 8,20 & 7,28 & $-0,92$ \\
9 & SPV 12,5 mm & CAP 30/45 & 5,40 & 5,82 & 0,42 \\
10 & SPV 9,5 mm & CAP 30/45 & 5,72 & 6,13 & 0,41 \\
\hline
\end{tabular}

No trecho T01 a variação entre os teores de pista e projeto ficou dentro do limite de variação aceitável de usina que é de $\pm 0,3 \%$. Nos trechos T02 e T03 os teores de pista ficam abaixo em $0,73 \%$ e $1,99 \%$ respectivamente. Entretanto, salienta-se que o teor de projeto para o trecho T03 é considerado alto, pela prática, para o tipo de mistura asfáltica em questão.

Os trechos T04 e T05 também apresentaram teores abaixo dos de projeto, $1,33 \%$ e $0,39 \%$ respectivamente, sendo no caso do T05, 0,39\% uma variação muito próxima da variação aceitável de projeto.

Para o trecho T06 a variação foi para cima, $0,68 \%$, resultando em um teor de $6,18 \%$, teor também considerado elevado para o tipo de mistura asfáltica. 0 trecho usinado com a faixa semidescontínua gap-graded do Caltrans, T07, apresentou uma variação de $0,92 \%$ abaixo do teor recomendado de projeto que foi de $8,2 \%$.

Os trechos T08 e T09, ambos usinados com ligante convencional, CAP 30/45 e com distribuição granulométrica distintas, SPV $12,5 \mathrm{~mm}$ e $9,5 \mathrm{~mm}$ respectivamente, apresentaram a mesma variação para baixo de $0,42 \%$ e 0,41\%. Para os teores de projeto próximos: o trecho T08 com 5,40\% e o trecho T09 com 5,72\%. 
Por último o trecho T10, com mesma distribuição granulométrica do trecho T07 e com ligante asfáltico convencional CAP 30/45, apresentou uma variação próxima de $1 \%$ para o teor de projeto de $6,41 \%$.

$\mathrm{Na}$ tabela 43 pode-se constatar que os ligantes asfálticos CAP 30/45 utilizado nos trechos T08 e T10 sofreram alterações no processo de estocagem do material. $O$ ensaio de retorno elástico mostrou que o ligante asfáltico empregado nos trechos T09 e T10 foram, 38,5\% e 41,5\% respectivamente. Valores não esperados para esse tipo de ligante asfáltico. Pode-se supor que, o tanque que recebeu o ligante asfáltico CAP 30/45 estivesse ainda com quantidade apreciável de ligante asfáltico modificado por polímero.

Em geral, pôde-se observar que ocorreram variações nos teores de ligantes asfálticos em praticamente todos os trechos, ora para cima, ora para baixo. Pela experiência laboratorial do autor da presente pesquisa em misturas asfálticas dos tipos empregadas nos trechos: T03, T04, T05, T07 e T10, os teores de projeto podem ser considerados acima de teores praticados, o que pode resultar um comportamento inadequado ao desempenho de deformação permanente em trilha de roda.

As granulometrias de cada trecho, obtidas com os agregados advindos do ensaio de extração de ligante asfáltico pelo método sox-let, também apresentaram variações em relação às granulometrias de projeto. A massa de mistura asfáltica submetida ao ensaio de extração de ligante asfáltico foi de aproximadamente $1300 \mathrm{~g}$, resultando em uma massa de agregado para determinação da granulometria aproximadamente $1250 \mathrm{~g}$.

Apresentam-se nas figuras 110 a 129 as distribuições granulométricas encontradas para cada camada de rolamento dos trechos da pista-teste, as distribuição granulométrica de projeto, bem como a adequação delas às suas respectivas faixas e também apresentam-se nesse conjunto de figuras as distribuições granulométricas associadas à linha de densificação máxima. 
Recorda-se, conforme descrito no item 2.3, que a proximidade da distribuição granulométrica à linha de densificação máxima com potência de 0,45 , proposta por Goode e Lufsey (1962), propicia um VAM suficientemente satisfatório à mistura, de maneira que, com a adição do ligante asfáltico, em quantidade adequada para atingir $4 \%$ de volume de vazios em corpos-de-prova tipo Marshall, resulta em uma mistura asfáltica com características estáveis quanto à deformação permanente em trilha de roda. $O$ afastamento para baixo da linha de densificação máxima produz misturas asfálticas com texturas mais rugosas e com afastamento oposto texturas mais finas. E ainda, o paralelismo à linha de densificação máxima, corresponde à distribuições granulométricas contínuas bem distribuídas, ao passo que, quando as distribuições granulométricas contínuas mostram-se com pequenas deficiências em suas distribuições, verifica-se um curvatura dessas, quando são locada em uma escala, em que as peneiras correspondem a potência de 0,45.

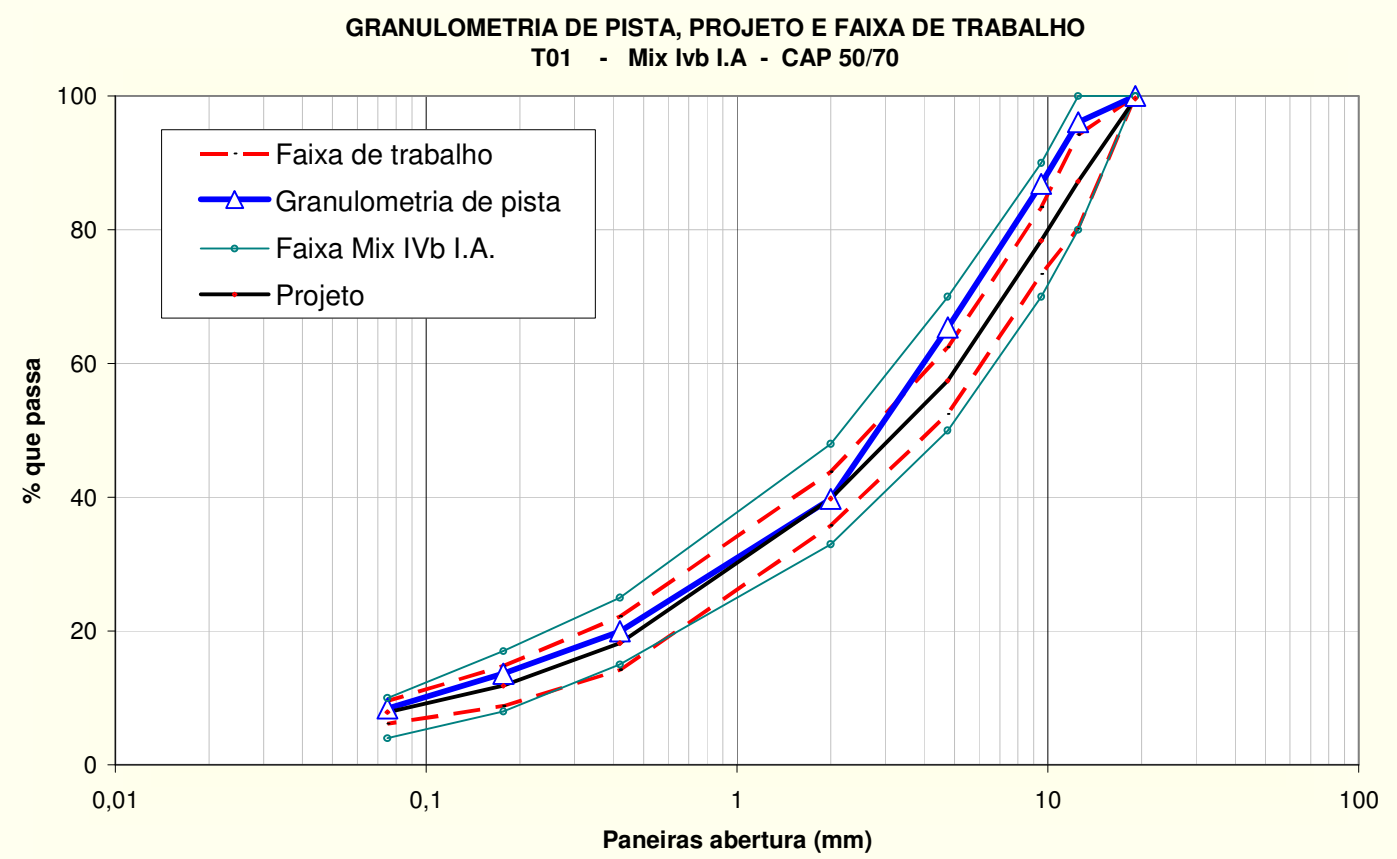

Figura 110 - Granulometria do trecho T01 em pista comparada à de projeto

A distribuição granulométrica da mistura asfáltica referente ao trecho T01, figura 110, apresentou-se ligeiramente mais fina a partir da peneira n. 10 (abertura 2,0 mm), situando-se fora da faixa de trabalho a partir da peneira $\mathrm{n} .4$ (abertura 4,76 mm). A distribuição granulométrica manteve-se dentro da faixa da especificação. 


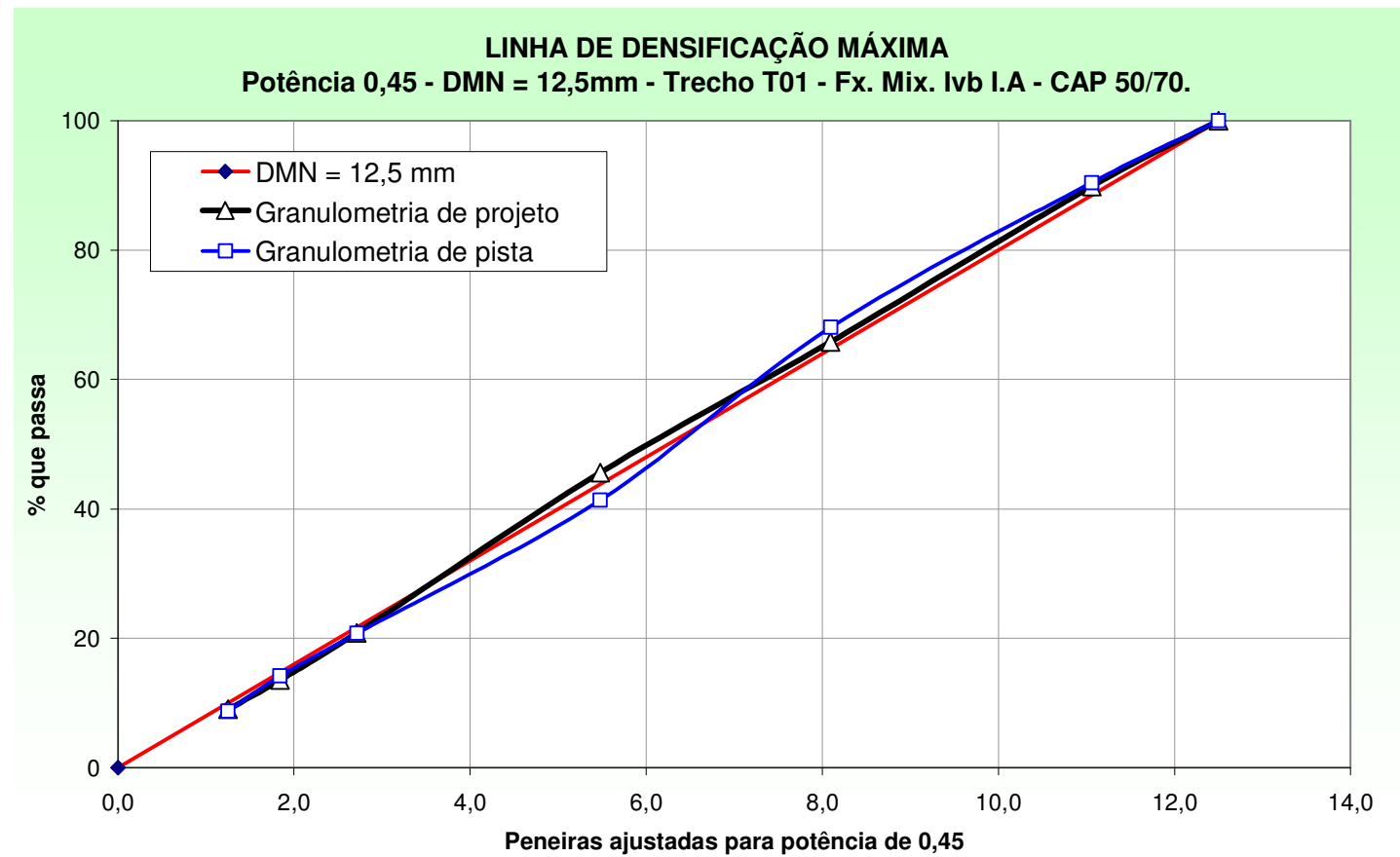

Figura 111 - Linha de densificação máxima - distr. granul. de projeto e de pista- trecho T01

Quanto à proximidade da linha de densificação máxima das duas distribuições granulométricas, figura 111 , praticamente a correspondente a de projeto situase sobre a linha de densificação máxima, já a distribuição granulométrica de pista para diâmetro superior a 4,76 mm situa-se acima e para diâmetros inferiores permanece abaixo, da linha de densificação máxima. Embora, a distribuição granulométrica de pista cruze a linha de densificação máxima, mantém-se muito próxima a ela.

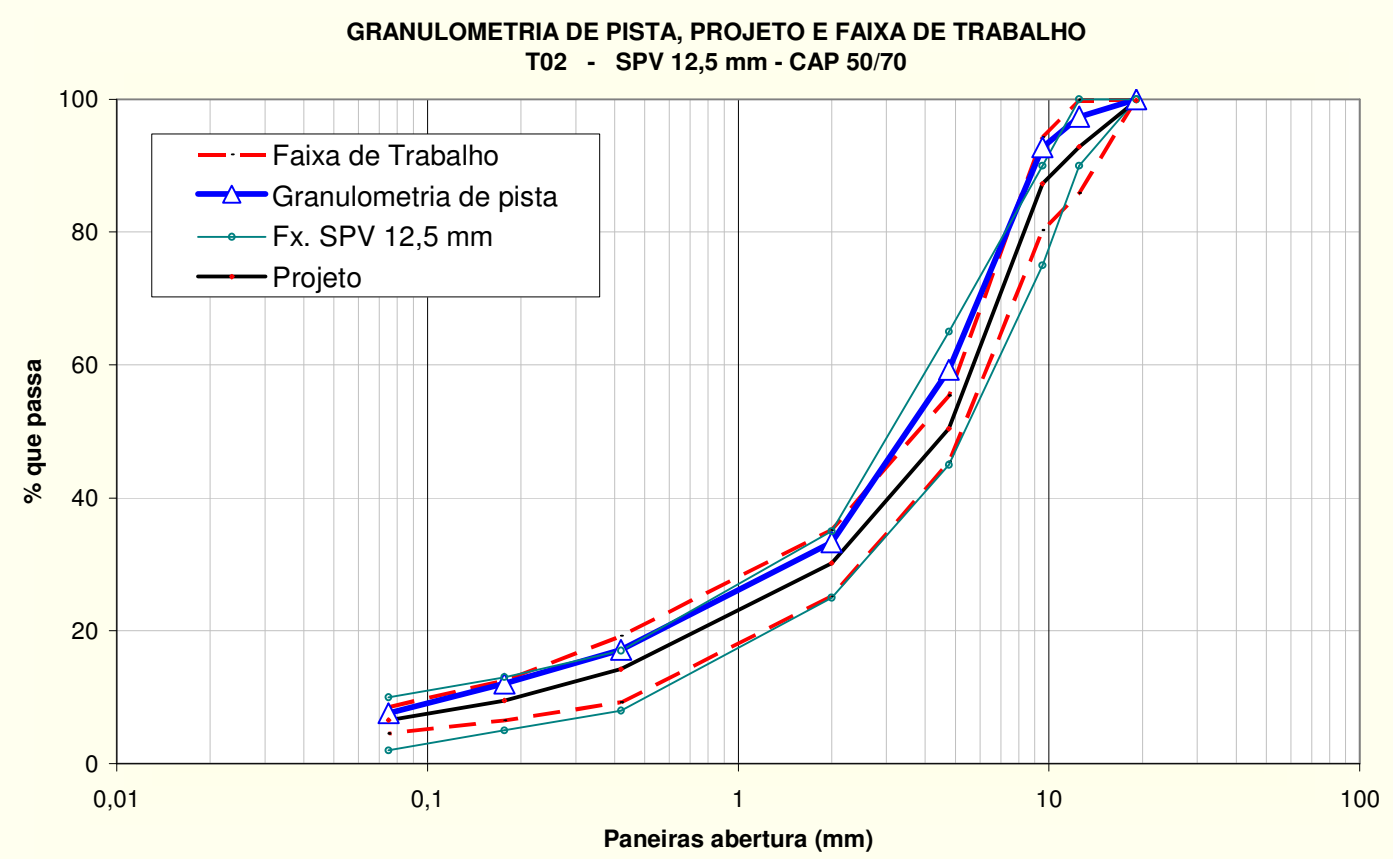


Figura 112 - Granulometria do trecho $\mathrm{T} 02 \mathrm{em}$ pista comparada à de projeto

Na figura 112 observe-se que a distribuição granulométrica da mistura asfáltica aplicada em pista no trecho T02 apresentou-se mais fina, em toda sua composição, do que a recomendada em projeto, tangenciando o limite superior da faixa de trabalho.

Esse afinamento também é verificado na figura 113 na distribuição granulométrica de pista. Observe-se que a distribuição granulométrica de projeto esta afastada da linha de densificação máxima para o ramo grosso e com o afinamento da distribuição granulométrica encontrado em pista, ficou ligeiramente mais próxima da linha de densificação máxima.

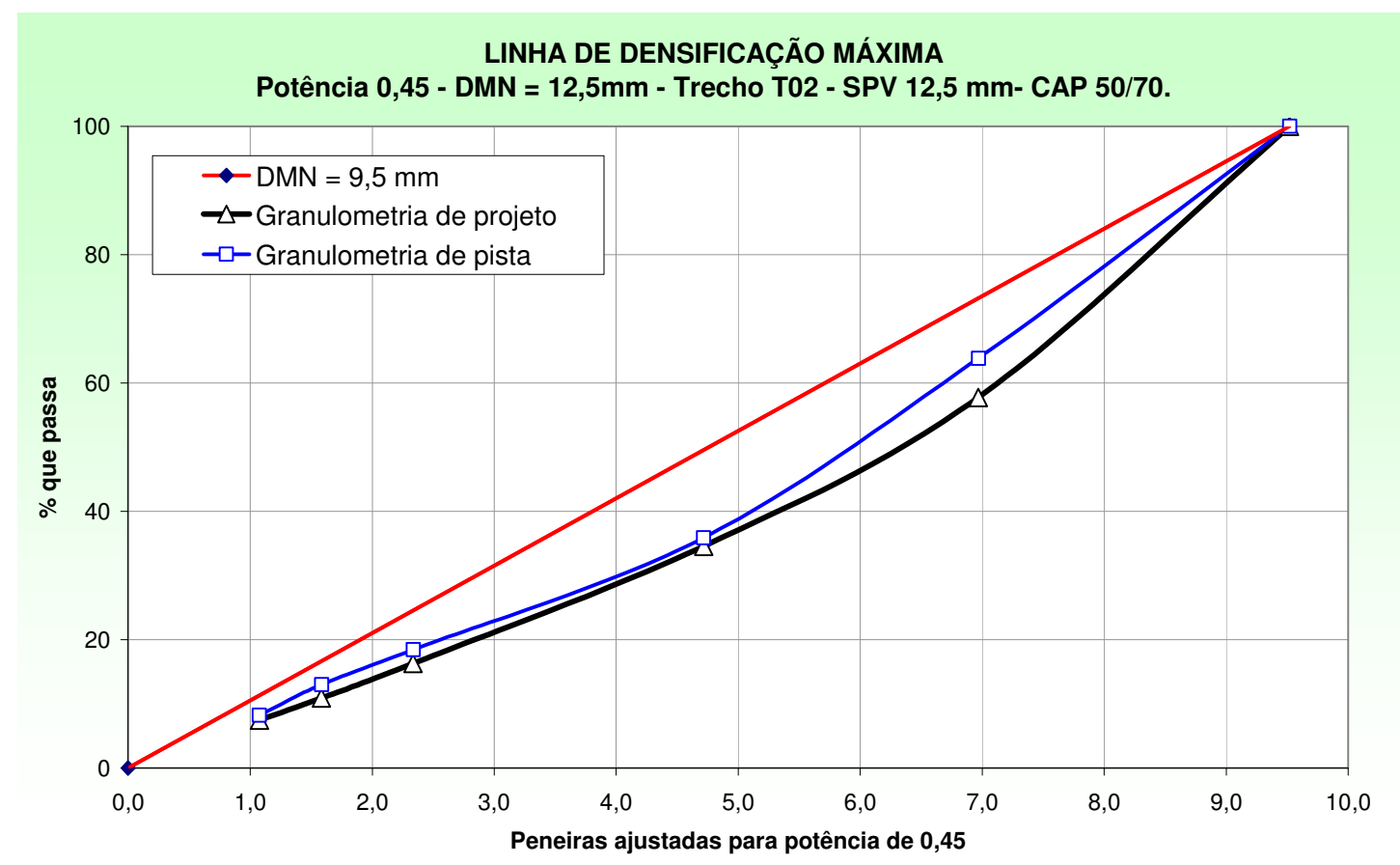

Figura 113 - Linha de densificação máxima - distr. granul. de projeto e de pista- trecho T02 


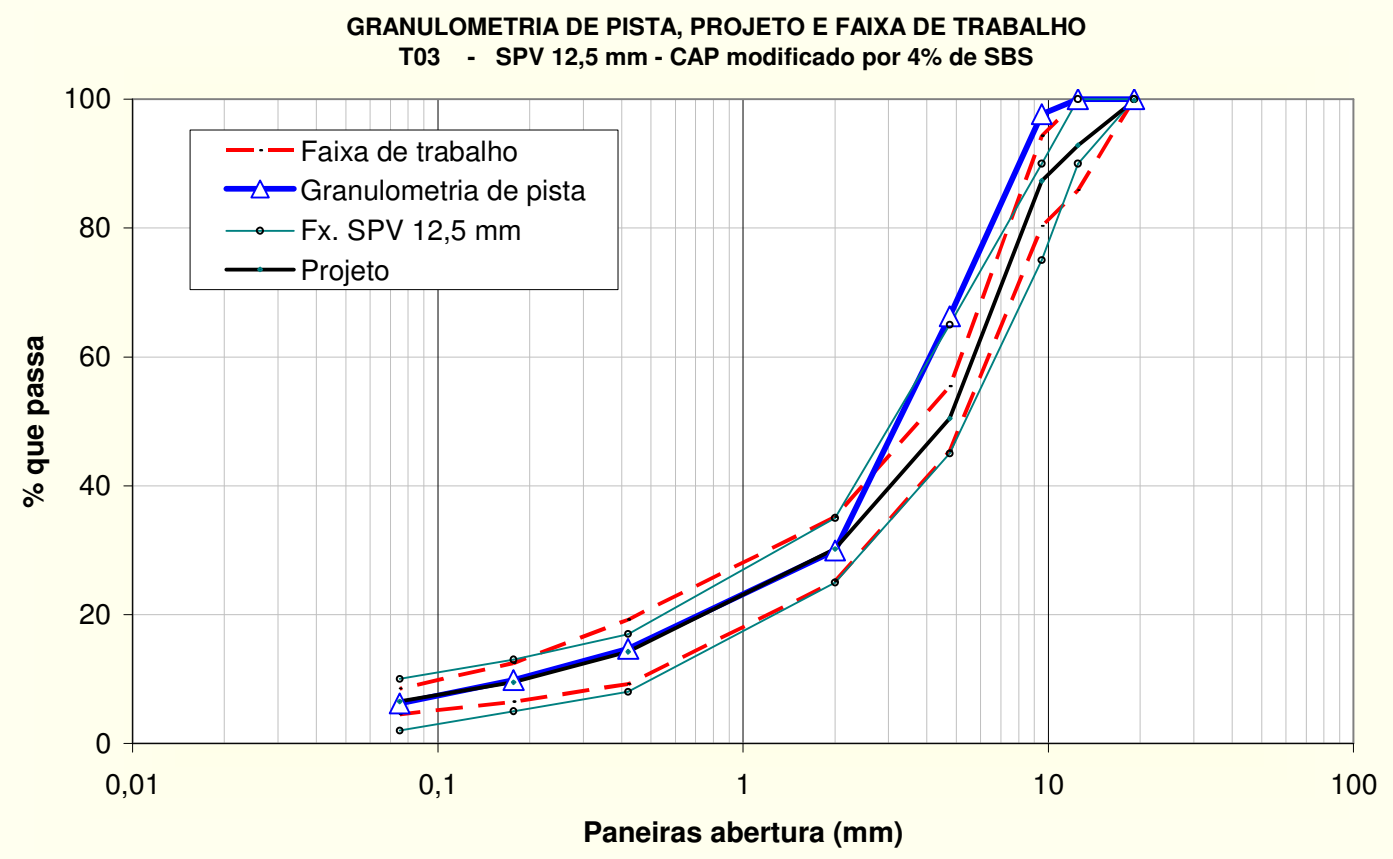

Figura 114 - Granulometria do trecho $\mathrm{T03} \mathrm{em}$ pista comparada à de projeto

No caso da distribuição granulométrica referente ao trecho T03 praticamente foi a mesma de projeto para as peneiras inferiores a n. 10 (abertura 2,0 mm) inclusive, figura 114. Para as peneiras de diâmetro maiores a distribuição granulométrica ficou mais fina, tangenciando o limite superior da faixa de especificação, apresentando um valor de aproximadamente $98 \%$ de material passante na peneira $3 / 8$ " (9,52 $\mathrm{mm}$ de abertura).

Esse afinamento da distribuição granulométrica de pista ocasiona uma alteração nos valor de DMN, conforme apresentado no item 2.4, resulta em uma mistura asfáltica com textura superficial menos rugosa. Outro fato a ser considerado é a propensão de ocorrerem falhas na estrutura do "esqueleto" pétreo da mistura asfáltica

Quanto a diâmetro máximo nominal, praticamente, temos a distribuição granulométrica de projeto com $\mathrm{DMN}=9,52 \mathrm{~mm}$ e a distribuição granulométrica de pista com $\mathrm{DMN}=4,76 \mathrm{~mm}$, ambas mostram-se afastadas da linha de densificação máxima. A distribuição granulométrica de pista mostrou-se bem mais fina que a de projeto, a ponto de se considerar um DMN menor, figura 115. 


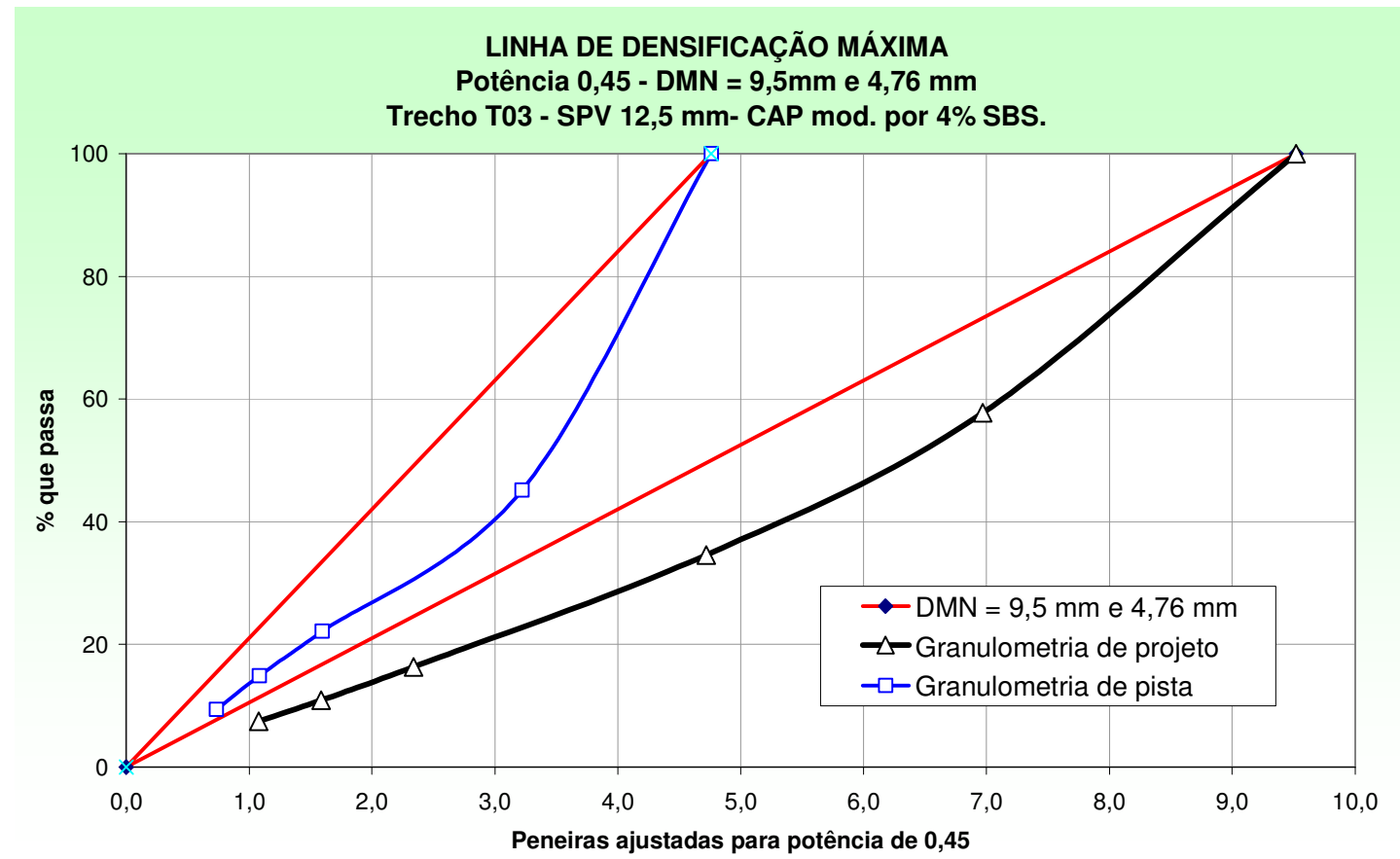

Figura 115 - Linha de densificação máxima - distr. granul. de projeto e de pista- trecho T03

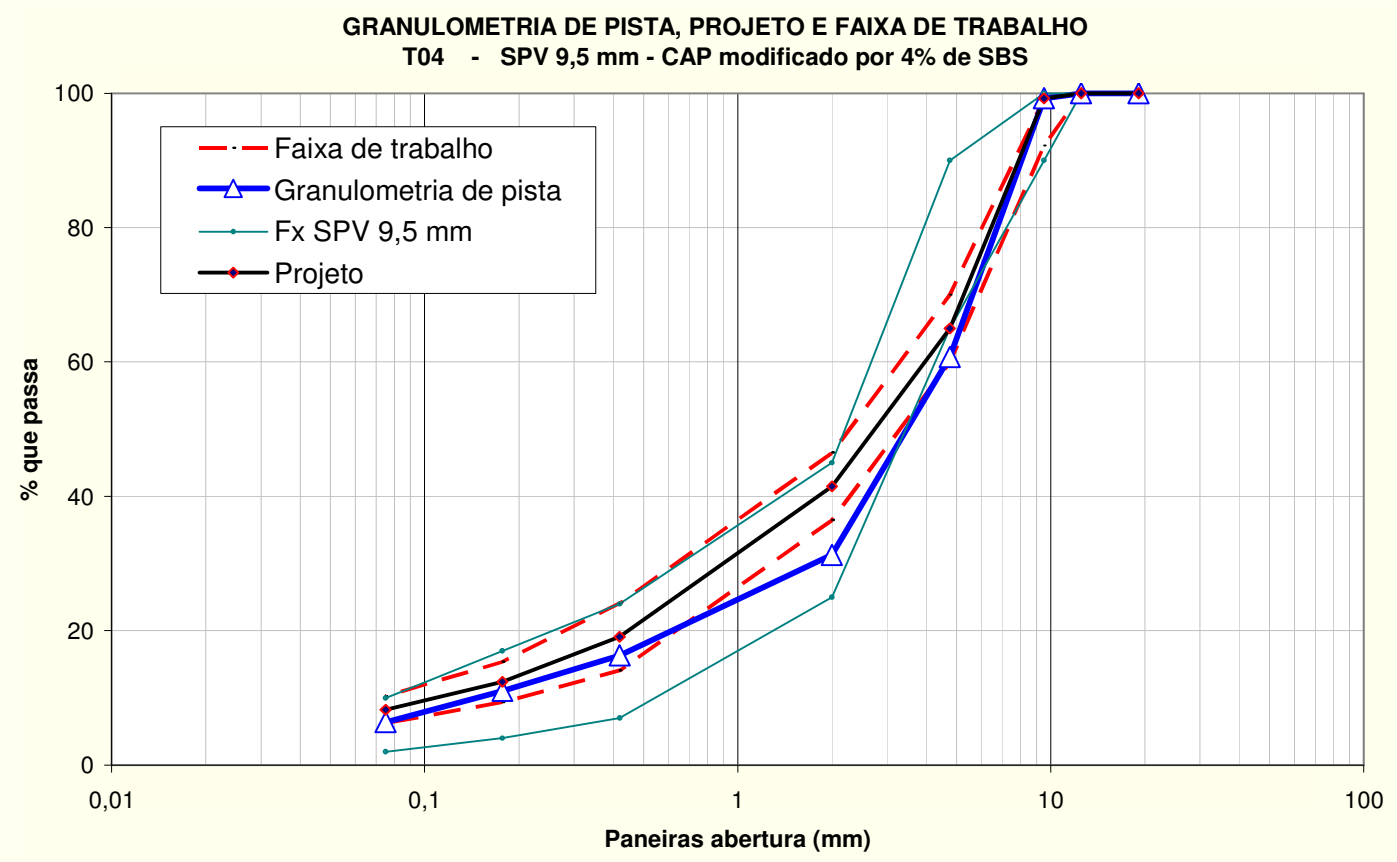

Figura 116 - Granulometria do trecho T04 em pista comparada à de projeto

No trecho T04 a distribuição granulométrica na peneira n. $10(2,0 \mathrm{~mm}$ de abertura) ficou mais grossa, com cerca de $31 \%$ de material passante nessa peneira, figura 116. Os limites da faixa de trabalho são de $36 \%$ a $46 \%$. 0 
restante da distribuição granulométrica atendeu a especificação da faixa de trabalho.

Essa parte mais grossa correspondente a peneira n. 10, pode ser observada na distribuição granulométrica de pista na figura 117. A distribuição granulométrica de projeto é paralela a linha de densificação máxima e a distribuição granulométrica de pista na mesma peneira mostrou-se mais grossa com uma descontinuidade.

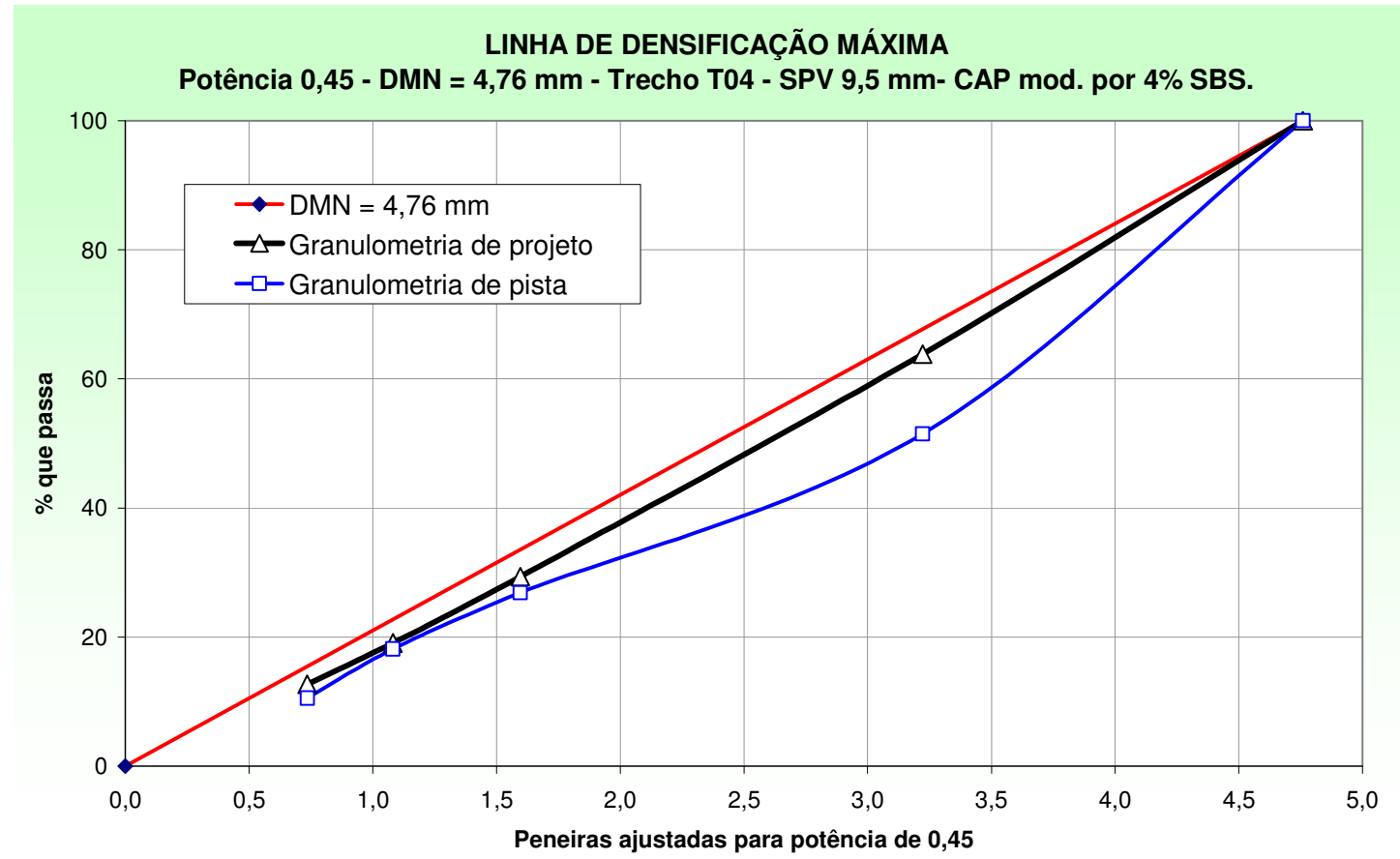

Figura 117 - Linha de densificação máxima - distr. granul. de projeto e de pista- trecho T04 


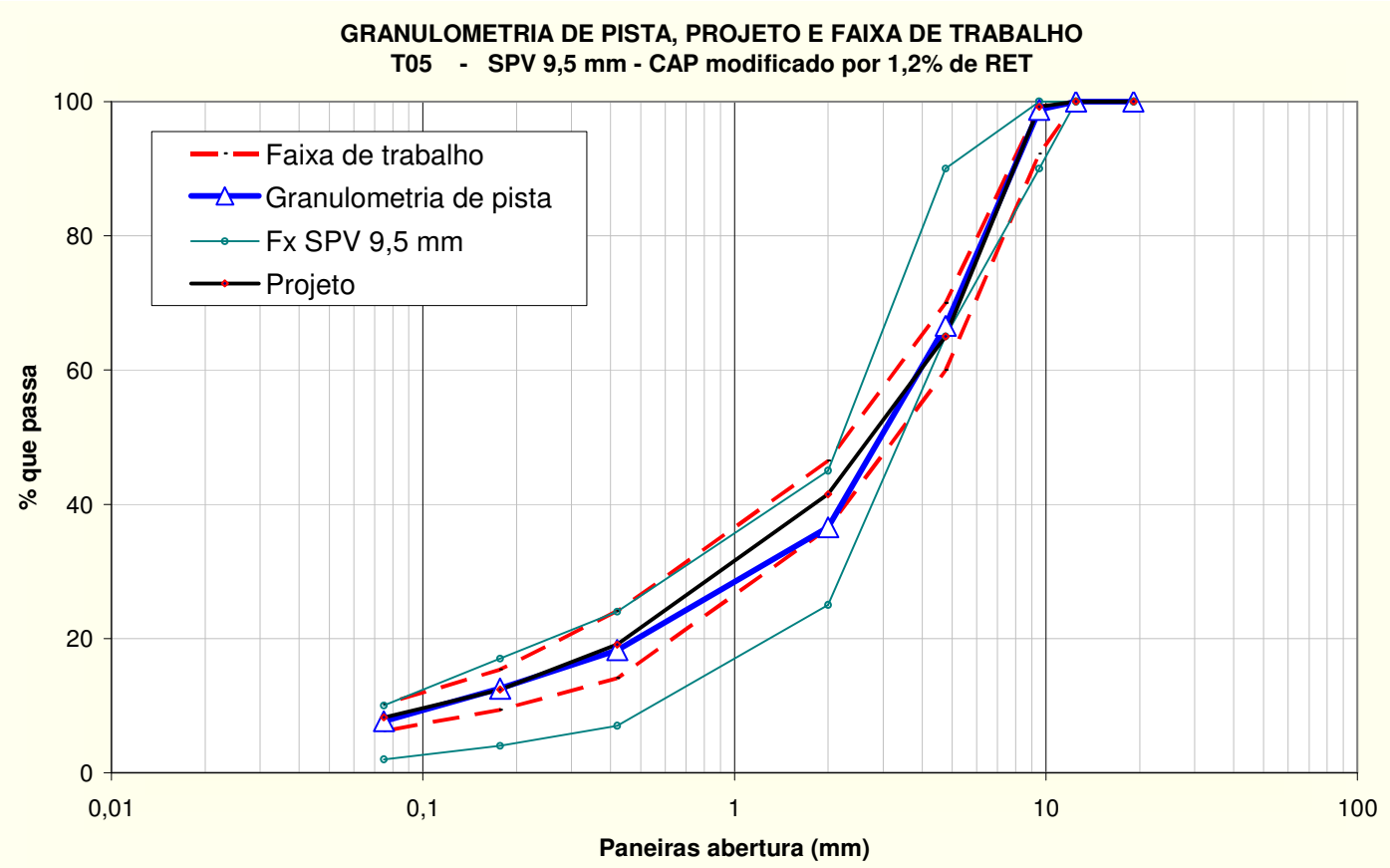

Figura 118 - Granulometria do trecho $\mathrm{T} 05 \mathrm{em}$ pista comparada à de projeto

A distribuição granulométrica de pista do trecho T05, apresentada na figura 118 , ficou dentro da faixa de trabalho especificada. Na peneira n. 10 (abertura 2,0 mm) a distribuição granulométrica tangencia o limite inferior da faixa de trabalho, mostrando-se mais grossa.

Da mesma forma, que descrito para o trecho T04, a distribuição granulométrica de pista do trecho T05 apresenta na peneira n. 10 mais grossa, figura 119. 
LINHA DE DENSIFICAÇÃO MÁXIMA

Potência 0,45 - DMN = 4,76 mm - Trecho T05 - SPV 9,5 mm- CAP mod. por 1,2\% RET.

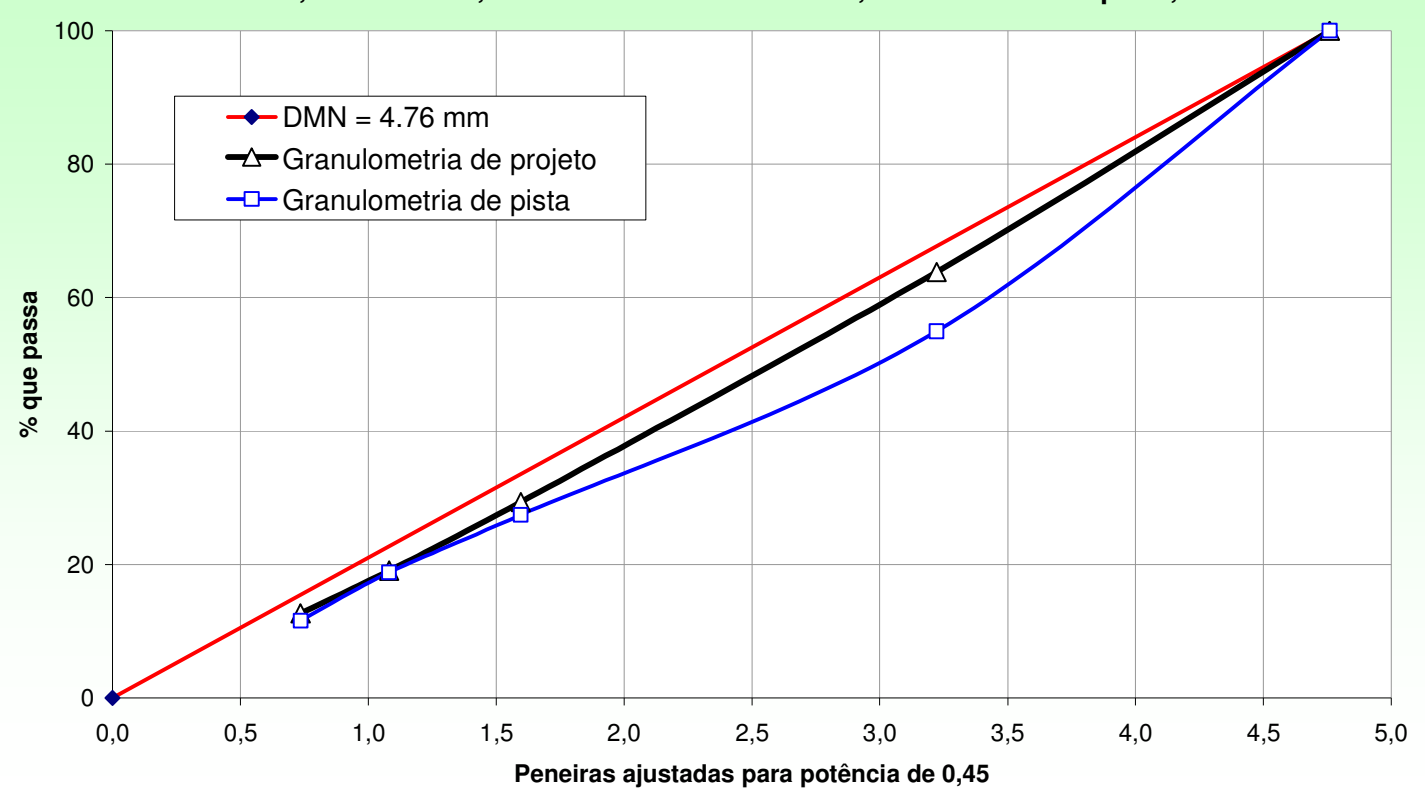

Figura 119 - Linha de densificação máxima - distr. granul. de projeto e de pista- trecho T05

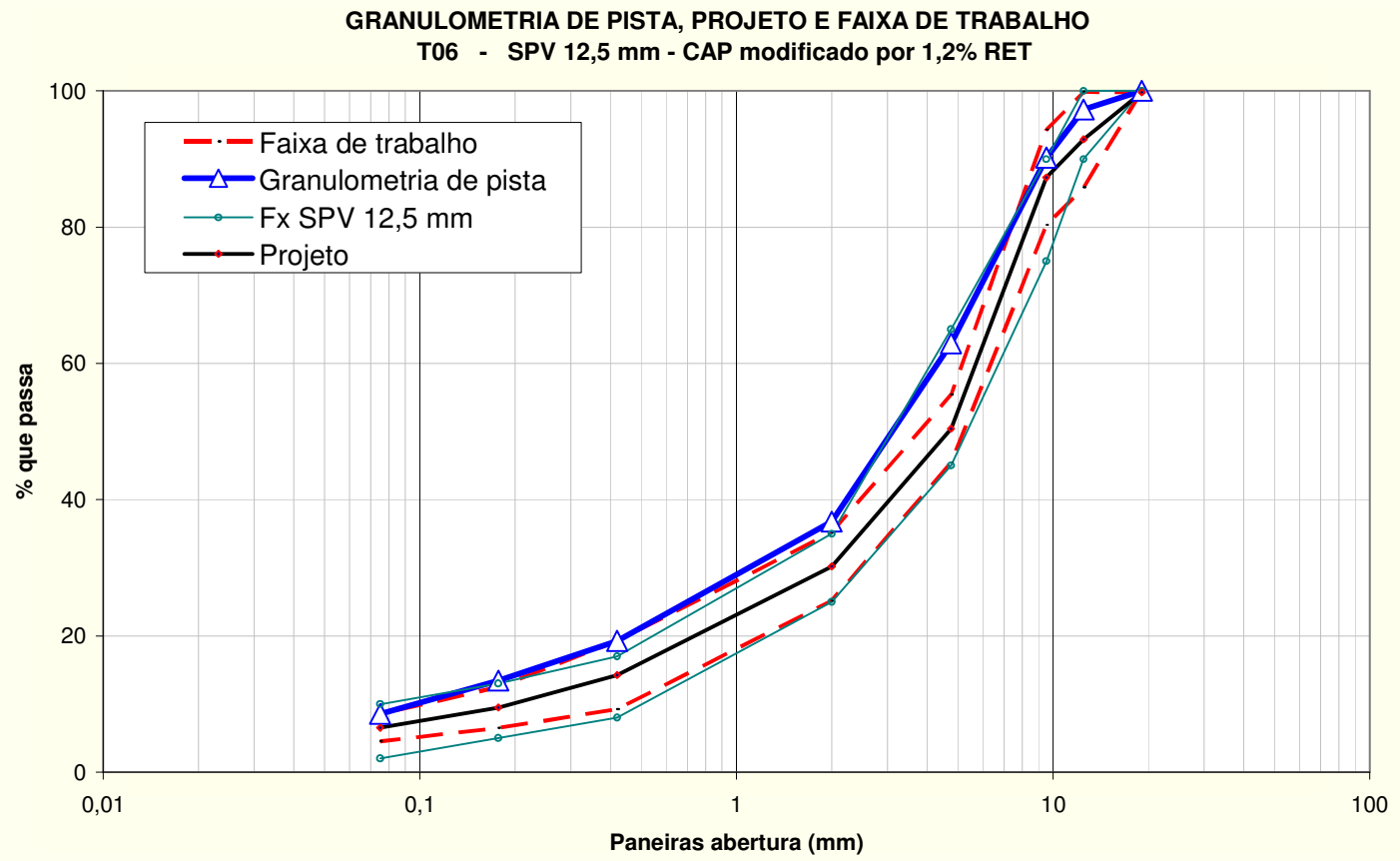

Figura 120 - Granulometria do trecho T06 em pista comparada à de projeto

Já a distribuição granulométrica referente ao trecho T06 afinou por igual tangenciando a parte superior do limite fino da faixa de trabalho, figura 120. Praticamente, a distribuição granulométrica permaneceu dentro da faixa granulométrica. 


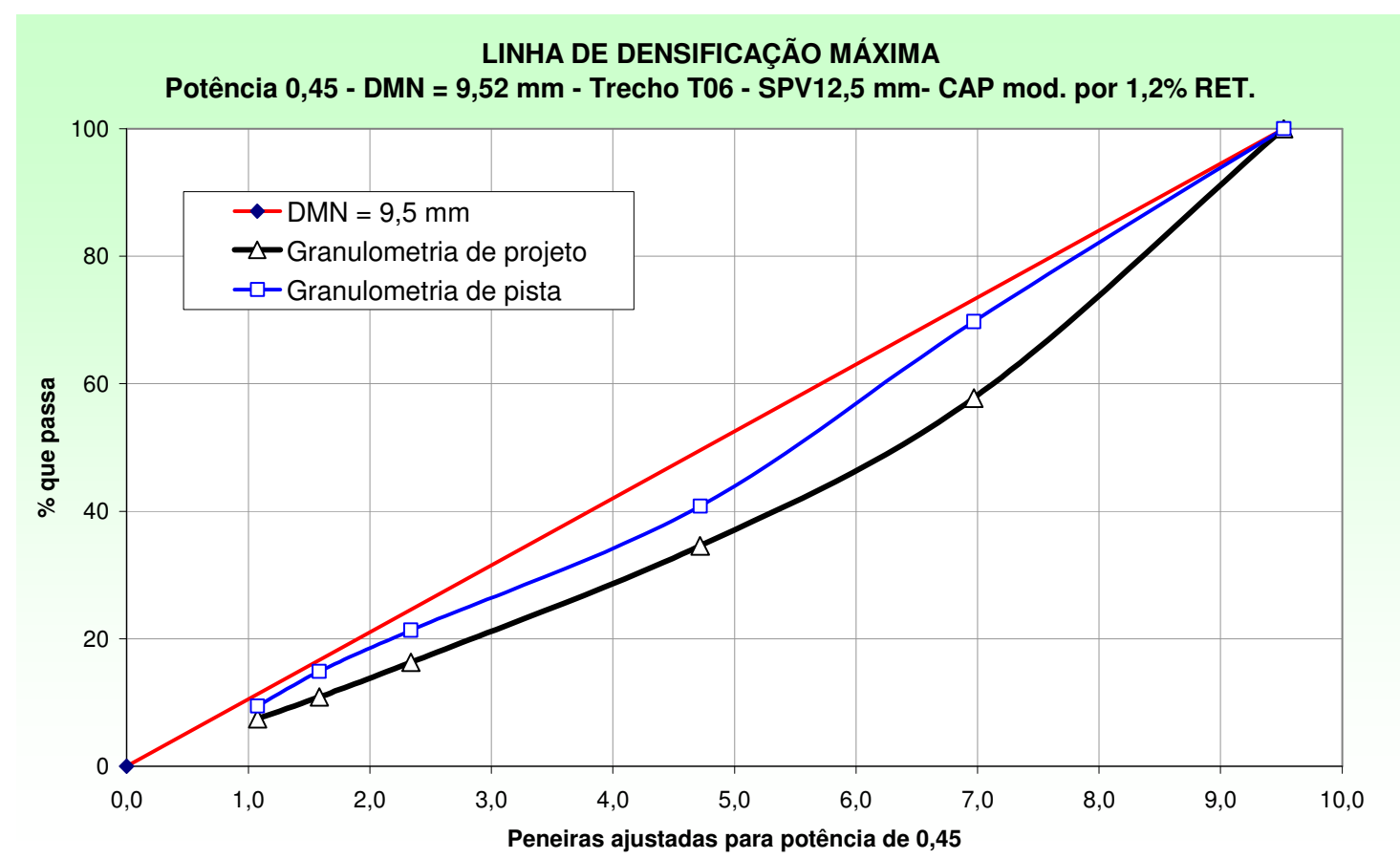

Figura 121 - Linha de densificação máxima - distr. granul. de projeto e de pista- trecho T06

A distribuição granulométrica de projeto do trecho T06 distanciou-se da linha de densificação máxima e com o afinamento da distribuição granulométrica de pista verifica-se uma aproximação à ela, figura 121. A mesma tendência observada anteriormente com os outros trechos.

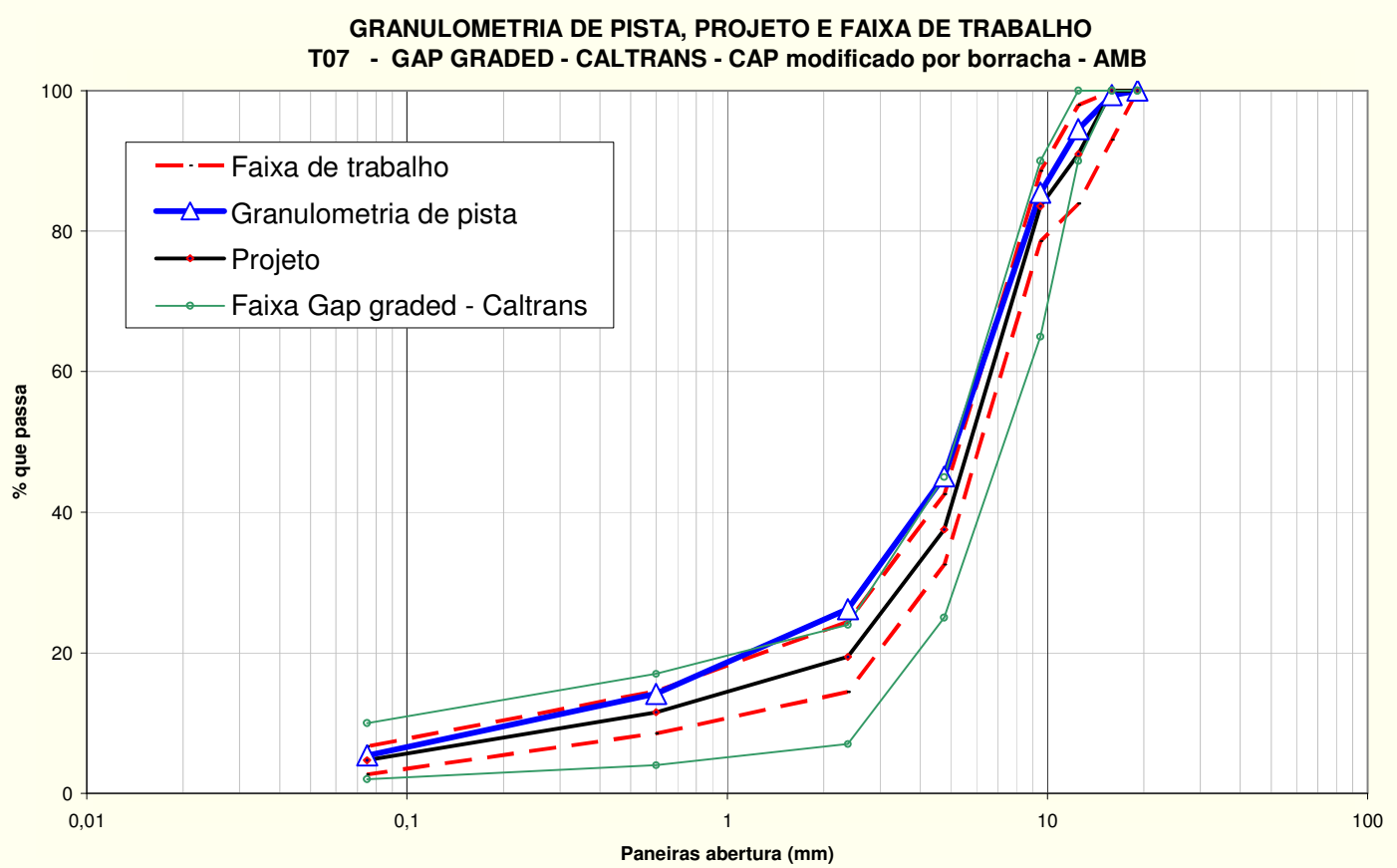

Figura 122 - Granulometria do trecho $\mathrm{T07}$ em pista comparada à de projeto 
$\mathrm{Na}$ figura 122 mostra-se a distribuição granulométrica do trecho T07, gapgraded do Caltrans usinado com ligante asfáltico modificado por borracha, apresentou uma distribuição tangenciando o limite superior da faixa de trabalho.

Conforme mencionado por Goode e Lufsey, (1962) distribuições granulométricas semidescontinuas mostram-se desfavoráveis para análise na carta de linha de densificação máxima. Entretanto, observe-se que com o afinamento da distribuição granulométrica de pista pôde-se verificar um distanciamento da distribuição granulométrica de projeto para o lado mais fino, figura 123.

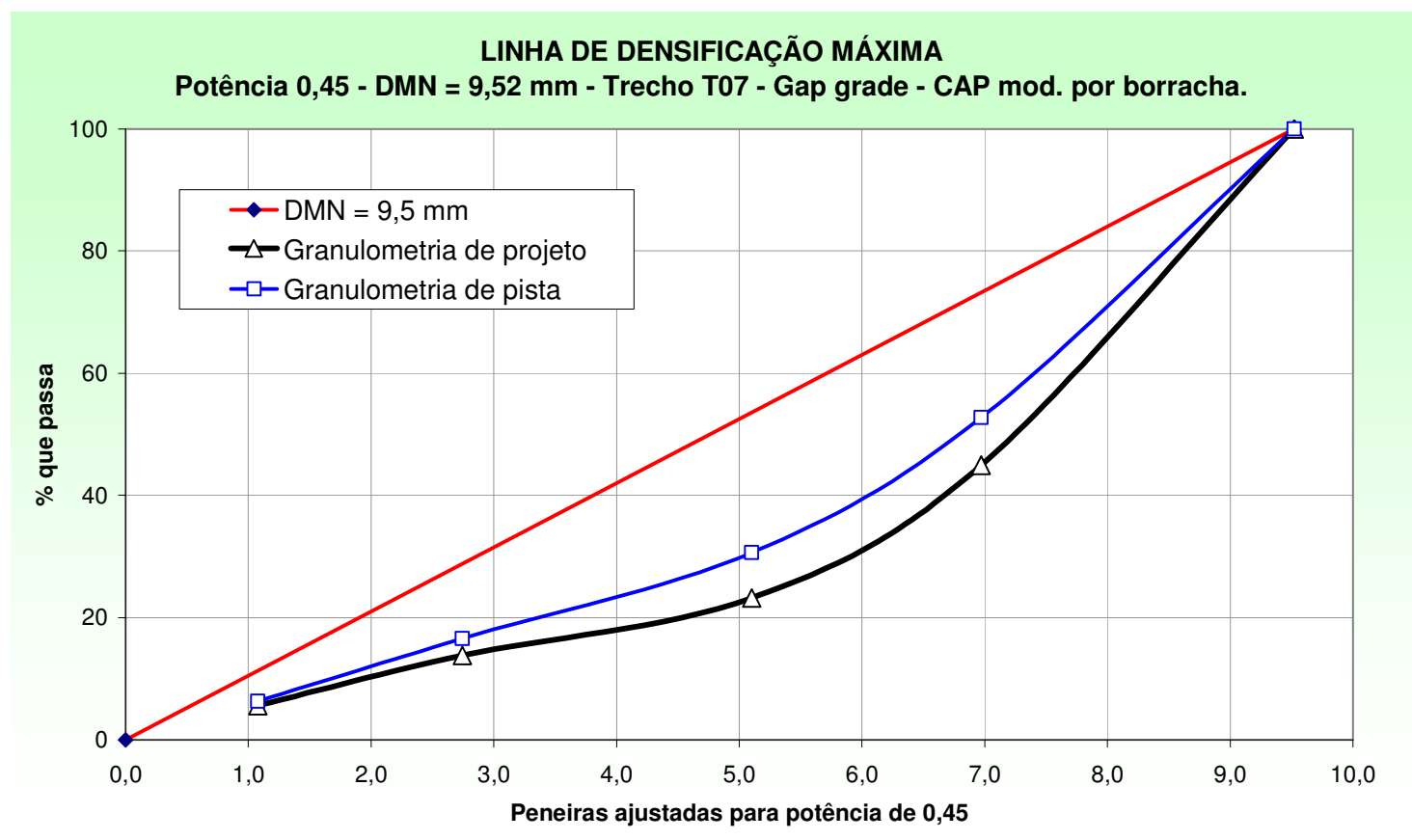

Figura 123 - Linha de densificação máxima - distr. granul. de projeto e de pista- trecho T07

Nesse caso, a distribuição granulométrica do trecho T08 assemelha-se muito com a encontrada no trecho T06, afinou por igual tangenciando a parte superior do limite fino da faixa de trabalho, figura 124. Da mesma forma, com o afinamento a distribuição granulométrica de pista aproximou-se da linha de densificação máxima, distanciando-se da distribuição granulométrica de projeto. Observe-se que a distribuição granulométrica para diâmetro acima de 4,76 foi bem distribuída, pois situou-se sobre a linha de densificação máxima, figura 125. 


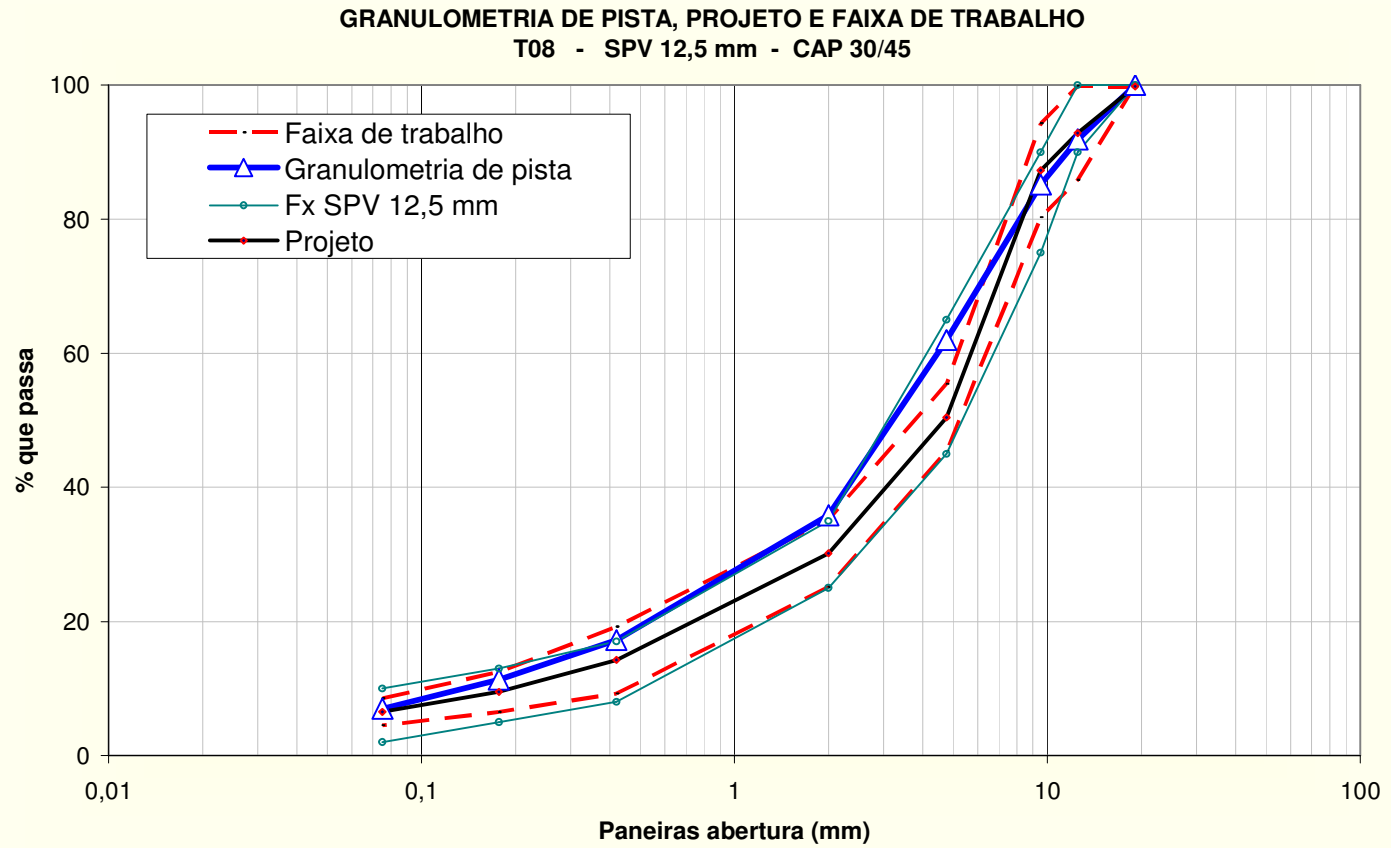

Figura 124 - Granulometria do trecho T08 em pista comparada à de projeto

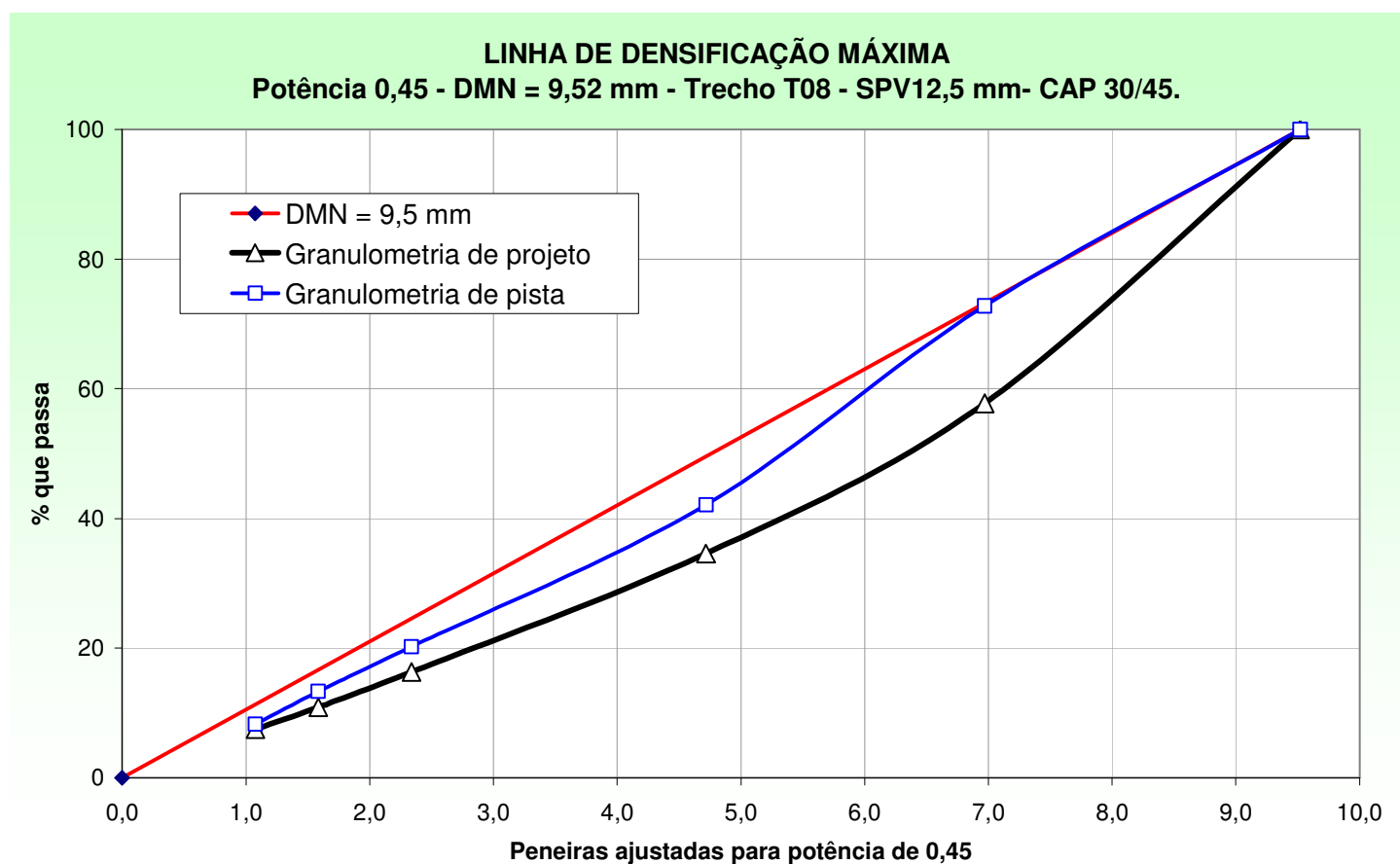

Figura 125 - Linha de densificação máxima - distr. granul. de projeto e de pista- trecho T08 


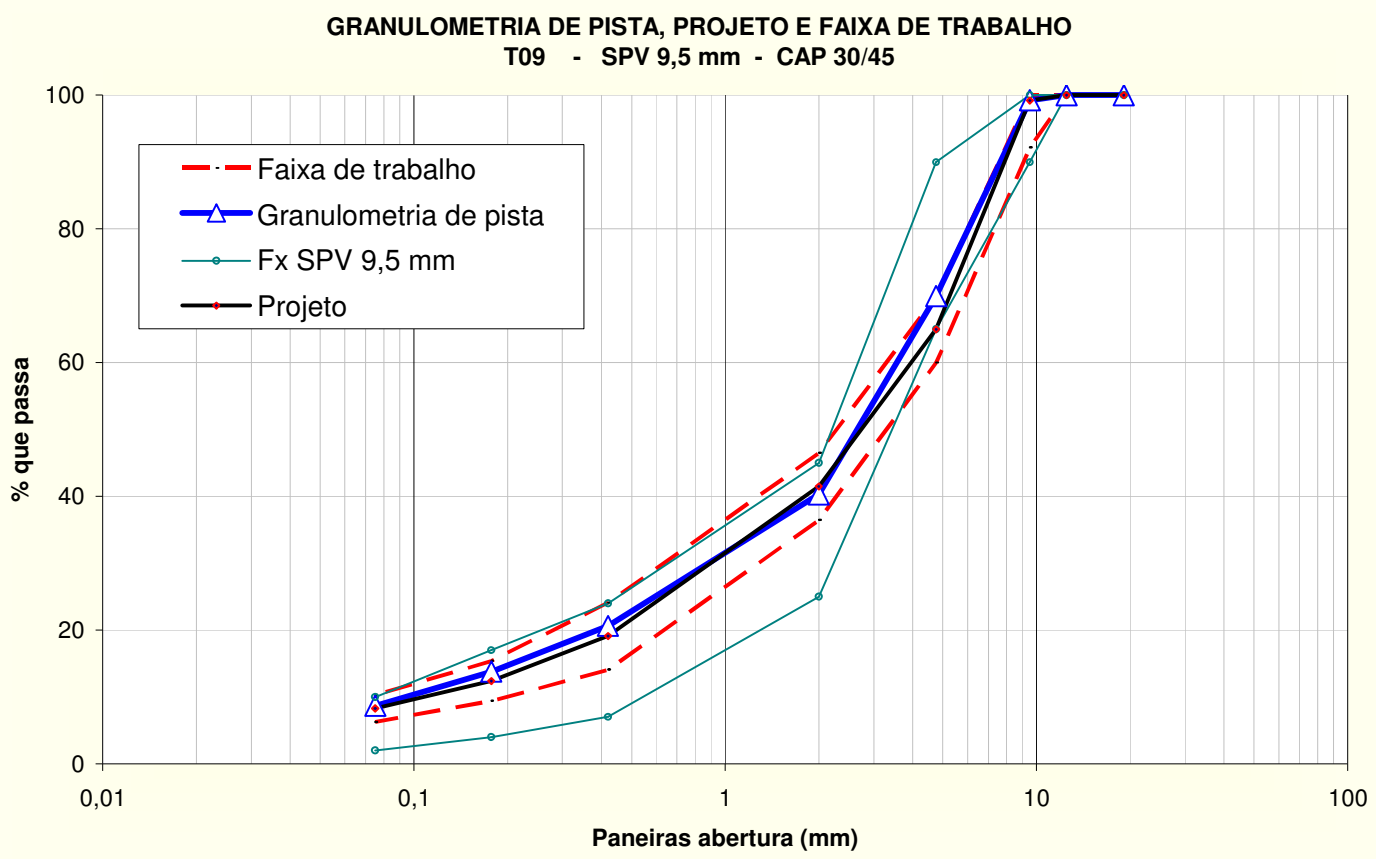

Figura 126 - Granulometria do trecho T09 em pista comparada à de projeto

Observe-se na figura 126 que a distribuição granulométrica de pista referente ao trecho T09 apresentou-se dentro dos limites especificados pela faixa granulométrica e também dos limites da faixa de trabalho. O DMN considerado foi de 4,76 mm e somente na peneira $\mathrm{n} .10$ (2,0 mm de abertura) a distribuição granulométrica de pista mostrou-se ligeiramente mais grossa, figura 127. 


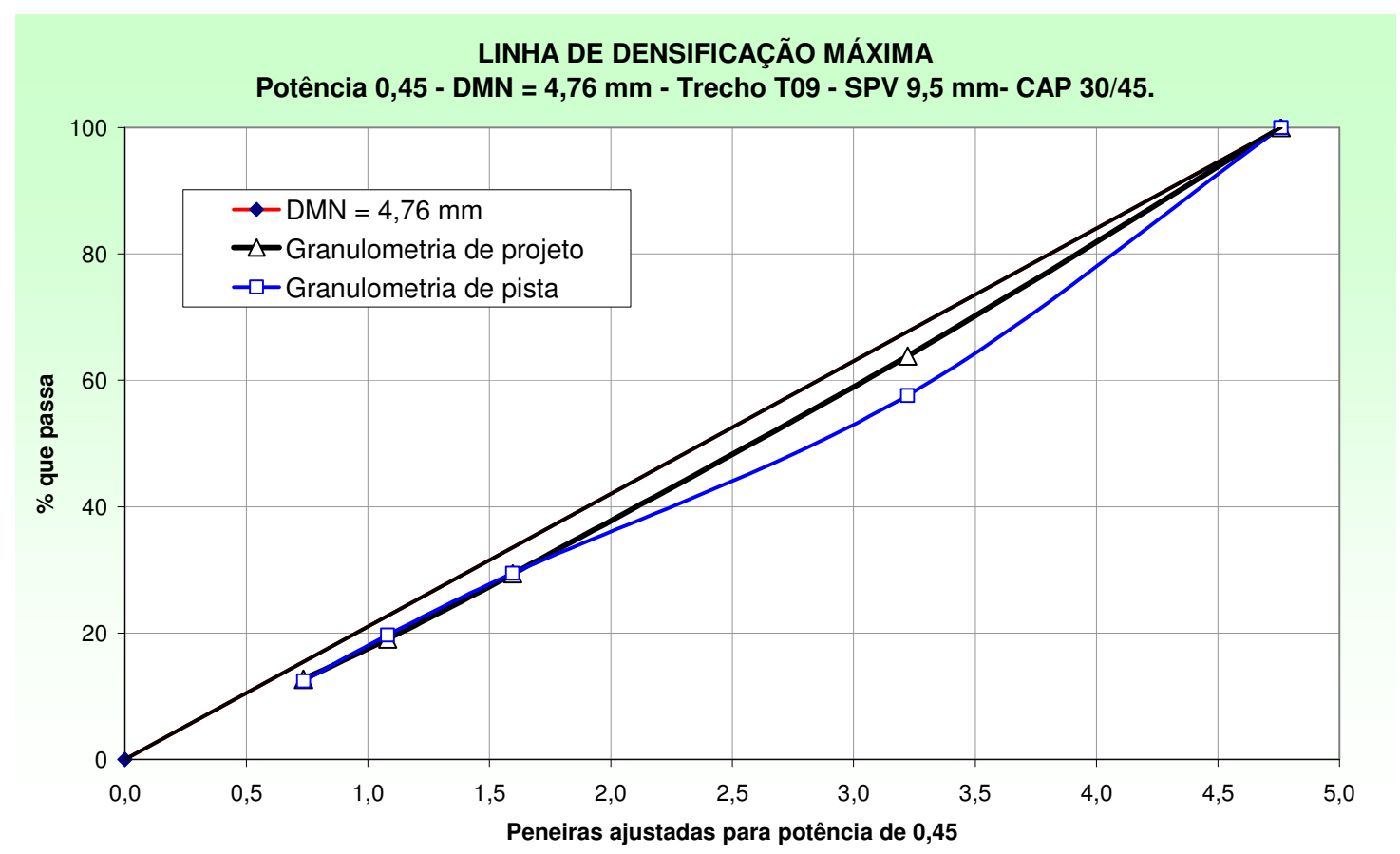

Figura 127 - Linha de densificação máxima - distr. granul. de projeto e de pista- trecho T09

Por fim, na figura 128 apresenta-se o trecho T10 de gap-graded do, cuja distribuição granulométrica assemelha-se a encontrada no trecho T07, tangenciando o limite superior da faixa de trabalho. Da mesma forma, conforme mencionado por Goode e Lufsey, (1962) distribuições granulométricas semidescontinuas mostram-se desfavoráveis para análise na carta de linha de densificação máxima. Entretanto, observe-se que com o afinamento da distribuição granulométrica de pista pôde-se verificar um distanciamento da distribuição granulométrica de projeto para o lado mais fino, figura 129. 
GRANULOMETRIA DE PISTA, PROJETO E FAIXA DE TRABALHO T10 - GAP GRADED - CALTRANS - CAP 30/45

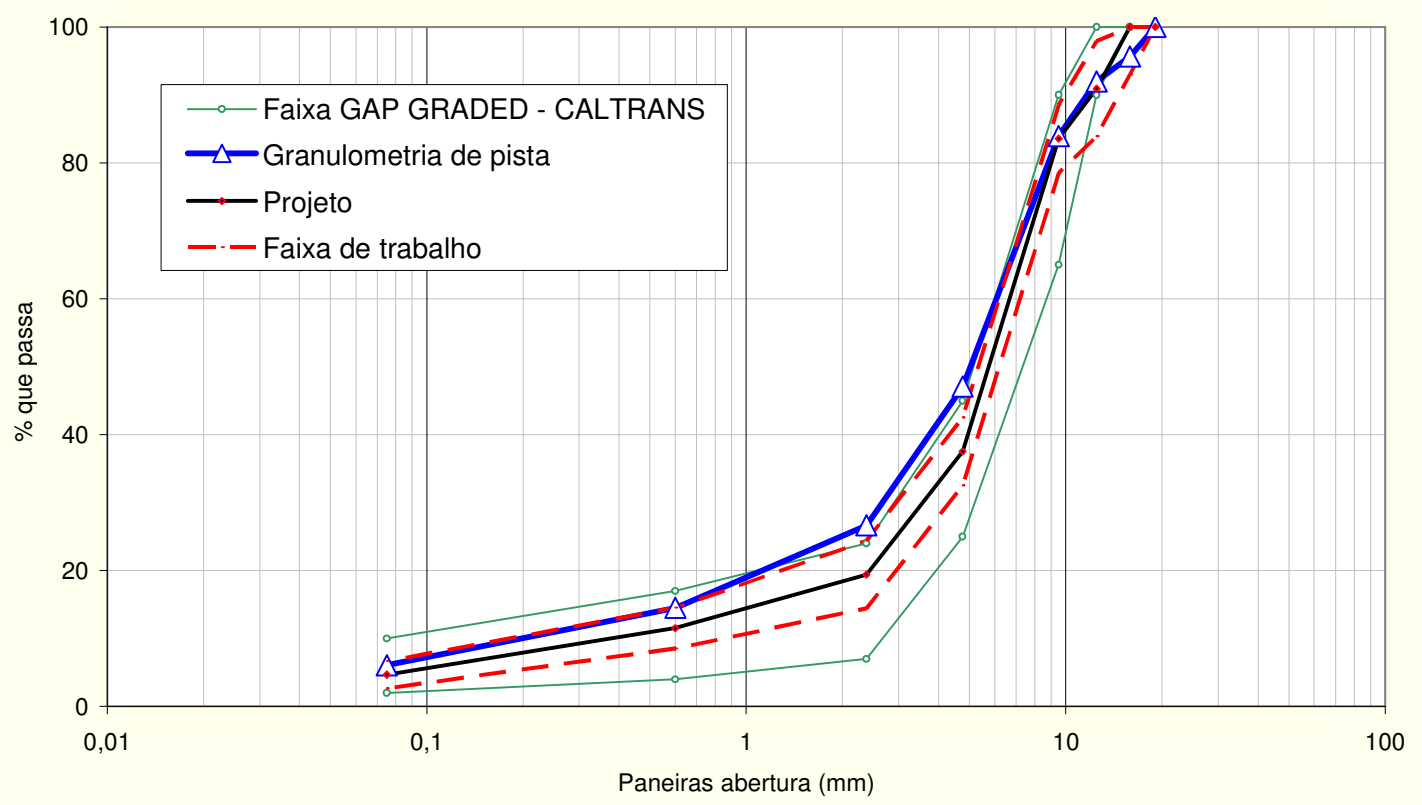

Figura 128 - Granulometria do trecho $\mathrm{T10}$ em pista comparada à de projeto

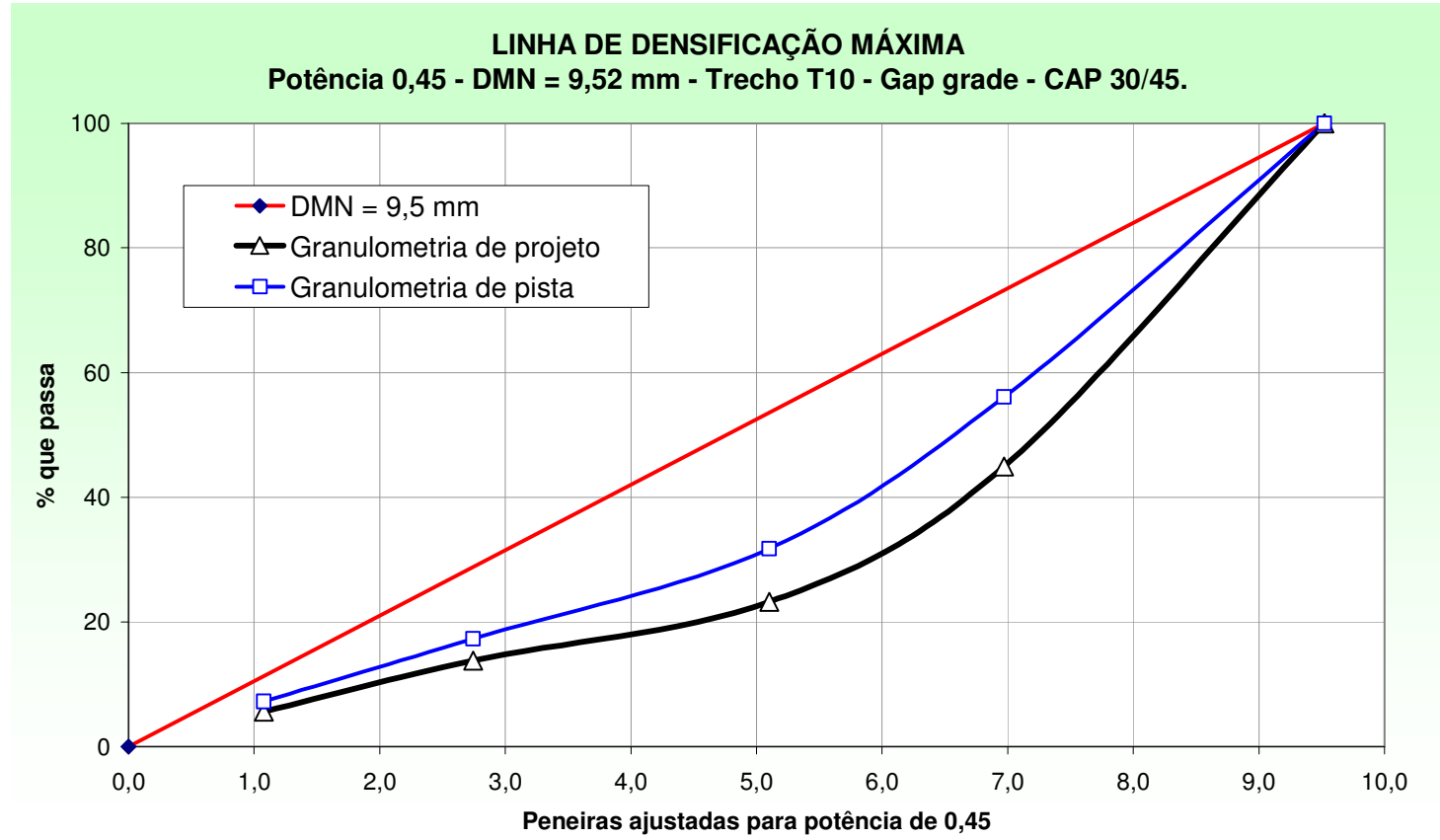

Figura 129 - Linha de densificação máxima - distr. granul. de projeto e de pista- trecho T10

\subsection{Camadas do pavimento da pista-teste}


Para a determinação dos tipos dos materiais e medida das espessuras de cada camada constituinte do pavimento da pista-teste, após a execução das novas camadas de rolamento foram feitas três cavas (janelas) de aproximadamente $1,5 \mathrm{~m} \times 0,8 \mathrm{~m}$, com profundidade suficiente para verificação do tipo de material e suas respectivas espessuras, nos trechos T01, T04 e T10, trechos escolhidos para serem submetidos ao ensaio com o simulador de tráfego móvel de campo, conforme descrito no item 3.12.

As espessuras e os tipos de materiais de cada camada do trecho T01 estão apresentados nas figuras 130 e 131.

\begin{tabular}{|c|c|c|}
\hline & $5 \mathrm{~cm}$ & CBUQ - capa nova \\
\hline & $9 \mathrm{~cm}$ & CBUQ - remanescente \\
\hline 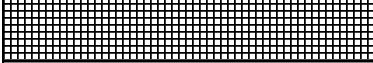 & $20 \mathrm{~cm}$ & BGS \\
\hline ย & $>50 \mathrm{~cm}$ & Solo + seixo \\
\hline
\end{tabular}

Figura 130 - Croqui de identificação dos materiais do pavimento da pista-teste - T01

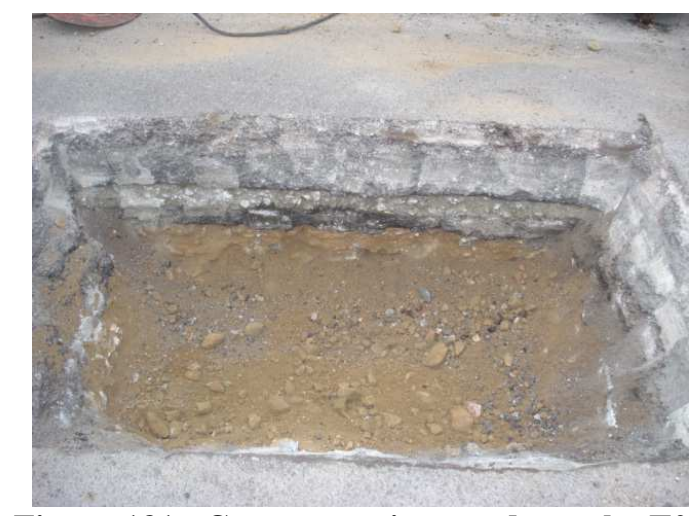

Figura 131 - Cava no pavimento do trecho T01

As espessuras e as camadas correspondentes ao trecho T04 estão apresentadas nas figuras 132 e 133.

\begin{tabular}{|c|c|c|}
\hline & $5 \mathrm{~cm}$ & CBUQ - capa nova \\
\hline & $10 \mathrm{~cm}$ & CBUQ - remanescente \\
\hline 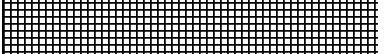 & $18 \mathrm{~cm}$ & BGS \\
\hline K้ & $>50 \mathrm{~cm}$ & Solo + seixo \\
\hline
\end{tabular}

Figura 132 - Croqui de identificação dos materiais do pavimento da pista-teste - T04 


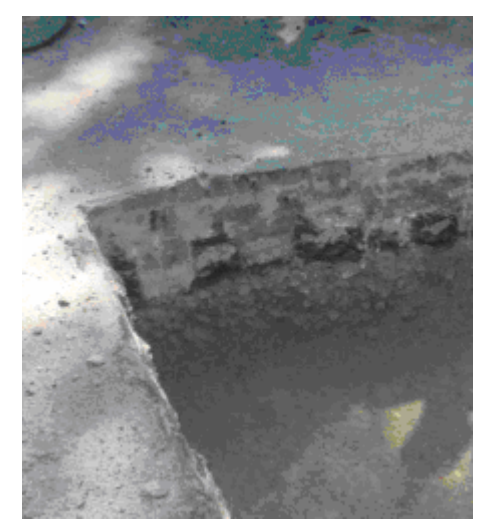

Figura 133 - Cava no pavimento do trecho T04

Nas figuras 134 e 135 estão as espessuras das camadas e a janela de sondagem respectivamente.

\begin{tabular}{|c|c|c|}
\hline & $5 \mathrm{~cm}$ & CBUQ - capa nova \\
\hline & $11 \mathrm{~cm}$ & CBUQ - remanescente \\
\hline 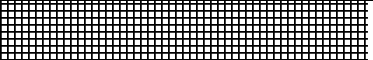 & $15 \mathrm{~cm}$ & BGS \\
\hline & $30 \mathrm{~cm}$ & Concreto de cimento \\
\hline & $8 \mathrm{~cm}$ & Brita 3/4"+ brita 3/8" \\
\hline 3 & & Solo + seixo \\
\hline
\end{tabular}

Figura 134 - Croqui de identificação dos materiais do pavimento da pista-teste - T10

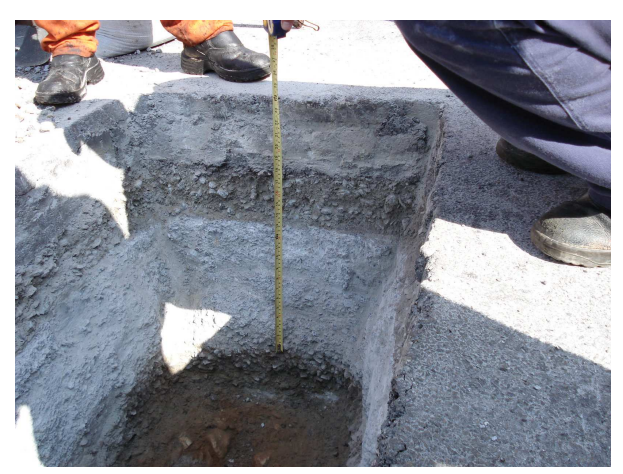

Figura 135 - Estrutura do pavimento da pista-teste do trecho T10

Observe-se que a estrutura correspondente ao trecho T10 difere dos demais trechos; apresenta uma camada de $30 \mathrm{~cm}$ de concreto, provavelmente construído antes dos demais trechos da terceira faixa que constituem atualmente os trechos 1 e 4 . A terceira faixa deve ter sido prolongada por problemas operacionais e os pavimentos não seguiram a estrutura existente. Constata-se que a partir da camada de concreto de cimento, as camadas 
praticamente se equivalem, com pequenas varições de espessura. A presença de camada de concreto de cimento faz com que a deflexão seja reduzida no trecho em questão. Com efeito, na figura 72, pôdem ser constatados os valores de deflexão obtidos antes e após a execução da pista-teste, e os valores de deflexão no trecho T10 estão na ordem de 10 a $20(0,01 \mathrm{~mm})$ enquanto para os demais trechos, as deflexões variaram entre 20 e $90(0,01 \mathrm{~mm})$.

\subsection{Simulador de tráfego móvel de campo}

\subsubsection{Trechos escolhidos para serem submetidos ao simulador de tráfego móvel de campo}

Devido à logística da pesquisa, somente 3 trechos foram submetidos ao ensaio acelerado com o simulador de tráfego móvel de campo durante o ano de 2009. A pesquisa contempla um total de 5 a 6 trechos. Os trechos restantes, conforme escopo inicial da pesquisa, serão ensaiados no ano de 2010, conforme os recursos de pesquisa forem disponibilizados pela Concessionária, autorizado pela ANTT.

Os trechos 1, 4 e 10 foram escolhidos para serem submetidos ao ensaio acelerado com o simulador de tráfego no ano de 2009. O trecho 1 foi selecionado por ser o de referência; os trechos 4 e 10 por apresentarem as melhores condições superficiais e de interesse direto para a Concessionária da pesquisa em questão. O trecho T04, por se tratar de uma mistura asfáltica de graduação fina e usinada com ligante asfáltico modificado por polímero SBS e o trecho T10 por se tratar de uma mistura tipo gap graded do Caltrans e usinado com ligante asfáltico modificado por borracha. A identificação, a localização e o tipo de mistura asfáltica dos trechos escolhidos para serem submetidos aos ensaios com o simulador de tráfego de ‘campo estão apresentadas na tabela 45 . 
Tabela 45 - Trechos escolhidos para ensaio acelerado com o simulador

\begin{tabular}{c|c|c|c|c}
\hline \multirow{2}{*}{ TRECHO } & \multicolumn{2}{|c|}{ Localizaça $(\mathbf{k m})$} & \multirow{2}{*}{ Tipo de CAP } & \multirow{2}{*}{$\begin{array}{c}\text { Faixa } \\
\text { Granulométrica }\end{array}$} \\
\cline { 2 - 3 } & in ício & fim & & Mix IVb (I.A.) \\
\hline 1 & $675+200$ & $675+000$ & CAP 50/70 & FX SPV - 9,5 mm \\
\hline 4 & $674+600$ & $674+400$ & CAP mod. por 4\% de SBS & Fap Graded \\
\hline 10 & $673+400$ & $673+200$ & CAP 30/45 & G
\end{tabular}

\subsubsection{Simulação do tráfego}

Embora a área solicitada pelo simulador de tráfego móvel compreenda uma extensão de até $12 \mathrm{~m}$ e largura de até $1 \mathrm{~m}$, a área considerada nos ensaios foi de $9 \mathrm{~m}$, com a extensão de interesse para análise de dados no experimento de 7,0 m. A largura solicitada no experimento foi de $0,7 \mathrm{~m}$.

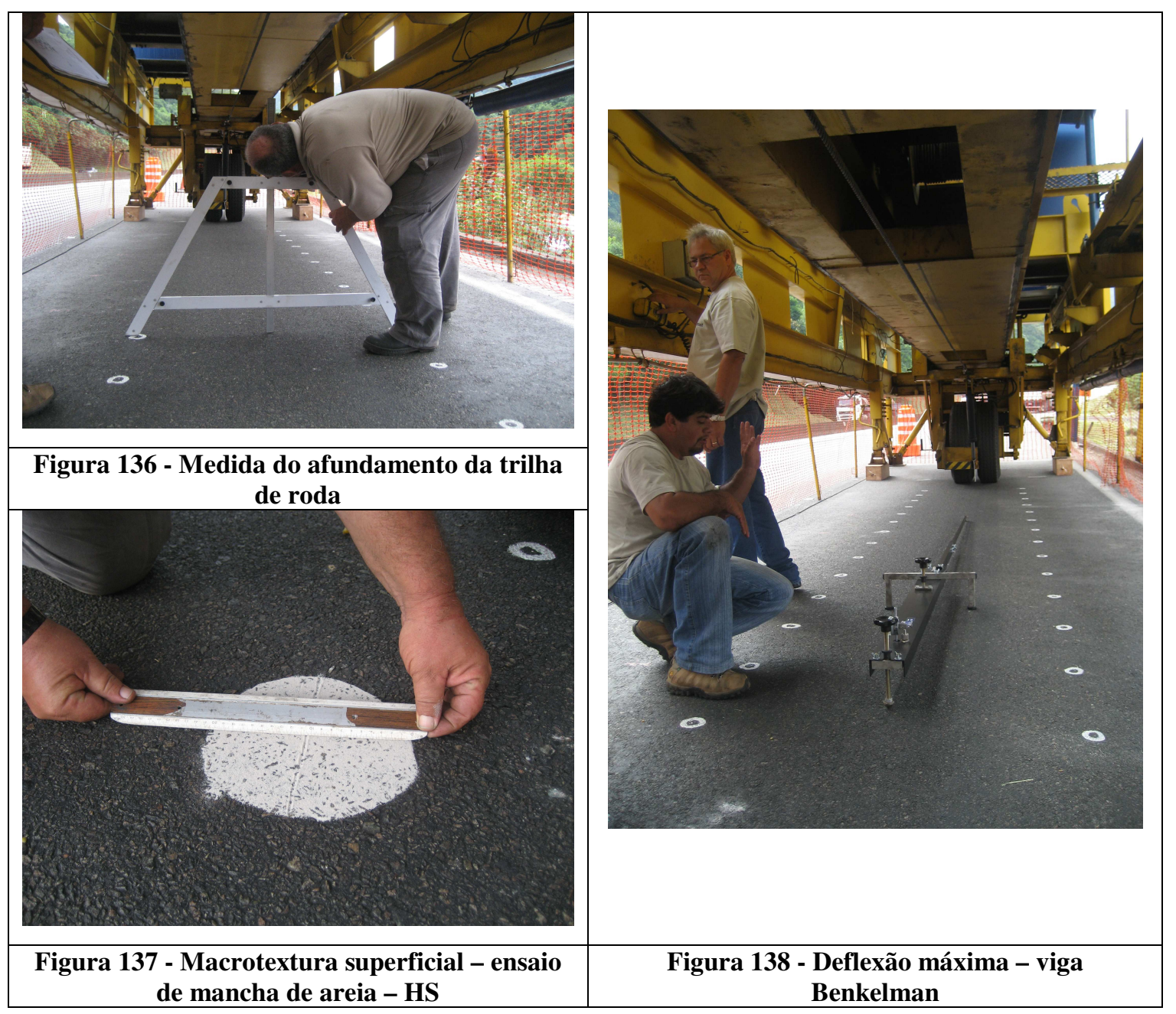


Foram realizadas medidas do afundamento da trilha de roda a cada $0,5 \mathrm{~m}$ no total de 15 pontos realizadas por meio de treliça metálica. - figura 136. A macrotextura superficial com o ensaio de altura média de mancha de areia HS, foi realizado a cada $1 \mathrm{~m}$, no total de 7 leituras por trecho simulado - figura 137 e a deflexão máxima com a viga Benkelman, foi realizada a cada $1 \mathrm{~m}$, no total de 7 leituras - figura 138. Foram feitas também avaliação visual de trincamento, com respectiva marcação na pista dos locais com trincas.

Esses ensaios foram realizados após os seguintes números de ciclos: 0, 100, $300,1.000,3.000,10.000$ e 20.000 . A partir de 20.000 ciclos foram realizadas leituras a cada 20.000 ciclos até o final do experimento.

\subsubsection{Carga no ensaio}

Foram utilizados duas intensidades de cargas diferentes no experimento, uma de 6,2 tf no semi-eixo com aplicação de solicitação de aproximadamente 500.000 ciclos. A carga legal no semi-eixo é de $5 \mathrm{tf}$, porém é de conhecimento geral que há um percentual de caminhões com excesso de carga de ordem de $20 \%$. Se considerados este acréscimo, tem-se 6 tf no semi-eixo. A aplicação de excesso de carga com relação à legal serve para acelerar ainda mais a solicitação, tornando os ciclos de carga mais severos. Uma segunda carga de 8,3 tf, com acréscimo na ordem de $60 \%$ da carga legal, também foi aplicada, com o número de solicitações em torno de 250.000 ciclos, totalizando 750.000 ciclos

A escolha da intensidade de carga do simulador de tráfego móvel implica diretamente no tempo de ensaio, que por sua vez, condiciona o custo que o equipamento gera para a realização da pesquisa. Normalmente tem-se utilizado cargas elevadas no sentido de se acelerar o surgimento dos defeitos e, assim, concluir a pesquisa. Entretanto, a aplicação de cargas elevadas em simulação desse tipo acaba por gerar, no topo da camada de rolamento, níveis de tensões elevadas e, não raras vezes, as camadas de rolamento sob a ação 
dessas tensões, rompem por cisalhamento. Esse tipo de ruptura compromete a interpretação dos resultados.

Percebe-se que a escolha da intensidade de carga é fator determinante, tanto na condução do ensaio para que se possa, com os resultados, ao final do experimento, associá-los ao tipo de tráfego da rodovia, como também na duração e, por conseguinte, no custo do experimento.

O período de equivalência temporal do simulador de tráfego móvel para as cargas de 6,2 tf e 8,3 tf para os trechos ensaiados estão apresentados no item 4.4.3.

A verificação das tensões atuantes na fibra inferior da camada asfáltica nova a partir da análise estrutural obtida com o programa Elsym 5, para os três trechos T01, T04 e T10 que foram sondados para verificação das camadas constituintes, conforme descrita no item 3.11, estão apresentadas na tabela 46.

Tabela 46 - Tensões atuantes na fibra inferior da camada asfáltica nova

\begin{tabular}{l}
\cline { 4 - 8 } \\
\cline { 3 - 7 }
\end{tabular}

\footnotetext{
*Valores de Módulo de Resiliência $\left(25^{\circ} \mathrm{C}\right)$ e coeficientes de Poisson considerados na análise.
} 
Observe-se que todos os três trechos apresentaram tensões atuantes de compressão, sinalizando que as camadas asfálticas da pista-teste não trabalham à tração, o que justifica a avaliação do potencial da formação da deformação permanente em trilha de roda como principal defeito.

Os deslocamentos obtidos com a retroanálise foram semelhantes aos obtidos em campo com o FWD, conforme figuras 70,71 e 72 , evidenciando que os módulos adotados na retroanálise foram compatíveis com os esperados das camadas, isto é, considerando as deflexões obtidas.

\subsubsection{Pressão de contato}

Núñes (1997) relata que obteve informações junto a locais de manutenção de sistemas de rodados rodoviários de que a pressão de enchimento utilizada em pneus $9,00 \times 20$ varia, geralmente, entre $0,70 \mathrm{MPa}$ e $0,77 \mathrm{MPa}$ (100 a $110 \mathrm{psi}$ ). Relata ainda que a área de contato determinada pela relação entre a carga de roda e a pressão de inflagem não se mantém constante com o aumento da carga. Isso se deve ao fato da área de contato se alterar com a pressão de inflagem dos pneus não linearmente. Na figura 139 mostra-se na área de contato deformações devido a variação na pressão de inflagem.

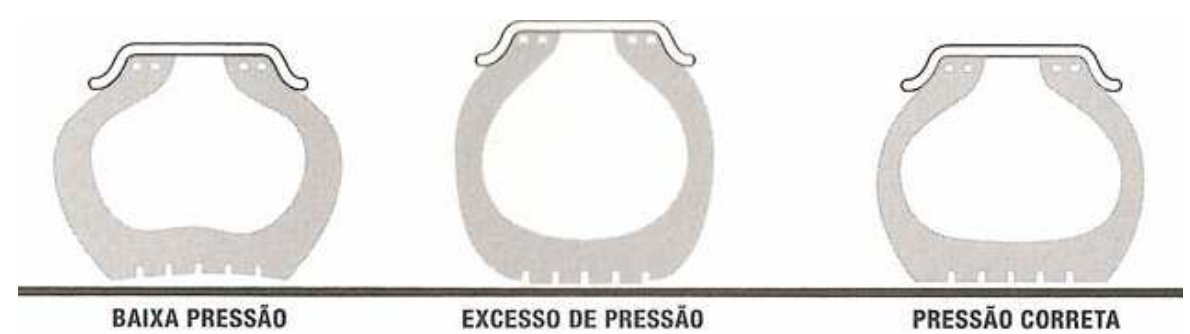

Figura 139- Variação da área de contato em função da pressão de inflagem

Os pneus utilizados no rodado do simulador de tráfego móvel é o mesmo estudado por Núñes; assim, a pressão de inflagem dos pneumáticos adotado no experimento foi de $0,7 \mathrm{MPa}$ (100 psi), e a carga no semi-eixo foi de $62 \mathrm{kN}$, sendo 3,1 kN por roda, por 500.000 ciclos. A área de contato, para simplificação, foi considerada circular e tem $434,78 \mathrm{~cm}^{2}\left(0,0434 \mathrm{~m}^{2}\right)$. Adotandose pressão de contato constante, tem-se, portanto, que os a tensão aplicada na 
superfície do revestimento pelos pneus do simulador de tráfego móvel foi de $690 \mathrm{kPa}\left(6,9 \mathrm{kgf} / \mathrm{cm}^{2}\right)$.

\subsubsection{Temperatura no ensaio acelerado}

As medidas da temperatura do ar foram feitas pelo menos 6 vezes ao dia, acompanhando a realização dos ensaios de afundamento em trilha de roda, deflexão e mancha de areia - HS e, incluindo duas medidas da temperatura: uma no início e outra ao final do dia.

Os ensaios com o simulador de tráfego móvel iniciaram em abril de 2009 no trecho T10, tendo sido finalizado em maio de 2009. A a temperatura ambiente média registrada durante a realização do ensaio foi de $24,1^{\circ} \mathrm{C}$ e desvio padrão de $3,6^{\circ} \mathrm{C}$.

O ensaio no trecho T04 foi iniciado no final de maio de 2009 e finalizado em julho do mesmo ano. Os registros de temperatura no início do ensaio nesse último trecho apontavam para uma redução de até $3^{\circ} \mathrm{C}$ na média da temperatura, devido ao período mais frio do ano. Assim, foi solicitado para a empresa Simular, responsável pelo equipamento, para que fossem instalados painéis de proteção em volta do simulador e também resistências elétricas (lâmpadas) que proporcionassem um aquecimento do local, aumentando a temperatura na superfície do local simulado. O objetivo de aumentar a temperatura foi de maneira que a média, correspondente ao trecho T10, fosse mantida também para o trecho T4. Com efeito, a temperatura média do ensaio foi de $23,4^{\circ} \mathrm{C}$ e desvio padrão de $4,2^{\circ} \mathrm{C}$. A temperatura é um parâmetro importante a ser controlado para a deformação permanente em trilha de roda, principalmente por se tratar de um experimento em que os resultados dos ensaios serão confrontados.

O sistema de aquecimento e os painéis de proteção instalados no simulador de tráfego móvel estão apresentados na figura 140. 


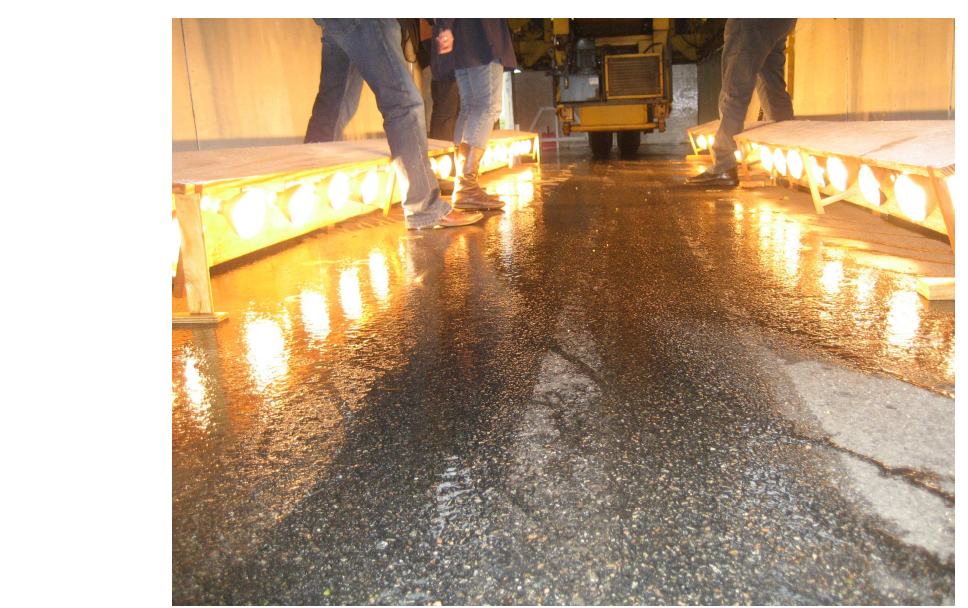

Figura 140 - Sistema de aquecimento e painéis de fechamento do simulador usado nesta pesquisa

Para o trecho T01 o ensaio foi iniciado no início de agosto de 2009 e finalizado em setembro de 2009. Para se manter a média da temperatura na ordem de 25ㄷ $\mathrm{C}$ o sistema de aquecimento e o fechamento lateral do simulador foi mantido durante todo o ensaio. A temperatura média nesse trecho foi de $26,2^{\circ} \mathrm{C}$ e desvio padrão de $3,7^{\circ} \mathrm{C}$.

\subsubsection{Local da faixa de tráfego submetido ao ensaio com 0 simulador de tráfego}

A execução do experimento deu-se no centro da terceira faixa, entre trilhas de roda, área ainda não submetida pela ação do tráfego. Duas determinantes contribuíram para a escolha deste local:

1a. determinante - após a construção da pista-teste alguns trechos apresentaram pequena deformação permanente logo no início da solicitação pelo tráfego e a submissão desses trechos ao ensaios com o simulador de tráfego de campo tornaria a interpretação dos resultados difíceis.

$2^{\mathrm{a}}$. - determinante - as condições de contorno da rodovia não permitem que se ensaie a trilha externa (a mais solicitada) da $3^{\text {a }}$. faixa pelo fato da rodovia não possuir acostamento e a condução do ensaio na trilha 
interna da $3^{\text {a }}$ faixa faz com que o equipamento ocupe a metade da $2^{a}$.faixa, obstruindo o fluxo do tráfego. 


\section{Capítulo 04}

\section{RESULTADOS E ANÁLISE DE ENSAIOS}

Apresentam-se nesse capítulo os resultados dos ensaios realizados em laboratório de compactação com a prensa de cisalhamento giratório - PCG e de deformação permanente em trilha de rodas das misturas asfálticas empregadas na pista-teste, usinadas no teor de projeto, no teor de ligante asfáltico utilizado em pista, determinado a posteriori por extração do ligante e no teor corrigido. Apresentam-se ainda os ensaios de deformação permanente realizados em campo com o simulador de tráfego móvel. Também é abordado o efeito temporal da carga do simulador de tráfego móvel de campo.

\subsection{Redução do volume de vazios com a deformação permanente de placas extraídas de pista}

Para facilitar a análise de resultados de laboratório apresentados a seguir, reproduz-se novamente os dados dos trechos e o teor de ligante de cada um da tabela 44 na tabela 47.

Tabela 47 - Diferença entre teores de ligante asfáltico de pista e de projeto

\begin{tabular}{c|c|c|c|c|c}
\hline \multirow{2}{*}{ Trecho } & \multirow{2}{*}{ Tipo de mistura } & \multirow{2}{*}{$\begin{array}{c}\text { Tipo de } \\
\text { ligante }\end{array}$} & \multicolumn{2}{|c|}{ Teor de Ligante (\%) } & Diferença \\
\cline { 4 - 5 } & & Projeto & Pista & $(\%)$ \\
\hline 1 & Mix IVb I.A. & CAP 50/70 & 5,20 & 5,51 & 0,31 \\
2 & SPV 12,5 mm & CAP 50/70 & 5,46 & 4,73 & $-0,73$ \\
3 & SPV 12,5 mm & $4 \%$ SBS & 6,20 & 4,21 & $-1,99$ \\
4 & SPV 9,5 mm & $4 \%$ SBS & 6,70 & 5,37 & $-1,33$ \\
5 & SPV 9,5 mm & $1,2 \%$ RET & 7,00 & 6,61 & $-0,39$ \\
6 & SPV 12,5 mm & $1,2 \%$ RET & 5,50 & 6,18 & 0,68 \\
7 & Gap graded & AMB & 8,20 & 7,28 & $-0,92$ \\
8 & SPV 12,5 mm & CAP 30/45 & 5,40 & 5,82 & 0,42 \\
9 & SPV 9,5 mm & CAP 30/45 & 5,72 & 6,13 & 0,41 \\
10 & Gap graded & CAP 30/45 & 6,41 & 5,38 & $-1,03$ \\
\hline
\end{tabular}

Conforme descrito anteriormente no item 3.10 foram extraídas 70 placas, sendo 7 placas de cada trecho. Em laboratório estas placas foram serrilhadas nas dimensões $17,5 \mathrm{~cm}$ de largura por $49,5 \mathrm{~cm}$ de comprimento e 
acondicionadas nos moldes metálicos do simulador de tráfego tipo LPC, conforme procedimento mostrado nas figuras 141 a 143.

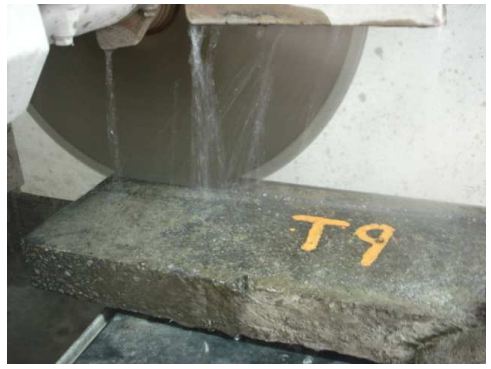

Figura 141 - Corte longitudinal da placa.

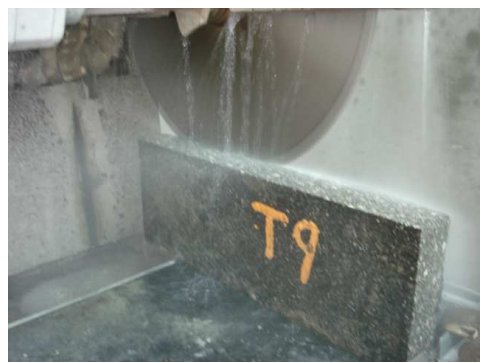

Figura 142 - Corte da altura da placa.

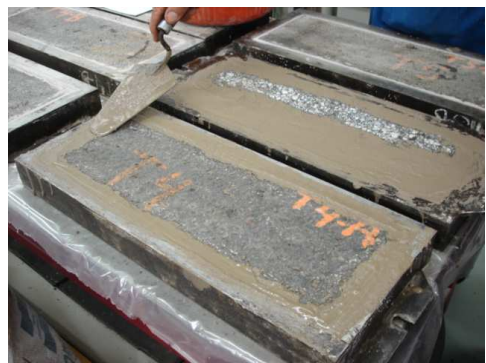

Figura 143 - Confinamento da placa no molde com argamassa.

Apresentam-se na figura 144 as 50 placas utilizadas nessa etapa do trabalho.

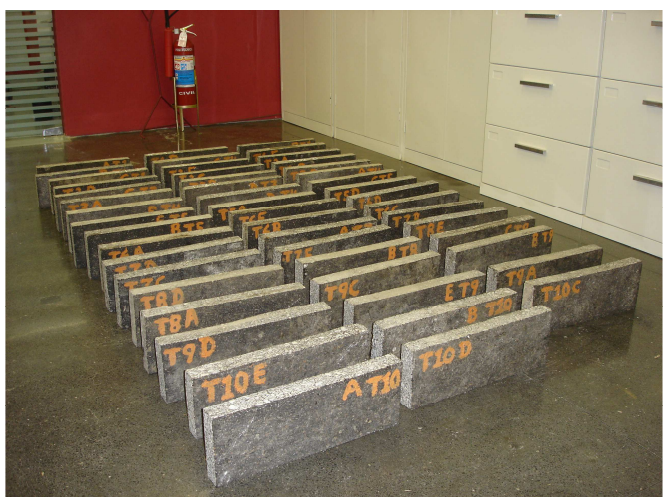

Figura 144 - Placas extraídas de pista e cortadas

Desse lote, foram determinados os volumes de vazios de cada uma através de pesagem hidrostática - figuras 145 e 146.

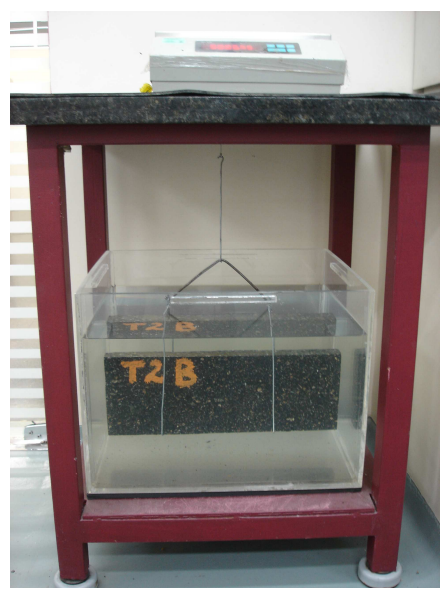

Figura 145 - Pesagem hidrostática das placas de pista

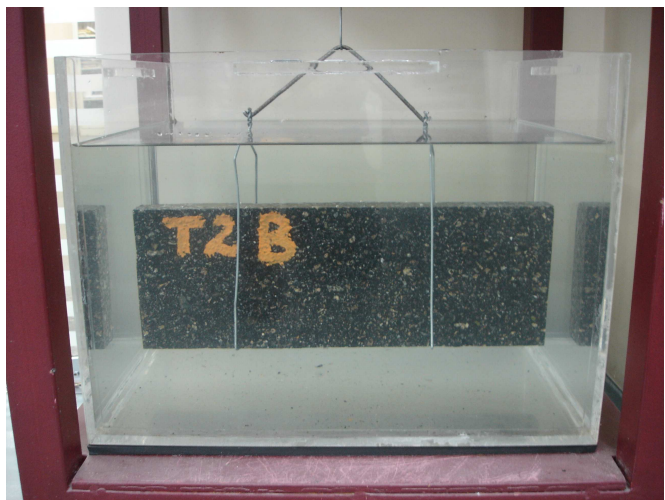

Figura 146 - Detalhe da pesagem hidrostática 
Após a determinação dos volumes de vazios de cada amostra extraída da pista, estas placas foram acondicionadas nos moldes e em seguida submetidas ao simulador de tráfego tipo LCP - orniereur, para a determinação da deformação permanente em trilha de roda. Cinco placas de cada trecho foram utilizadas para serem testadas. Cada placa destas 5 foi submetida a um número diferente de ciclos no simulador: 100, 300, 1.000, 3.000 e 30.000 ciclos.

Terminado o ensaio de deformação permanente em trilha de roda para cada número de ciclos pré-fixados, as seções das placas que sofreram a ação do pneu do simulador, foram cortadas e submetidas novamente à pesagem hidrostática para a determinação do volume de vazios.

Os resultados dos volumes de vazios relacionados com as deformações permanentes de cada placa estão apresentados na figura 147.

Teoricamente, quando a inclinação da curva da redução de vazios pela deformação permanente em trilha de roda é paralela a reta de igualdade, a redução de vazios corresponde à redução de volume ou seja é o afundamento; neste caso o afundamento é única e exclusivamente por consolidação. Em oposição, quando a inclinação é vertical, a redução de vazios é causada somente por fluência, ou seja, o afundamento é compensado por massa que se desloca e acumula-se nas bordas das placas.

Pode-se constatar que nas curvas da figura 147 a deformação permanente em trilha de roda ocorre simultaneamente por fluência e por consolidação. Misturas com baixos volumes de vazios iniciais apresentam inclinações acentuadas, 0 que denota um comportamento à deformação permanente em trilha de roda caracterizado por fluência principalmente, embora, observe-se trechos, para essas mesmas misturas, onde ocorrem simultaneamente redução por fluência e por consolidação. Já um comportamento à deformação permanente caracterizado mais por consolidação pode-se observar nas misturas asfálticas com vazios iniciais acima de $6 \%$. 


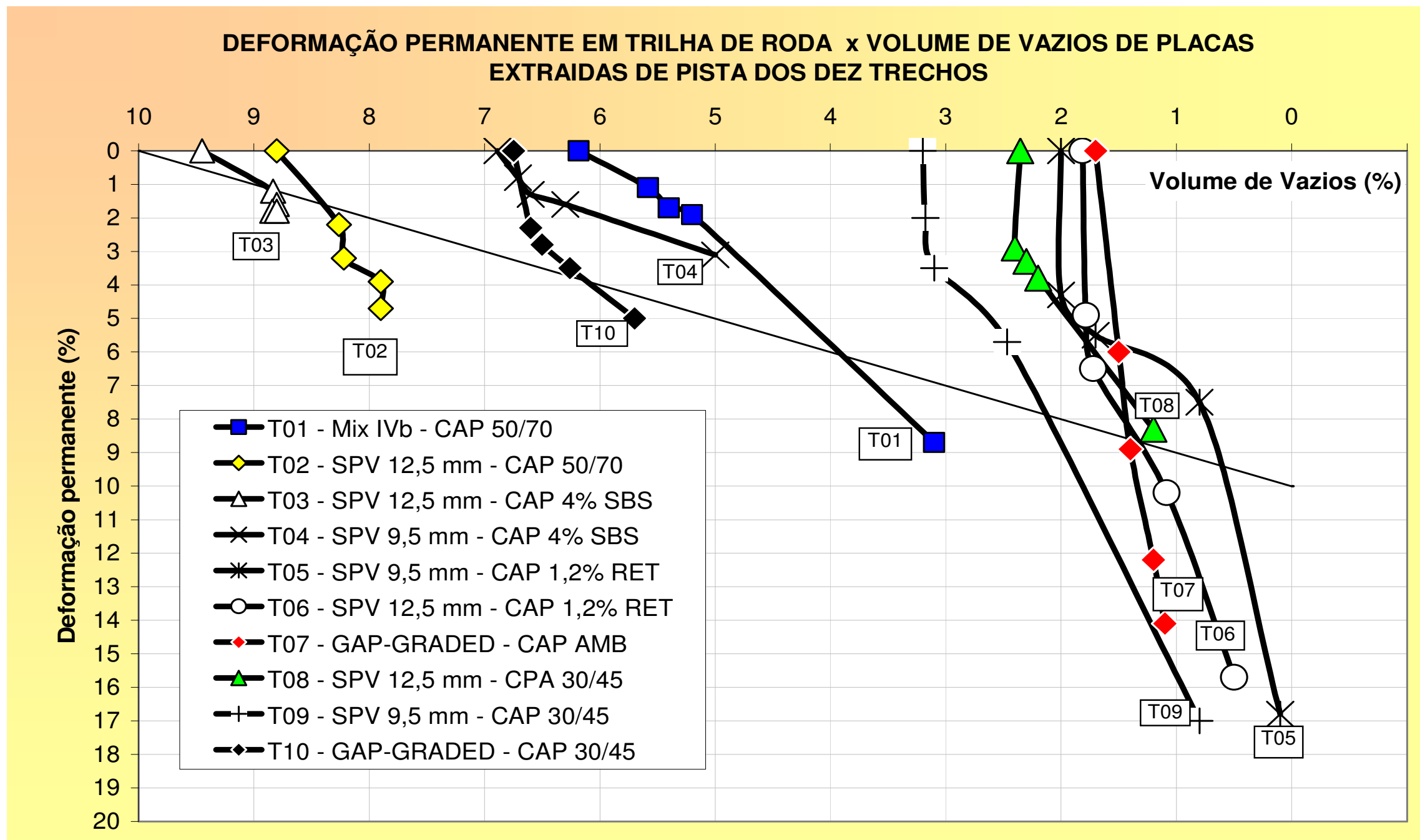

Figura 147 - Redução do volume de vazios com a deformação permanente em trilha de roda de laboratório deste experimento com placas de campo 
Para um estudo mais apurado, mais placas deveriam ter sido testadas e também incluídas placas para 10.000 ciclos. Porém a dificuldade de extração de tantas placas foi o fator condicionante mais forte no caso deste experimento. Para melhorar a acurácia na determinação dos volumes de vazios, dever-se-ia aplicar técnicas de determinação de vazios por raios gama, como é utilizado na França, ou por ressonância magnética, como no CENPES-PETROBRAS e na COPPE-URFJ. Porém estas facilidades não se encontravam disponíveis para esta pesquisa.

Para melhor análise da figura 147, os 10 trechos foram divididos em três grupos de evolução da redução dos vazios em função da deformação permanente. As misturas correspondentes aos trechos T05, T06, T07, T08 e T09 que caracterizam um grupo, apresentavam volumes de vazios iniciais relativamente baixos, na ordem de $2 \%$ a $3 \%$, e após terem sido submetidas ao simulador de tráfego de laboratório, o volume de vazios reduziu, em média de $2 \%$ após 30.000 ciclos. Para a mistura do trecho T09 a redução foi na ordem de $2,5 \%$, apontando um volume de vazios após 30.000 ciclos com o simulador de laboratório de 1,8\%. As deformações permanentes em trilha de roda para as cinco misturas asfálticas em foco apresentaram valores elevados, acima de $10 \%$, exceto para a mistura do trecho T08 que foi de $8,3 \%$.

Pode-se observar na tabela 47 que as misturas dos trechos T05, T06, T08 e T09 são de graduação contínua e densa, sendo que as misturas dos trechos T06, T08 e T09 apresentaram mais que $0,3 \%$ de excesso em ligante com relação ao indicado no projeto. A mistura do trecho T05, apesar de apresentar teor abaixo daquele de projeto, o resultado indica claramente que o teor projetado é excessivo e que, mesmo com 0,39\% a menos que o de projeto, a mistura ainda apresenta-se com teor em excesso. O mesmo pode ser constatado no projeto do Gap-graded, trecho T07, onde apesar de ter sido utilizado teor 0,92 abaixo do indicado em projeto, é ainda excessivo.

Em um outro grupo, podem-se incluir as misturas dos trechos T02 e T03. O primeiro apresentou um volume de vazios iniciais de $8,8 \%$ e sofreu uma redução na ordem de 1\%, já o trecho T03 os vazios iniciais foram de 9,5\% e 
finais de 8,8 com uma redução na ordem de 0,7\%. Estes valores de vazios iniciais indicam claramente que o teor de ligante empregado na obra está "pobre", abaixo do que seria o indicado para estas misturas. Observa-se pela tabela 47 anterior que no trecho T02, o teor empregado é 0,73\% menor que o de projeto, e que no caso do trecho T03 é 1,99\% menor! Observe-se que a deformação permanente em trilha de roda do trecho T02 após 30.000 ciclos foi de $4,7 \%$ e para o trecho T03 a deformação foi inferior a $2 \%$. Estes resultados correlacionam-se com o teor de ligante das misturas em foco:o teor de ligante asfáltico encontrado para a mistura do T02 foi de $4,75 \%$ e para o T03, o teor foi de 4,22. O teor reduzido de ligante auxilia na menor magnitude de afundamentos, embora outros fatores podem ser contribuintes: temperatura de usinagem e de execução, dentre outros aspectos relevantes. Deve-se ressaltar que os trechos T02 e T03 seriam rejeitados por um controle de compactação devido ao elevado volume de vazios iniciais. No entanto, para o teste, estes trechos eram válidos. Em termos de deformação permanente os resultados são baixos, porém para a fadiga, o desempenho dessas misturas asfálticas, provavelmente, não seriam bons, devido aos baixos teores de ligantes asfálticos apresentados.

Do terceiro grupo fazem parte as misturas dos trechos T01, T04 e T10, todas com volumes de vazios iniciais entre 6 e 7\%. As misturas T04 e T10 apresentaram boa resistência à deformação permanente em trilha de roda, $3,1 \%$ e $5,0 \%$ respectivamente, após 30.000 ciclos no simulador de tráfego tipo LCPC. O trecho T04 com vazios iniciais de $6,9 \%$ reduziu 1,9\% e o trecho T10, com os vazios iniciais de $6,8 \%$ foi para vazios finais de $5,8 \%$, com $1 \%$ de redução. Nestes dois trechos, os teores de ligante empregados na obra são inferiores aos indicados no projeto. Esta é uma das razões prováveis da compactação resultar em misturas com vazios entre 6 e $7 \%$.

O trecho T01, mistura usinada na faixa mix IVb I.A. com CAP 50/70, apresentou um volume de vazios iniciais de 6,2\% e após uma deformação permanente em trilha de roda de $8,3 \%$, os vazios finais foram de $3,1 \%$. Observa-se que o teor de ligante empregado na obra é 0,31\% acima daquele de projeto. No entanto, os vazios iniciais são de $6,2 \%$, que estão relacionados 
ao processo de compactação propriamente dito, com a possibilidade de emprego de temperatura inadequada na usinagem ou na compactação. $O$ valor de deformação permanente no simulador de tráfego relaciona-se conjuntamente ao teor em excesso e ao tipo de ligante. A mesma mistura asfáltica, com a mesma graduação, com teor de projeto e ligante convencional mais consistente ou ainda modificado, daria valores de afundamento inferiores ao determinado no teste de laboratório.

Pode-se verificar que a deformação permanente da mistura do trecho T01 de $3,1 \%$ foi por consolidação e a diferença, 5,2\% por fluência (deformação plástica), entretanto, pela forma da curva dessa mistura, figura 147, observe-se que tanto a parte da deformação por consolidação como também a parte de fluência ocorreram simultaneamente.

A simultaneidade da deformação por consolidação e por fluência é constatada para as misturas dos trechos T05, T06, T07, T08 e T09, consideradas aqui como do primeiro grupo. A deformação permanente por fluência foi mais acentuada, embora observe-se que uma pequena parcela de deformação permanente tenha ocorrido por consolidação. Já nas demais misturas do segundo e terceiro grupos as duas formas de deformação foram equivalentes se comparadas às misturas do primeiro grupo.

Os resultados de ensaios individuais de deformação permanente em trilha de roda de placas extraídas de cada trecho da pista fazem parte do Anexo II.

\subsection{Aptidão da compactação - PCG e deformação permanente em trilha de roda}

A dosagem das misturas asfálticas utilizadas na pista-teste foram feitas baseadas no método Marshall e os resultados encontrados estão apresentados no item 3.6 tabela 33. Com as placas extraídas da pista-teste e através de ensaios laboratoriais de extração e recuperação de ligante asfáltico, as 
divergências entre os teores de ligantes asfálticos de projeto e obtidos na pistateste estão apresentados na tabela 47. Com a determinação da granulometria das misturas de pista, foi possível reconstituir os traços da pista-teste em laboratório.

O objetivo da reconstituição das misturas asfálticas da pista-teste em laboratório foi de ensaiar essas misturas asfálticas na PCG, conforme o procedimento francês de dosagem de misturas asfálticas (LCP, 2007) e também com o ensaio de deformação permanente em trilha de roda com simulador de tráfego. Com esses ensaios é possível detectar incompatibilidades de formulação (principalmente quanto ao teor de ligante asfáltico) das misturas asfálticas da pista-teste quanto à deformação permanente em trilha de roda.

Embora ensaios prévios com 10 misturas asfálticas tenham sido feitos no simulador de tráfego de laboratório, a alteração de empresa responsável pela execução dos trechos da pista-teste provocou a impossibilidade de repetição dos ensaios com o material que efetivamente empregado na obra, antes de sua execução, como seria o desejável. Esta decisão foi tomada para não perder a oportunidade de execução da obra e da pesquisa, de maneira a não inviabilizar o cronograma de obras e apoio ao estudo.

\subsubsection{Ensaio com a prensa de cisalhamento giratório - PCG}

Os ensaios com a PCG e também com o simulador de tráfego para a determinação da deformação permanente em trilha de roda dividiram-se em duas partes. A primeira parte contemplou os dois ensaios com misturas asfálticas usinadas na granulometria e no teor de ligante asfáltico encontrado na pista-teste e na segunda parte o teor de ligante asfáltico foi corrigido, para cima ou para baixo, em função dos resultados da PCG e da deformação permanente encontrados na primeira parte e também esse novo teor (corrigido) 
foi baseado na experiência laboratorial do presente autor da pesquisa adquirida no Laboratório de Tecnologia de Pavimentação da USP.

A seguir são apresentados nas figuras 148 a 157 os resultados de aptidão de compactação com a PCG e os resultados de deformação permanente em trilha de roda das misturas asfálticas usinadas em laboratório para dois teores de ligantes asfálticos, para os 10 trechos em questão.

Para as misturas asfálticas correspondentes aos trechos T01, T02, T03, T06 e T08, as composições granulométricas possuem diâmetro máximo de $19,1 \mathrm{~mm}$ (3/4"); o valor de D (diâmetro máximo nominal - procedimento francês, descrito no item 2.4) é de $14 \mathrm{~mm}$, logo essas misturas asfálticas foram denominadas de $0 / 14$.

Nas misturas T04, T05 e T09 que apresentam em suas distribuições granulométricas o diâmetro máximo de $12,5 \mathrm{~mm}$, o valor de D para essas misturas foi de $10 \mathrm{~mm}$ pelo método francês; sua denominação foi de 0/10.

No LCP (2007), são especificados os limites máximos e mínimos de volume de vazios correspondentes ao número de giros que a mistura asfáltica deve apresentar para que a dosagem seja considerada adequada; em seguida devem ser submetidas ao próximo nível de ensaios, que é o de deformação permanente no simulador de tráfego tipo LCPC. Apresentam-se na tabela 48 esses limites praticados pelos franceses.

Tabela 48 - Volume de vazios - 0/10 e 0/14 (MANUEL LCP, 2007)

\begin{tabular}{|c|c|}
\hline \multicolumn{2}{|c|}{ Mistura } \\
\hline $\begin{array}{c}0 / 10 \\
(\mathrm{f} \times 9,5 \mathrm{~mm} \text { desta tese) }\end{array}$ & $\begin{array}{c}0 / 14 \\
(\mathrm{fx} 12,5 \mathrm{~mm} \text { desta tese) }\end{array}$ \\
\hline 5 & 4 \\
\hline 10 & 9 \\
\hline 60 & 80 \\
\hline
\end{tabular}


APTIDÃO DE COMPACTAÇÃO - PCG e DEFORMAÇÃO PERMANENTE EM TRILHA DE RODA Trecho - T01 - Fx. Mix Ivb I.A. - CAP 50/70 - Teor de ligante asfáltico de pista e corrigido

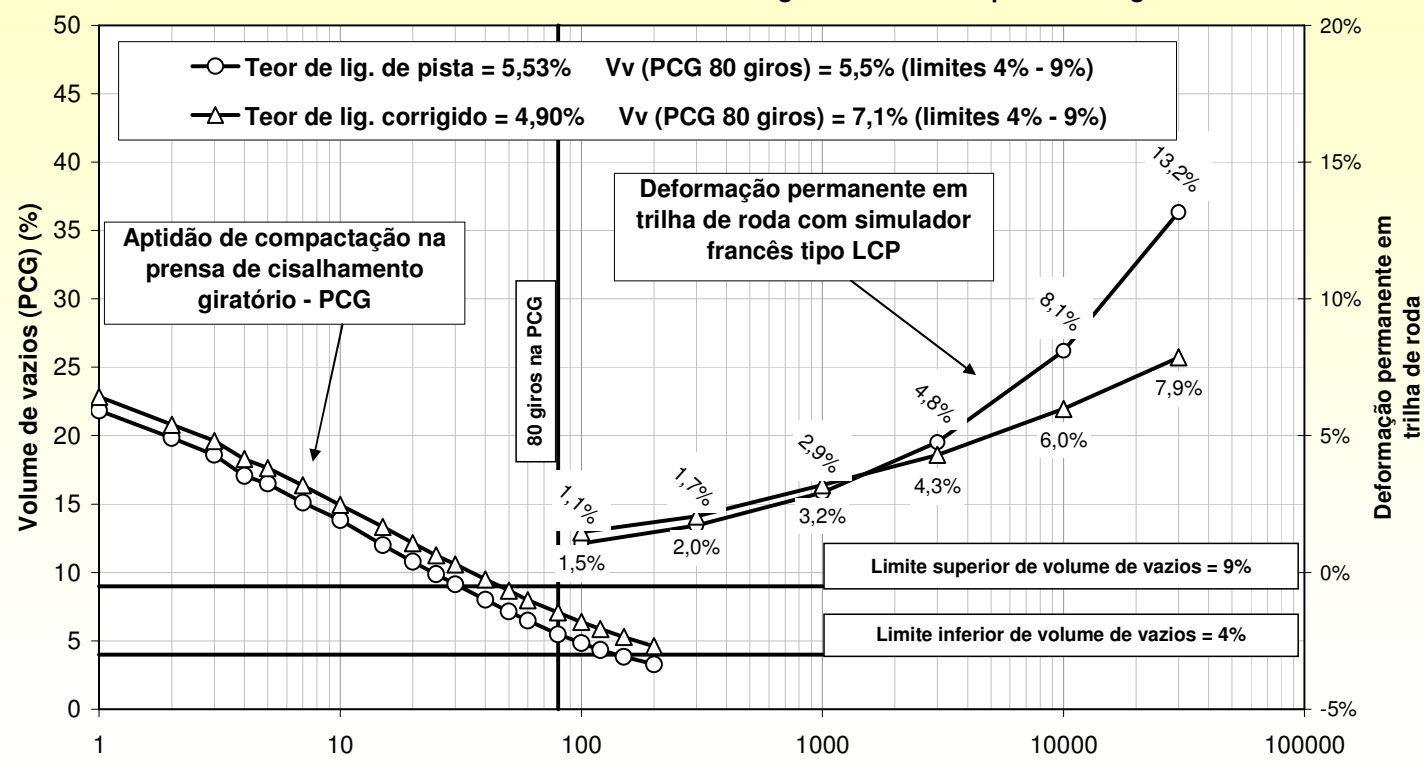

Número de Giros (n) (PCG) e Número de ciclos no simulador tipo LCP

Figura 148 - Aptidão de compactação - PCG e DP - trecho T01

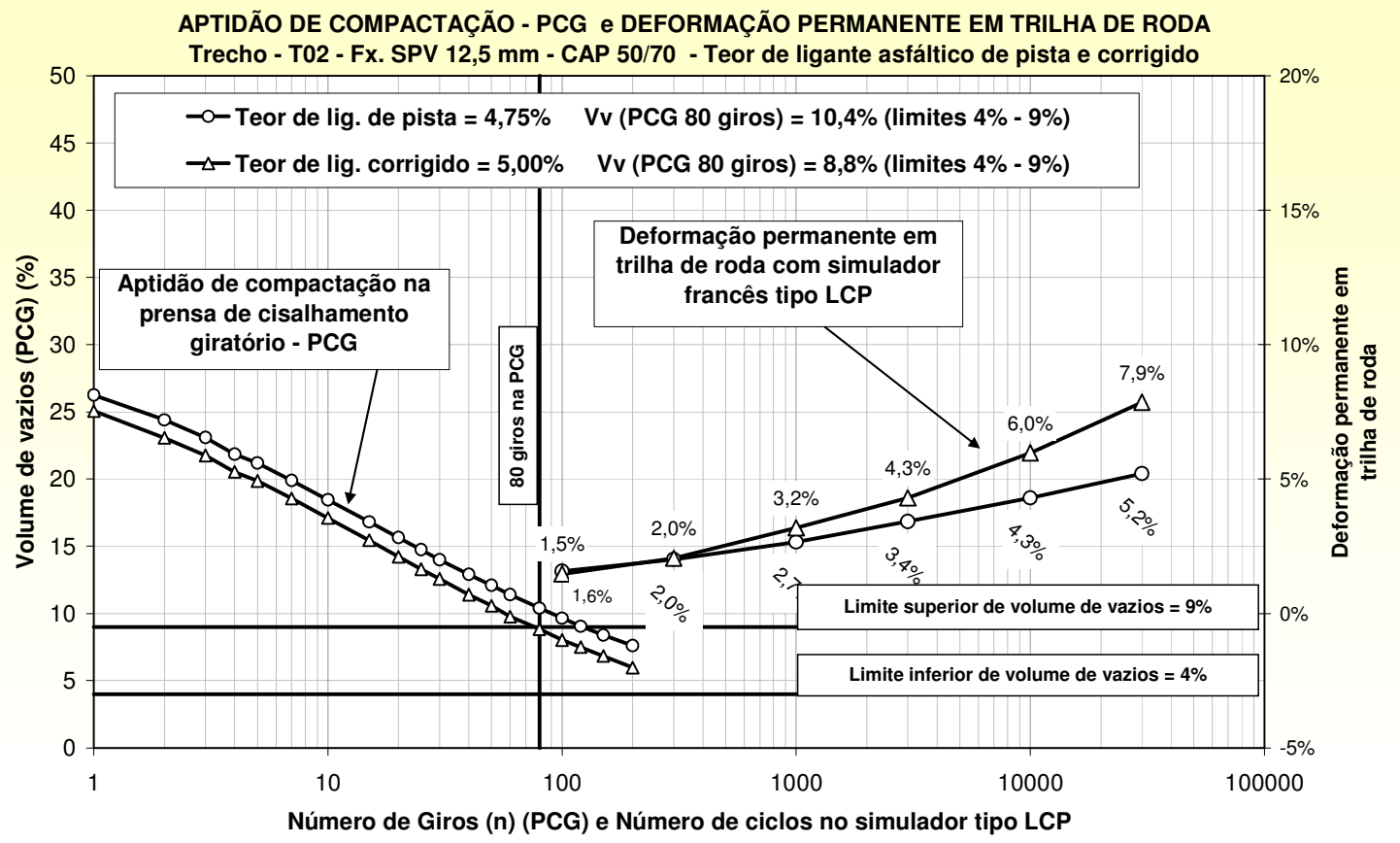

Figura 149 - Aptidão de compactação - PCG e DP - trecho T02 


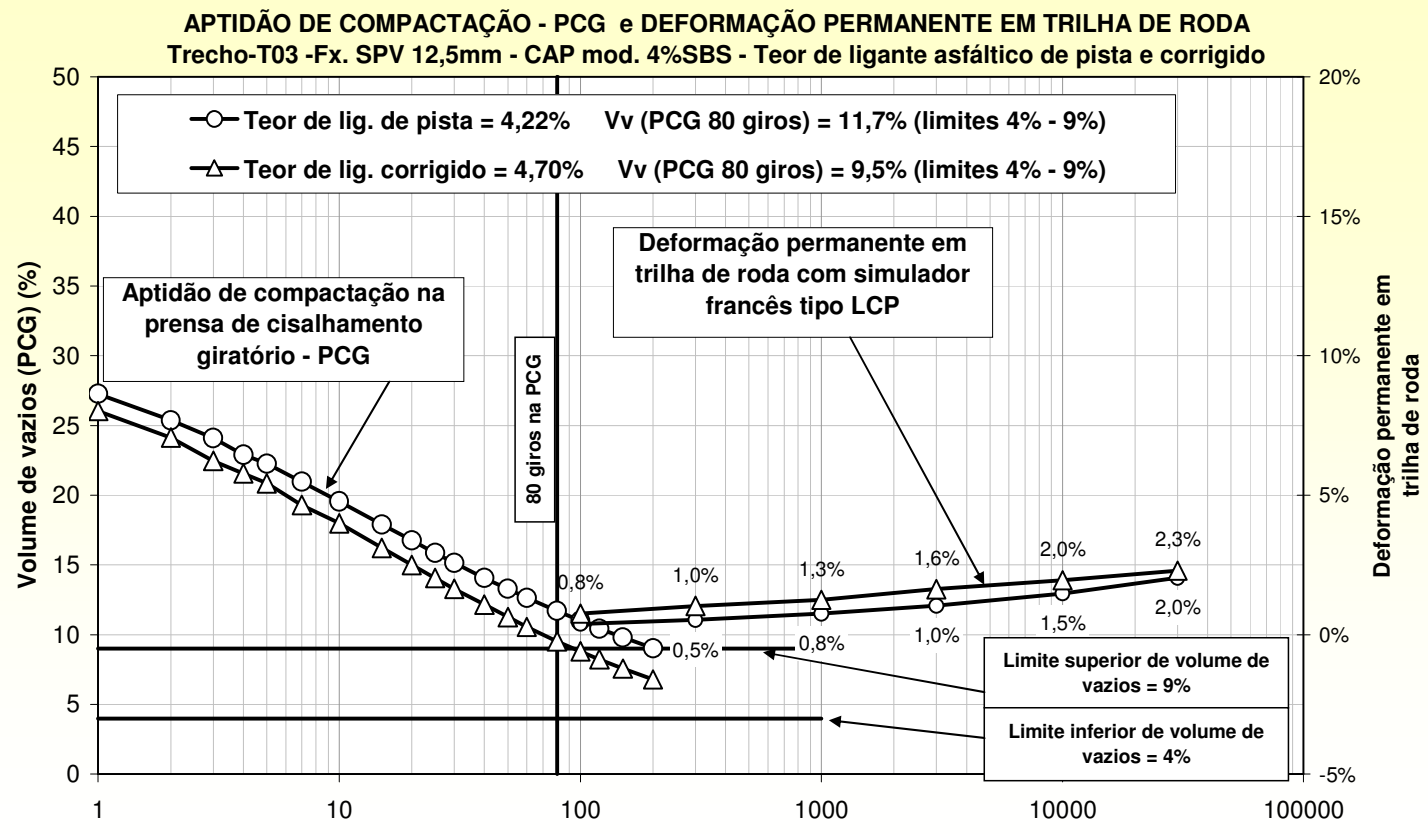

Número de Giros (n) (PCG) e Número de ciclos no simulador tipo LCP

Figura 150 - Aptidão de compactação - PCG e DP - trecho T03

APTIDÃO DE COMPACTAÇÃO - PCG e DEFORMAÇÃO PERMANENTE EM TRILHA DE RODA Trecho - T04-Fx. SPV 9,5 mm -CAP mod. 4\%SBS - Teor de ligante asfáltico de pista e corrigido

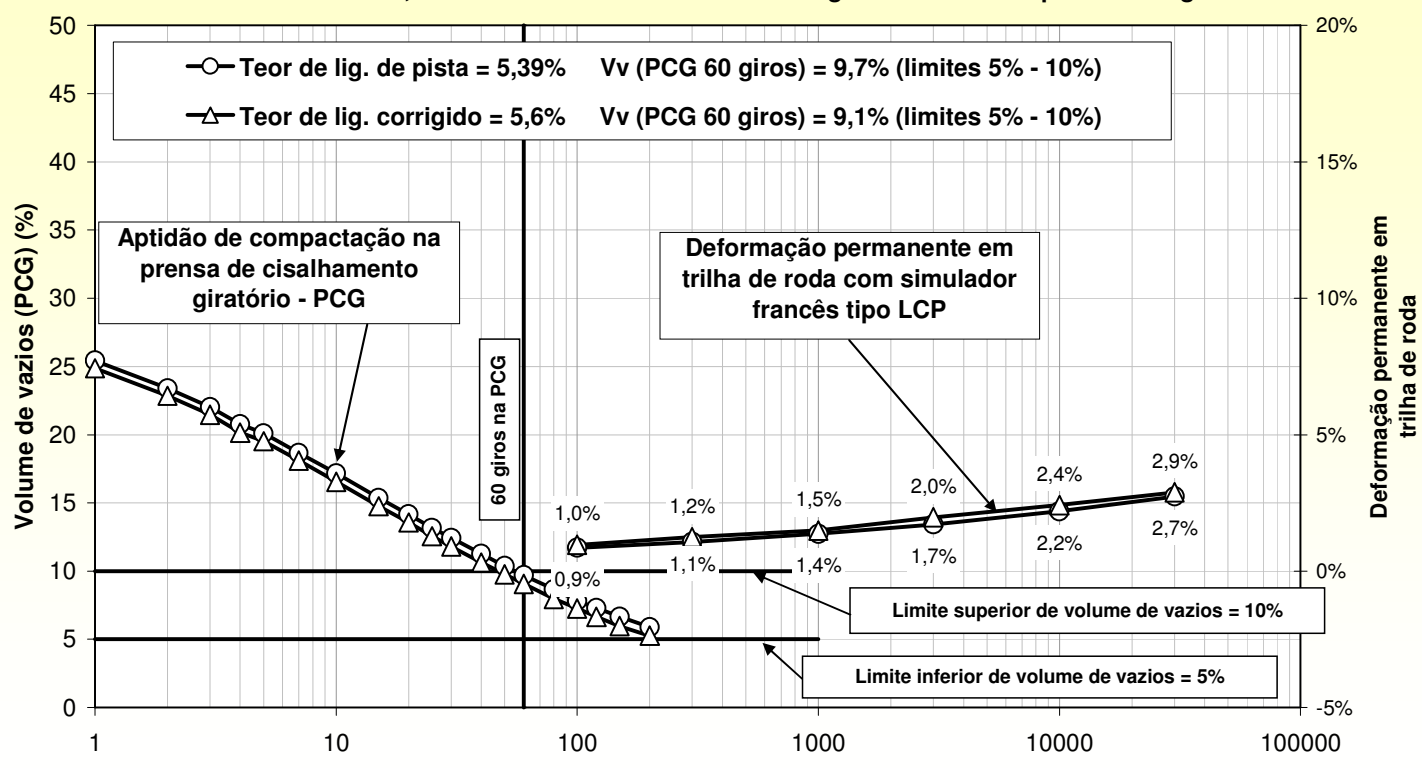

Número de Giros (n) (PCG) e Número de ciclos no simulador tipo LCP

Figura 151 - Aptidão de compactação - PCG e DP - trecho T04 
APTIDÃO DE COMPACTAÇÃO - PCG e DEFORMAÇÃO PERMANENTE EM TRILHA DE RODA Trecho. T05 FX. SPV 9,5 mm - CAP mod 1,2\%RET -Teor de ligante asfáltico de pista e corrigido

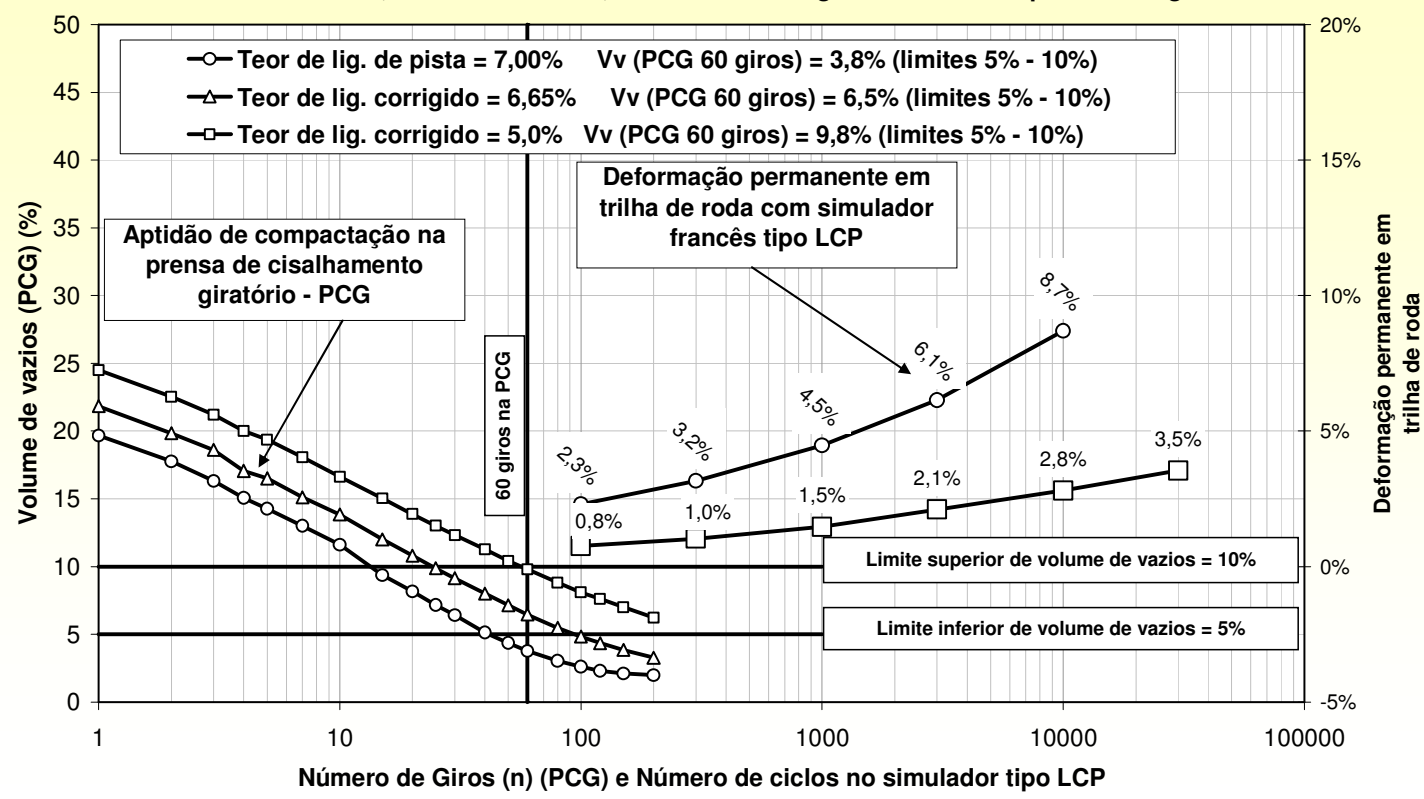

Figura 152 - Aptidão de compactação - PCG e DP - trecho T05

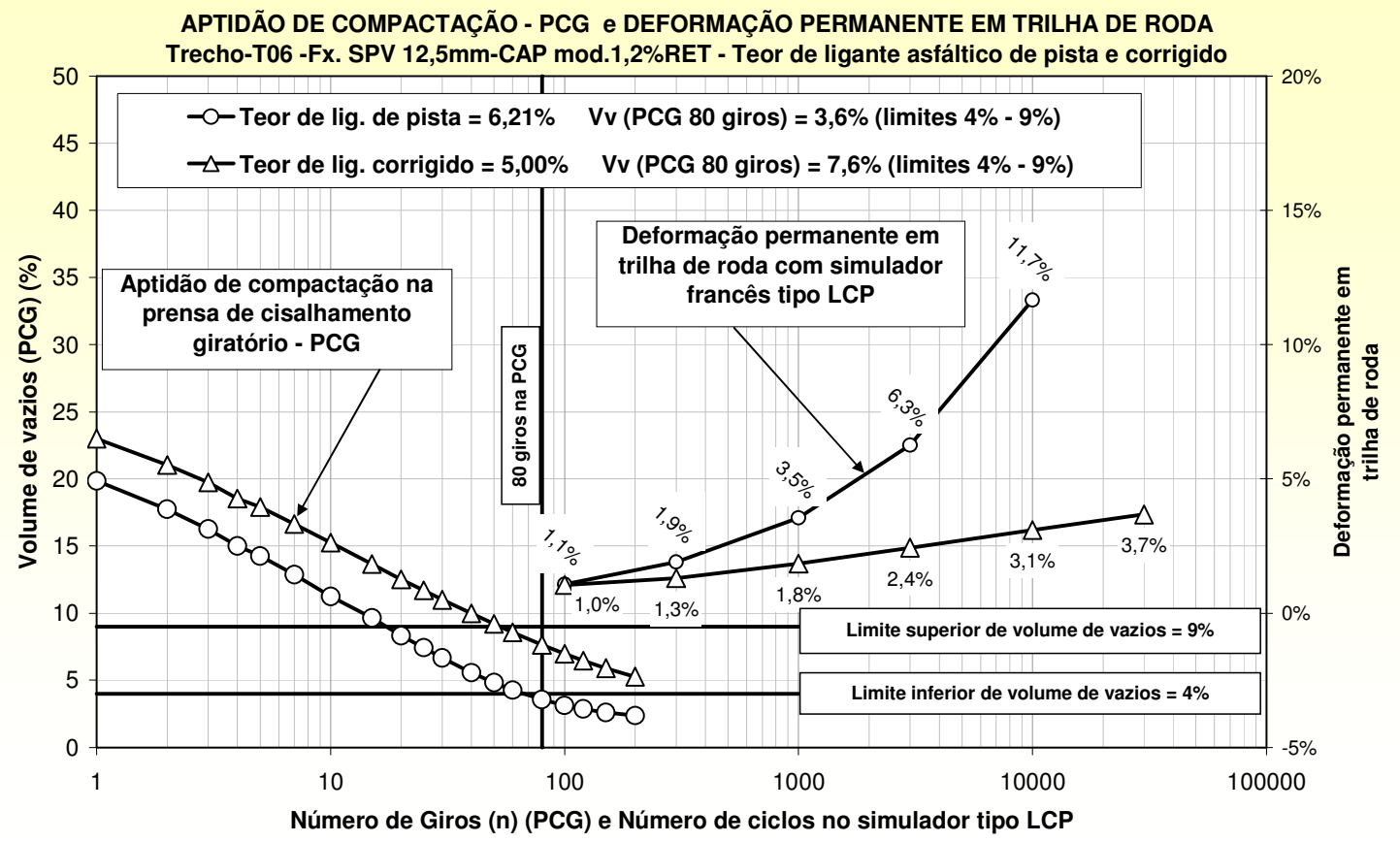

Figura 153 - Aptidão de compactação - PCG e DP - trecho T06 


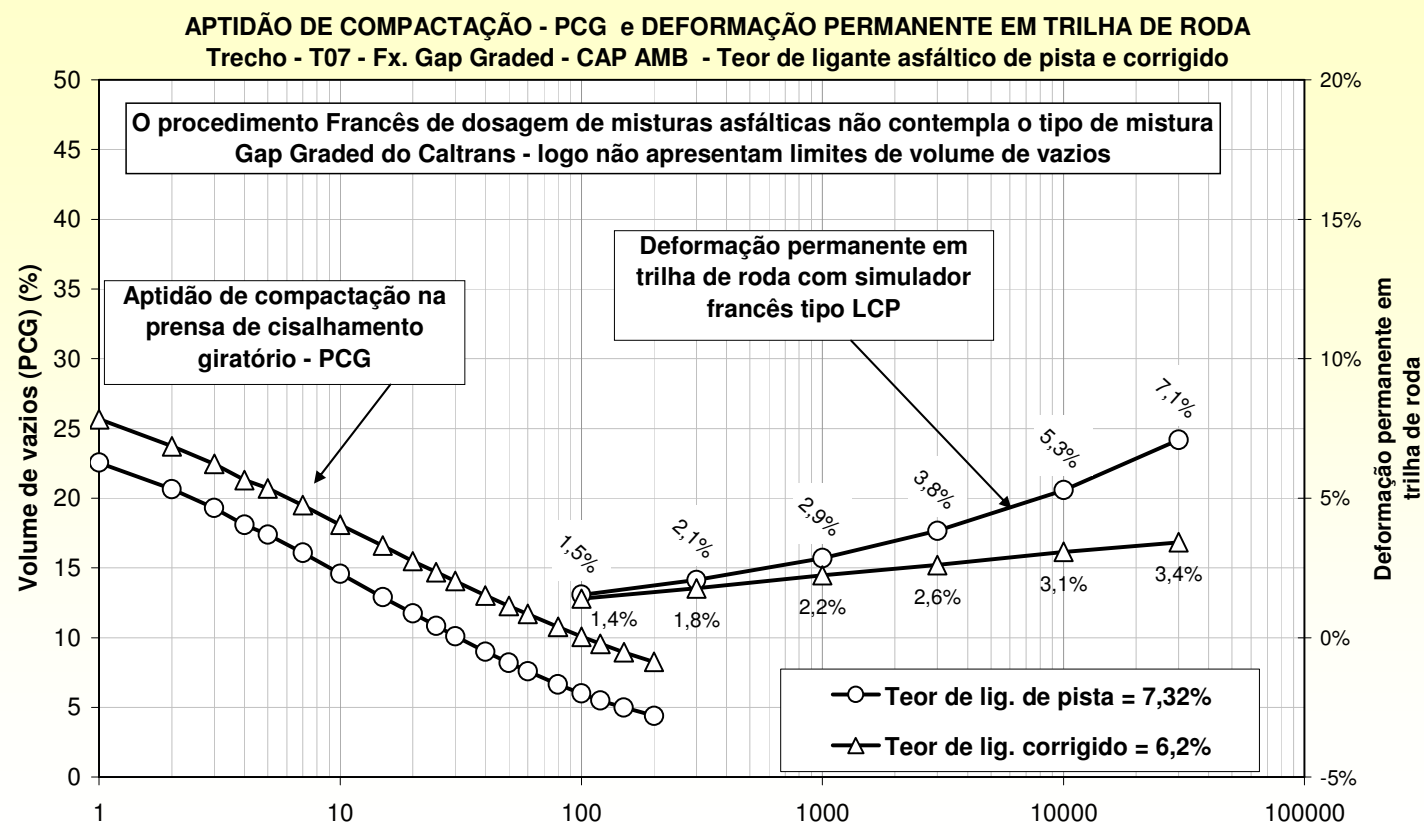

Número de Giros (n) (PCG) e Número de ciclos no simulador tipo LCP

Figura 154 - Aptidão de compactação - PCG e DP - trecho T07

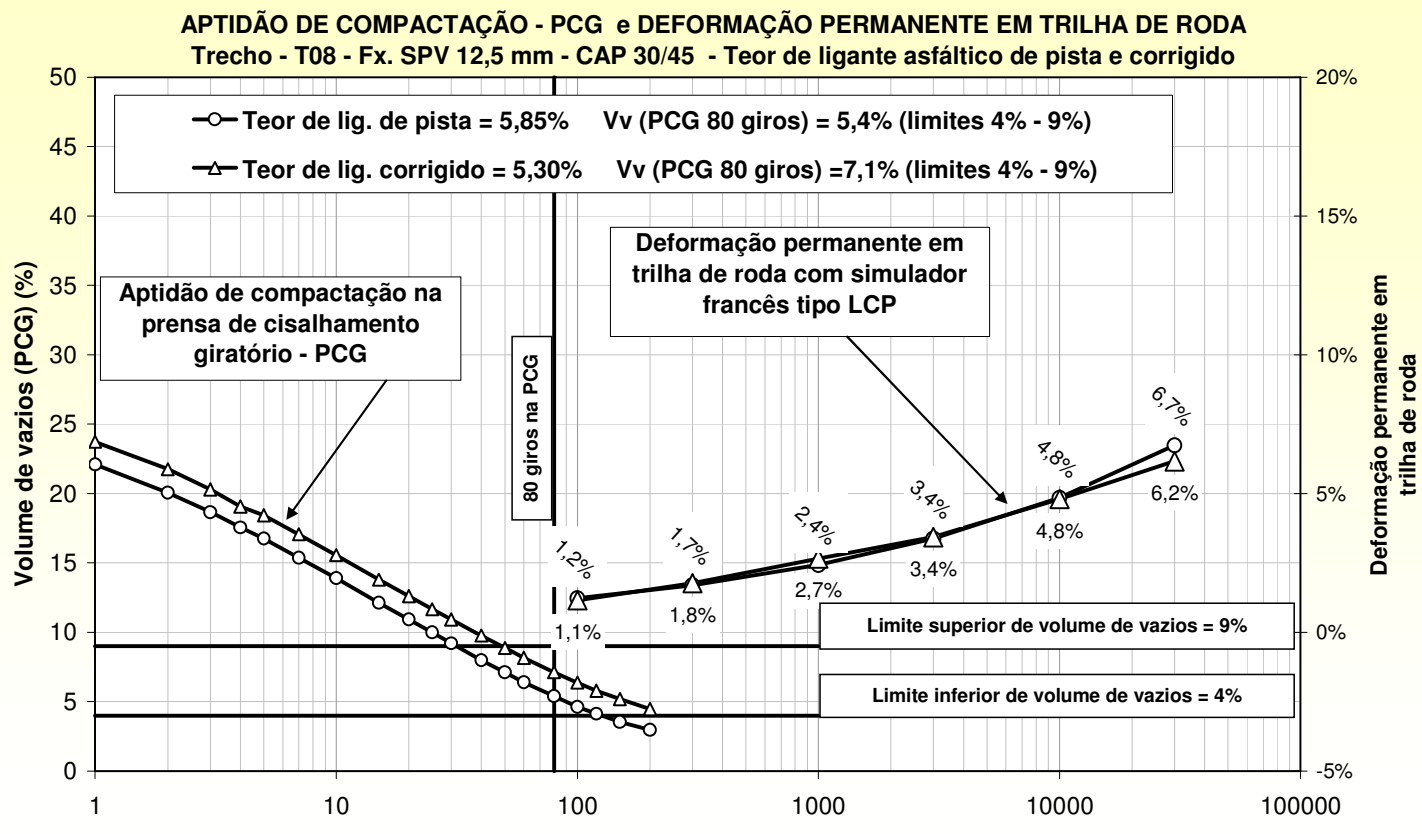

Número de Giros (n) (PCG) e Número de ciclos no simulador tipo LCP

Figura 155 - Aptidão de compactação - PCG e DP - trecho T08 


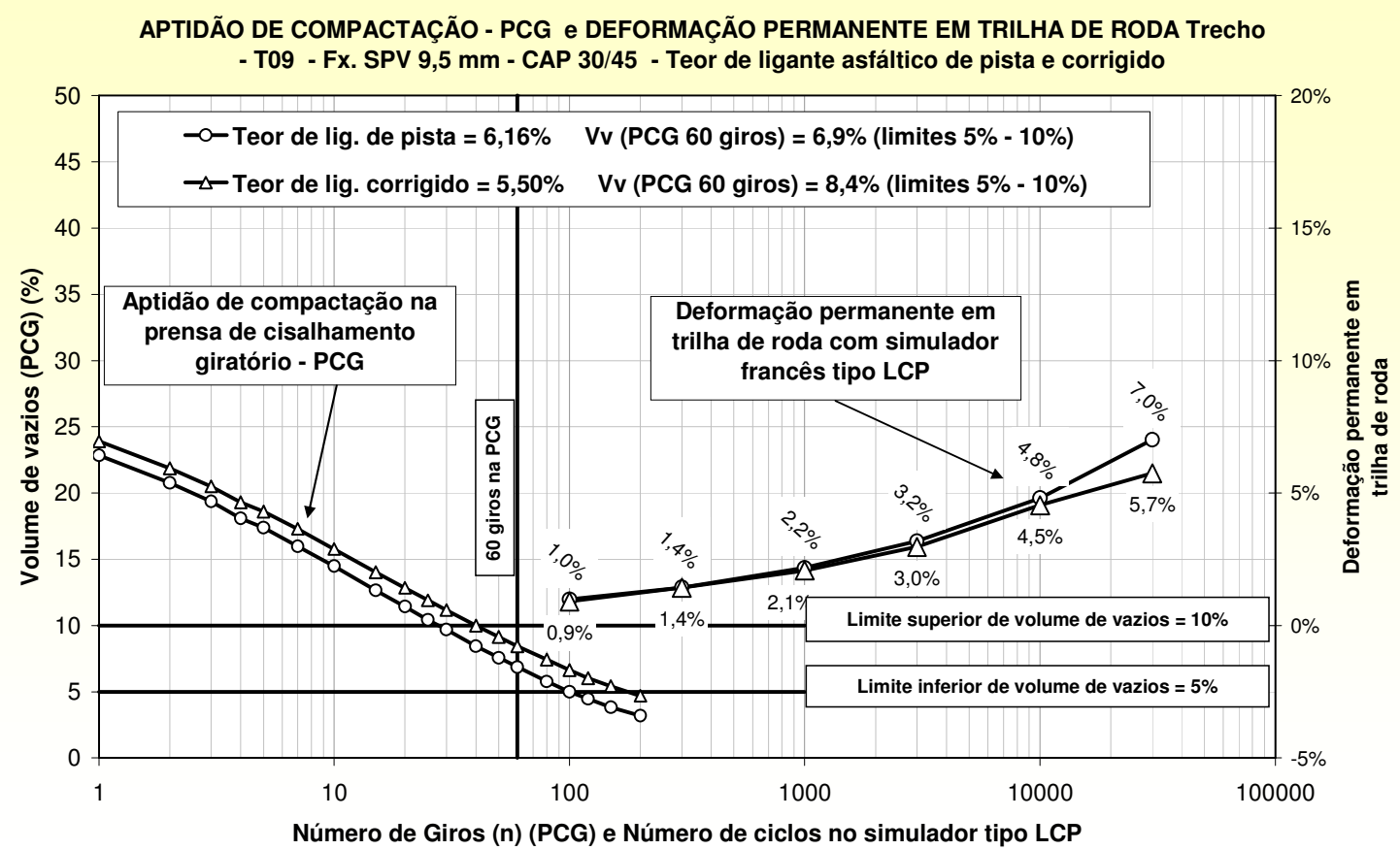

Figura 156 - Aptidão de compactação - PCG e DP - trecho T09

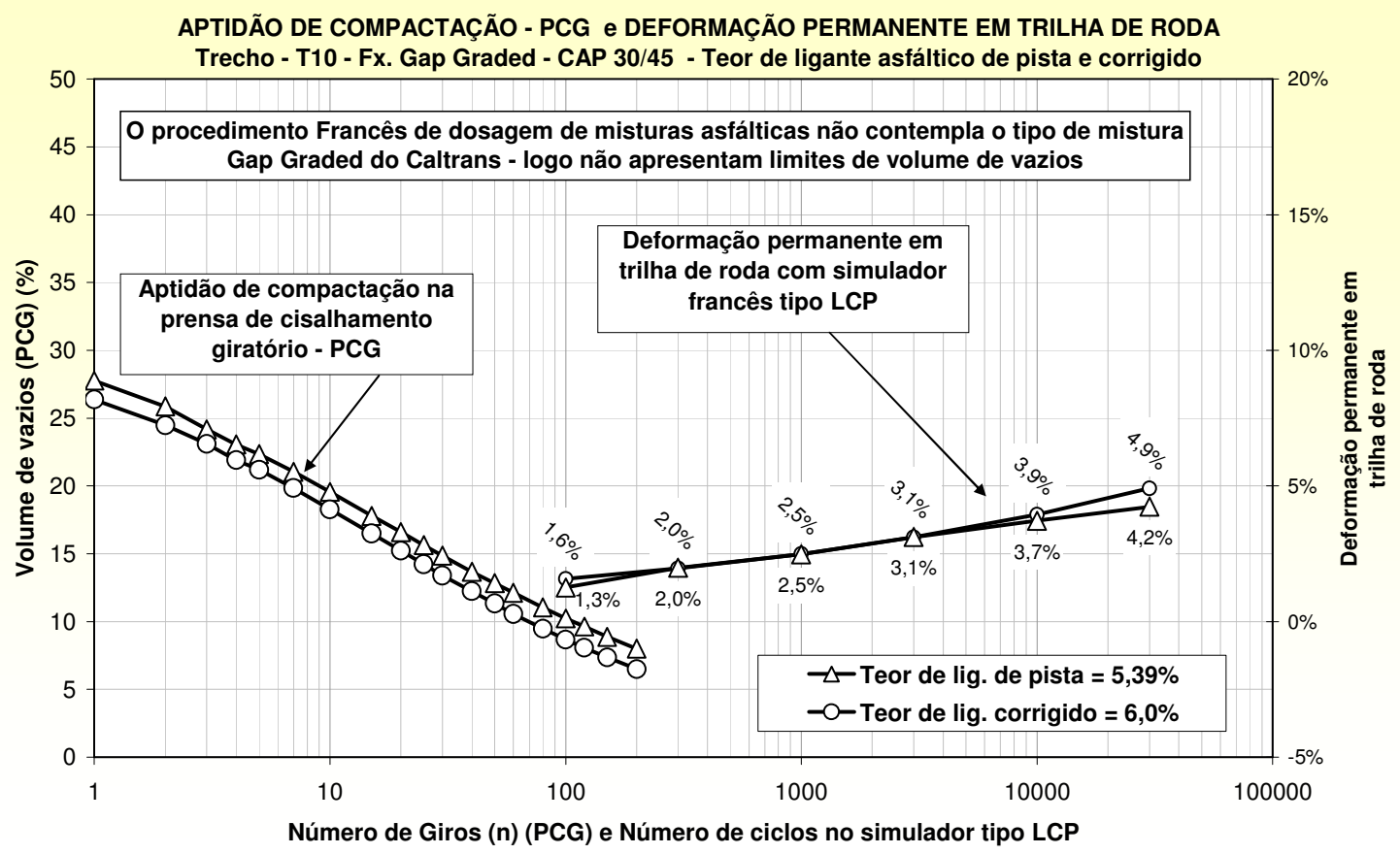

Figura 157 - Aptidão de compactação - PCG e DP - trecho T10

Na tabela 49 mostra-se o resumo dos resultados com a PCG e a deformação permanente em trilha de roda, apresentados nas figuras 148 a 157. 
Tabela 49 - Resumo dos valores da PCG e deformação permanente dos 10 trechos

\begin{tabular}{c|c|c|c|c|c|}
\hline \multirow{2}{*}{ Trecho } & \multicolumn{2}{|c|}{ Tipo de mistura } & \multicolumn{3}{c|}{ Teor de Pista } \\
\cline { 2 - 6 } n. & $\begin{array}{c}\text { Faixa } \\
\text { Granulometrica }\end{array}$ & $\begin{array}{c}\text { Tipo de } \\
\text { Ligante }\end{array}$ & $\begin{array}{c}\text { Teor lig. } \\
\%\end{array}$ & $\begin{array}{c}\text { PCG } \\
\% \text { Vv }\end{array}$ & $\begin{array}{c}\text { Dp } \\
\text { (\%) }\end{array}$ \\
\hline T01 & Mix Ivb I.A. & CAP 50/70 & 5,53 & 5,5 & 13,2 \\
T02 & SPV 12,5 mm & CAP 50/70 & 4,75 & 10,4 & 5,2 \\
T03 & SPV 12,5 mm & $4 \%$ SBS & 4,22 & 11,7 & 2,0 \\
T04 & SPV 9,5 mm & $4 \%$ SBS & 5,39 & 9,7 & 2,7 \\
T05 & SPV 9,5 mm & $1,2 \%$ RET & 7,00 & 3,8 & $8,7 / 18^{* *}$ \\
T06 & SPV 12,5 mm & $1,2 \%$ RET & 6,21 & 3,6 & $11,7 / 15,7^{\star *}$ \\
T07 & Gap Graded & AMB & 7,32 & $\left(^{*}\right)$ & 7,1 \\
T08 & SPV 12,5 mm & CAP 30/45 & 5,85 & 5,4 & 6,7 \\
T09 & SPV 9,5 mm & CAP 30/45 & 6,16 & 6,9 & 7,0 \\
T10 & Gap Graded & CAP 30/45 & 5,39 & $\left(^{*}\right)$ & 4,2 \\
\hline
\end{tabular}

\begin{tabular}{|c|c|c|c|c|}
\hline \multicolumn{3}{|c|}{ Teor corrigido } & \multicolumn{2}{|c|}{ PCG limites } \\
\hline $\begin{array}{c}\text { Teor lig. } \\
\%\end{array}$ & $\begin{array}{l}\text { PCG } \\
\% \text { VV }\end{array}$ & $\begin{array}{l}\text { Dp } \\
(\%)\end{array}$ & Giros & $\begin{array}{l}\text { mites } \\
\text { Vv (\%) }\end{array}$ \\
\hline 4,90 & 7,1 & 7,9 & 80 & 4 a 9 \\
\hline 5,00 & 8,8 & 7,9 & 80 & 4 a 9 \\
\hline 4,70 & 9,5 & 2,3 & 80 & 4 a 9 \\
\hline 5,60 & 9,1 & 2,9 & 60 & 5 a 10 \\
\hline 5,00 & 9,8 & 3,5 & 60 & 5 a 10 \\
\hline 5,00 & 7,6 & 3,7 & 80 & 4 a 9 \\
\hline 6,20 & $\left({ }^{*}\right)$ & 3,4 & & \\
\hline 5,30 & 7,1 & 6,2 & 80 & 4 a 9 \\
\hline 5,50 & 8,4 & 5,7 & 60 & 5 a 10 \\
\hline 6,00 & $\left({ }^{*}\right)$ & 4,9 & & \\
\hline
\end{tabular}

(*) tipo de mistura não contemplada pelo procedimento francês de dosagem

$\left.{ }^{(*}\right)$ valores extrapolados por regressão para $\mathbf{3 0 . 0 0 0}$ cilcos

Serão feitas comparações dos ensaios realizados com a PCG e com o simulador de tráfego, a cada dois tipos de misturas asfálticas, procurando-se evidenciar o desempenho associado ao tipo e teor de ligante asfáltico, e principalmente à distribuição granulométrica utilizada.

\section{Trechos T07 e T10}

Observe-se que nas figuras 154 e 157, correspondentes ao tipo de mistura asfáltica gap -graded do Caltrans, trechos T07 e T10 não são apresentados os limites máximos e mínimos dos vazios e, por conseguinte, não possuem um número de giros referência. Trata-se de um tipo de mistura asfáltica que não possui especificação francesa.

Observe-se na figura 154, correspondente ao trecho T07, faixa gap graded com ligante modificado por borracha, que com a redução no teor de ligante asfáltico de $7,32 \%$ de pista para teor corrigido de 6,20\%, ocorreu uma diminuição na deformação permanente em trilha de roda de $7,1 \%$ para $3,4 \%$ para placas moldadas em laboratório, denotando a sensibilidade do comportamento à deformação permanente face ao teor de ligante.

A mesma sensibilidade é constatada nas curvas de aptidão de compactação com a PCG. Registra-se que esses valores foram obtidos em misturas asfálticas usinadas em laboratório, pois a deformação permanente em trilha de roda em placas extraídas de pista foi superior, na ordem de 14\% para 30.000 ciclos. Provavelmente essa diferença está relacionada às condições com que a mistura asfáltica foi produzida na usina e compactada na pista, pois como se 
trata de ligante asfáltico modificado por borracha é necessário temperaturas mais elevadas na usinagem. Caso tenha ocorrido uma elevação acima da temperatura recomendada, o ligante asfáltico tornou-se menos viscoso o que acabou por propiciar um maior fechamento dos vazios em pista.

Para a mistura asfáltica correspondente ao trecho $T 10$, a mesma faixa do trecho T07 e usinada com o ligante asfáltico CAP 30/45, pode ser observado 0 mesmo tipo de comportamento frente à variação no teor de ligante asfáltico: com o aumento de $0,61 \%$ no teor, ocorreu um acréscimo da deformação permanente em trilha de roda de $0,7 \%$, passando de $4,2 \%$ para $4,9 \%$ aos 30.000 ciclos (figura 157).

O teor de ligante asfáltico inicial de 7,32\% no trecho T07 mostrou-se muito alto e a redução no teor para $6,20 \%$ (1,1\% abaixo) causou um impacto positivo na resistência à deformação permanente. No trecho T10, o teor corrigido foi de $6,0 \%, 0,2 \%$ abaixo do teor corrigido de 6,2\% do trecho T07, apresentou um resultado satisfatório de deformação permanente (4,9\% aos 30.000 ciclos). Essa pequena diferença nos teores de ligante asfáltico, 0,2\% ocasionou uma diferença relativamente grande na resistência à deformação permanente, mas também se deve à diferença nos tipos de ligantes utilizados em cada mistura. O ligante asfáltico modificado por borracha, devido à sua maior consistência e recuperação elástica, apresenta maior resistência à deformação permanente em trilha de roda. Ou seja, a reologia do ligante asfáltico tem um papel importante no teor de projeto e na deformação permanente.

Trecho T05 e T06

O trecho T05, faixa SPV $9,5 \mathrm{~mm}$ e ligante asfáltico modificado por $1,2 \%$ de RET com teor de ligante asfáltico de pista de $7,0 \%$, mostrou deformação permanente em trilha de roda elevada de 8,7\% para 10.000 ciclos. Extrapolando por regressão exponencial para 30.000 ciclos a deformação passaria para $18 \%$. Verificou-se para o trecho T06, mistura usinada na faixa SPV $12,5 \mathrm{~mm}$ com o mesmo ligante asfáltico, no teor de pista de $6,2 \%$, um valor de deformação permanente de 11,7\% para número de ciclos de 10.000 e 
extrapolando por regressão exponencial passaria a 15,7\% de deformação a 30.000 cilcos.

Com a redução para 5.0\% em ambas misturas dos trechos T05 e T06, os valores de deformação permanente em trilha de roda, passaram para 3,5\% e $3,7 \%$ para 30.000 ciclos respectivamente. Observe-se que para a faixa de 9,5mm, o teor de ligante empregado poderia ter sido maior, uma vez que o volume de vazios pela PCG foi de 9,8\%; a mistura com faixa de $12,5 \mathrm{~mm}$ apresentou $7,6 \%$ de vazios para o mesmo número de giros. A faixa $9,5 \mathrm{~mm}$ pode ser considerada "pobre" em ligante para o valor de 5,0\% de teor adotado (figuras 152 e 153).

\section{Trechos T08 e T09}

Comportamento semelhante aos observados nos trechos T05 e T06, pode ser observado nos trechos T08 e T09, com graduação SPV 12,5 mm e SPV 9,5 $\mathrm{mm}$ respectivamente, ambos usinados com ligante CAP 30/45. A variação de 0,55\% no teor da mistura do trecho T08 não propiciou ganhos significativos de resistência à deformação, passando de 6,7\% para 6,2\%. Para a graduação empregada, não se consegue reduzir significativamente a deformação permanente. A redução no teor de ligante pode auxiliar, mas poderá afetar 0 comportamento da mistura quanto à fadiga (figura 155).

Já para o trecho T09 apresentado na figura 149, faixa SPV 9,5 mm, distribuição granulométrica mais fina que a apresentada no trecho T08 e com o mesmo ligante asfáltico CAP 30/45, o valor final de deformação permanente em trilha de roda foi menor, $(5,7 \%)$ para um teor de ligante asfáltico de 5,50\%, e superior ao da T08. Note-se que, para o trecho T08, o teor de 5,3\% (0,2\% abaixo do apresentado do trecho T09) a deformação foi maior, (de 6,2\% contra 5,7\% no T09). Possivelmente, 5,30\% como teor corrigido ainda seja elevado para o tipo de graduação da mistura.

\section{Trechos T03 e T04}

Nesses dois trechos, figuras 150 e 151, foi utilizado ligante asfáltico modificado por 4\% de SBS. A diferença entre eles consiste na graduação: o trecho T03 
com faixa SPV $12,5 \mathrm{~mm}$ e o trecho T04 com SPV 9,5 mm. O trecho T03 com teor de ligante asfáltico de pista de 4,22\% apresentou um valor baixo de deformação permanente em trilha de roda (2,0\%). Um acréscimo de $0,48 \%$ no teor de ligante levou a um valor da deformação permanente praticamente inalterado de (2,3\%). O tipo de ligante asfáltico e os baixos teores propiciaram essa resistência à deformação permanente em trilha de roda.

A mistura asfáltica utilizada no trecho T04 possui característica mais fina, ou seja, com agregados de menor dimensão e maior superfície específica se comparada com a T03. Portanto, o teor de projeto é superior ao T03. Um teor de ligante inicial de 5,39\% apresentou uma deformação de 2,7\%; com uma correção de $0,21 \%$ no teor de ligante para cima, a deformação passou de 2,7\% para 2,9\%. Estes valores são baixos e são considerados excelentes no quesito de resistência à deformação permanente e o ligante asfáltico, devido as suas propriedades reológicas foi determinante para esse bom desempenho.

\section{Trechos T04, T05 e T09}

Comparando-se o trecho T04 com o trecho T09, que possuem a mesma distribuição granulométrica, teores corrigidos similares 5,6\% e 5,5\%, respectivamente, mas tipos de ligantes asfálticos diferentes, 4\% de SBS e CAP 30/45 respectivamente, apresentaram comportamento em laboratório à deformação permanente distintos: o trecho T04 com 2,9\% e trecho T09 com $5,7 \%$ de afundamento após 30.000 ciclos. Mais uma vez fica confirmada a importância da reologia do ligante asfáltico no comportamento à deformação permanente (figura 151 e 156).

O trecho T05, figura 152, usinado com ligante asfáltico modificado por 1,2\% de RET e teor de ligante de 5,0\%, apresentou uma deformação permanente de $3,5 \%$. Para esta mistura dever-se-ia ter utilizado um teor um pouco superior aos 5\% empregados na mistura para este ensaio, de modo a reduzir ligeiramente o volume de vazios aos 60 giros. Essas comparações evidenciam o bom comportamento à resistência a deformação permanente em trilha de roda do ligante asfáltico modificado por $4 \%$ de polímero, seguido pelo ligante modificado por $1,2 \%$ de RET. 


\section{Trechos T01 e T02}

Os trechos T01 e T02 mostrados nas figuras 148 e 149 utilizaram o ligante asfáltico convencional CAP 50/70, com diferenças quanto à graduação: o trecho T01 usinado na faixa mix IVb I.A. e o trecho T02 com a faixa SPV 12,5 $\mathrm{mm}$. Embora, sejam faixas diferentes, as distribuição granulométrica dos dois trechos ficaram relativamente próximas, conforme pode ser observadas nas figuras 65 e 66 . Com a correção no teor de ligante de 5,53\% para 4,9\% para trecho T01, a deformação caiu de 13,2 para 7,9\%. Este resultado realça a grande sensibilidade das misturas usinadas com CAP 50/70 quanto à deformação permanente. No trecho T02, elevando-se de 4,75\% para 5,0\% 0 teor de ligante, a deformação elevou-se de 5,2\% para 7,9\%, corroborando com o afirmado anteriormente. Deve-se ainda realçar que $4,75 \%$ de ligante levou a um volume de vazios de $10,4 \%$ na PCG, fora da especificação de 4 a $9 \%$ aos 80 giros. O valor de 7,9\% de deformação permanente obtido para as duas misturas T01 e T02 pode ser considerado relativamente alto frente às diretrizes de dimensionamento européias do Grupo COST 333, que limitam as deformações permanentes em $5 \%$ com emprego do simulador de tráfego francês tipo LCP, conforme descrito no item 2.7.3.2.

Trechos T02, T03, T06 e T08

Com mesma distribuição granulométrica na faixa $12,5 \mathrm{~mm}$, tem-se quatro trechos: T02, T03, T06 e T08. Comparando-se o trecho T02, com teor de ligante de 5,0\%, com o trecho T03, com teor de 4,7\%, tem-se que a deformação permanente aos 30.000 ciclos de $7,9 \%$ para o trecho T02 e de $2,3 \%$ no T03. Mais uma vez nesta comparação mostra-se a importância do teor de ligante nos afundamentos de trilha de roda. O trecho T03 deveria ter sido usinado com um teor mais próximo de 5,0\%, mas mesmo assim, supõe-se deformações inferiores ao T02.

No trecho T06, no mesmo teor corrigido de ligante que o T02, mas empregando asfalto modificado por RET, a deformação permanente foi de 3,7\%. Mais uma vez mostra-se o melhor desempenho dos asfaltos modificados por polímeros 
frente aos asfaltos convencionais CAP 50/70 quanto à resistência à deformação permanente.

O trecho T08, com teor de 5,3\% de CAP 30/45, apresentou deformação permanente de 6,2\%. O valor de afundamento poderia ter sido levemente reduzido com uma pequena redução de teor de ligante. Mesmo assim, os ligantes modificados apresentam-se mais eficientes que o CAP 30/45 quanto à resistência à deformação permanente.

Verifica-se que o tipo de ligante asfáltico CAP 50/70 é menos resistente à deformação permanente em trilha de roda que o convencional CAP 30/45 e que os ligantes asfálticos modificado por RET (trecho T06) e o modificado por polímero SBS (trecho T03).

\subsubsection{Deformação permanente - teores de ligante asfáltico de projeto, de pista e corrigido pela PCG}

Foram realizados ensaios de deformação permanente em trilha de roda no laboratório para as 10 misturas asfálticas utilizadas nos 10 trechos da pistateste, em três condições, todas usinadas em laboratório:

a) distribuição granulométrica e teor de ligante asfáltico do projeto original;

b) distribuição granulométrica e teor de ligante asfáltico de pista; e,

c) distribuição granulométrica de pista e teor de ligante asfáltico corrigido em função dos resultados com a PCG e com a deformação permanente em trilha de roda obtidos no item b.

Os resultados individuais de deformação permanente em trilha de roda de cada ensaio estão nos anexos I, II e III.

Na figura 158 está apresentado o resumo dos resultados das deformações permanentes em trilha de roda para 30.000 ciclos de ensaio no simulador de 
tráfego de laboratório tipo LCPC, para os seus respectivos teores de ligantes asfálticos para as três condições descritas.

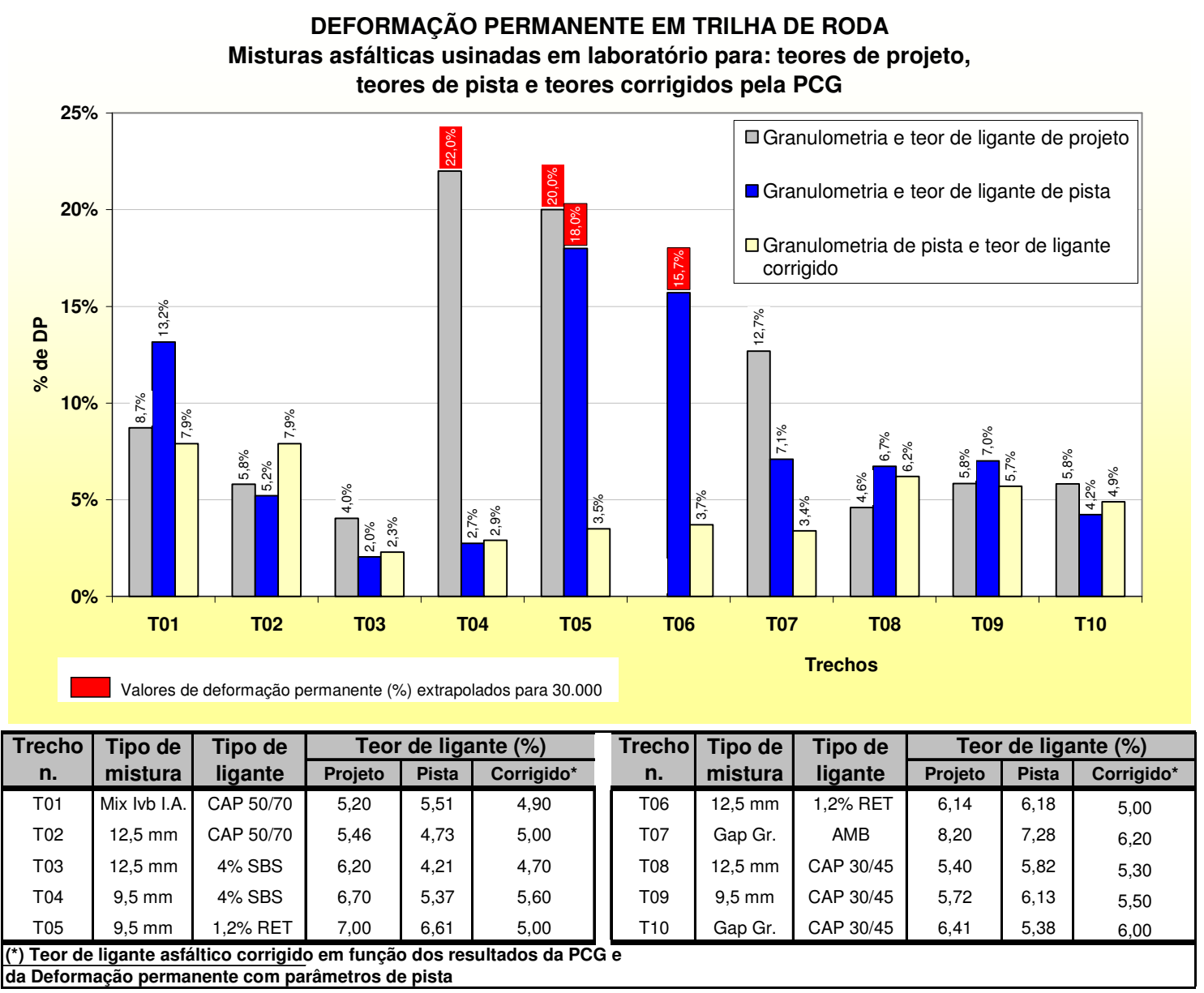

Figura 158 - Deformação permanente após 30.000 ciclos do simulador de tráfego LCPC de misturas asfálticas usinadas nos teores de ligante de projeto, de pista e corrigidos pela PCG

\subsubsection{Deformação permanente no teor de projeto}

Os trechos T03 e T08, para as condições de usinagem no teor de projeto apresentaram valores de deformação permanente em trilha de 4,0\% e 4,6\% respectivamente, mostrando boa resistência à deformação permanente, (figura 158). Os dois trechos são com curva granulométrica contínua, bem graduada, com diâmetro nominal de $12,5 \mathrm{~mm}$, sendo o T03 com asfalto modificado por polímero e T08 com CAP 30/45. É importante salientar que as amostras de ligantes asfálticos utilizados nos ensaios laboratoriais vieram diretamente da 
unidade de distribuição da Greca Asfaltos Ltda em Araucária PR, como já comentado.

As diretrizes européias limitam as deformações permanentes em 5\%, no simulador de tráfego francês tipo LCPC após 30.000 ciclos, no caso de misturas asfálticas densas, utilizadas como revestimento para tráfego pesado (fort) - acima de 2000 veículos comerciais diários, com eixo traseiro carregado de no mínimo 5 toneladas. Ou seja, se respeitados os teores de projeto, o limite preconizado seria atendido.

Os trechos T01 e T02, de graduação similar, embora sejam de mesma granulometria que os anteriores comentados, foram usinados com CAP 50/70, o que levou a maior deformação permanente, com valores de afundamento em trilha de roda situados entre $5 \%$ e $10 \%$.

As misturas dos trechos T09 e T10, usinadas nos teores de projeto, com CAP $30 / 45$ mostraram afundamentos em trilha de roda situados entre $5 \%$ e $10 \%$. A mistura T09 possui agregado de diâmetro DMN menor que a T08, o que a tornou um pouco mais susceptível à deformação permanente. A deformação registrada referente ao trecho T10, gap-graded, apresentou-se com afundamentos próximos a 5\%, porém superior a este limite.

A mistura asfáltica referente ao trecho T07, faixa gap graded do Caltrans usinada com ligante asfáltico modificado por borracha, apresentou valor elevado de deformação permanente em trilha de roda, 12,7\%. Essa baixa resistência está associada ao teor de ligante asfáltico de projeto elevado de 8,2\%, (possivelmente excessivo).

Os trechos T04 e T05, com teores de projeto de 6,7\% e 7,0\% respectivamente, foram os que apresentaram as menores resistências à deformação permanente: a mistura T04 usinada com asfalto modificado por SBS e a T05 com ligante modificado por $1,2 \%$ de RET. O ensaio de deformação permanente em trilha de roda para a mistura do trecho T04, com teor de projeto, apresentou valor de $15,4 \%$ de deformação para 17.715 ciclos; o valor de $22 \%$ que consta 
da figura 158 foi obtido por regressão da curva de evolução da deformação permanente, para 30.000 ciclos. A mistura do trecho T05 apresentou 13,0\% de deformação para apenas 10.000 ciclos; o valor de $20 \%$ de deformação que consta na figura 158 foi também obtido através de regressão para 30.000 ciclos. Possivelmente essa baixa resistência à deformação esteja associada aos elevados teores de ligantes asfálticos, apontando um erro de determinação destes teores inicialmente em projeto. É provável que o teor de projeto tenha sido obtido em laboratório para um material não condizente com aquele aplicado em pista.

Observe-se na figura 158 que não é apresentado o valor da deformação permanente da placa usinada no teor de projeto para o trecho T06 devido a problemas com o teor de ligante asfáltico na ocasião da usinagem.

As folhas de ensaios de deformação permanente em trilha de roda das placas usinadas no teor de projeto fazem parte do anexo I.

\subsubsection{Deformação permanente no teor de pista}

Na figura 158, a mistura do trecho T01 mostrou pouca variação entre o teor de ligante asfáltico de projeto e o teor de ligante encontrado em pista, 5,20\% e $5,51 \%$ respectivamente. O valor da deformação permanente em trilha de roda de $8,7 \%$ foi encontrado com a mistura asfáltica usinada no teor de projeto de $5,2 \%$. Na usinagem da mistura com o teor detectado em pista, 5,51\% a deformação permanente em trilha de roda foi de 13,2\%. Embora a variação entre os teores de ligantes asfálticos estejam dentro dos limites aceitáveis de usina, $+/-0,3 \%$, os resultados encontrados mostram que as misturas densas com ligante asfáltico de baixa consistência, como o CAP 50/70, apresentam grande sensibilidade à deformação permanente frente à variação no teor de ligante. Noutra possibilidade é que o teor de projeto seja elevado, devendo ser reduzido. Outro fator ainda a ser levantado é a diferença entre ligantes usados na usina e no laboratório: apesar de mesma procedência e classificação, 
podem apresentar variações de viscosidade e, por conseguinte, variações quanto à deformação permanente.

No trecho T02, o teor de ligante asfáltico de projeto foi de 5,46\% e a deformação permanente em trilha de roda para esse teor foi de 5,8\%. O teor de pista foi de 4,73\%, mostrando uma deformação permanente de 5,2\%. Uma variação a menos no teor de pista com relação ao projeto $(0,73 \%)$ propiciou uma pequena redução na deformação permanente em trilha de roda. Observese, no entanto, que o volume de vazios inicial em pista é elevado, figura 147, de aproximadamente $9 \%$, mostrando que o teor de ligante de pista é baixo. Ou seja, as deformações são relativamente controladas, apesar de superiores ao limite de $5 \%$, mas a mistura é pobre em ligante, o que leva à baixa resistência.

O mesmo comportamento pode ser observado com o trecho T03, mistura usinada na faixa SPV $12,5 \mathrm{~mm}$ e com ligante asfáltico modificado por $4 \%$ de SBS: o teor de projeto de 6,20\% resultou em deformação permanente em trilha de roda de $4,0 \%$ e quando da execução da pista-teste, o teor utilizado foi de $4,21 \%$, uma redução apreciável de $2 \%$ em teor de ligante. Este fato explica a razão pela qual a mistura pobre em ligante apresentou volume de vazios inicial superior a 9\% em campo figura 147. Essa redução no teor de ligante tornou a mistura asfáltica resistente à deformação permanente, apresentando um valor de 2,0\% após 30.000 ciclos. Além do baixo teor em ligante, pode-se associar a resistência à deformação permanente às características reológicas do ligante asfáltico modificado por SBS, visto que um acréscimo de $2 \%$ no teor (de pista para projeto) manteve a mistura com boa resistência à deformação permanente.

Para o trecho T04, a deformação permanente em trilha de roda com teor de projeto de $6,7 \%$ foi de $22 \%$ (obtido por regressão), ou seja, essa mistura asfáltica apresentou baixíssima resistência à deformação permanente em trilha de roda e deveria ter sido condenada. No entanto, acredita-se que o material testado em laboratório para projeto não seja condizente com o material colocado em pista. O teor de ligante asfáltico de pista foi de 5,37\%, na ordem de $1,3 \%$ menor do que o de projeto. A deformação permanente em trilha de 
roda para esse novo teor utilizado foi de 2,7\% para 30.000 ciclos, um ótimo resultado à deformação permanente em trilha de roda, condizente com o tipo de graduação e natureza do ligante modificado.

A mistura do trecho T05 mostra resultados de deformação permanente elevados, de $20 \%$ (obtido por regressão), para o teor de projeto (teor de ligante de $7 \%$ ) e de $18 \%$ (obtido também por regressão) para o teor de pista de 6,61\%. Observe-se que os teores de 7,0\% e 6,61\% são muito elevados e o material de projeto não deve ser condizente com o aplicado em pista. Embora o ligante asfáltico tenha sido modificado por 1,2\% de RET (Elvaloy), ligante consistente e que normalmente apresenta elevada resistência à deformação permanente, o excesso de teor nas misturas de projeto e de pista foi determinante para a baixa resistência à deformação permanente.

Tem-se observado o comportamento de misturas asfálticas quanto à deformação permanente em trilha de roda ao longo de vários anos no Laboratório de Tecnologia de Pavimentação, com o emprego do simulador de tráfego Francês tipo LCP - orniereur, e pôde-se constatar que misturas asfálticas com teores de ligante muito acima do teor de projeto apresentam valores elevados de deformação permanente em trilha de roda logo no início do ensaio. Caso seja dada continuidade ao ensaio, os resultados ficam prejudicados para possíveis correlações. Outro fato a ser considerado é o afundamento em relação à borda da amostra (sulco) ser muito grande e para que a leituras possam ser efetuadas, as bordas da mistura que sofreram deformação por fluência são removidas e, por conseguinte, a mistura passa a ter outro confinamento. Por este motivo, os franceses param os ensaios após deformações da ordem de $15 \%$.

O trecho T06, com mistura asfáltica de faixa granulométrica SPV 12,5 mm e ligante asfáltico modificado por 1,2\% de RET (Elvaloy), apresentou teor de ligante asfáltico de projeto de $6,14 \%$ e de pista de 6,18\%, praticamente 0 mesmo teor de ligante asfáltico. A deformação permanente foi elevada, atingindo $15,7 \%$ aos 30.000 ciclos (obtido por regressão) para o teor de pista, mostrando-se excessivo. Não foi possível comparar com a deformação no teor 
de projeto devido a erro no teor de ligante asfáltico na ocasião da usinagem. Reiterando o que foi constatado para o trecho T05, a definição e uso de teor de ligante excessivo levam ao surgimento de afundamentos, mesmo com ligantes modificados. Infelizmente houve erro de usinagem no laboratório e as placas foram perdidas para o ensaio com o teor de projeto.

A mistura asfáltica usinada na faixa granulométrica do gap graded do Caltrans e com ligante asfáltico modificado por borracha, trecho T07, apresentou um valor de deformação permanente em trilha de roda de 12,7\% para teor de projeto de $8,2 \%$ de ligante. Em pista, o teor de ligante encontrado foi de 7,28\%, com redução de 0,9\% com relação ao de projeto. Neste teor, a mistura usinada em laboratório, reproduzindo as condições de pista, apresentou afundamentos de $7,1 \%$. Deve-se ressaltar que é provável que a usinagem do material para campo tenha sido heterogênea, com teores variáveis em pista, visto que todas as placas extraídas não representou bem as condições gerais de pista. O teor obtido por extração e reproduzido em laboratório é ainda excessivo uma vez que mostrou valores de afundamentos aos 30.000 ciclos de 7,1\%. Em pista este foi o pior trecho quanto à deformação permanente, demonstrando que o teor ligante asfáltico foi excessivo e houve heterogeneidade na usinagem.

No trecho T08, mistura usinada na faixa SPV $12,5 \mathrm{~mm}$ com CAP 30/45, o teor de ligante asfáltico de projeto foi de $5,40 \%$ e para esse teor a deformação permanente em trilha de roda encontrada foi de 4,6\%. Já na execução da pista o teor utilizado foi de 5,82\%, um acréscimo de 0,42\%, valor suficiente para aumentar a deformação permanente em trilha de roda para $6,7 \%$.

Para o trecho T09, foi indicado um teor de projeto de 5,72\% com a faixa SPV 12,5mm e ligante CAP 30/45, tendo apresentado um valor de deformação permanente em trilha de roda de 5,8\% no simulador de tráfego LCPC após 30.000 ciclos. Na construção da pista-teste, o teor de ligante asfáltico utilizado foi de 6,13\%, (mais de 0,5\% acima daquele indicado em projeto) e, por conseguinte, a resistência à deformação permanente caiu, apresentando um valor de 7,0\%. Mais uma vez demonstra-se a sensibilidade das misturas 
densas ao excesso de ligante asfáltico quanto à resistência à deformação permanente em trilha de roda.

Finalmente, para o trecho T10, cujo projeto de mistura asfáltica gap-graded com CAP 30/45 apresentou um teor de ligante asfáltico de 6,41\%, a deformação permanente em trilha de roda foi de 5,8\%. Para o teor de ligante asfáltico de pista de 5,38\%, (0,42\% menor que o de projeto), a deformação permanente em trilha de roda foi de $4,2 \%$, redução de $1,6 \%$ no valor da deformação permanente.

As folhas de ensaios de deformação permanente em trilha de roda das placas usinadas no teor de pista fazem parte do anexo III.

\subsubsection{Deformação permanente no teor corrigido com os resultados obtidos da PCG}

Para a determinação do teor corrigido com os quais as misturas asfálticas deveriam ter sido usinadas, tomou-se como base os resultados da aptidão de compactação com a PCG e os resultados das deformações permanentes obtidos com as misturas asfálticas usinadas no teor de pista e de projeto. A experiência do Laboratório de Tecnologia de Pavimentação de mais de 15 anos de uso do simulador tipo LCPC foi também determinante para a fixação do valor que se denominou de "corrigido". As misturas usinadas com o teor de asfalto corrigido foram submetidas ao ensaio com a PCG, (figuras 148 a 157) e também ao simulador de tráfego LPC, cujos resultados constam da figura 158.

Observe-se na figura 158 que as misturas asfálticas T03, T04, T05, e T06, correspondentes às misturas com graduação contínua bem graduada e asfalto modificado com SBS e com RET, apresentaram aos 30.000 ciclos do simulador LPC afundamentos bem inferiores a $5 \%$. Nestes casos, o uso de asfalto modificado por polímero foi determinante para obtenção de resistência adequada quanto à deformação permanente. 
As misturas dos trechos T07 e T10, gap-graded, com asfalto borracha e CAP 30/45, respectivamente, e usinadas com teores de ligante asfáltico corrigidos apresentaram igualmente valores inferiores a 5\%. A conjunção de uma mistura descontínua com asfalto-borracha levou a valores de afundamento na trilha de roda na mesma ordem de grandeza que os obtidos para as misturas T03, T04, T05, e T06, contínuas com asfalto modificado por polímero. No caso da mistura do trecho T10, com CAP 30/45, o afundamento é inferior a 5\% aos 30.000 ciclos, porém levemente superior ao encontrado no T07, com asfalto-borracha. Para o asfalto-borracha do T07, empregou-se $6,2 \%$ de ligante, e para o T10: $6,0 \%$ de CAP 30/45. Apesar de $0,2 \%$ a mais de asfalto-borracha, observa-se pela PCG que aos 80 giros o volume de vazios da mistura T10 é 9\%, enquanto para o T07 os vazios foram de 11\%. Ou seja: maior quantidade de ligante não indica menor quantidade de vazios, para a mesma graduação, devido à viscosidade do ligante asfalto-borracha ser maior que a do convencional CAP 30/45. Ou seja, comparativamente, o T07 apresenta menor deformação frente ao T10 por ter sido empregado asfalto-borracha e o volume de vazios ser levemente superior.

As misturas T01, T02, T08 e T09, todas densas e bem-graduadas, com CAP 50/70 no T01 e T02 e CAP 30/45 no T08 e T09 apresentaram valores de 7,9\%, $7,9 \%, 6,2 \%$ e 5,7\% de deformação aos 30.000 ciclos, respectivamente. Embora os afundamentos estejam acima de $5 \%$, se fossem reduzidos os teores, as misturas poderiam apresentar menor deformação. Entretanto, salienta-se que essa redução poderia ocasionar problemas de resistência ao trincamento e à fadiga, permitindo a entrada de água na camada, o que é indesejável. Pode-se considerar que as características reológicas dos ligantes asfálticos CAP 30/45 e CAP 50/70 contribuem para que as misturas asfálticas estudadas apresentem afundamentos superiores a $5 \%$, sendo mais preponderante nas misturas com CAP 50/70.

As folhas de ensaios de deformação permanente em trilha de roda das placas usinadas no teor corrigidos pela PCG, fazem parte do anexo VI. 


\subsubsection{Deformação permanente de placas extraídas de pista e placas usinadas em laboratório no teor de ligante asfáltico de pista}

Conforme já mencionado foram extraídas placas de pista, serrilhas e acondicionadas nos moldes metálicos com a finalidade de obter a redução dos volumes de vazios em função da deformação permanente em trilha de roda, descrito no item 4.1 e figuras 141, 142 e 143. Apresentam-se na figura 159 os resultados dessas duas condições e no anexo II as folhas de ensaios de deformação permanente em trilha de roda de placas extraídas de pista de cada trecho.

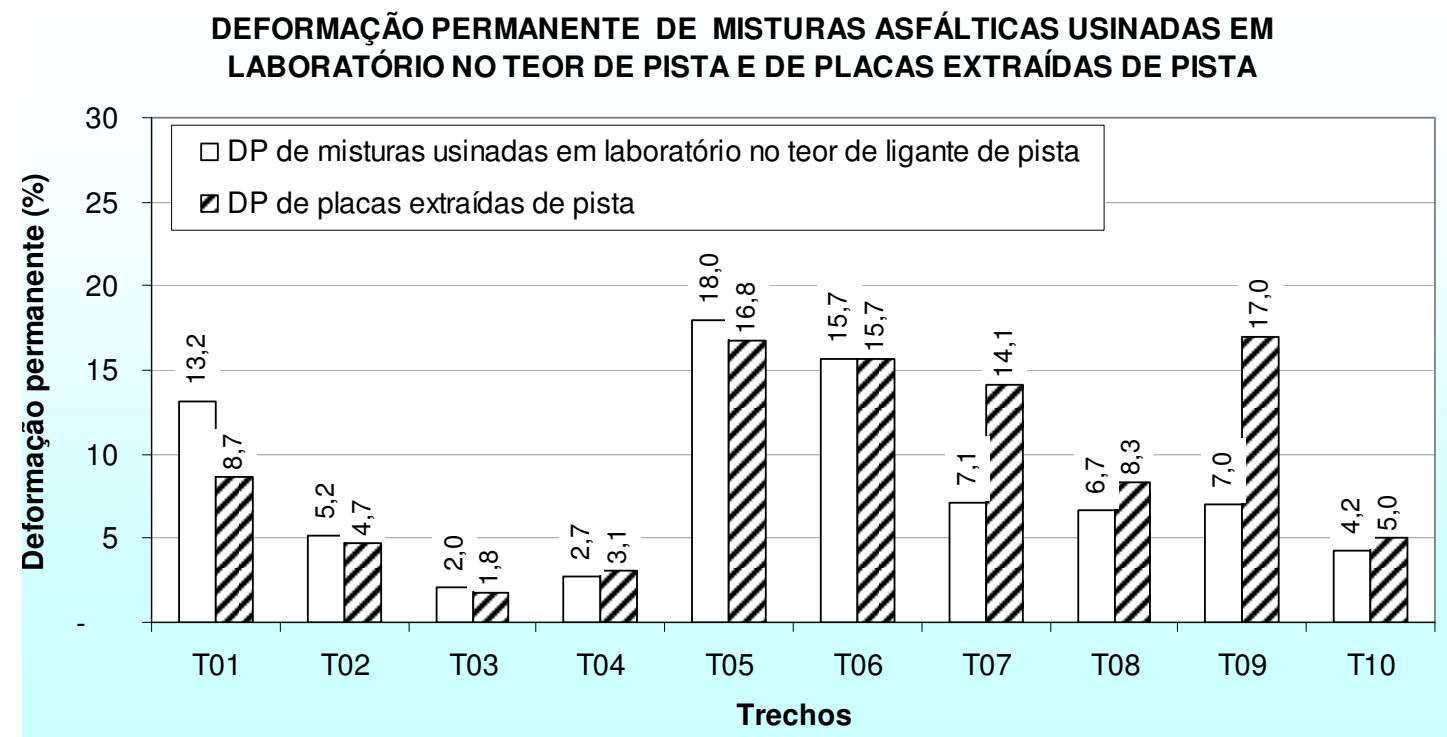

Figura 159 - Deformação permanente de misturas asfálticas de laboratório com teor de pista e de placas extraídas de pista

As misturas asfálticas correspondentes aos trechos T02, T03, T04 e T10 apresentaram valores de deformação permanente próximos, entre as duas condições e inferiores a 5\%. Os trechos T05 e T06 também foram similares, entretanto, com valores elevados entre $15,7 \%$ e 18,0\%. O trecho T08 mostra similaridade entre resultados, com valor entre 5 e $10 \%$.

Para as misturas asfálticas dos trechos T07 e T09, os valores de deformação permanente em trilha de roda com as misturas asfálticas usinadas em laboratório no teor de pista foram bastante inferiores às deformações com as placas extraídas de pista dos mesmos trechos. A mistura asfáltica do trecho 
T01 apresentou uma condição inversa das duas dos trechos anteriormente considerados (T07 e T09)

Diversos são os motivos que se pode elencar para explicar esses comportamentos de resistência entre as condições de misturas asfálticas usinadas em laboratório no teor de pista e de placas extraídas de pista, tais como:

- em usina, o agregado aquecido por tempo limitado por chama recebe o ligante que, por sua vez, é revolvido dentro do tambor secador (usina drum mix); a mistura asfáltica é transferida para o caminhão e, em seguida, distribuída e densificada por rolos compactadores de pneus e lisos,

- em laboratório os agregados são aquecidos em estufa por no mínimo 6 horas; em seguida, são transferidos para a misturadora, adiciona-se o ligante asfáltico onde os materiais são misturados, após a homogeneização a mistura é transferida para uma bandeja e é colocada em estufa onde fica em repouso por 2 horas, em seguida, é acondicionada nos moldes e compactada por rolo de pneu.

Deve-se ressaltar que o processo de compactação de laboratório é muito rigoroso, principalmente no controle das temperaturas de usinagem e de compactação, o que podem diferir do processo em usina e campo.

Além disso, a amostra dos ligantes asfálticos usados no laboratório pode não corresponder exatamente ao asfalto utilizado na usinagem das misturas asfálticas na ocasião da execução da pista-teste. Variações na viscosidade, devido a variações nas temperaturas empregadas, no processo de usinagem e principalmente de compactação podem se refletir nos resultados. O processo de laboratório é sujeito a menores variações. Na compactação com a mesa compactadora produzem-se misturas asfálticas com características mais próximas das de campo que o processo por compactação Marshall. No entanto, ainda há diferenças entre os processos de compactação laboratório (pneumático pela mesa compactadora e por impacto no caso do ensaio Marshall) e pista. 
Provavelmente variações ocorreram no processo de usinagem e de compactação das misturas asfálticas em campo, o que podem ter propiciado essas diferenças entre laboratório e campo, principalmente nos trechos T01, T07, e T09.

\subsection{Flecha de campo e deformação permanente em laboratório}

Após a construção da pista-teste foram executados levantamentos das flechas (afundamentos) na trilha de roda externa a cada $10 \mathrm{~m}$, em toda extensão da pista-teste. Foram executados três levantamentos: após 30 dias da abertura ao tráfego, um segundo após 6 meses e um terceiro após 13 meses. As médias dos valores das flechas encontrados e seus desvios-padrão estão na tabela 42 e apresentadas de forma resumida na figura 76 do item 3.9.4.

Juntamente com os registros dos afundamentos foram feitos levantamentos dos defeitos da superfície do pavimento, com o objetivo de determinar Índice de Gravidade Global - IGG, especificado pelo DNIT 006/2003 - figura 97 do item 3.9.5.

Nas figuras 160 e 161, apresentam-se comparativos entre os afundamentos registrados em campo após 1 mês e 6 meses da ação tráfego com as deformações permanentes das placas retiradas em pista e testadas em laboratório.

$\mathrm{O}$ número $\mathrm{N}$ acumulado em um mês, para as duas situações foram: a) sem computação de veículos comerciais com excesso de carga, conforme cálculos apresentados no item 4.4 .3 foi de $2,59 \times 10^{5}$ solicitações; b) considerando excesso de carga de $30 \%$ em $30 \%$ dos eixos carregados, tem-se $\mathrm{N}=5,79 \times$ $10^{5}$ solicitações (FEC do USACE). Observe-se que se trata de um número elevado para apenas 1 mês de solicitação do tráfego o que explica em parte os 
afundamentos elevados em alguns trechos. Outro fator é que o primeiro mês se deu em plena época de verão, com temperaturas muito elevadas.

A deformação permanente de laboratório no teor de pista da mistura asfáltica referente ao trecho T01 foi de 13,2\%, figura 160, apontando para uma baixa resistência à deformação. Com efeito, foi registrada uma flecha de $4,5 \mathrm{~mm}$ para o período de 1 mês.

Para a mistura asfáltica correspondente ao trecho T02, em laboratório a deformação permanente foi de 5,2\%, valor próximo ao limite especificado para aceite da mistura para que se possa assegurar a qualidade à não formação de afundamentos. Em pista, o valor da flecha foi de 1,3 $\mathrm{mm}$ em um mês.

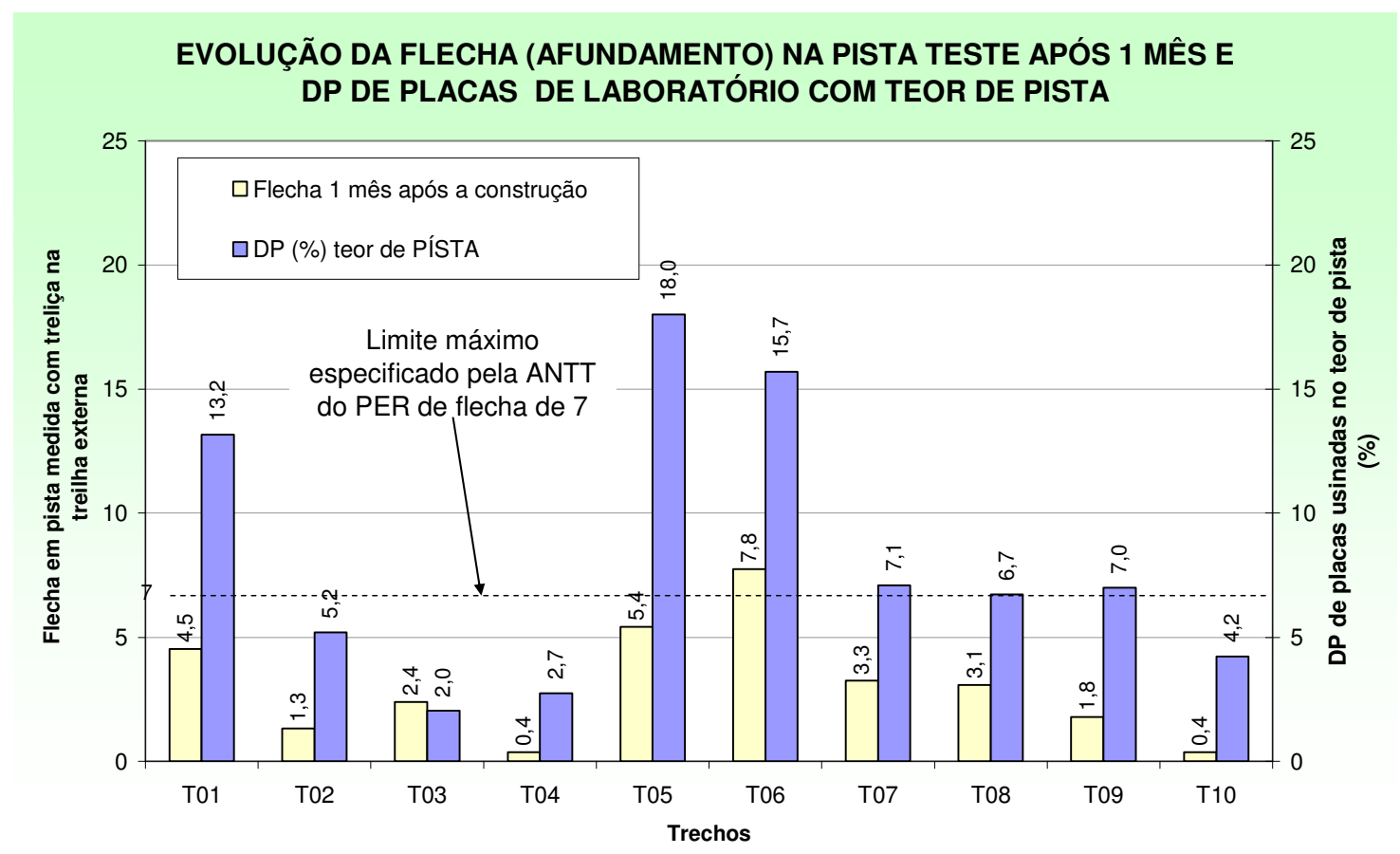

Figura 160 - Evolução da flecha após 1 mês de solicitação pelo tráfego comparada à deformação permanente de misturas asfálticas usinadas com o teor de pista após 30.000 ciclos

Os trechos T03 e T04 apresentaram deformação permanente em trilha de roda em placas de laboratório de 2,0\% e 2,7\% respectivamente, e as flechas observadas em campo foram de $2,4 \mathrm{~mm}$ para o trecho T03 e 0,4 $\mathrm{mm}$ para 0 trecho T04, condizentes com os valores de deformação de laboratório. 
Para os trechos T05 e T06 registraram-se valores elevados de flechas de 5,4 $\mathrm{mm}$ e 7,8 $\mathrm{mm}$ respectivamente com apenas 1 mês de solicitação pelo tráfego. Os resultados de laboratório previam mau comportamento para essas duas misturas: a deformação permanente do trecho T05 foi de 18,0\% e do trecho T06 a deformação computada foi de 15,7\%, demonstrando a baixa resistência à deformação permanente para essas misturas asfálticas.

A mistura usinada com a distribuição granulométrica gap-graded com ligante asfáltico modificado por borracha utilizada no trecho T07 apresentou uma deformação de 7,1\% no laboratório e em pista foi encontrada uma flecha de 3,3 $\mathrm{mm}$. Da mesma forma o trecho T08 com deformação permanente de 6,7\% em laboratório e com 3,1 mm de flecha em campo.

A mistura asfáltica empregada no trecho T09 apontou uma deformação de $7,0 \%$ em laboratório e em campo a flecha foi de 1,8 $\mathrm{mm}$.

Observe-se que as misturas asfálticas dos trechos T07, T08 e T09 apresentaram deformações próximas e acima do limite especificado e os valores de flechas para apenas 1 mês também foram elevados.

Por fim o trecho T10: nesse trecho a deformação permanente encontrada em laboratório foi de 4,2\% e a flecha medida em campo foi de apenas $0,4 \mathrm{~mm}$. Nesse trecho faz-se necessário alertar para o fato de o ligante asfáltico provavelmente estivesse em campo contaminado com ligante asfáltico modificado por polímero, pois o CAP 30/45 utilizado nesse trecho apresentou um retorno elástico de 45\%, conforme ensaios com os ligantes asfálticos recuperados que constam da tabela 42. Portanto, a validação laboratóriocampo fica extremamente prejudicada pois 0 material em pista não corresponde ao de laboratório, sendo impossível se prever comportamento.

$\mathrm{Na}$ figura 161 estão apresentadas as médias aritméticas (20 leituras) das flechas medidas na pista-teste, realizadas 6 meses após a abertura ao tráfego, juntamente com as deformações permanentes de misturas asfálticas usinadas em laboratório com o teor de ligante asfáltico de pista. O número $\mathrm{N}$ acumulado 
nesse período (6 meses), conforme cálculos apresentados no item 4.4.3, foi de $\mathrm{N}=3,47 \times 10^{6}$ solicitações, para um excesso de carga de $30 \%$, em $30 \%$ dos eixos carregados.

No trecho T01 ocorreu um acréscimo de $4,5 \mathrm{~mm}$ para $9,1 \mathrm{~mm}$ na flecha, demonstrando que a deformação permanente de 13,2\% obtida em laboratório mostrou-se coerente com o mau desempenho da mistura em pista. Os afundamentos em pista excederam os valores limites de $7 \mathrm{~mm}$ estabelecidos pelo PER, o que era possível prever em laboratório.

Da mesma forma os três trechos seguintes, T02, T03 e T04 apresentaram crescimento nas flechas de $1,3 \mathrm{~mm}$ para 2,1 $\mathrm{mm}$ no trecho T02, 2,4 $\mathrm{mm}$ para 2,8 mm no trecho T03 e 0,4 mm para 3,4 mm no trecho T04, sendo esse último o que apresentou maior variação.

Para os trechos T05 e T06, esperava-se crescimento acentuados nas flechas de pista pois o teor de ligante era excessivo em ambos casos. Com efeito, a flecha variou de 5,4 $\mathrm{mm}$ para 9,2 $\mathrm{mm}$ no trecho T05, e de 7,8 $\mathrm{mm}$ para 12,7 $\mathrm{mm}$ no trecho T06. Reitera-se aqui que esses valores elevados de flecha estão associados diretamente ao elevado teor de ligante asfáltico que as misturas asfálticas apresentaram e puderam ser previstos em laboratório a priori. Os valores excederam em campo o limite máximo de $7 \mathrm{~mm}$ estabelecido pelo PER e era possível prever que este fato ocorreria.

No trecho T07 o crescimento foi significativo passando de $3,3 \mathrm{~mm}$ para $7,1 \mathrm{~mm}$, o teor de ligante asfáltico de pista para esse trecho foi de 7,28\% (figura 158) 0 que corrobora novamente para justificar a baixa resistência à deformação de laboratório de $7,1 \%$ indicou o mau comportamento da mistura asfáltica. Além disso, neste trecho foi observado deformação permanente diferenciadas ao longo dos 200m após 1 mês de abertura ao tráfego. Essa diferenciação de comportamento em campo e a baixa resistência observada em laboratório, torna difícil avaliar o comportamento futuro com base nesses resultados. 


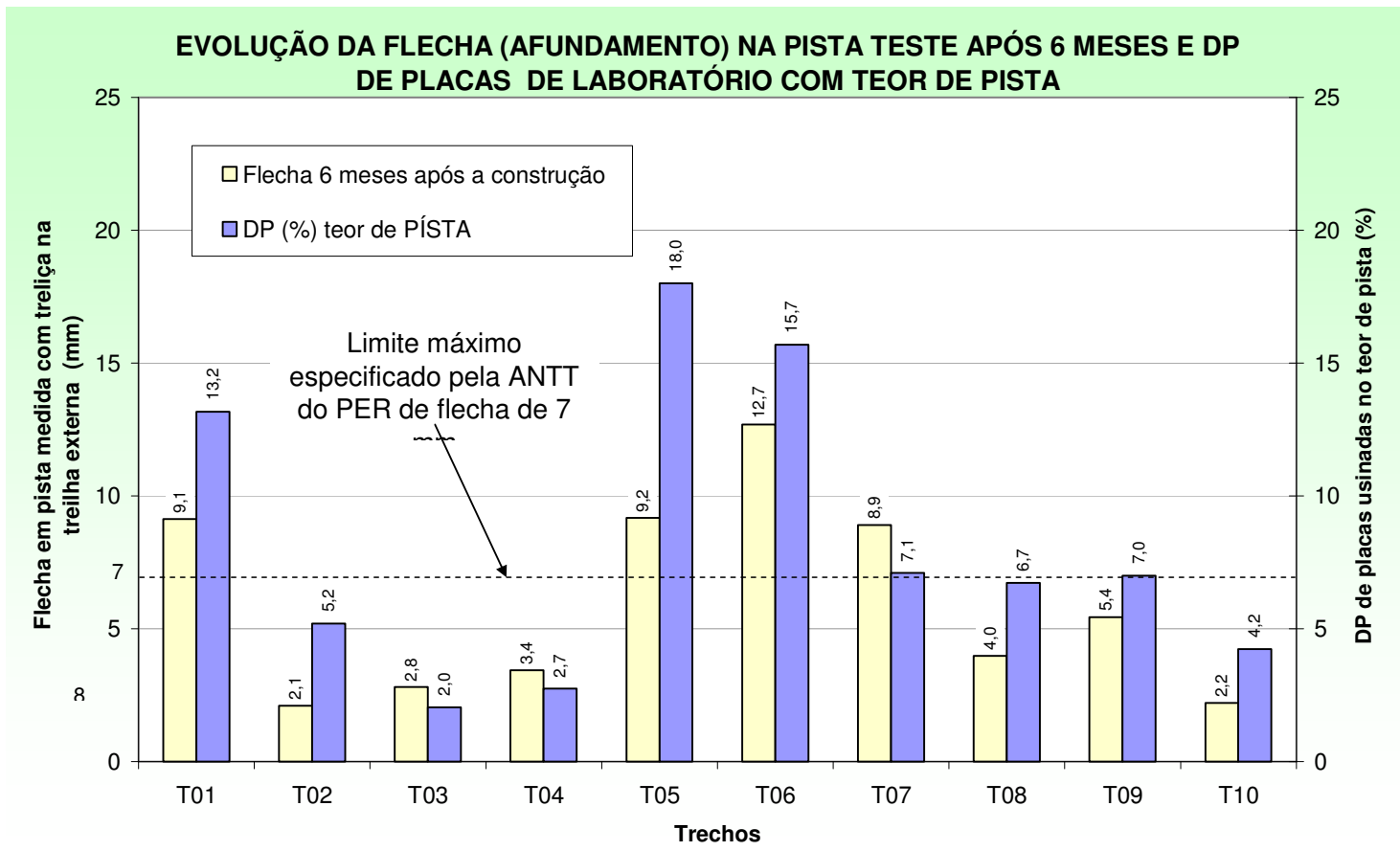

Figura 161 - Evolução da flecha após 6 mês de solicitação pelo tráfego comparada à deformação permanente de misturas asfálticas usinadas com o teor de pista

No trecho T08 ocorreu um pequeno acréscimo na flecha entre os períodos avaliados, de $3,1 \mathrm{~mm}$ para $4,0 \mathrm{~mm}$ e para o trecho T09 a variação foi maior: de 1,8 $\mathrm{mm}$ para 5,4 $\mathrm{mm}$ (3 vezes). A previsão de comportamento fica prejudicada pelo ligante usado em laboratório ser diferente do utilizado em campo.

Finalizando no trecho T10, com deformação em laboratório de 4,2\% ocorreu um crescimento convencional de $0,4 \mathrm{~mm}$ para $2,2 \mathrm{~mm}$. Salienta-se novamente quanto ao ligante asfáltico em pista certa recuperação elástica não esperada (contaminado no tanque da usina provavelmente). Nestes casos, é impossível utilizar os resultados de laboratório para prever comportamento em campo devido à variação entre ligantes, ou seja, as misturas não se correspondem.

\subsection{Deformação permanente de pista com simulador de tráfego de campo}

Três trechos foram submetidos ao ensaio com o simulador de tráfego móvel de campo: T01, T04 e T10. A escolha do trecho T01 foi feita por tratar-se do 
trecho referência; a seleção do trecho T04 deve-se ao fato de ser uma mistura de graduação mais fina e ter em sua composição o ligante asfáltico modificado por $4 \%$ de polímero SBS e o trecho T10 por ser uma mistura tipo gap-graded do Caltrans usinada com ligante convencional CAP 30/45. Além das razoes técnicas, estes trechos mostraram-se os mais próximos do esperado grau de compactação de campo. Os trechos T02 e T03 estavam com deficiência de ligante e volume de vazios elevado em pista; os trechos T05, T06, T07, T08 e T09, foram eliminados porque ora por causa do ligante em excesso, ora pelo grau de compactação tão elevado que reduziu os volumes de vazios iniciais a porcentagens indesejadas.

Além das medições das flechas, foram feitas também medições da evolução da textura e deflexões com a viga Benkelman. Essas medições foram feitas, tanto a cada paralisação para realização de leitura como também nas paradas para manutenção do simulador.

\subsubsection{Evolução da textura e deflexões com simulador de tráfego móvel de campo}

A evolução da textura superficial com os ensaios de mancha de areia (HS) e os levantamentos das deflexões com a viga Benkelman estão apresentados nas figuras 162 a 167.

Para o trecho T01 mostra-se na figura 162 a evolução da textura superficial com o ensaio de mancha de areia (HS). O resultado de cada ciclo é a média de 7 leituras, efetuadas longitudinalmente e no centro da seção da pista solicitada pelo semi-eixo do simulador de tráfego móvel. Os valores apontam que não houve alteração ao longo de 756.000 ciclos, mesmo com mudança da intensidade de carga a partir de 410.000 ciclos. Os valores foram em média de 0,5 mm, textura considerada média pelo Manual de Reabilitação do DNIT. Lembra-se que o tipo de faixa granulométrica empregada nesse trecho, mix IVb I.A., normalmente produz textura da ordem de grandeza de 0,4 mm a 0,6 mm. 
Ressalta-se ainda que se tem procurado utilizar misturas asfálticas com no mínimo 0,6mm de altura média de mancha de areia para reduzir eventuais problemas com aderência pneu/pavimento em pistas molhadas.

Quanto à deflexão para o trecho T01, os valores também não sofreram alterações significativas durante a simulação de tráfego com simulador de tráfego móvel de campo. Na figura 163, os valores de deflexão, corrigidos (linearmente) para a carga de $4,1 \mathrm{ff}^{10}$. No início do ensaio, as deflexões situaram-se em torno de $10(0,01 \mathrm{~mm})$ e a partir de 1.000 ciclos até o final do experimento, a média ficou em torno de $13(0,01 \mathrm{~mm})$, valores considerados baixos.

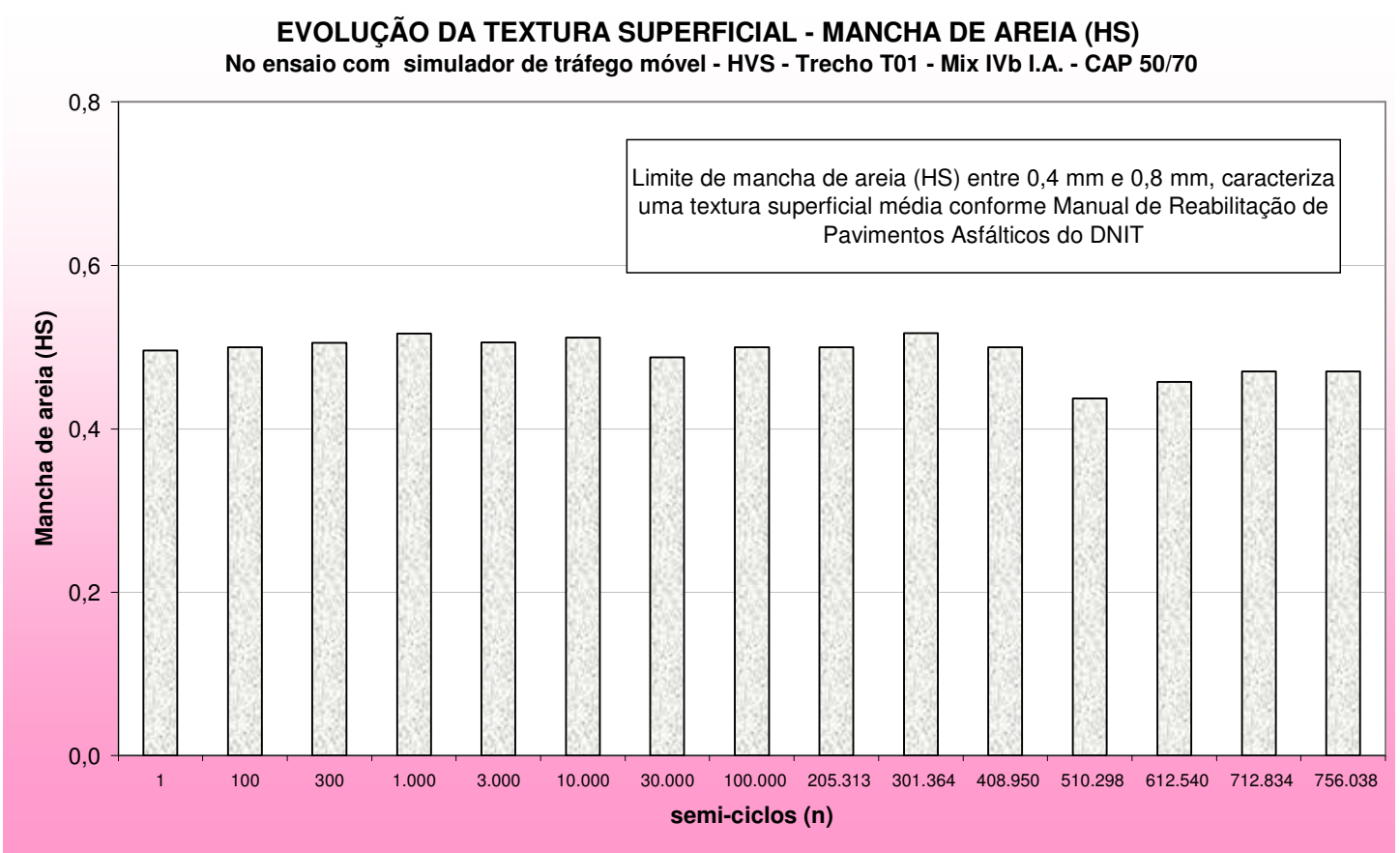

Figura 162 - Textura superficial com ensaio de mancha de areia (HS) - trecho T01

\footnotetext{
${ }^{10}$ A carga utilizada no simulador de tráfego móvel - Simular foi 6,2 tf no semi-eixo - $20 \%$ acima da carga legal, para 410.000 ciclos e carga de 8,2 tf $60 \%$ acima da carga legal, para 350.000 ciclos.
} 
Deflexões da Viga Benkelman -Ensaio com simulador de tráfego móvel - HVS Trecho T01 Mix IVb I.A. - CAP 50/70

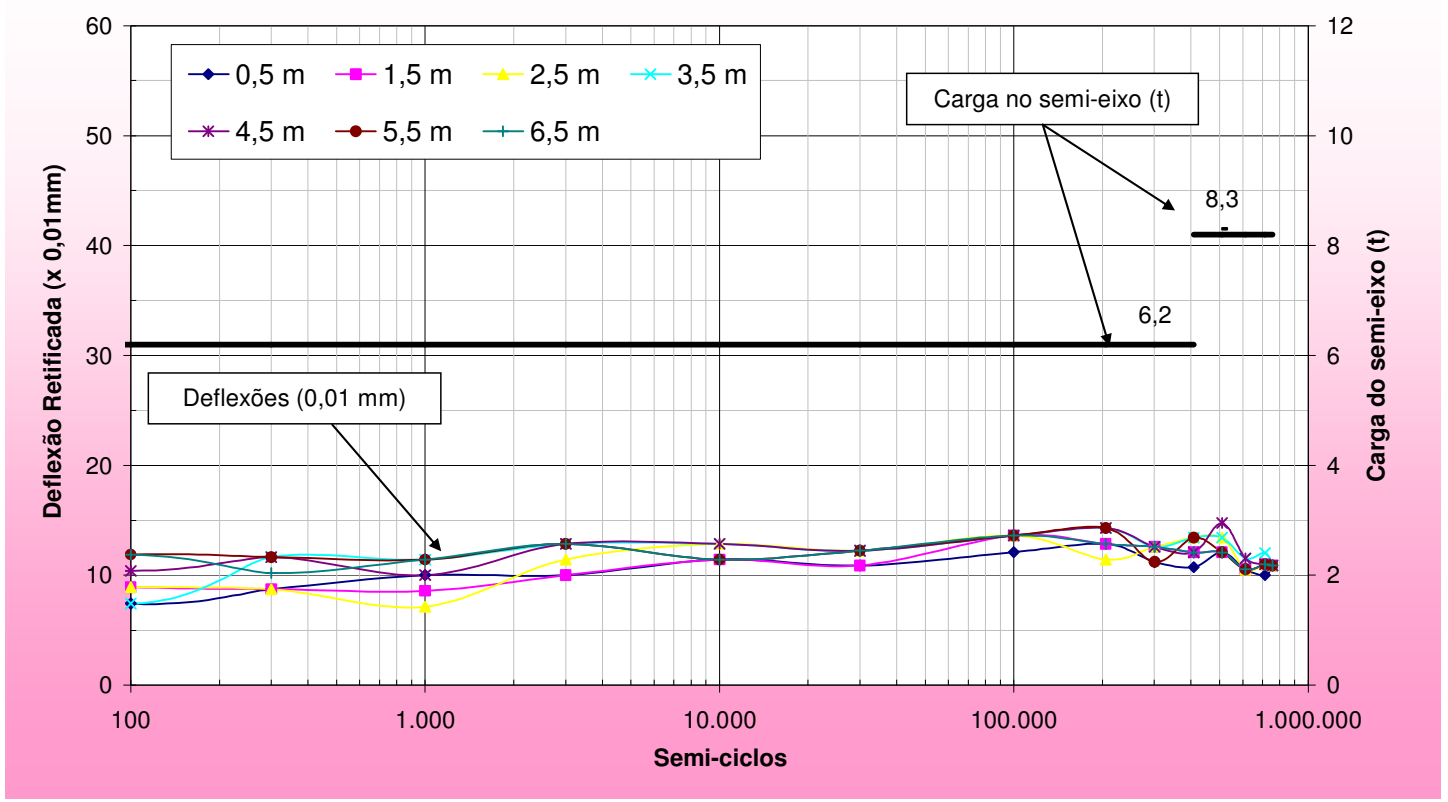

Figura 163 - Deflexões com a viga Benkelman no trecho T01

Para o trecho T04 mostra-se na figura 164 a evolução da textura superficial com o ensaio de mancha de areia (HS). O resultado de cada ciclo é a média de 7 leituras, efetuadas longitudinalmente e no centro da seção da pista solicitada pelo semi-eixo do simulador de tráfego móvel. Nesse caso, registram-se dois valores de HS, relacionados às duas diferentes cargas aplicadas no ensaio. Para a carga de 6,2 tf o valor de mancha de areia HS manteve-se em torno de 0,6 mm; com a mudança da carga para 8,3 tf após cerca de 500.000 ciclos, ocorreu uma diminuição na altura média da areia para aproximadamente 0,4 $\mathrm{mm}$. A mistura utilizada nesse trecho T04 foi a SPV $9,5 \mathrm{~mm}$ e o ligante asfáltico modificado por $4 \%$ de SBS. Com o aumento da carga ocorreu um fechamento da textura alterando o valor da mancha de $0,6 \mathrm{~mm}$ para cerca $0,4 \mathrm{~mm}$. A intensidade da carga inicial não causou modificações na superfície do pavimento, ao passo que com o acréscimo em mais de $30 \%$ na intensidade da carga causou a modificação da textura. É interessante ressaltar que apesar da trilha de roda não ser excessiva, a textura já mostra fechamento após solicitação de carga pesada. Este é um fato que se tem observado em campo com misturas densas e de esqueleto sólido bem travado: a redução de textura não necessariamente estará acompanhada por afundamento de trilha de roda. 
EVOLUÇÃO DA TEXTURA SUPERFICIAL - MANCHA DE AREIA (HS)

No ensaio com simulador de tráfego móvel - HVS - Trecho T04 - SPV 9,5 mm - CAP c/ 4\% de SBS

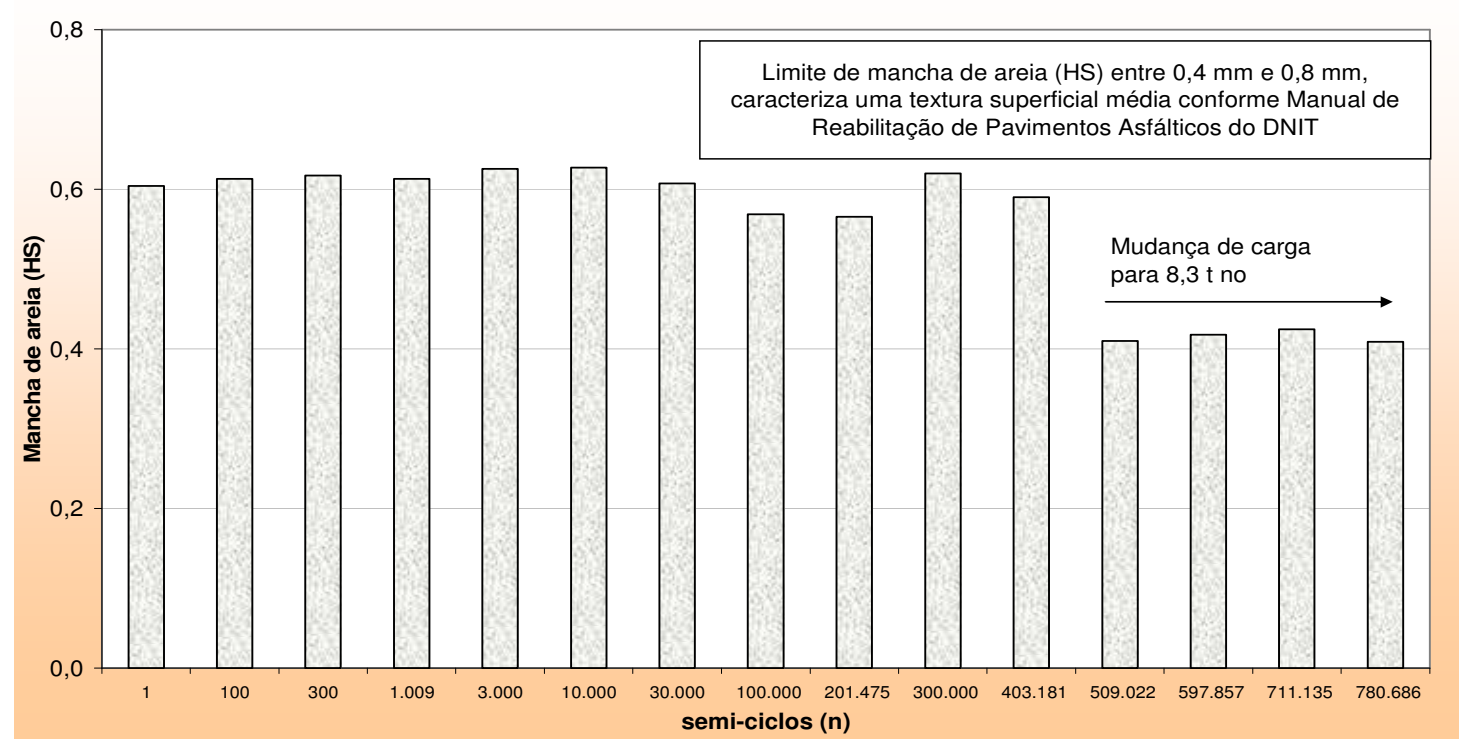

Figura 164 - Textura superficial com ensaio de mancha de areia (HS) - trecho T04

A deflexão para o trecho T04 foi maior que aquela encontrada no trecho T01; os valores permaneceram entre $20(0,01 \mathrm{~mm})$ e $30(0,01 \mathrm{~mm})$ para a carga inicial de 6,2 tf ao longo de cerca de 500.000 ciclos e após a mudança da carga para 8,3 t, a deflexão atingiu valores de $35(0,01 \mathrm{~mm})$ - figura 165 . Embora tenha ocorrido um crescimento nos valores de deflexão após o aumento da carga, não foi possível dar continuidade ao experimento, uma vez que o número de ciclos programado foi atingido.

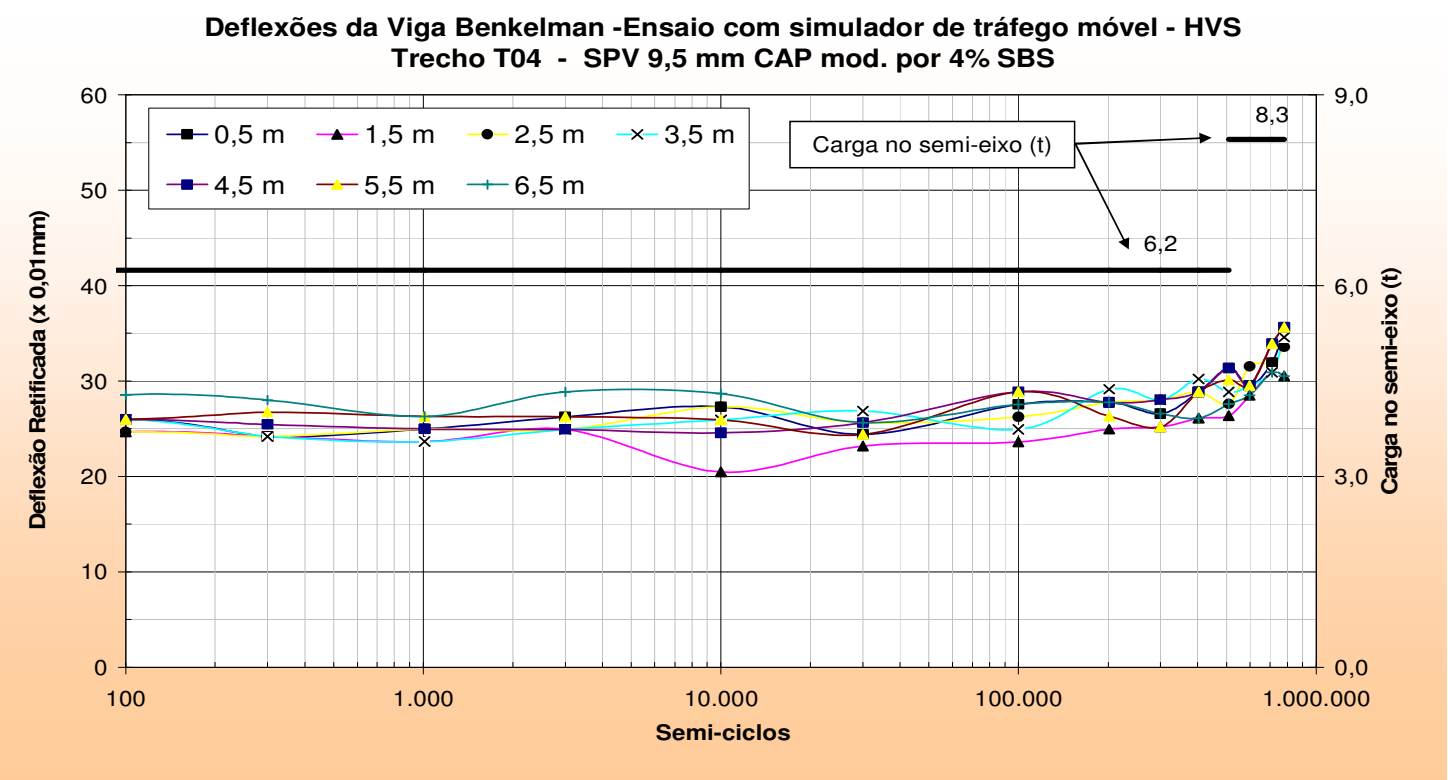

Figura 165 - Deflexões com a viga Benkelman no trecho T04 
Por fim, o trecho T10 da mistura asfáltica usinada na faixa do gap graded com ligante asfáltico CAP 30/45 não apresentou evolução da textura superficial HS durante a realização do ensaio com o simulador de tráfego móvel de campo. Os valores de HS encontrados foram constantes, ente $0,8 \mathrm{~mm}$ e 0,9 $\mathrm{mm}$, caracterizando uma macrotextura superficial considerada aberta ou grosseira, segundo Manual de Reabilitação de Pavimentos Asfálticos do DNIT, figura 166. Estes valores típicos de misturas asfálticas com distribuição granulométrica semidescontínuas, tipo gap-graded. Estes valores demonstram a boa estabilidade deste tipo de mistura asfáltica na permanência de textura. Deve-se ressaltar que além do esqueleto sólido, o principal responsável pela estabilidade, que é o ligante CAP 30/45 possivelmente estava contaminado por polímero.

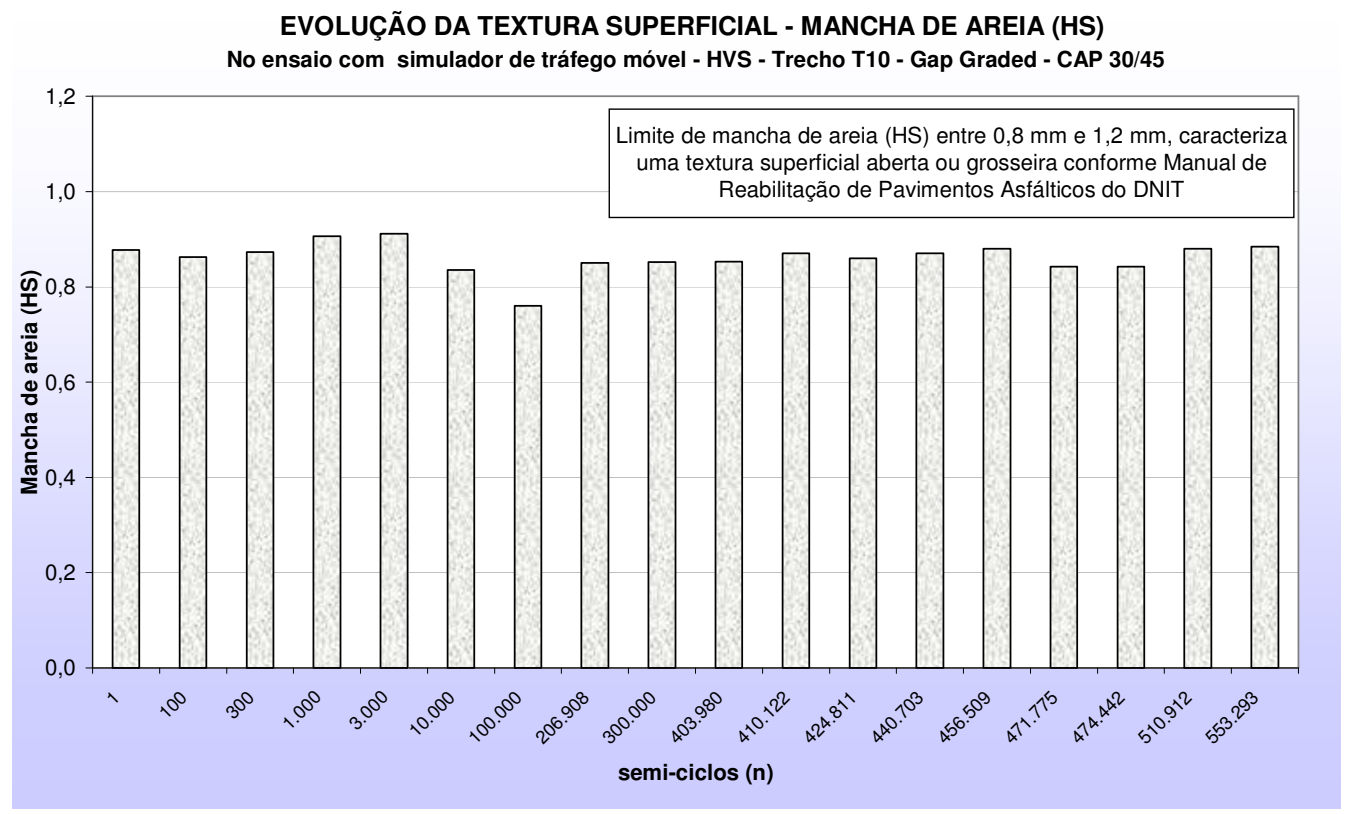

Figura 166 - Textura superficial com ensaio de mancha de areia (HS) - trecho T10

A deflexão desse trecho T10, figura 167 , foi baixa durante 0 ensaio com 0 simulador de tráfego móvel de campo, com valores médios entre $10(0,01 \mathrm{~mm})$ e $20(0,01 \mathrm{~mm})$. Observe-se que nas distâncias de $5,5 \mathrm{~m}$ e 6,5 m os valores foram maiores, na ordem de $30(0,01 \mathrm{~mm})$ para as 100.000 solicitações. Porém são leituras localizadas. 


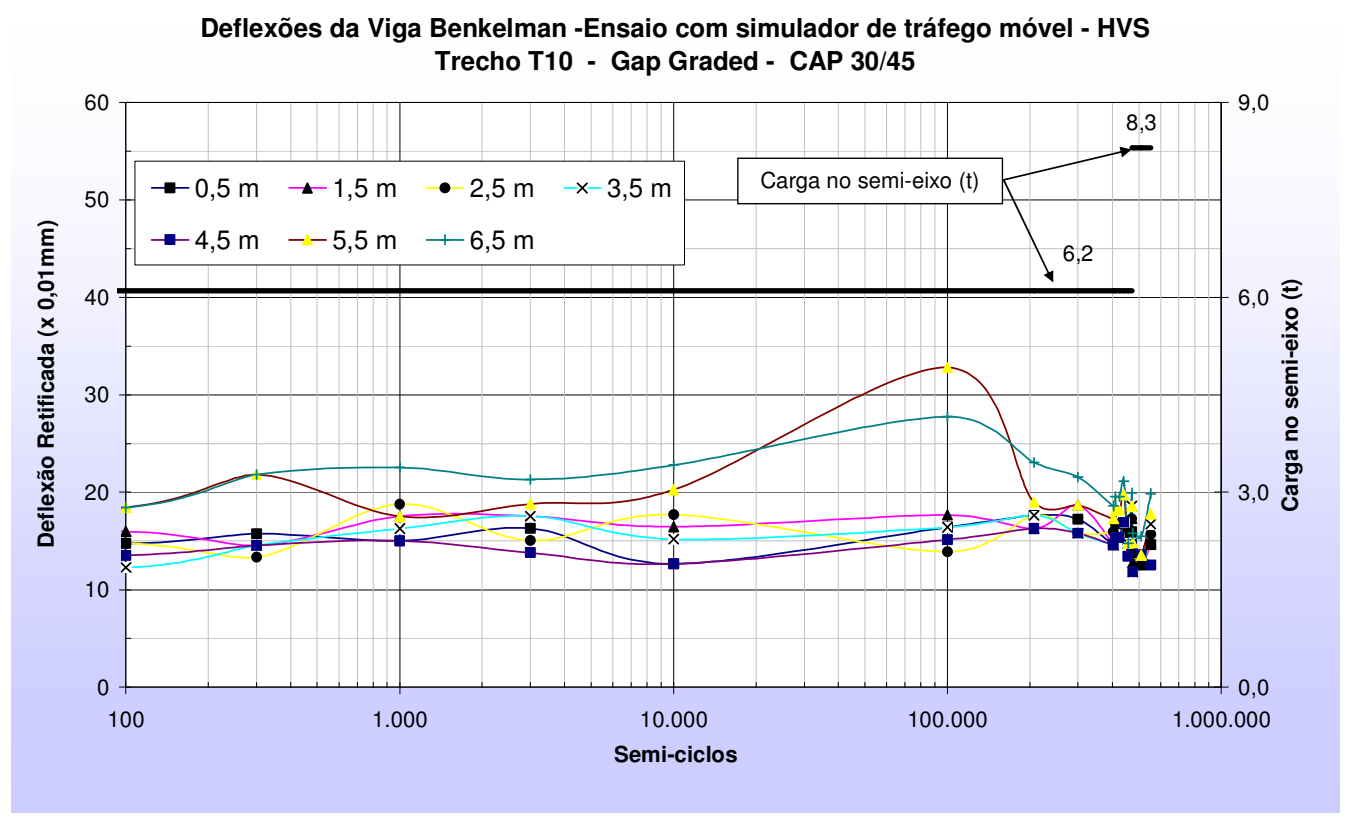

Figura 167 - Deflexões com a viga Benkelman no trecho T04.

Com a mudança de carga de 6,2 tf para 8,3 tf as deflexões permaneceram dentro dos limites de $10(0,01 \mathrm{~mm})$ e $20(0,01 \mathrm{~mm})$.

\subsubsection{Evolução das flechas com simulador de tráfego móvel de campo}

Conforme já mencionado durante eventuais paradas da simulação com simulador de tráfego móvel de campo, para a realização de leituras e também para a manutenção do equipamento foram efetuadas medições das flechas na área simulada. Os valores das flechas é o resultado da média aritmética de 15 leituras realizadas ao longo de toda a extensão solicitada pelo simulador.

Mostra-se na figura 168 o resultado das flechas em função do número de ciclos para os três trechos ensaiados, T01, T04 e T10. 


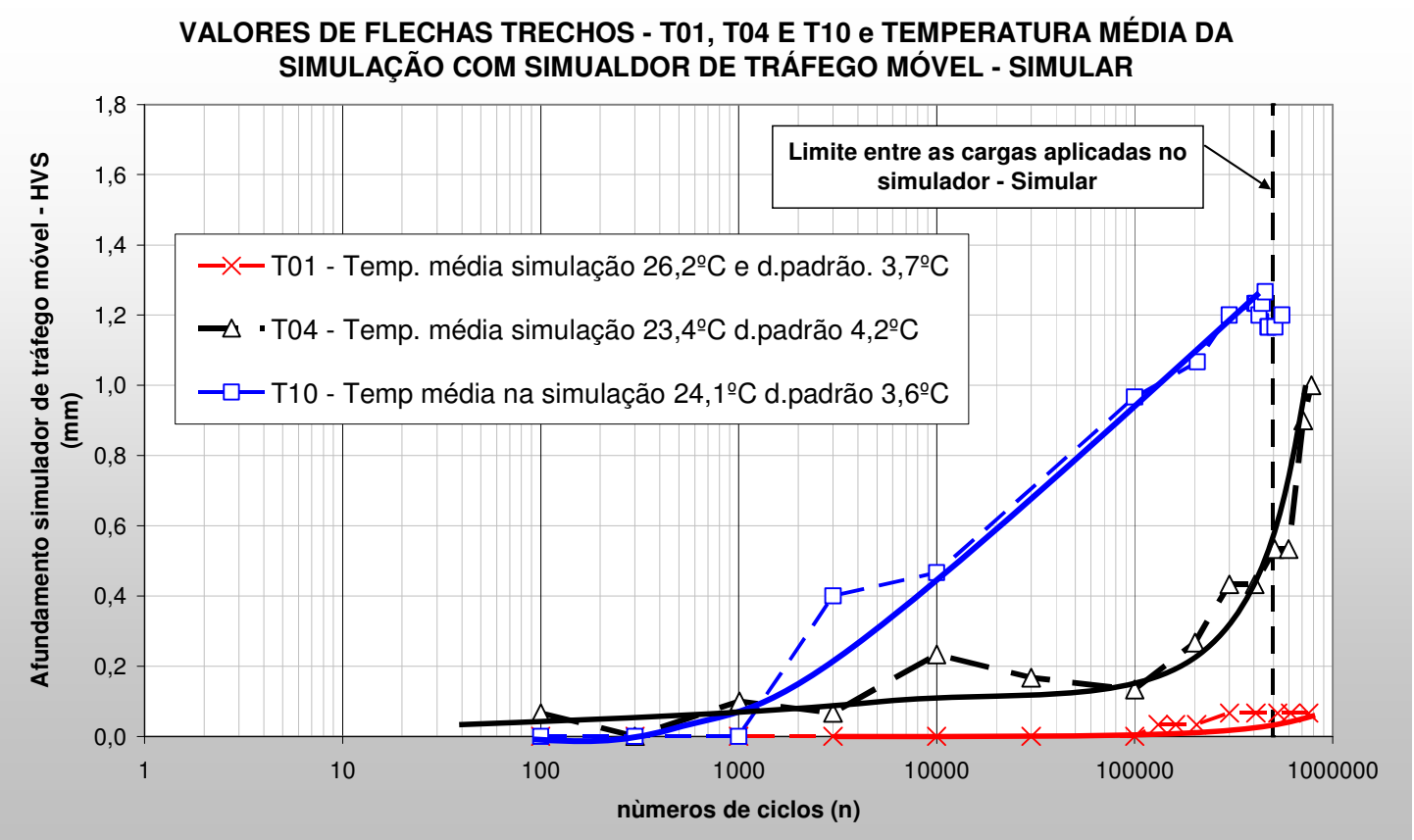

Figura 168 - Flechas registradas com o simulador de tráfego móvel de campo para os três trechos T01, T04 e T10 e as temperatura médias durante a simulação

As flechas registradas durante o ensaio com simulador de tráfego móvel de campo no trecho T01 estão apresentadas na figura 168. Foi traçada uma linha auxiliar para melhor interpretação da tendência dos valores das flechas.

O valor de afundamento registrado com o simulador foi muito baixo, na ordem de $0,07 \mathrm{~mm}$, com registros de afundamentos a partir de 100.000 ciclos.

Esse baixo valor no afundamento registrado com o simulador de tráfego móvel de campo, não condiz com as condições de superfície que o trecho apresenta desde a abertura ao tráfego. O afundamento medido após os períodos de 1, 6 e 13 meses de solicitação pelo tráfego foram de 4,5, 9,1 e 19,8 mm respectivamente, conforme figura 76 no item 3.9.4.

Possivelmente a carga aplicada pelo simulador estava errada, com valor abaixo do desejável de 6,2 tf. Esse trecho T01 não será alvo de análise de comparação entre resultados de campo com simulador de tráfego móvel de campo. 
Da mesma forma as flechas registradas durante o ensaio com o simulador no trecho T04 estão apresentadas na figura 168. O valor de afundamento registrado com o simulador de tráfego móvel de campo foi próximo de $0,5 \mathrm{~mm}$ para um número de solicitações de cerca de 500.000 para a carga de 6,2 tf e acréscimo de mais $0,5 \mathrm{~mm}$, totalizando um afundamento $1,0 \mathrm{~mm}$ para a carga de 8,3 tf com aproximadamente 280.000 solicitações.

No experimento com o simulador, considerando que todo afundamento de 1,0 $\mathrm{mm}$ tenha ocorrido na camada de $5 \mathrm{~cm}$ de rolamento, tem-se uma deformação permanente em trilha de roda de $2 \%$.

Mostram-se na figura 168 os valores das flechas para o trecho T10 com simulador. O número de solicitações foi de 553.000 , sendo que com 470.000 solicitações, a carga foi alterada de 6,2 tf para 8,3 tf.

Os valores de afundamento registrados foram baixos, com valor máximo de 1,2 $\mathrm{mm}$, observando que a partir de 300.000 solicitações, esse valor foi atingido e manteve-se por mais 253.000 solicitações, mesmo alterando a carga nas últimas 80.000 solicitações. Considerando que o afundamento de 1,2 mm tenha ocorrido somente na camada de rolamento, tem-se $2,4 \%$ de deformação permanente em trilha de roda causada pelo simulador.

\subsubsection{Efeito temporal da carga do simulador de tráfego}

Conforme procedimento anteriormente descrito no item 3.3, que determina o número $\mathrm{N}$ como resultado da contagem de tráfego efetuada na pista-teste, foi determinado esse número para os períodos de 1, 6 e 13 meses de solicitação do tráfego. Foi utilizado nessa determinação o $\mathrm{N}$ encontrado com FEC considerando $30 \%$ de excesso de carga. Também foram associadas a esses números, as flechas correspondentes observadas em pista para os mesmos períodos. Apresentam-se na tabela 50 os números $\mathrm{N}$ determinados pela contagem de tráfego na pista-teste e as respectivas flechas medidas em pista. 
Tabela 50 - Número $\mathrm{N}$ calculado para os período de 1, 6 e 13 meses com FEC da USACE e as flechas medidas em pista para os mesmos períodos

\begin{tabular}{c|ccccc}
\hline Período & \multicolumn{2}{|c|}{ N calculado } & \multicolumn{2}{c}{ Flechas } \\
\hline (mês) & Eixo Legal & Ex. excesso & T04 & T10 \\
\hline 1 & $2,59 \mathrm{E}+05$ & $5,79 \mathrm{E}+05$ & 0,4 & 0,4 \\
\hline 6 & $3,89 \mathrm{E}+05$ & $3,47 \mathrm{E}+06$ & 3,4 & 2,2 \\
\hline 13 & $3,67 \mathrm{E}+06$ & $8,20 \mathrm{E}+06$ & 14,6 & 6,6 \\
\hline
\end{tabular}

Para a determinação do número $\mathrm{N}$ relacionado ao número de ciclos com $\mathrm{o}$ simulador de tráfego móvel de campo, tomou-se como base as cargas e os números de ciclos mostrados na tabela 51 .

Tabela 51 - Número de ciclos submetidos por tipo de carga utilizada nos trechos T04 e T10

\begin{tabular}{c|c|c}
\hline Trecho & Carga (tf) & Ciclos (un) \\
\hline \multirow{2}{*}{ T04 } & 6,2 & 500.000 \\
& 8,3 & 280.000 \\
T10 & 6,2 & 470.000 \\
& 8,3 & 83.000 \\
\hline
\end{tabular}

Os fatores de equivalência de carga - FEC do USACE e da AASHTO, correspondentes às cargas $6,2 \mathrm{ff}$ e $8,3 \mathrm{tf}$ no semi-eixo podem ser obtidos através equações 23 e 24 respectivamente.

$$
\begin{aligned}
& F C=1,832 * 10^{-6} * P^{6,2542} \\
& F C=\left(\frac{P}{8,17}\right)^{4,32}
\end{aligned}
$$

onde: $\quad F C=$ fator de equivalência de carga

$$
\mathrm{P}=\text { carga }(\mathrm{tf})
$$

Para as cargas no eixo de $12,4 \mathrm{tf}$ e $16,6 \mathrm{tf}$, os FEC correspondentes ao eixo estão apresentados na 52. 
Tabela 52 - FEC do USACE e AASHTO para as cargas do simulador de tráfego

\begin{tabular}{c|c|c|c}
\hline \multicolumn{2}{c|}{ Carga (tf) } & \multicolumn{2}{c}{ FEC } \\
\hline Semi-eixo & Eixo & USACE & AASHTO \\
\hline 6,2 & 12,4 & 12,63 & 6,06 \\
8,3 & 16,6 & 78,29 & 21,38 \\
\hline
\end{tabular}

O produto do número de ciclos e os seus respectivos FEC resulta no número $\mathrm{N}$ representativo com o simulador de tráfego. Na tabela 53, apresentam-se para os trechos T04 e T10 o número N (função do FEC da USACE) e os respectivos valores de flechas encontrados com o simulador de tráfego móvel de campo.

Tabela 53 - Número N dos trechos T04 e T10 e as flechas encontradas com o simulador

\begin{tabular}{c|c|c|c}
\hline \multicolumn{5}{c}{ Trecho T04 } \\
\hline Ciclos & FEC & $\mathbf{N}$ & Flecha \\
\hline Simulador & USACE & simulador & Simulador \\
\hline 100 & 12,63 & $1,26 \mathrm{E}+03$ & 0,04 \\
\hline 1000 & 12,63 & $1,26 \mathrm{E}+04$ & 0,10 \\
\hline 10000 & 12,63 & $1,26 \mathrm{E}+05$ & 0,15 \\
\hline 100000 & 12,63 & $1,26 \mathrm{E}+06$ & 0,19 \\
\hline 500000 & 12,63 & $6,32 \mathrm{E}+06$ & 0,53 \\
\hline 280000 & 78,29 & $2,82 \mathrm{E}+07$ & 1,00 \\
\hline
\end{tabular}

\begin{tabular}{c|c|c|c}
\hline \multicolumn{5}{c}{ Trecho T10 } \\
\hline Ciclos & FEC & $\mathbf{N}$ & Flecha \\
\hline Simulador & USACE & simulador & Simulador \\
\hline 1000 & 12,63 & $1,26 \mathrm{E}+04$ & 0,10 \\
\hline 3000 & 12,63 & $3,79 \mathrm{E}+04$ & 0,40 \\
\hline 10000 & 12,63 & $1,26 \mathrm{E}+05$ & 0,47 \\
\hline 100000 & 12,63 & $1,26 \mathrm{E}+06$ & 0,97 \\
\hline 470000 & 12,63 & $5,94 \mathrm{E}+06$ & 1,17 \\
\hline 83000 & 78,29 & $1,24 \mathrm{E}+07$ & 1,2 \\
\hline
\end{tabular}

Plotando-se em um gráfico as flechas encontradas no trecho simulado pelo equipamento com seus respectivos valores de número $\mathrm{N}$ determinados, tabela 51 , pode-se verificar o efeito do tempo da carga do simulador de tráfego. Nas figuras 169 e 170 está apresentado o efeito do tempo do simulador do trecho T04 e T10, respectivamente.

Observe-se que os valores das flechas registradas com simulador de tráfego móvel de campo para no trecho T04 ficou muito inferior aos registrados em pista para os períodos de 1, 6 e 13 meses, mesmo com um número $\mathrm{N}$ muito superior aos determinados pelo tráfego para o período em questão. Registramse flechas de apenas $1,0 \mathrm{~mm}$ com $2,8 \times 10^{7}$ solicitações, em contrapartida têmse valores de flechas na ordem de 14,6 mm após 13 meses de solicitação pelo tráfego que resultou em um número $\mathrm{N}=8,20 \times 10^{6}$ solicitações (para FEC com $30 \%$ de excesso de carga), (figura 169). 
Considerando o número $\mathrm{N}$ determinado com $\mathrm{FEC}$ baseado no eixo máximo legal, observe-se no gráfico que se distancia mais dos valores observados com simulador de tráfego móvel de campo.

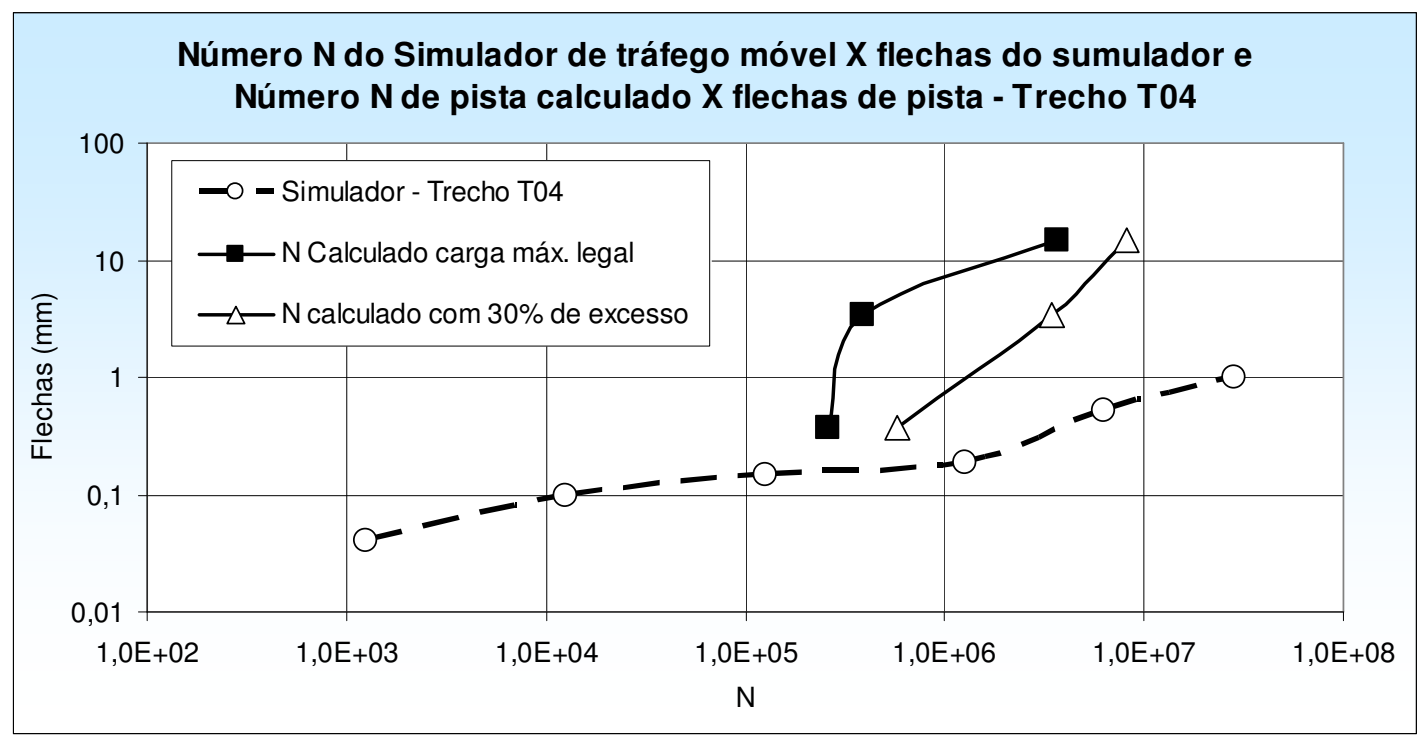

Figura 169 - Efeito temporal do simulador de tráfego móvel de campo - Trecho T04

Da mesma forma na figura 170 , tem-se a flecha de $1,2 \mathrm{~mm}$ para $1,24 \times 10^{7}$ solicitações, do simulador distanciando-se das condições observadas em pista com flecha no valor de 6,6 $\mathrm{mm}$ para um número $\mathrm{N}=8,20 \times 10^{6}$ solicitações (para FEC com $30 \%$ de excesso de carga) e, se considerar o número $\mathrm{N}$ para FEC com eixo máximo legal os valores com simulador e pista distanciam ainda mais. 


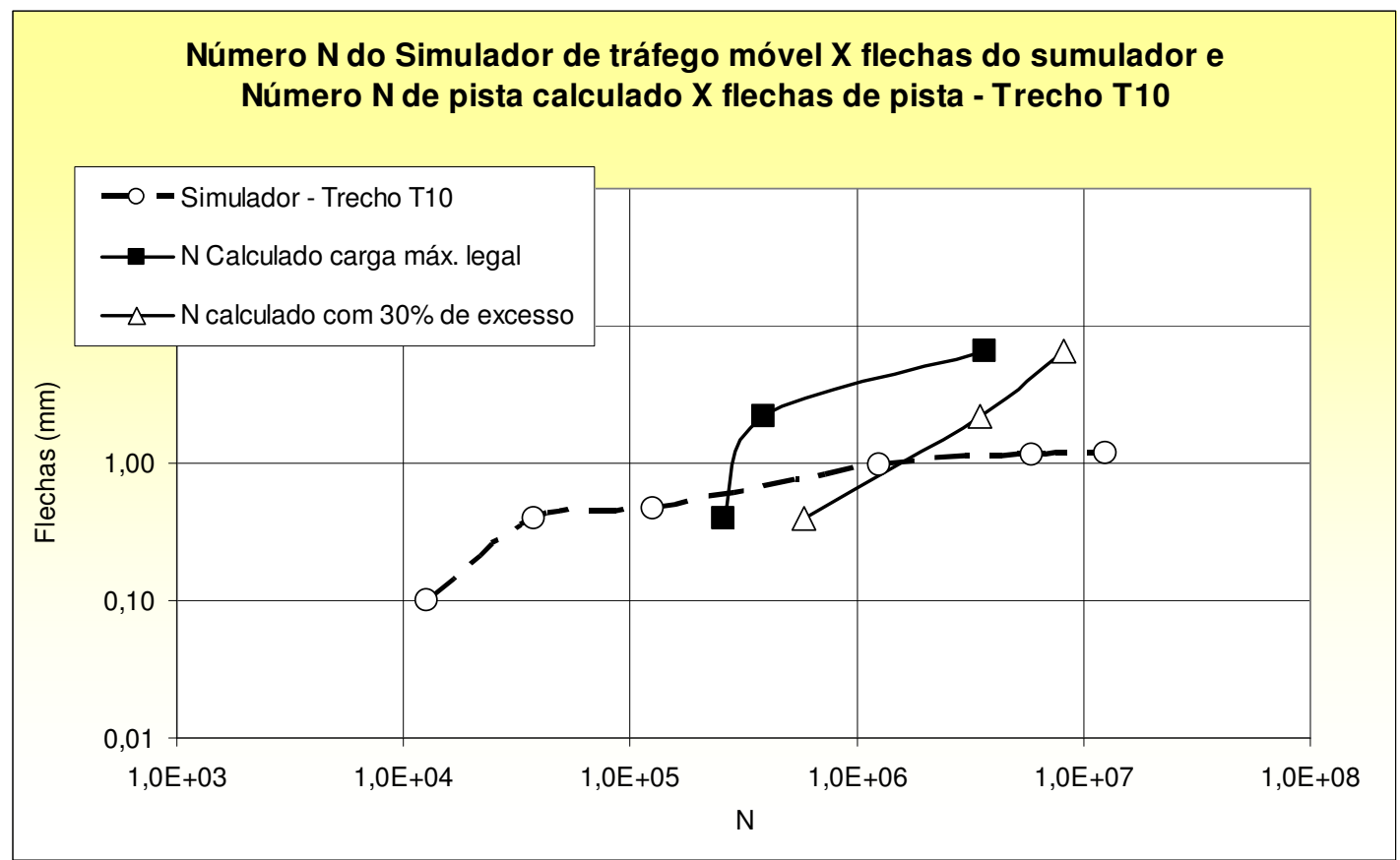

Figura 170 - Efeito temporal do simulador de tráfego móvel de campo - Trecho T10

Verifica-se uma variação no efeito temporal do simulador de tráfego móvel de campo comparado com as condições registradas em pista. Um dos fatores que certamente foi decisivo para essa falta de correlação a longo prazo, deve-se ao fato do ensaio com o simulador de tráfego móvel de campo ter sido realizado em época em que a temperatura ambiente manteve-se baixa, conforme registro na figura 168, em que as temperaturas durante a realização do ensaio foram em média $25^{\circ} \mathrm{C}$ e nessa faixa de temperatura as misturas asfálticas são mais resistentes à deformação permanente em trilha de roda. É difícil na realidade usar um fator que mostre a importância da temperatura ambiente elevada no número de repetições. Provavelmente se pudesse levar em conta como número de solicitações devido à maior temperatura, após 13 meses o $\mathrm{N}$ seria muito maior ao calculado. Este é um desafio para poder prever a influência sazonal no comportamento dos revestimentos asfálticos sujeitos a tráfego muito pesado e lento. Como transpor esta situação para o simulador de tráfego de pista é mais um desafio a ser enfrentado.

Apresentam-se na tabela 54 a hierarquização dos resultados de deformação permanente em trilha de roda das misturas asfálticas nas condições de ensaio: teor de ligante asfáltico de projeto, de placas extraídas de pista, teor de ligante 
asfáltico de pista, teor de ligante asfáltico corrigido, flechas em campo para 1, 6 e 13 meses e os afundamentos com o simulador de tráfego móvel de campo.

A hierarquização dos valores de deformação permanente em trilha de roda obtidos com as misturas asfálticas usinadas com teor corrigido pode-se verificar que os ligantes asfálticos convencionais apresentaram valores superiores a 5\%, em contrapartida os ligante modificados apresentaram valores de deformação permanente inferiores a 5\% para a mesma condição de teor de ligante asfáltico. 
Tabela 54 - Hierarquização de deformação permanente dos tipos de condições ensaiados de laboratório, flecha em campo e simulador de tráfego móvel de campo

\begin{tabular}{|c|c|c|c|c|c|c|c|c|c|c|}
\hline \multicolumn{3}{|c|}{ DADOS } & \multicolumn{4}{|c|}{ LABORATÓRIO - LPC } & \multicolumn{3}{|c|}{ CAMPO } & SMT de campo \\
\hline \multirow[t]{2}{*}{ TRECHOS } & \multicolumn{2}{|c|}{ TIPO DE MISTURA ASFÁLTICA } & $\begin{array}{c}\text { DEFORMAÇÃO PERMANENTE DE } \\
\text { MISTURAS ASFÁLTICAS USINADAS } \\
\text { EM LABORATÓRIO NOS TEORES DE } \\
\text { LIGANTE ASFÁLTICO DE PROJETO - } \\
\text { PÁGINA } 226 \text { E ANEXOI }\end{array}$ & \begin{tabular}{|c|} 
DEFORMAÇ̃̃OO \\
PERMANENTE DE \\
PLACAS EXTRAÍDAS DA \\
PISTA - PÁGINA 234 E \\
ANEXO II
\end{tabular} & $\begin{array}{l}\text { DEFORMÇÃO PERMANENTE DE } \\
\text { PLACAS USINADAS EM } \\
\text { LABORATÓRIO NO TEOR DE } \\
\text { LIGANTE ASFÁLTICO DA PISTA - } \\
\text { PÁGINA 234 E } 229 \text { E ANEXO III }\end{array}$ & $\begin{array}{l}\text { DEFORMACCÃO PERMANENTE DE } \\
\text { MISTURAS ASFÁLTICAS USINADAS EM } \\
\text { LABORATÓRIO NO TEOR DE LIGANTE } \\
\text { ASFÁLTICO CORRIGIDO PELA PCG - } \\
\text { PÁGINA 226 E ANEXO VI }\end{array}$ & \multicolumn{3}{|c|}{$\begin{array}{l}\text { LEVANTAMENTO DE FLECHAS DA } \\
\text { TRI E TER NA PISTA COM A } \\
\text { SOLICITACCÃO DE TRÁFEGO PARA AS } \\
\text { 3 CAMPANHAS - PÁGINA } 170 \text { E } \\
\text { ANEXO IV (mm) }\end{array}$} & $\begin{array}{l}\text { SIMULADOR DE TRÁFEGO MÓVEL - } \\
\text { SIMULAR - PÁGINA } 247 \text { E } 248\end{array}$ \\
\hline & FX. & LIGANTE & $\%$ & $\%$ & $\%$ & $\%$ & $1 \mathrm{MÊS}$ & 6 MESES & 13 MESES & $\mathrm{mm}$ \\
\hline 1 & Mix Ivb I.A. & CAP 50/70 & $\mathrm{T} 3-4,0$ & $\mathrm{~T} 3-1,8$ & $\mathrm{~T} 3-2,0$ & $\mathrm{~T} 3-2,3$ & $\mathrm{~T} 4-0,4$ & $\mathrm{~T} 2-2,1$ & $\mathrm{~T} 10-6,6$ & T-01 - 0,1 - não considerado \\
\hline 2 & SPV $12,5 \mathrm{~mm}$ & CAP $50 / 70$ & T8 $-4,6$ & $\mathrm{~T} 4-3,1$ & $\mathrm{~T} 4-2,7$ & $\mathrm{~T} 4-2,9$ & $\mathrm{~T} 10-0,4$ & $\mathrm{~T} 10-2,2$ & T4 - 14,6 & - \\
\hline 3 & SPV $12,5 \mathrm{~mm}$ & $4 \%$ SBS & $\mathrm{T} 2-5,8$ & $\mathrm{~T} 2-4,7$ & $\mathrm{~T} 10-4,9$ & $\mathrm{~T} 7-3,4$ & $\mathrm{~T} 2-1,3$ & $\mathrm{~T} 3-2,8$ & $\mathrm{~T} 2-18,8$ & - \\
\hline 4 & SPV $9,5 \mathrm{~mm}$ & $4 \% S B S$ & T9 $-5,8$ & $\mathrm{~T} 10-5,0$ & $\mathrm{~T} 2-5,2$ & $\mathrm{~T} 5-3,5$ & T9 - 1,8 & $\mathrm{~T} 4-3,4$ & T1 - 19,1 & $\mathrm{~T} 4-1$ \\
\hline 5 & SPV $9,5 \mathrm{~mm}$ & $1,2 \%$ RET & $\mathrm{T} 10-5,8$ & $T 8-8,3$ & T8 $-6,7$ & $\mathrm{~T} 6-3,7$ & $\mathrm{~T} 3-2,4$ & $T 8-4,0$ & T3- 23,4 & - \\
\hline 6 & SPV $12,5 \mathrm{~mm}$ & $1,2 \%$ RET & $\mathrm{T} 1-8,7$ & $\mathrm{~T} 1-8,2$ & $\mathrm{~T} 9-7,0$ & $\mathrm{~T} 10-4,9$ & $\mathrm{~T} 8-3,1$ & T9 $-5,4$ & T5 - 28,8 & - \\
\hline 7 & Gap Graded & $A M B$ & $\mathrm{~T} 7-12,7$ & $\mathrm{~T} 7-14,1$ & $\mathrm{~T} 7-7,1$ & T9 - 5,7 & $\mathrm{T} 7-3,3$ & $\mathrm{~T} 7-8,9$ & T9 - 31,1 & - \\
\hline 8 & SPV $12,5 \mathrm{~mm}$ & CAP $30 / 45$ & T5 - 20,0 & T6-15,7 & $\mathrm{T} 1-13,2$ & $T 8-6,2$ & $\mathrm{~T} 1-4,5$ & $\mathrm{~T} 1-9,1$ & $\mathrm{~T} 6-32,8$ & - \\
\hline 9 & SPV $9,5 \mathrm{~mm}$ & CAP $30 / 45$ & $\mathrm{~T} 4-22,0$ & $\mathrm{~T} 5-16,7$ & $\mathrm{~T} 6-15,7$ & $\mathrm{~T} 1-7,9$ & $\mathrm{~T} 5-5,4$ & $T 5-9,2$ & T8 - 38,3 & - \\
\hline 10 & Gap Graded & CAP $30 / 45$ & T6 - NÃO INCLUSO NA ANÁLISE & T9- 17,0 & $\mathrm{~T} 5-18,0$ & $\mathrm{~T} 2-7,9$ & $T 6-7,8$ & T6 - 12,7 & $\mathrm{TT}-58,6$ & $\mathrm{~T} 10-1,2$ \\
\hline
\end{tabular}




\section{Capítulo 05}

\section{CONCLUSÃO E RECOMENDAÇÕES}

Nesse capítulo são feitos comentários e a conclusão do trabalho. São feitas recomendações para trabalhos futuros sobre deformação permanente em misturas asfálticas empregadas como revestimento de pavimento, linha de pesquisa de mais de 15 anos do Laboratório de Tecnologia de Pavimentação da Escola Politécnica da USP.

\section{1 - COMENTÁRIOS}

\section{Condições de pista}

As flechas registradas nos dez trechos experimentais da pista-teste, após 13 meses, mostraram que as misturas asfálticas não resistiram à formação de afundamentos de trilha de roda imposta pelo tráfego muito pesado de caminhões, em sentido de pista ascendente, com baixa velocidade. Deve-se constatar que numa parte expressiva dos trechos experimentais, as medições realizadas com 6 meses de solicitação pelo tráfego já mostraram a baixa resistência à deformação permanente das misturas asfálticas testadas.

Os ensaios laboratoriais de deformação permanente com simulador de tráfego LCPC das misturas asfálticas empregadas em pista, com os teores de ligantes asfálticos acima do adequado, mostraram que era previsível que ocorreriam afundamentos em trilha de rodas. Os ensaios de todas as misturas, reproduzidos com as mesmas condições de pista tanto na distribuições granulométricas, como principalmente nos teores de ligantes asfálticos, mostraram a vulnerabilidade das misturas asfálticas na formação de deformação. Para as misturas asfálticas cuja previsibilidade aos afundamentos pelos resultados de laboratório não foi boa, as condições de laboratório não 
reproduziram a média de campo, seja pela variabilidade das condições de campo, seja pelo ligante asfáltico de campo que não condizia com aquele testado em laboratório.

Prensa de cisalhamento giratório - PCG

A utilização da PCG na aptidão de compactação das misturas asfálticas mostrou-se benéfica para a escolha do teor de ligante asfáltico, pois a curva de volume de vazios $\mathrm{x}$ número de giros é sensível ao teor de ligante asfáltico. De posse dos resultados de deformação permanente das placas usinadas nos teores de projeto e de pista, para os 10 trechos, a adoção de um teor corrigido para cada uma delas mostrou que as misturas asfálticas testadas poderiam apresentar, em sua maioria, resistência ao afundamentos de trilhas de rodas. A PCG foi empregada neste trabalho para corrigir o teor de ligante, mas pode ser empregada para alterar as proporções das frações de agregados para tornar a mistura com melhores características para a compactação.

\section{Simulador de tráfego móvel de campo}

A simulação de tráfego com o emprego do simulador de tráfego móvel de campo apresentou pequenos valores de flechas para o trecho T04 e T10. O simulador de tráfego, não pôde prever adequadamente o comportamento em campo destas misturas a longo prazo, possivelmente pelo fato do ensaio com o simulador de tráfego móvel ter sido realizado em época em que a temperatura ambiente manteve-se baixa.

As flechas registradas após 6 meses de tráfego na pista-teste, para esses dois trechos T04 e T10, foram 3,4 mm e 2,2 mm, respectivamente, e após 13 meses, esses valores passaram para $14,6 \mathrm{~mm}$ e $6,6 \mathrm{~mm}$. Estes valores são elevados para um período de 13 meses após abertura ao tráfego. Dentre as várias causas prováveis que explicam a diferença entre as flechas registradas em campo e as obtidas com o simulador de tráfego, pode-se citar a temperatura média da superfície do pavimento durante a realização do ensaio com o simulador de tráfego móvel que foi de $23,4^{\circ} \mathrm{C}$ com desvio padrão de 
$4,2^{\circ} \mathrm{C}$, para o trecho $\mathrm{T} 04$, e de $24,1^{\circ} \mathrm{C}$ com desvio padrão de $3,6^{\circ} \mathrm{C}$, para o $\mathrm{T} 10$. Com a chegada de estações mais quentes, houve um aumento das flechas de campo ocasionadas pela ação do tráfego. É difícil, na realidade, usar um fator numérico que mostre a importância da temperatura ambiente elevada para os defeitos de deformação permanente e corrija o número de repetições de carga real. Como transpor esta situação para o simulador de tráfego de pista é mais um desafio a ser enfrentado.

\section{Deformação permanente de laboratório}

Com base nos resultados de deformação permanente, para as condições de placas usinadas nos teores de projeto, de pista e nos corrigidos pela PCG, pôde-se verificar que o teor de ligante asfáltico e as características reológicas dos ligantes exerce um papel fundamental na resistência à deformação permanente em trilha de roda.

Com a correção dos teores de ligantes asfálticos, as misturas passaram a apresentar maior resistência à formação de trilha de roda. Os menores valores de afundamentos em laboratório foram conseguidos com as misturas com asfalto modificado por polímero SBS e por polímero RET, e com o asfaltoborracha. As misturas densas com CAP 30/45 exibem valores ligeiramente superiores de afundamentos que aquelas com asfaltos modificados, porém com melhor resistência à deformação permanente que as misturas com CAP 50/70. Este ligante, nas condições da amostra ensaiada, não demonstra comportamento adequado à deformação permanente para tráfego pesado e lento.

O LCP de 2007 especifica que para tráfego pesado em condições muito severas - tráfego intenso com mais de 2000 veículos diários com eixo carregado e condições climáticas com temperaturas médias elevadas, o limite aceitável de deformação permanente em trilha de roda em ensaios de laboratório com o equipamento francês, a $60^{\circ} \mathrm{C}$, nas condições especificadas de ensaio, deve ser inferior a 5\% para 30.000 ciclos. Para as condições de rodovias brasileiras sujeitas a elevado volume de tráfego, com um porcentual 
importante de veículos comerciais, e com as características climáticas de médias de temperatura elevadas ao longo do ano, torna-se imperativa a aplicação desse limite de 5\% neste ensaio laboratorial.

Nesse mesmo contexto, o procedimento de dosagem Superpave recomenda o acréscimo no Performance Grade PG dos ligantes asfálticos quando a rodovia apresenta condições mais severas de tráfego e com trechos em aclive, o que condiciona baixas velocidades, e temperaturas médias elevadas. O PG calculado para as condições da pista-teste não deve ser inferior a $70^{\circ} \mathrm{C}$. PG 70 ou superior é em geral alcançado por ligantes modificados e, em alguns casos, pelo CAP 30/45. Os ligantes asfálticos utilizados nessa pesquisa não foram avaliadas quanto ao $P G$

Essa pesquisa confirma a recomendação do Superpave através dos ensaios de deformação permanente em trilha de roda: as misturas asfálticas usinadas com os ligantes asfálticos menos consistentes, como o CAP 50/70, foram as que apresentaram os piores resultados frente à deformação permanente. As misturas asfálticas usinadas com ligantes asfálticos modificados foram as que melhor resistiram à formação de afundamentos. Pelo fato dessas últimas apresentarem menores valores de deformação permanente em trilha de roda, essas misturas suportam melhor a variação no teor de ligante asfáltico de usina que é de $\pm 0,3 \%$.

A distribuição granulométrica através do embricamento dos grãos colabora intensamente para a resistência à formação de trilha de roda. Entretanto, as mesmas distribuições granulométricas foram utilizadas para os ligantes asfálticos convencionais e modificados, denotando a importância das características reológicas dos ligantes asfálticos. As misturas descontínuas, bem concebidas quanto à graduação, mostram-se adequadas quanto à resistência à deformação permanente. Em laboratório constatou-se que ambas misturas gap-graded testadas atingiram resultados adequados, tanto com asfalto-borracha, quanto com CAP 30/45, embora este último tenha apresentado maior valor de afundamento frente ao asfalto-borracha. Em campo, a análise deste parâmetro ficou prejudicada pelo elevado teor de 
asfalto-borracha utilizado na usinagem do gap-graded. A mistura que apresentou menor afundamento da pista-teste em média foi o gap-graded com CAP 30/45, porém os ensaios posteriores mostraram que o ligante provavelmente estava contaminado com asfalto modificado por polímero.

\section{2 - CONCLUSÃO}

Face aos resultados obtidos na pesquisa indica-se a adoção do limite máximo de $5 \%$ de deformação permanente em trilha de roda, obtido com 0 equipamento francês tipo LCP - orniereur, em placas de $5 \mathrm{~cm}$ de espessura, para as misturas asfálticas brasileiras que serão submetidas a tráfego considerado pesado, com baixas velocidades e temperaturas médias de serviço elevadas. Para essas condições climáticas e de tráfego, não se deve utilizar ligantes asfálticos cujas características reológicas indiquem baixas consistências. As misturas densas e bem-graduadas podem oferecer resistência adequada à formação de trilha de roda, mas deve-se observar a macrotextura resultante dos revestimentos asfálticos para não gerar misturas de textura fechada ou muito fechada. As misturas asfálticas descontínuas constituem-se uma alternativa importante para a resistência à deformação permanente, porém devem ser bem concebidas quanto à graduação e o ligante adequadamente selecionado. $O$ trabalho mostra a importância de uma seleção prévia criteriosa da graduação e do tipo de ligante asfáltico, além de uma dosagem rigorosa, de preferência realizada com ensaios que possam prever comportamento mecânico, principalmente no caso de revestimentos asfálticos para vias de tráfego pesado.

\section{3 - RECOMENDAÇÕES}

Para a continuidade da pesquisa da pista-teste, levando-se em consideração os resultados obtidos com esse trabalho, recomenda-se que a pista-teste, como se encontra atualmente, seja fresada e que se executem dois novos trechos com tipos de misturas asfálticas diferentes, com 1000 metros de 
extensão cada um deles. Os resultados do presente trabalho indicam como soluções de revestimento asfáltico a serem testadas nas condições desta pista: uma mistura asfáltica com distribuição granulométrica gap-graded do Caltrans, usinada com ligante asfáltico modificado por borracha, e uma segunda com distribuição granulométrica densa e bem-graduada, SPV $12,5 \mathrm{~mm}$, usinada com ligante asfáltico modificado por polímero SBS ou modificado por RET.

Recomenda-se também que antes da execução dos trechos, sejam realizados todos os ensaios laboratoriais, tanto de dosagem como principalmente com a prensa de cisalhamento giratório (PCG) e com o simulador de tráfego LCPC para determinação da deformação permanente em trilha de roda.

Sugere-se também o ensaio de campo com o simulador de tráfego nos dois segmentos. A instalação de uma estação metereológica, juntamente ao trecho da pista-teste, permanentemente durante o período de avaliação do experimento e uma balança aferidora da carga do simulador de tráfego móvel de campo, instalada de forma permanente, para que se possa verificar carga atuante durante a simulação são igualmente sugeridas. 


\section{REFERÊNCIAS BIBLIOGRÁFICAS}

ASSOCIATION FRANÇAISE DE NORMALISATION, NORME EUROPÈENNE. 13108-1. Mélanges bitumineux: specification des matériaux - enrobés bitumineux. 2007.

ASSOCIATION FRANÇAISE DE NORMALISATION. 98-130 a 141. Essais relatifs aux chaussées - préparation des mélanges hydrocarbonés. Etude de la conformité d'un enrobé. 1993.

ASSOCIATION FRANÇAISE DE NORMALISATION. 98-251-1, Essais relatifs aux chaussées - préparation des mélanges hydrocarbonés. Essai de duriez. 1995.

ASSOCIATION FRANÇAISE DE NORMALISATION. 98-252 (1999), Essais relatifs aux chaussées: Essai à la presse à cisaillement giratoire - PCG, 1999.

ASSOCIATION FRANÇAISE DE NORMALISATION. 98-250-1 (1993), Préparation des Mélanges Hydrocarbonés, Partie 1: Fabrication d'un enrobé en laboratoire. 1993.

ASSOCIATION FRANÇAISE DE NORMALISATION. 98-250-2 Préparation des Mélanges Hydrocarbonés, Partie 2: Compactage des plaques. 1993.

ASSOCIATION FRANÇAISE DE NORMALISATION. 98-260-2. Essais relatifs aux chaussées, mesure des caractéristiques rhéologiques des mélanges hydrocarbonés partie 2 : Détermination du module complexe par flexion sinusoïdale. 1992.

ASSOCIATION FRANÇAISE DE NORMALISATION. 98-253-1.Essais relatifs aux chaussées: déformation permanente des mélanges hydrocarbonés - partie 1: Essai d'orniérage. 1993.

ASSOCIATION FRANÇAISE DE NORMALISATION. 98-261-1 (1993), Essais relatifs aux chaussées: détermination de la résistance en fatigue des mélanges hydrocarbonés partie 1: Essai par flexion à flèche constante, 1993.

AMERICAN SOCIETY FOR TESTING AND MATERIALS. C 125. Standard Definitions of Terms Relating to Concrete and Concrete Aggregates. USA.1995.

BAHIA, H. U. e FAHENN, A.F. Using the superpave gyratory compactor to estimate rutting resistance of hot-mix asphalt, Transportation Research Circular EC124, Practical approaches to hot-mix asphalt mix design and production quality control testing, pp. 45-61, Washington, D. C., EUA, Dezembro 2007.

BALDO, M, C.; ANDRADE, A.P.; MARTINS, M.L.O.F. E NERY, J.T. (2000) Análise da precipitação pluvial do estado de santa catarina associada com a anomalia da temperatura da superfície do oceano pacífico. Revista Brasileira de Agrometeorologia, Santa Maria, v. 8, n. 2, p. 283-293, 2000. Disponível em: http://www.sbagro.org.br/rbagro/pdfs lartigo304.pdf>.Acesso em: 05 de out. 2009 
BERNUCCI, L.B.; CAMPOS, O.S.; DOMINGUES, F.A.A.; MOMM,L.; CASTRO NETO, A.M.; RABAÇA,S.R. e FELTRIN, C. (1996). Estudos para a formulação de CBUQ considerando a deformação permanente para as rodovias da Rede DERSA. 30 Pavimentação. Salvador, BA, 1996. ABPv: v.1, p. 18-34.

BERNUCCI, L.B.; MOURA, E. e LEITE, I.M. (2002). Efeito do uso de asfaltos modificados nas propriedades mecâncias dos pavimentos asfálticos. ำ Simpósio sobre Obras Rodoviárias - RODO 2002. São Paulo, SP, 2002. ABGE: p. 147-157.

BERNUCCI, L.B.; MOURA, MOTTA, R.S. E FARIA,V.C. (2008). Avaliação comparativa da deformação permanente em misturas asfálticas produzidas com ligantes asfálticos convencionais e modificado por borracha. In: XXII ANPET, 2008, Fortaleza. XXII Congresso de Ensino e Pesquisa em Transportes.

BERTOLLO, S.A.M., (2002). Avaliação laboratorial de misturas asfálticas densasmodificadas com borracha reciclada de pneus. Tese de Doutorado. Escola de Engenharia de São Carlos USP.

BOTTIN FILHO,I.A. Estudos de misturas de areia-asfato pré-misturadas a quente. (1997). Tese de mestrado, UFRGS, 1997.

BROCK, J.D.; MAY, J.G. Segregation causes and cures. Technical Paper T-117, disponível em: http://www.tadrilling.co.uk/products/t-117.pdf>. Acesso em: 10 de ag. 2009.

BROUSSEAUD, Y.; DELORME,J.L.; HIERNAUX,R. Study of permanent deformations in asphalt with help of the Icpc whell tracking rutting tester: evaluation and future prospects, in $72^{\text {nd }}$ Annual Meeting of Transportations Research Board, USA. 1993.

BROW, S. F. (1988) Improved asphalt pavement engineering.Seventh AAPA, International Asphalt Conference, Brisbane .August 1988, pp $35-48$.

COMINSKI, R,J.; HUBER,G.A.; KENNEDY,T.W. e ANDERSON, M. (1994) The superpave mix design manual for new construction and overlays. Report $n$. SHRP-A-407. Strategic Highway Research Program. National Research Council 2101, Washington DC, 1994.

CONSELHO NACIONAL DE TRÂNSITO. Resolução Contran no62 de 21 de maio de 1998. Disponível em: <http://www.denatran.gov.br/resolucoes.htm> Acesso em: 15 de ag. 2009

CONSELHO NACIONAL DE TRÂNSITO. Resolução Contran no184 de 21

de outubro de 2002. Disponível em: <http://www.denatran.gov.br/resolucoes.htm> Acesso em: 15 de ag. 2009

CONSELHO NACIONAL DE TRÂNSITO. Resolução Contran no189 de 25 de janeiro de 2006. Disponível em: <http://www.denatran.gov.br/resolucoes.htm> Acesso em: 15 de ag. 2009

CONSELHO NACIONAL DE TRÂNSITO. Boletim Técnico. Disponível em: $<$ http://www.cnt.org.br/portal/(F(31Z6kvk-gLpZhlcFO9kOiMS5N17KoR- 
Xw0pwuQhfbNsMwiXvFqPcBb40or0OWNBz6i0VgmyyLIF0VtgNWxeE3Ir7JVTnSFpweeXs030s TiE1))/img/arquivos/Boletim\%20Estat\%C3\%ADstico\%20CNT\%20-\%202009.pdf>

Acesso em: 09 de out. 2009.

COOLEY, L.A.Jr.; et al. Loaded whell tests in to united states: state of the practice. NACT Report 00-04 Transportation Research E-Circular n. E-C016. USA 2000.

COPPEAD. Índices de transporte rodoviário. Instituto de Pós-graduação e Pesquisa em Administração, Universidade Federal do Rio de Janeiro. Rio de Janeiro, 2009. Disponível em: $<$ HTTP://www.centrodelogistica.com.br/new/ IndicesRodoviariosV7.pdf> Acesso em 15 de ag. 2009.

COOPER, K.E.; BROW, S.F. E POOLEY, G.R. (1985) The design of aggregate gradings for asphalt besecourse. Proc. Of the Association of Asphalt Paving Techonologists, Vol. 54 (1985), pp $324-346$.

CORTÉ, J.F., MOUTIER,F. e VAILLETEL, H. The PCG3, latest development in the technology of gyratory compactors, Revue Gén. Routes Aérodromes 771 (1999) 20-24.

COUTINHO NETO, B. e FABBRI, G.T.P. (2004). Ensaio de fluência uniaxial estático avaliação do efeito devido a redução do diâmetro do prato de aplicação de carga. Anais do XVIII Congresso de Pesquisa e Ensino em Transportes, ANPET, Florianópolis SC. v.1, p. 101-114.

DEPARTAMENTO DE ESTRADAS DE RODAGEM. ES-031. Pavimentos flexíveis - Concreto asfáltico. Rio de Janeiro 2006.

DEPARTAMENTO DE ESTRADAS DE RODAGEM PRO-006. Avaliação objetiva da superfície de pavimentos flexíveis e semi-rígidos - procedimento. Rio de Janeiro. 2003.

DEPARTAMENTO DE ESTRADAS DE RODAGEM. PRO 008. Levantamento visual contínuo para avaliação da superfície de pavimentos flexíveis e semi-rígidos. Rio de Janeiro. 2003.

DEPARTAMENTO DE ESTRADAS DE RODAGEM. 700 GTTR. Glossário de termos técnicos rodoviários. Rio de Janeiro.

DRESCHER, A.; KIM, J.; NEWCOMB, D., 1993 - Permanent Deformation in Asphalt Concrete, Journal of Materials in Civil Engineering, v 5, n.1, February 1993.

EMBRAPA. Disponível em: http://www.cnpf.embrapa.br/pesquisa/efb/clima.htm. Acesso em: 05 de out. 2009

FERNANDES, Jr, J.L. (1995). Investigação dos efeitos das solicitações do tráfego sobre o F\\desempenho de pavimentos. Tese de Doutorado. Escola de Engenharia de São Carlos USP 
FREIRE,A.C.F.O.R, Deformações permanentes de misturas betuminosas em pavimentos rodoviários, 2002. Tese de mestrado apresentada na Universidade de Coimbra, Portugal. 2002.

FRITZEN, M. A. Avaliação de soluções de reforço de pavimentos asfálticos com simulador de tráfego da rodovia rio teresópolis. 2005. Dissertação (Mestrado) Universidade Federal do Rio de Janeiro, COPPE. Rio de Janeiro - RJ. 2005.

GONÇALVES,F.P. Estudo experimental do desempenho de pavimentos flexíveis a partir de instrumentação e de ensaios acelerados. 2002. Tese (Doutorado em Geotecnia) Programa de Pós-Graduação em Engenharia Civil, UFRGS, Porto Alegre.

GOODE, J. F. e LUFSEY,L.A.. A new graphical chart for evaluating aggregate gradations. Proceedings of the Association of Asphalt Paving Technologists (AAPT), Vol. 31, 1962.

GRIMAUX,J.P.; HIERNAUX,R. Utilisation de l'orniéreur type Ipc, in Bulletin de Laison de laboratoires de Ponts et Chaussées, Special V, LCPC. França 1977.

GULER, M.; BAHIA,H. U.; BOSSCHER,P. J. e PLESHA, M. E. (2000) Development of a Device for Measuring Shear Resistance of HMA in the Gyratory Compactor. In Transportation Research Record: Journal of the Transportation Research Board, No. 1723, TRB, National Research Council, Washington, D.C., 2000, pp. 116-124.

GUO, R., e PROZZI, J.A. Predicting in service fatigue life of flexible pavements based on accelerated pavement testing. In: Transportation Research Bord $87^{\text {th }}$ Annual Meeting (CDrom). Washington. 2008.

HARMAN,T. BUKOWSKI,J.R. MOUTIER,F. HUBER,G. McGENNIS,R. History and future challenges of gyratory compaction. TRR 1789, 2001.

HARUN, M. H., e MOROSIUK, G. A Study of the performance of various bituminous surfacings for use on climbing lanes. In Proceedings: Eighth REAAA Conference, Taipei, 1721 April 1995.

HUANG,Y.H. Pavement analysis and design. 1ed. USA. 1993.

HUBER, G. A.; SHULER,T.S. Providing sufficient void space for asphalt cement: relationship of mineral aggregate voids and aggregate gradation. In Special Technical Publication. 1147 ASTM USA. 1992.

INMET, Instituto Nacional de Meteorologia, disponível em http://www.inmet.gov.br/sim/sonabra/convencionais.php. Acessado em 25/02/2010.

JOLIET.Y.; MALLOT,M. Precautions when interpreting rutting results from the LCPC traffic simulator, 2ํㅡㄹ Eurasphalt \& Eurobitume Congress Barcelona, 2000.

KANDHAL,P.S.; COOLEY,L.A.Jr. Accelerated laboratory rutting tests: evaluation of the asphalt oavement analyzer. National Cooperative Highway Research Program - Report n.508, 2003. 
KENNEDY,T.W.; HUBER,G.A.; HARRIGAN,E.T.; COMINSKI, R,J.; HUGHES,C.S.; QUINTUS,H.V.;MOULTHROP,J.S. (1994). The superpave mix design manual for new construction and overlays. Report n. SHRP-A-410. Strategic Highway Research Program. National Research Council 2101, Washington DC, 1994.

LEAHY,R.B.; McGENNIS, R.B., Asphalt mixes: materials, design and characterization. Asphalt Paving Technology, v.68A, Illinois, 1999.

LEITE, F.M.L. (1999) Estudo de prepare e caracterização de asfaltos modificados por polímero. Tese de doutorado. UFRJ. Rios Janeiro - RJ

LITTLE, D.N, BUTTON, J.W, YOUSSEF, H. Development of criteria to evaluate uniaxial creep data and asphalt concrete permanent deformation potential. Washington, D.C., Transportation Research Board, Transportations Research Record, 1417, 1993. p49-57.

MANUEL LPC (2007), Manuel LPC d'aide à la formulation des enrobés. Groupe de Travail RST "Formulation des enrobés". Laboratoire Central des Ponts et Chaussées. Paris, France.

MERIGHI, J.V. Estudo da deformação permanente de misturas asfálticas em laboratório. 1999. 275 p. Tese (Doutorado) - Escola Politécnica da USP-São Pulo. 1999.

METCALF, J. Application of full-scale accelerated pavement testing. National Cooperative Highway Research Program - NCHRP, Synthesis of Highway Practice 235. TRB, National Research Council, Washington, USA, 1996.

MONN, L. Estudos dos efeitos da granulometria sobre a macrotextura superficial do concreto asfáltico e seu comportamento mecânico. Tese ( Doutorado) - Escola Politécnica da Universidade de São Paulo, São Paulo, 1998.

MOURA, E. DE, Estudo do efeito de aditivos químicos e da cal como agentes melhoradores de adesividade em misturas asfálticas densas. 2001. 122 p. Dissertação (Mestrado) - Universidade de São Paulo. São Paulo 2001.

MOUTIER, F. La presse à cisaillement giratoire modèle de série. Bulletin de Liaison de Laboratoires des Ponts et Chaussées n.74 p 137-149, 1974.

MOUTIER, F. La presse à cisaillement giratoire. Bulletin de Liaison de Laboratoires des Ponts et Chaussées n.68 p 141-154, 1973.

MOUTIER, F. Prévision de la compactabilité des enrobés bitumineux a l'ide de la presse a cisaillement giratoire (PCG). Bulletin de Liaison de Laboratoires des Ponts et Chaussées n.121 p 29-40, 1982.

MOTTA, R.S.; BERNUCCI, L.L.B.; FARIA, V.C. E SOUZA, D.R. (2009). Efeito do tipo de ligante asfáltico na deformação permanente de revestimentos asfálticos. Associação Brasileira de Concessões Rodoviárias - ABCR, Florianópolis - SC 
NASCIMENTO, L. A. H. Nova abordagem da dosagem de misturas asfálticas densas com uso do compactador giratório e foco na deformação permanente. 2008. 204 p. Dissertação de Mestrado - Universidade Federal do Rio de Janeiro. COPPE/UFRJ. 2008.

NOGAMI, J.S. E VILLIBOR, D.F. (1995) Pavimentação de baixo custo com solos lateríticos. Ed. Villibor, São Paulo - SP

NÚNES. W. P., CERATTI,J.A.P., E OLIVEIRA, J.A. Análise experimental de pavimentos com camadas estruturais em basaltos alterados - o planejamento da pesquisa. ABPv Associação Brasileira de Pavimentação, 1995 v.3, p01, Cuiabá-MT.

NÚNES. W. P., Análise experimental de pavimentos rodoviários delgados com basaltos alterados. 1997. 271 p. Tese de Doutorado - Escola Federal do Rio Grande do Sul. RGS, 1997.

PINILLA, A. Aderência entre betumes asfálticos e agregados pétreos, Conselho Nacional de Pesquisas - IPR Instituto de Pesquisas Rodoviárias, Rio de Janeiro. 1965.

PREFEITURA MUNICIPAL DE GUARATUBA, Santa Catarina. Disponível em <http://www.guaratuba.pr.gov.br/site/index.php>. Acesso em 15 mai de 2009.

ROBERTS, F. L.; et al. Hot mix asphalt materials, mixture design, and construction. National Asphalt Pavement Association Education Foundation 2ed., Lanham 1996.

SA,M.F.P. (1996). Estudo da deformação permanente de misturas betuminosas através de ensaios estáticos e mecânicos. Tese de mestrado. COPPE/UFRJ. 1996.

SÁ, M. F. P. e L. M. G. MOTTA (1996) Utilização de Ensaios de creep estático e dinâmico para caracterização de misturas asfálticas. Anais de $13^{\circ}$ Encontro de Asfalto, IBP, p. 91-115

SANTANA, H.; GONTIJO, P;R.A. Seleção dos tipos de cap necessários à pavimentação no brasil - TT-n.01. Abeda - Associação Brasileira das Empresas Distribuidoras de Asfalto. São Paulo. 1984.

SILVA, P.D.E.A. Estudo do reforço de concreto de cimento portland (whitetopping) na pista circular experimental do instituto de pesquisa rodoviárias. 358p. Tese (doutorado) Universidade Federal do Rio de Janeiro, COPPE. Rio de Janeiro, 2001.

TAIRA, C. E FABBRI, G.T.P. (2001) Modelação viscoelástica de ensaios de influência estática e dinâmica de misturas asfálticas com asfaltos convencionais e modificado por polímero SBS. In: Reunião Anual de Pavimentação, 33., 2001, Florianópolis. Anais... Florianópolis, ABPv, 2001. p 250-65.

TERREL, R. L.; AL-SWAILMI, S. Role of pessimum voids concept in understanding moisture damage to aphalt concrete mixtures, TRR - Transportation Research Record, $n$. 1386 p. 31-37. 1993. 
UCPRC Disponível em:

<http://www.its.berkeley.edu/pavementresearch/PDF/HVS\%20Facts\%20at\%20a\%20glance.PD F>. Acesso em 21 de out. 2009.

UNE-EN 12697-22:2008+A1. Métodos de ensayos para mezclas bituminosas em caliente parte 22: ensayo de rodadura. Marzo 2008.

VALE, A., F. Método de uso de simuladores de tráfego linear móvel de pista para a determinação de comportamento e previsão de desempenho de pavimentos asfálticos. 2008. 302 p. Tese (Doutorado) - Escola Politécnica da Universidade de São Paulo. São Paulo, 2008.

VIANNA.A.A.D.;MOTTA,L.M.G. e DOMINGUES, R.G. (2003). Ensaio de compressão axial de CBUQ - uma nova técnica de medição das deformações. Anais do XVII Congresso de pesquisa em ensino em Transportes, ANPET, Tio de Janeiro. V.1 p.30-40.

VICTORINO, D. R., et al. Análise de desempenho de um pavimento flexível da rodovia br 290/rs solicitado por um simulador de tráfego móvel. Congresso ABCR, Florianópolis/SC. 2009 (CD rom).

WATSON, D.E., et al. Verification of superpave number of design gyration compaction levels for georgia. Transportation Research Record: Journal of the Transportation Research Board, No. 2057, Transportation Research Board of the National Academies, Washington,D.C., 2008, pp. 75-82. 


\section{Anexo I}

Ensaios de deformação permanente em trilha de roda de misturas asfálticas usinadas em laboratório nos teores de ligante asfáltico de projeto 


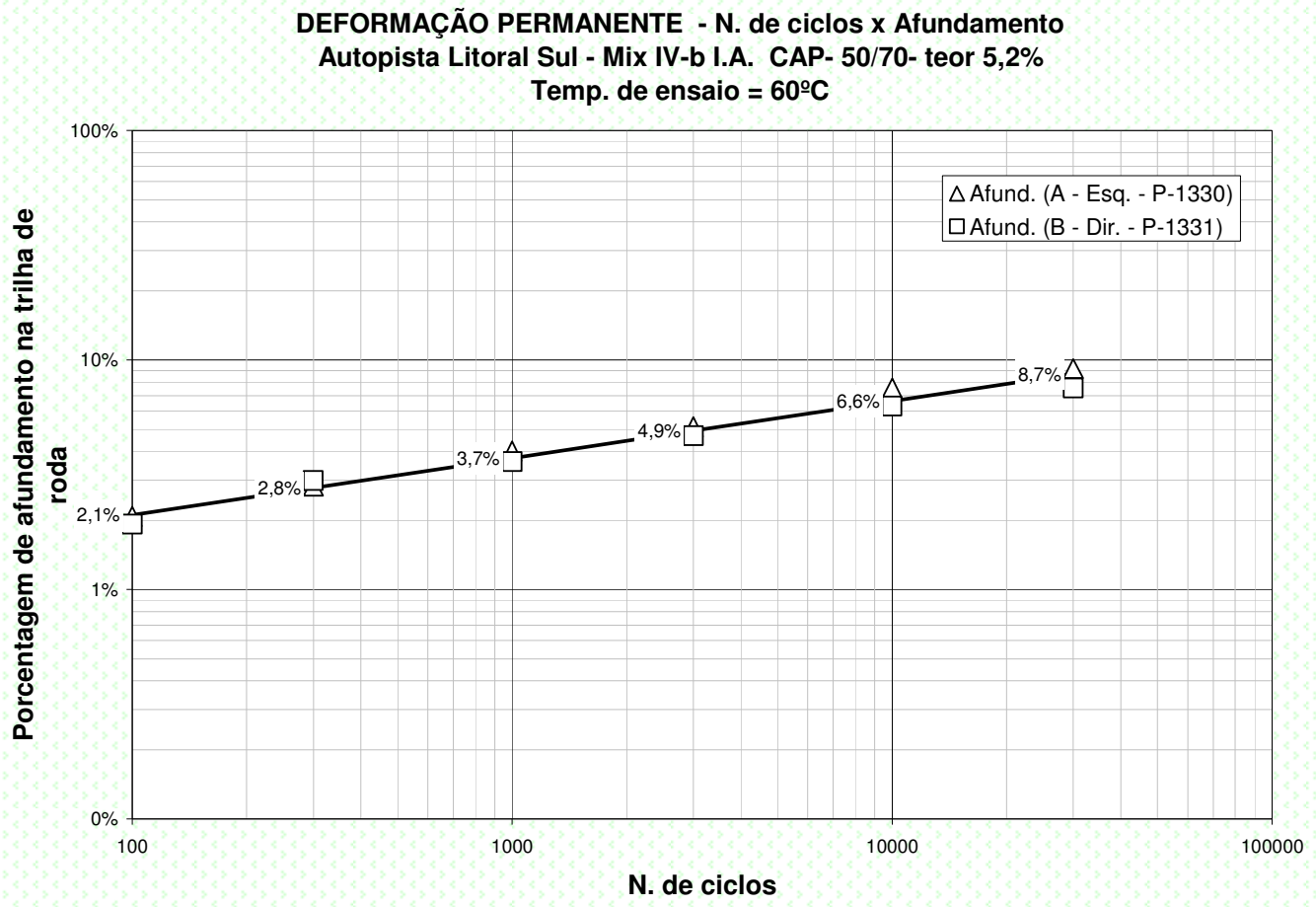

DEFORMAÇÃO PERMANENTE - N. de ciclos x Afundamento Autopista Litoral Sul - SVP $12,5 \mathrm{~mm}$. CAP- 50/70-teor 5,5\% Temp. de ensaio $=60^{\circ} \mathrm{C}$

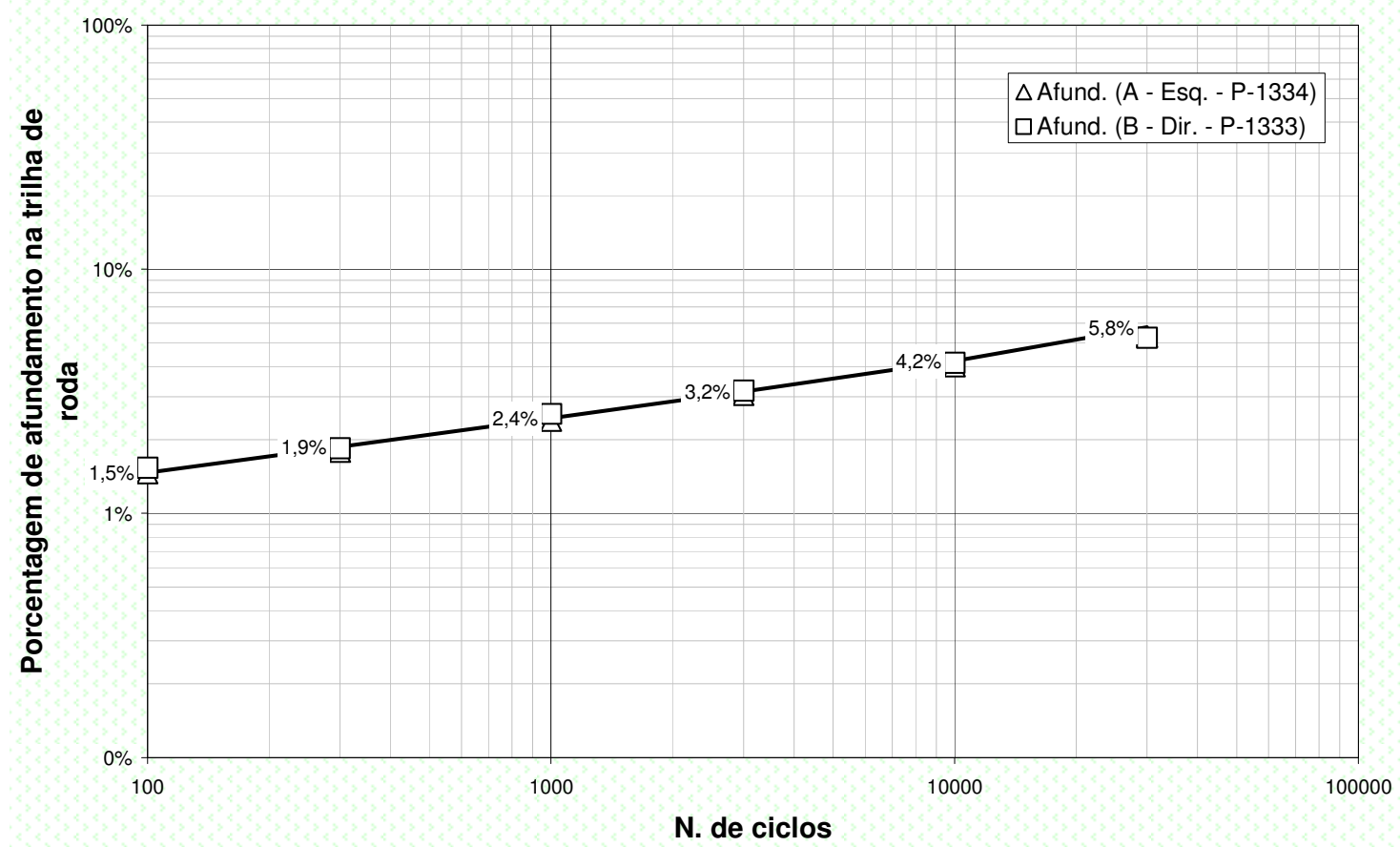


DEFORMAÇÃO PERMANENTE - N. de ciclos x Afundamento

Autopista Litoral Sul - SVP $12,5 \mathrm{~mm}$. CAP mod. por SBS - teor $6,2 \%$

Temp. de ensaio $=60^{\circ} \mathrm{C}$

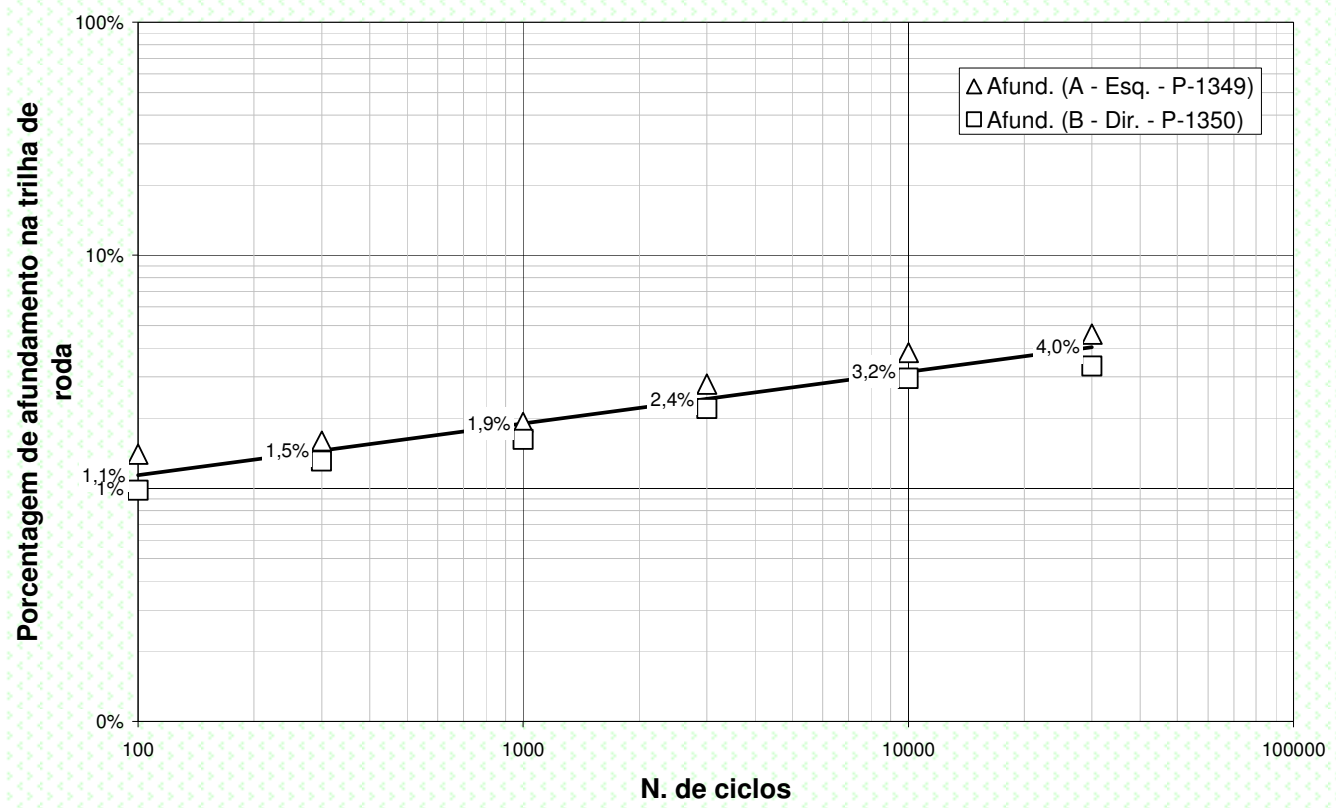

DEFORMAÇÃO PERMANENTE - N. de ciclos x Afundamento

Autopista Litoral Sul - SVP 9,5 mm. CAP mod por polímero SBS - teor 6,7\%

Temp. de ensaio $=60^{\circ} \mathrm{C}$

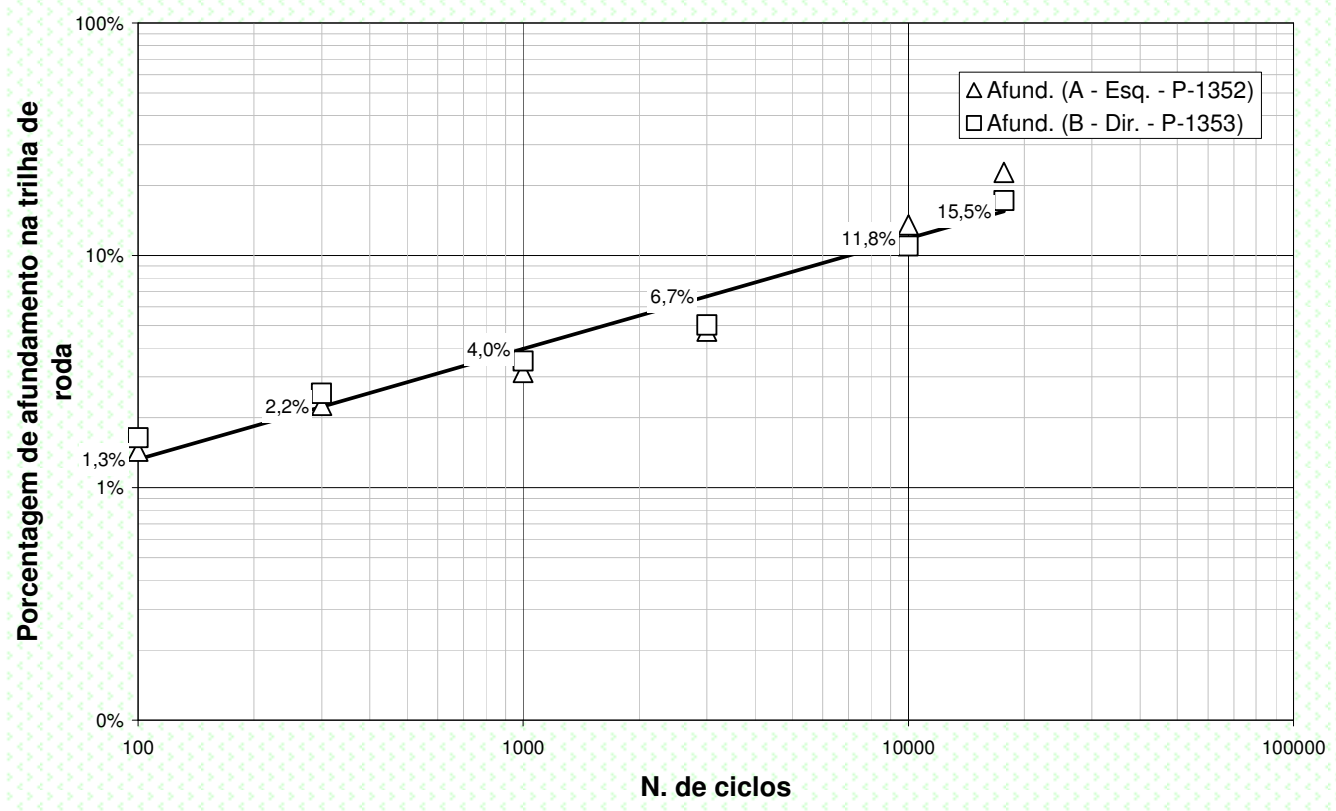




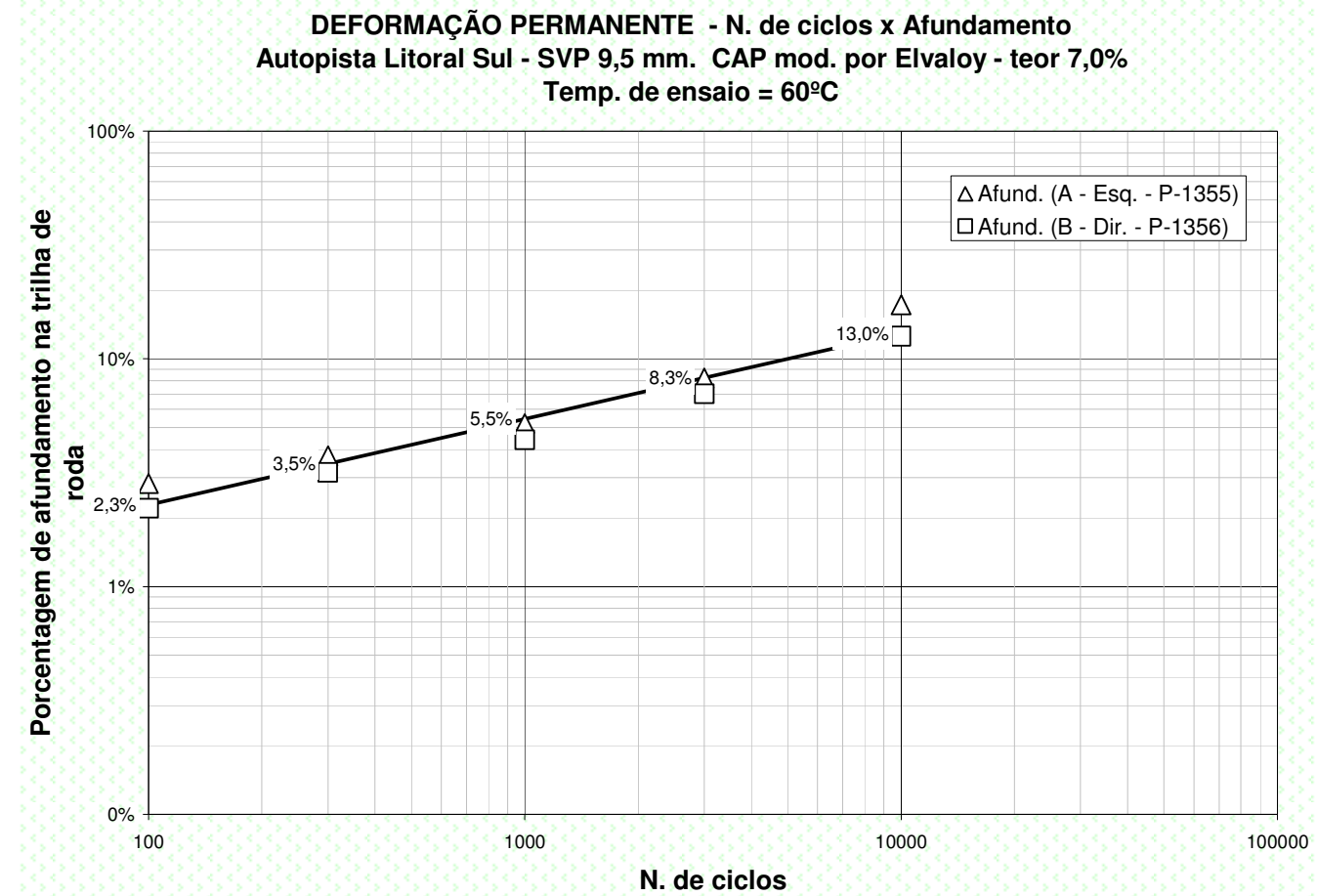

DEFORMAÇÃO PERMANENTE - N. de ciclos x Afundamento Autopista Litoral Sul - SVP $12,5 \mathrm{~mm}$. CAP mod. por Elvaloy - teor $5,5 \%$ Temp. de ensaio $=60^{\circ} \mathrm{C}$

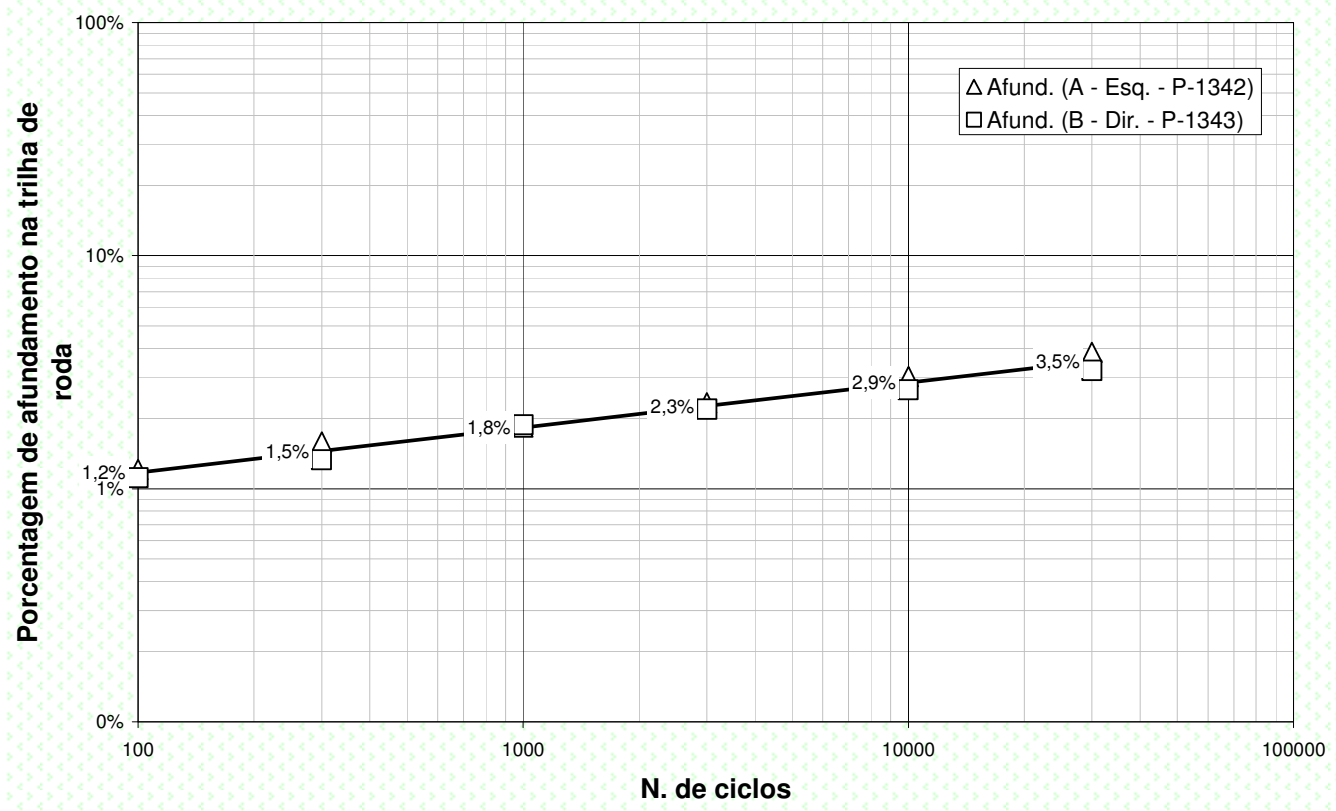

Obs. A mistura asfáltica referente ao trecho T06 $12,5 \mathrm{~mm}$ com RET foi usinada com teor de pista errado, teor de 5,5\% ao invés de 6,14, portanto, esse resultado não foi incluso na análise. 
DEFORMAÇÃO PERMANENTE - N. de ciclos x Afundamento

Autopista Litoral Sul - GAP - CAP- BPM- teor $8,2 \%$

Temp. de ensaio $=60^{\circ} \mathrm{C}$

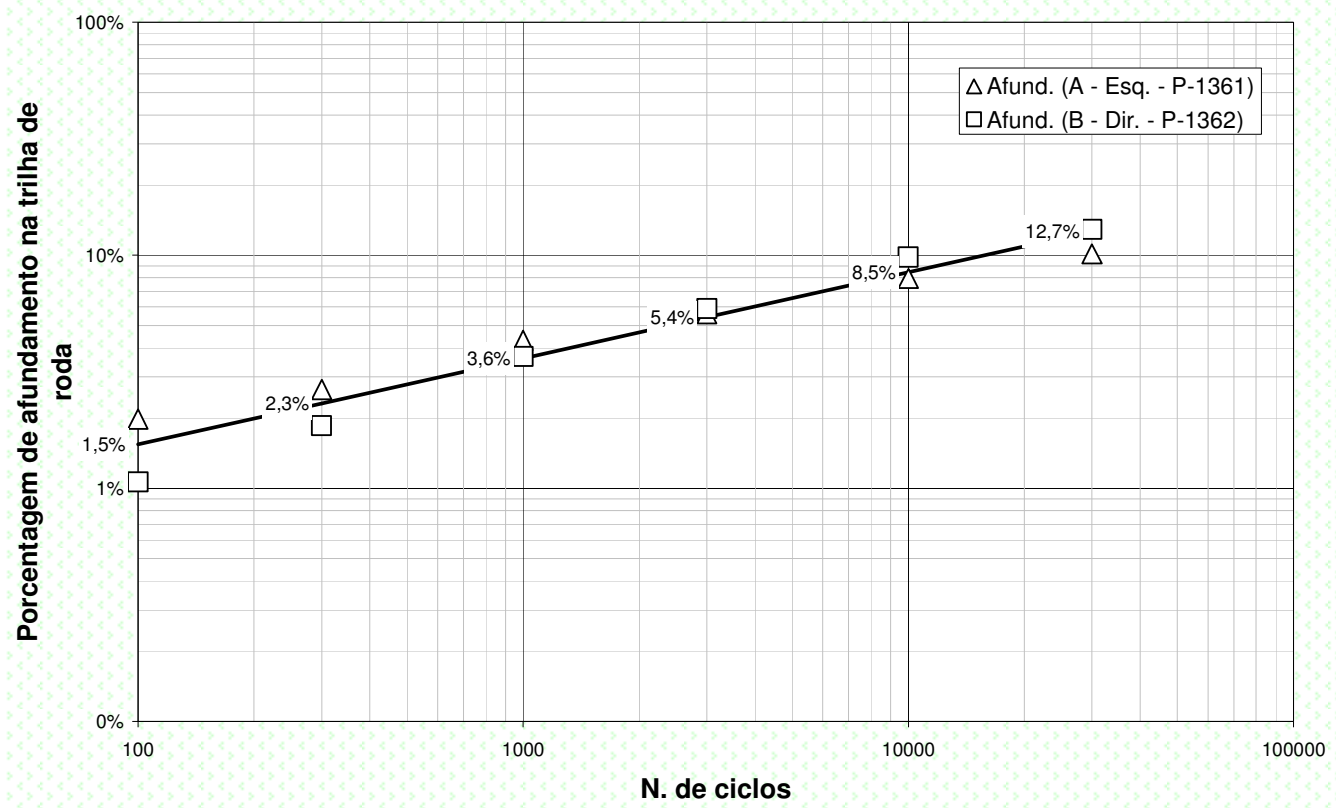

DEFORMACÃ̃ PERMANENTE - N. de ciclos x Afundamento Autopista Litoral Sul - SVP 12,5 mm. CAP- 30/45- teor 5,4\%

Temp. de ensaio $=60^{\circ} \mathrm{C}$

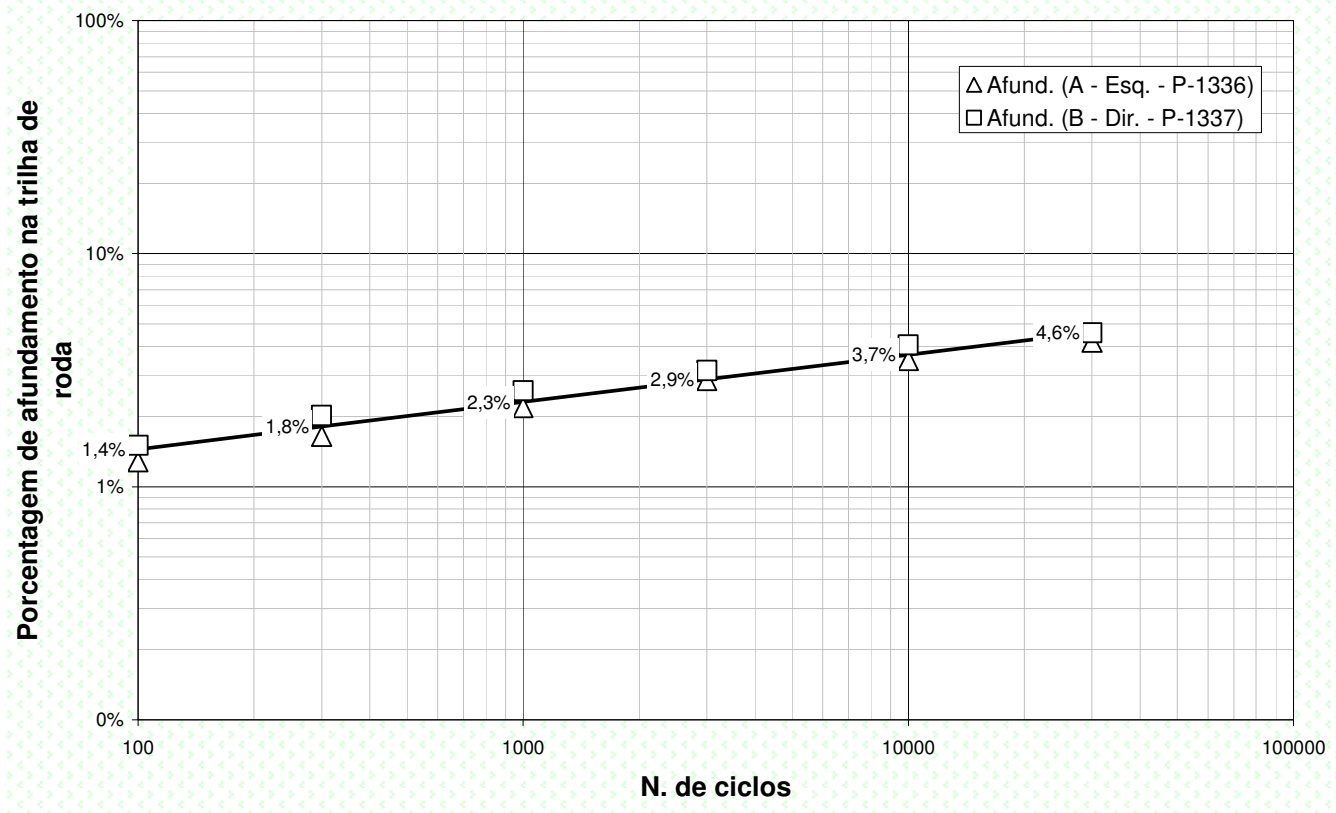



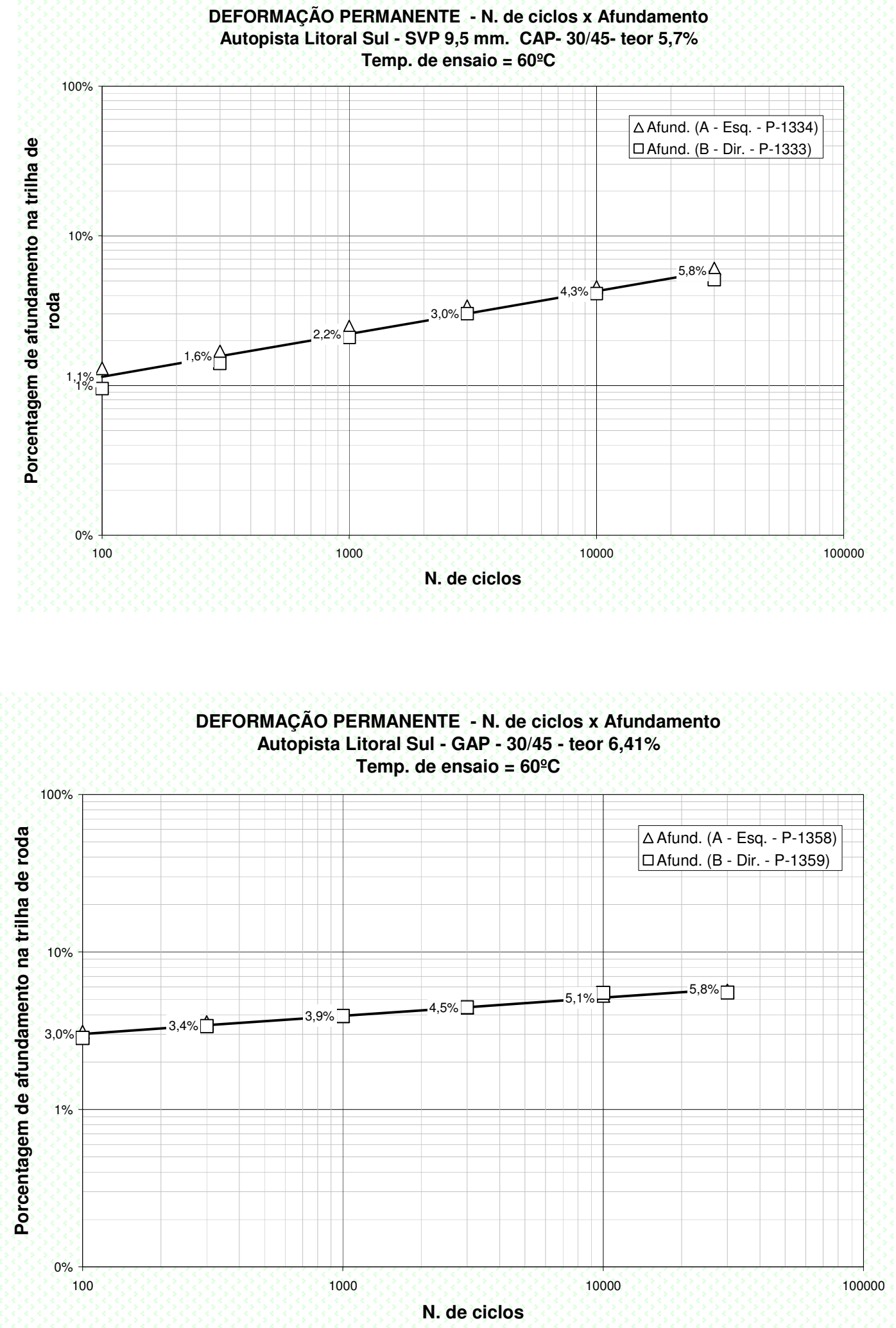


\section{Anexo II}

Ensaios de deformação permanente em trilha de roda de misturas asfálticas extraídas de pista 
DEFORMAÇÃO PERMANENTE - N. de ciclos x Afundamento

Pista teste - Mix Ivb - CAP 50/70

T01 - placa extraída de pista - Temp. de ensaio $=60^{\circ} \mathrm{C}$

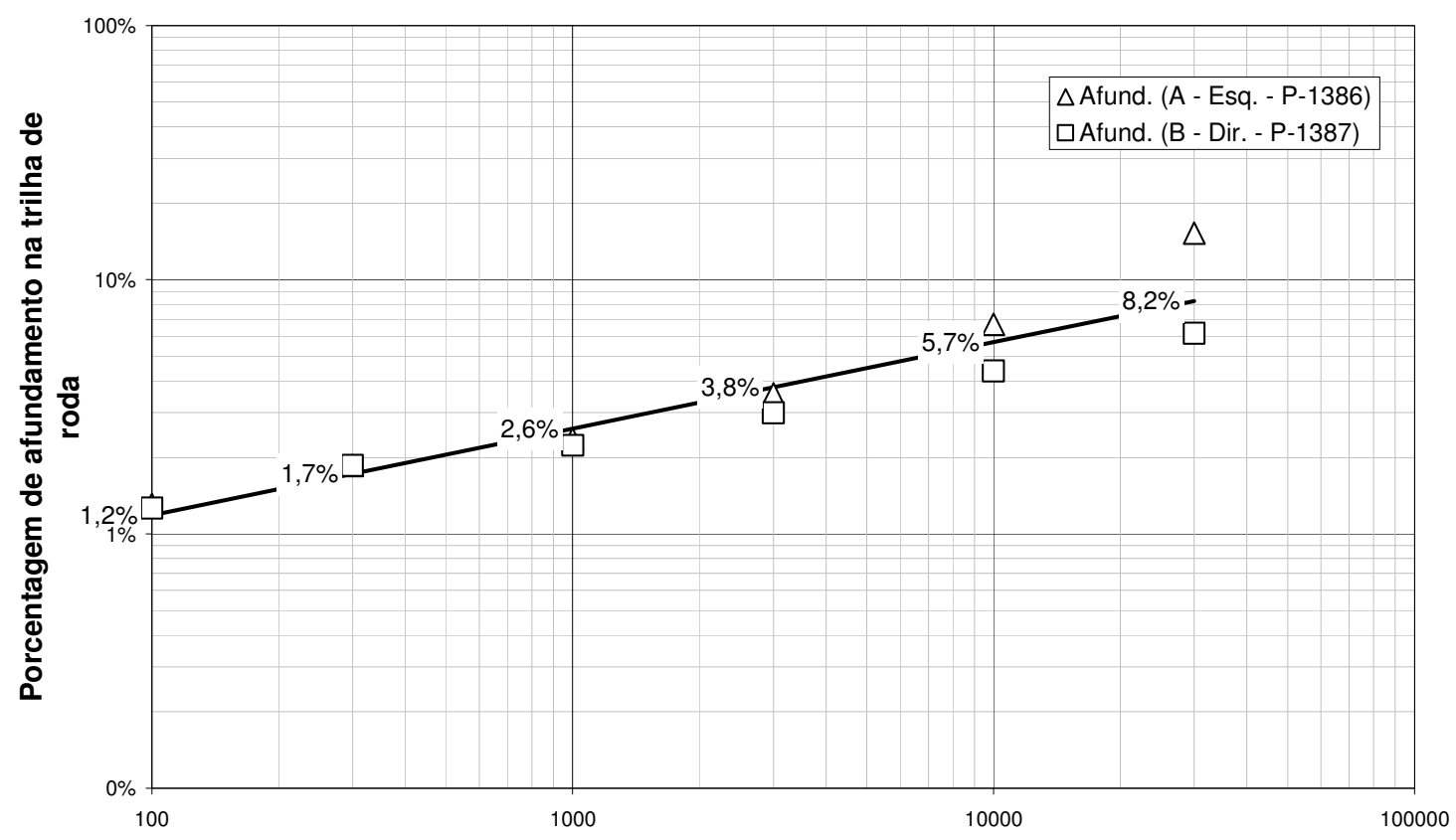

N. de ciclos

DEFORMAÇÃO PERMANENTE - N. de ciclos x Afundamento

Pista teste - SPV CAP- 50/70

T2 - placa extraída de pista - Temp. de ensaio $=60^{\circ} \mathrm{C}$

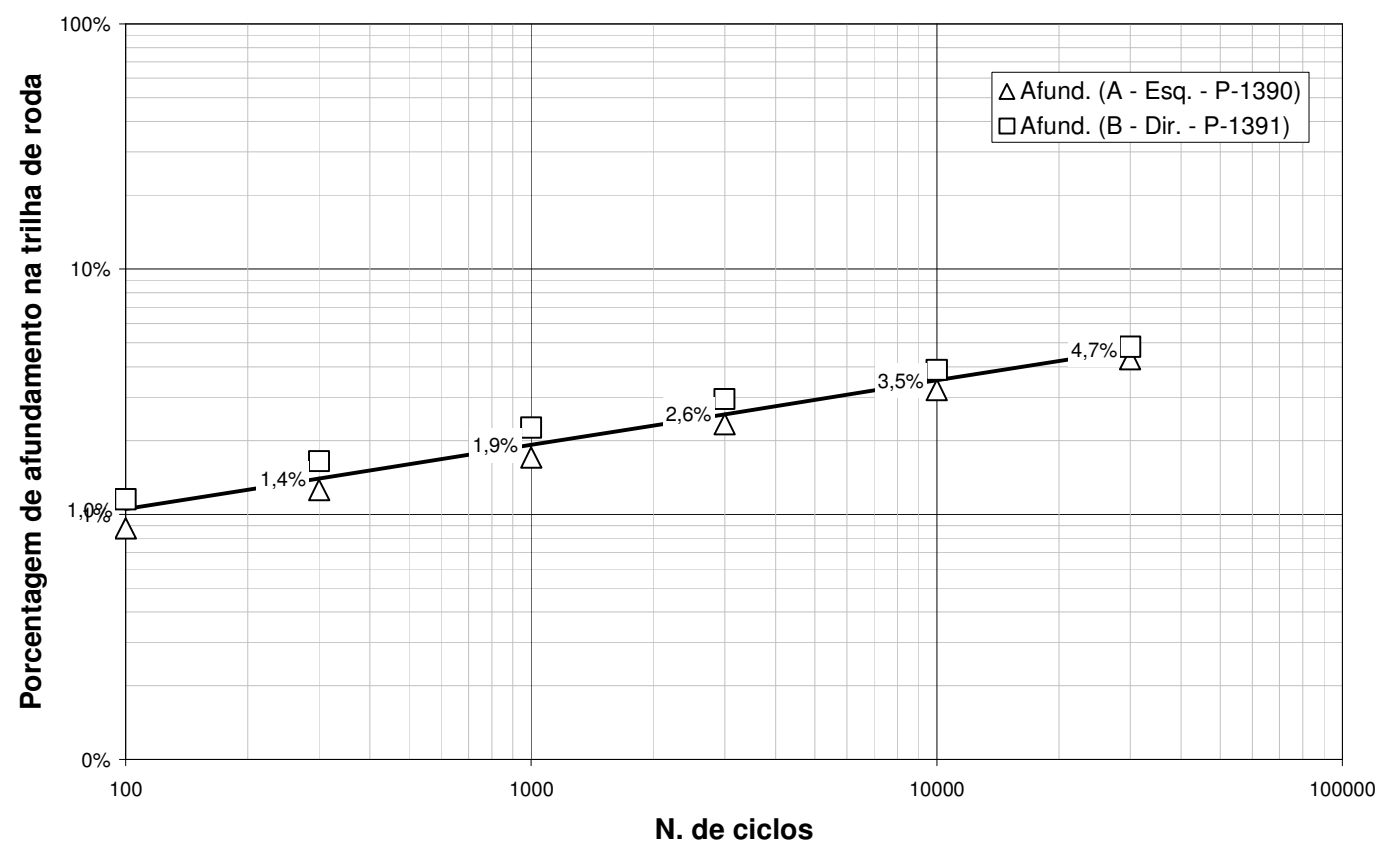


DEFORMAÇÃO PERMANENTE - N. de ciclos x Afundamento

Autopista Litoral Sul - SPV 12,5 CAP mod. porv 4\% SBS

T3 - placa extraída de pista - Temp. de ensaio $=60^{\circ} \mathrm{C}$

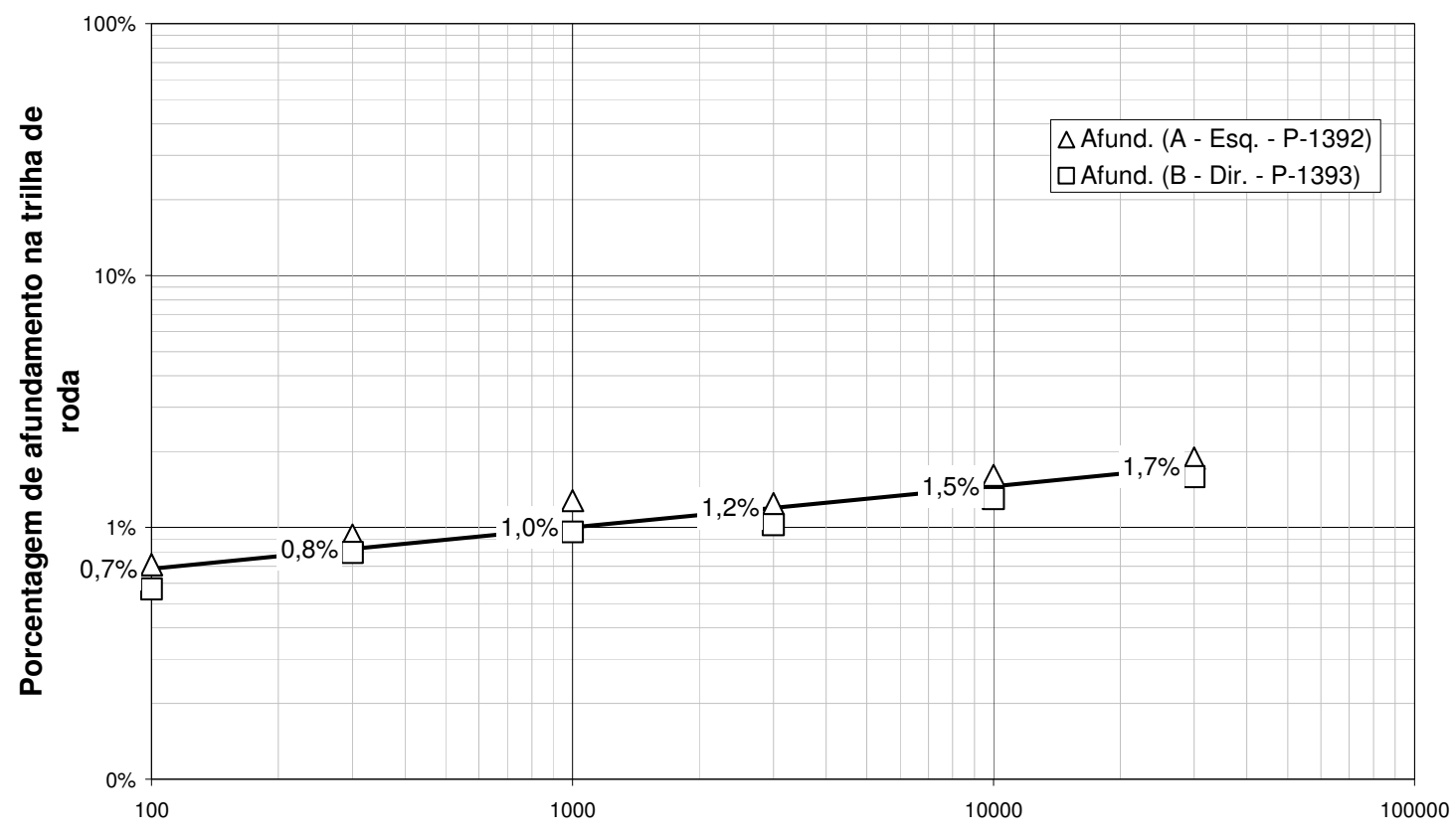

N. de ciclos

DEFORMAÇÃO PERMANENTE - N. de ciclos x Afundamento Autopista Litoral Sul - SPV $9,5 \mathrm{~mm}$ CAP mod. por $4 \%$ de SBS

T4 - placa extraída de pista - Temp. de ensaio $=60^{\circ} \mathrm{C}$

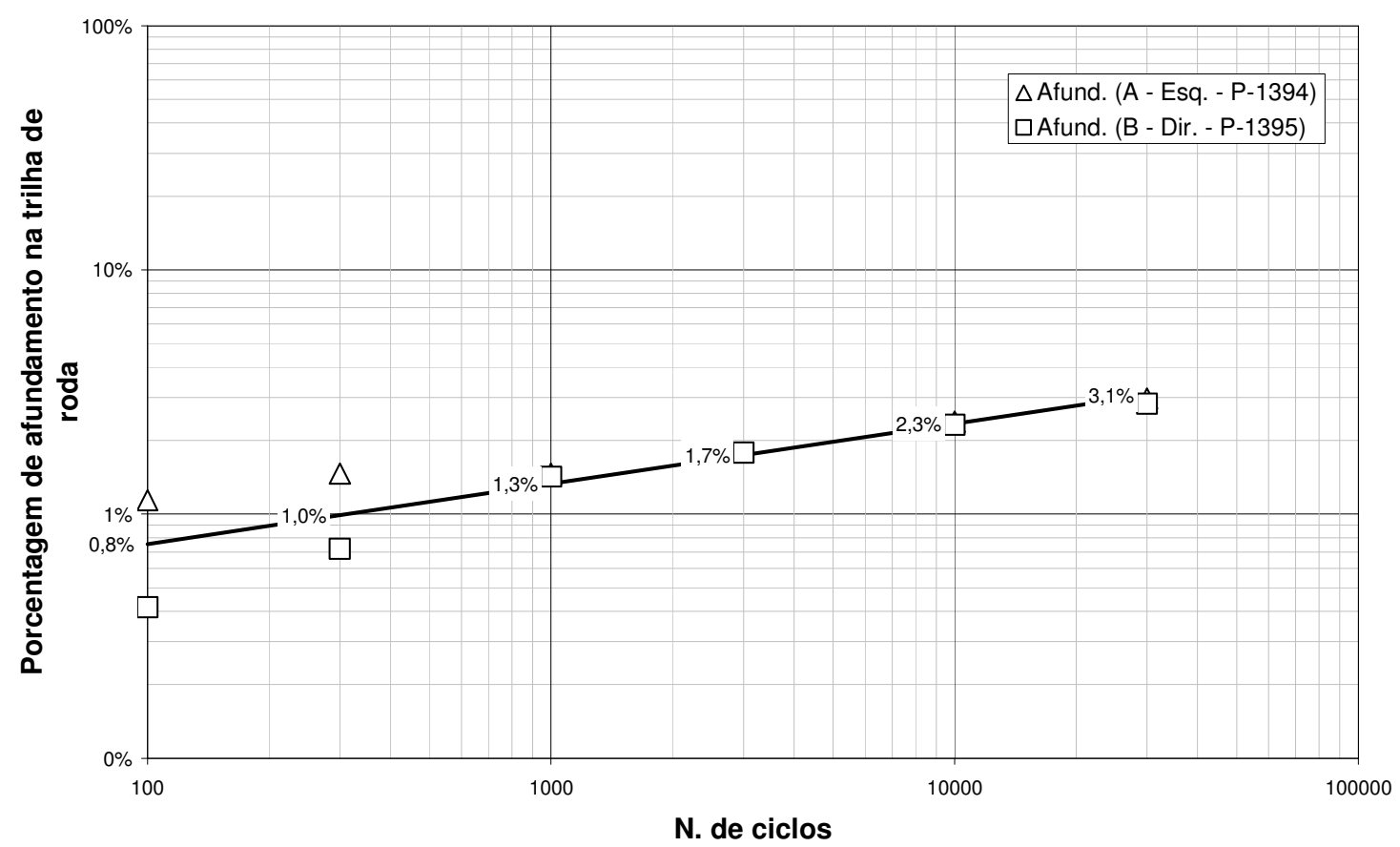


DEFORMAÇÃO PERMANENTE - N. de ciclos x Afundamento Autopista Litoral Sul - SPV 9,5 mm CAP mod. por 1,2\% de RET T5 - placa extraída de pista - Temp. de ensaio $=60^{\circ} \mathrm{C}$

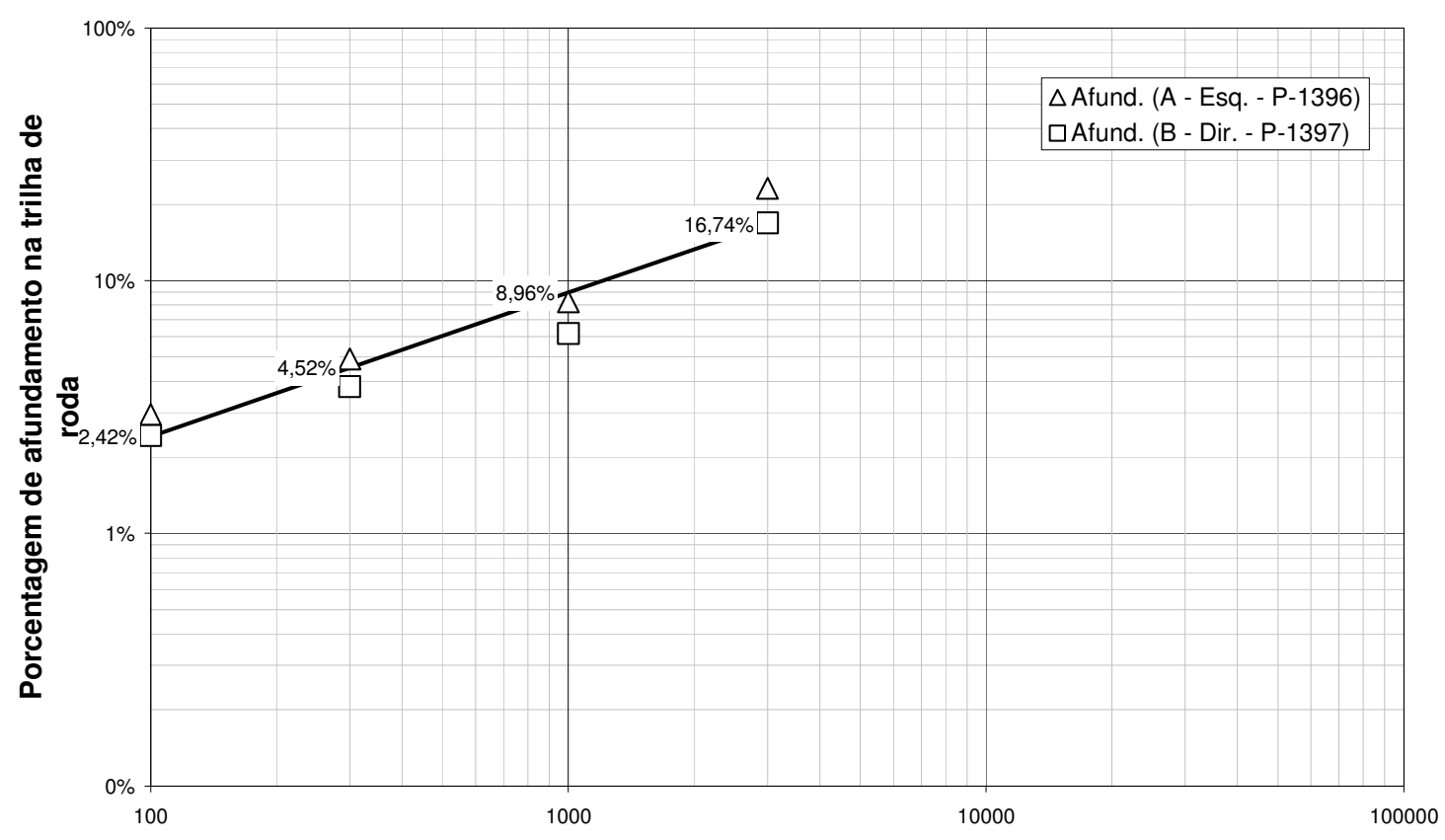

N. de ciclos

DEFORMAÇÃO PERMANENTE - N. de ciclos x Afundamento Autopista Litoral Sul - SPV $12,5 \mathrm{~mm}$ CAP mod. por $1,2 \%$ de RET

T6 - placa extraída de pista - Temp. de ensaio $=60^{\circ} \mathrm{C}$

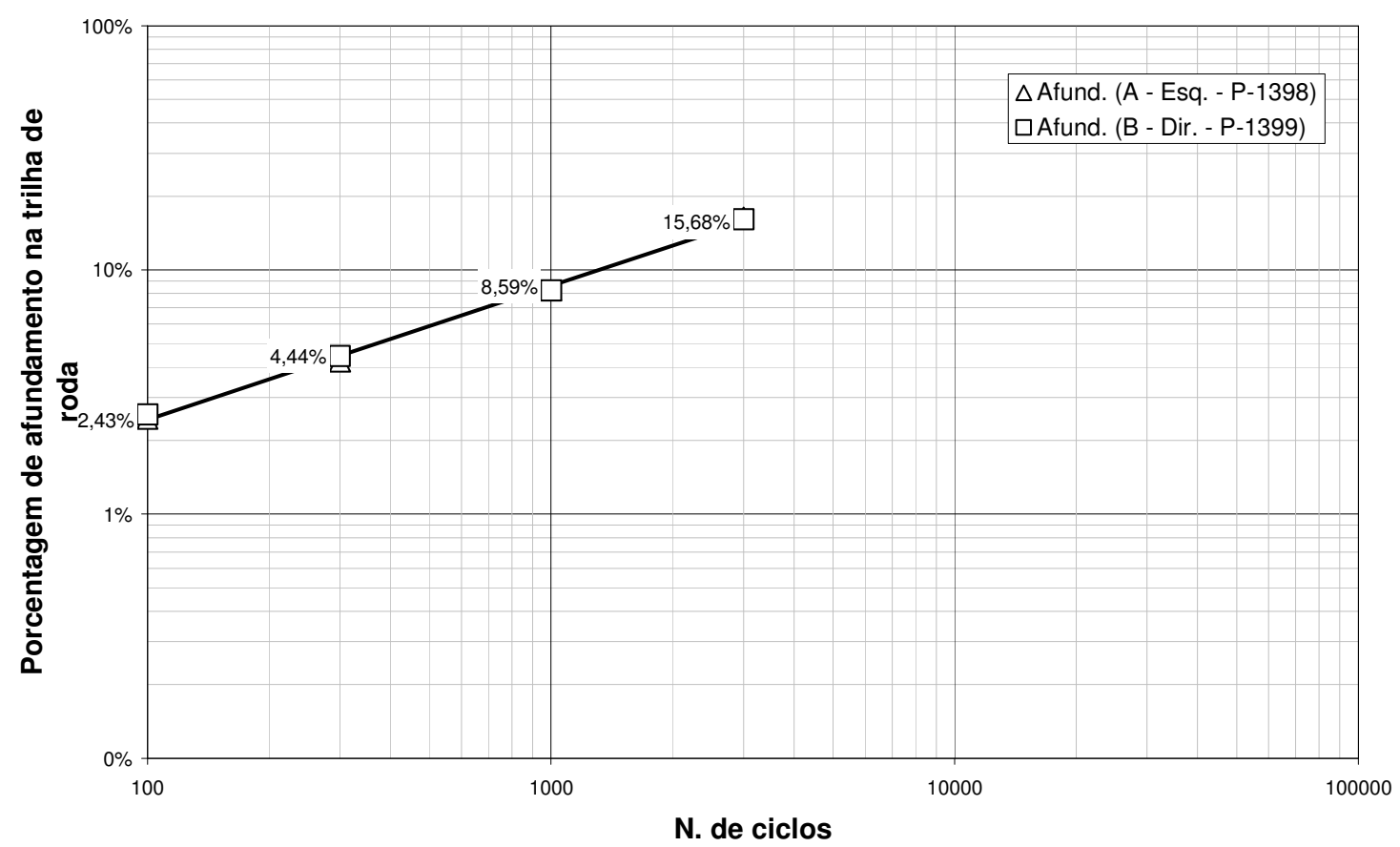


DEFORMAÇÃO PERMANENTE - N. de ciclos x Afundamento

Autopista Litoral Sul - GAP-GRADED - CAP mod. por Borracha

T7- placa extraída de pista - Temp. de ensaio $=60^{\circ} \mathrm{C}$

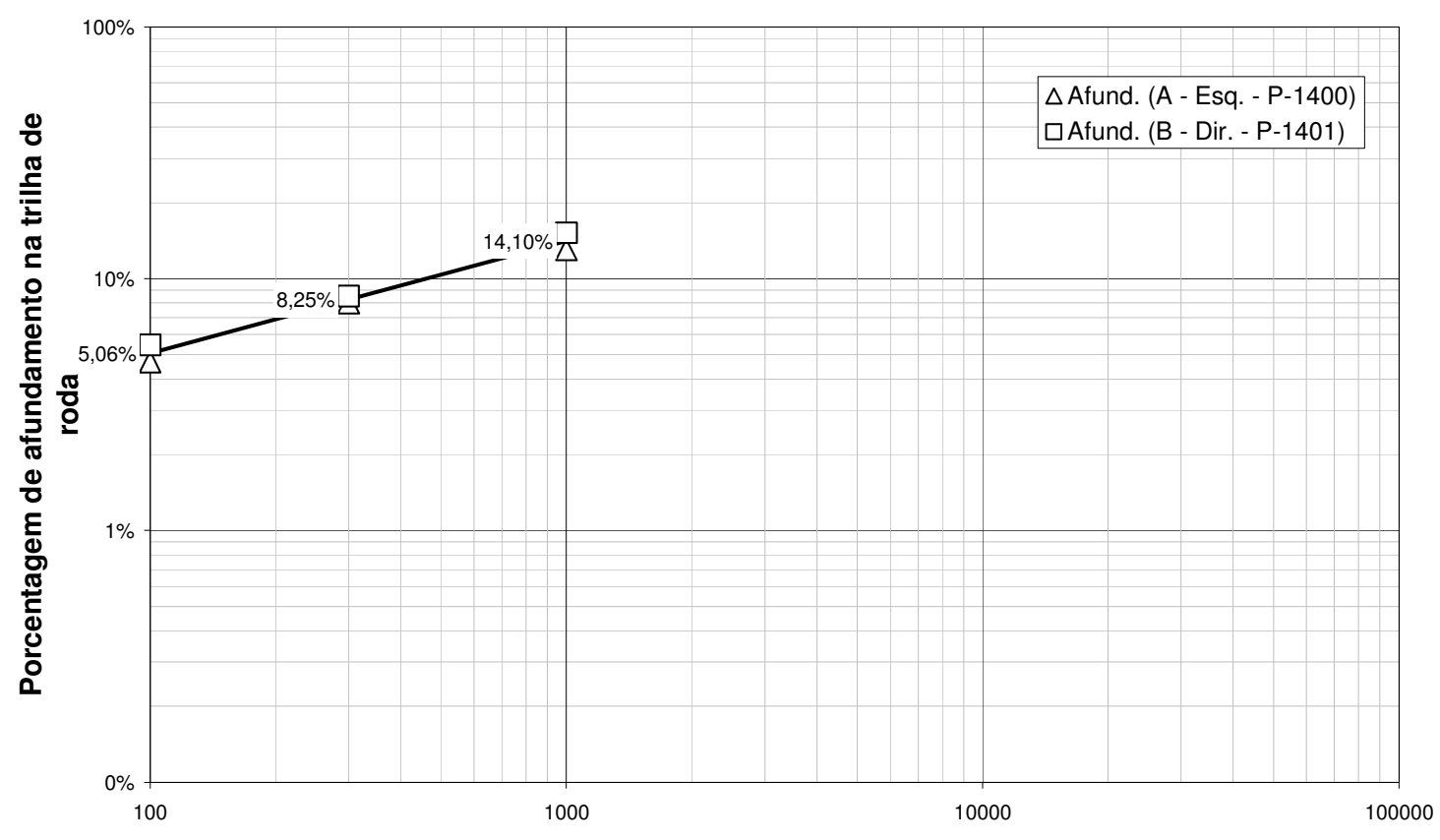

N. de ciclos

DEFORMAÇÃO PERMANENTE - N. de ciclos x Afundamento

Autopista Litoral Sul - Fx SPV 12,5mm - CAP- 30/45

T08 - placa extraída de pista - Temp. de ensaio $=60^{\circ} \mathrm{C}$

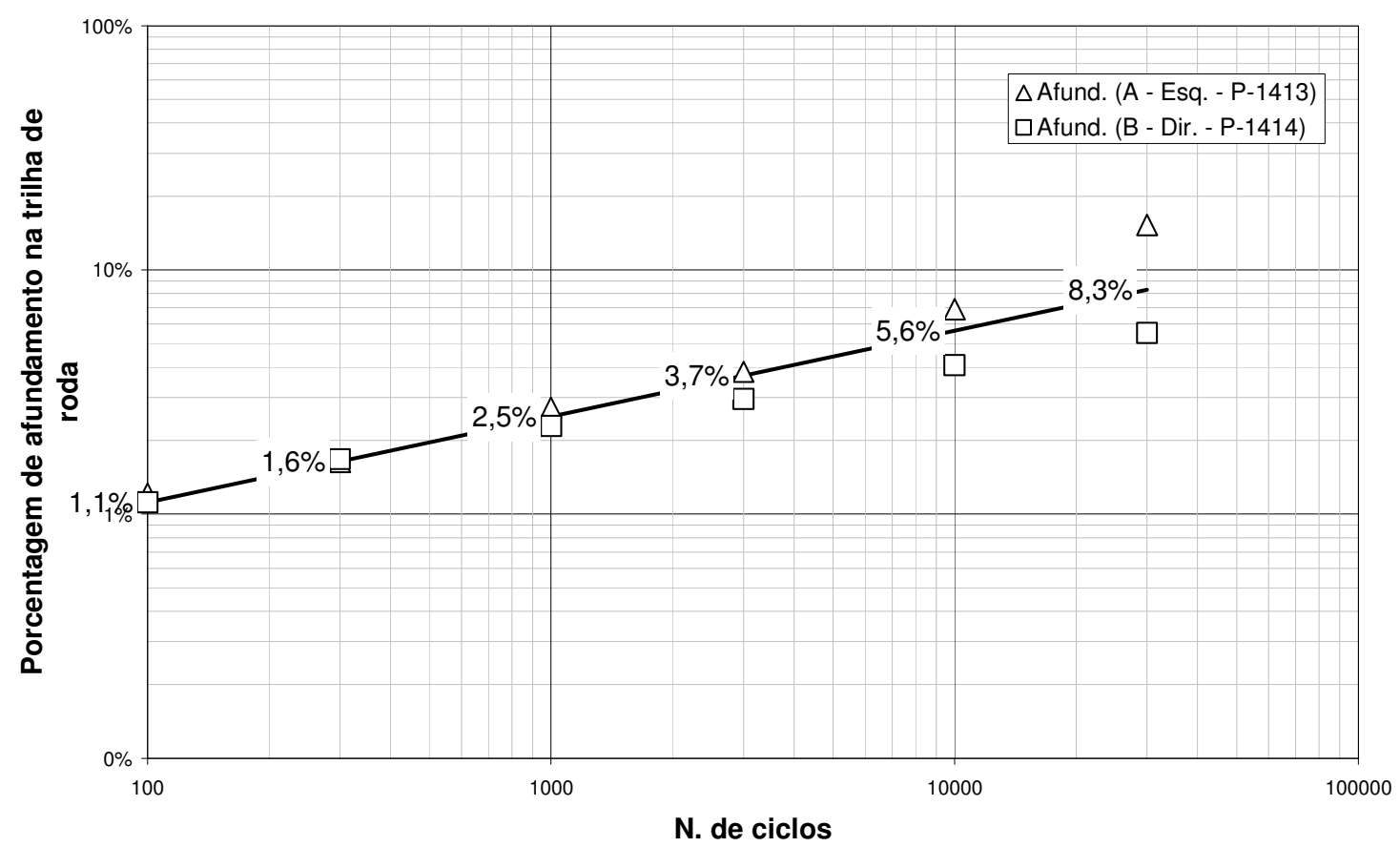




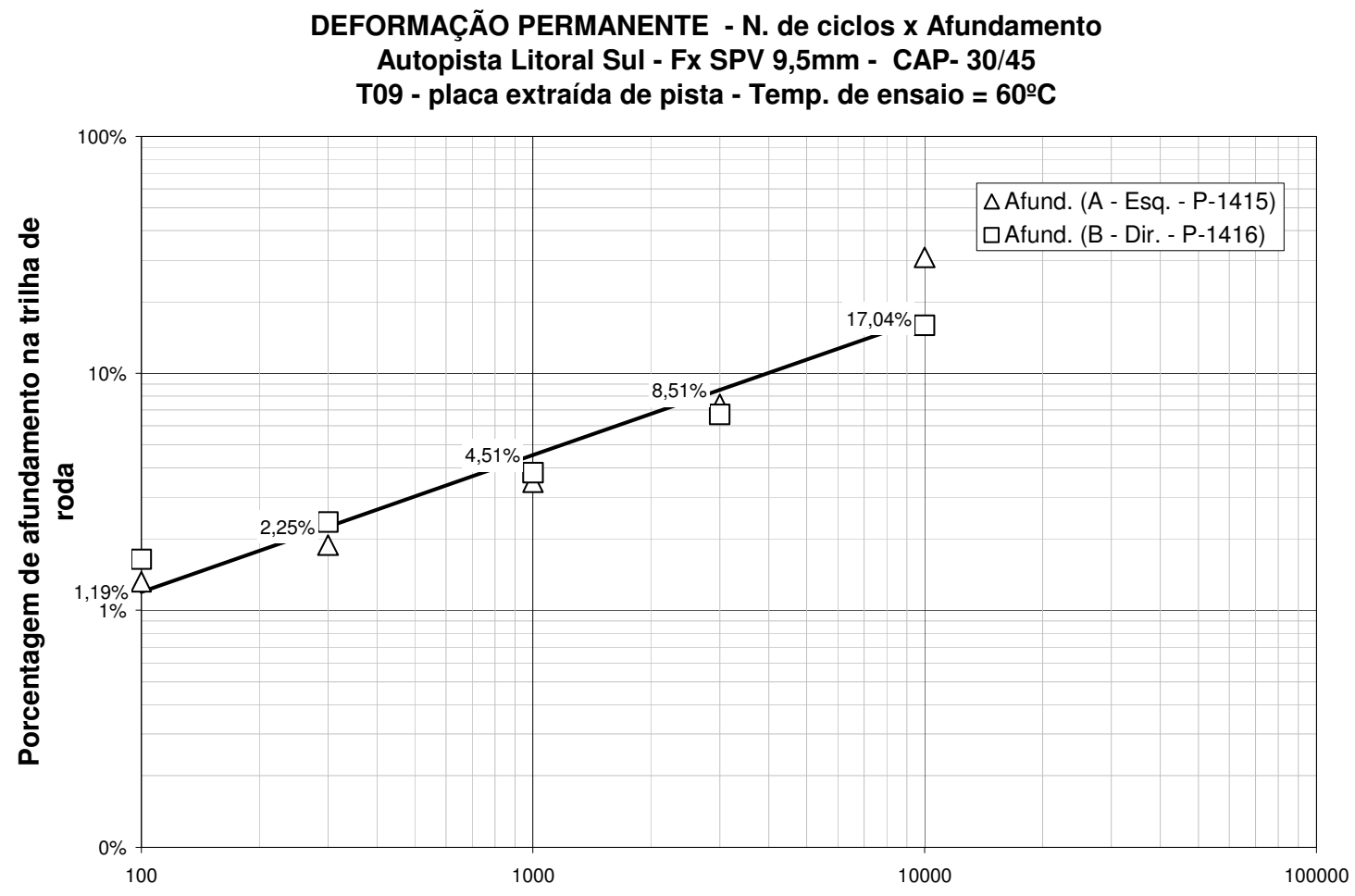

N. de ciclos

DEFORMAÇÃO PERMANENTE - N. de ciclos x Afundamento

Autopista Litoral Sul - Gap-Graded CAP- 30/45

T10 - placa extraída de pista Temp. de ensaio $=60^{\circ} \mathrm{C}$

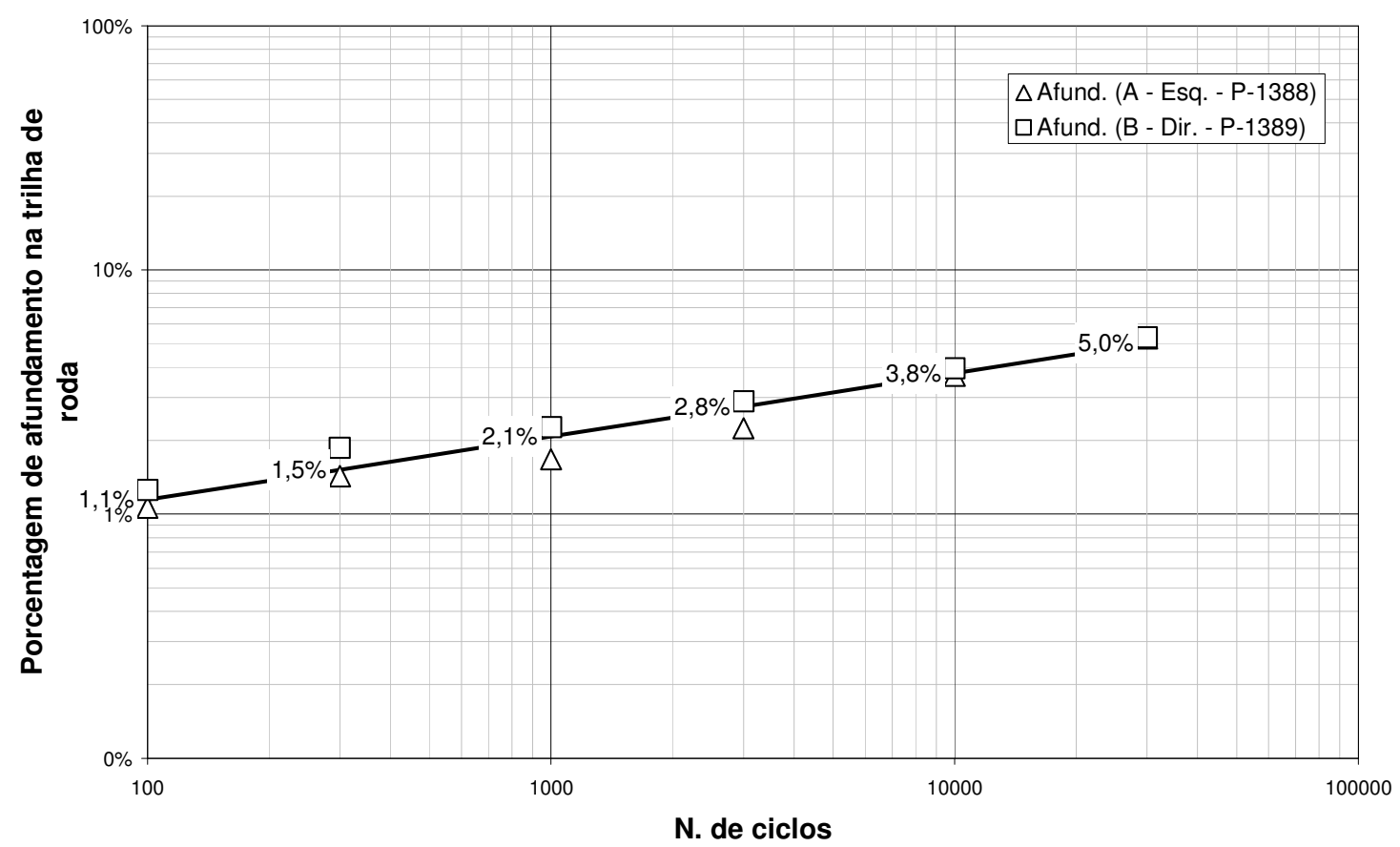




\section{Anexo III}

Ensaios de deformação permanente em trilha de roda de misturas asfálticas usinadas em laboratório no teor de ligante asfáltico de pista 


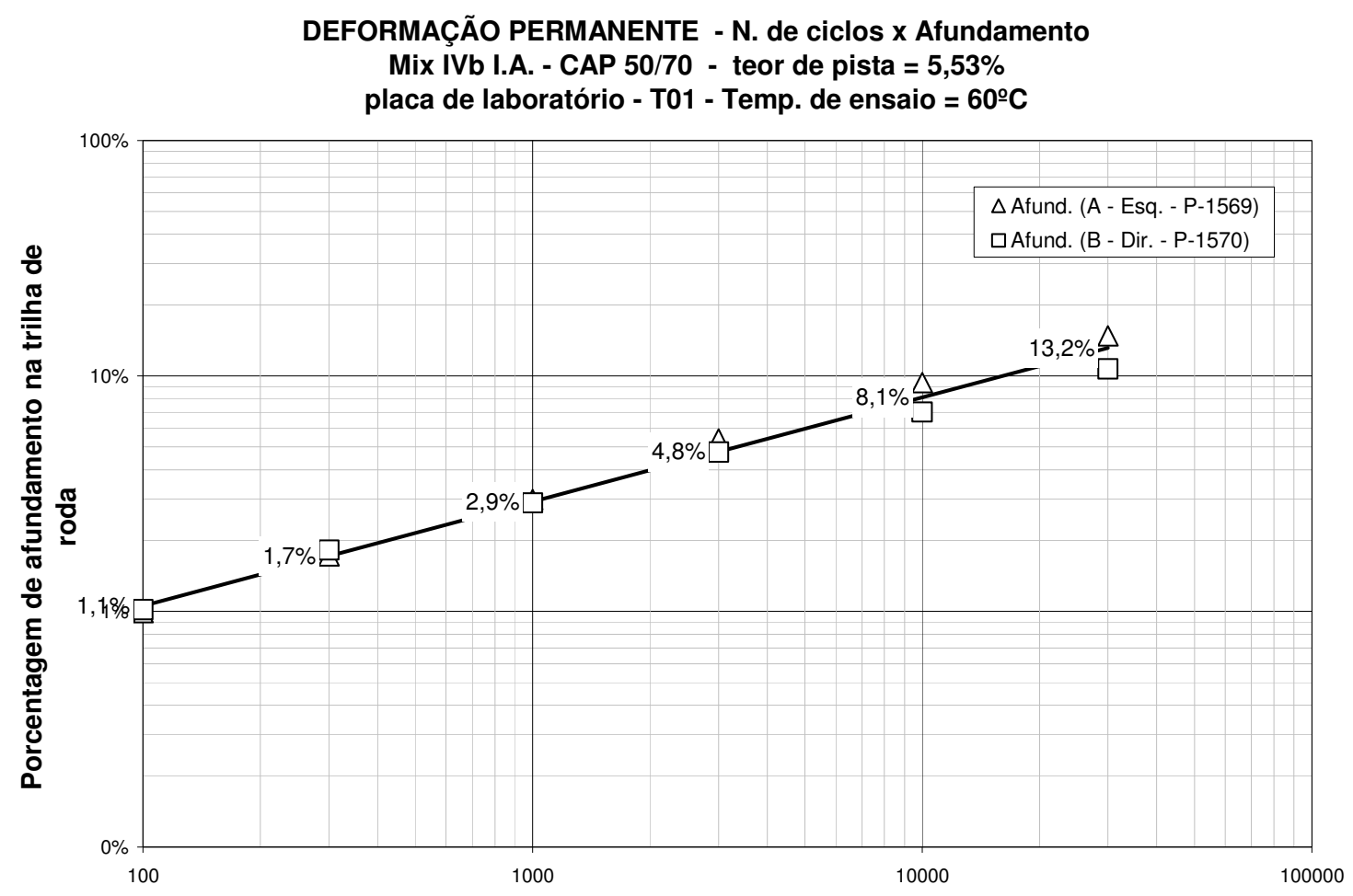

N. de ciclos

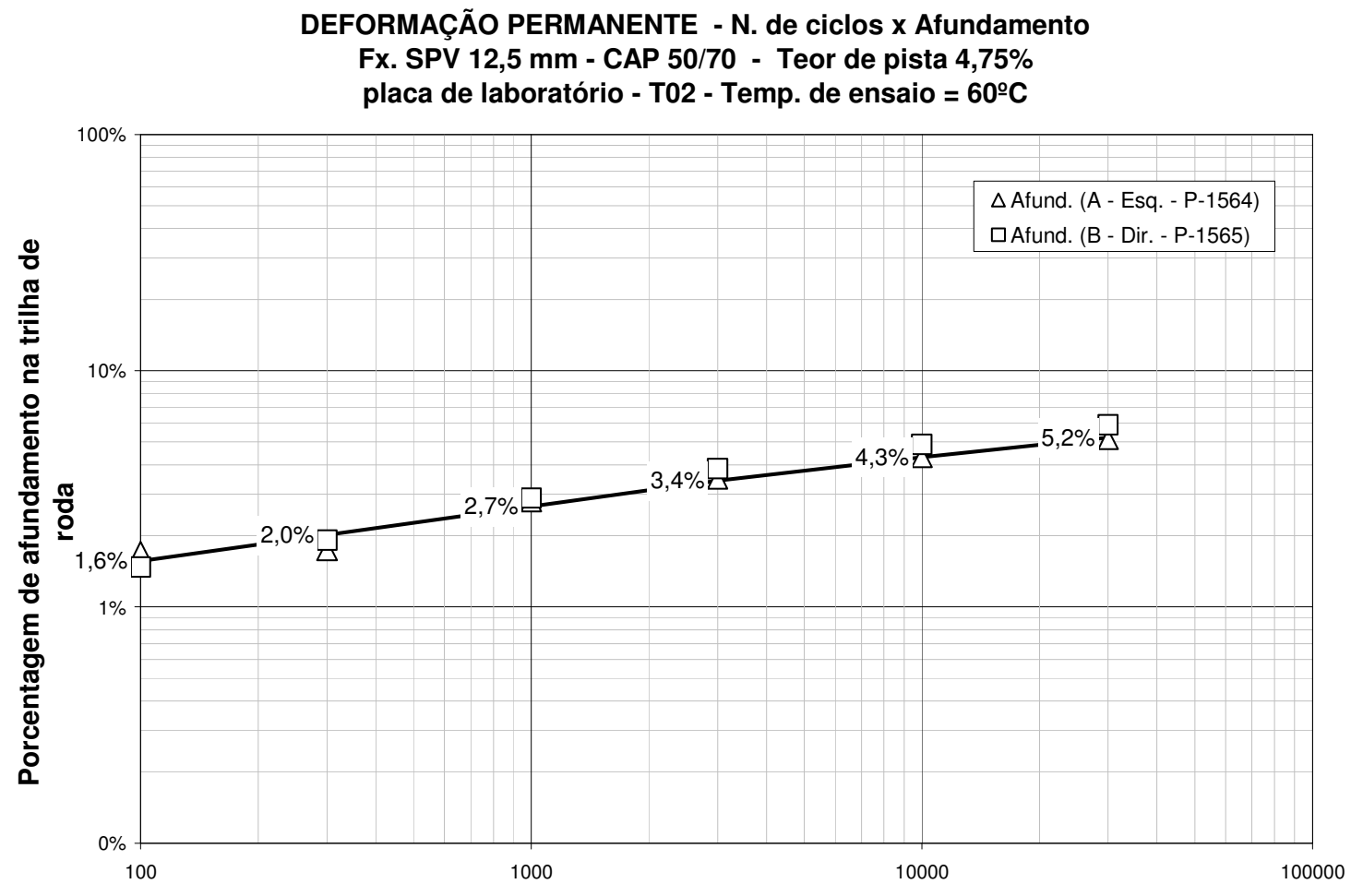

N. de ciclos 
DEFORMAÇÃO PERMANENTE - $\mathrm{N}$. de ciclos $x$ Afundamento

Fx. SPV 12,5 mm - CAP c/ 4\% SBS - Teor de pista $=4,22 \%$

placa de laboratório $-\mathrm{T03}-$ Temp. de ensaio $=60^{\circ} \mathrm{C}$

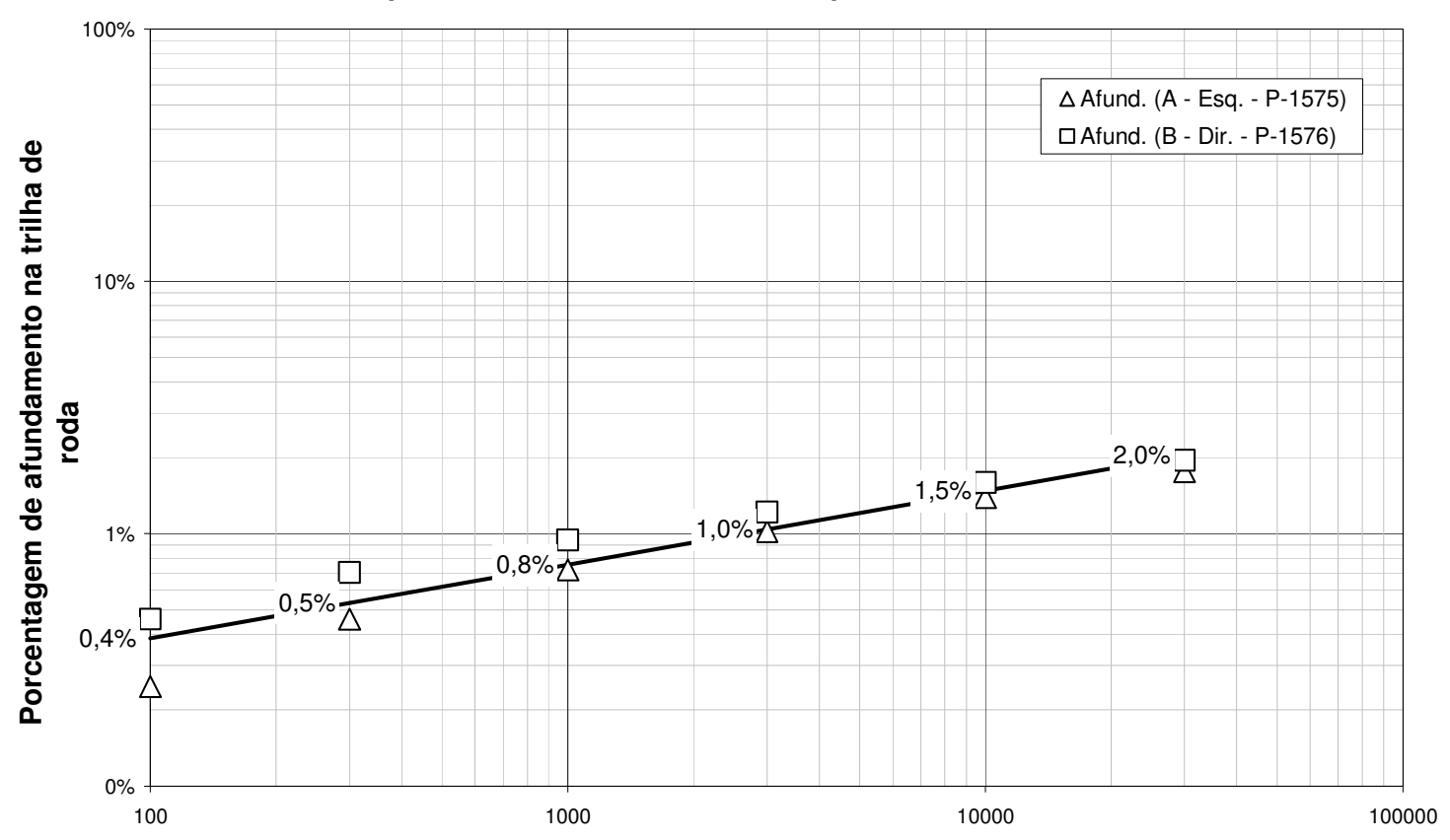

N. de ciclos

DEFORMAÇÃO PERMANENTE - N. de ciclos x Afundamento

Fx. SPV 9,5 mm - CAP c/ 4\% SBS - Teor de pista $=5,39 \%$ placa de laboratório $-\mathrm{T04}-\mathrm{Temp}$. de ensaio $=60^{\circ} \mathrm{C}$

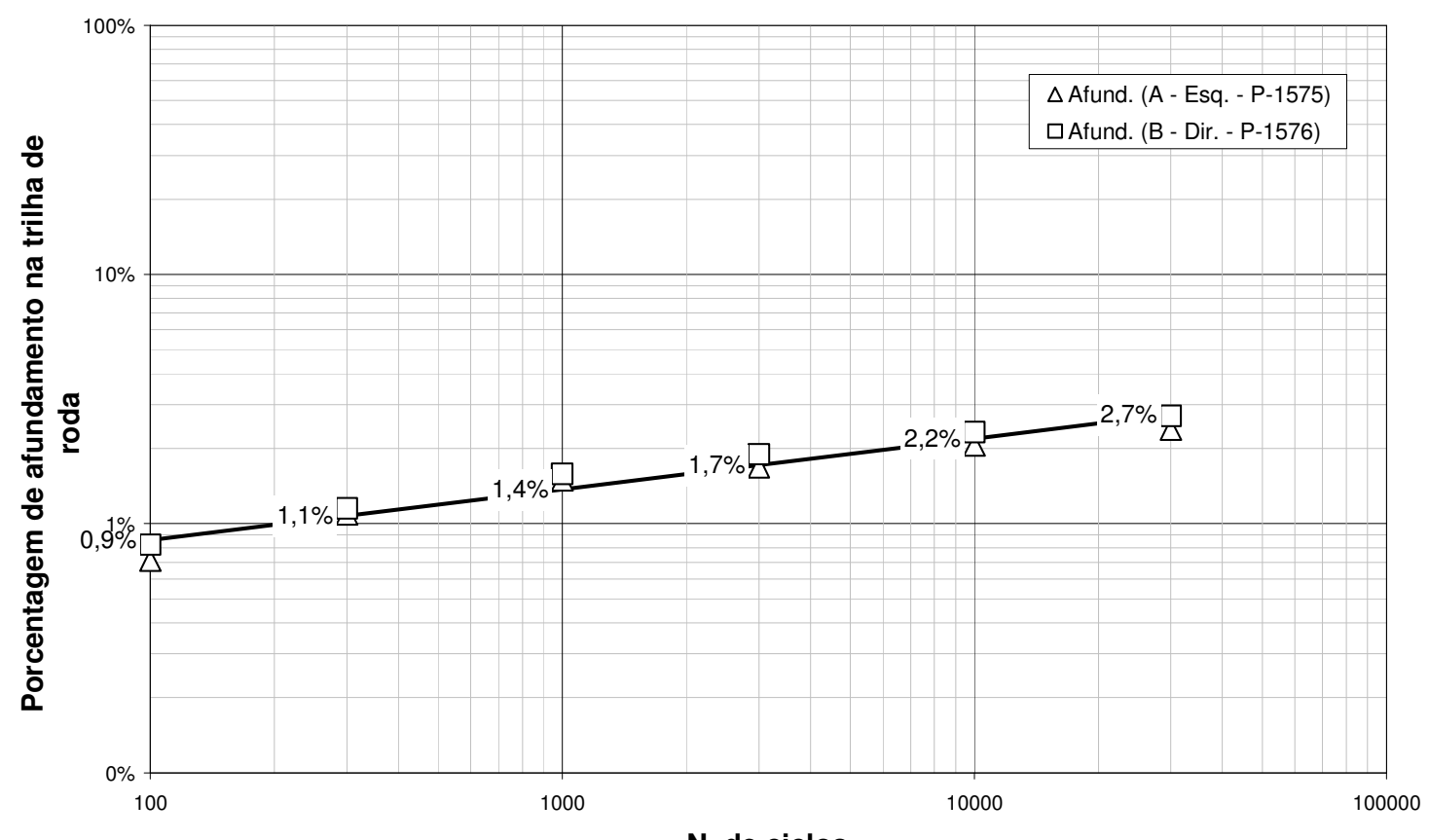

N. de ciclos 
DEFORMAÇÃO PERMANENTE - N. de ciclos x Afundamento

Fx. SPV 9,5 mm - CAP c/ 1,2 RET - Teor de pista $=6,65 \%$

placa de laboratório - T05 - Temp. de ensaio $=60^{\circ} \mathrm{C}$

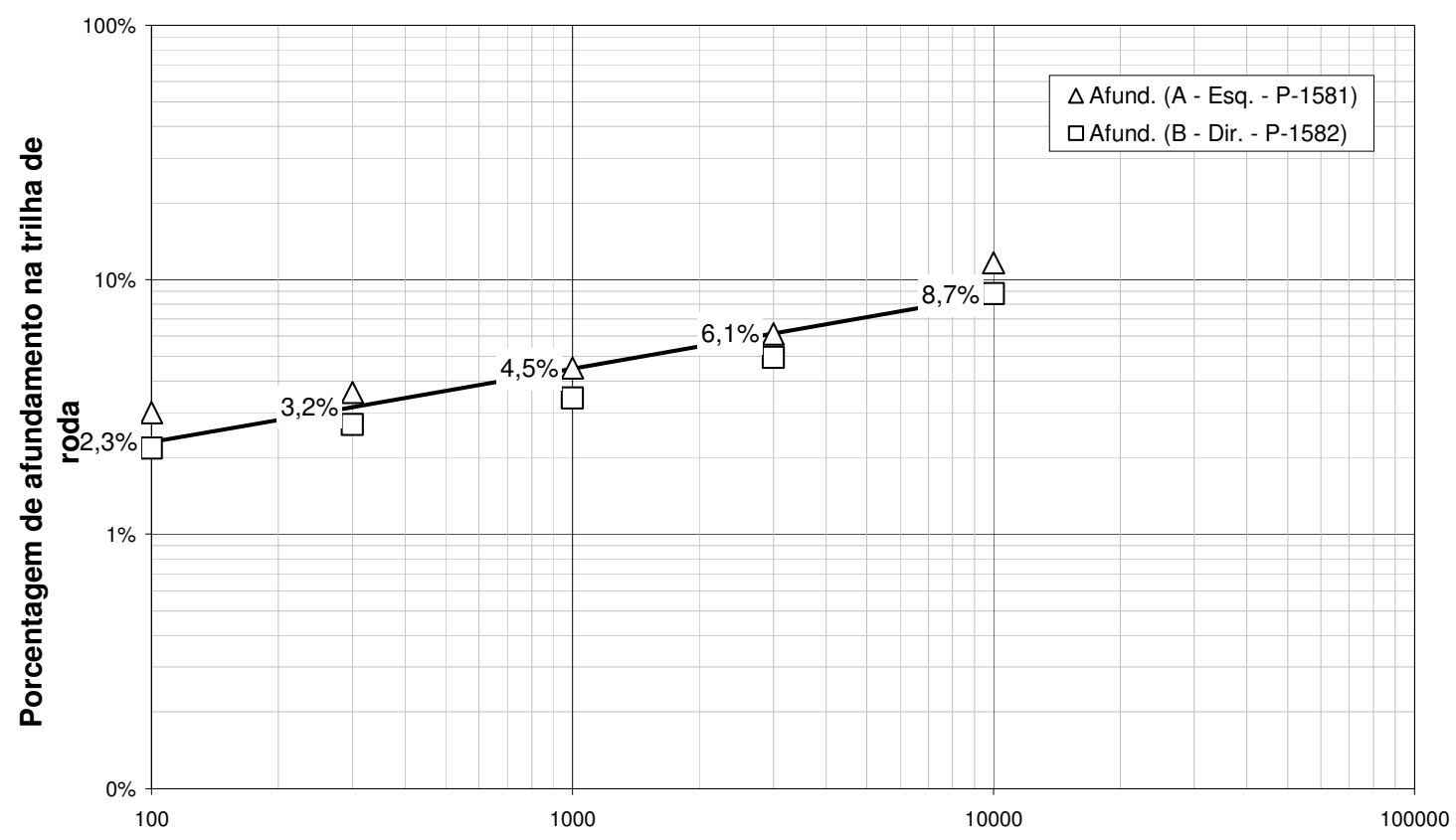

N. de ciclos

DEFORMAÇÃO PERMANENTE - N. de ciclos x Afundamento

Fx. SPV 12,5 mm - CAP c/ 1,2 RET - Teor dep ista $=6,21 \%$ placa de laboratório $-\mathrm{T06}-\mathrm{Temp}$. de ensaio $=60^{\circ} \mathrm{C}$

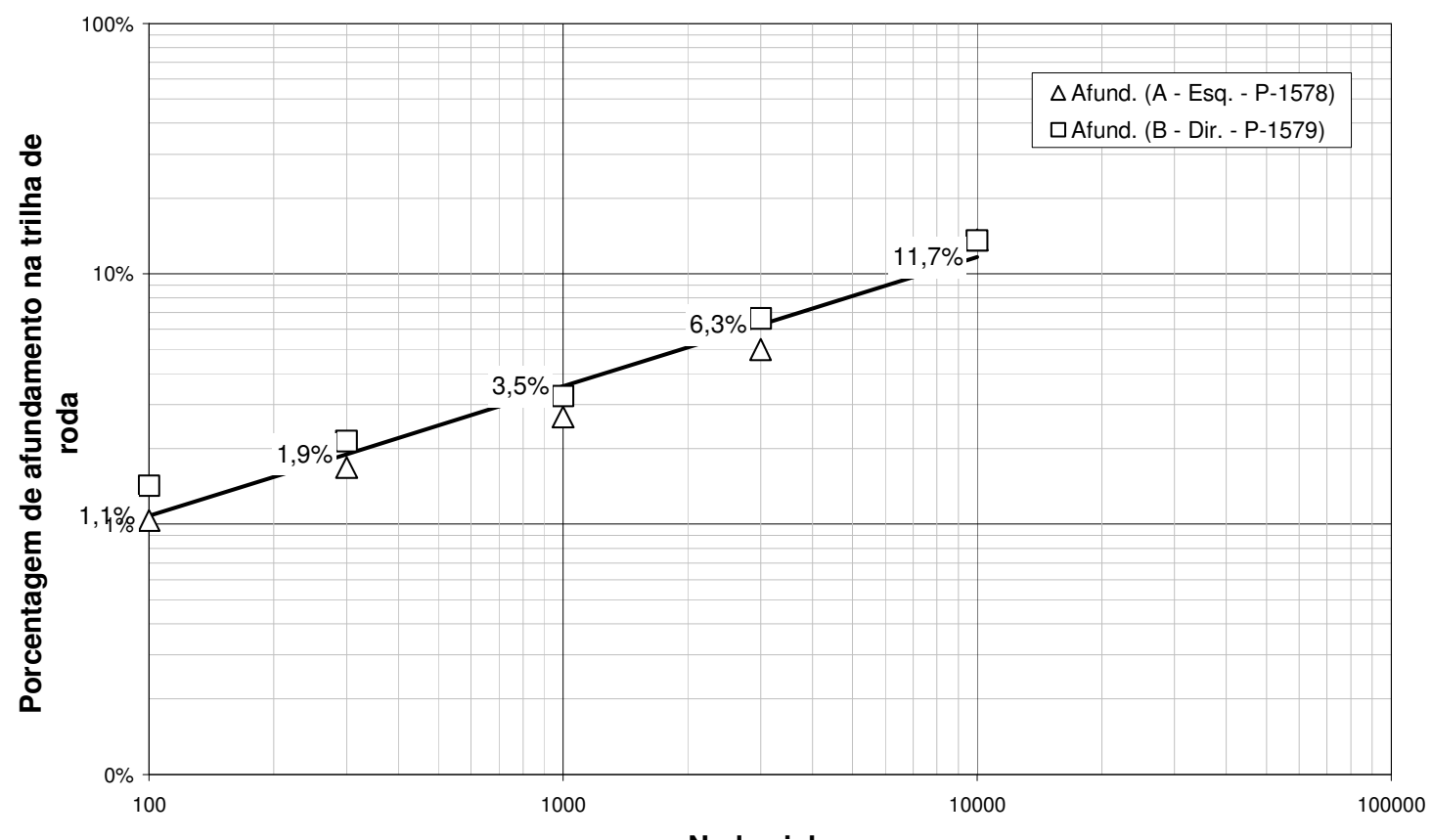

N. de ciclos 
DEFORMAÇÃO PERMANENTE - N. de ciclos x Afundamento

Fx. Gap-graded - CAP c/ borracha - Teor de pista $=7,32 \%$

placa de laboratório $-\mathrm{T07}-$ Temp. de ensaio $=60^{\circ} \mathrm{C}$

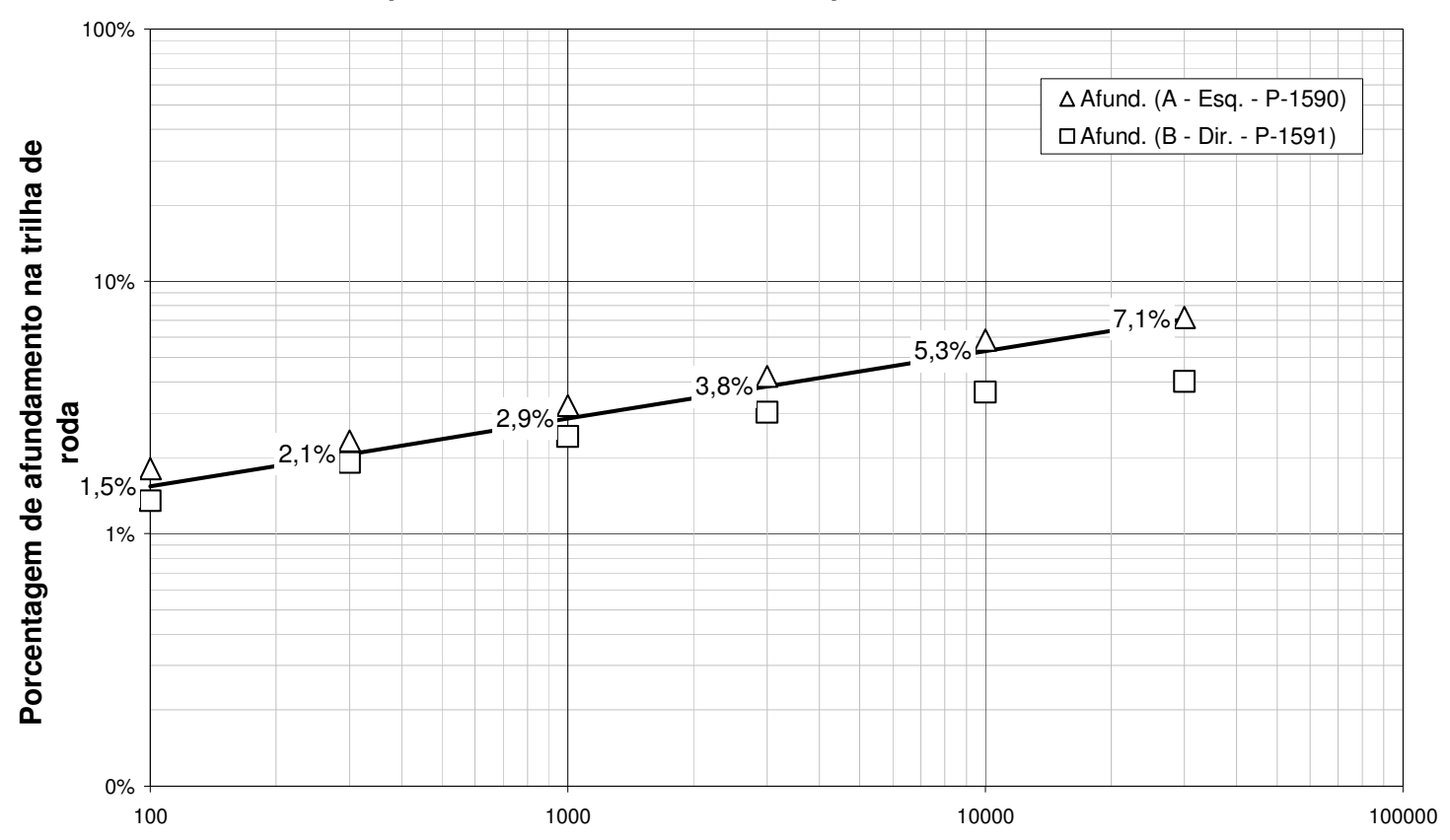

N. de ciclos

DEFORMAÇÃO PERMANENTE - N. de ciclos x Afundamento

Fx. SPV $12,5 \mathrm{~mm}$ - CAP $30 / 45$ - Teor de pista $=5,85 \%$

placa de laboratório $-\mathrm{T} 08-$ Temp. de ensaio $=60^{\circ} \mathrm{C}$

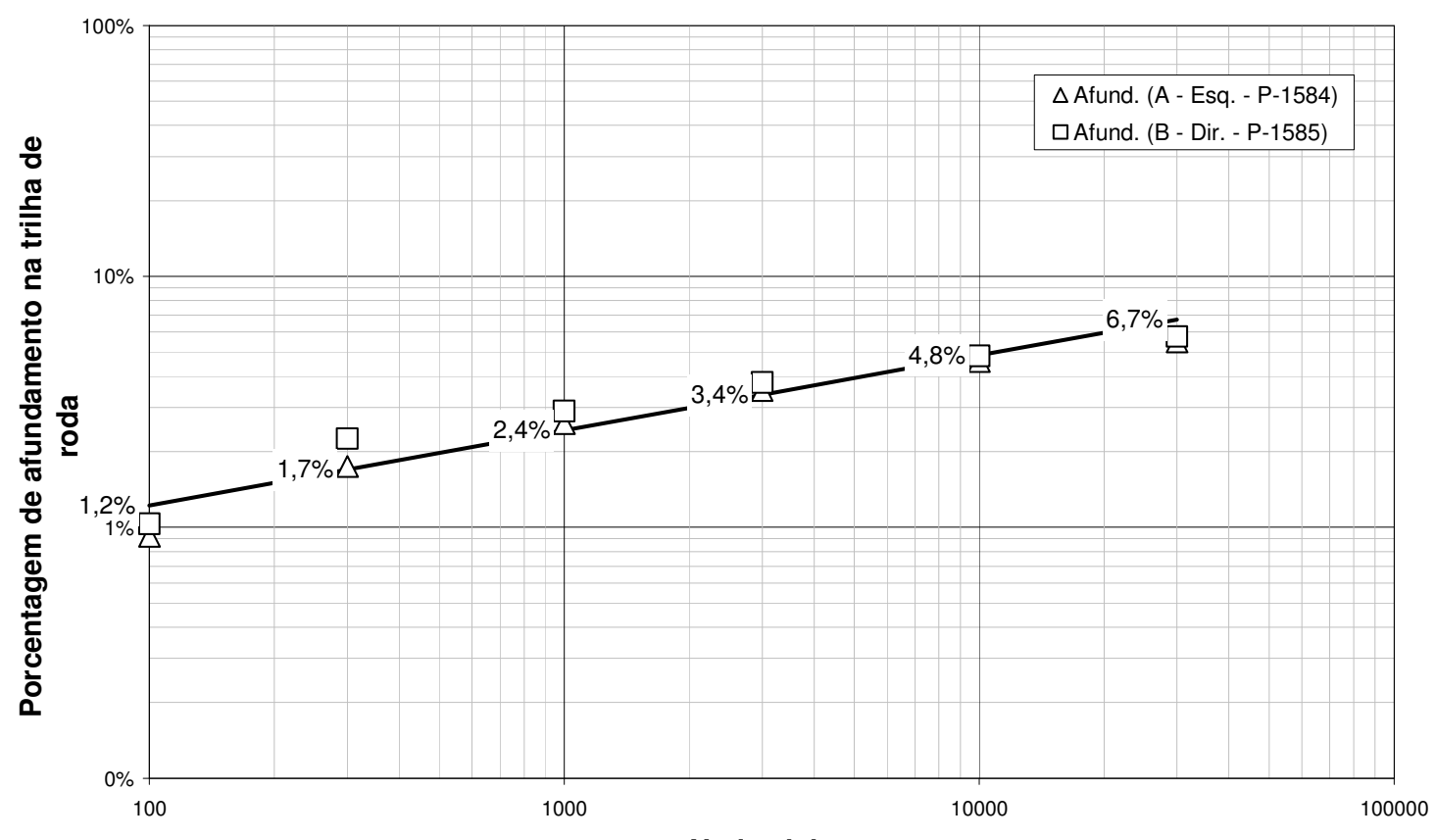

N. de ciclos 
DEFORMAÇÃO PERMANENTE - N. de ciclos x Afundamento

Autopista Litoral Sul - Fx. SPV 9,5 mm - CAP 30/45

placa de laboratório - T09 - Temp. de ensaio $=60^{\circ} \mathrm{C}$

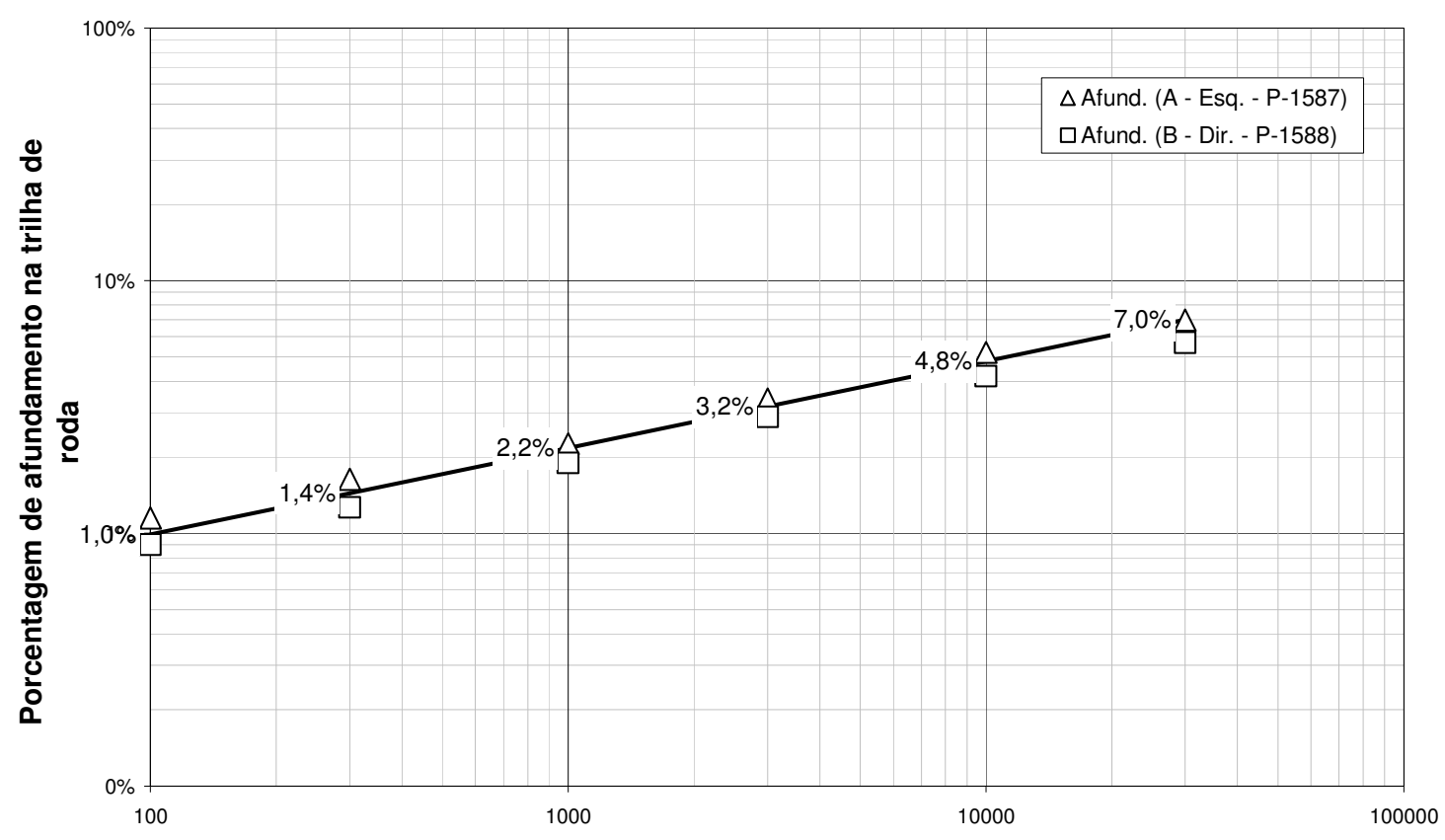

N. de ciclos

DEFORMAÇÃO PERMANENTE - N. de ciclos x Afundamento

Fx. Gap Graded - AMB - Teor de pista $=5,39 \%$

Placa de laboratório - T10 - Temp. de ensaio $=60^{\circ} \mathrm{C}$

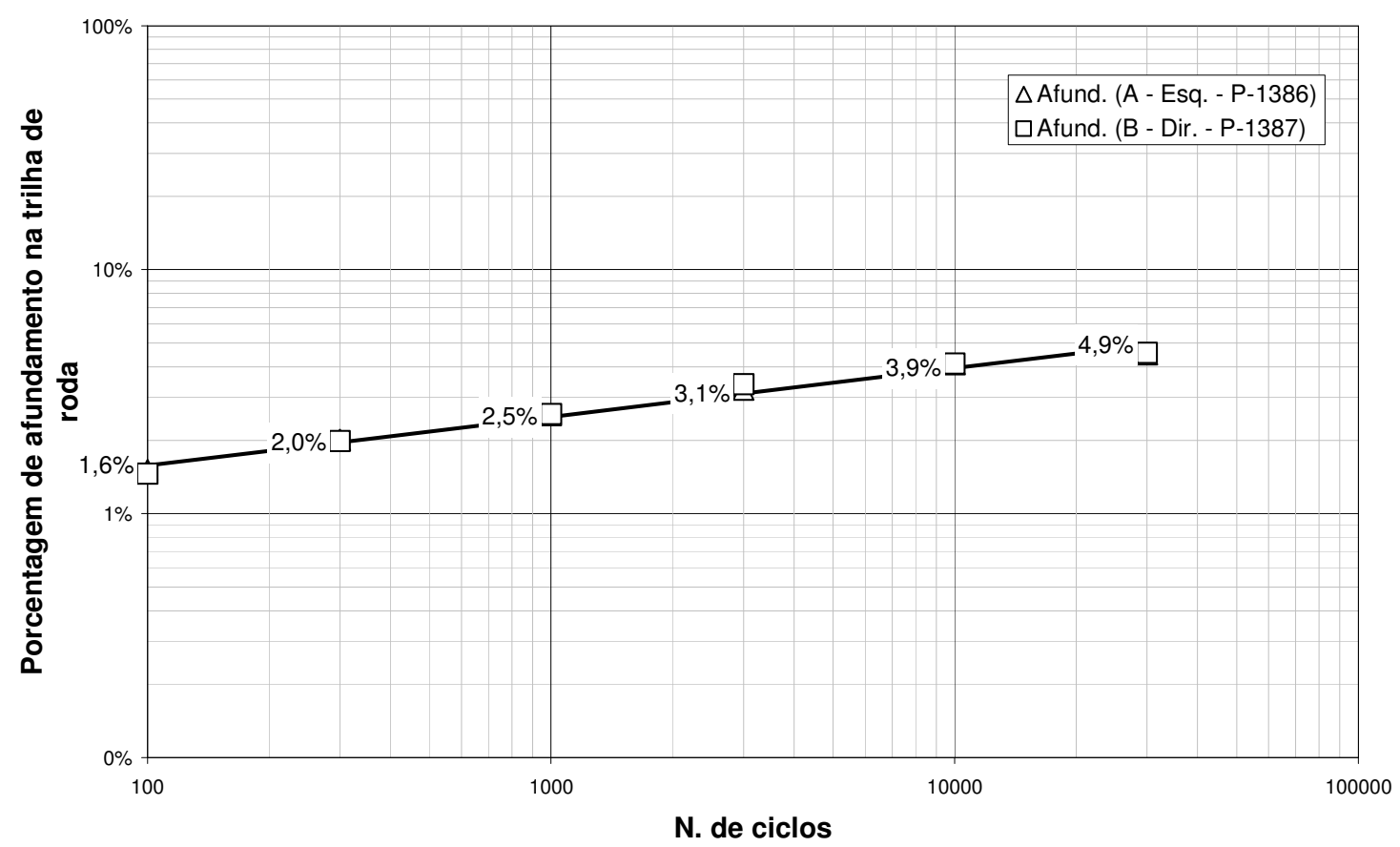


Anexo IV

Resultados do levantamento de flechas da TRI e TRE da $1^{a}$, $2^{a}$ e $3^{a}$. campanha de ensaio - 1,6 e 13 meses de solicitação pelo tráfego respectivamente 
Levantamento das flechas na $1^{\mathrm{a}}$ campanha (1 mês após abertura ao tráfego)

\begin{tabular}{|c|c|c|c|}
\hline \multicolumn{4}{|c|}{ Trilha de Roda } \\
\hline RODOVIA: & & BR 376 & T01 \\
\hline Posição & \multirow{2}{*}{ Dist. } & \multicolumn{2}{|c|}{ Flecha (mm) } \\
\hline $\mathrm{km}$ & & TRI & TRE \\
\hline $675+200$ & 0 & 10 & 5 \\
\hline $675+190$ & 10 & & \\
\hline $675+180$ & 20 & 8 & 10 \\
\hline $675+170$ & 30 & & \\
\hline $675+160$ & 40 & 9 & 7 \\
\hline $675+150$ & 50 & & \\
\hline $675+140$ & 60 & 2 & 5 \\
\hline $675+130$ & 70 & & \\
\hline $675+120$ & 80 & 5 & 4 \\
\hline $675+110$ & 90 & & \\
\hline 675100 & 100 & 2 & 3 \\
\hline $675+090$ & 110 & & \\
\hline $675+080$ & 120 & 4 & 4 \\
\hline $675+070$ & 130 & & \\
\hline $675+060$ & 140 & 5 & 5 \\
\hline $675+050$ & 150 & & \\
\hline $675+040$ & 160 & 4 & 2 \\
\hline $675+030$ & 170 & & \\
\hline $675+020$ & 180 & 3 & 3 \\
\hline $675+010$ & 190 & & \\
\hline $675+000$ & 200 & 1 & 1 \\
\hline & & & $\begin{array}{c}4,5 \\
6,07\end{array}$ \\
\hline
\end{tabular}

\begin{tabular}{|c|c|c|c|}
\hline \multicolumn{4}{|c|}{ Trilha de Roda } \\
\hline$\overline{\text { RODOVIA }}$ & & BR 376 & T02 \\
\hline Posição & Dist & Flecha & $(\mathrm{mm})$ \\
\hline km & & TRI & \begin{tabular}{|l|} 
TRE \\
\end{tabular} \\
\hline
\end{tabular}

\begin{tabular}{|c|c|c|c|}
\hline \multicolumn{4}{|c|}{ Trilha de Roda } \\
\hline RODOVIA: & \multicolumn{1}{|c|}{ BR 376 } & T03 \\
\hline Posição & \multirow{2}{*}{ Dist. } & \multicolumn{2}{|c|}{ Flecha (mm) } \\
\cline { 3 - 4 } \cline { 3 - 4 } & \multicolumn{2}{|c|}{ TRI } & TRE \\
\cline { 3 - 4 } & &
\end{tabular}

$\begin{array}{llll}674+990 & 10 & 2 & 0 \\ 674+980 & 20 & & \\ 674+970 & 30 & 1 & 1 \\ 674+960 & 40 & & \\ 674+950 & 50 & 0 & 0 \\ 674+940 & 60 & & \\ 674+930 & 70 & 1 & 2 \\ 674+920 & 80 & & \\ 674+910 & 90 & 1 & 1 \\ 674+900 & 100 & & \\ 674+890 & 110 & 2 & 2 \\ 674+880 & 120 & & \\ 674+870 & 130 & 2 & 2 \\ 674+860 & 140 & & \\ 674+850 & 150 & 3 & 2 \\ 674+840 & 160 & & \\ 674+830 & 170 & 1 & 1 \\ 674+820 & 180 & & \\ 674+810 & 190 & 5 & 1 \\ 674+800 & 200 & & \\ & & & 1,3 \\ & & & 0,5\end{array}$

$\begin{array}{cccc}674+790 & 10 & 0 & 5 \\ 674+780 & 20 & & \\ 674+770 & 30 & 0 & 1 \\ 674+760 & 40 & & \\ 674+750 & 50 & 1 & 2 \\ 674+740 & 60 & & \\ 674+730 & 70 & 1 & 7 \\ 674+720 & 80 & & \\ 674+710 & 90 & 4 & 2 \\ 674+700 & 100 & & \\ 674+690 & 110 & 1 & 1 \\ 674+680 & 120 & & \\ 674+670 & 130 & 1 & 1 \\ 674+660 & 140 & & \\ 674+650 & 150 & 1 & 3 \\ 674+640 & 160 & & \\ 674+630 & 170 & 0 & 0 \\ 674+620 & 180 & & \\ 674+610 & 190 & 1 & 2 \\ 674+600 & 200 & & \\ & & & 2,4 \\ & & & 4,49\end{array}$

\begin{tabular}{|c|c|c|c|}
\hline \multicolumn{4}{|c|}{ Trilha de Roda } \\
\hline RODOVIA: & & BR 376 & T04 \\
\hline Posição & \multirow{2}{*}{ Dist. } & \multicolumn{2}{|c|}{ Flecha $(\mathrm{mm})$} \\
\hline km & & TRI & TRE \\
\hline $674+590$ & 10 & 0 & 1 \\
\hline $674+580$ & 20 & & \\
\hline $674+570$ & 30 & 0 & 0 \\
\hline $674+560$ & 40 & & \\
\hline $674+550$ & 50 & 0 & 1 \\
\hline $674+540$ & 60 & & \\
\hline $674+530$ & 70 & 0 & 1 \\
\hline $674+520$ & 80 & & \\
\hline $674+510$ & 90 & 0 & 1 \\
\hline $674+500$ & 100 & & \\
\hline $674+490$ & 110 & 0 & 0 \\
\hline $674+480$ & 120 & & \\
\hline $674+470$ & 130 & 0 & 0 \\
\hline $674+460$ & 140 & & \\
\hline $674+450$ & 150 & 0 & 0 \\
\hline $674+440$ & 160 & & \\
\hline $674+430$ & 170 & 0 & 0 \\
\hline $674+420$ & 180 & & \\
\hline $674+410$ & 190 & 1 & 0 \\
\hline $674+400$ & 200 & & \\
\hline & & & 027 \\
\hline
\end{tabular}

Trilha de Roda

\begin{tabular}{|c|c|c|c|}
\hline \multicolumn{2}{|c|}{ RODOVIA: } & BR 376 & T05 \\
\hline Posição & \multirow{2}{*}{ Dist. } & \multicolumn{2}{|c|}{ Flecha $(\mathrm{mm})$} \\
\hline km & & TRI & TRE \\
\hline
\end{tabular}

$674+390 \quad 10$

$674+380 \quad 20$

$674+370 \quad 30$

$674+360 \quad 40$

$674+350 \quad 50$

$674+340 \quad 60$

$674+330 \quad 70$

$674+320 \quad 80$

$674+310 \quad 90$

$674+300 \quad 100$

$674+290 \quad 110$

$674+280 \quad 120$

$674+270 \quad 130$

$674+260 \quad 140$

$674+250 \quad 150$

$674+240 \quad 160$

$674+230 \quad 170$

$674+220 \quad 180$

$674+210 \quad 190$

$674+200 \quad 200$
Trilha de Roda

\begin{tabular}{|c|c|c|c|}
\hline \multicolumn{2}{|c|}{ RODOVIA: } & BR 376 & T06 \\
\hline Posição & \multirow{2}{*}{ Dist. } & \multicolumn{2}{|c|}{ Flecha $(\mathrm{mm})$} \\
\hline km & & TRI & TRE \\
\hline
\end{tabular}

$674+190$

$674+180 \quad 20$

$674+170 \quad 30$

$674+160 \quad 40$

$674+150 \quad 50$

$674+140 \quad 60$

$674+130 \quad 70$

$674+120 \quad 80$

$674+110 \quad 90$

$674+100 \quad 100$

$674+090 \quad 110$

$674+080 \quad 120$

$674+070 \quad 130$

$674+060 \quad 140$

$674+050 \quad 150$

$674+040 \quad 160$

$674+030 \quad 170$

$674+020 \quad 180$

$674+010 \quad 190$

$674+000 \quad 200$
$50 \quad 19$

$6 \quad 6$

$7 \quad 5$

$7 \quad 6$

$5 \quad 7$

$8 \quad 5$

63

$4 \quad 10$

49

$\begin{array}{ll}7 & 8\end{array}$

7,8

19,7 


\begin{tabular}{|c|c|c|c|}
\hline \multicolumn{4}{|c|}{ Trilha de Roda } \\
\hline RODOVIA & & BR 376 & T07 \\
\hline Posição & & Flecha & $(\mathrm{mm})$ \\
\hline km & & TRI & TRE \\
\hline
\end{tabular}

$673+990 \quad 10$

$673+980 \quad 20$

$673+970 \quad 30$

$673+960 \quad 40$

$673+950 \quad 50$

$673+940 \quad 60$

$673+930 \quad 70$

$673+920 \quad 80$

$673+910 \quad 90$

$673+900 \quad 100$

$673+890 \quad 110$

$673+880 \quad 120$

$673+870 \quad 130$

$673+860 \quad 140$

$673+850 \quad 150$

$673+840 \quad 160$

$673+830 \quad 170$

$673+820 \quad 180$

$673+810 \quad 190$

$673+800 \quad 200$

\begin{tabular}{|c|c|c|c|}
\hline \multicolumn{4}{|c|}{ Trilha de Roda } \\
\hline RODOVIA: & \multicolumn{1}{|c|}{ BR 376 } & T08 \\
\hline Posição & \multirow{2}{*}{ Dist. } & \multicolumn{2}{|c|}{ Flecha (mm) } \\
& km & TRI & TRE \\
\hline
\end{tabular}

$673+790 \quad 10$

$673+780 \quad 20$

$673+770 \quad 30$

$673+760 \quad 40$

$673+750 \quad 50$

$673+740 \quad 60$

$673+730 \quad 70$

$673+720 \quad 80$

$673+710 \quad 90$

$673+700 \quad 100$

$673+690 \quad 110$

$673+680 \quad 120$

$673+670 \quad 130$

$673+660 \quad 140$

$673+650 \quad 150$

$673+640 \quad 160$

$673+630 \quad 170$

$673+620 \quad 180$

$673+610 \quad 190$

$673+600 \quad 200$

\begin{tabular}{|c|c|c|c|}
\hline \multicolumn{4}{|c|}{ Trilha de Roda } \\
\hline RODOVIA: & \multicolumn{1}{|c|}{ BR 376} & T09 \\
\hline Posição & \multirow{2}{*}{ Dist. } & \multicolumn{2}{|c|}{ Flecha (mm) } \\
km & & TRI & TRE \\
\cline { 4 - 5 } & &
\end{tabular}

$673+590 \quad 10$

$673+580 \quad 20$

$673+570 \quad 30$

$673+560 \quad 40$

$673+550 \quad 50$

$673+540 \quad 60$

$673+530 \quad 70$

$673+520 \quad 80$

$673+510 \quad 90$

$673+500 \quad 100$

$673+490 \quad 110$

$673+480 \quad 120$

$673+470 \quad 130$

$673+460 \quad 140$

$673+450 \quad 150$

$673+440 \quad 160$

$673+430 \quad 170$

$673+420 \quad 180$

$673+410 \quad 190$

$673+400 \quad 200$

3

20

02

03

22

$0 \quad 2$

0

02

$\begin{array}{ll}0 & 1\end{array}$

1,8

0,84
03

\begin{tabular}{|c|c|c|c|}
\hline \multicolumn{4}{|c|}{ Trilha de Roda } \\
\hline RODOVIA: & & BR 376 & T10 \\
\hline Posição & \multirow{2}{*}{ Dist. } & \multicolumn{2}{|c|}{ Flecha $(\mathrm{mm})$} \\
\hline km & & TRI & $\overline{\text { TRE }}$ \\
\hline $673+390$ & 10 & 1 & 2 \\
\hline $673+380$ & 20 & & \\
\hline $673+370$ & 30 & 0 & 0 \\
\hline $673+360$ & 40 & & \\
\hline $673+350$ & 50 & 0 & 0 \\
\hline $673+340$ & 60 & & \\
\hline $673+330$ & 70 & 0 & 0 \\
\hline $673+320$ & 80 & & \\
\hline $673+310$ & 90 & 1 & 1 \\
\hline $673+300$ & 100 & & \\
\hline $673+290$ & 110 & 1 & 0 \\
\hline $673+280$ & 120 & & \\
\hline $673+270$ & 130 & 1 & 1 \\
\hline $673+260$ & 140 & & \\
\hline $673+250$ & 150 & 0 & 0 \\
\hline $673+240$ & 160 & & \\
\hline $673+230$ & 170 & 0 & 0 \\
\hline $673+220$ & 180 & & \\
\hline $673+210$ & 190 & 2 & 0 \\
\hline $673+200$ & 200 & & \\
\hline & & & 0,4 \\
\hline & & & 0,49 \\
\hline
\end{tabular}


Levantamento das flechas na $2^{\mathrm{a}}$ campanha (6 meses após abertura ao tráfego)

\begin{tabular}{|c|c|c|c|}
\hline \multicolumn{4}{|c|}{ Trilha de Roda } \\
\hline RODOVIA: & & BR 376 & $\mathrm{TC}$ \\
\hline Posição & \multirow{2}{*}{ Dist. } & \multicolumn{2}{|c|}{ Flecha $(\mathrm{mm})$} \\
\hline km & & TRI & TRE \\
\hline $675+200$ & 0 & 8 & 9 \\
\hline $675+190$ & 10 & & \\
\hline $675+180$ & 20 & 33 & 27 \\
\hline $675+170$ & 30 & & \\
\hline $675+160$ & 40 & 6 & 1 \\
\hline $675+150$ & 50 & & \\
\hline $675+140$ & 60 & 3 & 5 \\
\hline $675+130$ & 70 & & \\
\hline $675+120$ & 80 & 12 & 1 \\
\hline $675+110$ & 90 & & \\
\hline 675_100 & 100 & 5 & $\varepsilon$ \\
\hline $675+090$ & 110 & & \\
\hline $675+080$ & 120 & 7 & 3 \\
\hline $675+070$ & 130 & & \\
\hline $675+060$ & 140 & 10 & 5 \\
\hline $675+050$ & 150 & & \\
\hline $675+040$ & 160 & 6 & 2 \\
\hline $675+030$ & 170 & & \\
\hline $675+020$ & 180 & 2 & 4 \\
\hline $675+010$ & 190 & & \\
\hline$\pi$ & 200 & & \\
\hline
\end{tabular}

9,1

7,59

\begin{tabular}{|c|c|c|c|}
\hline \multicolumn{4}{|c|}{ Trilha de Roda } \\
\hline RODOVIA: & \multicolumn{1}{|c|}{ BR 376 } & T02 \\
\hline Posição & \multirow{2}{*}{ Dist. } & \multicolumn{2}{|c|}{ Flecha (mm) } \\
\cline { 3 - 4 } & & TRI & TRE \\
\cline { 3 - 4 } & &
\end{tabular}

$674+990 \quad 10 \quad 0 \quad 2$

$674+980 \quad 20$

$674+970 \quad 30$

$674+960 \quad 40$

$674+950 \quad 50$

$674+940 \quad 60$

$674+93070$

$674+920 \quad 80$

$674+910 \quad 90$

$674+900 \quad 100$

$674+890 \quad 110$

$674+880 \quad 120$

$674+870 \quad 130$

$674+860 \quad 140$

$674+850 \quad 150$

$674+840 \quad 160$

$674+830 \quad 170$

$674+820 \quad 180$

$674+810 \quad 190$

$674+800 \quad 200$

$\begin{array}{ll}0 & 2 \\ 1 & 2 \\ 1 & 2 \\ 2 & 2 \\ 7 & 3 \\ 1 & 2 \\ 1 & 2 \\ 2 & 0 \\ 1 & 1 \\ 3 & 5 \\ & 2,1 \\ & 1,66\end{array}$

$\begin{array}{cccc}674+790 & 10 & 4 & 0 \\ 674+780 & 20 & & \\ 674+770 & 30 & 2 & 3 \\ 674+760 & 40 & & \\ 674+750 & 50 & 2 & 3 \\ 674+740 & 60 & & \\ 674+730 & 70 & 1 & 3 \\ 674+720 & 80 & & \\ 674+710 & 90 & 3 & 2 \\ 674+700 & 100 & & \\ 674+690 & 110 & 3 & 4 \\ 674+680 & 120 & & \\ 674+670 & 130 & 2 & 4 \\ 674+660 & 140 & & \\ 674+650 & 150 & 3 & 4 \\ 674+640 & 160 & & \\ 674+630 & 170 & 3 & 3 \\ 674+620 & 180 & & \\ 674+610 & 190 & 2 & 2 \\ 674+600 & 200 & & \mathbf{2 , 8} \\ & & & \mathbf{1 , 0 4}\end{array}$

Trilha de Roda

\begin{tabular}{|c|c|c|c|}
\hline RODOVIA: & & BR 376 & T04 \\
\hline Posição & \multirow{2}{*}{ Dist } & \multicolumn{2}{|c|}{ Flecha $(\mathrm{mm})$} \\
\hline km & & TRI & TRE \\
\hline
\end{tabular}

$\begin{array}{lllll}674+590 & 10 & 0 & 0 \\ 674+580 & 20 & & \end{array}$

$674+570 \quad 30$

$674+560 \quad 40$

$674+550 \quad 50$

$674+540 \quad 60$

31

22

$674+530 \quad 70$

$674+520 \quad 80$

$674+510 \quad 90$

$674+500 \quad 100$

$674+490 \quad 110$

$674+480 \quad 120$

$674+470 \quad 130$

$674+460 \quad 140$

$674+450 \quad 150$

$674+440 \quad 160$

$674+430 \quad 170$

$674+420 \quad 180$

$674+410 \quad 190$

$674+400 \quad 200$

Trilha de Roda

\begin{tabular}{|c|c|c|c|}
\hline \multicolumn{2}{|c|}{ RODOVIA: } & BR 376 & T05 \\
\hline Posição & \multirow{2}{*}{ Dist. } & \multicolumn{2}{|c|}{ Flecha (mm) } \\
\hline & & TRI & TR \\
\hline
\end{tabular}

$674+390 \quad 10$

6

9

$674+380 \quad 20$

$674+370 \quad 30$

$674+360 \quad 40$

$674+350 \quad 50$

$674+340 \quad 60$

$674+330 \quad 70$

$674+320 \quad 80$

$674+310 \quad 90$

$674+300 \quad 100$

$674+290 \quad 110$

$674+280 \quad 120$

$674+270 \quad 130$

$674+260 \quad 140$

$674+250 \quad 150$

$674+240 \quad 160$

$674+230 \quad 170$

$674+220 \quad 180$

$674+210 \quad 190$

$674+200 \quad 200$

$6 \quad 7$

Trilha de Roda

\begin{tabular}{|c|c|c|c|}
\hline \multicolumn{2}{|c|}{ RODOVIA: } & BR 376 & T06 \\
\hline Posição & \multirow{2}{*}{ Dist. } & \multicolumn{2}{|c|}{ Flecha $(\mathrm{mm})$} \\
\hline km & & TRI & TRE \\
\hline
\end{tabular}

$674+190$

$674+180 \quad 20$

$674+170 \quad 30$

$10 \quad 25$

$674+160 \quad 40$

$674+150 \quad 50$

$11 \quad 12$

$3 \quad 8$

$674+140 \quad 60$

$674+130 \quad 70$

$674+120 \quad 80$

$674+110 \quad 90$

$674+100 \quad 100$

$674+090 \quad 110$

$674+080 \quad 120$

$674+070 \quad 130$

$674+060 \quad 140$

$674+050 \quad 150$

$674+040 \quad 160$

$674+030 \quad 170$

$674+020 \quad 180$

$674+010 \quad 190$

$674+000 \quad 200$

99

$16 \quad 14$

$10 \quad 10$

$\begin{array}{ll}7 & 7\end{array}$

$7 \quad 9$

$0 \quad 19$

$5 \quad 12$

$9 \quad 10$ 


\begin{tabular}{|c|c|c|c|}
\hline \multicolumn{4}{|c|}{ Trilha de Roda } \\
\hline RODOVIA & & BR 376 & T07 \\
\hline Posição & & Flecha ( & $(\mathrm{mm})$ \\
\hline km & & TRI & TRE \\
\hline
\end{tabular}

$673+980 \quad 20$

$673+970 \quad 30$

$673+960 \quad 40$

$673+950 \quad 50$

$673+940 \quad 60$

$673+930 \quad 70$

$673+920 \quad 80$

$673+910 \quad 90$

$673+900 \quad 100$

$673+890 \quad 110$

$673+880 \quad 120$

$673+870 \quad 130$

$673+860 \quad 140$

$673+850 \quad 150$

$673+840 \quad 160$

$673+830 \quad 170$

$673+820 \quad 180$

$673+810 \quad 190$

$673+800 \quad 200$
$673+990 \quad 10$

\begin{tabular}{|c|c|c|c|}
\hline \multicolumn{4}{|c|}{ Trilha de Roda } \\
\hline RODOVIA: & \multicolumn{1}{|c|}{ BR 376 } & T08 \\
\hline Posição & \multirow{2}{*}{ Dist. } & \multicolumn{2}{|c|}{ Flecha (mm) } \\
& & TRI & TRE \\
& &
\end{tabular}

$673+790 \quad 10$

$673+780 \quad 20$

$673+770 \quad 30$

$673+760 \quad 40$

$673+750 \quad 50$

$673+740 \quad 60$

$673+730 \quad 70$

$673+720 \quad 80$

$673+710 \quad 90$

$673+700 \quad 100$

$673+690 \quad 110$

$673+680 \quad 120$

$673+670 \quad 130$

$673+660 \quad 140$

$673+650 \quad 150$

$673+640 \quad 160$

$673+630 \quad 170$

$673+620 \quad 180$

$673+610 \quad 190$

$673+600 \quad 200$

8,9

4,51

Trilha de Roda

\begin{tabular}{|c|c|c|c|}
\hline RODOVIA: & & BR 376 & T10 \\
\hline Posição & \multirow{2}{*}{ Dist } & \multicolumn{2}{|c|}{ Flecha $(\mathrm{mm})$} \\
\hline km & & TRI & TRE \\
\hline
\end{tabular}

$673+390 \quad 10$

$673+380 \quad 20$

$673+370 \quad 30$

$673+360 \quad 40$

$673+350 \quad 50$

$673+340 \quad 60$

$673+330 \quad 70$

$673+320 \quad 80$

$673+310 \quad 90$

$673+300 \quad 100$

$673+290 \quad 110$

$673+280 \quad 120$

$673+270 \quad 130$

$673+260 \quad 140$

$673+250 \quad 150$

$673+240 \quad 160$

$673+230 \quad 170$

$673+220 \quad 180$

$673+210 \quad 190$

$673+200 \quad 200$

4,0
D padr $\quad 2,2$

$0 \quad 6$

03

$0 \quad 0$

$0 \quad 0$

11

10

23

02

34

23

\begin{tabular}{|c|c|c|c|}
\hline \multicolumn{4}{|c|}{ Trilha de Roda } \\
\hline RODOVIA: & \multicolumn{1}{|c|}{ BR 376} & T09 \\
\hline Posição & \multirow{2}{*}{ Dist. } & \multicolumn{2}{c|}{ Flecha (mm) } \\
km & & TRI & TRE \\
\cline { 4 - 5 } & &
\end{tabular}

$673+590 \quad 10$

$673+580 \quad 20$

$673+570 \quad 30$

$673+560 \quad 40$

$673+550 \quad 50$

$673+540 \quad 60$

$673+530 \quad 70$

$673+520 \quad 80$

$673+510 \quad 90$

$673+500 \quad 100$

$673+490 \quad 110$

$673+480 \quad 120$

$673+470 \quad 130$

$673+460 \quad 140$

$673+450 \quad 150$

$673+440 \quad 160$

$673+430 \quad 170$

$673+420 \quad 180$

$673+410 \quad 190$

$673+400 \quad 200$
5

04

$\begin{array}{ll}0 & 4\end{array}$

04

$0 \quad 6$

$\begin{array}{ll}0 & 7\end{array}$

$4 \quad 5$

$4 \quad 6$

17

5,4

1,17
26 
Levantamento das flechas na $3^{\mathrm{a}}$ campanha (13 meses após abertura ao tráfego)

\begin{tabular}{|c|c|c|c|}
\hline \multicolumn{4}{|c|}{ Trilha de Roda } \\
\hline RODOVIA: & & BR 376 & T01 \\
\hline Posição & \multirow{2}{*}{ Dist } & \multicolumn{2}{|c|}{ Flecha $(\mathrm{mm})$} \\
\hline km & & TRI & TRE \\
\hline $675+200$ & 0 & 3 & 25 \\
\hline $675+190$ & 10 & 2 & 10 \\
\hline $675+180$ & 20 & 3 & 7 \\
\hline $675+170$ & 30 & 5 & 12 \\
\hline $675+160$ & 40 & 8 & 45 \\
\hline $675+150$ & 50 & 4 & 22 \\
\hline $675+140$ & 60 & 3 & 51 \\
\hline $675+130$ & 70 & 108 & 73 \\
\hline $675+120$ & 80 & 12 & 20 \\
\hline $675+110$ & 90 & 5 & 24 \\
\hline $675 \_100$ & 100 & 2 & 11 \\
\hline $675+090$ & 110 & 3 & 7 \\
\hline $675+080$ & 120 & 5 & 6 \\
\hline $675+070$ & 130 & 1 & 8 \\
\hline $675+060$ & 140 & 6 & 11 \\
\hline $675+050$ & 150 & 4 & 15 \\
\hline $675+040$ & 160 & 6 & 6 \\
\hline $675+030$ & 170 & 4 & 14 \\
\hline $675+020$ & 180 & 6 & 17 \\
\hline $675+010$ & 190 & 7 & 12 \\
\hline $675+000$ & 200 & 3 & 5 \\
\hline & & Média & 19,1 \\
\hline & & D padr & 17,3 \\
\hline
\end{tabular}

\begin{tabular}{|c|c|c|c|}
\hline \multicolumn{4}{|c|}{ Trilha de Roda } \\
\hline RODOVIA: & \multicolumn{2}{|c|}{ BR 376 } & T02 \\
\hline Posição & \multirow{2}{*}{ Dist. } & Flecha (mm) \\
\cline { 3 - 4 } & & TRI & TRE \\
\hline
\end{tabular}

\begin{tabular}{|c|c|c|c|}
\hline \multicolumn{4}{|c|}{ Trilha de Roda } \\
\hline RODOVIA: & \multicolumn{1}{|c|}{ BR 376 } & T03 \\
\hline Posição & \multirow{2}{*}{ Dist. } & Flecha (mm) \\
\cline { 3 - 4 } & & TRI & TRE \\
\hline
\end{tabular}

$\begin{array}{cccc}674+990 & 10 & 5 & 92 \\ 674+980 & 20 & 3 & 28 \\ 674+970 & 30 & 2 & 18 \\ 674+960 & 40 & 7 & 12 \\ 674+950 & 50 & 5 & 10 \\ 674+940 & 60 & 5 & 15 \\ 674+930 & 70 & 4 & 12 \\ 674+920 & 80 & 5 & 28 \\ 674+910 & 90 & 9 & 16 \\ 674+900 & 100 & 3 & 18 \\ 674+890 & 110 & 7 & 37 \\ 674+880 & 120 & 10 & 12 \\ 674+870 & 130 & 7 & 8 \\ 674+860 & 140 & 5 & 9 \\ 674+850 & 150 & 6 & 11 \\ 674+840 & 160 & 6 & 8 \\ 674+830 & 170 & 5 & 12 \\ 674+820 & 180 & 14 & 7 \\ 674+810 & 190 & 19 & 20 \\ 674+800 & 200 & 5 & 3 \\ & & \text { Média } & \mathbf{1 8 , 8} \\ & & \text { D padr } & \mathbf{1 9 , 1}\end{array}$

$\begin{array}{cccc}674+790 & 10 & 3 & 8 \\ 674+780 & 20 & 0 & 3 \\ 674+770 & 30 & 2 & 3 \\ 674+760 & 40 & 7 & 6 \\ 674+750 & 50 & 2 & 9 \\ 674+740 & 60 & 2 & 12 \\ 674+730 & 70 & 1 & 7 \\ 674+720 & 80 & 3 & 5 \\ 674+710 & 90 & 3 & 11 \\ 674+700 & 100 & 8 & 5 \\ 674+690 & 110 & 32 & 8 \\ 674+680 & 120 & 33 & 60 \\ 674+670 & 130 & 17 & 42 \\ 674+660 & 140 & 11 & 17 \\ 674+650 & 150 & 6 & 13 \\ 674+640 & 160 & 4 & 6 \\ 674+630 & 170 & 8 & 7 \\ 674+620 & 180 & 45 & 48 \\ 674+610 & 190 & 34 & 92 \\ 674+600 & 200 & 0 & 105 \\ & & \text { Média } & \mathbf{2 3 , 4} \\ & & \text { D padr } & \mathbf{3 0 , 3}\end{array}$

\begin{tabular}{|c|c|c|c|}
\hline \multicolumn{4}{|c|}{ Trilha de Roda } \\
\hline RODOVIA: & & BR 376 & T04 \\
\hline Posição & \multirow{2}{*}{ Dist. } & \multicolumn{2}{|c|}{ Flecha (mm) } \\
\hline km & & TRI & TRE \\
\hline $674+590$ & 10 & 2 & 32 \\
\hline $674+580$ & 20 & 0 & 4 \\
\hline $674+570$ & 30 & 2 & 4 \\
\hline $674+560$ & 40 & 5 & 5 \\
\hline $674+550$ & 50 & 2 & 2 \\
\hline $674+540$ & 60 & 5 & 4 \\
\hline $674+530$ & 70 & 3 & 3 \\
\hline $674+520$ & 80 & 3 & 10 \\
\hline $674+510$ & 90 & 2 & 7 \\
\hline $674+500$ & 100 & 4 & 4 \\
\hline $674+490$ & 110 & 5 & 5 \\
\hline $674+480$ & 120 & 4 & 5 \\
\hline $674+470$ & 130 & 10 & 22 \\
\hline $674+460$ & 140 & 4 & 5 \\
\hline $674+450$ & 150 & 12 & 22 \\
\hline $674+440$ & 160 & 17 & 13 \\
\hline $674+430$ & 170 & 12 & 23 \\
\hline $674+420$ & 180 & 48 & 3 \\
\hline $674+410$ & 190 & 38 & 41 \\
\hline $674+400$ & 200 & 34 & 78 \\
\hline & & Média & 14,6 \\
\hline & & D padr & 18,5 \\
\hline
\end{tabular}

\begin{tabular}{|c|c|c|c|}
\hline \multicolumn{4}{|c|}{ Trilha de Roda } \\
\hline \multicolumn{2}{|l|}{ RODOVIA: } & BR 376 & T05 \\
\hline Posição & \multirow{2}{*}{ Dist. } & \multicolumn{2}{|c|}{ Flecha (mm) } \\
\hline km & & TRI & TRE \\
\hline $674+390$ & 10 & 22 & 36 \\
\hline $674+380$ & 20 & 18 & 38 \\
\hline $674+370$ & 30 & 13 & 35 \\
\hline $674+360$ & 40 & 10 & 35 \\
\hline $674+350$ & 50 & 21 & 38 \\
\hline $674+340$ & 60 & 38 & 33 \\
\hline $674+330$ & 70 & 22 & 40 \\
\hline $674+320$ & 80 & 4 & 28 \\
\hline $674+310$ & 90 & 24 & 31 \\
\hline $674+300$ & 100 & 30 & 19 \\
\hline $674+290$ & 110 & 22 & 18 \\
\hline $674+280$ & 120 & 17 & 22 \\
\hline $674+270$ & 130 & 15 & 16 \\
\hline $674+260$ & 140 & 20 & 21 \\
\hline $674+250$ & 150 & 19 & 28 \\
\hline $674+240$ & 160 & 12 & 12 \\
\hline $674+230$ & 170 & 12 & 34 \\
\hline $674+220$ & 180 & 14 & 31 \\
\hline $674+210$ & 190 & 5 & 15 \\
\hline $674+200$ & 200 & 9 & 45 \\
\hline & & Média & 28,8 \\
\hline & & D padr & 9,5 \\
\hline
\end{tabular}

\begin{tabular}{|c|c|c|c|}
\hline \multicolumn{4}{|c|}{ Trilha de Roda } \\
\hline RODOVIA: & & \multicolumn{3}{|c|}{ BR 376 } & T06 \\
\hline Posição & \multirow{2}{*}{ Dist. } & \multicolumn{3}{c|}{ Flecha (mm) } \\
\cline { 4 - 5 } km & & TRI & TRE \\
\hline $674+190$ & 10 & 18 & 25 \\
$674+180$ & 20 & 37 & 38 \\
$674+170$ & 30 & 35 & 33 \\
$674+160$ & 40 & 34 & 44 \\
$674+150$ & 50 & 38 & 24 \\
$674+140$ & 60 & 39 & 28 \\
$674+130$ & 70 & 28 & 42 \\
$674+120$ & 80 & 24 & 45 \\
$674+110$ & 90 & 48 & 51 \\
$674+100$ & 100 & 45 & 45 \\
$674+090$ & 110 & 35 & 28 \\
$674+080$ & 120 & 28 & 28 \\
$674+070$ & 130 & 40 & 35 \\
$674+060$ & 140 & 32 & 38 \\
$674+050$ & 150 & 12 & 20 \\
$674+040$ & 160 & 18 & 31 \\
$674+030$ & 170 & 17 & 25 \\
$674+020$ & 180 & 55 & 55 \\
$674+010$ & 190 & 26 & 8 \\
$674+000$ & 200 & 75 & 12 \\
& & Média & $\mathbf{3 2 , 8}$ \\
& & D padr & $\mathbf{1 2 , 3}$ \\
\hline
\end{tabular}




\begin{tabular}{|c|c|c|c|}
\hline \multicolumn{4}{|c|}{ Trilha de Roda } \\
\hline RODOVIA: & & BR 376 & T07 \\
\hline Posição & \multirow{2}{*}{ Dist. } & \multicolumn{3}{|c|}{ Flecha $(\mathbf{m m})$} \\
\cline { 4 - 5 } km & & TRI & TRE \\
\hline $673+990$ & 10 & 47 & 53 \\
$673+980$ & 20 & 54 & 55 \\
$673+970$ & 30 & 49 & 58 \\
$673+960$ & 40 & 55 & 70 \\
$673+950$ & 50 & 53 & 68 \\
$673+940$ & 60 & 62 & 80 \\
$673+930$ & 70 & 59 & 68 \\
$673+920$ & 80 & 57 & 75 \\
$673+910$ & 90 & 60 & 73 \\
$673+900$ & 100 & 45 & 47 \\
$673+890$ & 110 & 44 & 52 \\
$673+880$ & 120 & 36 & 36 \\
$673+870$ & 130 & 18 & 15 \\
$673+860$ & 140 & 23 & 73 \\
$673+850$ & 150 & 51 & 65 \\
$673+840$ & 160 & 50 & 70 \\
$673+830$ & 170 & 63 & 82 \\
$673+820$ & 180 & 47 & 65 \\
$673+810$ & 190 & 38 & 53 \\
$673+800$ & 200 & 16 & 13 \\
& & Média & $\mathbf{5 8 , 6}$ \\
& & D padr & $\mathbf{1 9 , 1}$
\end{tabular}

\begin{tabular}{|c|c|c|c|}
\hline \multicolumn{4}{|c|}{ Trilha de Roda } \\
\hline \multicolumn{2}{|l|}{ RODOVIA: } & BR 376 & T08 \\
\hline Posição & \multirow{2}{*}{ Dist. } & \multicolumn{2}{|c|}{ Flecha (mm) } \\
\hline km & & TRI & TRE \\
\hline $673+790$ & 10 & 15 & 13 \\
\hline $673+780$ & 20 & 23 & 32 \\
\hline $673+770$ & 30 & 30 & 45 \\
\hline $673+760$ & 40 & 30 & 50 \\
\hline $673+750$ & 50 & 35 & 68 \\
\hline $673+740$ & 60 & 35 & 60 \\
\hline $673+730$ & 70 & 30 & 46 \\
\hline $673+720$ & 80 & 23 & 36 \\
\hline $673+710$ & 90 & 22 & 25 \\
\hline $673+700$ & 100 & 26 & 35 \\
\hline $673+690$ & 110 & 30 & 45 \\
\hline $673+680$ & 120 & 50 & 53 \\
\hline $673+670$ & 130 & 52 & 72 \\
\hline $673+660$ & 140 & 18 & 21 \\
\hline $673+650$ & 150 & 12 & 18 \\
\hline $673+640$ & 160 & 20 & 26 \\
\hline $673+630$ & 170 & 27 & 34 \\
\hline $673+620$ & 180 & 24 & 22 \\
\hline $673+610$ & 190 & 28 & 29 \\
\hline $673+600$ & 200 & 42 & 35 \\
\hline & & Média & 38,3 \\
\hline & & D padr & 16,4 \\
\hline
\end{tabular}

\begin{tabular}{|c|c|c|c|}
\hline \multicolumn{4}{|c|}{ Trilha de Roda } \\
\hline \multicolumn{2}{|c|}{ RODOVIA: } & BR 376 & T09 \\
\hline Posição & \multirow{2}{*}{ Dist. } & \multicolumn{2}{|c|}{ Flecha $(\mathrm{mm})$} \\
\hline km & & TRI & $\overline{\text { TRE }}$ \\
\hline $673+590$ & 10 & 31 & 35 \\
\hline $673+580$ & 20 & 40 & 42 \\
\hline $673+570$ & 30 & 45 & 46 \\
\hline $673+560$ & 40 & 37 & 48 \\
\hline $673+550$ & 50 & 32 & 50 \\
\hline $673+540$ & 60 & 33 & 38 \\
\hline $673+530$ & 70 & 30 & 27 \\
\hline $673+520$ & 80 & 34 & 35 \\
\hline $673+510$ & 90 & 25 & 25 \\
\hline $673+500$ & 100 & 21 & 31 \\
\hline $673+490$ & 110 & 25 & 34 \\
\hline $673+480$ & 120 & 14 & 25 \\
\hline $673+470$ & 130 & 26 & 30 \\
\hline $673+460$ & 140 & 10 & 23 \\
\hline $673+450$ & 150 & 15 & 23 \\
\hline $673+440$ & 160 & 13 & 24 \\
\hline $673+430$ & 170 & 17 & 22 \\
\hline $673+420$ & 180 & 29 & 28 \\
\hline $673+410$ & 190 & 19 & 28 \\
\hline $673+400$ & 200 & 8 & 8 \\
\hline & & Média & 31,1 \\
\hline & & D padr & 10,2 \\
\hline
\end{tabular}

\begin{tabular}{|c|c|c|c|}
\hline \multicolumn{4}{|c|}{ Trilha de Roda } \\
\hline RODOVIA: & & BR 376 & T10 \\
\hline Posição & \multirow{2}{*}{ Dist. } & \multicolumn{2}{|c|}{ Flecha $(\mathrm{mm})$} \\
\hline km & & TRI & TRE \\
\hline $673+390$ & 10 & 6 & 8 \\
\hline $673+380$ & 20 & 7 & 5 \\
\hline $673+370$ & 30 & 5 & 6 \\
\hline $673+360$ & 40 & 4 & 7 \\
\hline $673+350$ & 50 & 50 & 5 \\
\hline $673+340$ & 60 & 8 & 6 \\
\hline $673+330$ & 70 & 6 & 5 \\
\hline $673+320$ & 80 & 5 & 9 \\
\hline $673+310$ & 90 & 5 & 7 \\
\hline $673+300$ & 100 & 8 & 6 \\
\hline $673+290$ & 110 & 8 & 8 \\
\hline $673+280$ & 120 & 6 & 8 \\
\hline $673+270$ & 130 & 4 & 6 \\
\hline $673+260$ & 140 & 6 & 6 \\
\hline $673+250$ & 150 & 8 & 7 \\
\hline $673+240$ & 160 & 4 & 6 \\
\hline $673+230$ & 170 & 4 & 6 \\
\hline $673+220$ & 180 & 11 & 7 \\
\hline $673+210$ & 190 & 5 & 7 \\
\hline $673+200$ & 200 & 5 & 6 \\
\hline & & Média & 6,6 \\
\hline & & D padr & 1,1 \\
\hline
\end{tabular}


Anexo $V$

Levantamento das temperaturas diárias da Cidade de INDAIAL SC Cidade próxima ao local da pista-teste e de mesma altitude. 
Temperaturas diárias do ano de 2009 das medidas na estação metereológica localizada na Cidade de Indaial SC.Y19

\begin{tabular}{|c|c|c|c|c|c|c|c|c|c|c|c|c|c|c|c|c|c|}
\hline \multirow{2}{*}{ Dia } & \multicolumn{2}{|c|}{ Temp. ${ }^{\circ} \mathrm{C}$} & \multirow{2}{*}{ Dia } & \multirow{2}{*}{\multicolumn{2}{|c|}{ Temp. ${ }^{\circ} \mathrm{C}$}} & & Tem & p. ${ }^{\circ} \mathrm{C}$ & & Tem & p. ${ }^{\circ} \mathrm{C}$ & & \begin{tabular}{|l|} 
Tem \\
\end{tabular} & p. ${ }^{\circ} \mathrm{C}$ & & Tem & p. ${ }^{\circ} \mathrm{C}$ \\
\hline & Máx. & Mín. & & & & Dia & \begin{tabular}{|l|} 
Máx. \\
\end{tabular} & Mín. & Dia & Máx. & Mín. & Dia & Máx. & Mín. & Dia & Máx. & Mín. \\
\hline $01 / 01 / 2009$ & 30,4 & 23,6 & $12 / 03 / 2009$ & 32,3 & 23 & $21 / 05 / 2009$ & 27 & 17 & $30 / 07 / 2009$ & 19 & 12 & $08 / 10 / 2009$ & 20 & 16,4 & $17 / 12 / 2009$ & 29 & 21,9 \\
\hline $02 / 01 / 2009$ & 23,5 & 20,2 & $13 / 03 / 2009$ & 32,4 & 21 & $22 / 05 / 2009$ & 26 & 15 & $31 / 07 / 2009$ & 14 & 11 & $09 / 10 / 2009$ & 20 & 14,5 & $18 / 12 / 2009$ & 30 & 18,9 \\
\hline 03/01/2009 & 26,1 & 19,6 & $14 / 03 / 2009$ & 32 & 19 & 23/05/2009 & 28 & 16 & $01 / 08 / 2009$ & 19 & 10,8 & $10 / 10 / 2009$ & 24 & 14,9 & $19 / 12 / 2009$ & 31 & 20,8 \\
\hline $04 / 01 / 2009$ & 23,7 & 16,7 & $15 / 03 / 2009$ & 34 & 17 & $24 / 05 / 2009$ & 26 & 17 & 02/08/2009 & 23 & 15,8 & $11 / 10 / 2009$ & 26 & 15,5 & 20/12/2009 & 34 & 20 \\
\hline $05 / 01 / 2009$ & 26,9 & 15 & $16 / 03 / 2009$ & 24 & 21 & $25 / 05 / 2009$ & 25 & 18 & 03/08/2009 & 22 & 13,8 & $12 / 10 / 2009$ & 25 & 18,8 & $21 / 12 / 2009$ & 35 & 22,7 \\
\hline $06 / 01 / 2009$ & 29,8 & 15 & $17 / 03 / 2009$ & 32,5 & 20 & $26 / 05 / 2009$ & 25 & 17 & $04 / 08 / 2009$ & 22 & 9,1 & $13 / 10 / 2009$ & 26 & 16,4 & $22 / 12 / 2009$ & 29 & 23,5 \\
\hline 07/01/2009 & 32,2 & 15,8 & $18 / 03 / 2009$ & 27,3 & 21 & $27 / 05 / 2009$ & 21 & 20 & 05/08/2009 & -- & 14 & $14 / 10 / 2009$ & 25 & 15 & $23 / 12 / 2009$ & 30 & 21,4 \\
\hline $08 / 01 / 2009$ & 35,4 & 18,8 & $19 / 03 / 2009$ & 26,3 & 20 & $28 / 05 / 2009$ & 21 & 17 & $06 / 08 / 2009$ & 28 & 14,4 & $15 / 10 / 2009$ & 30 & 18,1 & $24 / 12 / 2009$ & 27 & 23,4 \\
\hline $09 / 01 / 2009$ & 31,5 & 21 & $20 / 03 / 2009$ & 26,9 & 21 & 29/05/2009 & 18 & 15 & $07 / 08 / 2009$ & 18 & 13,3 & $16 / 10 / 2009$ & 22 & 16,1 & $25 / 12 / 2009$ & 36 & 23 \\
\hline $10 / 01 / 2009$ & 29 & 19,8 & $21 / 03 / 2009$ & 32,2 & 20 & $30 / 05 / 2009$ & 17 & 15 & 08/08/2009 & -- & 14 & $17 / 10 / 2009$ & 18 & 13,4 & $26 / 12 / 2009$ & 34 & 23,4 \\
\hline $11 / 01 / 2009$ & 29,7 & 19,9 & $22 / 03 / 2009$ & 32,3 & 20 & $31 / 05 / 2009$ & 21 & 16 & 09/08/2009 & 20 & 16,9 & $18 / 10 / 2009$ & 26 & 16,3 & $27 / 12 / 2009$ & 35 & 23,8 \\
\hline $12 / 01 / 2009$ & 35,5 & 18,9 & $23 / 03 / 2009$ & 32,7 & 21 & $01 / 06 / 2009$ & 18 & 9,5 & $10 / 08 / 2009$ & 22 & 15,9 & $19 / 10 / 2009$ & 21 & 17,7 & $28 / 12 / 2009$ & 36 & 21,8 \\
\hline $13 / 01 / 2009$ & 30,1 & 19,8 & $24 / 03 / 2009$ & 31,6 & 22 & 02/06/2009 & 18 & 8,3 & $11 / 08 / 2009$ & 23 & 9,3 & $20 / 10 / 2009$ & 32 & 18,1 & $29 / 12 / 2009$ & 38 & 24,2 \\
\hline $14 / 01 / 2009$ & 35,2 & 20,1 & $25 / 03 / 2009$ & 25,1 & 21 & 03/06/2009 & 18 & 5,6 & $12 / 08 / 2009$ & 23 & 8,9 & 21/10/2009 & 29 & 17,1 & $30 / 12 / 2009$ & 36 & 25,4 \\
\hline $15 / 01 / 2009$ & 35,1 & 21 & $26 / 03 / 2009$ & 30 & 20 & $04 / 06 / 2009$ & 19 & 4,9 & $13 / 08 / 2009$ & 25 & 13,3 & 22/10/2009 & 26 & 18,7 & $31 / 12 / 2009$ & 27 & 23,7 \\
\hline $16 / 01 / 2009$ & 29,6 & 21,6 & $27 / 03 / 2009$ & 31,7 & 19 & $05 / 06 / 2009$ & 24 & 4,6 & $14 / 08 / 2009$ & -- & 15,5 & $23 / 10 / 2009$ & 29 & 19,7 & & & \\
\hline $17 / 01 / 2009$ & 25 & 20,1 & $28 / 03 / 2009$ & 32,8 & 21 & $06 / 06 / 2009$ & 22 & 7,3 & $15 / 08 / 2009$ & 27 & 16,3 & $24 / 10 / 2009$ & 27 & 20,1 & & & \\
\hline $18 / 01 / 2009$ & 33,8 & 20,2 & $29 / 03 / 2009$ & 32,4 & 18 & 07/06/2009 & 20 & 11 & $16 / 08 / 2009$ & 28 & 15,4 & $25 / 10 / 2009$ & 27 & 20,1 & & & \\
\hline $19 / 01 / 2009$ & 26 & 22,7 & $30 / 03 / 2009$ & 31,3 & 21 & 08/06/2009 & 22 & 8,3 & $17 / 08 / 2009$ & -- & 16 & $26 / 10 / 2009$ & 31 & 19,1 & & & \\
\hline $20 / 01 / 2009$ & 29,1 & 19,9 & $31 / 03 / 2009$ & 33,9 & 21 & 09/06/2009 & 22 & 13 & $18 / 08 / 2009$ & 21 & 17,8 & $27 / 10 / 2009$ & 22 & 16,3 & & & \\
\hline $21 / 01 / 2009$ & 28,3 & 17,3 & $01 / 04 / 2009$ & 32,3 & 21 & $10 / 06 / 2009$ & 22 & 15 & $19 / 08 / 2009$ & 27 & 16,1 & $28 / 10 / 2009$ & 24 & 15,1 & & & \\
\hline $22 / 01 / 2009$ & 27,3 & 15,9 & $02 / 04 / 2009$ & 24,5 & 20 & $11 / 06 / 2009$ & 25 & 16 & $20 / 08 / 2009$ & -- & 15,5 & $29 / 10 / 2009$ & 29 & 17,7 & & & \\
\hline 23/01/2009 & 28,8 & 16,1 & $03 / 04 / 2009$ & 28,1 & 19 & $12 / 06 / 2009$ & 22 & 15 & $21 / 08 / 2009$ & 22 & 10,6 & $30 / 10 / 2009$ & 32 & 18,3 & & & \\
\hline $24 / 01 / 2009$ & 28,2 & 16,9 & $04 / 04 / 2009$ & 32 & 20 & $13 / 06 / 2009$ & 22 & 11 & $22 / 08 / 2009$ & 21 & 8,3 & $31 / 10 / 2009$ & 34 & 20,9 & & & \\
\hline $25 / 01 / 2009$ & 27,9 & 19,9 & $05 / 04 / 2009$ & 31,3 & 23 & $14 / 06 / 2009$ & 22 & 8,1 & $23 / 08 / 2009$ & 20 & 13,6 & $01 / 11 / 2009$ & 33 & 21,3 & & & \\
\hline $26 / 01 / 2009$ & 27,6 & 21,9 & $06 / 04 / 2009$ & 31,5 & 22 & $15 / 06 / 2009$ & 21 & 8,5 & $24 / 08 / 2009$ & 25 & 15,1 & $02 / 11 / 2009$ & 34 & 22,2 & & & \\
\hline 27/01/2009 & 28,6 & 21,4 & $07 / 04 / 2009$ & 33,8 & 21 & $16 / 06 / 2009$ & 19 & 14 & $25 / 08 / 2009$ & 25 & 16,4 & 03/11/2009 & 35 & 21,2 & & & \\
\hline 28/01/2009 & 28,7 & 22,2 & $08 / 04 / 2009$ & 31,8 & 22 & $17 / 06 / 2009$ & 20 & 12 & $26 / 08 / 2009$ & 25 & 13,5 & $04 / 11 / 2009$ & 36 & 20,4 & & & \\
\hline $29 / 01 / 2009$ & 32,4 & 22,6 & $09 / 04 / 2009$ & 31,5 & 20 & $18 / 06 / 2009$ & 22 & 10 & $27 / 08 / 2009$ & 28 & 14,5 & $05 / 11 / 2009$ & 36 & 23 & & & \\
\hline $30 / 01 / 2009$ & 35,6 & 20,1 & $10 / 04 / 2009$ & 29 & 18 & $19 / 06 / 2009$ & 23 & 12 & $28 / 08 / 2009$ & 29 & 17,1 & $06 / 11 / 2009$ & 31 & 23,8 & & & \\
\hline $31 / 01 / 2009$ & 34,8 & 20,8 & $11 / 04 / 2009$ & 29 & 13 & 20/06/2009 & 25 & 15 & $29 / 08 / 2009$ & 29 & 12,5 & $07 / 11 / 2009$ & 32 & 23 & & & \\
\hline $01 / 02 / 2009$ & 34,6 & 19,7 & $12 / 04 / 2009$ & 29,7 & 16 & $21 / 06 / 2009$ & 25 & 13 & $30 / 08 / 2009$ & 29 & 15,3 & $08 / 11 / 2009$ & 25 & 21,4 & & & \\
\hline $02 / 02 / 2009$ & 31,3 & 20,7 & $13 / 04 / 2009$ & 30,8 & 19 & $22 / 06 / 2009$ & 23 & 14 & $31 / 08 / 2009$ & 28 & 16,4 & $09 / 11 / 2009$ & 26 & 18,1 & & & \\
\hline 03/02/2009 & 28,7 & 22,5 & $14 / 04 / 2009$ & 34 & 20 & 23/06/2009 & 20 & 14 & $01 / 09 / 2009$ & -- & 16,9 & $10 / 11 / 2009$ & 30 & 20,9 & & & \\
\hline $04 / 02 / 2009$ & 31,2 & 21,9 & $15 / 04 / 2009$ & 27,5 & 19 & $24 / 06 / 2009$ & 19 & 16 & $02 / 09 / 2009$ & 27 & 18,1 & $11 / 11 / 2009$ & 30 & 21,7 & & & \\
\hline 05/02/2009 & 29,4 & 21,3 & $16 / 04 / 2009$ & 27,7 & 17 & $25 / 06 / 2009$ & 18 & 13 & 03/09/2009 & 24 & 17,1 & $12 / 11 / 2009$ & 31 & 22,2 & & & \\
\hline 06/02/2009 & 32,7 & 21,5 & $17 / 04 / 2009$ & 29 & 16 & $26 / 06 / 2009$ & 19 & 14 & $04 / 09 / 2009$ & -- & 18,7 & $13 / 11 / 2009$ & 30 & 22,6 & & & \\
\hline 07/02/2009 & 30,6 & 24,5 & $18 / 04 / 2009$ & 27,7 & 15 & 27/06/2009 & 16 & 13 & 05/09/2009 & 27 & 16,2 & $14 / 11 / 2009$ & 32 & 21,2 & & & \\
\hline 08/02/2009 & 32,8 & 23,3 & $19 / 04 / 2009$ & 31,9 & 15 & $28 / 06 / 2009$ & 19 & 14 & $06 / 09 / 2009$ & 20 & 17,4 & $15 / 11 / 2009$ & 30 & 22,3 & & & \\
\hline 09/02/2009 & 28,6 & 23,9 & $20 / 04 / 2009$ & 23,4 & 18 & $29 / 06 / 2009$ & 23 & 16 & $07 / 09 / 2009$ & 25 & 16,4 & $16 / 11 / 2009$ & 25 & 20,7 & & & \\
\hline $10 / 02 / 2009$ & 28 & 21,6 & $21 / 04 / 2009$ & 22,9 & 17 & $30 / 06 / 2009$ & 25 & 15 & 08/09/2009 & 21 & 16,7 & $17 / 11 / 2009$ & 28 & 18,8 & & & \\
\hline $11 / 02 / 2009$ & 32,7 & 23,5 & $22 / 04 / 2009$ & 20 & 18 & 01/07/2009 & 22 & 8 & 09/09/2009 & 19 & 15,7 & $18 / 11 / 2009$ & 31 & 22,2 & & & \\
\hline $12 / 02 / 2009$ & 31 & 20,7 & $23 / 04 / 2009$ & 25,8 & 18 & 02/07/2009 & 21 & 13 & $10 / 09 / 2009$ & -- & 14,9 & $19 / 11 / 2009$ & -- & 23,3 & & & \\
\hline $13 / 02 / 2009$ & 30 & 17,9 & $24 / 04 / 2009$ & 27,4 & 18 & 03/07/2009 & 20 & 12 & $11 / 09 / 2009$ & 20 & 16,3 & $20 / 11 / 2009$ & 31 & 21,6 & & & \\
\hline $14 / 02 / 2009$ & 29,7 & 18,4 & $25 / 04 / 2009$ & 25,8 & 19 & 04/07/2009 & 23 & 11 & $12 / 09 / 2009$ & 19 & 16,7 & $21 / 11 / 2009$ & 24 & 20,3 & & & \\
\hline $15 / 02 / 2009$ & 30,1 & 19,8 & $26 / 04 / 2009$ & 29,5 & 18 & $05 / 07 / 2009$ & 18 & 9,3 & $13 / 09 / 2009$ & -- & 16,9 & $22 / 11 / 2009$ & 27 & 19,2 & & & \\
\hline $16 / 02 / 2009$ & 27,2 & 20,7 & $27 / 04 / 2009$ & 29,8 & 18 & 06/07/2009 & 18 & 15 & $14 / 09 / 2009$ & 22 & 17,3 & $23 / 11 / 2009$ & 33 & 19,3 & & & \\
\hline $17 / 02 / 2009$ & 30,2 & 22,7 & $28 / 04 / 2009$ & 29,8 & 18 & $07 / 07 / 2009$ & 26 & 16 & $15 / 09 / 2009$ & 22 & 16,3 & $24 / 11 / 2009$ & 30 & 23,1 & & & \\
\hline $18 / 02 / 2009$ & 32,8 & 23,3 & $29 / 04 / 2009$ & 28,4 & 20 & 08/07/2009 & 26 & 15 & $16 / 09 / 2009$ & 26 & 17,7 & $25 / 11 / 2009$ & 30 & 24,1 & & & \\
\hline $19 / 02 / 2009$ & 32,5 & 22,3 & $30 / 04 / 2009$ & 28,8 & 17 & 09/07/2009 & 20 & 18 & $17 / 09 / 2009$ & -- & 18,9 & 26/11/2009 & 34 & 23,1 & & & \\
\hline $20 / 02 / 2009$ & 32,6 & 22,5 & $01 / 05 / 2009$ & 21,6 & 18 & $10 / 07 / 2009$ & 21 & 15 & $18 / 09 / 2009$ & 20 & 16,3 & 27/11/2009 & 30 & 21,4 & & & \\
\hline $21 / 02 / 2009$ & 33 & 22,7 & $02 / 05 / 2009$ & 25,7 & 17 & $11 / 07 / 2009$ & 18 & 15 & $19 / 09 / 2009$ & 26 & 16,4 & $28 / 11 / 2009$ & 31 & 23,1 & & & \\
\hline $22 / 02 / 2009$ & 34,6 & 20,7 & 03/05/2009 & 26,5 & 16 & $12 / 07 / 2009$ & 21 & 9,9 & $20 / 09 / 2009$ & 26 & 11 & $29 / 11 / 2009$ & 34 & 21,7 & & & \\
\hline 23/02/2009 & 35,6 & 22,3 & $04 / 05 / 2009$ & 25,1 & 19 & $13 / 07 / 2009$ & 21 & 9,4 & 21/09/2009 & 19 & 15,4 & $30 / 11 / 2009$ & 31 & 21,2 & & & \\
\hline $24 / 02 / 2009$ & 26,3 & 21,5 & $05 / 05 / 2009$ & 28,5 & 16 & $14 / 07 / 2009$ & 22 & 10 & $22 / 09 / 2009$ & 20 & 16,3 & $01 / 12 / 2009$ & 33 & 22,2 & & & \\
\hline $25 / 02 / 2009$ & -- & 19,9 & $06 / 05 / 2009$ & 27,6 & 15 & $15 / 07 / 2009$ & 17 & 12 & 23/09/2009 & 29 & 18 & $02 / 12 / 2009$ & 33 & 21,2 & & & \\
\hline $26 / 02 / 2009$ & 27,5 & 20,6 & $07 / 05 / 2009$ & 25,4 & 9,6 & $16 / 07 / 2009$ & 16 & 14 & $24 / 09 / 2009$ & 24 & 11,7 & $03 / 12 / 2009$ & 34 & 20,6 & & & \\
\hline $27 / 02 / 2009$ & 32 & 22,4 & $08 / 05 / 2009$ & 21 & 13 & $17 / 07 / 2009$ & 26 & 14 & $25 / 09 / 2009$ & 21 & 12,3 & $04 / 12 / 2009$ & 26 & 21,4 & & & \\
\hline $28 / 02 / 2009$ & 28,5 & 21,8 & $09 / 05 / 2009$ & 23,7 & 17 & $18 / 07 / 2009$ & 24 & 15 & 26/09/2009 & 23 & 15 & 05/12/2009 & 23 & 17,9 & & & \\
\hline 01/03/2009 & 34,6 & 22,9 & $10 / 05 / 2009$ & 28 & 18 & $19 / 07 / 2009$ & 21 & 13 & 27/09/2009 & 23 & 16,9 & $06 / 12 / 2009$ & 30 & 19,2 & & & \\
\hline 02/03/2009 & 37,8 & 23 & $11 / 05 / 2009$ & 26,1 & 17 & 20/07/2009 & 20 & 12 & 28/09/2009 & 24 & 18,9 & $07 / 12 / 2009$ & 30 & 20,1 & & & \\
\hline 03/03/2009 & 34,8 & 22,3 & $12 / 05 / 2009$ & 27,9 & 17 & 21/07/2009 & 21 & 12 & 29/09/2009 & 20 & 14,2 & 08/12/2009 & 29 & 21,3 & & & \\
\hline 04/03/2009 & 33,6 & 23,4 & $13 / 05 / 2009$ & 27,3 & 18 & $22 / 07 / 2009$ & 20 & 15 & $30 / 09 / 2009$ & 21 & 12,2 & 09/12/2009 & 27 & 19,9 & & & \\
\hline 05/03/2009 & 37,6 & 25,1 & $14 / 05 / 2009$ & 22,3 & 19 & 23/07/2009 & 15 & 11 & 01/10/2009 & 17 & 11,9 & $10 / 12 / 2009$ & 26 & 20,6 & & & \\
\hline 06/03/2009 & 33,6 & 22,7 & $15 / 05 / 2009$ & 20,1 & 13 & 24/07/2009 & 16 & 6,5 & 02/10/2009 & 25 & 15 & $11 / 12 / 2009$ & 28 & 21,3 & & & \\
\hline 07/03/2009 & 28,5 & 22,3 & $16 / 05 / 2009$ & 22,4 & 7,5 & $25 / 07 / 2009$ & 13 & 7,3 & 03/10/2009 & 20 & 15,8 & $12 / 12 / 2009$ & 29 & 22,9 & & & \\
\hline 08/03/2009 & 27,7 & 22,3 & $17 / 05 / 2009$ & 24 & 10 & $26 / 07 / 2009$ & 20 & 11 & 04/10/2009 & 22 & 15,9 & $13 / 12 / 2009$ & 29 & 15,5 & & & \\
\hline 09/03/2009 & 31,1 & 22,3 & $18 / 05 / 2009$ & 21,7 & 13 & 27/07/2009 & 17 & 3,5 & 05/10/2009 & 25 & 18,1 & $14 / 12 / 2009$ & 30 & 17,7 & & & \\
\hline $10 / 03 / 2009$ & 27,2 & 20,5 & $19 / 05 / 2009$ & 25,7 & 13 & 28/07/2009 & 17 & 13 & 06/10/2009 & -- & 18,4 & $15 / 12 / 2009$ & 33 & 20,8 & & & \\
\hline 11/03/2009 & 27,2 & 22,2 & $20 / 05 / 2009$ & 27,3 & 17 & $29 / 07 / 2009$ & 23 & 13 & 07/10/2009 & 23 & 18,5 & $16 / 12 / 2009$ & 33 & 22,7 & & & \\
\hline
\end{tabular}


Anexo VI

Ensaios de deformação permanente em trilha de roda de misturas asfálticas usinadas em laboratório no teor de ligante asfáltico corrigido pela PCG. 

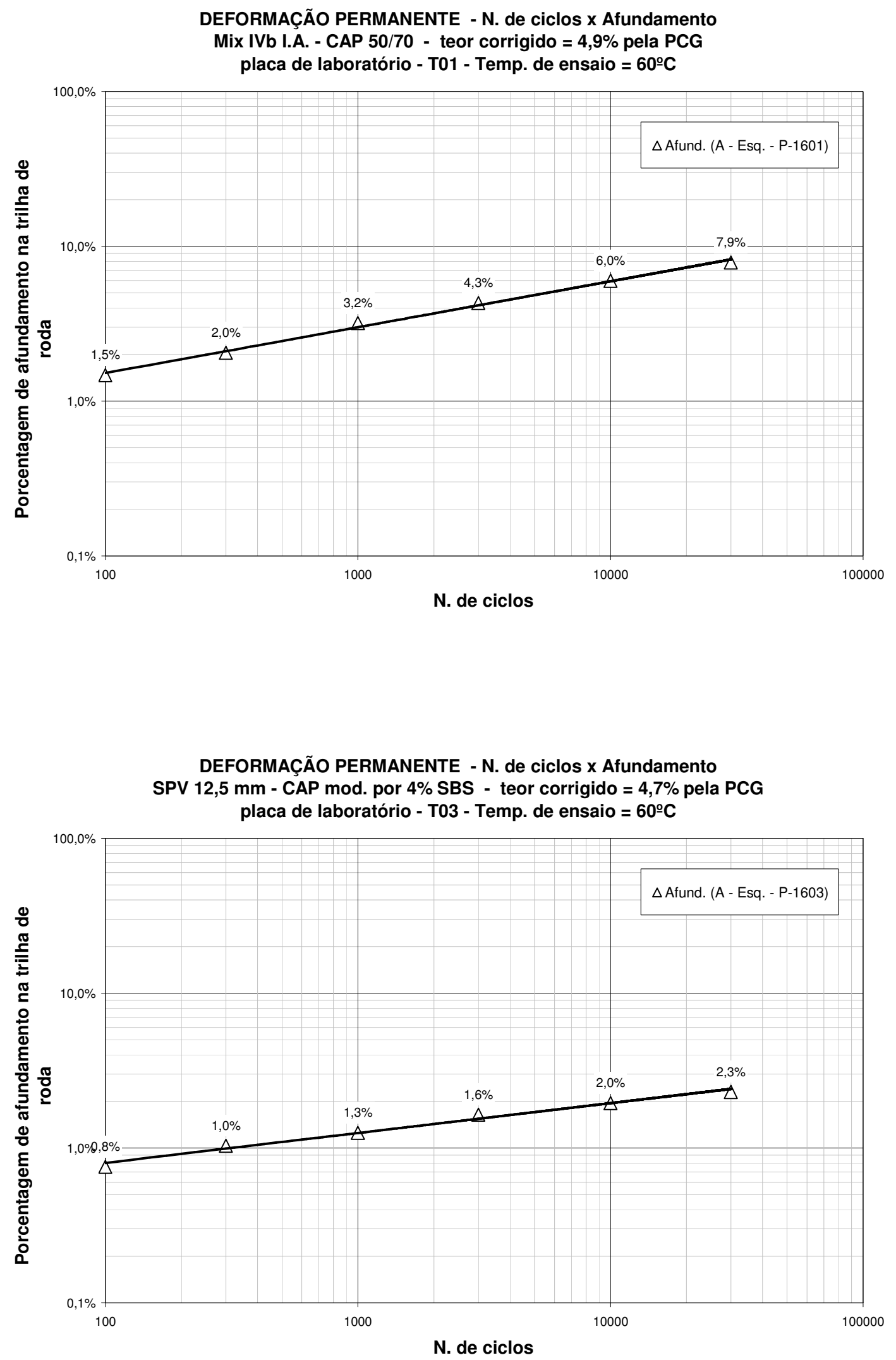
DEFORMAÇÃO PERMANENTE - N. de ciclos x Afundamento

SPV $9,5 \mathrm{~mm}$ - CAP mod. por $4 \%$ SBS - teor corrigido $=5,6 \%$ pela PCG

placa de laboratório - T04 - Temp. de ensaio $=60^{\circ} \mathrm{C}$

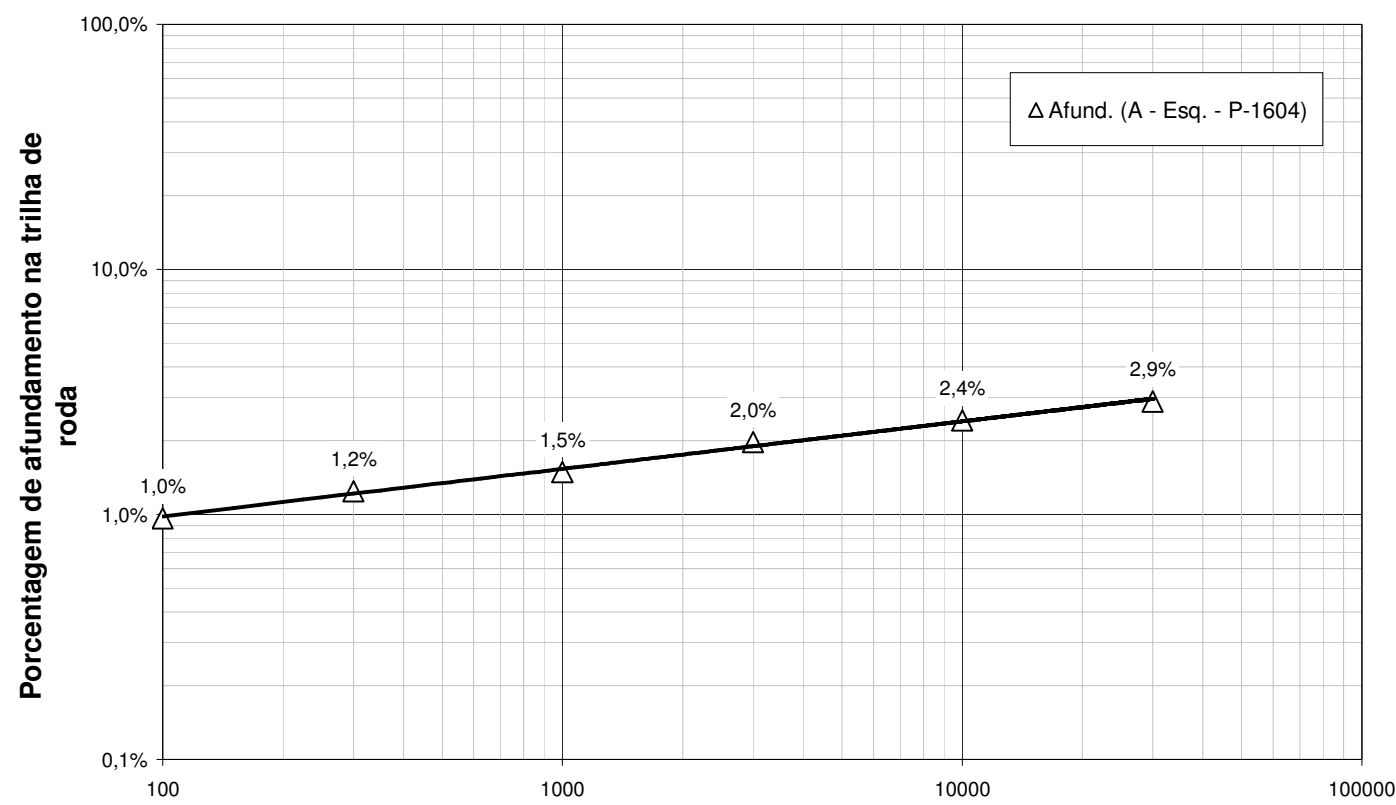

N. de ciclos

DEFORMAÇÃO PERMANENTE - N. de ciclos x Afundamento

SPV 9,5 mm - CAP $30 / 45$ - teor corrigido $=5,0 \%$ pela PCG

placa de laboratório - T05 - Temp. de ensaio $=60^{\circ} \mathrm{C}$

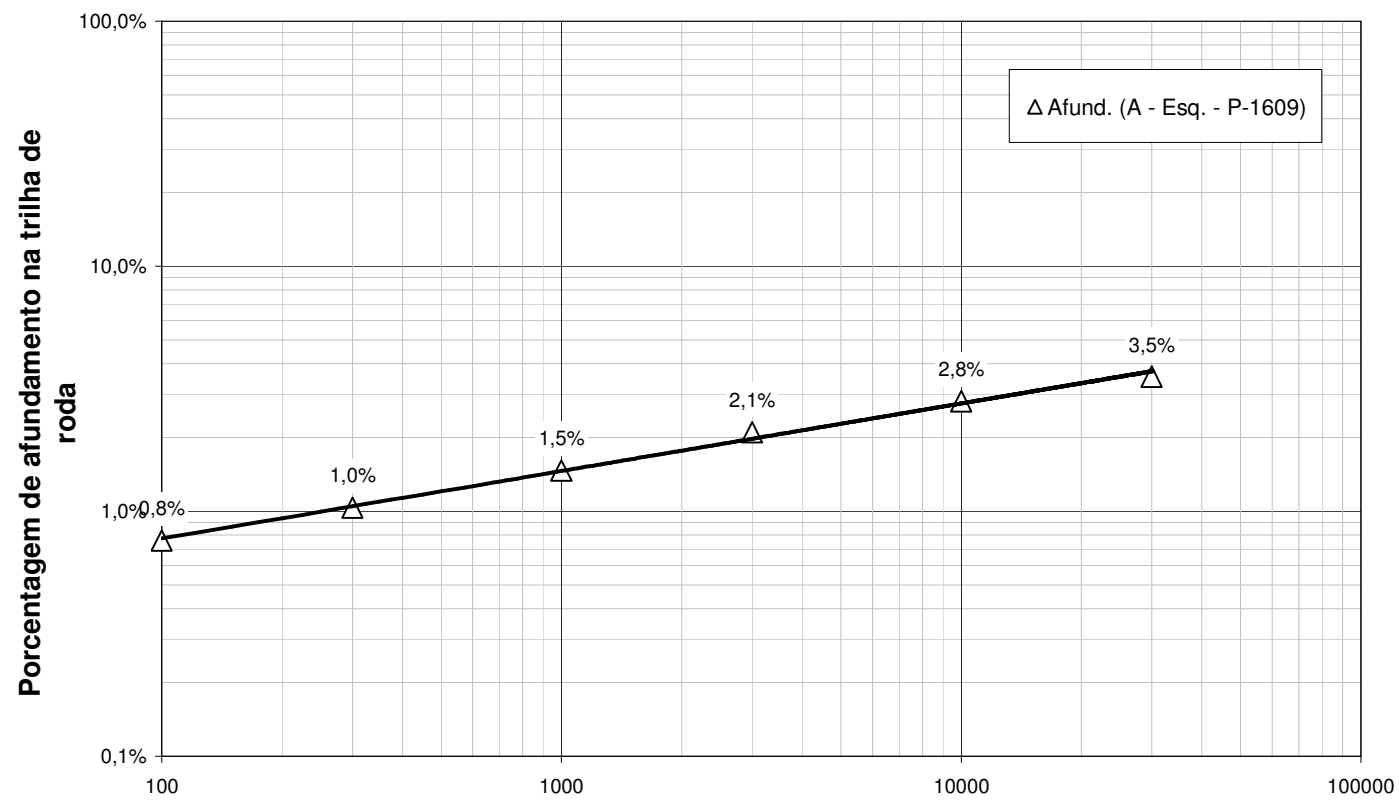

N. de ciclos 
DEFORMAÇÃO PERMANENTE - $\mathrm{N}$. de ciclos $x$ Afundamento

SPV $12,5 \mathrm{~mm}$ - CAP mod. por $1,2 \%$ RET - teor corrigido $=5,0 \%$ pela PCG placa de laboratório $-\mathrm{T} 06-\mathrm{Temp}$. de ensaio $=60^{\circ} \mathrm{C}$

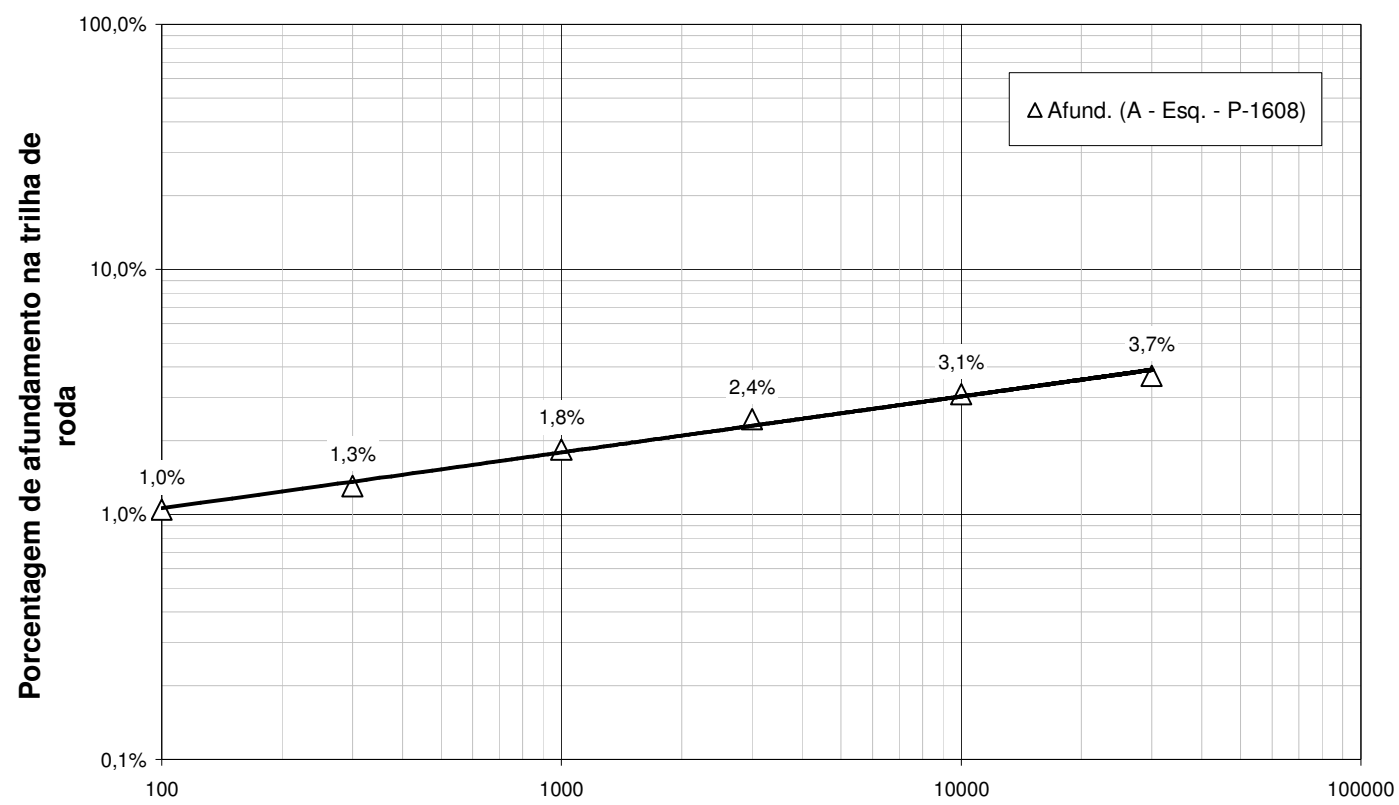

N. de ciclos

DEFORMAÇÃO PERMANENTE - N. de ciclos x Afundamento

Gap Graded CALTRANS - CAP mod. por borracha - teor corrigido $=6,2 \%$ pela PCG placa de laboratório $-\mathrm{T} 07-\mathrm{Temp}$. de ensaio $=60^{\circ} \mathrm{C}$

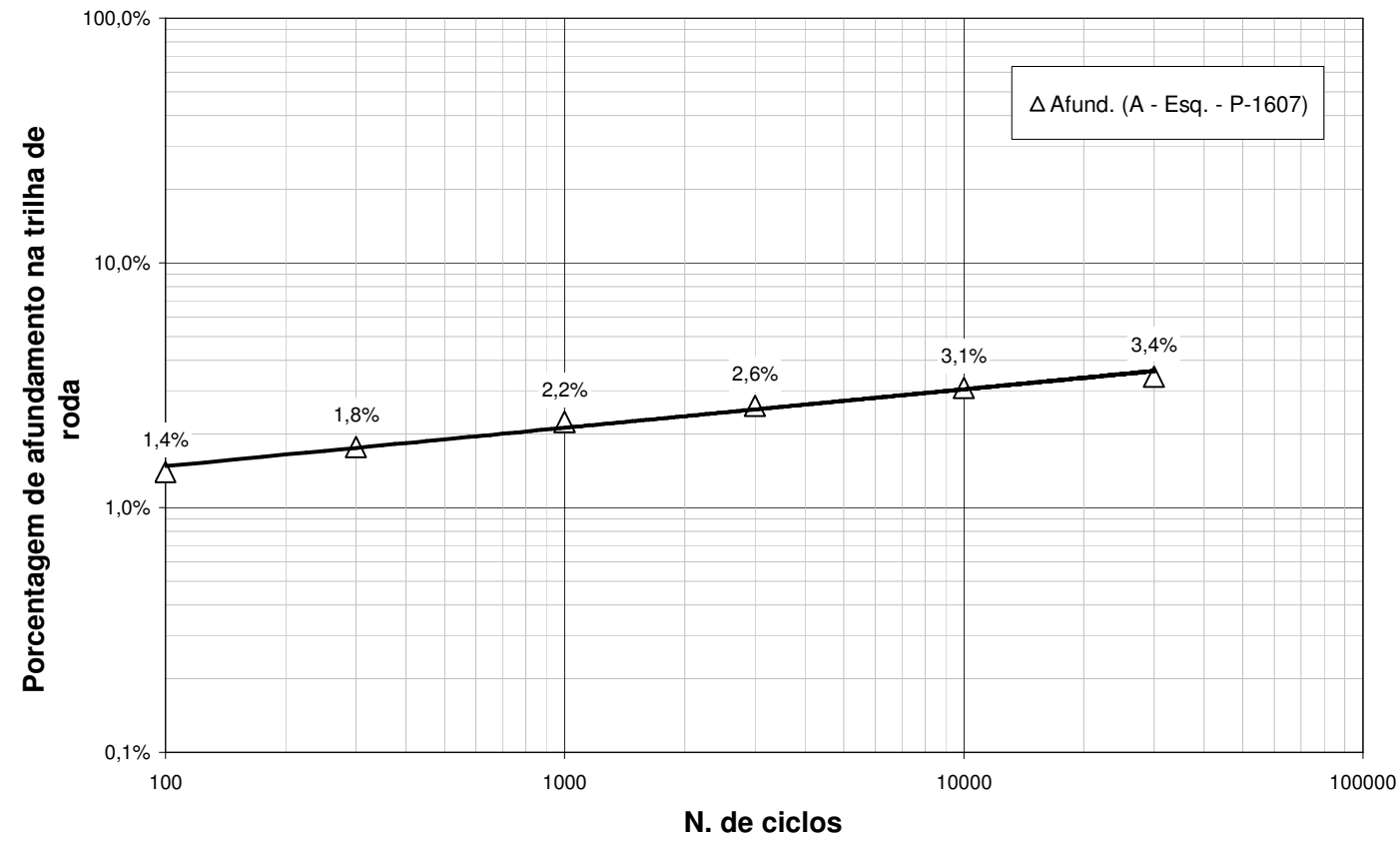




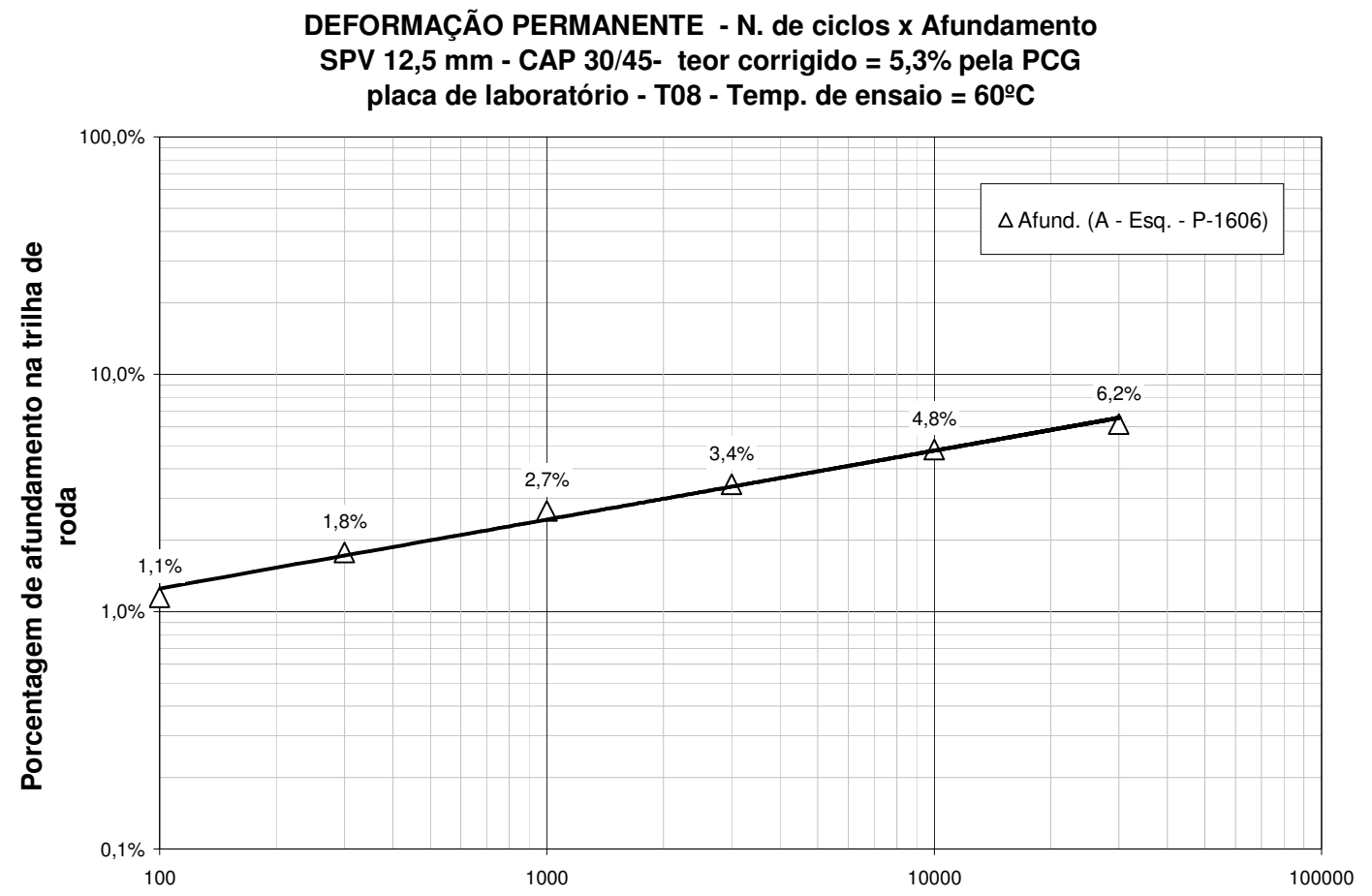

N. de ciclos

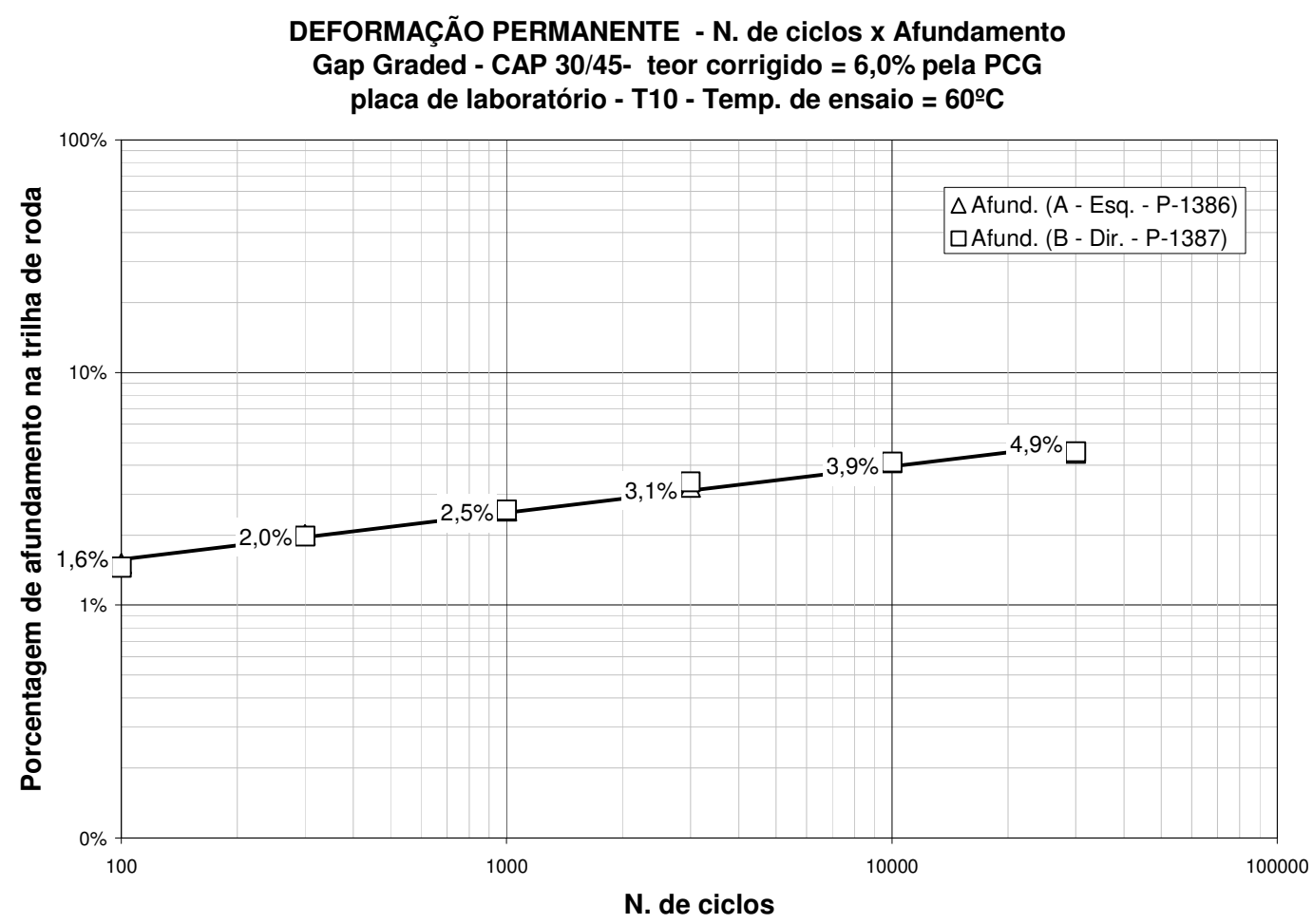

